\title{
NUEVAS ESTRATEGIAS DE DISEÑO AUTOMATIZADO \\ DE COMPONENTES PASIVOS PARA SISTEMAS DE COMUNICACIONES DE ALTA FRECUENCIA
}

\author{
José Vicente Morro Ros
}

Director: Dr. Héctor Esteban González

Tesis Doctoral presentada en la Universidad Politécnica de Valencia para la obtención del título de Doctor Ingeniero de Telecomunicación

Valencia, Septiembre 2011 



\section{ÍTACA}

Cuando salgas en el viaje, hacia Ítaca desea que el camino sea largo, pleno de aventuras, pleno de conocimientos.

A los Lestrigones y a los Cíclopes, al irritado Poseidón no temas,

tales cosas en tu ruta nunca hallarás, si elevado se mantiene tu pensamiento, si una selecta emoción tu espíritu y tu cuerpo embarga.

A los Lestrigones y a los Cíclopes, y al feroz Poseidón no encontrarás, si dentro de tu alma no los llevas, si tu alma no los yergue delante de ti.

Desea que el camino sea largo.

Que sean muchas las mañanas estivales en que con cuánta dicha, con cuánta alegría entres a puertos nunca vistos: detente en mercados fenicios, y adquiere las bellas mercancías, ámbares y ébanos, marfiles y corales, y perfumes voluptuosos de toda clase, cuanto más abundantes puedas perfumes voluptuosos; anda a muchas ciudades Egipcias a aprender y aprender de los sabios. Siempre en tu pensamiento ten a Ítaca.

Llegar hasta allí es tu destino.

Pero no apures tu viaje en absoluto.

Mejor que muchos años dure: y viejo ya ancles en la isla, rico con cuanto ganaste en el camino, sin esperar que riquezas te dé Ítaca. Ítaca te dio el bello viaje.

Sin ella no hubieras salido al camino.

Otras cosas no tiene ya que darte.

Y si pobre la encuentras, Ítaca no te ha engañado.

Sabio así como llegaste a ser, con experiencia tanta, ya habrás comprendido las Ítacas qué es lo que significan. 



\section{Agradecimientos}

La historia del trabajo escrito en estas páginas empezó el día que entré en el despacho de Vicente Boria buscando a alguien que me dirigiera mi proyecto fin de carrera. Ese día supuso un punto de inflexión en mi vida. Encontré lo que buscaba, sin saber donde me metía. Le agradezco el apoyo recibido y la oportunidad de formar parte, prácticamente desde el principio, del Grupo de Aplicaciones de las Microondas. Conozco pocos grupos de trabajos tan cohesionados, tan colaboradores y a la vez tan competentes. No tengo más que elogios para mis compañeros de grupo: Ana, Santi, Pablo, Benito, Mariam, Luis, Jordi, Marini, Fermín, Ángel Belenguer, Ángel San Blas, ... espero que podamos seguir muchos años trabajando juntos.

Quiero aquí mencionar a Héctor Esteban y a Carmen Bachiller, compañeros y amigos, sin cuya ayuda e ilimitada paciencia esta tesis no habría llegado a buen puerto. Siempre han estado ahí cuando los he necesitado. Nunca podré agradecerles lo suficiente su inestimable apoyo.

Por último, me gustaría agradecer a mis padres y mi hermana la infinita paciencia que han tenido conmigo durante estos años.

Espero no haberme olvidado de nadie. Gracias a todos.

Gandía

José Vicente Morro Ros

1 de Septiembre de 2011 



\section{Resumen}

Los filtros de microondas son elementos clave en todos los sistemas de comunicaciones ya que permiten discriminar una determinada frecuencia o gama de frecuencias de una señal que pasa a través de él. Si nos centramos en los filtros de microondas para aplicaciones vía satélite, el constante aumento de los servicios que deben prestar los satélites de comunicaciones ha llevado a que el espectro radioeléctrico esté más congestionado. Lo que ha producido una enorme demanda de filtros de altas prestaciones que satisfagan unas especificaciones muy estrictas.

Hasta la fecha las aplicaciones comerciales de microondas principalmente vienen utilizando filtros en tecnología guiada compuestos únicamente de metal, debido principalmente a sus bajas pérdidas y a la gran capacidad de manejo de potencia. Como consecuencia, el análisis de este tipo de filtros ha sido objeto de numerosos estudios, lo que ha permitido a la industria del sector su fabricación y comercialización. Sin embargo, los filtros metálicos tienen restricciones significativas, especialmente cuando se diseñan para satélites de comunicaciones u otras aplicaciones espaciales, ya que su peso y tamaño suelen ser elevados muy a menudo y, debido a que operan en el vacío, el efecto Multipactor limita considerablemente la potencia que dichos filtros pueden transmitir.

En la actualidad, están surgiendo nuevas topologías de filtros avanzados basadas en la tecnología de filtros con dieléctricos. Estas nuevas topologías ofrecen una reducción importante en masa y volumen de alrededor del $50 \%$ comparado con la tecnología solo metal y una gran estabilidad térmica para aplicaciones de alta potencia. Además, estas topologías muestran un descenso importante del riesgo de ruptura por efecto Multipactor o descarga en vacío entre las superficies metálicas, y consecuentemente el filtro podría transmitir una potencia mayor.

Por lo tanto, durante los últimos años se ha producido un rápido desarrollo de herramientas de análisis electromagnético (EM) muy precisas. Este hecho junto con el incremento de las capacidades computacionales de los ordenadores modernos, ha hecho posible la simulación precisa de este tipo de estructuras en un reducido tiempo. Pero a pesar de todos los esfuerzos realizados hasta la fecha en este campo de actividad, en la etapa de diseño de los citados filtros suele requerirse la intervención manual de un usuario experto de los diversos 
programas que permiten analizar y diseñar estas estructuras. Esta intervención ralentiza el proceso de diseño de los citados filtros, y no garantiza la obtención de la solución óptima. Todo ello, ha producido una necesidad de desarrollar herramientas CAD (Computer Aided Design) basadas en el uso de simuladores electromagnéticos precisos y eficientes.

El objetivo general de esta Tesis consiste en el desarrollo de nuevas estrategias de diseño automatizado de filtros avanzados para comunicaciones espaciales con el objetivo de integrarlas dentro de herramientas CAD. Para ello, se seguirán las técnicas clásicas de diseño para filtros de microondas descritas en la bibliografía y se adaptarán a las nuevas topologías bajo diseño. Ello obligará al desarrollo e implementación de diferentes estrategias de optimización basadas en: la síntesis del punto inicial, la segmentación de la estructura bajo diseño, la hibridación de diferentes algoritmos de optimización y el concepto de mapeado espacial. Sin embargo, todas ellas deberán cumplir las siguientes premisas: robustez, eficiencia y precisión.

Estas nuevas estrategias se han utilizado para el diseño de varios filtros novedosos en plano $\mathrm{H}$, que se presentan en esta Tesis, con diferentes topologías que incluyen desde filtros inductivos en plano $\mathrm{H}$ todo metálicos hasta filtros en modo evanescente con resonadores dieléctricos. El comportamiento de estos filtros en términos de respuesta en frecuencia, ancho de banda libre de espurios y potencia transmitida sin riesgo de ruptura por efecto Multipactor, se ha evaluado mediante las herramientas de análisis utilizadas por las estrategias de diseño y, en algunos casos, también con medidas hechas en filtros fabricados expresamente. 


\section{Resum}

Els filtres de microones són elements clau en tots els sistemes de comunicacions ja que permeten discriminar una determinada freqüència o gamma de freqüències d'un senyal que passa a través d'ells. Si ens centrem en els filtres de microones per a aplicacions via satèl-lit, el constant augment dels serveis que han de prestar els satèl-lits de comunicacions ha portat que l'espectre radioelèctric estiga més congestionat. El que ha produït una enorme demanda de filtres d'altes prestacions que satisfacen unes especificacions molt estrictes.

Fins a la data, les aplicacions comercials de microones utilitzen principalment filtres en tecnologia guiada compostos únicament de metall, degut principalment a les seues baixes pèrdues i a la gran capacitat de maneig de potència. Com a conseqüència, l'anàlisi d'aquest tipus de filtres ha sigut objecte de nombrosos estudis, la qual cosa ha permès a la indústria del sector la seua fabricació i comercialització. No obstant això, els filtres metàl-lics tenen restriccions significatives, especialment quan es dissenyen per a satèl-lits de comunicacions o altres aplicacions espacials, ja que molt sovint el seu pes i grandària solen ser elevats i, pel fet que operen en el buit, l'efecte Multipactor limita considerablement la potència que els dits filtres poden transmetre.

En l'actualitat, estan sorgint noves topologies de filtres avançats basades en la tecnologia de filtres amb dielèctrics. Aquestes noves topologies oferixen una reducció d'al voltant del $50 \%$ en massa i volum comparat amb la tecnologia només metall i una gran estabilitat tèrmica per a aplicacions d'alta potència. A més, aquestes topologies mostren un descens important del risc de ruptura per efecte Multipactor o descarrega en buit entre les superfícies metàl-liques, i conseqüentment el filtre podria transmetre una potència major.

Per tant, durant els últims anys s'ha produït un ràpid desenvolupament de ferramentes d'anàlisi electromagnètica (EM) molt precises. Aqueste fet junt amb l'increment de les capacitats computacionals dels ordinadors moderns, ha fet possible la simulació precisa d'aquest tipus d'estructures en un reduït temps. Però a pesar de tots els esforços realitzats fins a la data en aquest camp d'activitat, en l'etapa de disseny dels esmentats filtres sol requerir-se la intervenció manual d'un usuari expert dels diversos programes que permeten analitzar i dissenyar aquestes estructures. Aquesta intervenció ralentitza el procés de disseny dels esmentats filtres, i no garantix l'obtenció de la solució òptima. Tot això, ha produït un necessitat 
de desenvolupar ferramentes CAD (Computer Aided Design) basades en l'ús de simuladors electromagnètics precisos i eficients.

L'objectiu general d'aquesta Tesi consisteix en el desenvolupament de noves estratègies de disseny automatitzat de filtres avançats per a comunicacions espacials amb l'objectiu d'integrar-les dins de ferramentes CAD. Per això, se seguiran les tècniques clàssiques de disseny per a filtres de microones descrites en la bibliografia i s'adaptaran a les noves topologies baix disseny. Això obligarà al desenvolupament i implementació de diferents estratègies d'optimització basades en: la síntesi del punt inicial, la segmentació de l'estructura baix disseny, la hibridació de diferents algoritmes d'optimització i el concepte de space mapping. No obstant això, totes elles hauran de complir les premisses següents: robustesa, eficiència i precisió.

Aquestes noves estratègies s'han utilitzat per al disseny d'uns quants filtres nous en pla $\mathrm{H}$, que es presenten en aquesta Tesi, amb diferents topologies que inclouen des de filtres inductius en pla $\mathrm{H}$ tot metàl-lics fins a filtres en mode evanescent amb ressonadors dielèctrics. El comportament d'estos filtres en termes de resposta en frequiència, amplada de banda lliure d'espuris i potència transmesa sense risc de ruptura per efecte Multipactor, s'ha avaluat per mitjà de les ferramentes d'anàlisi utilitzades per les estratègies de disseny i, en alguns casos, també amb mesures fetes en filtres fabricats expressament. 


\section{Abstract}

Microwave filters are key devices in the equipment of many communication systems which perform signal processing functions, specifically to remove unwanted frequency components from the signal. If we focus on microwave filters for satellite applications, the continuous increase of the services to be provided by communication satellites has crowded the electromagnetic spectrum. This fact has provoked a huge demand for high-performance filters that meet stringent specifications

Microwave filters for space systems have been historically implemented in metallic waveguide technology, mainly due to low losses and high power handling capability issues. As a result, this area has experienced significant improvements in theoretical, technological, and performance subjects. However, these filters have significant drawbacks, especially when they are designed for satellite and other spatial applications, since their weight and size may often be too high, and due to work on vacuum the Multipactor effect limits considerably the power that the filter can handle.

Nowadays, new topologies of H-plane waveguide filters loaded with dielectric resonators are been developed. These new topologies show a $50 \%$ reduction on weight and volume compared with all-metal technology and a great thermal stability for high power applications. Moreover, these topologies have also reduced the risk of Multipactor effect between the metallic surfaces, consequently the filter can handle more power without inducing a Multipactor breakdown.

Over the past years, the extremely fast development of precise electromagnetic (EM) analysis tools as well as the increase in the computation capabilities of modern computers, have made possible the accurate simulation of this type of structures. Nevertheless, from a designer point of view, more efforts should be devoted to the integration of such fast and accurate simulation methods into automated Computer Aided Design (CAD) tools.

The main aim of this Thesis is the development of new strategies for the automated design of advanced filters for satellite communication systems in order to integrate them into CAD tools. To do this, classical design techniques described in the bibliography will be followed and adapted to the new topologies under design. This will involve the development and 
implementation of different optimization strategies based on: structure segmentation, hybrid optimization and space mapping. However, all these strategies have to meet the following characteristics: robustness, efficiency and accuracy.

These new design strategies have been used in the design of several new $\mathrm{H}$ plane filters presented in this Thesis, with different topologies from all metallic $\mathrm{H}$ plane filters to evanescent mode $\mathrm{H}$ plane filters. The performance of these filters in terms of frequency response, out of band rejection and power handling without risk of Multipactor has been evaluated through the analysis and, sometimes, measurements of the manufactured filters. 


\section{Índice general}

Agradecimientos $\quad$ V

$\begin{array}{lll}\text { Resumen } & \text { VII }\end{array}$

Resum IX IX I I

$\begin{array}{lll}\text { Abstract } & \text { XI }\end{array}$

1. Introducción 1

1.1. Motivación ........................ 1

1.2. Estado del arte . . . . . . . . . . . . . . . . . . . . 2

1.3. Objetivos de la tesis y plan de trabajo f . . . . . . . . . . 8

1.4. Estructura de la tesis . . . . . . . . . . . . . . . . 12

2. Índice de artículos $\quad 15$

2.1. Filtros propagativos en plano $\mathrm{H} \ldots \ldots \ldots \ldots$

2.1.1. Fast Automated Design of Waveguide Filters Using Aggressive Space Mapping With a New Segmentation Strategy and a Hybrid Optimization Algorithm ................. 16

2.2. Filtros propagativos en plano $\mathrm{H}$ con esquinas redondeadas . . . . . . . 18 
2.2.1. New Multimodel Aggressive Space Mapping Technique for the efficient design of complex microwave circuits . . . . . . . . .

2.2.2. Optimization techniques for the efficient design of low-cost satellite filters considering new light materials . . . . . . . . . . .

2.2.3. Efficient Modal Analysis of Arbitrarily Shaped H-Plane Two-Port Waveguide Devices using the 2D Parallel-Plate Green's Function

2.2.4. Highly Efficient Grouping Strategy for the Analysis of Two-Port Arbitrarily Shaped H-Plane Waveguide Devices . . . . . . . . . .

2.3. Filtros propagativos en plano $\mathrm{H}$ con postes dieléctricos $\ldots \ldots \ldots$

2.3.1. Automated Design of Complex Waveguide Filters for Space Systems: A Case Study . . . . . . . . . . . . . . . . . . . .

2.3.2. New efficient and robust automated design strategy for $\mathrm{H}$ plane direct-coupled-cavities filters with dielectric resonators . . . . . . .

2.3.3. El método SQP de optimización con restricciones aplicado al diseño

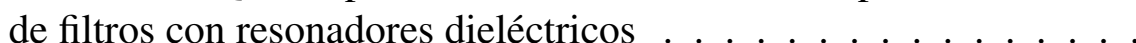

2.3.4. Efficient Technique for the Cascade Connection of Multiple Two Port Scattering Matrices ..........................

2.4. Filtros evanescentes con resonadores dieléctricos . . . . . . . . . . 26

2.4.1. CAD of Evanescent Mode Waveguide Filters with Circular Dielectric Resonators . . . . . . . . . . . . . . . . . . . . . . . .

2.4.2. Optimización multiobjetivo aplicado al diseño de filtros evanescentes con resonadores dieléctricos . . . . . . . . . . . . .

2.4.3. Hybrid mode matching method for the efficient analysis of metal and dielectric rods in $\mathrm{H}$ Plane rectangular waveguide devices . . . . . .

2.5. Capacidad de manejo de potencia . . . . . . . . . . . . .

2.5.1. Hybrid full-wave simulator for the multipaction modelling of lowcost H-plane filters . . . . . . . . . . . . . . . 
2.5.2. Comparative Study of Multipactor Breakdown in Waveguide Hplane Filters Loaded with Dielectric Resonators . . . . . . . . . 30

\section{Artículos}

3.1. Fast Automated Design of Waveguide Filters Using ASM . . . . . . . . . . 31

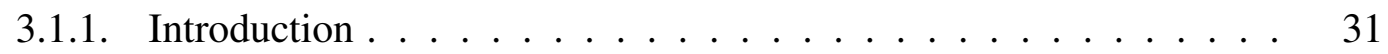

3.1.2. Review of Aggressive Space Mapping . . . . . . . . . . . . . . 33

3.1.3. Segmentation . . . . . . . . . . . . . . . 34

3.1.4. Automated design of waveguide filters . . . . . . . . . . . . . . 34

3.1.5. Results ........................ 42

3.1.6. Conclusions . . . . . . . . . . . . . . . 53

3.2. New Multimodel ASM for the efficient design of complex microwave circuits 54

3.2.1. Introduction . . . . . . . . . . . . . . . . 54

3.2.2. Overview of the original Aggressive Space Mapping Method . . . . 55

3.2.3. Multimodel ASM (MASM) . . . . . . . . . . . . 56

3.2.4. Results . . . . . . . . . . . . . . . 57

3.2.5. Conclusions . . . . . . . . . . . . . . . . 61

3.3. Design of satellite filters considering new light materials . . . . . . . 62

3.3.1. Introduction . . . . . . . . . . . . . . . 62

3.3.2. Design procedure . . . . . . . . . . . . . . 63

3.3.3. Design of $\mathrm{H}$ Plane filters with rounded corners . . . . . . . . . 64

3.3.4. Fabrication and measurement .............. 67

3.3.5. Conclusions . . . . . . . . . . . . . . . . 71 
3.4. Modal Analysis of Arbitrarily Shaped H-Plane Two-Port Waveguide Devices 72

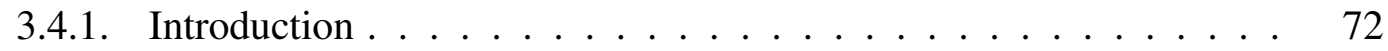

3.4.2. Problem formulation . . . . . . . . . . . 73

3.4.3. MoM discretization . . . . . . . . . . . . . . . 74

3.4.4. Computation of scattering parameters . . . . . . . . 76

3.4.5. Convergence analysis . . . . . . . . . . . . . . 79

3.4.6. Results ..................... 83

3.4.7. Conclusions . . . . . . . . . . . . . . 88

3.5. Analysis of Two-Port Arbitrarily Shaped H-Plane Waveguide Devices . . 90

3.5.1. Introduction . . . . . . . . . . . . 90

3.5.2. Acceleration Procedure . . . . . . . . . . . . . . . . 91

3.5.3. Results .......................... 99

3.5.4. Conclusions . . . . . . . . . . . . . . . . . 103

3.6. Automated Design of Complex Waveguide Filters . . . . . . . . . . . . . 105

3.6.1. Introduction . . . . . . . . . . . . . . . 105

3.6.2. Aggressive Space Mapping Method . . . . . . . . . . . . . 105

3.6.3. Aggressive Space Mapping with Segmentation and Hybridization . 106

3.6.4. Results . . . . . . . . . . . . . . . 107

3.6.5. Conclusions . . . . . . . . . . . . . . . 111

3.7. Automated Design of filters with dielectric resonators . . . . . . . . . . . 112

3.7.1. Introduction . . . . . . . . . . . . . . . 112

3.7.2. New automated design strategy . . . . . . . . . . . . 113 
3.7.3. Results ....................... . . 114

3.7.4. Conclusions . . . . . . . . . . . . . . . . . . 115

3.8. Optimización con restricciones aplicado al diseño de filtros . . . . . . . . 116

3.8.1. Introducción . . . . . . . . . . . . . . . . . 116

3.8.2. El método SQP . . . . . . . . . . . . . . . . . . . . 117

3.8.3. Aplicación al diseño de filtros con resonadores dieléctricos . . . . . 119

3.8.4. Conclusiones . . . . . . . . . . . . . . . . 123

3.9. Cascade Connection of Multiple Two Port Scattering Matrices . . . . . . . 124

3.9.1. Introduction . . . . . . . . . . . . . . . . . . 124

3.9.2. Conversion to ABCD matrices . . . . . . . . . . . . . . . 125

3.9.3. Connection of Scattering Matrices by Pairs . . . . . . . . . . . . . 127

3.9.4. New Method for the Efficient Connection of $N$ Multimodal Scattering Matrices . . . . . . . . . . . . . . . . . . 127

3.9.5. Results . . . . . . . . . . . . . . . . . . 132

3.9.6. Conclusions . . . . . . . . . . . . . . . . . . . 137

3.10. CAD of Evanescent Mode Waveguide Filters . . . . . . . . . . . . . . 139

3.10.1. Introduction . . . . . . . . . . . . . . . . . . 139

3.10.2. Analysis and Design of the Structure . . . . . . . . . . . . 139

3.10.3. Results . . . . . . . . . . . . . . . . . . 140

3.10.4. Conclusions . . . . . . . . . . . . . . . . . . . . 142

3.11. Optimización multiobjetivo aplicado al diseño de filtros evanescentes . . . 143

3.11.1. Introducción . . . . . . . . . . . . . . . . . 143 
3.11.2. El método de consecución de objetivos . . . . . . . . . . . . . . 144

3.11.3. Aplicación al diseño de filtros en modo evanescente con resonadores dieléctricos . . . . . . . . . . . . . . . . . 147

3.11.4. Conclusiones . . . . . . . . . . . . . . . . . 151

3.12. Hybrid MM method for the analysis of metal and dielectric rods $\ldots \ldots$. . 153

3.12.1. Introduction . . . . . . . . . . . . . . . 153

3.12.2. Description of the method . . . . . . . . . . . 155

3.12.3. Centered circular post _. . . . . . . . . . . . . . . 159

3.12.4. Arbitrarily shaped obstacles . . . . . . . . . . . . . . . 166

3.12.5. Results . . . . . . . . . . . . . . . . . 170

3.12.6. Conclusions . . . . . . . . . . . . . . . . . . 174

3.13. Hybrid full-wave simulator for the multipaction modelling . . . . . . . 175

3.13.1. Introduction . . . . . . . . . . . . . . 175

3.13.2. Field-based multipaction modelling procedure . . . . . . . . 176

3.13.3. Hybrid full-wave simulator . . . . . . . . . . . . . . . . 178

3.13.4. Results . . . . . . . . . . . . . . . . 181

3.13.5. Conclusion . . . . . . . . . . . . . . . . 185

3.14. Multipactor Breakdown iw Waveguide Filters . . . . . . . . . . . 186

3.14.1. Introduction . . . . . . . . . . . . . . . . 186

3.14.2. Multipactor breakdown in waveguide filters . . . . . . . . . . 186

3.14.3. Distribution of electromagnetic field inside the filters . . . . . . . 188

3.14.4. Results . . . . . . . . . . . . . . . . . 191 
$\begin{array}{ll}\text { 4. Discusión general de resultados } & 197\end{array}$

4.1. Filtros propagativos en plano H . . . . . . . . . . . . . . . . . . . . 197

4.2. Filtros propagativos en plano $\mathrm{H}$ con esquinas redondeadas . . . . . . . . 210

4.2.1. Implementación original . . . . . . . . . . . . . . 210

4.2.2. Mejora computacional . . . . . . . . . . . . . . . 217

4.2.3. Diseño directo . . . . . . . . . . . . . . . . . 221

4.3. Filtros propagativos en plano $\mathrm{H}$ con postes dieléctricos . . . . . . . . . 224

4.3.1. Implementación original . . . . . . . . . . . . . . . . . 224

4.3.2. Comparación de tecnologías . . . . . . . . . . . . . 225

4.3.3. Matriz de dispersión $(\mathrm{S})$. . . . . . . . . . . . . . . . . 240

4.4. Filtros evanescentes con resonadores dieléctricos . . . . . . . . . . . . . 244

$\begin{array}{ll}\text { 5. Conclusiones y líneas futuras } & 257\end{array}$

$\begin{array}{ll}\text { Lista de Acrónimos } & 261\end{array}$

$\begin{array}{ll}\text { Bibliografía } & 263\end{array}$ 


\section{Capítulo 1}

\section{Introducción}

\subsection{Motivación}

El objetivo general de esta tesis consiste en el desarrollo de nuevas estrategias de diseño de filtros avanzados para comunicaciones espaciales. Se estudia un tipo particular de filtros: aquellos basados en tecnología guiada con o sin resonadores dieléctricos, ya que prestan las mismas prestaciones que los filtros que se utilizan habitualmente en sistemas de comunicaciones espaciales. Sin embargo, su diseño no resulta sencillo.

El origen de esta tesis doctoral está en una evolución de una serie de líneas de investigación ya iniciadas en el Grupo de Aplicaciones de Microondas (GAM) adscrito al Instituto de Telecomunicaciones y Aplicaciones Multimedia (iTEAM) de la Universidad Politécnica de Valencia (UPV). En dicho Grupo, la tesis realizada por el Dr. Santiago Cogollos Borrás [CB02] permite analizar guías de onda de sección transversal arbitraria utilizando matrices de inmitancias (impedancias y admitancias) generalizadas; mientras que la tesis realizada por el Dr. Héctor Esteban González [EG02] caracteriza el caso de guías rectangulares con postes dieléctricos de sección arbitraria mediante el uso de matrices de dispersión generalizadas. A su vez, la tesis realizada por el Dr. Ángel Belenguer Martínez [BM09] proporciona una técnica que permite la solución eficiente de problemas bidimensionales en guía rectangular. Finalmente, la tesis realizada por la Dra. María Carmen Bachiller Martín [BM10] supone una mejora de las técnicas desarrolladas en [CB02] y [EG02], ya que presenta una técnica eficiente que enlaza las dos técnicas anteriores. Esto permite el análisis de dispositivos de microondas compuestos por la combinación de secciones de guías de sección transversal y secciones de guías con obstáculos dieléctricos.

La novedad de esta tesis radica en el hecho de desarrollar una serie de técnicas de diseño e integrarlas junto con las técnicas de análisis anteriores en una herramienta de Diseño Asistido 
por Ordenador (CAD) que nos permita diseñar de forma automatizada y eficiente diferentes topologías de filtros de microondas. Además, las técnicas de diseño que se desarrollarán en la tesis pueden extenderse al diseño de otros dispositivos de microondas más complejos, tales como los multiplexores en tecnología guiada y otras topologías de filtros en modo evanescente que involucren la presencia de postes resonantes dieléctricos.

\subsection{Estado del arte}

Desde finales de los años 60, cuando el primer satélite de la serie Intelsat fue lanzado, el número y las aplicaciones de los sistemas de comunicaciones vía satélite han crecido de forma exponencial. Si bien surgieron para prestar servicios de voz intercontinental, gracias a sus propiedades de cobertura global, en los últimos cuarenta años el uso de los satélites de comunicaciones se ha extendido a otras muchas aplicaciones, como por ejemplo, la difusión de señales de radio y televisión, observación remota de la Tierra, radionavegación y comunicaciones móviles [MB10]. Tal y cómo se indica en [KCT92, $\left.\mathrm{CFG}^{+} 92\right]$ los dispositivos de microondas, y en particular los filtros, son elementos claves presentes en la carga útil de los satélites anteriormente mencionados. Encontrándose en [MJY80] una completa revisión de las diferentes topologías de los filtros así como sus características eléctricas. Sin embargo, tal y cómo se indica en [KCT92], la topología concreta de los filtros empleados dependerá tanto de su aplicación como de las necesidades de filtrado requeridas por la carga útil del satélite.

El rango de frecuencias en los que se utilizan los filtros de microondas es muy amplio (desde unos cientos de megahercios hasta los $40 \mathrm{GHz}$ ), dependiendo del servicio de telecomunicación que presta la carga útil. Por ejemplo, los servicios de navegación y comunicaciones móviles vía satélite habitualmente operan en las bandas L (1-2 GHz) y S (2-4 GHz), mientras que las aplicaciones de observación remota suelen emplear la banda C (4-8 GHz). En el rango de las aplicaciones comerciales, los mayores requerimientos de los sucesivos servicios prestados por los satélites de telecomunicación, básicamente calidad de servicio, ha supuesto a su vez un aumento constante de las frecuencias de operación. Así pues, si los primeros satélites de comunicación fija (Fixed Service Satellite (FSS)) operaban a bajas frecuencias $(6 / 4 \mathrm{GHz}$ y $8 / 7 \mathrm{GHz})$, los más modernos ya se encuentran prestando servicio en la banda $\mathrm{Ku}(12-18 \mathrm{GHz})$, y es de esperar en los próximos años un salto a la banda de frecuencias de $30 / 50 \mathrm{GHz}\left[\mathrm{CFG}^{+}\right.$92].

Además de su uso en los sistemas de comunicaciones vía satélite, los filtros de microondas poseen una gran importancia debido a que también se emplean en diversas aplicaciones de las telecomunicaciones, tales como sistemas de acceso inalámbrico (IEEE 802.11 (Wi-Fi), Worldwide Interoperability for Microwave Access (WiMAX),Wireless Local Loop (WLL), Local Multipoint Distribution System (LMDS), y Multipoint Video Distribution System (MVDS)), y sistemas de comunicaciones móviles (Global System for Mobile Commu- 
nications (GSM), Universal Mobile Telecommunication System (UMTS)) [CMR99].

Si nos centramos en los filtros de microondas para aplicaciones vía satélite, el constante aumento de los servicios que deben prestar los satélites de comunicaciones ha llevado a que el espectro radioeléctrico esté cada vez más congestionado. Lo que ha producido una enorme demanda de filtros de altas prestaciones que satisfagan unas especificaciones muy estrictas. Los filtros deben tener una alta selectividad para evitar interferencias, junto con un retardo de grupo constante y una respuesta en amplitud plana en la banda de paso para minimizar la degradación de la señal. Además, deben poder ser utilizados a altas potencias conservando una buena estabilidad térmica y poseer una baja masa y volumen. Por lo tanto, uno de los principales problemas cuando se diseñan filtros de microondas consiste en encontrar una solución de compromiso entre la respuesta eléctrica del filtro (selectividad, pérdidas de inserción, retardo de grupo), las consideraciones físicas del dispositivo (masa, volumen), tiempo de desarrollo, y coste de fabricación [Sny07]. Sin olvidar los siguientes efectos asociados al manejo de alta potencia: rotura por multipactor, rotura por ionización, productos de intermodulación pasivos (PIM) y estabilidad mecánica debido a las variaciones térmicas [Min07]. Todo ello ha supuesto una creciente complejidad en el diseño y fabricación de dichos componentes. Lo cual supone un mayor esfuerzo tecnológico por parte de las empresas fabricantes de estos dispositivos.

En la figura 1.1 se muestra cuál ha sido la evolución de los requisitos típicos de potencia en función de la banda de frecuencia mientras que en la tabla 1.1 se muestra un resumen genérico de las diferentes consideraciones que se deben tener en cuenta a la hora de diseñar un filtro para aplicaciones vía satélite

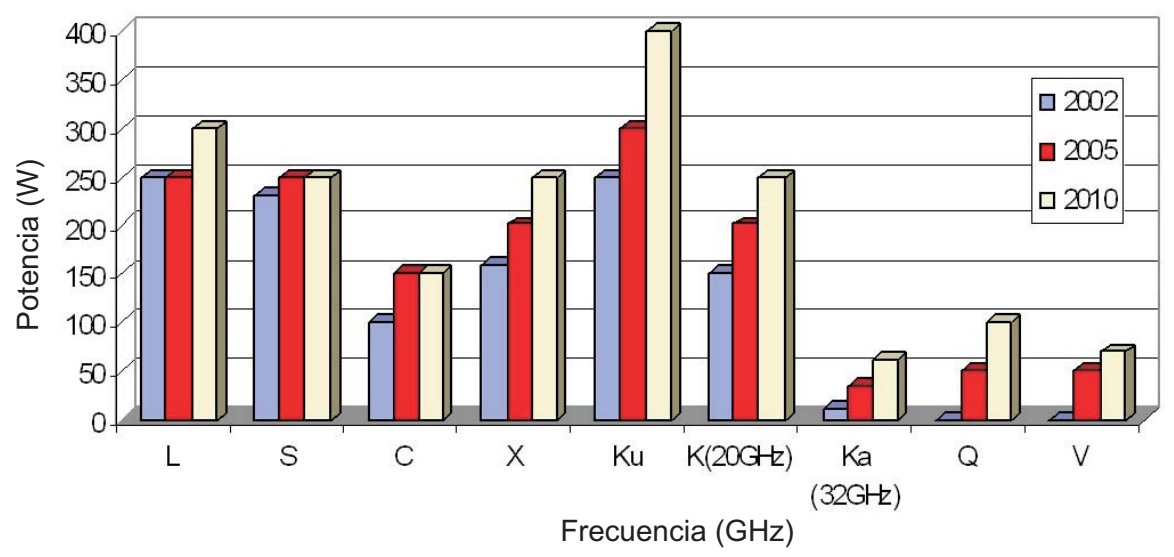

Figura 1.1: Evolución de los requisitos típicos de potencia en diferentes bandas de frecuencia para aplicaciones vía satélite (Fuente European Space Agency (ESA)).

Los filtros de microondas para aplicaciones vía satélite se han implementado de forma histórica en tecnología guiada compuestos únicamente de metal (Figura 1.2(a)), debido prin- 


\begin{tabular}{|l|l|}
\hline Aplicación & Respuesta eléctrica. \\
& Especificaciones mecánicas \\
& Entorno de funcionamiento \\
& Coste \\
\hline Físicas & Topología \\
& Realizabilidad \\
& Layout deseado \\
& Volumen \\
\hline Potencia & Estabilidad térmica \\
& Rotura por multipactor \\
& Rotura por ionización del gas \\
& Interferencias por PIM \\
& Otras \\
\hline Fabricación & Fresado (milling) \\
& Fundido (die-casting) \\
& Grabado (etching) \\
& Metalización \\
& Electroconformado (electroforming) \\
& Electroerosión (spark erosion o Electrical Discharge Machining (EDM)) \\
& Otros \\
\hline Sellado y otras consideraciones & A mano \\
& Robotizado \\
\hline Ajuste & No ajustable \\
& Ajustado a mano \\
\hline
\end{tabular}

Tabla 1.1: Consideraciones genéricas de diseño de filtros de microondas. 
cipalmente a sus bajas pérdidas y a la gran capacidad de manejo de potencia [UB93]. Como consecuencia, el análisis y diseño de este tipo de filtros ha sido objeto de numerosos estudios, lo que ha permitido a la industria del sector su fabricación y comercialización. Sin embargo, debido a la creciente necesidad de reducción de masa y volumen, están surgiendo nuevas topologías de filtros avanzados basadas en la tecnología de filtros con dieléctricos (Figura 1.2(b)). Estas nuevas topologías ofrecen una reducción importante en masa y volumen de alrededor del 50 por ciento comparado con la tecnología sólo metal y una gran estabilidad térmica para aplicaciones de alta potencia [Hun01].

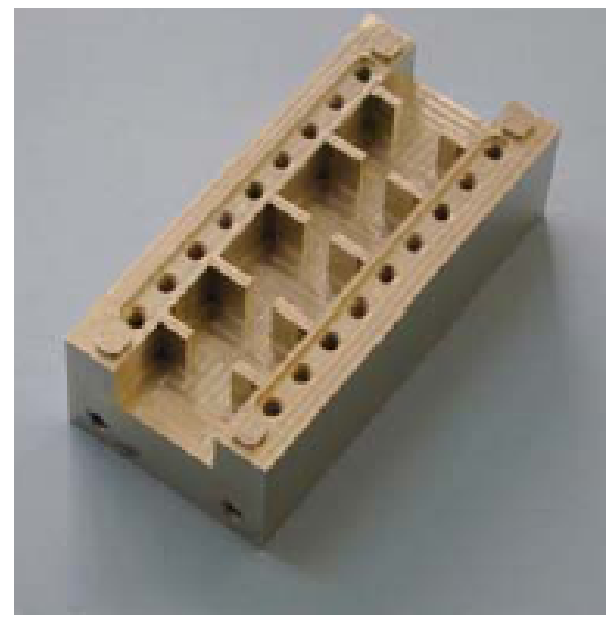

(a)

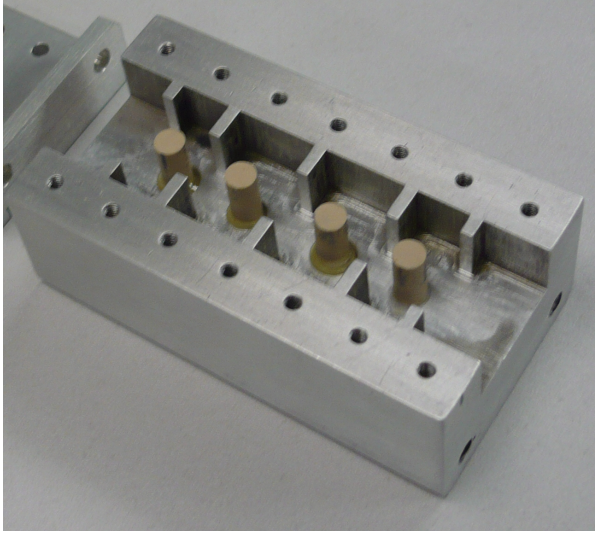

(b)

Figura 1.2: Filtros propagativos de cavidades acopladas en plano H. 1.2(a) Sin postes dieléctricos en las cavidades resonantes. 1.2(b) Con postes dieléctricos en las cavidades resonantes.

Por lo tanto, durante los últimos años se ha producido un rápido desarrollo de herramientas de análisis electromagnético (EM) muy precisas. Este hecho junto con el incremento de las capacidades computacionales de los ordenadores modernos, ha hecho posible la simulación precisa de este tipo de estructuras en un reducido tiempo. Pero a pesar de todos los esfuerzos realizados hasta la fecha en este campo de actividad, en la etapa de diseño de los citados filtros suele requerirse la intervención manual de un usuario experto de los diversos programas que permiten analizar y diseñar estas estructuras. Esta intervención ralentiza el proceso de diseño de los citados filtros, y no garantiza la obtención de la solución óptima. Todo ello ha producido una necesidad de desarrollar herramientas CAD basadas en el uso de simuladores electromagnéticos precisos y eficientes, tal y cómo se indica en [SBS02, BM04].

Hasta el momento varias herramientas comerciales informáticas basadas en métodos numéricos (tales como HFSS, CST Microwave Studio, Fest 3D) permiten llevar a cabo el análisis y diseño de este tipo de estructuras, pero requieren de un tiempo de computación muy elevado durante el proceso de análisis. Esto afecta de manera dramática al diseño automatizado de dichas estructuras, ya que sin una herramienta de análisis eficiente, el diseño 
automatizado resulta excesivamente costoso. Como consecuencia de todo esto, la integración de metodologías de análisis más eficientes, específicamente dedicadas al análisis de este tipo de estructuras, junto con técnicas de diseño en herramientas CAD se considera como una de las más importantes necesidades del sector de las presentes y futuras comunicaciones.

El término CAD si lo interpretamos de una forma estricta significa cualquier proceso de diseño donde se utiliza el ordenador como una herramienta. Sin embargo, habitualmente el término CAD implica que sin utilizar el ordenador, ese proceso de diseño hubiera sido imposible de realizar o hubiera sido más difícil, más caro, y hubiera requerido más tiempo. En la figura 1.3 se muestra un diagrama de flujo típico de un proceso de diseño asistido por ordenador de un dispositivo de microondas. Para implementar un proceso de diseño de un filtro de microondas en el cual se pretenda recuperar unas especificaciones dadas, una aproximación CAD se convierte en un elemento necesario. Cuando se utiliza una aproximación CAD, las modificaciones experimentales del filtro (las cuales son inevitables en cualquier proceso de diseño convencional) se sustituyen por un proceso de optimización realizado por el ordenador a partir de un diseño inicial.

En la actualidad existen diversas técnicas y metodologías para diseñar filtros de microondas dentro de un entorno CAD. De hecho, en la literatura se pueden encontrar diferentes artículos que son una revisión del estado del arte del proceso de diseño de filtros como es el caso de [LSM02] y [LC84], permitiendo a los diseñadores elegir el método que mejor se adecúe a la topología y a las características del filtro. Pero todas ellas seguirán el diagrama de flujo mostrado en la figura 1.3.

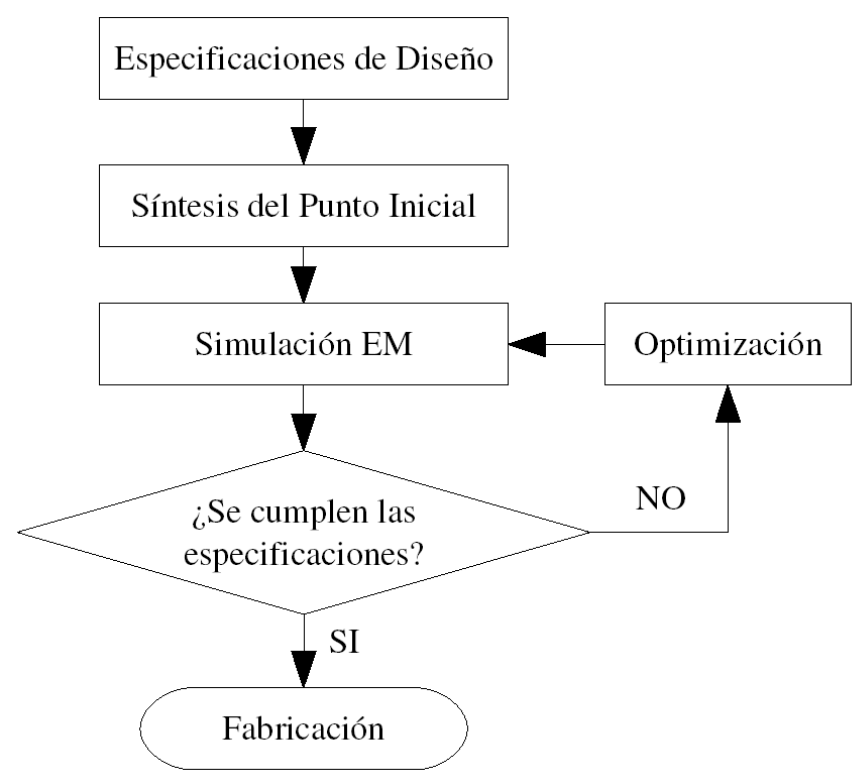

Figura 1.3: Diagrama de flujo de un proceso de diseño asistido por ordenador. 
Un proceso de diseño de filtros de microondas, independientemente de la estructura física que se pretende diseñar, se inicia siempre con un conjunto de especificaciones dadas o un conjunto de objetivos de diseño para el dispositivo. Seguidamente se iniciará la fase de síntesis. Esta fase estará compuesta de dos pasos secuenciales: en primer lugar haciendo uso de las técnicas de síntesis clásicas [Zve05] obtendremos un circuito, basado en elementos concentrados, cuya respuesta es la respuesta eléctrica buscada; y a continuación se buscará una adecuada equivalencia entre los elementos concentrados y los elementos distribuidos de la estructura bajo diseño, obteniendo las dimensiones físicas iniciales de la estructura. Si la estructura es sencilla, el segundo paso se puede realizar haciendo uso de aproximaciones circuitales de la estructura real del filtro [Mar86]. Sin embargo, dada la complejidad de algunas estructuras, esta fase se puede fusionar con la fase de optimización del proceso de diseño asistido por ordenador.

Una vez obtenida la estructura inicial deberemos verificar si cumple con las especificaciones de diseño. Para ello haremos uso de una herramienta de análisis electromagnético. Si los resultados no verifican las especificaciones de diseño deberemos modificar mediante un proceso de optimización la estructura inicial hasta obtener un nuevo punto. A continuación, se obtendrá la respuesta electromagnética de la nueva estructura y se verificará si se cumple con las especificaciones de diseño. Este proceso de análisis, comparación con las especificaciones y modificación de los parámetros de diseño, se repetirá hasta que se cumplan las especificaciones. Sin embargo, utilizar una herramienta de análisis electromagnético de propósito general dentro de la fase de optimización puede llegar a ser un gran problema, ya que aún siendo pequeño el número de variables a optimizar, el tiempo que puede emplear la herramienta para simular la estructura puede llegar a ser prohibitivo.

La optimización es una herramienta muy poderosa, pero debe aplicarse con cuidado. De hecho, sin un buen punto inicial, hasta la más elegante y robusta estrategia de optimización puede no ser capaz de encontrar una solución aceptable.

Cuando el diseño satisfaga las especificaciones, el filtro se puede fabricar y probar. Si los datos medidos cumplen las especificaciones, el proceso de diseño ha finalizado. En cualquier otro caso, el diseño necesita repetirse. Algunas modificaciones pueden necesitarse si el modelado del dispositivo no es suficientemente preciso. Idealmente, las modificaciones deben ser muy pequeñas, siendo el principal objetivo de cualquier método CAD minimizar el número de iteraciones experimentales. De esta forma, una herramienta CAD puede reducir de forma drástica el tiempo y el coste del proceso de diseño mientras que se mejora su calidad.

En esta tesis se pretende implementar un procedimiento de diseño asistido por ordenador que dé solución a los problemas que se plantea en todas las herramientas CAD: necesidad de obtener un buen punto inicial, elevado coste computacional de las herramientas de análisis electromagnético, y robustez de la estrategia de optimización. Para ello debe: 
- Mejorar la robustez del proceso de optimización. Tradicionalmente, en la fase de optimización se modifican todos los parámetros físicos de la estructura bajo diseño a la vez. Este enfoque hace que la búsqueda de la estructura que cumpla las especificaciones se convierta en un problema no escalable y que no garantice la convergencia de la solución. Por ello, en esta tesis se pretende dividir el proceso de diseño en un número simple de pasos [AG97, Gug94] de forma que en cada uno de los pasos sólo se modifique un número pequeño de parámetros físicos de la estructura bajo diseño.

- Mejorar la eficiencia del proceso de optimización. Para ello, en cada uno de los pasos de optimización se utilizará una combinación adecuada de diferentes métodos de optimización.

- Reducir del coste computacional asociado al proceso de optimización. Uno de las principales inconvenientes que tienen los procesos de optimización se debe a que para cada posible solución se debe obtener la respuesta eléctrica de la estructura (con una herramienta de análisis electromagnético) para poderla comparar con las especificaciones de diseño, lo que hace que el coste computacional del proceso se dispare. Por ello, en esta tesis se pretende utilizar la filosofía de diseño del mapeado espacial [BCD $\left.{ }^{+} 04\right]$.

- Sintetizar el punto inicial. Tal y cómo se ha indicado anteriormente, un elemento clave de todo proceso de optimización consiste en la obtención de un buen punto de partida. Por lo tanto, en esta tesis se pretende implementar diferentes técnicas de síntesis que nos garanticen la obtención de un buen punto inicial [MJY80, Coh57, $\left.\mathrm{STB}^{+} 10\right]$.

Este procedimiento de diseño no se ha utilizado todavía por diferentes razones: la falta de disponibilidad de métodos eficientes de análisis de estructuras no canónicas, así como la dificultad de encontrar una estructura de segmentación del proceso de diseño adecuada junto con la dificultad de síntesis de un buen punto inicial.

\subsection{Objetivos de la tesis y plan de trabajo}

El objetivo final de esta tesis consiste en el desarrollo de nuevas estrategias de diseño de filtros avanzados para comunicaciones espaciales. Se eligió este tema de tesis ya que presenta dos aspectos novedosos y que resultan de gran aplicación práctica: las nuevas topologías y técnicas de fabricación de filtros de microondas permiten obtener dispositivos de menor tamaño y peso, pero con las mismas prestaciones que los filtros que se utilizan habitualmente en sistemas de comunicaciones espaciales. Además, la integración de las diferentes estrategias de diseño dentro de una herramienta CAD permitirá reducir de forma drástica los costes de diseño de estos dispositivos, que hasta ahora se hacía de forma manual. 
Para la consecución de este objetivo de carácter global se pretenden alcanzar los siguientes logros parciales:

1. Estudio de los antecedentes y del estado actual del tema. Se está realizando un exhaustivo trabajo de búsqueda bibliográfica con tal de, por una parte, comprobar la necesidad y relevancia del trabajo que se va a realizar, y por otra, averiguar las actuales técnicas de diseño de tales dispositivos.

2. Diseño de filtros de microondas. Para ello se seguirá las técnicas de diseño para filtros descritas de forma minuciosa en diferentes libros y artículos, entre los que se puede citar [JB08, Col00, Bud98, Poz04, CMK07] y que se resume en el diagrama de flujo presentado en la figura 1.3. Lo que nos planteara las siguientes tareas:

a) Síntesis del punto inicial. En esta actividad se deberá obtener un punto de partida para el proceso de optimización. Sin embargo, la aplicación directa de la teoría de síntesis de redes al diseño de filtros de microondas sólo es posible en un número muy reducido de casos debido a las limitaciones impuestas por las estructuras a construir. Por lo tanto, para hacer el proceso de síntesis más viable se utilizarán las técnicas de síntesis propuestas en [MJY80, Coh57, $\mathrm{STB}^{+}$10, JBKB98].

b) Segmentación. Para mejorar la velocidad y la robustez del proceso de optimización se debe descomponer éste en un número simple de etapas tal y cómo se indica en [AG97, Gug94] de forma que en cada una de ellas sólo se modifique un número limitado de parámetros. Por lo tanto, se debe buscar la división de la fase de optimización que mejor se adecúe a la estructura bajo diseño.

c) Hibridación. La eficiencia así como la robustez del proceso de optimización se puede mejorar de forma drástica utilizando una combinación adecuada de algoritmos de optimización en lugar de utilizar un único algoritmo. De forma que al inicio del proceso de optimización se utilicen algoritmos de optimización robustos pero poco eficientes (computación evolutiva [Mic11, Gol89, HH04], simplex [NM65]) y, después de algunas iteraciones, cuando la solución este cerca del mínimo se utilizan métodos de gradiente (Broyden Fletcher Goldfarb Shanno (BFGS) [PTVF07, Fle00]) para refinar la solución. Los métodos de optimización que se proponen, clasificados en función de su tipo, se indican a continuación:

1) Computación evolutiva: algoritmos genéticos y estrategia evolutivas.

2) Métodos de búsqueda directa: simplex y búsqueda directa con rotación de coordenadas [Ban69].

3) Métodos del gradiente: Broyden Fletcher Goldfarb Shanno y mínimos cuadrados.

Se implementarán las tres tipologías de algoritmos citados y se obtendrá cual es la estrategia de hibridación más adecuada para cada tipología de filtro y etapa de 
segmentación. Además, se explorarán otras familias de algoritmos de optimización menos clásicas, cómo es el caso de los algoritmos de optimización con restricciones (Sequential Quadratic Programming (SQP) [Fle00]) y los algoritmos de optimización multiobjetivo (método de consecución de objetivos [GH75]), para explorar diferentes oportunidades que ofrecen las nuevas topologías de filtros a diseñar.

d) Mapeado espacial. Cuando simulamos estructuras electromagnéticas habitualmente tenemos que considerar una solución de compromiso entre la velocidad y la precisión. Con estructuras complejas el coste de simulaciones exactas puede llegar a ser prohibitivo. La filosofía del mapeado espacial se puede utilizar para reducir la carga computacional del proceso de diseño utilizando diferentes herramientas (modelos) de simulación con diferente precisión y eficiencia. En sus interpretaciones clásicas (Space Mapping (SM) y Aggressive Space Mapping (ASM) $\left[\mathrm{BBS}^{+} 94, \mathrm{BBS}^{+}\right.$95]) se utilizan dos herramientas de simulación: una eficiente pero no muy precisa (modelo grueso), y otra muy precisa pero poco eficiente (modelo fino). De forma que se desplaza la carga computacional al modelo grueso, y se reduce de forma global el coste de computación, mientras que la precisión se garantiza utilizando el modelo fino. En la actualidad se están dedicando muchos recursos para mejorar la robustez y el rendimiento de esta filosofía $\left[\mathrm{BCD}^{+}\right.$04]. Algunas de estas iniciativas son el Trust Region Aggressive Space Mapping (TRASM) [BBB $\left.{ }^{+} 98\right]$, el cual integra los conceptos de región de confianza con el ASM, y multiple coarse model SM [KB08], el cual mejora la precisión del modelo grueso básico utilizando un mapeado espacial con un modelo grueso auxiliar. Se propone:

1) Implementar la técnica del ASM.

2) Desarrollar e implementar una variante de la filosofía del mapeado espacial que además de ser robusta tenga en cuenta las nuevas topologías de dispositivos a diseñar.

Se deben aplicar las dos alternativas al diseño de filtros avanzados de microondas, como los que nos ocupan en este trabajo, y comparar su eficiencia.

3. Diseño de filtros avanzados de microondas. Con el objeto de verificar las técnicas de diseño desarrolladas en la tesis se diseñarán las siguientes estructuras, comparando los resultados con la bibliografía y simuladores comerciales:

a) Filtros propagativos de cavidades acopladas en plano $\mathrm{H}$ (Figura 1.4(a)). El primer diseño bajo consideración es una implementación clásica de la tecnología de cavidades acopladas en guía de onda rectangular. En esta tecnología, las cavidades están acopladas mediante iris inductivos. El objetivo de este diseño es obtener la estructura clásica con la que comparar las ventajas de las nuevas topologías.

b) Filtros propagativos de cavidades acopladas en plano $\mathrm{H}$ con esquinas redondeadas (Figura 1.5). Para fabricar los filtros anteriores, existen diferentes técnicas 


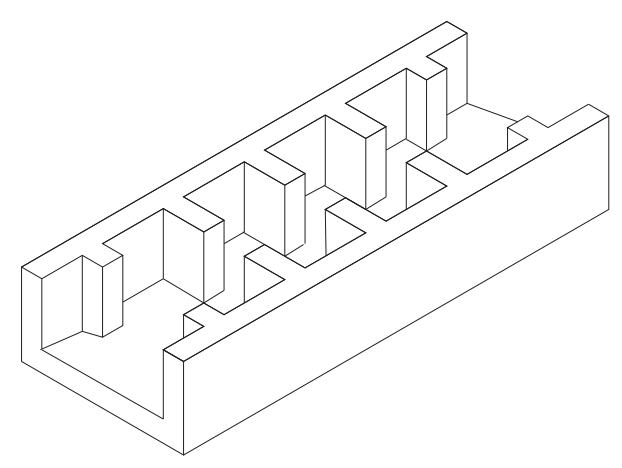

(a)

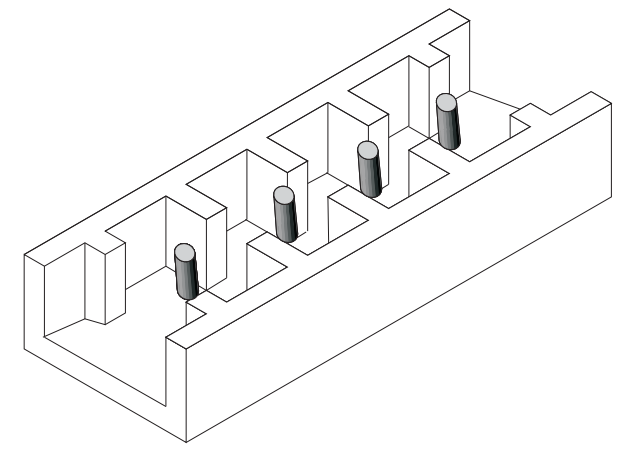

(b)

Figura 1.4: Filtros propagativos de cavidades acopladas en plano H. 1.4(a) Sin postes dieléctricos en las cavidades resonantes. 1.4(b) Con postes dieléctricos en las cavidades resonantes.

que difieren en su precisión y coste. En las aplicaciones vía satélite se necesitan componentes de alta precisión. Por lo tanto, las técnicas de fabricación más adecuadas son electroconformado y electroerosión, pero son muy caras. Por otro lado, las técnicas de fabricación controladas por ordenador: fresado y fundido, son mucho más económicas pero introducen esquinas redondeadas que modifican la respuesta eléctrica. El hecho de tener en consideración la presencia de estas esquinas en el proceso de diseño permite recuperar la respuesta deseada minimizando el coste de fabricación.

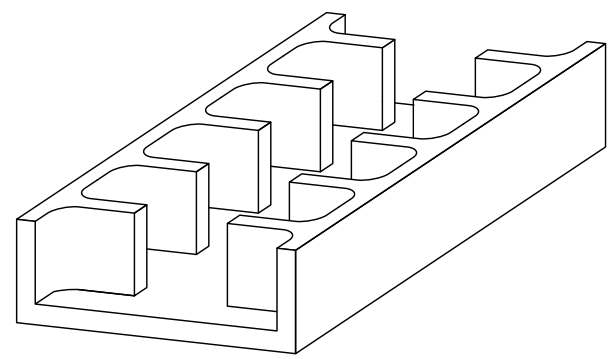

(a)

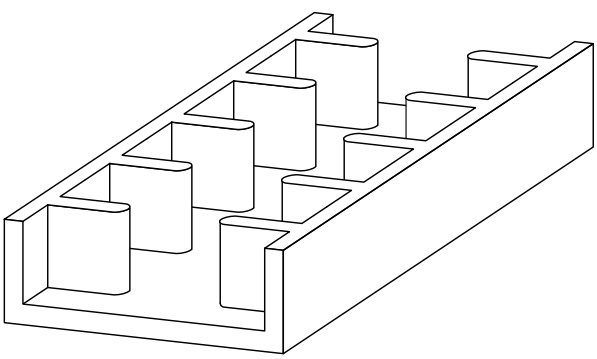

(b)

Figura 1.5: Filtros propagativos de cavidades acopladas en plano H. 1.5(a) Esquinas redondeadas en las cavidades resonantes. 1.5(b) Esquinas redondeadas en las ventanas de acoplo.

c) Filtros propagativos de cavidades acopladas en plano $\mathrm{H}$ con resonadores dieléctricos (Figura 1.4(b)). Estos filtros deberán proporcionar notables reducciones en masa y volumen, conservando su respuesta en frecuencia, si los comparamos con los filtros de cavidades acopladas todo metal. Estas reducciones deberán conservarse con independencia del número de polos del filtro.

d) Filtros evanescentes con resonadores dieléctricos(1.6). En estos filtros se consi- 
gue la resonancia gracias a inserciones de material dieléctrico en la estructura del filtro. El objetivo es comprobar que la misma respuesta se puede conseguir mediante filtros con postes dieléctricos, que deberían ser de menor volumen y masa que los filtros en tecnología todo metal.

e) Fabricación, medida y validación de la herramienta. Se fabricarán y medirán algunos de los prototipos diseñados para comprobar que se cumplen las especificaciones.

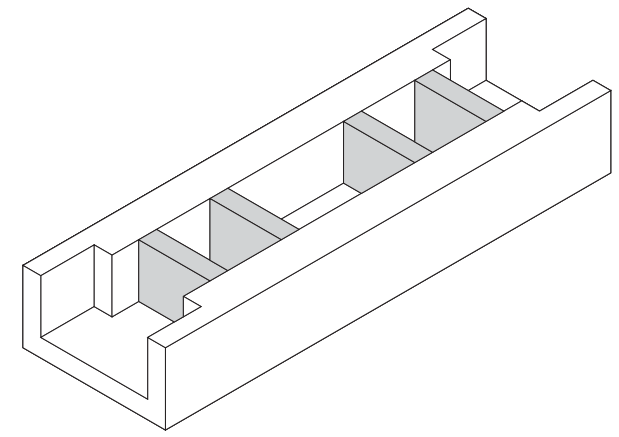

(a)

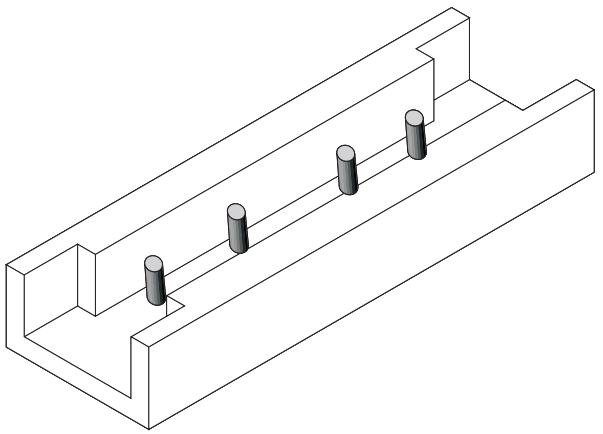

(b)

Figura 1.6: Filtro en modo evanescente con resonadores dieléctricos. 1.6(a) Resonadores dieléctricos de sección rectangular. 1.6(b) Resonadores dieléctricos de sección circular.

\subsection{Estructura de la tesis}

La presente tesis se ha estructurado como una compilación de artículos, por lo que se ha organizado en los siguientes capítulos:

- Capítulo 1. Este capítulo introductorio presenta el problema planteado y su estado del arte, los objetivos detallados que se pretenden alcanzar y el plan de trabajo para conseguirlos.

- Capítulo 2. En este capítulo se presentan los artículos que componen la tesis para ello el capítulo se ha dividido en 5 bloques temáticos. Además, junto a la ficha bibliográfica se presenta un resumen de cada uno de los artículos. En este resumen se pretende mostrar las principales aportaciones del citado artículo al contexto de la tesis, así cómo justificar cada una de las diferentes líneas de investigación que se han seguido durante el desarrollo de la presente tesis.

- Capítulo 3. Este capítulo contiene todos los artículos que componen esta tesis ordenados según el criterio indicado en capítulo 2. 
- Capítulo 4. En este capítulo se analizan los resultados presentados en los artículos que componen la tesis junto con aquellos resultados que todavía no han sido publicados.

- Capítulo 5. La tesis finaliza estableciendo las principales conclusiones que se han extraído del trabajo realizado, así como las posibles líneas de investigación futuras. 


\section{Capítulo 2}

\section{Índice de artículos}

El objetivo de esta tesis consiste en el desarrollo de estrategias de diseño de filtros de microondas con el propósito de integrarlas dentro de una herramienta de diseño asistido por ordenador (CAD). Sin embargo, debido a las diferentes topologías de filtros que se pretenden abordar en esta tesis fue necesario definir una filosofía de diseño denominada FALLAS. Este marco de diseño común obliga a que todas las herramientas de diseño cumplan las siguientes características:

- Modularidad. La integración de nuevos módulos de diseño, análisis y optimización no debe alterar el funcionamiento de los módulos existentes. Lo que obliga a definir una serie de interfaces entre los diferentes módulos que operan entre sí.

- Multilenguaje. La herramienta de diseño debe ser capaz de integrar módulos programados en diferentes lenguajes de programación: $\mathrm{C}, \mathrm{C}++$, Fortran, etc.

- Flexible. La herramienta debe ser capaz de manejar diferentes estrategias de optimización en función del dispositivo bajo diseño. Por lo tanto, el diseñador deberá ser capaz de definir el proceso de optimización que mejor se adecúe a la tipología del filtro bajo diseño. Segmentando el proceso de diseño de la forma que se considere más adecuada y escogiendo los algoritmos de optimización más adecuados a emplear.

- Eficiencia y precisión. Debe garantizar que el tiempo de computación sea el mínimo indispensable garantizando la precisión de la solución obtenida.

- Robustez. El proceso de diseño debe funcionar correctamente independientemente de las especificaciones del dispositivo bajo diseño.

- Automatización. Una vez fijada la estrategia de optimización, para una determinada estructura, la única intervención del usuario final debe ser para introducir las especificaciones de diseño del dispositivo. 
Por lo tanto, en este capítulo se presenta una relación, ordenada según temática, de todos los artículos que describen las diferentes herramientas de diseño asistido por ordenador que componen la presente tesis. Cumpliendo todas ellas la filosofía de diseño anteriormente expuesta.

Para justificar las aportaciones de cada artículo al contexto de la tesis junto con la reseña bibliográfica se ha incluido un breve resumen de cada uno de ellos.

\subsection{Filtros propagativos de cavidades acopladas en plano $\mathbf{H}$}

El primer diseño bajo consideración en la presente tesis es una implementación clásica de la tecnología de cavidades acopladas en guía de onda rectangular, por lo que en este apartado se enumeran todos los artículos relacionados con esta temática.

\subsubsection{Fast Automated Design of Waveguide Filters Using Aggressive Space Mapping With a New Segmentation Strategy and a Hybrid Optimization Algorithm (Ver sección 3.1)}

\section{A. Cita bibliográfica}

- Autores: J. V. Morro, P. Soto, H. Esteban, V. Boria, C. Bachiller, M. Taroncher, S. Cogollos y B. Gimeno.

- Revista: Microwave Theory and Techniques, IEEE Transactions on

- Año: 2005.

- Volumen: 53.

- Número: 4.

- Paginas: 1130-1142.

- Palabras clave: Diseño asistido por ordenador, optimización de circuitos, filtros de microondas de cavidades acopladas, mapeado espacial agresivo (ASM), segmentación, hibridación de algoritmos de optimización, algoritmos de optimización. 


\section{B. Resumen}

En este artículo se presenta la primera herramienta de diseño asistido por ordenador que implementa la filosofía de diseño de FALLAS. Ésta se aplica al diseño de filtros propagativos de cavidades acopladas en plano $\mathrm{H}$ con y sin elementos de ajuste (postes de sintonía).

Uno de los principales inconvenientes que se encuentran todas las herramientas de diseño automatizado consiste en encontrar una solución de compromiso entre la eficiencia del proceso de diseño y la precisión de la solución obtenida, ya que el diseño preciso de estructuras electromagnéticas puede suponer un coste computacional inalcanzable. Para superar esta limitación, y seguir cumpliendo con la filosofía de diseño, la herramienta presentada en el artículo emplea la técnica del mapeado espacial agresivo (ASM) [BBS $\left.{ }^{+} 95\right]$.

La técnica del ASM se utiliza para reducir la carga computacional utilizando dos herramientas de simulación de diferente precisión y eficiencia: el modelo grueso y el modelo fino. Además, define dos espacios de trabajo: el espacio de optimización y el espacio de validación, asociados al modelo grueso y al modelo fino respectivamente. De esta forma, la mayor parte del proceso de diseño se realiza en el espacio de optimización, utilizando el modelo grueso, mientras que la precisión del proceso se garantiza mediante el uso del modelo fino en el espacio de validación. En [BBS $\left.{ }^{+} 95\right]$ se utilizó cómo modelo grueso un modelo circuital y como modelo fino una herramienta de simulación electromagnética. Sin embargo, debido a la complejidad de la estructura bajo diseño, en esta implementación de la técnica ASM se decidió emplear la misma herramienta de análisis modal para implementar los dos modelos. De esta forma, se reduce la diferencia entre los dos espacios, y gracias a la adecuada selección del número de modos de cada modelo se garantiza la eficiencia y la precisión en cada uno de los modelos. A pesar de todo, el ASM no garantiza la robustez de la fase de optimización (ver figura 1.3).

Para garantizar la robustez del proceso de diseño, otra de las características impuestas por FALLAS, la herramienta propuesta divide el proceso de optimización en un número simple de pasos. De forma que en cada paso sólo se modifica un número limitado de parámetros en lugar de modificar todos los parámetros de la estructura a la vez. Además, en lugar de utilizar un único algoritmo de optimización se utiliza la hibridación de diferentes algoritmos de optimización, de forma que en función de lo cerca o lo lejos que nos encontremos de la solución óptima se utilizará un tipo de algoritmo de optimización u otro. Así, se garantiza la robustez y la mejora en la eficiencia del proceso de optimización.

En el artículo se presenta la estrategia de segmentación empleada, que es una mejora de la propuesta en [Gug94, AG97], junto con la hibridación de los siguientes algoritmos de optimización: búsqueda directa, simplex y BFGS, que se empleará en cada paso del proceso de optimización.

Finalmente, en el artículo se demuestran las mejoras aportadas por cada una de las técni- 
cas empleadas y adaptadas a la topología bajo diseño, mediante el diseño y fabricación de diferentes filtros en cavidades acopladas en plano $\mathrm{H}$ con o sin postes de sintonía con diferentes especificaciones eléctricas: número de cavidades, frecuencia central, ancho de banda, pérdidas de inserción, etc.

\subsection{Filtros propagativos de cavidades acopladas en plano $H$ con esquinas redondeadas}

Para fabricar filtros de cavidades acopladas en plano $\mathrm{H}$, existen diferentes técnicas que difieren en precisión y coste. Si nos centramos en las técnicas de fabricación de bajo coste: fresado y fundido, estas técnicas de fabricación introducen esquinas redondeadas que modifican su respuesta. Por lo tanto, en la presente sección se describen los artículos que se centran en el diseño y análisis de filtros de microondas que tengan en cuenta los defectos introducidos por el proceso de manufactura.

\subsubsection{New Multimodel Aggressive Space Mapping Technique for the efficient design of complex microwave circuits. (Ver sección 3.2)}

\section{A. Cita bibliográfica}

- Autores: J. V. Morro, H. Esteban, V. E. Boria, C. Bachiller, y A. Coves.

- Datos publicación: Microwave Symposium Digest, 2005 IEEE MTT-S International.

- Año: 2005.

- Número de páginas: 4

- Palabras clave: Diseño automatizado, métodos de optimización, ASM multimodelo, filtros de cavidades acopladas en plano $\mathrm{H}$, técnicas de fabricación.

\section{B. Resumen}

El principal problema que presentan los prototipos fabricados para validar la herramienta de diseño presentada en el artículo anterior es el desalineamiento en frecuencia entre la respuesta de la estructura diseñada y la respuesta del prototipo fabricado. Observándose que éste se debe fundamentalmente a la gran sensibilidad de la respuesta del filtro a las tolerancias de fabricación. Lo que obliga a colocar tornillos de sintonía en las cavidades y en 
las ventanas de acoplo para compensar dicho efecto. Por lo que en el presente artículo se presenta una herramienta CAD de filtros de cavidades acopladas en plano $\mathrm{H}$ que tenga en cuenta los defectos del proceso de fabricación. Donde los principales defectos del proceso de fabricación son la presencia de esquinas redondeadas en las ventanas de acoplo y en las cavidades resonantes.

Para cumplir con los objetivos de la filosofía de diseño de FALLAS, en el presente artículo se presenta una nueva estrategia de diseño: el Multimodel Aggressive Space Mapping (MASM). En el presente artículo se justifica la necesidad de esta nueva técnica de análisis debido a que el ASM no es capaz de converger a una solución válida cuando los espacios de validación y optimización son muy diferentes.

La técnica presentada, que es una variante del ASM original, utiliza un modelo grueso (que no tiene en cuenta la presencia de los defectos de fabricación) y $N-1$ modelos finos de precisión creciente (que si que tienen en cuenta la presencia de los defectos de fabricación). De esta forma, mediante $N-1$ iteraciones se reduce de forma gradual la diferencia entre el espacio de optimización y los $N-1$ espacios de validación. Lo que garantiza la robustez del proceso de diseño, mientras que la eficiencia del proceso se sigue garantizando gracias al uso de un modelo grueso.

Finalmente, en el artículo se demuestra la eficiencia y la robustez de la nueva técnica desarrollada mediante el diseño de diferentes filtros de microondas teniendo en cuenta la presencia de esquinas redondeadas tanto en las ventanas de acoplo como en las cavidades resonantes.

\subsubsection{Optimization techniques for the efficient design of low-cost sate- llite filters considering new light materials. (Ver sección 3.3)}

\section{A. Cita bibliográfica}

- Autores: J. V. Morro, H. Esteban, V. E. Boria, C. Bachiller y A. Belenguer.

- Revista: International Journal of RF and Microwave Computer-Aided Engineering

- Año: 2008.

- Volumen: 18.

- Número: 2.

- Paginas: 168-175.

- Palabras clave: Diseño asistido por ordenador, métodos de optimización, ASM, MASM, filtros de cavidades acopladas en plano $\mathrm{H}$, técnicas de fabricación. 


\section{B. Resumen}

En el presente artículo se presenta una nueva técnica de fabricación de filtros de microondas de cavidades acopladas en plano $\mathrm{H}$, basada en el uso de magnesio en lugar de aluminio, la cual permite reducciones de la masa del dispositivo de alrededor del $50 \%$. Sin embargo, esta técnica adolece de los mismos defectos que las técnicas de fabricación empleadas en los prototipos presentadas en $\left[\mathrm{MSE}^{+} 05\right]$, la presencia de las esquinas redondeadas:

- En las ventanas de acoplo: Debidas al fresado del molde (die-casting).

- En las cavidades resonantes: Debidas al fresado directo (milling).

Junto con la nueva técnica de fabricación, también se presenta una nueva herramienta CAD para esta tipología de filtros teniendo en cuenta sus defectos de fabricación. Esta nueva herramienta hace uso de la técnica del MASM [ $\left.\mathrm{MEB}^{+} 05\right]$, por lo que presenta el estudio realizado para determinar el número de modelos necesarios por el MASM que garantizan la robustez y la eficiencia del proceso de diseño. Finalmente, el artículo termina con la presentación de las medidas de los prototipos diseñados con la nueva herramienta CAD y fabricados con magnesio.

Como se resalta en el artículo, existe una cierta desviación entre la respuesta obtenida y la deseada. Para determinar la razón de esta desviación en el artículo se comenta el resultado del control dimensional realizado a los prototipos fabricados. Concluyéndose que la nueva técnica de fabricación tiene unas tolerancias en las dimensiones de $\pm 10 \mu m$, la cuál es superior a las tolerancias típicas requeridas para fabricar filtros de microondas para aplicaciones espaciales $( \pm 5 \mu m)$.

\subsubsection{Efficient Modal Analysis of Arbitrarily Shaped H-Plane Two- Port Waveguide Devices using the 2D Parallel-Plate Green's Fun- ction. (Ver sección 3.4)}

\section{A. Cita bibliográfica}

- Autores: A. Belenguer, H. Esteban, V. E. Boria, J. V. Morro, y C. Bachiller.

- Revista: IET Microwaves Antennas and Propagation.

- Año: 2009.

- Volumen: 3. 
- Número: 1.

- Paginas: 62-70.

- Palabras clave: Guía de onda de sección arbitraria, función de Green 2D, Method of Moments (MoM), filtros de guía de onda de cavidades acopladas.

\section{B. Resumen}

En este artículo se presenta una mejora, tanto en eficiencia como en precisión, de la herramienta de simulación $\left[\mathrm{ECB}^{+} 02 \mathrm{~b}\right]$ que se utiliza como modelo fino en la herramienta CAD presentada en $\left[\mathrm{MEB}^{+} 08\right]$.

Aunque no es objeto de la presente tesis el desarrollo y la mejora de los módulos de análisis electromagnético que componen las diferentes herramientas CAD desarrolladas, se colaboró en el desarrollo de la nueva herramienta de simulación con el objetivo de integrarla dentro de la herramienta CAD indicada anteriormente. Mostrándose en los resultados del artículo las respuestas de los filtros diseñados con la versión actualizada de la herramienta CAD.

\subsubsection{Highly Efficient Grouping Strategy for the Analysis of Two-Port Arbitrarily Shaped H-Plane Waveguide Devices. (Ver sección} 3.5)

A. Cita bibliográfica

- Autores: A. Belenguer, H. Esteban, V. E. Boria, C. Bachiller, y J. V. Morro.

- Revista: Microwave Theory and Techniques, IEEE Transactions on

- Año: 2009.

- Volumen: 57.

- Número: 2.

- Paginas: 352-360.

- Palabras clave: Guía de onda de sección arbitraria, función de Green 2D, MoM, filtros de guía de onda de cavidades acopladas. 


\section{B. Resumen}

En este artículo se presenta una mejora en la eficiencia numérica del método de análisis presentado en $\left[\mathrm{BEB}^{+} 09\right]$. Al igual que en el artículo anterior, se colaboró de forma intensa en esta mejora con el objeto de reducir el coste computacional de la herramienta CAD de diseño de filtros de cavidades acopladas teniendo en cuenta la presencia de los defectos de fabricación.

La mejora en la eficiencia de la herramienta de análisis ha permitido reducir de forma sustancial el coste computacional de la herramienta CAD (el tiempo de diseño se ha reducido al orden de varios minutos), tal y cómo se mostrará en el capítulo 4 de la presente tesis.

Finalmente, en el artículo se demuestra la precisión de la nueva versión de la herramienta CAD con el diseño de varios filtros de cavidades acopladas teniendo en cuenta la presencia de las esquinas redondeadas tanto en las ventanas de acoplo como en las cavidades resonantes debido a los defectos de fabricación.

\subsection{Filtros propagativos de cavidades acopladas en plano H con resonadores dieléctricos}

Uno de los elementos críticos en los sistemas de comunicaciones vía satélite es la masa de la carga útil, por lo que el uso de filtros de cavidades acopladas en plano $\mathrm{H}$ con resonadores dieléctricos supone un gran avance, ya que este tipo de filtros presentan una gran reducción de la masa y el volumen del dispositivo si los comparamos con su equivalente sin materiales dieléctricos. Por lo que en la presente sección se enumeran los artículos asociados al análisis y diseño de este tipo de filtros de microondas.

\subsubsection{Automated Design of Complex Waveguide Filters for Space Sys- tems: A Case Study. (Ver sección 3.6)}

\section{A. Cita bibliográfica}

- Autores: J. V. Morro, H. Esteban, C. Bachiller, y V. E. Boria

- Revista: International Journal of RF and Microwave Computer-Aided Engineering

- Año: 2007.

- Volumen: 11. 
- Número: 1.

- Paginas: 128-131.

- Palabras clave: Diseño asistido por ordenador, métodos de optimización, ASM, filtros de cavidades acopladas en plano $\mathrm{H}$ con/sin postes de sintonía, filtros de cavidades acopladas en plano $\mathrm{H}$ con postes dieléctricos.

\section{B. Resumen}

En este artículo se presenta una primera aproximación al diseño de filtros de microondas con postes dieléctricos en las cavidades resonantes, en él se implementa una adaptación de la estrategia de optimización presentada en $\left[\mathrm{MSE}^{+} 05\right]$. Pero en esta implementación se utiliza un algoritmo genético para obtener un punto inicial, y elimina la segmentación de la estructura, debido al elevado acoplamiento entre las cavidades resonantes. Sin embargo, para garantizar la eficiencia y la precisión del proceso de diseño se sigue utilizando el ASM.

Finalmente, el artículo concluye demostrando la reducción de tamaño mediante el diseño de un filtro de cavidades acopladas en plano $\mathrm{H}$ cargado con postes dieléctricos en las cavidades resonantes.

\subsubsection{New efficient and robust automated design strategy for $H$ pla- ne direct-coupled-cavities filters with dielectric resonators. (Ver sección 3.7)}

\section{A. Cita bibliográfica}

- Autores: J. V. Morro, C. Bachiller, H. Esteban, y V. E. Boria.

- Datos publicación: Antennas and Propagation Society International Symposium 2006, IEEE.

- Año: 2006.

- Páginas: 597-600.

- Palabras clave: Diseño automatizado, métodos de optimización, optimización multinivel, filtros de cavidades acopladas en plano $\mathrm{H}$ con postes dieléctricos. 


\section{B. Resumen}

En este artículo se presenta una herramienta CAD para el diseño de filtros de cavidades acopladas con postes dieléctricos en las cavidades resonantes. En él se presenta cómo principales aportaciones: la fase de obtención del punto inicial del proceso de optimización y la estrategia de diseño empleada.

Una de las limitaciones a las que se enfrenta el proceso de diseño de este tipo de dispositivos es la ausencia de un buen punto inicial, por lo que en esta herramienta CAD la fase de síntesis del punto inicial se ha sustituido por un proceso de optimización basado en la hibridación de un algoritmo evolutivo junto con el algoritmo del simplex.

La estrategia de diseño descrita en este artículo se basa en la segmentación de la estructura y la hibridación de diferentes algoritmos de optimización (evolutivos, simplex, BFGS), pero tiene como novedad la realización de una optimización en dos niveles. En el primer nivel la estrategia de optimización utiliza un modelo grueso con una baja precisión pero elevada eficiencia, mientras que en el segundo nivel la estrategia de optimización utiliza otro modelo grueso con una mayor precisión. De esta forma se mejora la convergencia y la eficiencia del proceso de diseño.

Finalmente, en el artículo se demuestran la robustez y la eficiencia de la nueva herramienta $\mathrm{CAD}$, mediante el diseño de diferentes filtros de cavidades acopladas en plano $\mathrm{H}$ con resonadores dieléctricos con diferentes especificaciones: frecuencia central, número de resonadores, permitividades de los postes dieléctricos $\left(\varepsilon_{r}\right)$.

\subsubsection{El método SQP de optimización con restricciones aplicado al di- seño de filtros con resonadores dieléctricos. (Ver sección 3.8)}

\section{A. Cita bibliográfica}

- Autores: P. Gómez, H. Esteban, J. V. Morro, C. Bachiller, y V. E. Boria.

- Datos publicación: CD de actas de la URSI 2006.

- Año: 2006.

- Páginas: 879-883.

- Palabras clave: Diseño automatizado, métodos de optimización, filtros de cavidades acopladas en plano $\mathrm{H}$ con postes dieléctricos. 


\section{B. Resumen}

En la herramienta CAD presentada en [MBEB06] se observó que si se utilizaban algoritmos clásicos que no tuvieran en cuenta restricciones en los parámetros de diseño de la estructura en numerosas ocasiones la solución tendía hacia valores sin sentido físico (p. ej. longitudes negativas). Por lo que la estrategia de optimización empleada utilizaba una estrategia evolutiva que sí que tenía en cuenta las restricciones. Sin embargo, a pesar de ser un algoritmo muy robusto su convergencia es muy lenta.

En este artículo se presenta un mejora de la estrategia de optimización presentada en [MBEB06] basada en una implementación del algoritmo de Programación Cuadrática Secuencial (SQP). Este algoritmo converge de forma más rápida que los algoritmos genéticos o evolutivos, y además permite establecer restricciones, lineales o no, en las que se combinan varios parámetros de diseño.

En este artículo, además de presentar la implementación del SQP utilizada se describe la nueva estrategia de optimización empleada. En ella, el uso de los algoritmos evolutivos se reduce a la obtención del punto inicial.

Para finalizar, en el artículo se demuestra las bondades de la nueva estrategia mediante el diseño de un filtro de cavidades acopladas con una permitividad eléctrica relativa elevada $\left(\varepsilon_{r}=30\right)$.

\subsubsection{Efficient Technique for the Cascade Connection of Multiple Two Port Scattering Matrices. (Ver sección 3.9)}

\section{A. Cita bibliográfica}

- Autores: C. Bachiller, H. Esteban, V. E. Boria, A. Belenguer, y J. V. Morro.

- Revista: Microwave Theory and Techniques, IEEE Transactions on

- Año: 2007.

- Volumen: 55.

- Número: 9.

- Paginas: 1880-1886.

- Palabras clave: Conexión en cascada de circuitos y sistemas, matrices de dispersión, filtros de guía de onda. 


\section{B. Resumen}

En este artículo se presenta una mejora en la eficiencia numérica del método de análisis presentado en $\left[\mathrm{BEB}^{+} 05\right]$. Al igual que en otros artículos anteriores, se colaboró de forma intensa en esta mejora con el objeto de reducir el coste computacional de la herramienta CAD de diseño de filtros de cavidades acopladas cargados con postes dieléctricos presentada en [MBEB06].

La mejora en la eficiencia de la herramienta de análisis ha permitido su incorporación en la herramienta CAD indicada anteriormente. Mostrándose en los resultados del artículo las respuestas de los filtros diseñados con la versión actualizada de la herramienta CAD.

\subsection{Filtros evanescentes con resonadores dieléctricos}

La última tipología de filtros avanzados para comunicaciones vías satélite que se va a estudiar en la presente tesis doctoral son los filtros evanescentes con resonadores dieléctricos, este tipo de filtros presenta cómo principales ventajas: reducción de la masa y volumen, un gran incremento de la banda de rechazo. Todas estas ventajas hacen que su diseño de forma automatizada sea un área en la que se está mostrando un elevado interés. En la presente sección se detallan los artículos que describen el trabajo realizado en el diseño de este tipo de dispositivos.

\subsubsection{CAD of Evanescent Mode Waveguide Filters with Circular Die- lectric Resonators. (Ver sección 3.10)}

\section{A. Cita bibliográfica}

- Autores: C. Bachiller, H. Esteban, V. E. Boria, J. V. Morro, M. Taroncher, y B.Gimeno.

- Datos publicación: Antennas and Propagation Society International Symposium 2006, IEEE.

- Año: 2006.

- Páginas: 1567-1570.

- Palabras clave: Diseño automatizado, métodos de optimización, optimización multinivel, filtros evanescentes cargados con postes dieléctricos. 


\section{B. Resumen}

En el presente artículo se presentan de forma conjunta el módulo de análisis de filtros en modo evanescente y la herramienta CAD en la que está integrado.

Al igual que sucedía con el diseño de filtros de cavidades acopladas en plano $\mathrm{H}$ con postes dieléctricos, al no disponerse de una buena estrategia de síntesis del punto inicial, la herramienta $\mathrm{CAD}$ descrita integra la fase de síntesis con el proceso de optimización mediante la hibridación de un algoritmo evolutivo con el algoritmo del descenso del simplex.

Finalmente, en la sección de resultados se verifica las bondades de esta nueva topología de filtros mediante el diseño de uno, comparándose sus dimensiones y su rechazo fuera de la banda de paso, con filtros de cavidades acopladas en plano $\mathrm{H}$ con o sin postes dieléctricos que cumplen las mismas especificaciones eléctricas: frecuencia central, ancho de banda, pérdidas de retorno.

\subsubsection{Optimización multiobjetivo aplicado al diseño de filtros evanes- centes con resonadores dieléctricos. (Ver sección 3.11)}

A. Cita bibliográfica

- Autores: A. Marco, J. V. Morro, H. Esteban, C. Bachiller, y V. E. Boria.

- Datos publicación: CD de actas de la URSI 2008.

- Año: 2008.

- Páginas: 4.

- Palabras clave: Diseño automatizado, métodos de optimización, filtros evanescentes cargados con postes dieléctricos.

\section{B. Resumen}

El desarrollo de nuevos dispositivos persigue la consecución de varios objetivos a la vez, de hecho a la hora de diseñar filtros en modo evanescente se persigue minimizar el tamaño del dispositivo junto con el incremento del ancho de banda libre de espurios. Estas nuevas especificaciones representan una serie de objetivos adicionales a la hora de diseñar filtros de microondas. Por lo tanto, se necesita aplicar una optimización multiobjetivo.

En el presente artículo se presenta una implementación del algoritmo de optimización multiobjetivo Goal Attainment que reduce el problema a varias optimizaciones con un sólo 
objetivo. Para estas optimizaciones se hace uso de la hibridación de diferentes algoritmos de optimización con el propósito de asegurar la robustez, la eficiencia y el manejo de diferentes tipos de restricciones.

El método de optimización se integrará en la herramienta de diseño CAD presentada en el artículo anterior, con el propósito de manejar dos objetivos: cumplir las especificaciones eléctricas indicadas y maximizar el ancho de banda libre de espurios.

El presente artículo concluye demostrando el correcto funcionamiento del algoritmo implementado mediante el diseño de un filtro de modo evanescente con postes dieléctricos.

\subsubsection{Hybrid mode matching method for the efficient analysis of me- tal and dielectric rods in $\mathrm{H}$ Plane rectangular waveguide devices. (Ver sección 3.12)}

\section{A. Cita bibliográfica}

- Autores: C. Bachiller, H. Esteban, H. Mata, M. A. Valdés, V. E. Boria, y J. V. Morro

- Revista: Microwave Theory and Techniques, IEEE Transactions on

- Año: 2010.

- Volumen: 59.

- Número: 12.

- Paginas: 3634-3644.

- Palabras clave: Filtros de microondas, guías de onda cargadas con dieléctricos, Mode Matching (MM).

\section{B. Resumen}

Una de las características que persigue la estrategia de diseño es la precisión de los resultados, por lo que en el presente artículo se colaboró en la mejora de la precisión del módulo de análisis incluido en la herramienta CAD de filtros en modo evanescente.

Para finalizar, en el artículo se demuestra la mejora en la nueva herramienta de análisis mediante el diseño de varios filtros con resonadores dieléctricos. 


\subsection{Análisis del efecto de rotura por Multipactor en los fil- tros estudiados en la tesis}

El último paso antes de acabar de diseñar un dispositivo de microondas consiste en determinar su capacidad de manejo de potencia, es decir, analizar el efecto multipactor.

El efecto de multipactor consiste en una descarga eléctrica que se produce en dispositivos que se encuentran en el vacío. Esta se debe a una avalancha de electrones en presencia de un campo eléctrico de alta frecuencia llegando a dañar seriamente el dispositivo. Por lo tanto, en los siguientes artículos se describe el análisis del efecto multipactor realizado a los dispositivos avanzados de microondas diseñados en esta tesis.

\subsubsection{Hybrid full-wave simulator for the multipaction modelling of low-cost H-plane filters. (Ver sección 3.13)}

\section{A. Cita bibliográfica}

- Autores: H. Esteban, J. V. Morro, V. E. Boria, C. Bachiller, B. Gimeno, y L. Conde.

- Datos publicación: In Proc. of MULCOPIM 2003, ESTEC (ESA).

- Año: 2003.

- Páginas: 16.

- Palabras clave: Análisis electromagnético, multipactor, filtros de cavidades acopladas en plano $\mathrm{H}$ con esquinas redondeadas.

\section{B. Resumen}

En este artículo se presenta el análisis de la capacidad de manejo de potencia de los filtros con esquinas redondeadas debido a los defectos de fabricación, en él se demuestra que la presencia de las esquinas redondeadas no afectan a su capacidad de manejo de potencia. 


\subsubsection{Comparative Study of Multipactor Breakdown in Waveguide H-plane Filters Loaded with Dielectric Resonators (Ver sección 3.14)}

\section{A. Cita bibliográfica}

- Autores: C. Bachiller, H. Esteban, F. Diaz, V.E. Boria y J.V. Morro.

- Datos publicación: 6th ESTEC International Workshop on Multipactor, Corona and Passive Intermodulation in Space RF Hardware.

- Año: 2008.

- Páginas: 8.

- Palabras clave: Análisis electromagnético, multipactor, filtros de microondas con resonadores dieléctricos.

\section{B. Resumen}

En este último artículo se describe el análisis realizado a los filtros diseñados con postes dieléctricos, demostrando que los filtros que disponen de resonadores dieléctricos son capaces de manejar una mayor potencia sin riesgo a que se produzca el efecto de multipactor. Esto se debe a que el máximo del campo eléctrico siempre se concentra en el centro del poste. Además, se concluye que la estructura con mayor capacidad de manejo de potencia son los filtros evanescentes con postes dieléctricos. 


\section{Capítulo 3}

\section{Artículos}

\subsection{Fast Automated Design of Waveguide Filters Using Aggressive Space Mapping With a New Segmentation Strategy and a Hybrid Optimization Algorithm}

\subsubsection{Introduction}

Passive waveguide filters, such as H-plane filters [Gug94], tunable filters [BGA98], dualmode filters [OSTT95] and dielectric resonator filters $\left[\mathrm{BBC}^{+} 03\right]$, are key devices in the equipment of many microwave and millimeter-wave communication systems, such as communication satellites, mobile communication systems and radio links [KCT92]. The use of waveguide filters in such systems is essentially due to their adequate electrical response versus a very good handling of power effects.

Over the past years, the extremely fast development of precise electromagnetic (EM) analysis tools (finite element (FE) method [KS86b, WP86], finite-difference time-domain (FDTD) method [TH05], hybrid numerical/analytical methods [LLAP83, ECB ${ }^{+}$02a]), as well as the increase in the computation capabilities of modern computers, have made possible the accurate simulation of very complex waveguide structures in reduced computation times. Nevertheless, from a designer point of view, more efforts should be devoted to the integration of such fast and accurate simulation methods into automated CAD tools. This topic is therefore receiving a considerable attention in the recent technical literature [Ban97].

The accurate design of electromagnetic structures requires a trade-off between accuracy and computation time. When designing complex structures, the use of a very accurate simula- 
tion tool can be unaffordable. The well-known Aggressive Space Mapping (ASM) technique $\left[\mathrm{BBS}^{+} 95\right]$ can then be used to reduce the computational burden by using two different simulation tools of different accuracy and efficiency. ASM has already been successfully proved with inter-digital filters [BBCH97] and 3-D structures in rectangular waveguide, e. g. mitered bends and multi-step transformers $\left[\mathrm{BBC}^{+}\right.$97]. A first approach to the design of H-plane filters has also been presented in [BBCO97] and [MES $\left.{ }^{+} 02 \mathrm{~b}\right]$. In [BBCO97] the Finite Element Method is used as the fine model and a Mode-Matching technique is employed for the fast/coarse simulations, whereas in $\left[\mathrm{MES}^{+} 02 \mathrm{~b}\right]$ the same modal analysis tool based on the Generalized Impedance Matrix (GIM) has been used for both spaces.

Although ASM has proved to be very useful for electromagnetic design purposes, there is still much research dedicated to improve the performance of ASM. In [BBGM99], a hybrid ASM algorithm (HASM) is proposed that switches between ASM and direct optimization in order to improve the robustness of the design process. Another possibility is to apply a segmentation strategy. The traditional design optimization procedures operate on all the optimization parameters at the same time [ADS95]. When designing complex structures that involve a large number of design parameters, such as high order direct-coupled waveguide filters, the speed and robustness of the optimization process can be greatly improved by decomposing the structure as recently proposed in [Gug94, AG97]. This new technique takes profit of the particular nature of the structure under design by dividing the design optimization process into a number of simple steps. In each step there is only a small number of design parameters so that the efficiency and robustness of the overall design process is increased. This segmentation scheme, however, fails to properly account for the coupling among all parts of the structure until the last step is reached, where the whole structure is refined in a final optimization. The result is that the last step is time-consuming since this step is started with dimensions of the structure that are still far from the optimum values.

Moreover, as proposed in $\left[\mathrm{MES}^{+} 03\right]$, the design process can still be improved in each step if a suitable combination of several optimization algorithms is used instead of using a single all-purpose technique, such as genetic algorithms [ $\left.\mathrm{LJK}^{+} 00\right]$. However, in [MES $\left.{ }^{+} 03\right]$, the shift from one optimization algorithm to another one is performed when a maximum number of function evaluations is reached, and no information of the convergence progress of each algorithm is exploited.

In this work a completely automated CAD tool which does not require human intervention is proposed for the accurate design of coupled cavity filters. The CAD tool implements the ASM technique, where the same modal analysis technique has been used as fine and coarse model, as proposed in [MES $\left.{ }^{+} 02 \mathrm{~b}\right]$. In each model, the different accuracy and efficiency is achieved by using a different number of modes. In this paper the optimum number of modes for each model has been thoroughly studied for H-plane filters with and without tuning elements. The use of a new segmentation strategy together with hybrid optimization is proposed in order to improve the performance of ASM. These extensions to ASM have been implemented into a novel CAD tool, and its performance has been tested with the design of 
several H-plane filters, for space and radio communication applications. The results show an efficiency improvement due both to the use of the new segmentation strategy and the hybridization scheme based on a specific combination of optimization algorithms. The shift from one algorithm to another is based on convergence indicators, thus improving the efficiency of the hybrid strategy proposed in $\left[\mathrm{MES}^{+} 03\right]$. In addition, the robustness and quality of the final design are also improved and successfully tested for different $\mathrm{H}$-plane filter orders. The completely automated design of two tunable H-plane coupled cavity filters for space applications is successfully solved in this paper. It is the first time, to the authors' knowledge, that the tuning procedure has been performed without human intervention. In order to validate this novel CAD procedure, two prototypes have been designed, manufactured, and measured.

The paper is organized as follows. A review of the ASM and segmentation techniques is presented, respectively, in sections 3.1.2 and 3.1.3. The novel CAD tool is described in section 3.1.4. The results obtained with the CAD tool for several filter examples are discussed in section 3.1.5. Finally, some conclusions are briefly outlined in section 3.1.6.

\subsubsection{Review of Aggressive Space Mapping}

The ASM techniques assumes the existence of two simulation tools of different accuracy and efficiency: the coarse model and the fine model. The coarse model is efficient but not very accurate, and the fine model is accurate but not very efficient. This procedure moves the computational burden to the coarse model, thus reducing the overall computation time, while the accuracy is still guaranteed by the use of the fine model. The vector of parameters in the coarse and fine model are referred to as $\mathbf{x}_{o s}$ and $\mathbf{x}_{e m}$, respectively. The space of $\mathbf{x}_{o s}$ is called optimization space (OS), and the space of $\mathbf{x}_{e m}$ is called validation space (VS). The first step in the ASM technique is to find the optimal vector of parameters $\mathrm{x}_{o s}^{*}$ in the OS. Next a mapping $P$ between the OS and the VS is established [BBS $\left.{ }^{+} 95\right]$

$$
\mathbf{x}_{o s}=\mathbf{P}\left(\mathbf{x}_{e m}\right)
$$

For each point $\mathbf{x}_{e m}$ in VS, the corresponding point $\mathbf{x}_{o s}$ in OS is sought through a parameter extraction procedure $\left[\mathrm{BBS}^{+} 95\right]$, in which the following error is minimized

$$
\underset{\mathbf{x}_{o s}}{\operatorname{minimize}}\left\|\mathbf{R}_{e m}\left(\mathbf{x}_{e m}\right)-\mathbf{R}_{o s}\left(\mathbf{x}_{o s}\right)\right\|
$$

where $\mathbf{R}_{o s}$ and $\mathbf{R}_{e m}$ are the responses in the coarse and fine models, respectively, and $\|\cdot\|$ is a suitable norm.

The objective of ASM is to minimize the function

$$
\mathbf{f}\left(\mathbf{x}_{e m}\right)=\mathbf{P}\left(\mathbf{x}_{e m}\right)-\mathbf{x}_{o s}^{*}
$$

The final design in the VS occurs when the mapping is accomplished and $\mathbf{f}\left(\mathbf{x}_{e m}\right)=0$ $\left(\mathbf{P}\left(\mathbf{x}_{e m}\right)=\mathbf{x}_{o s}^{*}\right)$. 
At each iteration $i$ the $i$-th value in the solution of (3.3) is $\mathbf{x}_{e m}^{(i)}$. The next value is obtained as:

$$
\mathbf{x}_{e m}^{(i+1)}=\mathbf{x}_{e m}^{(i)}+\mathbf{h}^{(i)}
$$

where $\mathbf{h}^{(i)}$ is computed using a quasi-Newton step (linear approximation):

$$
\mathbf{B}^{(i)} \mathbf{h}^{(i)}=-\mathbf{f}\left(\mathbf{x}_{e m}\right)
$$

and $\mathbf{B}^{(i)}$ is an approximation to the Jacobian of the vector $\mathbf{f}$ with respect to $\mathbf{x}_{e m}$ at the $i$-th iteration. The Broyden's update [Bro65] is used to update matrix B at each iteration.

\subsubsection{Segmentation}

In [Gug94, AG97] a novel segmentation strategy was proposed for the design of some filter structures, such as H-plane coupled cavity filters composed of $N$ resonant cavities and $N+1$ coupling windows. Basically, this strategy consists on designing at each step $i$, only the parameters related to the $i$-th cavity (dimensions of that cavity, of the two adjacent coupling windows, and of the previous cavity), and using for the rest of the dimensions of the $i-1$ first cavities the values obtained in the former iterations. At each step $i$ only the response of the first $i$ cavities is simulated and compared with an objective response for that structure. This segmentation technique transforms a slow multidimensional design process into several efficient and robust design steps, where a small number of parameters are designed at the same time. There is the risk, however, that the coupling among all cavities (not just among adjacent cavities) is not properly designed due to this classical segmentation strategy.

\subsubsection{Automated design of waveguide filters}

The fast CAD tool presented in this paper is fully described in this section. The CAD tool implements ASM with a new segmentation strategy and a hybrid optimization algorithm in order to design H-plane coupled cavity filters. The combination of ASM, segmentation and hybridization has always revealed to increase the robustness, accuracy and efficiency of the complex design process of real waveguide filters, where multiple local minima usually appear according to the authors' experience. The design procedure used in this tool can be easily applied to the automated design of other microwave filters, such as evanescent mode, dielectric resonator and dual-mode filters. The CAD tool is fully automated, so that no human intervention is needed in the whole design process, except at the beginning for introducing the specifications of the filter that must be designed. 


\section{A. H-plane coupled cavity filters}

The CAD tool automatically designs H-plane coupled cavity filters in rectangular waveguide with and without tuning elements. The structures of these filters are depicted in figures 3.1 and 3.2. The filter shown in figure 3.2 includes tuning elements both in the coupling windows and the resonant cavities. These tuning elements are necessary for adjusting the response of low-cost manufacturing filters in order to satisfy the specifications after fabrication, or for the mass-production of cheap filters with tunable responses [BGA98].

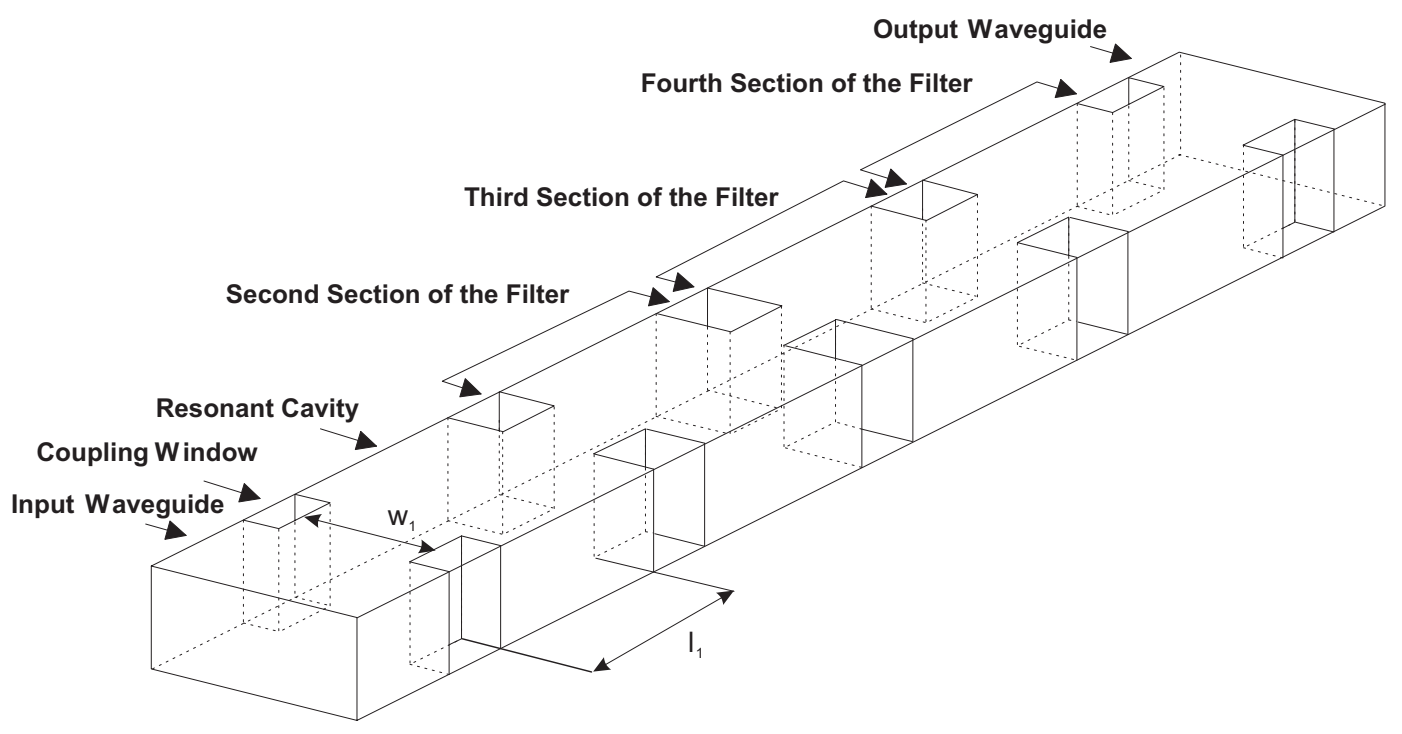

Figura 3.1: A four cavities H-plane rectangular waveguide filter

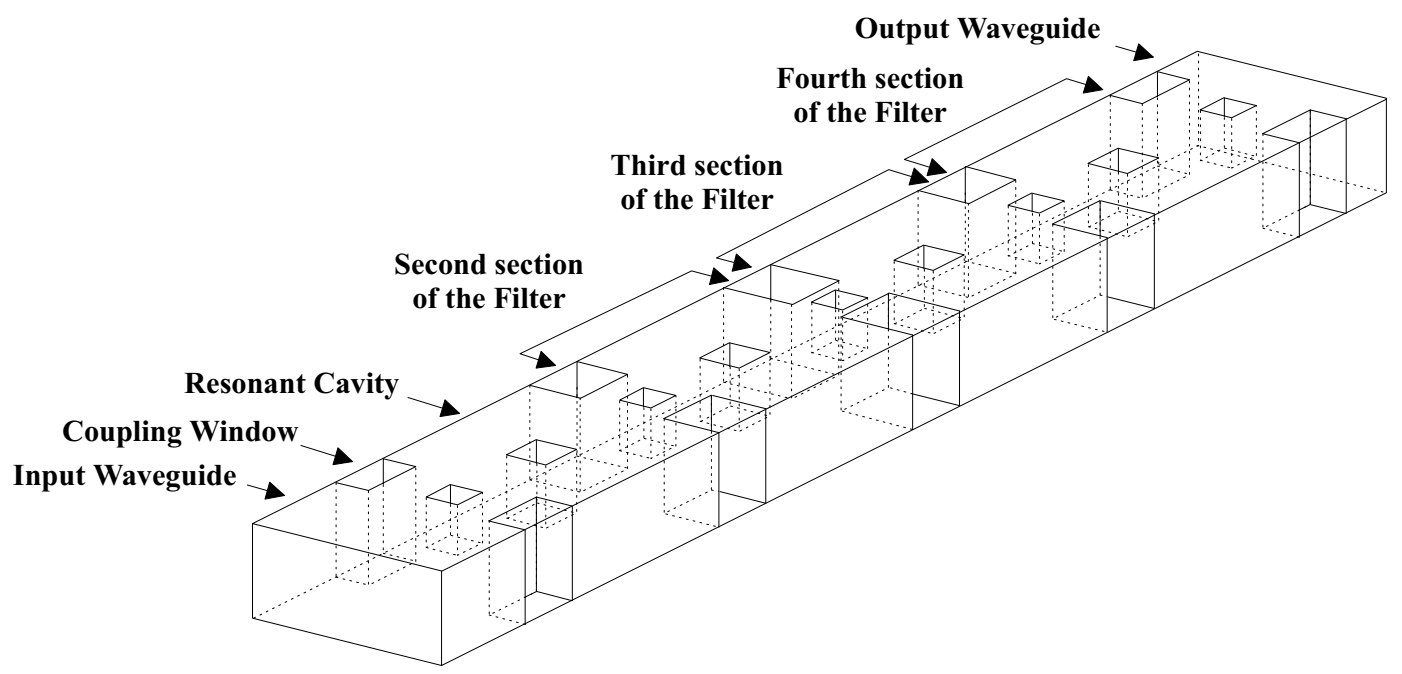

Figura 3.2: A four cavities tunable H-plane rectangular waveguide filter 
In order to use a numerically efficient simulation tool, the tuning elements (usually screws) are modeled as square section posts (see figure 3.2). Therefore, both structures in figure 3.1 and 3.2 can be decomposed as a cascaded connection of uniform waveguide sections, and so modal methods can be used to analyze their electromagnetic behavior [CGS00]. The integral equation formulation reported in [GG98] has been employed for the characterization of the discontinuities between each pair of two adjacent uniform waveguide sections. Such formulation requires the knowledge of the modes that propagate inside each waveguide section. The modes of the non-standard waveguide sections (the ridge waveguides of the filter that model the tuning elements), and the coupling coefficients of such modes with the modes of the standard rectangular waveguide, have been computed using the very accurate and efficient BI-RME method described in [CBZ84, Arc96].

\section{B. ASM implementation}

The ASM requires two different types of design optimizations. In first place, an optimization must be performed in order to obtain $\mathrm{x}_{o s}^{*}$. This optimization minimizes the difference between the OS response $\mathbf{R}_{o s}\left(\mathbf{x}_{o s}^{*}\right)$ and an ideal response which satisfies the specifications of the filter that we are designing. Next, a parameter extraction must be performed in each ASM iteration in order to find the point $\mathbf{x}_{o s}=\mathbf{P}\left(\mathbf{x}_{e m}\right)$ that minimizes (3.2).

The ideal transfer function needed for the minimization that seeks for $\mathrm{x}_{o s}^{*}$ has been obtained by the well-known prototype composed of impedance inverters and half-wavelength transmission lines described in [MJY80]. It is very important to start this optimization from a good initial point in order to accelerate the overall design process and improve its robustness. In order to obtain a good starting point, the design parameter of each coupling window is adjusted to provide the normalized inverter parameter $\bar{K}$ of the ideal network under monomode incidence [BP99]. Next, the synchronously tuned property of this type of filters is exploited to enforce the waveguide cavities loaded with their input and output coupling windows to resonate at the filter center frequency, thus obtaining the initial dimension of the resonant cavity design parameter. This procedure has been fully-automated by using the coarse simulator in combination with Brent's root finding method [PTVF07].

In the optimization that minimizes (3.2), the objective function is computed comparing the reflection or transmission coefficient (in logarithmic scale) of the corresponding segmented structure provided by the fine tool at $x_{\mathrm{em}}^{(i)}$. The use of the logarithmic scale may lead to large error at the frequencies where the reflection or transmission zeroes occur. The Huber function with $k=5$ is used to construct the objective function. The Huber function treats large errors like the $\ell_{1}$ norm, thus increasing the robustness against such errors, but still behaves like the $\ell_{2}$ norm for small errors $\left[\mathrm{BCB}^{+} 93\right]$. In order to increase the robustness against the large errors, upper and lower thresholds are fixed so that the errors that exceed these limits are ignored. 
The same modal simulator has been used both as coarse and fine model in ASM. When used as fine model, the number of accessible modes, the number of basis functions in the Method of Moments (MoM) and the number of kernel terms in the integral equation technique [GG98] are high enough to obtain very accurate results. On the other hand, when used as coarse model, a small number of modes is considered in order to obtain a faster simulator at the expense of a poorer precision.

Table 3.1 compares the modal parameters used for analyzing H-plane and tunable coupled cavity filters with the coarse and fine models. The CPU time required to analyze a four cavity filter (201 frequency points) in a $2 \mathrm{GHz}$ Pentium IV PC platform is also included. It can be observed in the table that for the H-plane filter without tuning elements, the coarse model is only 4.5 times faster than the fine model. This is due to the simplicity of the structure, that makes both the coarse and the fine model very fast. However, for the more complex filter including tuning elements, the coarse model is more than 250 times faster than the fine model. As a consequence, a greater increase of efficiency due to the use of ASM can be expected for these filters with tuning elements.

\begin{tabular}{|c|c|c||c|c|}
\hline \multirow{2}{*}{ Parameter } & \multicolumn{2}{|c||}{ H-plane filter } & \multicolumn{2}{c|}{ Tunable H-plane filter } \\
\cline { 2 - 5 } & fine model & coarse model & fine model & coarse model \\
\hline \hline Accessible modes & 8 & 2 & 30 & 8 \\
\hline Basis functions & 30 & 8 & 350 & 20 \\
\hline Kernel terms & 90 & 30 & 2000 & 115 \\
\hline Time (s) & 0.22 & 0.05 & 382.13 & 1.44 \\
\hline
\end{tabular}

Tabla 3.1: Parameters of the modal simulator when used as fine and coarse model

\section{Segmentation}

The segmentation strategy proposed in [Gug94, AG97] can fail to properly design the coupling among all cavities (not just among adjacent cavities), as already discussed in section 3.1.3. To solve this problem, new steps have been added to the original segmentation strategy in this work. The resulting new segmentation strategy designs the filter through the following types of steps:

\section{C.1. Ordinary step}

The parameters related to cavity $i$ are designed simulating the $i$ first cavities and using for the rest of the parameters of the $i-1$ first cavities the values obtained in former iterations. The error function is computed comparing the response of the $i$ first cavities with the ideal response. The ideal response of the $i$ first cavities is obtained using the first $i$ resonators of the prototype composed of impedance inverters and half-wavelength transmission lines. In 
this step only the transmission coefficient $S_{21}$, whose curve can be easily fitted, is used to build the error function.

\section{C.2. Coupling step}

Each time that three consecutive cavities have been designed, a new design optimization process of the $S_{21}$ parameter adjusts at the same time all the design parameters of the cavities previously designed. This step achieves the required small changes in the values of the parameters due to couplings from near cavities.

\section{C.3. Central cavity step}

For symmetric filters, when the central cavity is reached, and the first half of the filter has been designed step by step, a new optimization is performed considering the whole structure of the filter, but only the dimensions of the central cavity are finely adjusted, thus considering the coupling among all the cavities. The error function is computed comparing again the $S_{21}$ parameter.

\section{C.4. Full structure step}

A final step is made in order to refine the design and take into account all possible interactions among cavities. The whole filter is simulated and all the dimensions are designed at the same time, where the starting point is the result of the previous steps. As we are near the minimum, the reflection coefficient $S_{11}$ is used now to construct the error function.

\begin{tabular}{|c|c|c|c|c|}
\hline Step & Structure simulated & Design parameters & Error function & Performed \\
\hline \hline ordinary & $i$ first cavities & dimensions of cavity $i$ & $S_{21}$ & for each cavity \\
\hline coupling & $i$ first cavities & dimensions of the $i$ first cavities & $S_{21}$ & each three cavities \\
\hline central cavity & whole & dimensions of the central cavity & $S_{21}$ & once \\
\hline full structure & whole & dimensions of all the cavities & $S_{11}$ & once \\
\hline
\end{tabular}

Tabla 3.2: Characteristics of each step of the segmentation strategy

The characteristics of each step of the segmentation strategy are summarized in table 3.2.

The segmentation technique described in [Gug94, AG97] only performs the ordinary and the full structure steps. As a consequence, in the $i$-th ordinary step, the $i$-th cavity is designed considering only the cavities in its left side, whereas the cavities in the right side have not been considered yet. In successive ordinary steps $(i+1, i+2, \ldots)$, the cavities in the right side are designed but the coupling among these cavities and the $i$-th cavity can not be properly 
modeled since the dimensions of the $i$-th cavity are no longer changed until the final step, when the whole structure is simulated and designed.

This problem is minimized with the new segmentation strategy by adding the coupling and central cavity steps. With these steps, the coupling among cavities is modeled in a more progressive way. Therefore, when the final full structure step is reached, the dimensions of the whole filter are closer to the optimum, and the risk to be trapped in a local minimum is lower. Besides, the number of iterations needed to converge will also be lower. This will reduce significantly the overall design time since the iterations in this step are highly time consuming because the whole structure is simulated.

The examples shown in the Results section prove that with the new segmentation strategy the efficiency and robustness of the whole design process has been noticeably increased.

\section{Hybrid optimization}

Both the efficiency and robustness of the optimization process can be drastically improved when a suitable combination of optimization algorithms is followed instead of using a single algorithm.

If only a gradient method is used, it may fail to reach the optimum if the starting point is far from it. On the other hand, the use of a robust method such as the simplex method or a genetic algorithm, largely used in circuit design, ensures convergence but at the cost of a low efficiency.

In the automated design procedure presented in this paper, the design process has been improved in each step of the segmentation strategy using a suitable combination of optimization algorithms. Robust non-gradient methods (Direct search and simplex) are used at the beginning, and, after some iterations, when we are close to the minimum, an efficient gradient algorithm (Broyden Fletcher Goldfarb Shanno) is used to refine the solution.

In [BBGM99], a hybrid ASM algorithm (HASM) is presented. The HASM switches from ASM to direct optimization when ASM does not perform properly, and then switches back to ASM. The hybrid optimization described in this section does not leave ASM at any time. Instead, it uses a suitable combination of optimization algorithms in each parameter extraction of the ASM, and also in the optimization needed to obtain $\mathrm{x}_{o s}^{*}$. This combination of algorithms is expected to perform better than one algorithm alone.

Next the basic features of the three optimization algorithms used in the hybridized optimization process are briefly described, together with some new features implemented in this work in order to improve their performance: 


\section{Direct search with coordinate rotation}

This simple algorithm gives a quick approach to the whereabouts of the minimum, but converges very slowly compared to other methods when we are very close to such minimum. It is used when we do not have a good starting point. A variation of the methods described in [Ban69] and [Ros60] has been implemented. The new features are:

- The step length after each coordinate rotation iteration is set according to the distance advanced in that iteration. If no advance has been made, the step length is increased in order to explore farther regions.

- In the direct search iteration across a line, only steps that reduce the error function are accepted. If a step leads to a worse point, the step length is reduced and a new movement is tried until the step length is below some threshold value.

\section{Downhill simplex method}

This well-known method [NM65] performs better than gradient methods far from the minimum, but worse when we are very near, due to the fact that it does not compute the derivatives of the function. A multidimensional simplex is constructed and iterative reflection and expansion movements lead this simplex to the minimum. Most simplex algorithms form the new vertexes of the initial simplex adding a fix quantity to each coordinate of the starting point [PTVF07]. When the design parameters are not equal range, it is better to form the new vertexes of the initial simplex adding a percent increase on each coordinate of the starting point, as it has been implemented in this novel CAD procedure.

\section{Broyden Fletcher Goldfarb Shanno (BFGS) method}

This is a gradient method, suitable to reach the minimum efficiently once we are close to it. The Broyden-Fletcher-Goldfarb-Shanno method [PTVF07] combines the advantages of the Steepest descent and the Newton-Raphson methods. This method requires the estimation of the inverse of the Hessian matrix $\mathbf{H}^{-1}$ of the error function. The initial guess for this matrix is the identity matrix, and its value is updated in each iteration according to the Broyden iteration. In the automated design procedure a restart has been included each time that $\nabla \mathbf{U}^{j+1}=\nabla \mathbf{U}^{j}$ or $\left(\mathbf{x}^{j+1}-\mathbf{x}^{j}\right)\left(\nabla \mathbf{U}^{j+1}-\nabla \mathbf{U}^{j}\right)$ is below a small threshold, where $\mathbf{x}^{j}$ and $\nabla \mathbf{U}^{j}$ are the position (parameter vector) and the gradient of the error function in the $j$-th iteration, respectively. This restart has been added to the method because there are some practical situations in filter design where the error function is locally a tilted plane, and the advance direction determined by the BFGS algorithm is a constant line across that plane. In that situation, a move forward or backward supposes no change in the error function, and no change (or very small) in its gradient $\left(\nabla U^{j+1}=\nabla U^{j}\right)$, though the minimum has not been reached yet. In that case the standard BFGS stops. In the implementation used in this CAD procedure, the restart enables the advance in the steepest descent direction in the next iteration, going down the tilted plane. 
The most suitable combination of optimization algorithms depends on the confidence that we have on the proximity of the starting point to the minimum. Therefore, a different hybridization strategy has been adopted for each step of the segmentation procedure (see types of segmentation steps in section C):

- Ordinary step In this step the parameters related with the $i$-th cavity are designed. Since this is the first time that these parameters are designed, there is a small probability that the starting point is very close to the minimum. The optimization starts, therefore, with the direct search with coordinate rotation algorithm in order to approach the minimum. The search is then continued with the simplex method. At this point we are close to the minimum, and the BFGS method is used.

- Coupling step Each time that three consecutive cavities are designed, the parameters of the first $i$ cavities are all re-designed at the same time. In this case we should be close to the minimum, so only simplex and BFGS are used.

- Central cavity step When the central cavity is reached, the whole structure is simulated, but only the parameters related to the central cavity are designed. Since it is the first time that we simulate the whole structure, we might be far from the optimum, so three optimization algorithms are used (direct search with coordinate rotation, simplex and BFGS).

- Full structure step In this final step, the whole structure is simulated and the parameters of all the cavities are re-designed together. In this case, only the simplex and BFGS algorithms are used to minimize the error.

The shift from one kind of algorithm to the other one is controlled by the parameter termination tolerance $\mathbf{x}_{\mathrm{tol}}$, the termination tolerance of the error function $\left(f_{\mathrm{tol}}\right)$, and the maximum number of function evaluations $\left(n F_{\max }\right)$ permitted to each method. $f_{\text {tol }}$ is higher for the first algorithm, and its value is decreased in each subsequent algorithm. The shift from one algorithm to another, as well as the rest of the whole design process, is fully automated, so that no human intervention is needed.

The tables 3.3, 3.4 and 3.5 show the specific combination of algorithms and the scheme followed to shift from one to other algorithm for each segmentation strategy step. This scheme has proved to be highly efficient and robust, as shown in the next section.

\begin{tabular}{|c|c|c|c|}
\hline Optimization algorithm & $n F_{\max }$ & $\mathbf{x}_{\text {tol }}$ & $\mathbf{f}_{\text {tol }}$ \\
\hline \hline Direct search & 100 & $\frac{t o l}{40}$ & $10^{-4}$ \\
\hline Simplex & 400 & $\frac{t o l}{40}$ & $10^{-6}$ \\
\hline BFGS & 400 & $\frac{t o l}{40}$ & $10^{-9}$ \\
\hline
\end{tabular}

Tabla 3.3: Termination criteria for the hybridized optimization strategy. Ordinary and central cavity steps 


\begin{tabular}{|c|c|c|c|}
\hline Optimization algorithm & $n F_{\max }$ & $\mathbf{x}_{\text {tol }}$ & $\mathbf{f}_{\text {tol }}$ \\
\hline \hline Simplex & 400 & $\frac{t o l}{100}$ & $10^{-6}$ \\
\hline BFGS & 400 & $\frac{t o l}{100}$ & $10^{-9}$ \\
\hline
\end{tabular}

Tabla 3.4: Termination criteria for the hybridized optimization strategy. Coupling step

\begin{tabular}{|c|c|c|c|}
\hline Optimization algorithm & $n F_{\max }$ & $\mathbf{x}_{\text {tol }}$ & $\mathbf{f}_{\text {tol }}$ \\
\hline \hline Simplex & 400 & $\frac{t o l}{100}$ & $10^{-1}$ \\
\hline BFGS & 400 & $\frac{t o l}{100}$ & $10^{-2}$ \\
\hline
\end{tabular}

Tabla 3.5: Termination criteria for the hybridized optimization strategy. Full structure step

\subsubsection{Results}

The ASM procedure with segmentation and hybrid optimization has been implemented in a fully-automated CAD tool, so no human intervention is needed in the whole design process. This tool has been applied to the fast and automated design of several examples which are fully described next.

\section{A. Automated design of high-order H-plane waveguide filters for space applications at K-Band}

The first example under consideration is a conventional seven-pole H-plane waveguide filter for space applications at the $\mathrm{K}$ band. The ideal transfer function chosen is a standard Chebychev response of $200 \mathrm{MHz}$ bandwidth centered at $17.55 \mathrm{GHz}$ with the following design specifications:

$$
\begin{cases}\left|S_{11}\right| \geq-3 d B, & \text { for } f \leq 17,435 \mathrm{GHz} \text { and } f \geq 17,665 \mathrm{GHz} \\ \left|S_{11}\right| \leq-20 d B, & \text { for } 17,45 \leq f \leq 17,65 \mathrm{GHz}\end{cases}
$$

The cavity lengths and coupling aperture widths of the filter have been chosen as design parameters (see figure 3.1). The input and output waveguides of the filter, as well as the resonant cavities, are standard WR-62 waveguides $(a=15.80 \mathrm{~mm}, b=7.90 \mathrm{~mm})$. The length of all the coupling windows have been chosen to be $3.60 \mathrm{~mm}$. Table 3.6 shows the initial values of the design parameters $\left(\mathbf{x}_{o S}^{(0)_{G}}\right)$. This good $(\mathrm{G})$ starting point has been calculated according to the method described in section B. The optimum point in OS $\left(\mathbf{x}_{o s}^{*}\right)$ and the final solution in VS $\left(\mathbf{x}_{e m}\right)$ after the ASM with segmentation and hybrid optimization are also shown in Table 3.6. 


\begin{tabular}{|c|c|c|c|}
\hline Design Parameters & $\mathbf{x}_{o s}^{(0)_{G}}$ & $\mathbf{x}_{o s}^{*}$ & $\mathbf{x}_{e m}$ \\
\hline$w_{1}=w_{8}(\mathrm{~mm})$ & 6.908 & 6.981 & 6.969 \\
\hline$l_{1}=l_{7}(\mathrm{~mm})$ & 8.244 & 8.192 & 8.187 \\
\hline$w_{2}=w_{7}(\mathrm{~mm})$ & 4.597 & 4.650 & 4.630 \\
\hline$l_{2}=l_{6}(\mathrm{~mm})$ & 9.215 & 9.203 & 9.200 \\
\hline$w_{3}=w_{6}(\mathrm{~mm})$ & 4.291 & 4.324 & 4.302 \\
\hline$l_{3}=l_{5}(\mathrm{~mm})$ & 9.301 & 9.297 & 9.294 \\
\hline$w_{4}=w_{5}(\mathrm{~mm})$ & 4.235 & 4.265 & 4.244 \\
\hline$l_{4}(\mathrm{~mm})$ & 9.314 & 9.310 & 9.307 \\
\hline
\end{tabular}

Tabla 3.6: Design parameters for a symmetric H-plane filter centered at $17.55 \mathrm{GHz}$ using a good starting point

Figure 3.3(a) compares the filter responses of the coarse model at $\mathbf{x}_{o s}^{(0)_{G}}$ and $\mathbf{x}_{o s}^{*}$ with the corresponding ideal response function. Figure 3.3(b) shows the comparison between the response of the fine model at $\mathrm{x}_{e m}$ and the response of the coarse model at $\mathrm{x}_{o s}^{*}$. It can be observed that the desired objective function has been satisfactorily recovered in the VS, after only 2 ASM iterations.

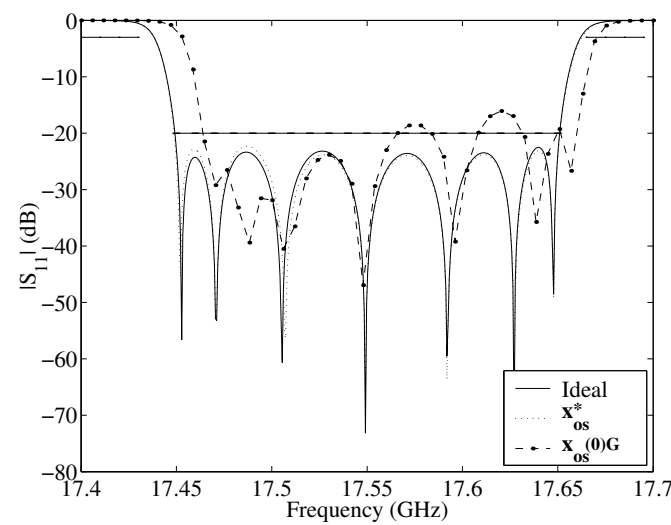

(a)

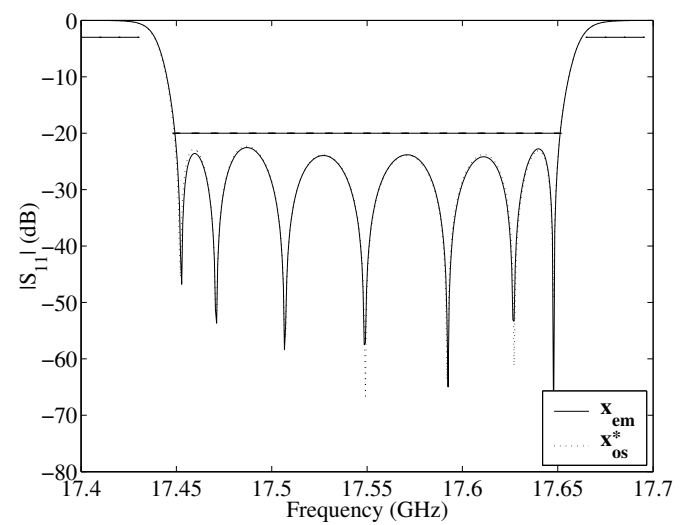

(b)

Figura 3.3: Responses of the waveguide filter with a good starting point. (a) Coarse model responses at $\mathbf{x}_{o s}^{*}$ and $\mathbf{x}_{o s}^{(0)_{G}}$ versus the ideal response. (b) Coarse model response at $\mathbf{x}_{o s}^{*}$ versus the fine model response at $\mathbf{x}_{e m}$

In order to test the robustness of the design procedure proposed, the same H-plane filter was also designed using a bad starting point. Table 3.7 shows the values of the design parameters for the bad starting point $\mathbf{x}_{o s}^{(0)_{B}}$, the optimum point in OS $\left(\mathbf{x}_{o s}^{*}\right)$ and the final solution in VS $\left(\mathbf{x}_{e m}\right)$ after 3 ASM iterations. 


\begin{tabular}{|c|c|c|c|}
\hline Design Parameters & $\mathbf{x}_{o s}^{(0)_{B}}$ & $\mathbf{x}_{o s}^{*}$ & $\mathbf{x}_{e m}$ \\
\hline$w_{1}=w_{8}(\mathrm{~mm})$ & 7.000 & 6.979 & 6.972 \\
\hline$l_{1}=l_{7}(\mathrm{~mm})$ & 8.400 & 8.193 & 8.185 \\
\hline$w_{2}=w_{7}(\mathrm{~mm})$ & 4.700 & 4.650 & 4.631 \\
\hline$l_{2}=l_{6}(\mathrm{~mm})$ & 9.400 & 9.202 & 9.199 \\
\hline$w_{3}=w_{6}(\mathrm{~mm})$ & 4.400 & 4.324 & 4.302 \\
\hline$l_{3}=l_{5}(\mathrm{~mm})$ & 9.100 & 9.297 & 9.294 \\
\hline$w_{4}=w_{5}(\mathrm{~mm})$ & 4.100 & 4.264 & 4.244 \\
\hline$l_{4}(\mathrm{~mm})$ & 9.400 & 9.310 & 9.308 \\
\hline
\end{tabular}

Tabla 3.7: Design parameters for a symmetric H-plane filter centered at $17.55 \mathrm{GHz}$ using a bad starting point

The filter responses obtained with the coarse model at $\mathbf{x}_{o s}^{*}$ and $\mathbf{x}_{o s}^{(0)_{B}}$ are compared with the ideal response in figure 3.4(a). The fine model response at $\mathbf{x}_{e m}$ is compared with the coarse model response at $\mathrm{x}_{o s}^{*}$ in figure 3.4(b). It can be observed that the ideal response has also been satisfactorily recovered in the VS though the initial point was not a good one. A comparison between tables 3.6 and 3.7 reveals that the final design is almost identical in both cases. This proves the robustness of the implemented design strategy.

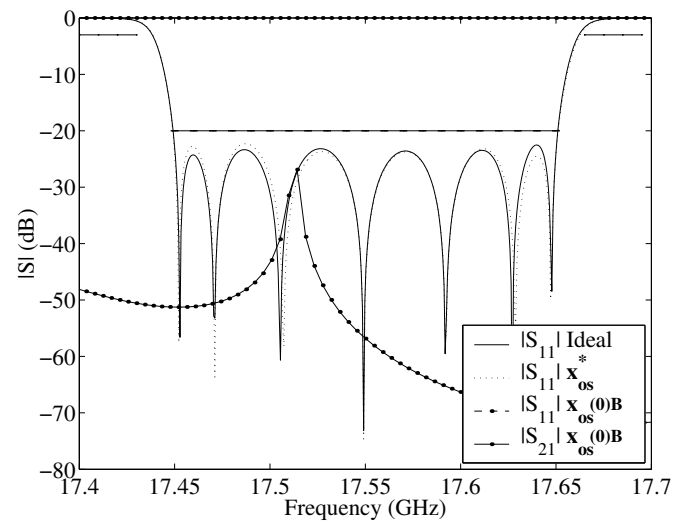

(a)

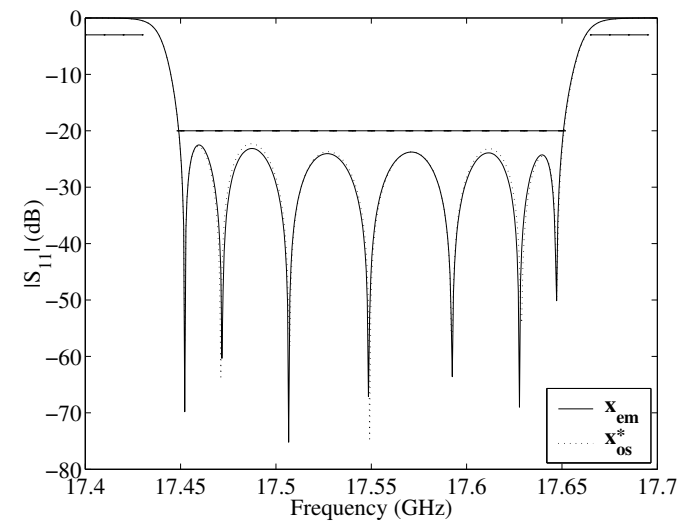

(b)

Figura 3.4: Responses of the waveguide filter with a bad starting point. (a) Coarse model responses at $\mathbf{x}_{o s}^{*}$ and $\mathbf{x}_{o S}^{(0)_{B}}$ versus the ideal response. (b) Coarse model response at $\mathbf{x}_{o S}^{*}$ versus the fine model response at $\mathbf{x}_{e m}$

Although the robustness of the design procedure allows the use of a bad starting point, it must be noted that there is a great reduction in the overall design time if a good starting point is used, as the automated design tool does. Table 3.8 shows the improvement of the whole design process when a good starting point is used. 


\begin{tabular}{|c|c|c|c|c|}
\hline & $U\left(\mathbf{x}_{o s}^{(0)}\right)$ & $U\left(\mathbf{x}_{o s}\right)^{*}$ & $U\left(\mathbf{x}_{e m}\right)$ & time (s) \\
\hline Good Starting Point & 89.5095 & 0.127785 & 0.376295 & 91 \\
\hline Bad Starting Point & 674.81 & 0.490858 & 1.38307 & 134 \\
\hline
\end{tabular}

Tabla 3.8: Performance comparison in the design of an H-plane filter with and without a good starting point

The improvement in the performance of the design process due to the use of ASM and the segmentation strategy is tested in Table 3.9. The table shows in each case the final error in VS, the computation time and whether the design specifications are fulfilled or not. A Pentium IV at $2.4 \mathrm{GHz}$ has been used to obtain the results.

\begin{tabular}{|c|c|c|c|c|}
\hline & $\begin{array}{c}\text { Segmentation } \\
+ \text { Hybrid + ASM }\end{array}$ & $\begin{array}{c}\text { Segmentation } \\
\text { +Hybrid }\end{array}$ & $\begin{array}{c}\text { Hybrid } \\
+ \text { ASM }\end{array}$ & Hybrid \\
\hline $\mathrm{U}\left(\mathrm{x}_{e m}\right)$ & 0.376295 & 0.886946 & 2852.05 & 5.46484 \\
\hline $\mathrm{t}(\mathrm{s})$ & 91 & 139 & 868 & 2683 \\
\hline Fulfill specifications & Yes & Yes & No & No \\
\hline
\end{tabular}

Tabla 3.9: Performance comparison in the design of an H-plane filter with and without segmentation and ASM

The results of table 3.9 prove that the robustness of the design is highly increased with the segmentation strategy. When the segmentation is not used, and although the design starts from a good point near the optimum, the design process fails to reach a point where the specifications are fulfilled. On the other hand, the use of ASM does not greatly improve the design process. This is due to the fact that the fine simulation tool is highly efficient for these H-plane filters. In the case of more complex structures, such as the filters with tuning elements that will be analyzed later, the difference on efficiency between the coarse and fine models will be greater, and therefore the improvement due to ASM will be also highly increased.

The role of the hybrid optimization in the performance of the design process is analyzed in Table 3.10. The H-plane filter has been designed using only one optimization algorithm in each step of the segmentation strategy, and the results are compared with the use of the hybrid optimization. The value of the error function at $\mathbf{x}_{o s}^{*}$ in OS, the error at $\mathbf{x}_{e m}$ in VS, the design time and whether the specifications are fulfilled or not are displayed in the table. The time reduction due to the use of hybrid optimization is in all cases greater than a factor of 2 when compared with only one optimization algorithm. 


\begin{tabular}{|c|c|c|c|c|c|}
\hline & Hybrid & $\begin{array}{c}\text { Coordinate } \\
\text { Rotation }\end{array}$ & Simplex & BFGS & $\begin{array}{c}\text { Simple Genetic } \\
\text { Algorithm }\end{array}$ \\
\hline $\mathrm{U}\left(\mathrm{x}_{o s}^{*}\right)$ & 0.127785 & 21.27 & 0.410488 & 0.265051 & 9.0845 \\
\hline $\mathrm{U}\left(\mathbf{x}_{e m}\right)$ & 0.376295 & 962.74 & 0.350748 & 0.945036 & 14.1816 \\
\hline $\mathrm{t}(\mathrm{s})$ & 91 & 174 & 200 & 203 & 2753 \\
\hline Fulfill specifications & Yes & No & Yes & Yes & No \\
\hline
\end{tabular}

Tabla 3.10: Performance comparison in the design of an H-plane filter with and without hybrid optimization

The performance of the new segmentation strategy proposed in this paper is compared with the performance of the original strategy described in [AG97]. Table 3.11 shows that the new segmentation strategy reduces significantly the design time.

\begin{tabular}{|c|c|c|}
\hline & Original Segmentation Strategy & New Segmentation Strategy \\
\hline$U\left(\mathbf{x}_{o s}^{*}\right)$ & 0.127785 & 0.127785 \\
\hline$U\left(\mathbf{x}_{e m}\right)$ & 0.533504 & 0.376295 \\
\hline $\mathrm{t}(\mathrm{s})$ & 125 & 91 \\
\hline
\end{tabular}

Tabla 3.11: Performance comparison in the design of an H-plane filter using the original and the new segmentation strategy

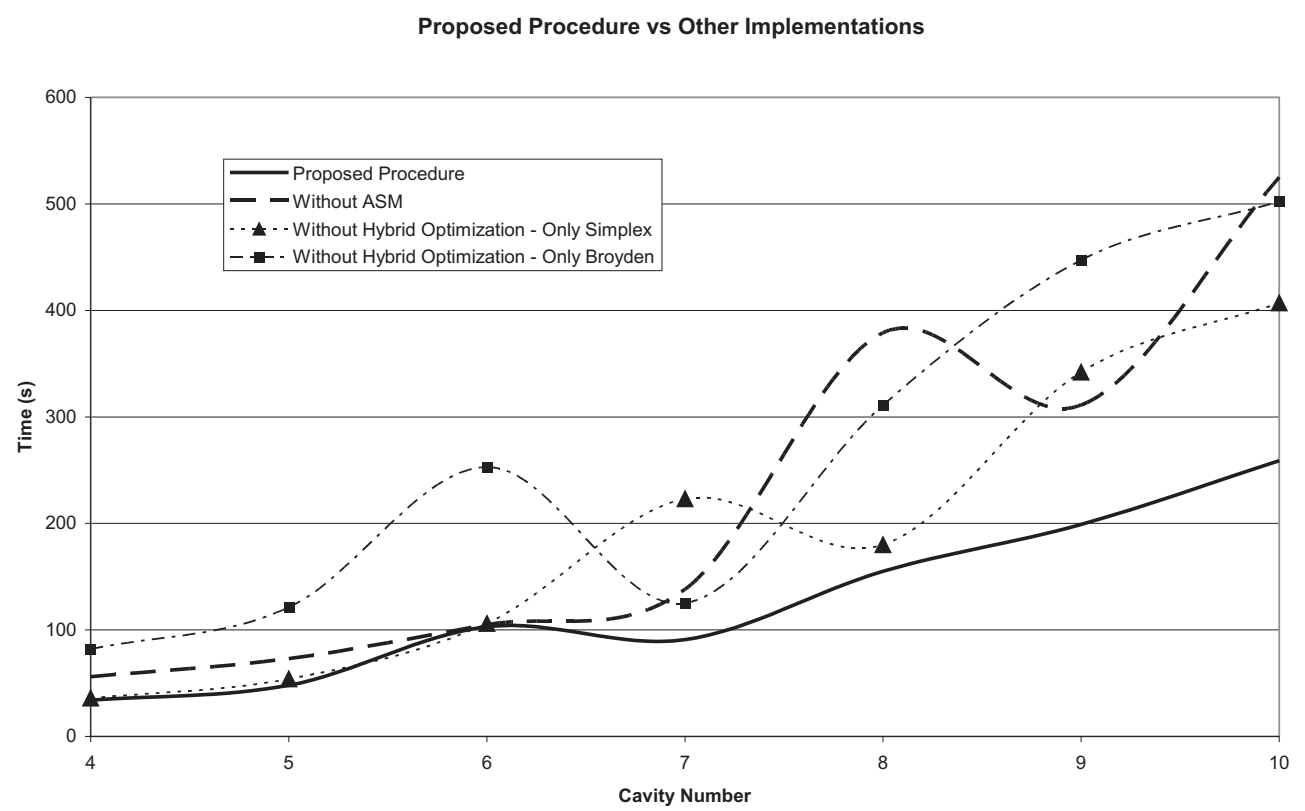

Figura 3.5: Design time vs. number of cavities for the design procedure proposed and other design procedures 
Finally, the variation of the design time versus the number of resonator cavities for an $\mathrm{H}$-plane filter without tuning elements is represented in figure 3.5. It can be observed that there is a significant time reduction when the proposed design procedure is used for all filter orders, thus proving the robustness of the design method. The curve of the time required to design without segmentation is not depicted because in that case the design specifications are not fulfilled after finishing the design procedure.

\section{B. Automated Design of an LMDS prototype at Ka-Band}

The CAD tool has also been used for the practical design of a real 4-pole microwave filter in the Ka-Band used at the input front-end of an LMDS receiver. This filter is centered at $28 \mathrm{GHz}$ with a bandwidth of $800 \mathrm{MHz}$ and the following design specifications:

$$
\begin{cases}\left|S_{11}\right|>-0,044 d B, & \text { for } f \leq 27 \mathrm{GHz} \text { and } f \geq 28 \mathrm{GHz} \\ \left|S_{11}\right| \leq-20 d B, & \text { for } 27,5 \leq f \leq 28,3 \mathrm{GHz}\end{cases}
$$

The input and output waveguides of this filter are standard WR-28 $(a=7.112 \mathrm{~mm}$, $b=3.556 \mathrm{~mm}$ ), whereas the cavity widths are all equal to $8.636 \mathrm{~mm}$ (non-homogeneous structure). The length of all the coupling windows is $2.5 \mathrm{~mm}$. The lengths of the cavities and the widths of the coupling windows have been chosen as the design parameters. The optimum values of the design parameters of the filter provided by the CAD tool are shown in table 3.12. They were obtained after 4 ASM iterations.

\begin{tabular}{|c|c|c|}
\hline Filter dimensions & Nominal & Real \\
\hline$a_{1}=a_{5}(\mathrm{~mm})$ & 4.924 & 4.939 \\
\hline$l_{1}=l_{4}(\mathrm{~mm})$ & 4.681 & 4.696 \\
\hline$a_{2}=a_{4}(\mathrm{~mm})$ & 3.784 & 3.799 \\
\hline$l_{2}=l_{3}(\mathrm{~mm})$ & 5.540 & 5.555 \\
\hline$a_{3}(\mathrm{~mm})$ & 3.563 & 3.578 \\
\hline
\end{tabular}

Tabla 3.12: Dimensions of an LMDS filter at $28 \mathrm{GHz}$ 


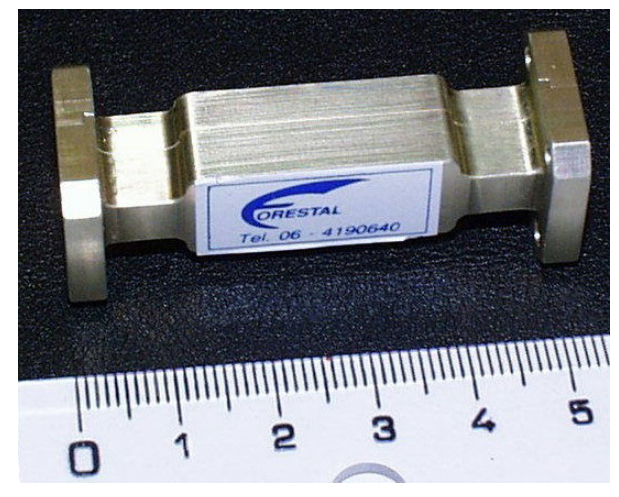

(a)

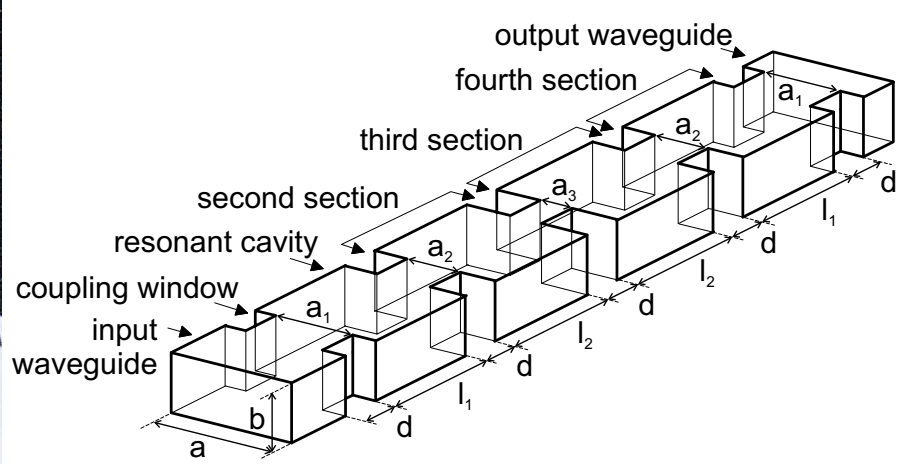

(b)

Figura 3.6: Manufactured prototype of an LMDS filter at $28 \mathrm{GHz}$. (a) External view. (b) Inner structure

In order to validate the design, a prototype of the LMDS filter was manufactured using a low cost spark erosion technique (with mechanical tolerances of \pm 20 microns) without silver plating and alignment pins. The filter is made of two symmetric E-plane halves in order to minimize losses. Figure 3.6 shows an external view and an scheme of the inner structure of the prototype.

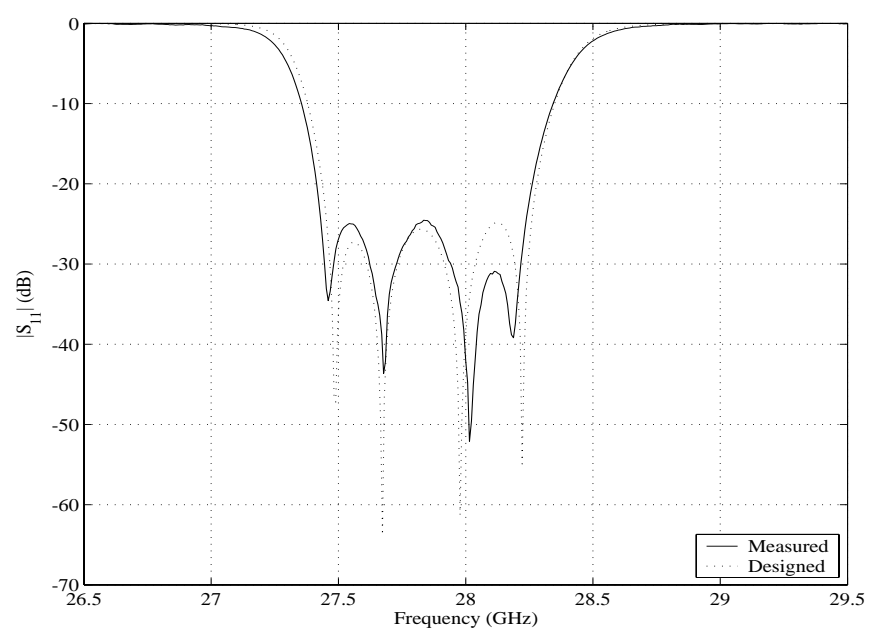

Figura 3.7: Comparison between CAD results and measurements for the LMDS filter

A successful comparison between the simulated response of the filter with the real manufactured dimensions (see table 3.12) and the measurements of the manufactured prototype is shown in figure 3.7, whereas a misalignment between measurements and results for the nominal solution has been observed by the authors. This can be attibuted to the greater sensitivity of the filter response to the manufacturing tolerances at higher frequencies. Therefore, 
if a low cost manufacturing technique, like the one used in this work, is employed, a final mechanical alignment of the filter response will be required. Nevertheless, the nominal design provided by our CAD tool is the best starting point for the mechanical alignment process, thus saving costs. Besides, as it will be demonstrated in the next section, our CAD tool can also be employed to provide a good estimation of the tuning elements dimensions, thus reducing costs also in the alignment process.

\section{Automated design of tunable H-plane filters for space and radio-communication systems}

In order to test the performance of the new design procedure with more complex structures, two tunable H-plane coupled cavity filters have been considered. These filters were originally designed and manufactured in the work presented in [BGA98], where the design was performed manually. These same filters have been re-designed with the novel CAD tool. The tuning elements are penetrating posts of square cross section placed at the center of each cavity and each coupling window (see figure 3.2). As proposed in [BGA98], the use of these tuning posts allows the use of a common base structure for obtaining filters at different frequency bands. The only difference in the filters at each frequency band is the penetration of the tuning posts.

The ideal filter responses have been chosen to be standard four-pole Chebychev curves of $300 \mathrm{MHz}$ bandwidth, $0.02 \mathrm{~dB}$ ripple, and centered at 11 and $13 \mathrm{GHz}$, respectively.

The input and output waveguides, as well as the resonant cavities, are standard WR-75 waveguides ( $a=19.050 \mathrm{~mm}, b=9.525 \mathrm{~mm}$ ). The thickness of all the coupling windows is set to $2 \mathrm{~mm}$. In order to set the cavity lengths and the widths of the coupling windows, a four-pole Chebychev filter without tuning elements centered at $13 \mathrm{GHz}$ with a $300 \mathrm{MHz}$ bandwidth and 0.02 ripple has been designed. Then the cavity lengths and the widths of the windows of the tunable filter are copied from the filter without tuning elements, and the values are slightly reduced, so that the ideal responses at $11 \mathrm{GHz}$ and $13 \mathrm{GHz}$ can be recovered using tuning elements, since the tuning elements can reduce the central frequency of the filter and increase the bandwidth. This means that both filters present the same base structure and they only differ in the penetration of the tuning posts. The final values for the cavity lengths and the widths of the windows are reported in table 3.13. 


\begin{tabular}{|c|c|}
\hline $1^{\text {st }}$ and $5^{\text {th }}$ coupling widths $(\mathrm{mm})$ & 8.700 \\
\hline $1^{\text {st }}$ and $3^{\text {rd }}$ cavity lengths $(\mathrm{mm})$ & 10.500 \\
\hline $2^{\text {nd }}$ and $4^{\text {th }}$ coupling widths $(\mathrm{mm})$ & 5.100 \\
\hline $2^{\text {nd }}$ and $4^{\text {th }}$ cavity lengths $(\mathrm{mm})$ & 13.300 \\
\hline $3^{\text {rd }}$ coupling width $(\mathrm{mm})$ & 5.100 \\
\hline
\end{tabular}

Tabla 3.13: Length of the cavities and width of the coupling windows for the filters with tuning elements

The design parameters for both filters are the penetration depths of the tuning posts. The side of the posts is set to $4 \mathrm{~mm}$ in the cavities, whereas in the coupling window it is set to 2 $\mathrm{mm}$.

The starting point $\mathbf{x}_{o s}^{(0)}$ required by the initial optimization in the OS has been determined following the technique described in section B. Since this technique does not consider highorder mode couplings between adjacent tuning elements for computing the depth of the posts in the coupling windows, the initial guess of $\mathrm{x}_{o s}^{*}$ is worst than the one obtained for the case with no tuning posts. Nevertheless, the resulting starting point is good enough to efficiently converge to the optimum point in the OS using the segmentation and hybrid optimization technique proposed in this paper. The values of the penetration depths corresponding to $\mathbf{x}_{o s}^{(0)}$ and $\mathrm{x}_{o s}^{*}$ for both filters are reported in table 3.14.

\begin{tabular}{|c|c|c|c|c|c|c|c|c|}
\hline \multirow{2}{*}{$\begin{array}{c}\text { Design } \\
\text { parameters }\end{array}$} & \multicolumn{4}{|c|}{ Filter at $11 \mathrm{GHz}$} & \multicolumn{4}{|c|}{ Filter at $13 \mathrm{GHz}$} \\
\hline & $\mathbf{x}_{o s}^{(0)}$ & $\mathbf{x}_{o s}^{*}$ & $\mathbf{x}_{e m}$ & $\mathrm{x}^{[\mathrm{B}}$ & $98 \mathbf{X}_{o s}(0)$ & $\mathbf{X}_{o s}^{*}$ & $\mathbf{x}_{e m}$ & $\mathrm{x}^{[\mathrm{B}}$ \\
\hline$h_{w i n 1}(\mathrm{~mm})=h_{w i n 5}(\mathrm{~mm})$ & 3.300 & 3.358 & 3.339 & 3.366 & 0.713 & 0.501 & 0.196 & 0.792 \\
\hline$h_{c a v 1}(\mathrm{~mm})=h_{\text {cav } 3}(\mathrm{~mm})$ & 3.289 & 3.306 & 3.309 & 3.298 & 1.825 & 1.836 & 1.825 & 1.816 \\
\hline$h_{\operatorname{win} 2}(\mathrm{~mm})=h_{\operatorname{win} 4}(\mathrm{~mm})$ & 4.389 & 4.038 & 4.006 & 4.078 & 2.335 & 1.963 & 1.913 & 2.141 \\
\hline$h_{\text {cav } 2}(\mathrm{~mm})=h_{\text {cav } 4}(\mathrm{~mm})$ & 2.914 & 2.972 & 2.980 & 2.972 & 0.447 & 0.487 & 0.455 & 0.456 \\
\hline$h_{\text {win } 3}(\mathrm{~mm})$ & 3.991 & 3.512 & 3.467 & 3.570 & 0.804 & 0.757 & 0.655 & 0.986 \\
\hline
\end{tabular}

Tabla 3.14: Design parameters for the two inductive filters with tuning elements

Figure 3.8 compares the ideal response of the filters at 11 and $13 \mathrm{GHz}$ with the response of the coarse model at $\mathbf{x}_{o s}^{*}$. As expected, a very good agreement can be observed between the ideal response and the optimum response in the OS. 


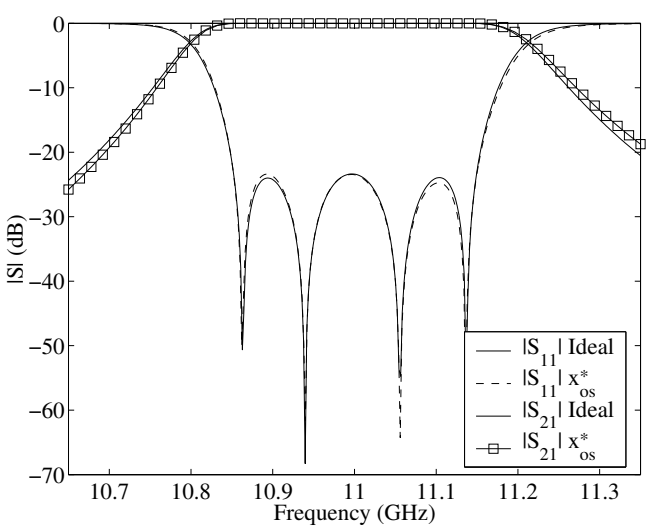

(a)

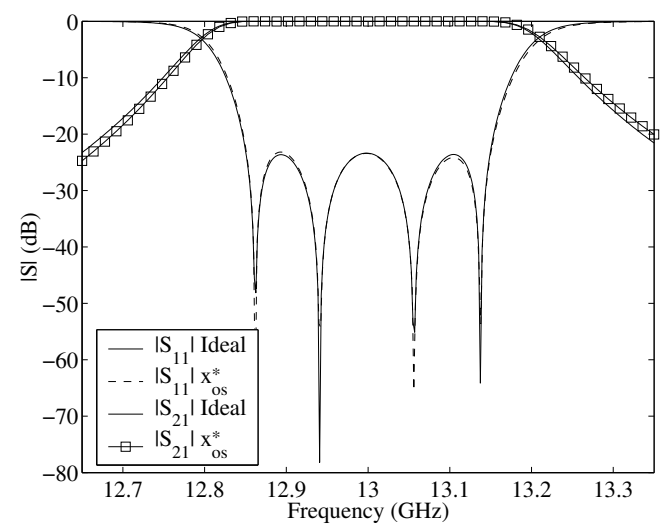

(b)

Figura 3.8: $\mathrm{H}$-plane filters with tuning elements. Response of the coarse model at $\mathrm{x}_{o s}^{*}$ versus the ideal response. (a) $11 \mathrm{GHz}$. (b) $13 \mathrm{GHz}$

The design with ASM using segmentation and hybrid optimization required 3 ASM iterations for both filters under severe convergence criterion. The final dimensions are also shown in table 3.14. An excellent agreement between the optimum response in the OS and the response of the fine model at $\mathbf{x}_{e m}$ can be observed in figure 3.9. The small distance between $R_{o s}\left(\mathrm{x}_{o s}^{*}\right)$ and $R_{e m}\left(\mathbf{x}_{e m}\right)$ proves that in spite of the huge reduction in CPU time between the fine and coarse models, the simulation and optimization spaces are still quite similar, and a reduced number of ASM iterations (i.e. fine simulations) is required to complete the design procedure.

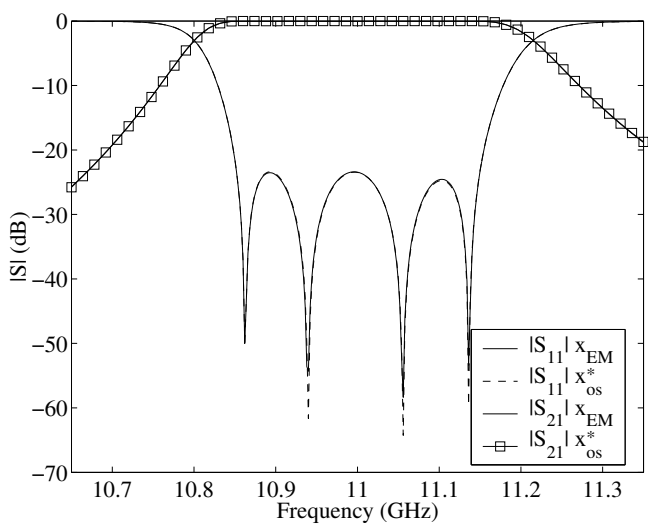

(a)

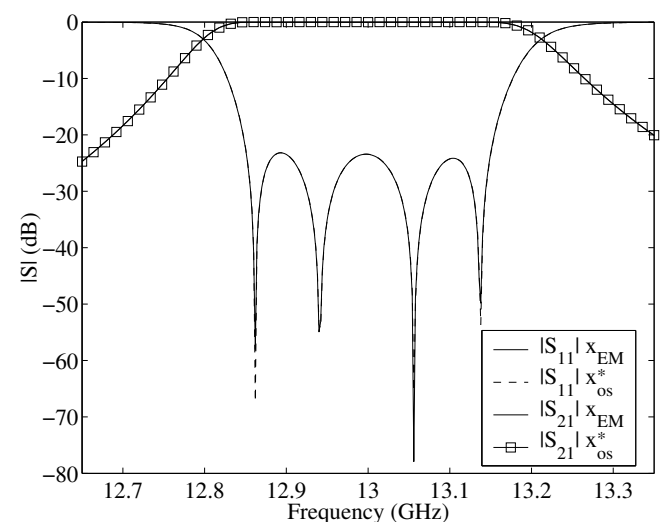

(b)

Figura 3.9: H-plane filters with tuning elements. Response of the coarse model at $\mathrm{x}_{o s}^{*}$ versus the response of the fine model at $\mathbf{x}_{e m}$. (a) $11 \mathrm{GHz}$. (b) $13 \mathrm{GHz}$ 
The dimensions of the filters obtained by the original manual design are also included in table 3.14 for comparative purposes. The similarity between such dimensions and those obtained with the new CAD tool proves that both procedures lead to very close optimal solutions, thus confirming the accuracy of the new automated approach. However, the manual procedure following [BGA98] took several full-time working days of an experienced filter designer.

The design of the filters with the novel CAD procedure required a total CPU time of 49'50" (11 GHz) and 33'42" (13 GHz) in a PC with Pentium IV processor at $1.7 \mathrm{GHz}$. Since the fine model is about 250 times slower than the coarse model, the total CPU time required for the direct design of such filters without ASM would be of about 25 hours for each case. This represents an improvement by a factor of 30, and clearly proves the advantages of using ASM for the design of complex waveguide devices. The authors have tried to increase the efficiency of the coarse model by reducing the number of modes considered, but in all the cases an increase in the global CPU time of the design procedure has been observed due to the higher differences between the optimization and validation spaces.

For economical reasons, the filters were manufactured in [BGA98] using a low cost spark erosion technique (with mechanical tolerances of \pm 20 microns). The filters are composed of two different pieces, an H-plane base structure common to both filters, and a separated top including all the tuning elements for each filter (see figure 3.10). The measured results in [BGA98] are compared with our nominal design results in figure 3.11. As we can observe in this figure, the two filter responses have been esentially recovered, thus validating the design procedure, even though there are some miasalignments that can be attibuted to the low cost fabrication technique employed.

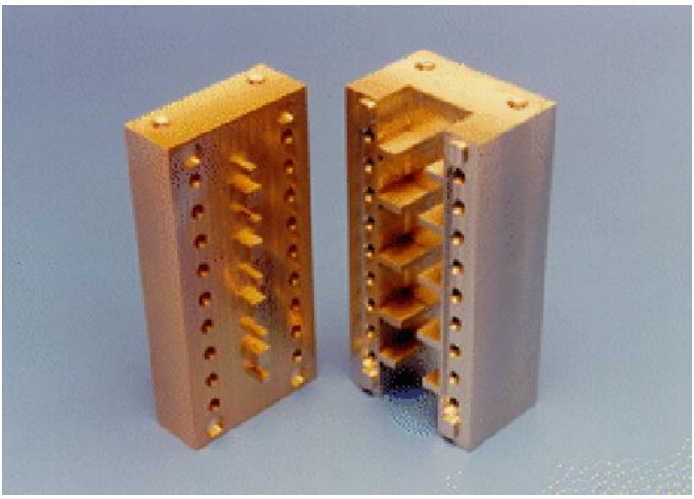

(a)

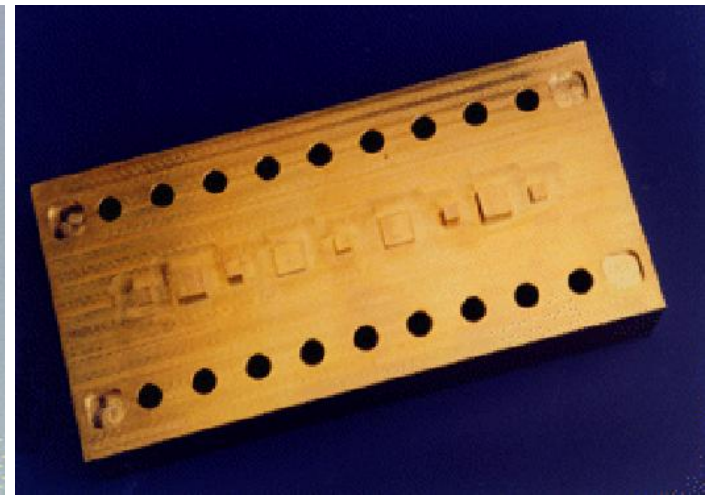

(b)

Figura 3.10: Manufactured filters with tuning elements at 11 and $13 \mathrm{GHz}$ originally presented in [BGA98]. (a) Common base and $11 \mathrm{GHz}$ top. (b) $13 \mathrm{GHz}$ top 


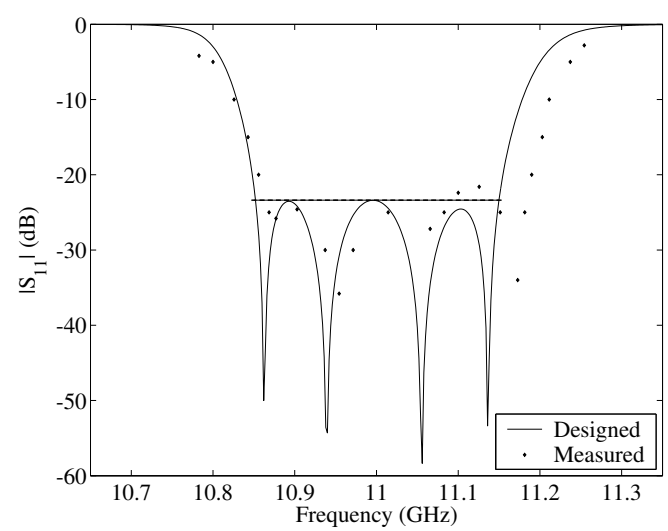

(a)

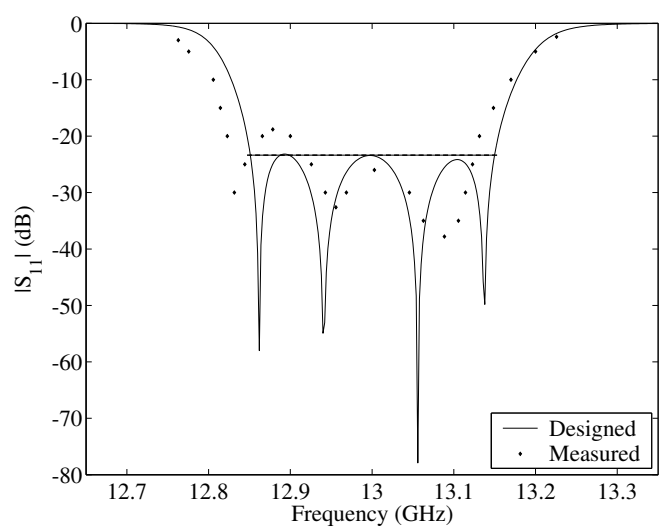

(b)

Figura 3.11: Comparison of the designed response with the measurements presented in [BGA98]. (a) $11 \mathrm{GHz}$. (b) $13 \mathrm{GHz}$

\subsubsection{Conclusions}

An efficient and accurate CAD tool for the automated design of waveguide filters has been presented in this paper. The CAD tool improves both the efficiency and robustness of the widely-used ASM technique using a new segmentation procedure and a suitable hybridization of several optimization algorithms. In addition, the use of the same modal analysis tool for both the fine and coarse model reveals to be of high interest for the design of complex structures, since it is possible to highly increase the efficiency of the coarse model without producing a severe misalignment between the optimization and validation spaces.

The performance of the CAD tool proposed has been tested with the design of several H-plane coupled cavity waveguide filters. The results obtained clearly show that the segmentation and the hybrid optimization both provide an important increase in the robustness and efficiency with regard to classical ASM implementations. Finally, this novel CAD tool has been applied to the design of a real LMDS filter at $28 \mathrm{GHz}$ and two tunable $\mathrm{H}$-plane coupled cavity waveguide filters centered at 11 and $13 \mathrm{GHz}$ for space applications. The prototypes have been successfully manufactured and measured, thus proving the reliability of the CAD tool developed. It must also be noted the fully automation of the design process, where no human intervention is needed. This tool can also be used in the automated design procedure of more complex passive waveguide structures, such as evanescent mode filters, corrugated filters, filters with dielectric posts, low cost manufactured filters (with rounded corners), as well as manifold diplexers and multiplexers based on such filters. 


\subsection{New Multimodel Aggressive Space Mapping Techni- que for the efficient design of complex microwave cir- cuits}

\subsubsection{Introduction}

The accurate design of electromagnetic structures requires a trade-off between accuracy and computation time. When designing complex structures the use of an accurate simulation tool can be unaffordable. The well-known Aggressive Space Mapping (ASM) technique [BBS $\left.{ }^{+} 95\right]$ can then be used to reduce the computational burden by using two different simulation tools: an efficient but not very accurate tool (coarse model) in the optimization space (OS), and an accurate but not very efficient tool (fine model) in the validation space (VS). This procedure moves the computational burden to the OS, thus reducing the overall computation time, while the accuracy is still guaranteed by the use of the fine model.

ASM has proved to be very useful for electromagnetic design. However, sometimes it may not be possible to find a mapping between the optimization and validation spaces due to the non-uniqueness of the parameter extraction phase. This happens especially when the coarse and fine models are severely misaligned. Therefore there has been significant research dedicated to improve the robustness and performance of ASM. One of this initiatives is the Trust Region ASM (TRASM) $\left[\mathrm{BBB}^{+} 98\right]$, which integrates a trust region methodology with the ASM, ensuring that each iteration improves the alignment between spaces. To improve the uniqueness of the extraction phase, a recursive multipoint parameter extraction is implemented. Nevertheless, severe differences between the coarse and fine models may cause the TRASM algorithm to be trapped in local minima. In order to avoid this problem, the Hybrid ASM (HASM) [BBGM99] exploits both the TRASM and direct optimization, smoothly switching from TRASM to direct optimization if the TRASM is not converging. However, the use of direct optimization with the fine model may be unaffordable for complex structures. The surrogate model-based SM optimization uses a surrogate model that is a combination of a coarse model mapped in frequency a linearization of the fine model. The surrogate model, however, is faster that the fine model at the expense of a lower accuracy.

As an alternative to the aforementioned extensions of ASM, we present a new strategy, the Multimodel Aggressive Space Mapping (MASM). When the coarse and fine models are severely misaligned, the MASM introduces intermediate models with increasing accuracy thus filling the gap between the coarse and the fine model. In the first phase of MASM, a standard ASM procedure is used to map the coarse and the first intermediate model. Since the difference of the coarse model with the first intermediate model is smaller than with the fine model, the misalignment between spaces is also smaller and so is the risk of not finding a suitable mapping between spaces. Once the mapping between the coarse and the 
first intermediate model is finished, a new ASM iteration maps the coarse and the second intermediate model. The process continues until the last iteration where the mapping between the coarse and fine model is performed. This method avoids the use of direct optimization with the fine model, thus minimizing the number of fine model simulations. On the other hand, it still preserves the maximum accuracy since no surrogate model is used.

The performance of the MASM has been tested with the practical design of several $\mathrm{H}$ plane coupled cavities filters considering the presence of rounded corners. The rounded corners appear due to the finite precision of the manufacturing process $\left[\mathrm{CBS}^{+} 01\right]$ (i.e milling, spark erosion, electro-forming, die-casting).

\subsubsection{Overview of the original Aggressive Space Mapping Method}

The original ASM describes the behavior of a system by models in two spaces: the optimization space (OS), denoted by $\mathbf{X}_{o s}$, and the validation space (VS), denoted by $\mathbf{X}_{e m}$. We represent the designable model parameters in these spaces by the vectors $\mathbf{x}_{o s}$ and $\mathbf{x}_{e m}$, respectively.

The objective of the ASM procedure is to find the optimum point $\mathbf{x}_{e m}$ in VS that minimizes the following non-linear function:

$$
\mathbf{f}\left(\mathbf{x}_{e m}\right)=\mathbf{P}\left(\mathbf{x}_{e m}\right)-\mathbf{x}_{o s}^{*}
$$

where $\mathbf{x}_{o s}^{*}$ is the optimum point in OS and $\mathbf{P}\left(\mathbf{x}_{e m}\right)$ is the point in OS that satisfies $\mathbf{R}_{f}\left(\mathbf{x}_{e m}\right)=\mathbf{R}_{c}\left(\mathbf{P}\left(\mathbf{x}_{e m}\right)\right), \mathbf{R}_{f}$ and $\mathbf{R}_{c}$ being the vectors with the responses of the fine and coarse models. The ASM procedure finishes when $\left\|\mathbf{f}\left(\mathbf{x}_{e m}\right)\right\|$ is below some threshold $\eta$ near zero.

At each iteration $j$, the next iterate is found by a quasi-Newton iteration:

$$
\mathbf{x}_{e m}^{(j+1)}=\mathbf{x}_{e m}^{(j)}+\mathbf{h}^{(j)}
$$

where $\mathbf{x}_{e m}^{(0)}=\mathbf{x}_{o s}^{*}$ and $\mathbf{h}^{(j)}$ solves the linear system:

$$
\mathbf{B}^{(j)} \mathbf{h}^{(j)}=-\mathbf{f}^{(j)}
$$

$\mathbf{B}^{(j)}$ is an approximation to the Jacobian matrix and is obtained from $\mathbf{B}^{(j-1)}$ using the 
Broyden update:

$$
\mathbf{B}^{(j)}=\mathbf{B}^{(j-1)}+\frac{\mathbf{f}^{(j)} \mathbf{h}^{(j-1)^{T}}}{\mathbf{h}^{(j-1)^{T}} \mathbf{h}^{(j-1)}}
$$

where $\mathbf{B}^{(0)}$ is the identity matrix, $\mathbf{f}^{(j)}=\mathbf{P}\left(\mathbf{x}_{e m}^{(j)}\right)-\mathbf{x}_{o s}^{*}$, and $\mathbf{P}\left(\mathbf{x}_{e m}^{(j)}\right)$ is obtained solving the following parameter extraction problem:

$$
\mathbf{P}\left(\mathbf{x}_{e m}^{(j)}\right)=\mathbf{x}_{o s}^{(j)}=\underset{\mathbf{x}_{o s}}{\arg \operatorname{mín}}\left\|\mathbf{R}_{f}\left(\mathbf{x}_{e m}^{(j)}\right)-\mathbf{R}_{c}\left(\mathbf{x}_{o s}\right)\right\|
$$

\subsubsection{Multimodel ASM (MASM)}

In MASM the behaviour of the system to be designed is described by $N$ models in $N$ spaces: the optimization space, denoted by $\mathbf{X}_{o s}$, and $N-1$ validation spaces, denoted by $\left.\mathbf{X}_{e m}\right|_{i}, i \in[1, \ldots, N-1]$. We represent the design parameters in these spaces by the vectors $\mathbf{x}_{o s}$ and $\left.\mathbf{x}_{e m}\right|_{(i)}$ respectively.

For $j>i$, model $j$ in the validation space $\left.\mathbf{X}_{e m}\right|_{j}$ is more accurate than model $i$ in the validation space $\left.\mathbf{X}_{e m}\right|_{i}$. And model $i$ requires less computation time than model $j$.

The MASM proceeds in $N-1$ iterations. Each iteration $i$ performs a traditional ASM between the coarse model and the model $i$. This allows to gradually map the coarse model to the finest model $N-1$ through $N-1$ intermediate mappings, avoiding the possibility of being trapped in local minima when the coarse model and the finest model are severely misaligned. The coarse model, that is, the fastest model, is always used in the optimization space for all iterations, and thus the efficiency is guaranteed. And the accuracy of the result is also guaranteed by the use of the finest model in the last iteration.

In order to take profit of the advance made in each iteration, the initial guess for the approximation of the Jacobian matrix is fixed to the final value of that matrix in the former iteration.

The MASM is implemented through the following steps:

1. $i=1$.

2. A traditional ASM procedure maps the coarse and the $i$ models minimizing the following non-linear function: 


$$
\mathbf{f}_{i}\left(\left.\mathbf{x}_{e m}\right|_{i}\right)=\mathbf{P}_{i}\left(\left.\mathbf{x}_{e m}\right|_{i}\right)-\mathbf{x}_{o s}^{*}
$$

where $\mathbf{P}_{i}\left(\left.\mathbf{x}_{e m}\right|_{i}\right)$ satisfies

$$
\mathbf{R}_{f_{i}}\left(\left.\mathbf{x}_{e m}\right|_{i}\right)=\mathbf{R}_{c}\left(\mathbf{P}_{i}\left(\left.\mathbf{x}_{e m}\right|_{i}\right)\right)
$$

$\mathbf{R}_{f_{i}}$ being the vector with the response of model $i$.

3. The point that minimizes $\mathbf{f}_{i}\left(\left.\mathbf{x}_{e m}\right|_{i}\right)$ is searched through an iterative process. At each iteration $j,\left.\mathbf{x}_{e m}\right|_{i} ^{(j+1)}$ is obtained by the quasi-Newton iteration:

$$
\left.\mathbf{x}_{e m}\right|_{i} ^{(j+1)}=\left.\mathbf{x}_{e m}\right|_{i} ^{(j)}+\left.\mathbf{h}\right|_{i} ^{(j)}
$$

where the step $\left.\mathbf{h}\right|_{i} ^{(j)}$ is defined by

$$
\left.\left.\mathbf{B}\right|_{i} ^{(j)} \mathbf{h}\right|_{i} ^{(j)}=-\left.\mathbf{f}\right|_{i} ^{(j)}
$$

and $\left.\mathbf{B}\right|_{i} ^{(j)}$ is updated according to (3.11) and $\mathbf{P}_{i}\left(\left.\mathbf{x}_{e m}\right|_{i} ^{(j)}\right)$ is obtained through the correspondent parameter extraction.

4. If $i=1,\left.\mathbf{x}_{e m}\right|_{i} ^{(0)}=\mathbf{x}_{o s}^{*}$, otherwise $\left.\mathbf{x}_{e m}\right|_{i} ^{(0)}=\left.\mathbf{x}_{e m}\right|_{i-1} ^{*},\left.\mathbf{x}_{e m}\right|_{i-1} ^{*}$ being the optimum point in the model $i-1$.

5. If $i=0,\left.\mathbf{B}\right|_{i} ^{(0)}=\mathbf{I}$, otherwise $\left.\mathbf{B}\right|_{i} ^{(0)}=\left.\mathbf{B}\right|_{i-1} ^{*}$

6. When $\left\|\mathbf{f}_{i}\left(\left.\mathbf{x}_{e m}\right|_{i} ^{(j+1)}\right)\right\|$ is below some threshold $\eta_{i}$ the $i$-th iteration ends, and $\left.\mathbf{x}_{e m}\right|_{i} ^{*}=$ $\left.\mathbf{x}_{e m}\right|_{i} ^{(j+1)},\left.\mathbf{B}\right|_{i} ^{*}=\left.\mathbf{B}\right|_{i} ^{(j)}$

7. $i=i+1$.

8. The process is repeated until $i=N-1$, and $\left.\mathbf{x}_{e m}\right|_{N-1} ^{*}$, the optimum point in the finest model, is obtained.

\subsubsection{Results}

The MASM has been integrated into the CAD tool presented in $\left[\mathrm{MEB}^{+} 04\right]$, which enhances the original ASM algorithm with a segmentation and hybridization strategy. Instead of designing the whole structure at the same time, the segmentation strategy divides the design process into a number of simple steps. In each step there is only a small number of design parameters so that the efficiency and the robustness of the overall design process is increased. Moreover, the design process is improved using a hybridization of several optimization 
algorithms in each step. This hybridization technique uses a suitable combination of different optimization algorithms (direct search, simplex, Broyden Fletcher Goldfarb Shanno) instead of using only one. The combination of algorithms differs from one step to the other according to the expected proximity to the global minimum and the expected behaviour of the error surface, so that the robustness and efficiency of the optimization process is increased.

The CAD tool of $\left[\mathrm{MEB}^{+} 04\right]$ with the improved version of ASM described in this work has been applied to the design of a H-plane coupled cavities filters for satellite communication. We have taken into account the appearance of rounded corners in the coupling windows due to the use of die casting for its fabrication. With other fabrication techniques, the rounded corners are placed on the resonant cavities, near the lateral walls of the guide. Since the electromagnetic flux is almost zero in those places, the effect of these corners is not very significant [KM02]. On the other hand, with die casting fabrication the rounded corners are placed in the coupling windows where the electromagnetic flux is high. Thus, they significantly affect the electric behaviour of the filter, producing huge changes in the filter response even with small radii of the rounded corners.

The coarse model has been chosen to be a very efficient modal simulator which analyzes the filters without rounded corners, thus taking profit of the simplicity of the geometry. The planar discontinuities are characterized formulating an Integral Equation which is solved using the Method of Moments (MoM) according to the traditional Galerkin procedure [GG98]. For the fine model, a general purpose full-wave simulator able to analyze H-plane structures with arbitrary geometry $\left[\mathrm{ECB}^{+} 02 \mathrm{~b}\right]$ has been selected. This simulator uses a combination of numerical (MoM) and modal techniques, and it has proved to be 10 times faster than other general-purpose commercial software like Ansoft HFSS (see $\left[\mathrm{ECB}^{+} 02 \mathrm{~b}\right]$ ).

Since the electrical responses of the same filter with and without rounded corners are very different, the coarse and the fine model are severely misaligned. Thus, the new MASM has been used. The $N-1$ fine models are constructed using the same general purpose fullwave simulator, but with different accuracy for each model. The accuracy (and therefore the efficiency) of the fine models is controlled with the number of basis functions in the MoM $\left(N_{b}\right)$, and the number of guided modes used to expand the guided waves inside each resonant cavity $\left(N_{m}\right)$. Up to three different fine models have been used:

- Fine model 1: $N_{b}=75, N_{m}=5$

- Fine model 2: $N_{b}=100, N_{m}=7$

- Fine model 3: $N_{b}=200, N_{m}=9$

In order to test the new MASM, we have designed a six-pole $\mathrm{H}$ plane coupled cavities filter with two different radii at the rounded corners in the coupling windows $(r=1 \mathrm{~mm}$ and 
$\mathrm{r}=2 \mathrm{~mm}$ ). The ideal transfer function is a standard six-pole Chebychev response of $300 \mathrm{MHz}$ bandwidth centered at $13,86 \mathrm{GHz}$ with $-25 \mathrm{~dB}$ of return loss. The input and output waveguides of the filter are standard WR-75 waveguides ( $a=19,05 \mathrm{~mm}, \mathrm{~b}=9,525 \mathrm{~mm})$ and the resonant cavities are non standard waveguides with a width of $22 \mathrm{~mm}$ and a height of $9,525 \mathrm{~mm}$. The cavity lengths and the widths of the coupling windows have been chosen as design parameters.

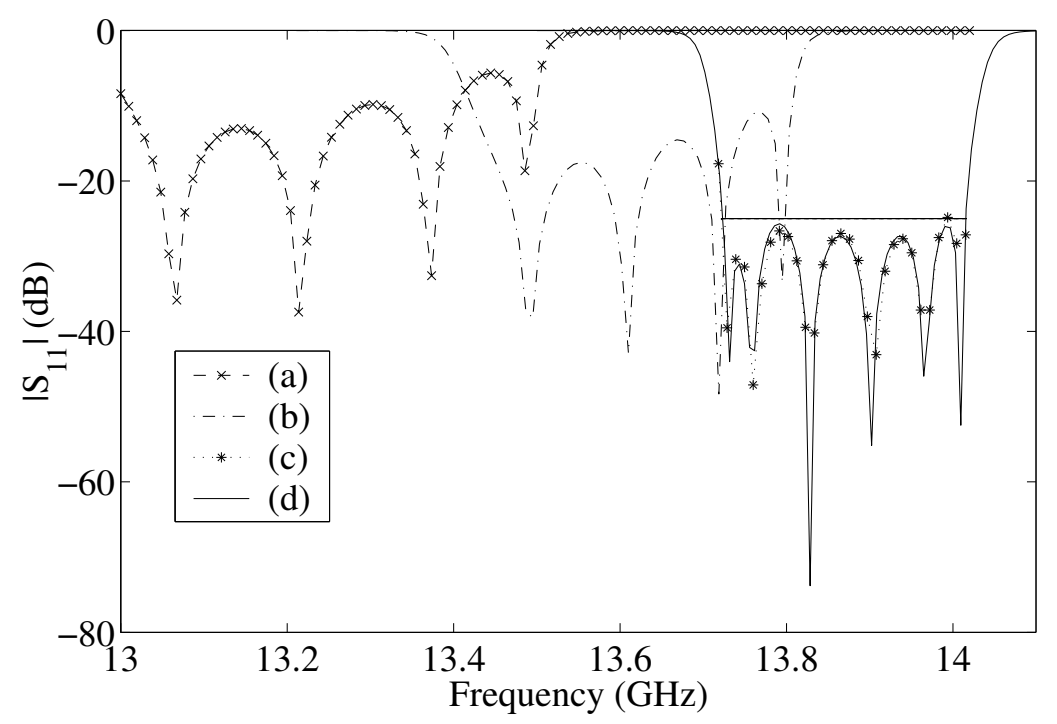

Figura 3.12: Coarse-model response vs the fine-model response at $\mathbf{x}_{o s}^{*}$. (a) $\mathbf{R}_{f_{3}}\left(\mathbf{x}_{o s}^{*}\right)$, $r=2 \mathrm{~mm}$, (b) $\mathbf{R}_{f_{3}}\left(\mathbf{x}_{o s}^{*}\right), r=1 \mathrm{~mm}$, (c) Ideal, (d) $\mathbf{R}_{o s}\left(\mathbf{x}_{o s}^{*}\right)$

In order to evaluate the misalignment between the coarse and finest model (fine model 3 ), the response of both models to the optimum point in OS $\left(\mathrm{x}_{o s}^{*}\right)$ is shown in Fig. 3.12 for $r=1 \mathrm{~mm}$ and $r=2 \mathrm{~mm}$. It can be observed that there is a significant difference in the responses. This difference increases with the radii of the rounded corners.

Tables 3.15 and 3.16 show the results of the design of the six-pole $\mathrm{H}$ plane filter with MASM. The number of models $N$, the number of simulations performed with the $N-1$ fine models, the final value of the error function $\left(\mathbf{U}\left(\mathbf{x}_{e m}\right)\right)$, and the total design time are presented in the tables for $r=1 \mathrm{~mm}$ (table 3.15) and $r=2 \mathrm{~mm}$ (table 3.16). For $N=2$ only the coarse and the fine model 3 have been used. For $N=3$ the coarse, the fine model 1 and the fine model 3 have been used. And for $N=4$ the coarse and fine models 1, 2 and 3 have been used.

When $N=2$, MASM is reduced to a traditional ASM procedure. It can be observed that in this case the design takes almost $8 \mathrm{~h}$ for $r=1 \mathrm{~mm}$, and no solution is found for $r=2 \mathrm{~mm}$, since the coarse and fine model 3 are severely misaligned. For $N=3$ the results improve for 


\begin{tabular}{|c|c|c|c|}
\hline $\begin{array}{c}\text { Number of } \\
\text { Models (N) }\end{array}$ & $\begin{array}{c}\text { Simulations with } \\
\text { the fine models }\end{array}$ & $\mathbf{U}\left(\mathbf{x}_{\mathbf{e m}}\right)$ & Design Time \\
\hline 2 & 4 & 1.68 & $7 \mathrm{~h} 52^{\prime}$ \\
\hline 3 & $3+3$ & 0.315 & $7 \mathrm{~h} 0^{\prime}$ \\
\hline 4 & $3+3+2$ & 0.5 & $6 \mathrm{~h} 24^{\prime}$ \\
\hline
\end{tabular}

Tabla 3.15: $r=1 \mathrm{~mm}$

\begin{tabular}{|c|c|c|c|}
\hline $\begin{array}{c}\text { Number of } \\
\text { Models (N) }\end{array}$ & $\begin{array}{c}\text { Simulations with } \\
\text { the fine models }\end{array}$ & $\mathbf{U}\left(\mathbf{x}_{\mathbf{e m}}\right)$ & Design Time \\
\hline 2 & No convergence & - & - \\
\hline 3 & $3+2$ & 2.35 & $5 \mathrm{~h} 8^{\prime}$ \\
\hline 4 & $3+2+1$ & 4.29 & $4 \mathrm{~h} 10^{\prime}$ \\
\hline
\end{tabular}

Tabla 3.16: $r=2 \mathrm{~mm}$

both $r=1 \mathrm{~mm}$ and $r=2 \mathrm{~mm}$. And this improvement is increased when four models $(N=4)$ are used, thus proving that MASM improves both the efficiency and robustness for the case when the coarse and fine models are severely misaligned. The result obtained with $N=4$ for $r=2 \mathrm{~mm}$ can not be further improved increasing $N$ since only one iteration of the finest model (fine model 3) has been necessary, and that is the minimum that we can afford to get the maximum accuracy.

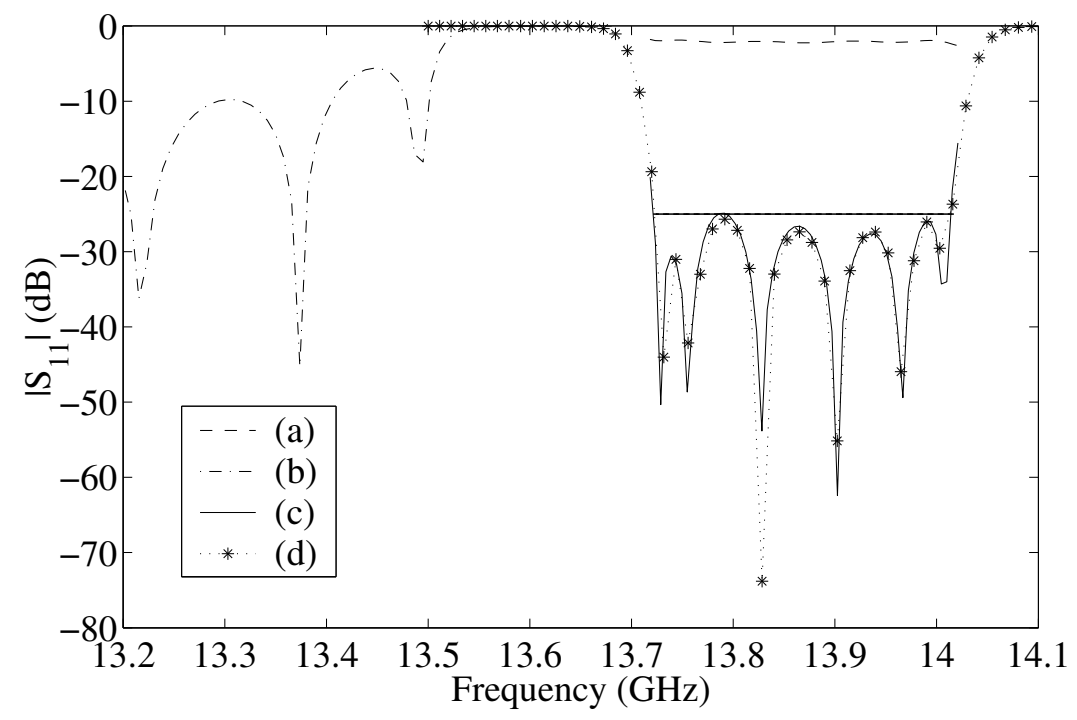

Figura 3.13: Evolution of the responses of the fine models at their first iteration for MASM with $N=4$ and $r=2 \mathrm{~mm}$. (a) $\mathbf{R}_{f_{1}}\left(\left.\mathbf{x}_{e m}\right|_{1} ^{(0)}\right)$, (b) $\mathbf{R}_{f_{2}}\left(\left.\mathbf{x}_{e m}\right|_{2} ^{(0)}\right)$, (c) $\mathbf{R}_{f_{3}}\left(\left.\mathbf{x}_{e m}\right|_{3} ^{(0)}=\left.\mathbf{x}_{e m}\right|_{3} ^{*}\right)$, (d) $\mathbf{R}_{o s}\left(\mathbf{x}_{o s}^{*}\right)$ 
Figure 3.13 shows the evolution of the responses of the different fine models at their first iteration for $N=4$ and $r=2 \mathrm{~mm}$. It can be observed that the distance with the ideal response is gradually reduced at each new step of MASM, until the ideal response is recovered with the finest model (fine model 3). Only one simulation with this model has been necessary, thus ensuring efficiency and accuracy.

\subsubsection{Conclusions}

In this paper an extension of the well known Aggressive Space Mapping technique (ASM) used for the design of complex microwave circuits has been presented. The extension, called Multimodel ASM (MASM) uses several fine models with increasing accuracy so that the mapping between the coarse model and the finest model is gradually performed in an iterative way.

The MASM algorithm avoids the use of direct optimization with the fine model, thus reducing the computational time. On the other hand, the robustness of the algorithm is guaranteed by the use of multiple models that reduce the gap between the coarse and fine models, gradually mapping both spaces.

A six-pole $\mathrm{H}$ plane coupled cavities filter with rounded corners in the coupling windows due to the fabrication with die casting has been designed. The results have proved that MASM is able to design the filter where traditional ASM fails. Besides, MASM increases the efficiency of the design process reducing the number of simulations with the finest model. 


\subsection{Optimization techniques for the efficient design of low- cost satellite filters considering new light materials}

\subsubsection{Introduction}

Passive waveguide filters are key elements in satellite communications systems. Coupled cavities $\mathrm{H}$ plane filters manufactured with milling techniques is one of the most economic choices with a reasonable compromise of low losses, low volume, and high power handling capability $\left[\mathrm{CBS}^{+} 01\right]$. When milling is used for fabrication, and since the diameter of the drill is not zero, it is impossible to mechanize perfect square corners. When milling is used to directly mechanize the cavities in a metallic body, the rounded corners appear in the resonant cavities (see Fig. 3.14(a)). However, if the milling is used to mechanize a mould which is later used to cast the filter, the rounded corners appear in the coupling windows (see Fig. 3.14(b)).

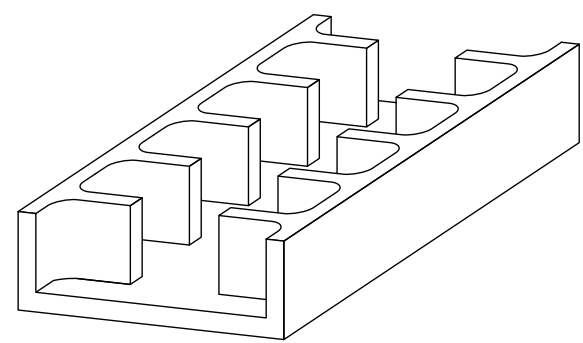

(a) Rounded corners in the resonant cavities

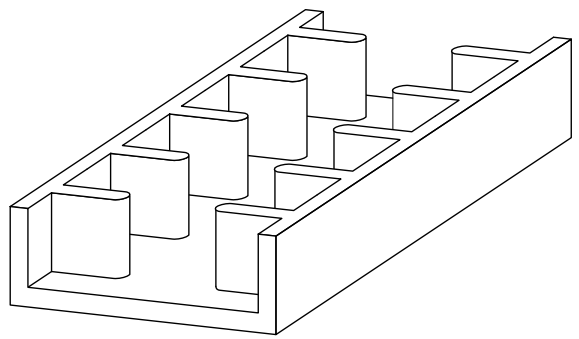

(b) Rounded corners in the coupling windows

Figura 3.14: Coupled cavities H plane filters with rounded corners due to milling

When the rounded corners are not considered in the design phase, a deviation appears between the measured and predicted electrical response [KM02]. This deviation is traditionally corrected using tuning elements (i.e. screws) that must be adjusted by human intervention, thus increasing the overall production costs. However, recent efforts are being dedicated to develop new automated design procedures which take into account the presence of rounded corners [Pag95, $\mathrm{ABR}^{+}$97] with the aim of avoiding the use of tuning elements, thus reducing the production costs significantly. Since the design of filters with rounded corners requires the electromagnetic simulation of a complex structure that mixes circular and rectangular geometries, direct optimization can be unaffordable. To overcome this difficulty, the well-known Aggressive Space Mapping (ASM) technique [BBS ${ }^{+95}$ ] can be used. ASM reduces the computational burden by using two different simulation tools: an efficient but not very accurate tool (coarse model), and an accurate but not very efficient tool (fine model). This procedure moves the computational burden to the coarse model, thus reducing the overall computation time, while the accuracy is still guaranteed by the use of the fine 
model. There has been significant research dedicated to improve the robustness and performance of Space Mapping (SM) $\left[\mathrm{BCD}^{+} 04\right]$. Some of this initiatives are the Trust Region ASM (TRASM) [BBB $\left.{ }^{+} 98\right]$, which integrates a trust region methodology with the ASM, the Hybrid ASM (HASM) [BBGM99], which exploits both the TRASM and direct optimization, implicit SM [BCNI04], which extracts selected preassigned parameters to match the coarse and fine models, neural SM [BBI $\left.{ }^{+} 00\right]$ and neural inverse space mapping [BIRZ03], which make use of neural networks methodologies, or Multimodel Aggressive Space Mapping (MASM) $\left[\mathrm{MEB}^{+} 05\right]$, which introduces intermediate models with increasing accuracy thus filling the gap between the coarse and the fine model. Among all SM techniques, MASM is a good choice in this case since it gradually maps the coarse and fine models without using direct optimization at any stage, thus designing in a robust and efficient manner. And at the same time the maximum accuracy is still guaranteed since no surrogate model is used.

In this paper we use a suitable combination of several design techniques (segmentation, hybridization of algorithms, ASM and MASM) in order to efficiently design several lowcost satellite waveguide filters with rounded corners of large radius due to milling with low tolerances. A systematic study of the convenience of using ASM or MASM for the design of these filters is performed for the first time. Three of these filters have been manufactured in order to validate the process. A novel lighter material has also been used in order to reduce weight and to test the compatibility of the low cost manufacture with the use of lighter materials.

\subsubsection{Design procedure}

\subsubsection{ASM}

In this ASM implementation the coarse model is a very efficient modal simulator which analyzes H-plane filters without rounded corners, thus taking profit of the simplicity of the geometry. The planar discontinuities are characterized formulating an Integral Equation which is solved using the Method of Moments (MoM) according to the traditional Galerkin procedure [GG98]. The fine model is a general purpose full-wave simulator able to analyze $\mathrm{H}$-plane structures with arbitrary geometry, including H-plane filters with rounded corners $\left[\mathrm{ECB}^{+} 02 \mathrm{~b}\right]$. It has proved to be 10 times faster than other general-purpose commercial software like Ansoft HFSS (see $\left[\mathrm{ECB}^{+} 02 \mathrm{~b}\right]$ ). However, the direct optimization of the H-plane filters with the fine model would be unaffordable because it still needs $663 \mathrm{sec}$. to simulate a three-cavity H-plane filter in a $2 \mathrm{GHz}$ Pentium 4 PC Platform, while the coarse model only needs $0.023 \mathrm{sec}$. Therefore, the use of ASM in this implementation is clearly justified. 


\subsubsection{Multimodel ASM (MASM)}

MASM introduces intermediate models with increasing accuracy thus filling the gap between the coarse and the fine model. In this work, the $N-1$ fine models of MASM are constructed using the same general purpose full-wave simulator that is used as fine model for ASM, but with different accuracy for each model. The accuracy (and therefore the efficiency) of the fine models is controlled with the number of basis functions in the MoM $\left(N_{b}\right)$, and the number of guided modes used to expand the guided waves inside each resonant cavity $\left(N_{m}\right)$. Up to three different fine models have been used:

- Fine model 1 (F1): $N_{b}=75, N_{m}=5$

- Fine model 2 (F2): $N_{b}=100, N_{m}=7$

- Fine model 3 (F3): $N_{b}=200, N_{m}=9$

\subsubsection{Segmentation and hybridization of optimization algorithms}

The speed and robustness of the optimization process can be greatly improved by decomposing the structure as proposed in $\left[\mathrm{MSE}^{+} 05\right]$, where the design of $\mathrm{H}$-plane filters is segmented into several steps. Both the efficiency and robustness of the optimization process can still be drastically improved when a suitable combination of optimization algorithms is used instead of using a single algorithm. In this case, a robust non-gradient method (simplex) is used at the beginning, and, after some iterations, when we are close to the minimum, an efficient gradient algorithm (Broyden Fletcher Goldfarb Shanno) is used to refine the solution, as proposed in $\left[\mathrm{MES}^{+} 02 \mathrm{~b}\right]$.

The error function that is minimized is computed comparing the simulated response (either reflection of transmission parameter) with the ideal response of an ideal network composed of impedance inverters and half-wavelength transmission lines. The Huber norm with $k=5\left[\mathrm{BCB}^{+} 93\right]$ has been used to compare simulated and ideal responses.

\subsubsection{Design of $\mathrm{H}$ Plane filters with rounded corners}

Several microwave waveguide filters have been designed. All these filters are $\mathrm{H}$ plane coupled cavities filters with rounded corners either in the resonant cavities (see Fig. 3.15(a)) or in the coupling windows (see Fig. 3.15(b)). 


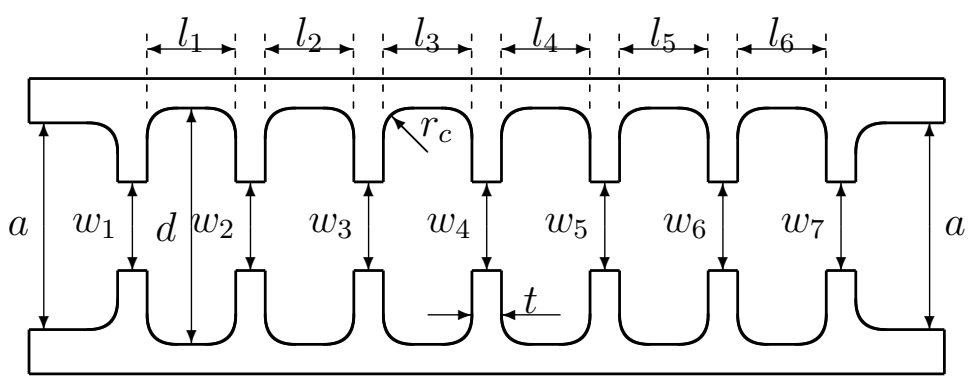

(a) Rounded corners in the resonant cavities

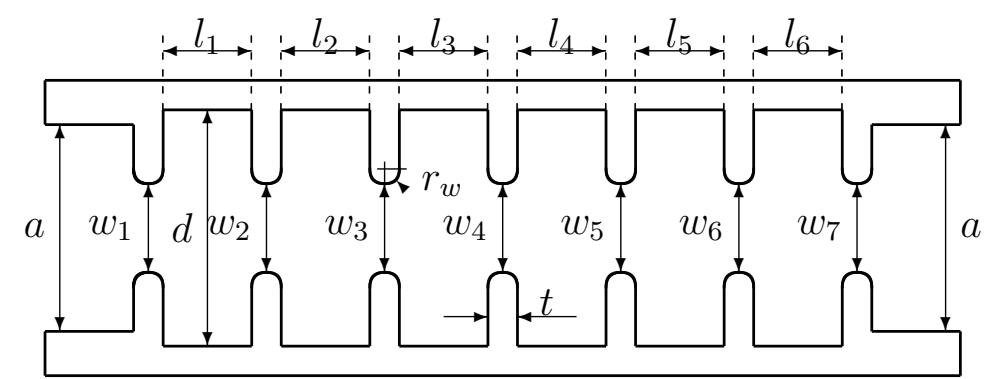

(b) Rounded corners in the coupling windows

Figura 3.15: Top view of the filters with rounded corners

The non-homogeneous filters have all been designed with the following specifications: 6 resonant cavities, WR-75 $(\mathrm{a}=19,05 \mathrm{~mm}, \mathrm{~b}=9,525 \mathrm{~mm})$ input and output waveguides, width of resonant cavities $d$ equal to $22 \mathrm{~mm}$, central frequency $f_{0}=13.869 \mathrm{GHz}$, bandwidth $B W=291 \mathrm{MHz}$, and return losses $L_{R}>25 \mathrm{~dB}$.

The cavity lengths $\left(l_{1}, l_{2}\right.$ and $l_{3}$ in Figs. 3.15(a) and 3.15(b)) and the widths of the coupling windows $\left(w_{1}, w_{2}, w_{3}\right.$ and $w_{4}$ in Figs. 3.15(a) and 3.15(b)) have been chosen as design parameters. Since the filter is symmetric, $l_{4}=l_{3}, l_{5}=l_{2}, l_{6}=l_{1}, w_{5}=w_{3}, w_{6}=w_{2}$, and $w_{7}=w_{1}$. The other dimensions are fixed.

In all cases the filter design has been performed using Multimodel Aggressive Space Mapping (MASM). As already explained, the coarse model (C model) is a very efficient modal simulator which analyzes the filters without rounded corners. This simulator needs only 48 s (Pentium IV @ 2.4 GHz) to find the optimum point with the coarse model, thanks to the use of the segmentation and hybridization of optimization algorithms. Since the fine model is around 30.000 times slower that the coarse model, that means that the direct optimization with the fine model would take around 400 hours. Therefore, it is clearly justified in this case the use of a Space Mapping technique, either ASM or MASM, in order to reduce the design time.

The three different fine models (F1, F2 and F3) have been used for MASM. Several combinations of these models have been tried in order to design filters with different radius in the resonant cavities $\left(r_{c}=1 \mathrm{~mm}, 2 \mathrm{~mm}, 3 \mathrm{~mm}\right.$ and $\left.4 \mathrm{~mm}\right)$ or in the coupling windows 
$\left(r_{w}=0.25 \mathrm{~mm}, 0.5 \mathrm{~mm}, 1 \mathrm{~mm}, 1.5 \mathrm{~mm}\right.$ and $2 \mathrm{~mm}$ ). The results of the design with ASM and MASM of all these filters are presented in Table 3.17. When the coarse model (C) and the fine model 3 (F3) are used, MASM is reduced to a traditional ASM procedure.

\begin{tabular}{|c|c|c|c|c|c|}
\hline \multicolumn{2}{|c|}{$\operatorname{Radius(mm)}$} & Models & $\begin{array}{l}\text { Simulations with } \\
\text { the fine models }\end{array}$ & Final error & Design time \\
\hline \multirow{12}{*}{$r_{w}=0$} & \multirow{3}{*}{$r_{c}=1$} & $\overline{\mathrm{C}+\mathrm{F} 3}$ & 2 & 1.89 & 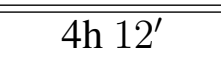 \\
\hline & & $\mathrm{C}+\mathrm{F} 2+\mathrm{F} 3$ & $2+2$ & 0.41 & $5 \mathrm{~h} 04^{\prime}$ \\
\hline & & $\mathrm{C}+\mathrm{F} 1+\mathrm{F} 2+\mathrm{F} 3$ & $5+4+3$ & 0.55 & $9 \mathrm{~h} 21^{\prime}$ \\
\hline & \multirow{3}{*}{$r_{c}=2$} & $\mathrm{C}+\mathrm{F} 3$ & 2 & 1.85 & $4 \mathrm{~h} 12^{\prime}$ \\
\hline & & $\mathrm{C}+\mathrm{F} 2+\mathrm{F} 3$ & $2+3$ & 3.69 & $7 \mathrm{~h} 15^{\prime}$ \\
\hline & & $\mathrm{C}+\mathrm{F} 1+\mathrm{F} 2+\mathrm{F} 3$ & $5+5+3$ & 1.06 & $9 \mathrm{~h} 46^{\prime}$ \\
\hline & \multirow{3}{*}{$r_{c}=3$} & $\mathrm{C}+\mathrm{F3}$ & 2 & 1.81 & 4h $12^{\prime}$ \\
\hline & & $\mathrm{C}+\mathrm{F} 2+\mathrm{F} 3$ & $3+2$ & 0.54 & $5 \mathrm{~h} 33^{\prime}$ \\
\hline & & $\mathrm{C}+\mathrm{F} 1+\mathrm{F} 2+\mathrm{F} 3$ & $5+3+2$ & 1.22 & $6 \mathrm{~h} 46^{\prime}$ \\
\hline & \multirow{3}{*}{$r_{c}=4$} & $\mathrm{C}+\mathrm{F3}$ & 2 & 2.20 & $5 \mathrm{~h} 07^{\prime}$ \\
\hline & & $\mathrm{C}+\mathrm{F} 2+\mathrm{F} 3$ & $3+3$ & 0.49 & $9 \mathrm{~h} 15^{\prime}$ \\
\hline & & $\mathrm{C}+\mathrm{F} 1+\mathrm{F} 2+\mathrm{F} 3$ & $5+3+2$ & 7.77 & $7 \mathrm{~h} 59^{\prime}$ \\
\hline \multirow{15}{*}{$r_{c}=0$} & \multirow{3}{*}{$r_{w}=0.25$} & $\overline{\mathrm{C}+\mathrm{F} 3}$ & 3 & 1.76 & 4h $27^{\prime}$ \\
\hline & & $\mathrm{C}+\mathrm{F} 2+\mathrm{F} 3$ & $3+2$ & 0.53 & $4 \mathrm{~h} 02^{\prime}$ \\
\hline & & $\mathrm{C}+\mathrm{F} 1+\mathrm{F} 2+\mathrm{F} 3$ & $3+3+2$ & 1.09 & $4 \mathrm{~h} 37^{\prime}$ \\
\hline & \multirow{3}{*}{$r_{w}=0.5$} & $\mathrm{C}+\mathrm{F} 3$ & 2 & 2.83 & $3 \mathrm{~h} 35^{\prime}$ \\
\hline & & $\mathrm{C}+\mathrm{F} 2+\mathrm{F} 3$ & $3+2$ & 0.36 & $4 \mathrm{~h} 15^{\prime}$ \\
\hline & & $\mathrm{C}+\mathrm{F} 1+\mathrm{F} 2+\mathrm{F} 3$ & $3+3+2$ & 0.83 & $4 \mathrm{~h} 44^{\prime}$ \\
\hline & \multirow{3}{*}{$r_{w}=1$} & $\mathrm{C}+\mathrm{F} 3$ & 3 & 3.08 & $6 \mathrm{~h} 08^{\prime}$ \\
\hline & & $\mathrm{C}+\mathrm{F} 2+\mathrm{F} 3$ & $3+2$ & 0.54 & $4 \mathrm{~h} 26^{\prime}$ \\
\hline & & $\mathrm{C}+\mathrm{F} 1+\mathrm{F} 2+\mathrm{F} 3$ & $3+3+2$ & 0.84 & $4 \mathrm{~h} 50^{\prime}$ \\
\hline & \multirow{3}{*}{$r_{w}=1.5$} & $\mathrm{C}+\mathrm{F} 3$ & 3 & 2.84 & $6 \mathrm{~h} 54^{\prime}$ \\
\hline & & $\mathrm{C}+\mathrm{F} 2+\mathrm{F} 3$ & $3+2$ & 0.51 & $4 \mathrm{~h} 37^{\prime}$ \\
\hline & & $\mathrm{C}+\mathrm{F} 1+\mathrm{F} 2+\mathrm{F} 3$ & $3+3+2$ & 0.66 & $4 \mathrm{~h} 56^{\prime}$ \\
\hline & \multirow{3}{*}{$r_{w}=2$} & $\mathrm{C}+\mathrm{F} 3$ & 5 & 21.25 & $12 \mathrm{~h} 48^{\prime}$ \\
\hline & & $\mathrm{C}+\mathrm{F} 2+\mathrm{F} 3$ & $3+2$ & 0.43 & $4 \mathrm{~h} 48^{\prime}$ \\
\hline & & $\mathrm{C}+\mathrm{F} 1+\mathrm{F} 2+\mathrm{F3}$ & $3+2+2$ & 0.72 & $4 \mathrm{~h} 41^{\prime}$ \\
\hline
\end{tabular}

Tabla 3.17: Design results for filters with rounded corners in the coupling windows

It can be observed that for the case of rounded corners in the resonant cavities ASM requires less computation time than MASM independently of the radius of the rounded corners. This is due to the fact that the flux of EM power is very low near the rounded corners and therefore the responses of the filters without rounded corners (coarse model) and with rounded corners (fine model) are very similar. So the use of MASM is not necessary in this case, since MASM is most suitable for cases where the coarse and fine models are very dif- 
ferent. It must be noted that in all cases MASM provides a slightly better design (lower value of the error) although at the cost of a much greater computation time.

When the rounded corners are placed in the coupling windows, they are much closer to the center of the guide where the flux of EM power is maximum. Therefore the difference between the coarse and fine models is much greater now, and so MASM performs better. Results from Table 3.17 show that the performance of ASM decreases drastically as the radius increases. It can also be observed that MASM with three models performs better (less time and smaller error) than with four models in all cases except for the largest radius $\left(r_{w}=2 \mathrm{~mm}\right)$, with the largest misalignment between coarse and fine models, where MASM with four models designs in less time (though still with greater error).

\subsubsection{Fabrication and measurement}

Three of the filters with larger radius from Table 3.17 have been manufactured with milling techniques and with a new lighter material (magnesium). Two of these filters have rounded corners in the resonant cavities with radius $r_{c}=3 \mathrm{~mm}$ and $r_{c}=4 \mathrm{~mm}$, and the third one has the rounded corners in the coupling window with radius $r_{w}=2 \mathrm{~mm}$. The designs used for fabrication have been emphasized with bold writing in Table 3.17. Table 3.18 shows the dimensions provided by the design process for each one of the three filters.

\begin{tabular}{|c|c|c|c|}
\hline \multirow{2}{*}{ Dimensions } & \multicolumn{2}{|c|}{ ASM } & MASM $(\mathbf{C + F 1 + F 2 + F 3 ) ~}$ \\
\cline { 2 - 4 } & $\begin{array}{c}\mathbf{r}_{c}=\mathbf{3} \mathbf{~ m m} \\
\mathbf{r}_{w}=\mathbf{0} \mathbf{~ m m}\end{array}$ & $\begin{array}{c}\mathbf{r}_{c}=\mathbf{4} \mathbf{~ m m} \\
\mathbf{r}_{w}=\mathbf{0} \mathbf{~ m m}\end{array}$ & $\begin{array}{c}\mathbf{r}_{c}=\mathbf{0} \mathbf{~ m m} \\
\mathbf{r}_{w}=\mathbf{2} \mathbf{~ m m}\end{array}$ \\
\hline \hline$a$ & 19.05 & 19.05 & 19.05 \\
\hline$d$ & 22.00 & 22.00 & 22.00 \\
\hline$t$ & 3.844 & 3.844 & 4.500 \\
\hline$w_{1}=w_{7}$ & 9.284 & 9.289 & 8.768 \\
\hline$w_{2}=w_{6}$ & 6.344 & 6.348 & 5.837 \\
\hline$w_{3}=w_{5}$ & 5.814 & 5.816 & 5.311 \\
\hline$w_{4}$ & 5.738 & 5.739 & 5.235 \\
\hline$l_{1}=l_{6}$ & 9.770 & 9.809 & 9.159 \\
\hline$l_{2}=l_{5}$ & 11.118 & 11.166 & 10.581 \\
\hline$l_{3}=l_{4}$ & 11.273 & 11.322 & 10.752 \\
\hline
\end{tabular}

Tabla 3.18: Designed dimensions of the manufactured filters

Figure 3.16(a) compares the simulated reflection coefficient of the three filters selected for fabrication. The dimensions of the filters that have been used for these simulations are the 


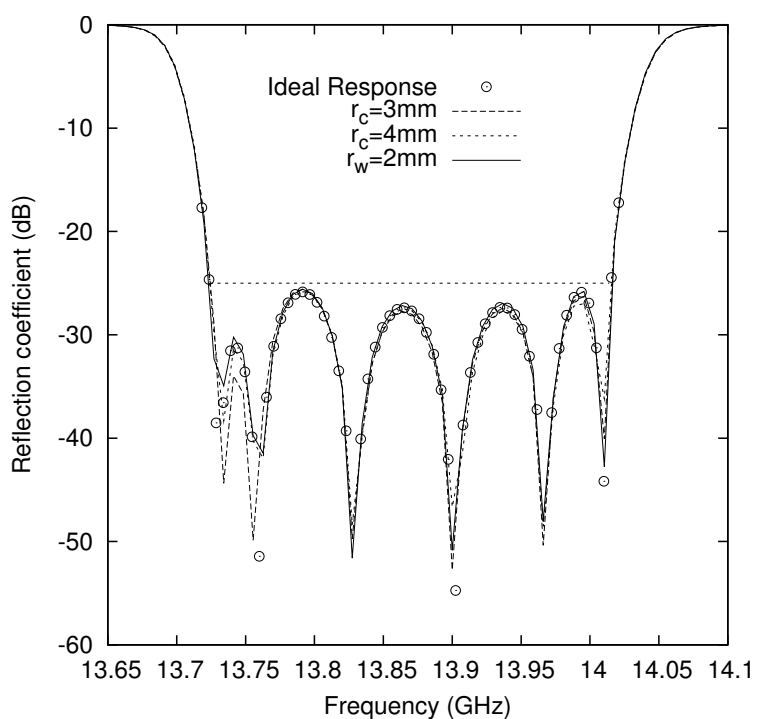

(a) Comparison of the final designs of the three filters with the ideal response and the specifications

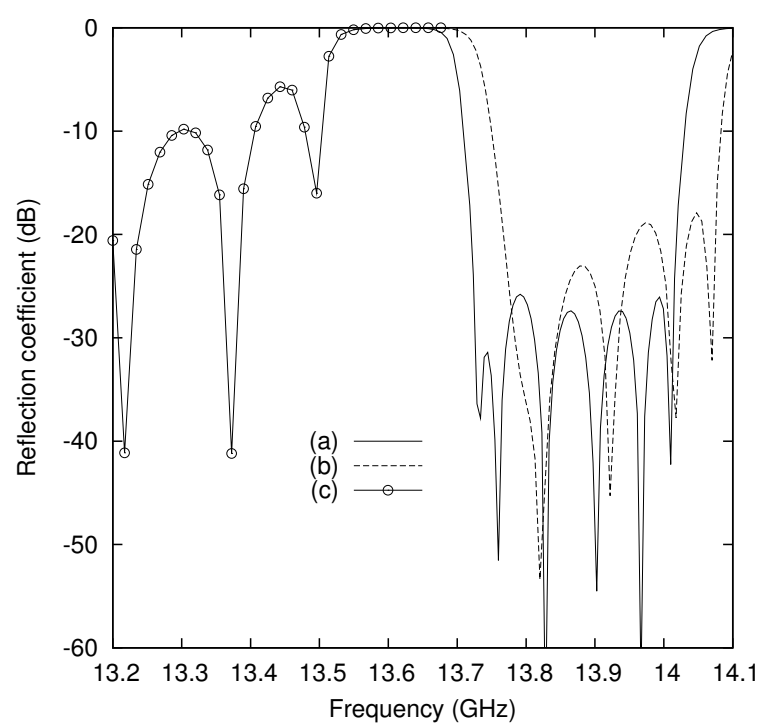

(b) Misalignment between spaces. (a) Coarse model, (b) Fine model, $r_{c}=4 \mathrm{~mm}$, (c) Fine model, $r_{w}=2 \mathrm{~mm}$

Figura 3.16: Simulated reflection coefficient $\left|S_{11}\right|$

values depicted in Table 3.18, that is, the optimum point in the finest model, the fine model 3. And the simulator used for these simulations is the most accurate one (fine model 3). It can be appreciated that the three designs provide responses with very good agreement with the ideal response and compliant with the specifications.

In Figure 3.16(b) the misalignment between the coarse and finest model (fine model 3 ) for $r_{c}=4 \mathrm{~mm}$ and $r_{w}=2 \mathrm{~mm}$ is shown. It can be observed that with rounded corners in the coupling windows of radius $2 \mathrm{~mm}$ the response with the fine model 3 is very different from the response with the coarse model (without rounded corners). However, if the rounded corners are placed in the resonant cavities, the fine model response is quite similar to that of the coarse model, even though the radius of the rounded corners now is double $(4 \mathrm{~mm})$ than before $(2 \mathrm{~mm})$. This again reinforces the idea that when the rounded corners are placed near the center of the guide (maximum of EM flux), the influence is greater.

Figure 3.17 shows some pictures of the three manufactured prototypes. The body of the filters is made of magnesium, lighter than the aluminum, which is the material presently used in the satellite communications industry. It has been demonstrated that when magnesium is used instead of aluminum, a weight reduction of $50 \%$ is obtained. After milling the structure, a layer of an electrochemical deposition of silver over a bed of nickel is placed on the surface to ensure a 10 microns conducting covering.

The electrical responses of the three prototypes have been measured with an HP8510C 


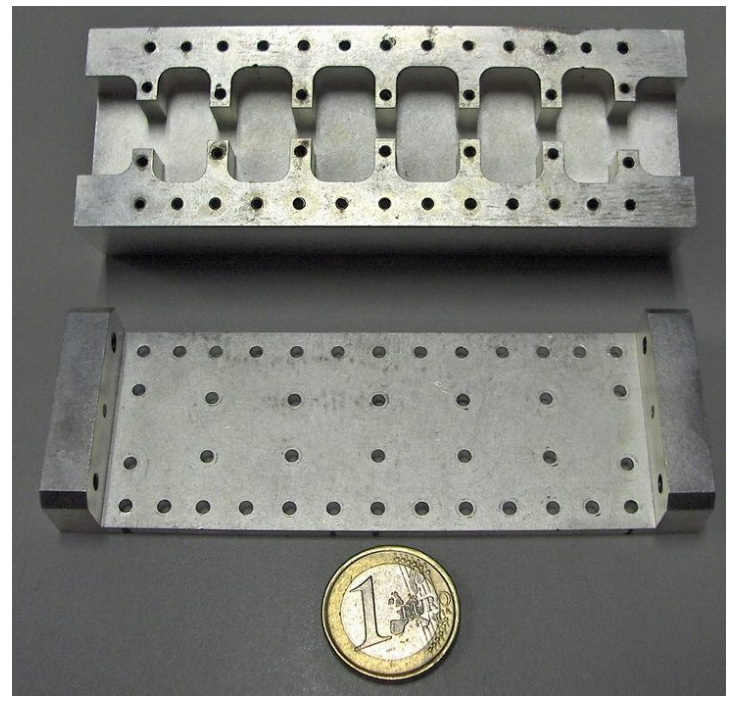

(a) $r_{c}=3 \mathrm{~mm}, r_{w}=0 \mathrm{~mm}$

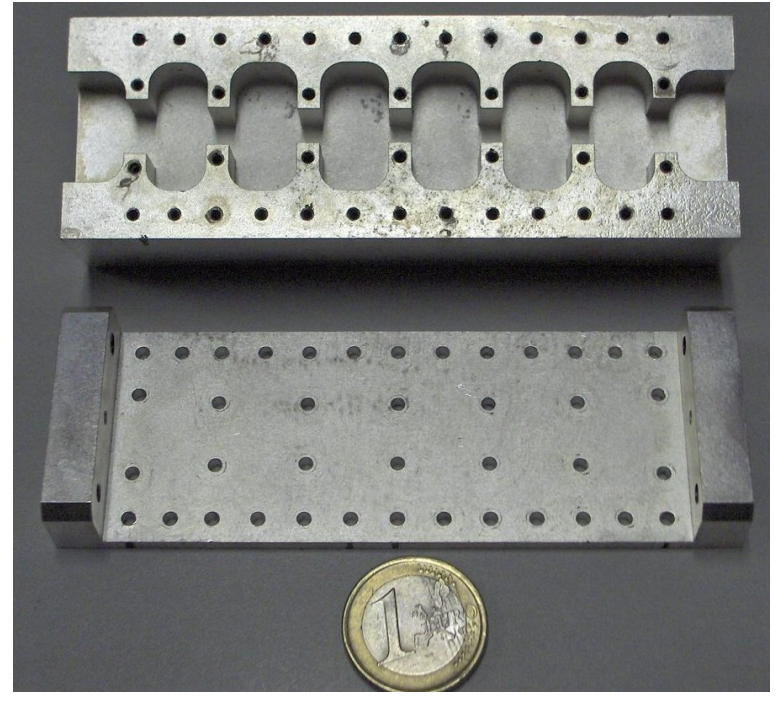

(b) $r_{c}=4 \mathrm{~mm}, r_{w}=0 \mathrm{~mm}$

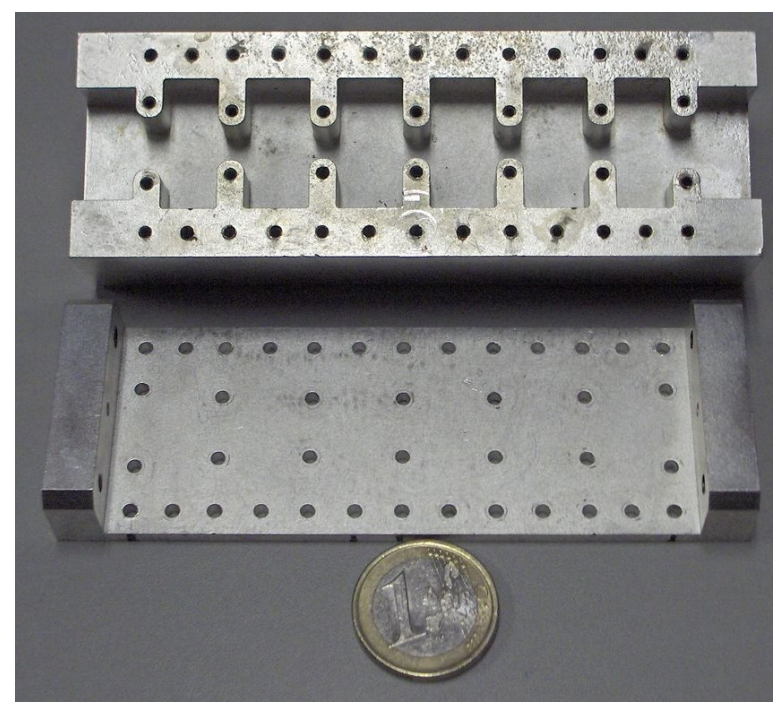

(c) $r_{c}=0 \mathrm{~mm}, r_{w}=2 \mathrm{~mm}$

Figura 3.17: Prototypes of $\mathrm{H}$ plane coupled cavities filters with rounded corners manufactured with milling techniques

Network Analyzer. The measured reflection coefficient of the three prototypes is compared in Fig. 3.18(a) with the ideal response. The measurements show a frequency shift in relation with the ideal response for the two prototypes with rounded corners in the resonant cavities. This shift is of around $50 \mathrm{MHz}$ for the filter with $r_{c}=3 \mathrm{~mm}$, and $80 \mathrm{MHz}$ for $r_{c}=4 \mathrm{~mm}$. In the case of the prototype with rounded corners in the coupling windows there is not a significant frequency shift, but the return loss has decreased from $25 \mathrm{~dB}$ to $\sim 15 \mathrm{~dB}$. To check the cause of this disagreement between the ideal response and the measurements, a dimensional control of the three prototypes has been performed. The dimensional control had a tolerance of 


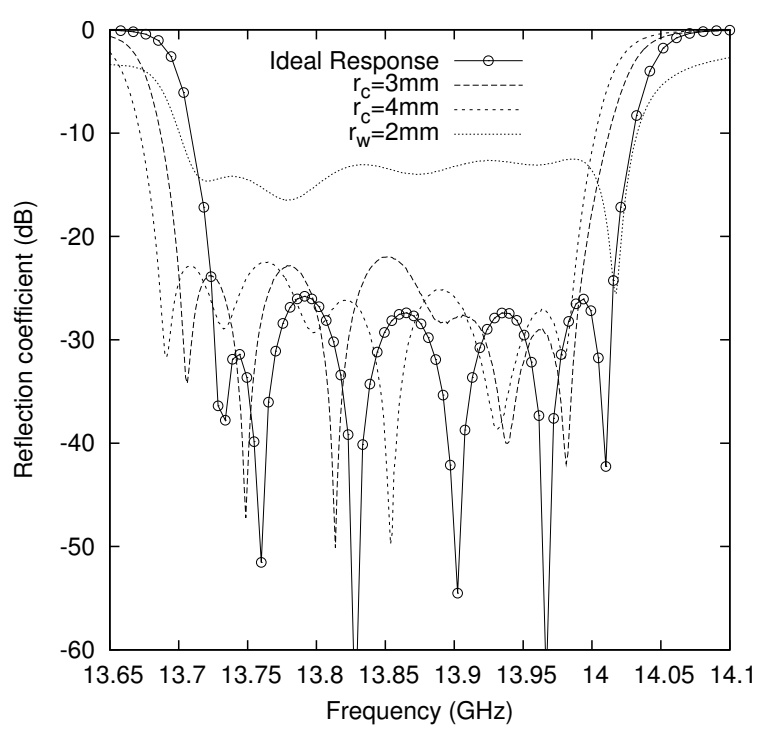

(a) Comparison with ideal response

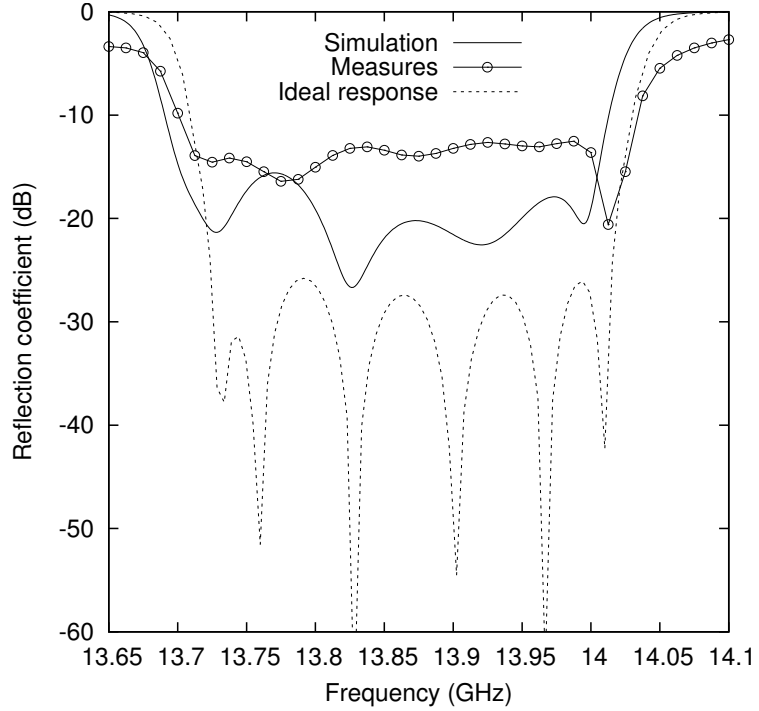

(b) Comparison with simulation after dimensional control for the filter with $r_{w}=2 \mathrm{~mm}$

Figura 3.18: Reflection coefficient of the three prototypes measured with a Network analyzer

\pm 10 microns. The dimensional control showed that the lengths and widths of the prototype in some cases differ from the designed dimensions up to 15 or 20 microns. Moreover, the disagreement in the radii of the rounded corners is up to 85 microns for $r_{c}=3 \mathrm{~mm}$ and $72 \mathrm{mi}$ crons for $r_{c}=4 \mathrm{~mm}$ and $r_{w}=2 \mathrm{~mm}$. This low tolerances surely explain the differences in the electrical responses of the prototypes in relation with the ideal response. Again the position of the rounded corners is very important, since the low tolerances are especially in the radius of the rounded corners, and therefore the measurements are much more deviated when the rounded corners are near the center of the guide.

The dimensions obtained with the dimensional control after fabrication have been used in a simulation in order to test the validity of the simulator. Figure 3.18(b) shows that the simulator response when the dimensions of the prototype $\left(r_{w}=2 \mathrm{~mm}\right)$ are used is in good agreement with the electrical response of the prototype, thus proving that the deviation between the ideal response and the response of the prototypes is due to the tolerances of the new fabrication process based on magnesium. When this new fabrication process improves, and the typical tolerances of the space industry ( \pm 5 microns) are achieved, we can expect that the nominal results from the design will allow the fabrication of prototypes with very good responses, including the effect of the rounded corners with large radius, without any need of tuning after fabrication, with a new lighter material, and with low fabrication costs. 


\subsubsection{Conclusions}

A new fabrication method for satellite waveguide filters has been presented in this paper. This method based on magnesium provides a weight reduction of $50 \%$ in relation with fabrication with aluminum. Depending on the milling technique employed, the rounded corners appear in the resonant cavities or in the coupling windows. A suitable combination of design techniques (ASM, MASM, segmentation and hybridization of optimization algorithms) has been used to design $\mathrm{H}$ plane coupled cavities filters with rounded corners of large radius. Three prototypes have been manufactured, and their responses have been measured with a network analyzer. When this new fabrication method is improved and achieves the typical tolerances of the space industry, low cost fabrication with lighter materials is expected to be possible without the need of tuning elements. 


\subsection{Efficient Modal Analysis of Arbitrarily Shaped H- Plane Two-Port Waveguide Devices using the 2D Parallel-Plate Green's Function}

\subsubsection{Introduction}

The integral-equation (IE) technique has been widely applied to the accurate analysis of antennas and scattering problems in free-space [PRM97, CJMS00]. In order to solve the integral equations arising in such problems, where no boundary conditions are imposed to the required Green's function, the well-known Method of Moments (MoM) is typically employed [Har01]. This set of numerical techniques can also be successfully applied to electromagnetic problems with boundary conditions, such as the full-wave analysis of H-plane problems in waveguide technology [GN90, $\left.\mathrm{RMM}^{+} 92, \mathrm{CABP} 96\right]$. This kind of problems are of great practical interest, since many rectangular waveguide devices based on inductive metal obstacles are widely used in telecommunication applications, as it can be inferred from several recent publications [Gug94, $\mathrm{ABR}^{+}$97, YVP98, $\mathrm{MW}$ 9, $\mathrm{ECB}^{+}$02b].

In order to solve $\mathrm{H}$-plane rectangular waveguide problems, it is necessary to make use of an appropriate Green's function including the corresponding metal boundary conditions, which represents the scattering of an infinite line source between two parallel plates [Tai94]. The Green's function for a parallel-plate waveguide (PPW), defined as the summation of a series of guided modes [Col90], has been previously used to solve the scattering of a single inductive post in a rectangular waveguide [LLAP83, LSA84]. Other IE techniques have also made use of such Green's function for the analysis of an arbitrary number of 2D metallic posts placed inside a rectangular waveguide [LALP84, AB84]. However, the proposed PPW Green's function consists of slowly convergent series, whose convergence rate has been accelerated either using the Kummer's transformation [LLAP83, AB84], or employing particular basis functions in the application of MoM [LALP84]. Nevertheless, the kind of inductive geometries that can be successfully considered following such techniques is restricted.

In this paper, we propose an alternative solution for improving the accuracy and numerical efficiency related to the modal analysis of arbitrarily shaped H-plane 2-port waveguide devices using the PPW Green's function. Instead of directly evaluating the cited Green's function in series form, we propose to evaluate first the integrals related to the application of the MoM-based integral-equation technique considering spatially distributed currents, and then proceed with the summation of the resulting terms. Proceeding in this way, we prove that the convergence rate of this new algorithm is increased with regard to any other previous classical solution. Furthermore, the use of distributed sources also allows to place them along the metallic contour of the scatterer, thus greatly improving the accuracy related to this new 
analysis technique. For validating all the advantages related to this new technique, we have successfully applied it to the full-wave analysis of several inductively coupled rectangular waveguide filters, even considering typical rounded corners mechanization effects related to milling manufacturing techniques.

\subsubsection{Problem formulation}

The aim of this work is the analysis of H-plane structures in rectangular waveguide technology. These structures, when fed with the fundamental mode $T E_{10}$, only excite $T E_{n 0}$ modes [Bal89]. If we use the coordinate system of Figure 3.19, this means that only $H_{x}$, $H_{y}$ and $E_{z}$ components are nonzero. Thus, the analysis can be reduced to a $2 \mathrm{D} z$-invariant scattering problem with $T M^{z}$ incidence, and it is not necessary to consider the upper and lower walls of the guide.

The incident $\left(E_{z}^{i}\right)$ and scattered fields $\left(E_{z}^{s}\right)$ can be related through [PRM97]:

$$
E_{z}^{s}(x, y)=\jmath k \eta \int_{T} J_{z}\left(x \prime, y^{\prime}\right) G\left(x, y ; x \prime, y^{\prime}\right) d t^{\prime}
$$

where $T$ stands for the scatterer contour, $k$ is the wave number, $\eta$ is medium impedance, $(x, y)$ is the location of the field point, $\left(x^{\prime}, y^{\prime}\right)=\left(x \prime(t \prime), y^{\prime}\left(t^{\prime}\right)\right)$ is the source point, and $G$ is the PPW Green's function.

The PPW Green's function represents the scattering of a line source placed at $\left(x^{\prime}, y^{\prime}\right)$ between two parallel plates. Thus, it must accomplish the following boundary conditions:

$$
G\left(x, 0, x \prime, y^{\prime}\right)=0 \quad G\left(x, a, x \prime, y^{\prime}\right)=0
$$

and the following wave equation:

$$
\nabla^{2} G\left(x, y ; x^{\prime}, y^{\prime}\right)+k^{2} G\left(x, y ; x^{\prime}, y^{\prime}\right)=\delta\left(x-x^{\prime}\right) \delta\left(y-y^{\prime}\right)
$$

It is possible to obtain an analytical expression for $G$ in series form [Duf01]:

$$
G\left(x, y ; x^{\prime}, y^{\prime}\right)=\frac{\jmath}{a} \sum_{m=1}^{\infty} \frac{\sin \left(\frac{m \pi}{a} y\right) \sin \left(\frac{m \pi}{a} y^{\prime}\right)}{\beta_{m}} e^{-\jmath \beta_{m}\left|x-x^{\prime}\right|}
$$

where $\beta_{m}=\sqrt{k^{2}-\left(\frac{m \pi}{a}\right)^{2}}$

In this case, the electric field has only $z$ component, so the total field must vanish at the contour of the scatterers:

$$
\left.E_{z}^{s}\right|_{T}+\left.E_{z}^{i}\right|_{T}=0
$$




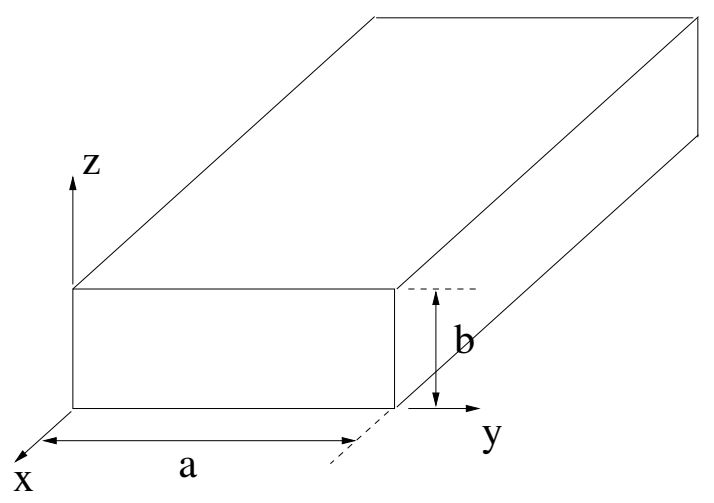

Figura 3.19: Coordinate system used in the rectangular waveguide

which leads to

$$
E_{z}^{i}(x, y)=-\jmath k \eta \int_{T} J_{z}\left(x^{\prime}, y^{\prime}\right) G\left(x, y, x^{\prime}, y^{\prime}\right) d t^{\prime}
$$

where $(x, y)$ is any point along the contour of the scatterers.

\subsubsection{MoM discretization}

To discretize (3.22) using MoM, pulses are used as basis functions and deltas as test functions, which is known as point matching [Har01].

The contour of the 2D scatterers is split into a finite set of cells, $c_{n} n=1,2, \ldots, N$. Each basis function $n$ is a pulse that will be nonzero only inside the $n$th cell:

$$
p_{n}(t)= \begin{cases}1, & \text { if } \mathrm{t} \in c_{n} \\ 0, & \text { elsewhere }\end{cases}
$$

The current is approximated by a linear combination of the basis functions:

$$
J_{z}(x, y)=J_{z}(x(t), y(t))=J_{z}(t) \approx \sum_{n=1}^{N} j_{n} p_{n}(t)
$$

Substituting in (3.22),

$$
E_{z}^{i}(x, y)=-\jmath k \eta \sum_{n=1}^{N} j_{n} \int_{c_{n}} G\left(x, y, x^{\prime}, y^{\prime}\right) d t^{\prime}
$$


Using $N$ delta functions placed at the center of each cell as test functions, we obtain

$$
E_{z}^{i}\left(x_{m}, y_{m}\right)=\sum_{n=1}^{N} j_{n}\left[-\jmath k \eta \int_{c_{n}} G\left(x_{m}, y_{m}, x^{\prime}, y^{\prime}\right) d t^{\prime}\right]
$$

where $\left(x_{m}, y_{m}\right)$ is the center of the $m$ th cell. In matrix form we have,

$$
E_{z}^{i}\left(x_{m}, y_{m}\right)=\sum_{n=1}^{N} Z_{m n} j_{n}, \quad m \in[1, \cdots, N]
$$

where

$$
Z_{m n}=-\jmath k \eta \int_{c_{n}} G\left(x_{m}, y_{m}, x^{\prime}, y^{\prime}\right) d t^{\prime}
$$

In order to compute the elements $Z_{m n}$, we will treat all cells as if they were strips, with a straight contour. This will speed up the calculations, and not much error will be introduced because all cells will be electrically very small. Using this approximation, we obtain

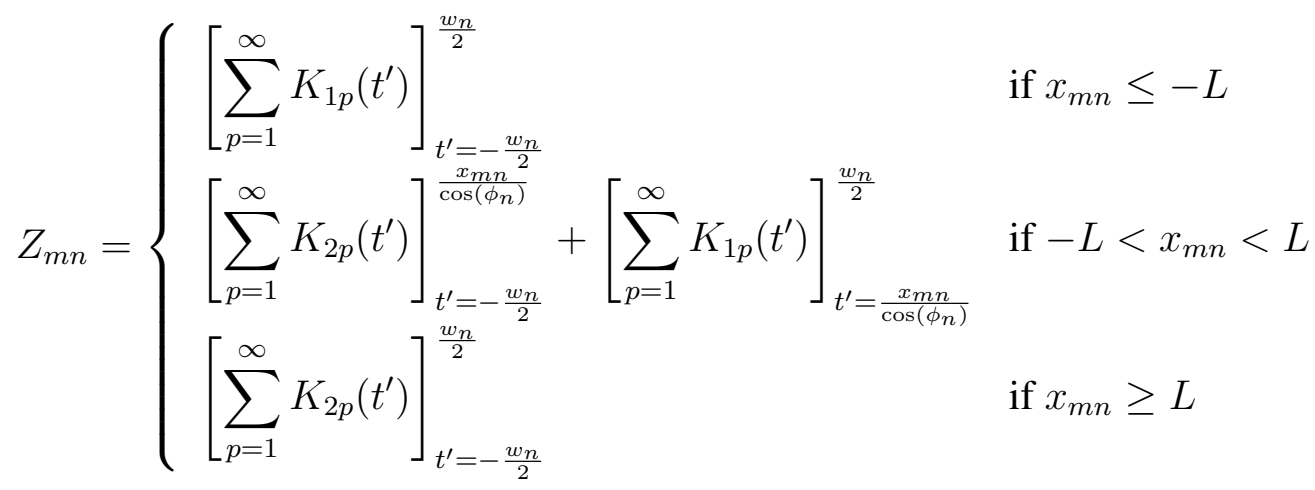

where

$$
\begin{aligned}
& K_{1 p}\left(t^{\prime}\right)=\frac{k \eta}{a} \cdot \frac{\sin \left(\frac{p \pi}{a} y_{m}\right)}{\beta_{p}} \cdot \frac{\left\{k_{1} \cos (\theta)-k_{2} \sin (\theta)\right\} e^{k_{2} t^{\prime}}}{-\left(k_{1}^{2}+k_{2}^{2}\right)} e^{j \beta_{p} x_{m n}} \\
& K_{2 p}\left(t^{\prime}\right)=\frac{k \eta}{a} \cdot \frac{\sin \left(\frac{p \pi}{a} y_{m}\right)}{\beta_{p}} \cdot \frac{\left\{k_{1} \cos (\theta)+k_{2} \sin (\theta)\right\} e^{-k_{2} t^{\prime}}}{-\left(k_{1}^{2}+k_{2}^{2}\right)} e^{-j \beta_{p} x_{m n}}
\end{aligned}
$$


and

$$
\begin{aligned}
L & =\frac{w_{n}}{2} \cos \left(\phi_{n}\right) \\
\theta & =k_{1} t^{\prime}+k_{3} \\
x_{m n} & =x_{m}-x_{n} \\
k_{1} & =\frac{p \pi}{a} \sin \left(\phi_{n}\right) \\
k_{2} & =-j \beta_{p} \cos \left(\phi_{n}\right) \\
k_{3} & =\frac{p \pi}{a} y_{n}
\end{aligned}
$$

In the above expressions, $\left(x_{n}, y_{n}\right), w_{n}$ and $\phi_{n}$ mean, respectively, the center position, length, and angle with the $x$ axis of the $n$th cell.

The main advantage of this new method is that the series in (3.29) converge faster than the series of the original Green's function of equation (3.20).

\subsubsection{Computation of scattering parameters}

Solving the matrix system defined by (3.27), we obtain the amplitudes $j_{n}$ of the basis functions that approximate the current along the surface of the scatterers. This information must be used to compute the scattering parameters that characterize the guided structure.

Since only $T E_{p 0}$ modes are excited in the structure, the electric field can be expanded in terms of these modes according to the following expression [Mar86]:

$$
\begin{aligned}
E_{z}(x, y) & =\sum_{p=1}^{\infty} a_{i}^{p}(x) \sqrt{\frac{2 Z_{0 p}}{a b}} \sin \left(\frac{p \pi}{a} y\right) \\
& +\sum_{p=1}^{\infty} b_{i}^{p}(x) \sqrt{\frac{2 Z_{0 p}}{a b}} \sin \left(\frac{p \pi}{a} y\right)
\end{aligned}
$$

where $i=1$ for the input guide, $i=2$ for the output guide, and:

$$
\begin{aligned}
a_{1}^{p}(x) & =a_{1}^{p} e^{-j \beta_{p} x} \\
a_{2}^{p}(x) & =a_{2}^{p} e^{j \beta_{p} x} \\
b_{1}^{p}(x) & =b_{1}^{p} e^{j \beta_{p} x} \\
b_{2}^{p}(x) & =b_{2}^{p} e^{-j \beta_{p} x} \\
Z_{0 p} & =\omega \mu / \beta_{p}
\end{aligned}
$$


The scattering parameters are defined as

$$
S_{i j}^{(p, q)}=\left.\frac{b_{i}^{p}\left(X_{i}\right)}{a_{j}^{q}\left(X_{j}\right)}\right|_{a_{i}^{q}\left(X_{i}\right)=0, \forall q, a_{j}^{p}\left(X_{j}\right)=0, \forall p \neq q}
$$

where $X_{i}(i=[1,2])$ is the $x$ coordinate of the position of the reference planes at the input $(i=1)$ and output $(i=2)$ ports.

Substituting (3.20) and (3.24) in (3.17), we obtain the field scattered by any object placed inside the guide, that is, between the parallel plates:

$$
\begin{aligned}
& E_{z}^{s}\left(X_{2}, y\right)=\sum_{p=1}^{\infty} \sin \left(\frac{p \pi}{a} y\right) e^{-j \beta_{p} X_{2}} \sum_{n=1}^{N} j_{n} A_{p n}^{+} e^{j \beta_{p} x_{n}} \\
& E_{z}^{s}\left(X_{1}, y\right)=\sum_{p=1}^{\infty} \sin \left(\frac{p \pi}{a} y\right) e^{j \beta_{p} X_{1}} \sum_{n=1}^{N} j_{n} A_{p n}^{-} e^{-j \beta_{p} x_{n}}
\end{aligned}
$$

where

$$
\begin{aligned}
& A_{p n}^{+}=-\frac{k \eta}{a} \frac{1}{\beta_{p}} \frac{\left[\left\{k_{1} \cos (\theta)+k_{2} \sin (\theta)\right\} e^{-k_{2} t^{\prime}}\right]_{-w_{n} / 2}^{w_{n} / 2}}{-\left(k_{1}^{2}+k_{2}^{2}\right)} \\
& A_{p n}^{-}=-\frac{k \eta}{a} \frac{1}{\beta_{p}} \frac{\left[\left\{k_{1} \cos (\theta)-k_{2} \sin (\theta)\right\} e^{k_{2} t^{\prime}}\right]_{-w_{n} / 2}^{w_{n} / 2}}{-\left(k_{1}^{2}+k_{2}^{2}\right)}
\end{aligned}
$$

and $\theta=k_{1} t^{\prime}+k_{3}$.

Comparing (3.39) and (3.40) with (3.32), we can derive the amplitudes of the waves scattered by the object inside the guide at the input and output reference planes:

$$
\begin{aligned}
b_{1}^{p}\left(X_{1}\right) & =e^{j \beta_{p} X_{1}} \sqrt{\frac{a b}{2 Z_{0 p}} \sum_{n=1}^{N} j_{n} A_{p n}^{-} e^{-j \beta_{p} x_{n}}} \\
b_{2}^{p}\left(X_{2}\right) & =e^{-j \beta_{p} X_{2}} \sqrt{\frac{a b}{2 Z_{0 p}}} \sum_{n=1}^{N} j_{n} A_{p n}^{+} e^{j \beta_{p} x_{n}}
\end{aligned}
$$

To compute $S_{11}$ and $S_{21}$, we excite the guide with the following incident field:

$$
E_{z}^{i}(x, y)=\sin \left(\frac{q \pi}{a} y\right) e^{-\jmath \beta_{q} x}
$$

and use equation (3.27) to compute the weights $j_{n}$ that define the current induced over the surface of the metallic object placed inside the guide. These weights are substituted in (3.43). 
Comparing (3.44) with (3.32), we derive the value of the incident waves to the object inside the guide at the input and output reference planes:

$$
\begin{aligned}
& a_{1}^{q}(x)=\sqrt{\frac{a b}{2 Z_{0 q}}} e^{-j \beta_{q} x} \\
& a_{2}^{q}(x)=0
\end{aligned}
$$

Finally,

$$
\begin{aligned}
S_{11}^{(p, q)} & =\frac{b_{1}^{p}\left(X_{1}\right)}{a_{1}^{q}\left(X_{1}\right)} \\
& =\frac{\sqrt{Z_{0 q}} e^{j \beta_{p} X_{1}}}{\sqrt{Z_{0 p}} e^{-j \beta_{q} X_{1}}} \sum_{n=1}^{N} j_{n} A_{p n}^{-} e^{-j \beta_{p} x_{n}}
\end{aligned}
$$

For $S_{21}$, we have to distinguish between two possibilities:

- $q=p$ :

$$
\begin{aligned}
S_{21}^{(p, p)} & =\frac{b_{2}^{p}\left(X_{2}\right)+a_{1}^{p}\left(X_{2}\right)}{a_{1}^{p}\left(X_{1}\right)} \\
& =\frac{e^{-j \beta_{p} X_{2}}}{e^{-j \beta_{p} X_{1}}}\left(\sum_{n=1}^{N} j_{n} A_{p n}^{+} e^{j \beta_{p} x_{n}}+1\right)
\end{aligned}
$$

- $q \neq p$ :

$$
\begin{aligned}
S_{21}^{(p, q)} & =\frac{b_{2}^{p}\left(X_{2}\right)}{a_{1}^{q}\left(X_{1}\right)} \\
& =\frac{\sqrt{Z_{0 q}} e^{-j \beta_{p} X_{2}}}{\sqrt{Z_{0 p}} e^{-j \beta_{q} X_{1}}} \sum_{n=1}^{N} j_{n} A_{p n}^{+} e^{j \beta_{p} x_{n}}
\end{aligned}
$$

To compute $S_{12}$ and $S_{22}$, we change the excitation to the second port:

$$
E_{z}^{i}(x, y)=\sin \left(\frac{q \pi}{a} y\right) e^{\jmath \beta_{q} x}
$$

and recompute the current weights $j_{n}$. Now, the incident waves are defined as:

$$
\begin{aligned}
& a_{1}^{q}(x)=0 \\
& a_{2}^{q}(x)=\sqrt{\frac{a b}{2 Z_{0 q}}} e^{j \beta_{q} x}
\end{aligned}
$$


and:

$$
\begin{gathered}
S_{22}^{(p, q)}=\frac{\sqrt{Z_{0 q}} e^{-j \beta_{p} X_{2}}}{\sqrt{Z_{0 p}} e^{j \beta_{q} X_{2}}} \sum_{n=1}^{N} j_{n} A_{p n}^{+} e^{j \beta_{p} x_{n}} \\
S_{12}^{(p, p)}=\frac{e^{j \beta_{p} X_{1}}}{e^{j \beta_{p} X_{2}}}\left(\sum_{n=1}^{N} j_{n} A_{p n}^{-} e^{-j \beta_{p} x_{n}}+1\right) \\
S_{12}^{(p, q)}=\frac{\sqrt{Z_{0 q}} e^{j \beta_{p} X_{1}}}{\sqrt{Z_{0 p}} e^{j \beta_{q} X_{2}}} \sum_{n=1}^{N} j_{n} A_{p n}^{-} e^{-j \beta_{p} x_{n}}
\end{gathered}
$$

\subsubsection{Convergence analysis}

The computation of the $Z_{m n}$ elements of equation (3.29) involves the summation of an infinite series over the index $p$. This series must be truncated, and only a finite number of terms $P$ can be considered in the computer.

Following the same idea of [LLAP83, LSA84, LALP84, AB84], we can define an auxiliary series that allows us to accelerate the summation of (3.29). In order to do that, we substitute $\beta_{p}$ and $k_{1}^{2}+k_{2}^{2}$ by asymptotically equivalent expressions:

$$
\begin{aligned}
& \beta_{p}=-j \sqrt{\left(\frac{p \pi}{a}\right)^{2}-k^{2}} \longleftrightarrow-\jmath \frac{p \pi}{a} \\
& k_{1}^{2}+k_{2}^{2}=\left(\frac{p \pi}{a}\right)^{2}-k^{2} \cos ^{2} \phi \longleftrightarrow\left(\frac{p \pi}{a}\right)^{2}-\left(\frac{\pi}{a}\right)^{2} p
\end{aligned}
$$

The original and the equivalent expressions converge when $p \rightarrow \infty$.

Substituting $\beta_{p}$ and $k_{1}^{2}+k^{2}$ in (3.30) by their asymptotically equivalent expressions we obtain two new series:

$$
\begin{gathered}
K_{1}^{\prime}\left(t^{\prime}\right)=\sum_{p=2}^{\infty} \frac{k \eta}{a} \frac{\sin \left(\frac{p \pi}{a} y_{m}\right)}{-\jmath \frac{p \pi}{a}} \frac{\left\{k_{1} \cos (\theta)-k_{2}^{\prime} \sin (\theta)\right\} e^{k_{2}^{\prime} t^{\prime}}}{-\left(\left(\frac{p \pi}{a}\right)^{2}-\left(\frac{\pi}{a}\right)^{2} p\right)} e^{\frac{p \pi}{a} x_{m n}}=\sum_{p=2}^{\infty} K_{1 p}^{\prime}\left(t^{\prime}\right) \\
K_{2}^{\prime}\left(t^{\prime}\right)=\sum_{p=2}^{\infty} \frac{k \eta}{a} \frac{\sin \left(\frac{p \pi}{a} y_{m}\right)}{-\jmath \frac{p \pi}{a}} \frac{\left\{k_{1} \cos (\theta)+k_{2}^{\prime} \sin (\theta)\right\} e^{-k_{2}^{\prime} t^{\prime}}}{-\left(\left(\frac{p \pi}{a}\right)^{2}-\left(\frac{\pi}{a}\right)^{2} p\right)} e^{-\frac{p \pi}{a} x_{m n}}=\sum_{p=2}^{\infty} K_{2 p}^{\prime}\left(t^{\prime}\right)
\end{gathered}
$$


where $k_{2}^{\prime}=-\frac{p \pi}{a} \cos \left(\phi_{n}\right)$.

Using the following expression:

$$
\sum_{p=2}^{\infty} \frac{\varepsilon^{p}}{p(p-1)}=(1-\varepsilon) \log (1-\varepsilon)+\varepsilon \text { if }|\varepsilon| \leq 1
$$

the series in (3.55) and (3.56) can be summed analytically:

$$
\begin{aligned}
& K_{1}^{\prime}\left(t^{\prime}\right)=\frac{k \eta}{a} \frac{\jmath}{2}\left(\frac{a}{\pi}\right)^{2}\left[\sin \phi_{n} \operatorname{Im}\left(M_{1}\left(t^{\prime}\right)+M_{2}\left(t^{\prime}\right)\right)-\cos \phi_{n} \operatorname{Re}\left(M_{1}\left(t^{\prime}\right)-M_{2}\left(t^{\prime}\right)\right)\right] \\
& K_{2}^{\prime}\left(t^{\prime}\right)=\frac{k \eta}{a} \frac{\jmath}{2}\left(\frac{a}{\pi}\right)^{2}\left[\sin \phi_{n} \operatorname{Im}\left(M_{3}\left(t^{\prime}\right)+M_{4}\left(t^{\prime}\right)\right)+\cos \phi_{n} \operatorname{Re}\left(M_{3}\left(t^{\prime}\right)-M_{4}\left(t^{\prime}\right)\right)\right]
\end{aligned}
$$

where:

$$
\begin{aligned}
& M_{i}\left(t^{\prime}\right)=\left(1-m_{i}\left(t^{\prime}\right)\right) \log \left(1-m_{i}\left(t^{\prime}\right)\right)+m_{i}\left(t^{\prime}\right), \quad i \in[1,2,3,4] \\
& m_{1}\left(t^{\prime}\right)=e^{\frac{\pi}{a}\left[J\left(y_{m}+y_{n}+t^{\prime} \sin \phi_{n}\right)+\left(x_{m}-x_{n}-t^{\prime} \cos \phi_{n}\right)\right]} \\
& m_{2}\left(t^{\prime}\right)=e^{\frac{\pi}{a}\left[\jmath\left(y_{m}-y_{n}-t^{\prime} \sin \phi_{n}\right)+\left(x_{m}-x_{n}-t^{\prime} \cos \phi_{n}\right)\right]} \\
& m_{3}\left(t^{\prime}\right)=e^{\frac{\pi}{a}\left[\jmath\left(y_{m}+y_{n}+t^{\prime} \sin \phi_{n}\right)-\left(x_{m}-x_{n}-t^{\prime} \cos \phi_{n}\right)\right]} \\
& m_{4}\left(t^{\prime}\right)=e^{\frac{\pi}{a}\left[\jmath\left(y_{m}-y_{n}-t^{\prime} \sin \phi_{n}\right)-\left(x_{m}-x_{n}-t^{\prime} \cos \phi_{n}\right)\right]}
\end{aligned}
$$

Using the auxiliary series previously defined we can reformulate the series of (3.29) and give raise to a new expression that converges faster:

$$
\sum_{p=1}^{\infty} K_{i p}\left(t^{\prime}\right)=K_{i 1}\left(t^{\prime}\right)+\sum_{p=1}^{\infty}\left\{K_{i p}\left(t^{\prime}\right)-K_{i p}^{\prime}\left(t^{\prime}\right)\right\}+K_{i}^{\prime}\left(t^{\prime}\right), \quad i \in[1,2]
$$

The convergence ratio for the series of (3.61) in the worst case (when $x_{m n}=0$ and $Z_{m n}$ represents the interaction between cells not separated along the propagation direction) is:

$$
\left[\frac{p}{\sqrt{p^{2}-\left(\frac{k a}{\pi}\right)^{2}}\left[p^{2}-\left(\frac{k a \cos \phi}{\pi}\right)^{2}\right]}-\frac{1}{p(p-1)}\right]
$$

This convergence ratio is greater than in the method presented in [AB84], where the convergence ratio is:

$$
\left[\frac{1}{\sqrt{p^{2}-\left(\frac{k a}{\pi}\right)^{2}}}-\frac{1}{p}\right]
$$




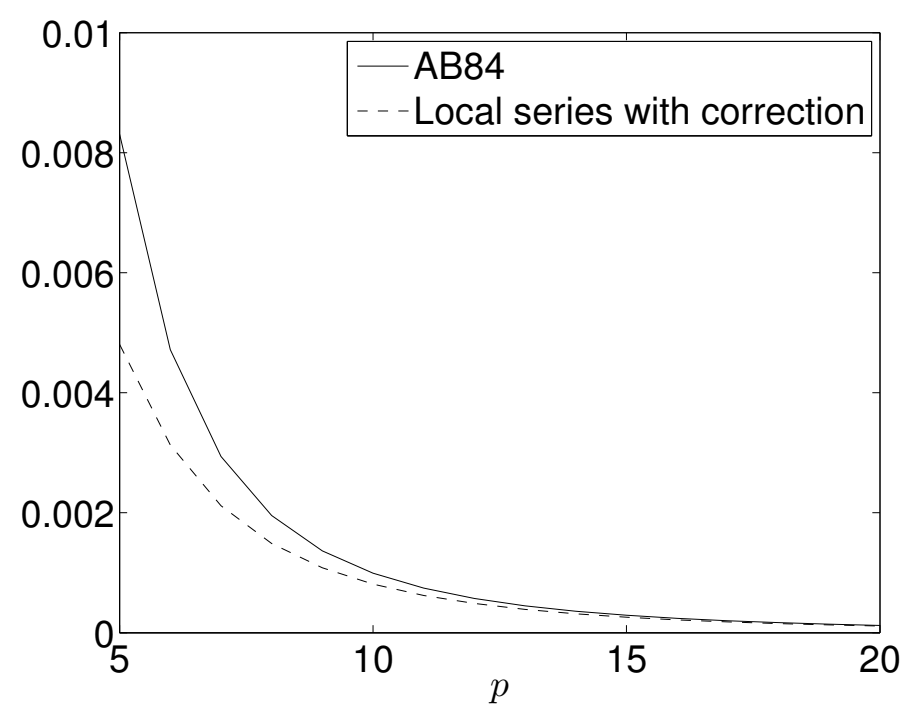

Figura 3.20: Convergence of the corrected series used in the computation of the elements of $\overline{\bar{Z}}$ in $[\mathrm{AB} 84]$ and in this work.

The decreasing term of (3.62) tends to zero faster than the term of (3.63) [AB84], as shown in figure 3.20.

In addition it is necessary to consider that in [AB84] the summation of the series provides with the evaluation of the PPW Green's function, which still must be integrated to obtain the $Z_{m n}$ elements. The authors of [AB84] propose a numerical integration of the summed Green's function, which means that the Green's function needs to be evaluated (and the series summed) several times according to the chosen quadrature rule. In this paper we have integrated analytically the terms of the series prior to its summation. Thus, once the fasterconvergent series has been summed, we have already obtained the $Z_{m n}$ elements, which implies an additional gain in efficiency when compared with the method of [AB84].

A convergence analysis for the corrected series of (3.61) must be performed in order to fix the optimum value of $P$, the maximum value of $p$ that we use to truncate the series. For that purpose, we must first note that this optimum number $P$ strongly depends on the separation $x_{m n}=x_{m}-x_{n}$ along the propagation direction ( $x$ axis) between cells $m$ and $n$. When the cells are far away along $x$, we need very few terms of the series to accurately evaluate it since the exponential terms in (3.30), (3.55) and (3.56) vanish very quickly as $p$ increases. In consequence, two different values for $P$ must be sought. One for the case when $x_{m n}=0$ (worst case), and another for the case when $x_{m n} \neq 0$. We have called $P_{\max }$ to the maximum value of $p$ used to truncate the series when $x_{m n}=0$. When $x_{m n} \neq 0$, we have decided to truncate the series when the modulus of the exponential $e^{-\jmath \beta_{p}\left|x_{m n}\right|}$ decays below a threshold value $\eta$ or $p$ reaches $P_{\max }$, whichever occurs first. 
In order to fix $P_{\max }$, figure 3.21 shows the convergence of the reflection coefficient of the filter of figure 3.32 as a function of $P_{\text {max }}$. For these calculations $\eta$ has been fixed to $10^{-3}$. Results are shown for different densities of MoM basis functions per wavelength $\left(N_{d}\right)$. These results show a great stability and a smooth convergence behaviour when $P_{\max }$ varies. We have chosen $P_{\max }=50$, which ensures very good accuracy in the results.

Figure 3.22 studies the influence of the threshold value $\eta$ in the convergence of the method. As shown in the figure, with $\eta=10^{-3}$ the method has already converged, and this value has been used for all calculations.

Finally, the convergence of the method with the density of MoM basis functions per wavelength is analyzed in Figure 3.23. With $N_{d}=100$, the results are stable, and this value has been used in all calculations. This value is valid for straight segments of the contour of the scatterer. However, the rounded segments are approximated by small straight cells, which makes necessary a higher density of cells, depending on the radius of the curvature of these rounded segments. Figure 3.24 analyzes the convergence of the method with the number of straight cell per radian $\Omega$. All calculations have been made with a density of $\Omega>24 / \pi$ cells per radian for the rounded segments of the scatterer contour.

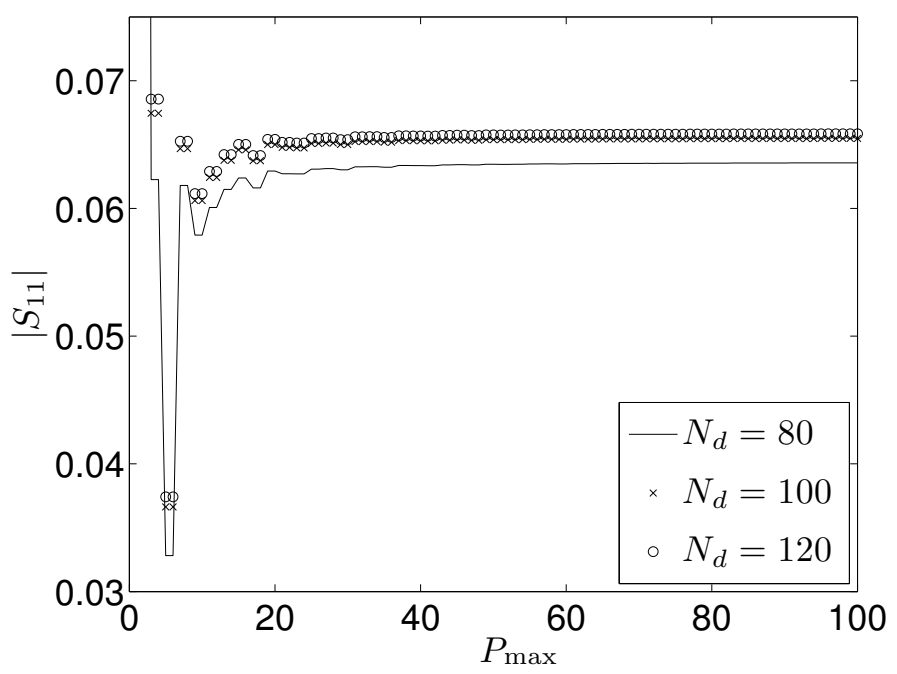

Figura 3.21: Convergence of $S_{11}$ with the number of modes $P_{\max }$ used to truncate the series of (3.61) when $x_{m n}=0$. Results are shown for various densities of MoM basis functions $\left(N_{d}\right)$. Results taken from the analysis of the filter of figure 3.30 at $f=11 \mathrm{GHz} . \eta=10^{-3}$. 


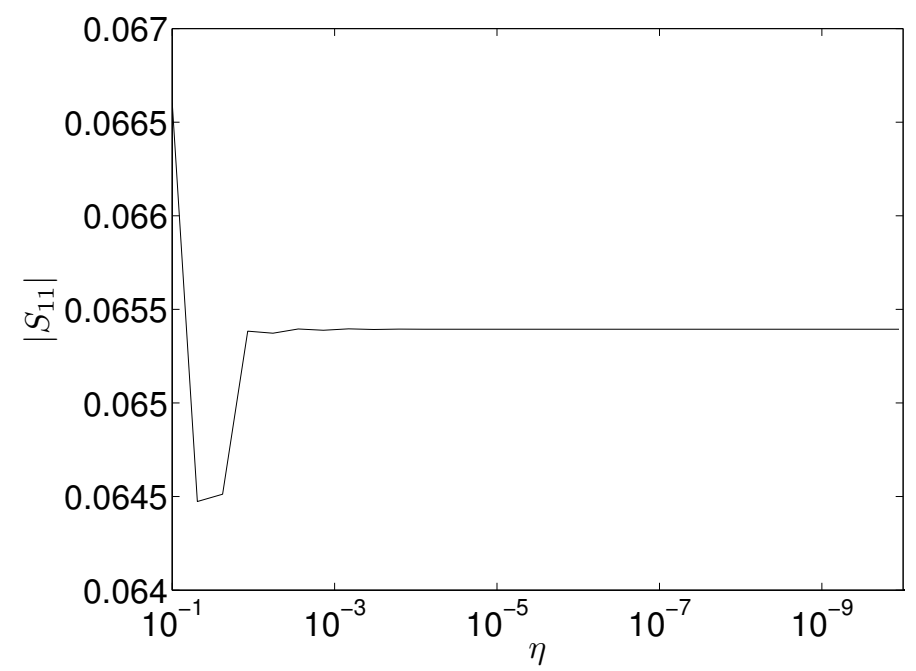

Figura 3.22: Convergence of $S_{11}$ with $\eta$, the threshold value used to truncate the series of (3.61) when $x_{m n} \neq 0$. Results taken from the analysis of the filter of figure 3.30 at $f=11$ GHz. $P_{\max }=50$ and $N_{d}=100$.

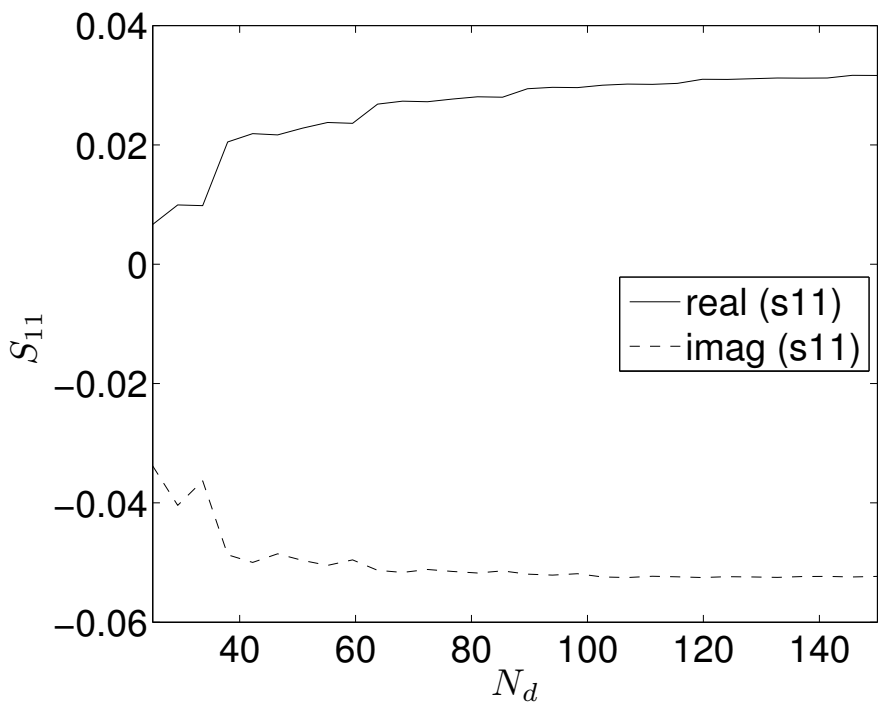

Figura 3.23: Convergence of $S_{11}$ with $N_{d}$, the density of MoM basis functions per wavelength. Results taken from the analysis of the filter of figure 3.30 at $f=11 \mathrm{GHz}$. $P_{\max }=50$ and $\eta=10^{-3}$.

\subsubsection{Results}

The efficiency and accuracy of this new method are tested with the analysis of several $\mathrm{H}$ plane structures in rectangular waveguide. An Intel(R) Pentium(R) $4 \mathrm{CPU}$ of $3.00 \mathrm{GHz}$ 


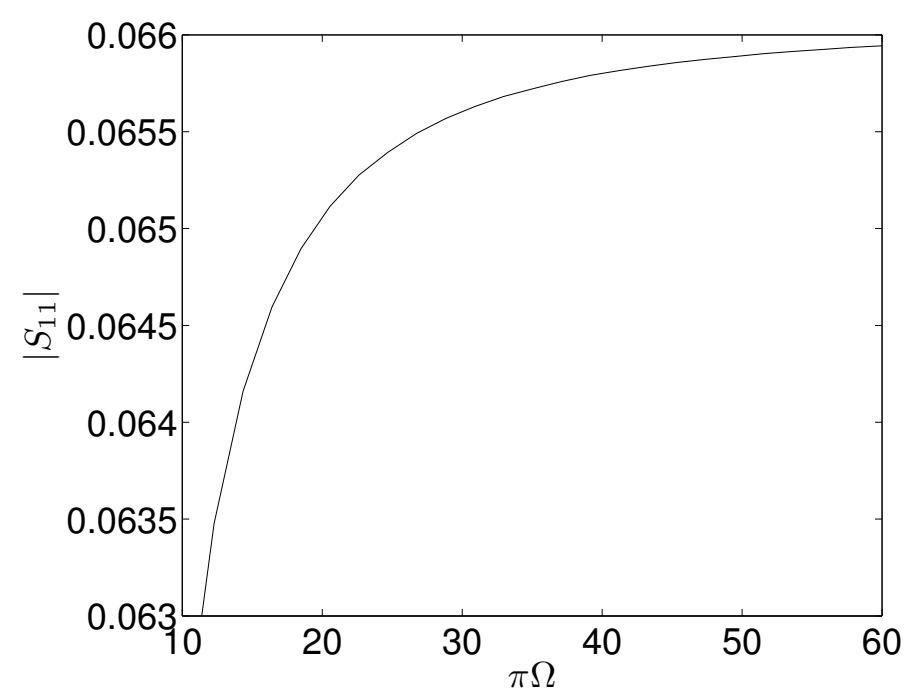

Figura 3.24: Convergence of $S_{11}$ with $\Omega$, the density of MoM basis functions per radian in curved segments. Results taken from the analysis of the filter of figure 3.32 at $f=11 \mathrm{GHz}$. $P_{\max }=50, \eta=10^{-3}$ and $N_{d}=100$.

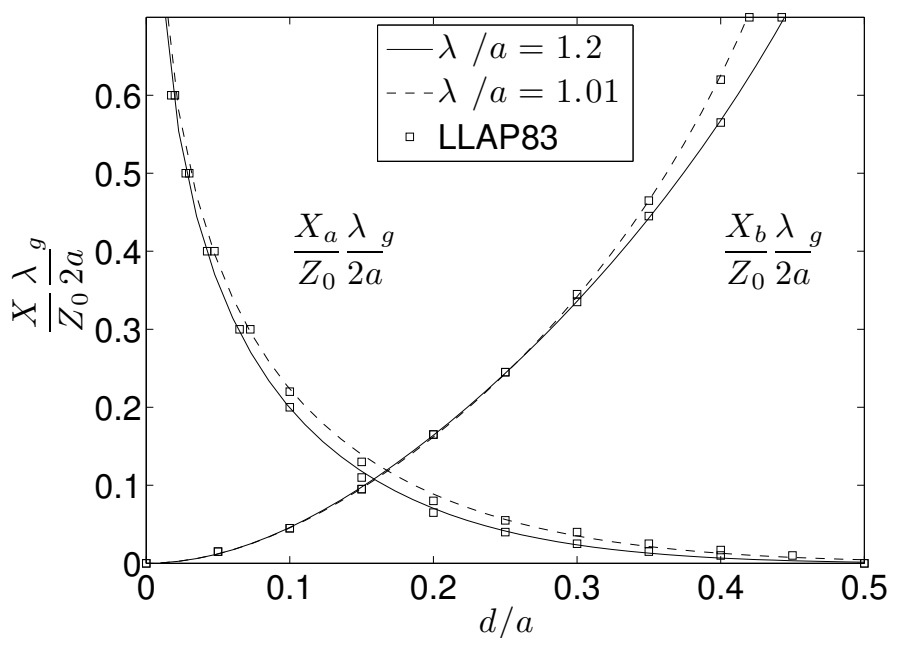

Figura 3.25: Circuital parameters of a centered metallic cylinder of diameter $d\left(P_{\max }=50\right.$, $\eta=10^{-3}, N_{d}=100$ and $\Omega=24 / \pi$ ).

and $1 \mathrm{~GB}$ of RAM has been used for all the calculations.

The analysis of a centered and an off-centered circular metallic post is presented in Figures 3.25 and 3.26. The equivalent circuital parameters $X_{a}$ and $X_{b}$ of the obstacle (see definition in [Mar86]) computed with the new method are compared with the results of [LLAP83]. The off-centered cylinder is placed at $x=0,3 a$, where $a$ is the waveguide width. A good agreement between both results can be observed. The CPU time required by the new method 


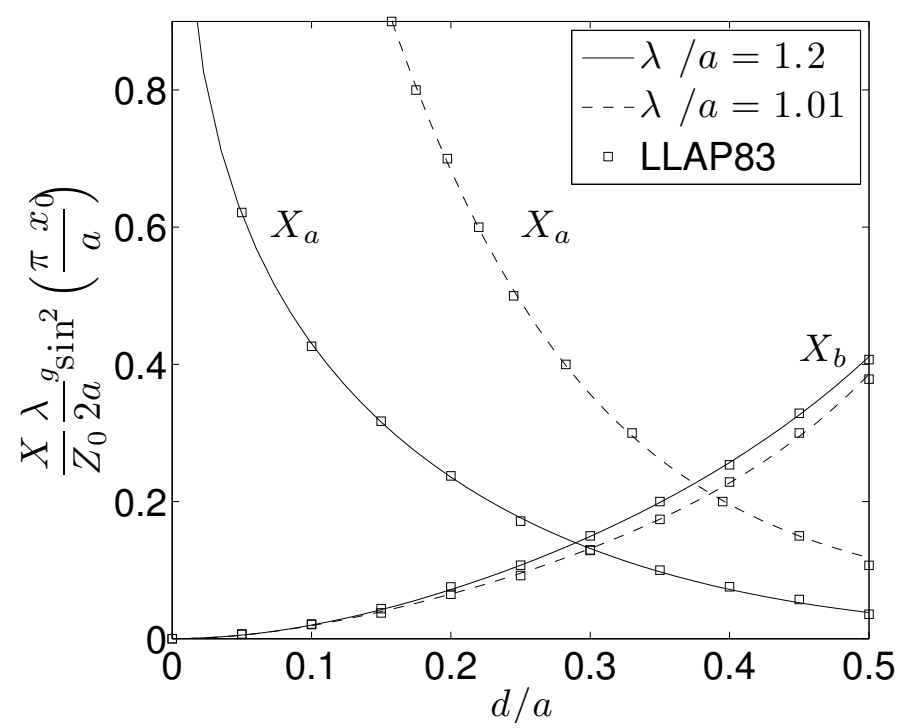

Figura 3.26: Circuital parameters of an off-centered metallic cylinder of diameter $d\left(P_{\max }=\right.$ $50, \eta=10^{-3}, N_{d}=100$ and $\Omega=24 / \pi$ ).

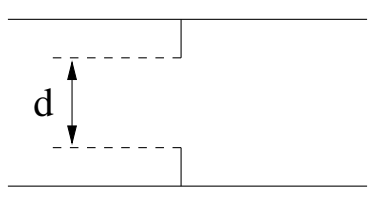

Window

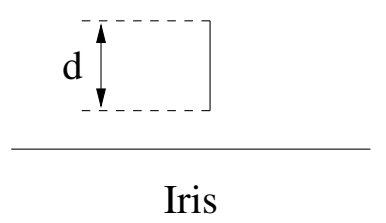

Iris

Figura 3.27: Iris and window analyzed with the new method.

was only $0.1 \mathrm{~s}$ per point. 


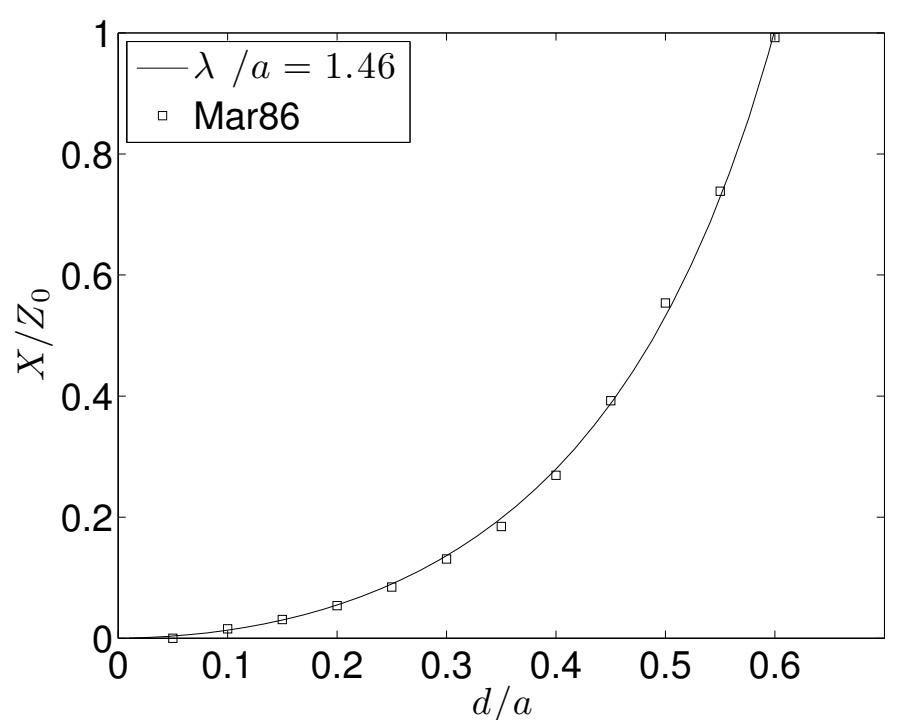

Figura 3.29: Equivalent inductance of the centered window $\left(N_{d}=100, P_{\max }=50, \eta=\right.$ $\left.10^{-3}\right)$.

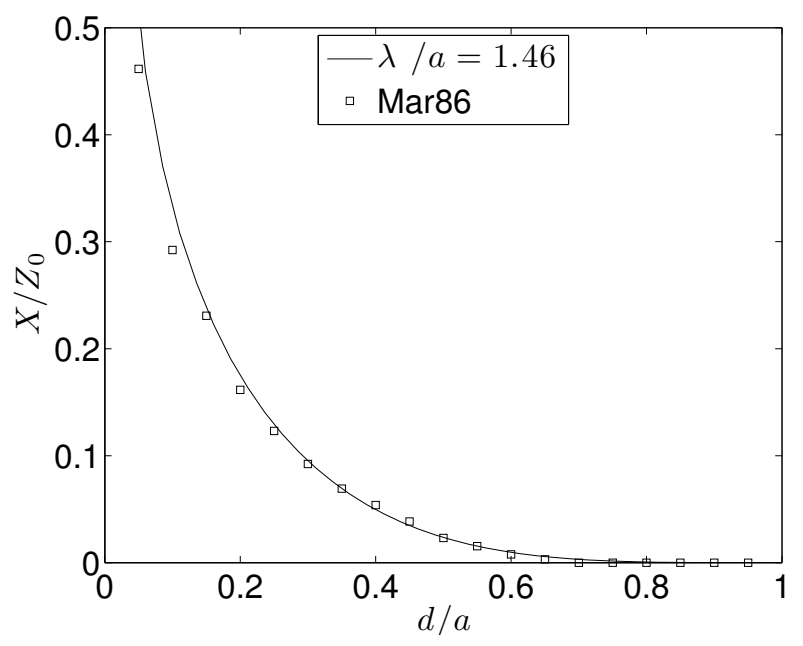

Figura 3.28: Equivalent inductance of the centered metallic iris $\left(N_{d}=100, P_{\max }=50\right.$, $\left.\eta=10^{-3}\right)$.

The new method has also been used for computing the equivalent inductance of an iris and a window centered inside the waveguide, as shown in Figure 3.27. The results have been successfully compared with [Mar86] in Figures 3.28 and 3.29. The CPU time required by the new method was $0.01 \mathrm{~s}$ per point for the iris, and $0.02 \mathrm{~s}$ for the window.

The new method has also been tested with more complex waveguide structures. First, it has been used to analyze a standard H-plane waveguide filter with four rectangular resonator cavities. A top view of the filter with all the dimensions is presented in Figure 3.30. The filter 
electrical response is centered at $11 \mathrm{GHz}$, and the bandwidth is $300 \mathrm{MHz}$.

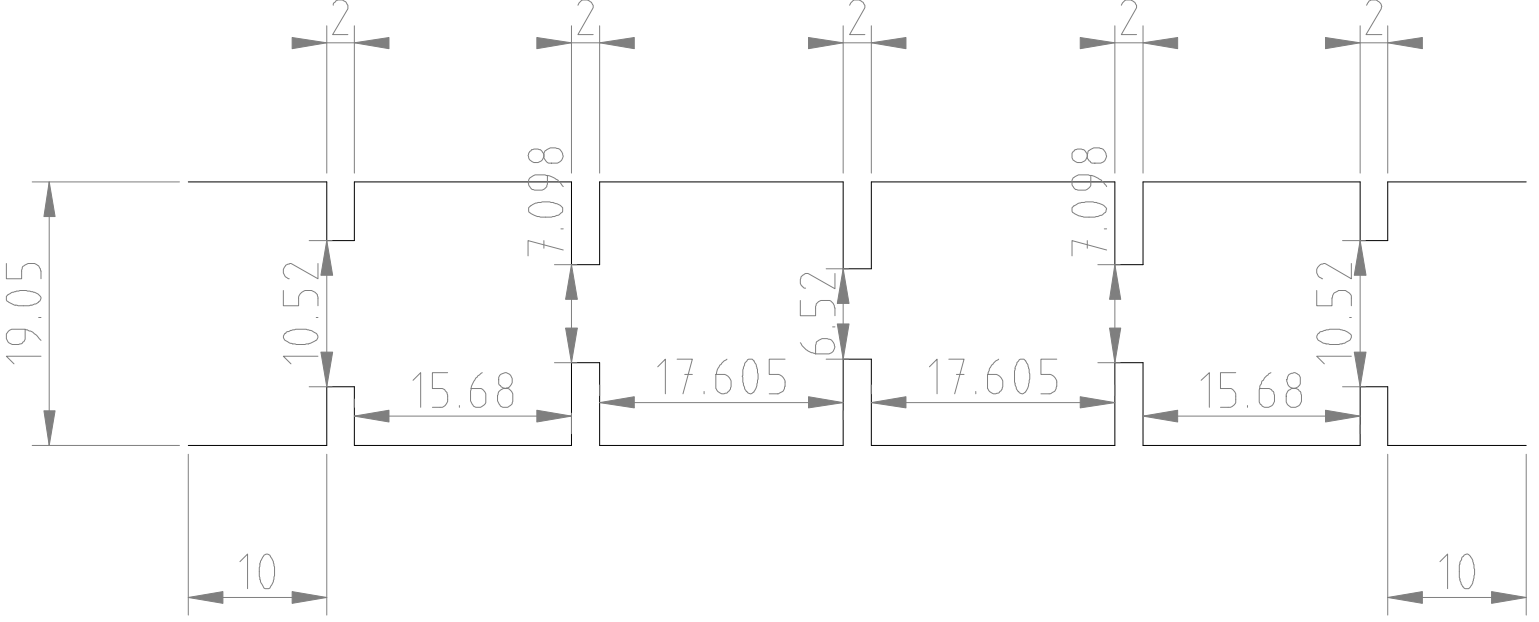

Figura 3.30: Filter with resonator cavities. All dimensions are in $\mathrm{mm}$.

The scattering parameters of the filter are presented in Figure 3.31. A good agreement with the results of [BE97] can be observed. The CPU time was $0.55 \mathrm{~s}$ per frequency point.

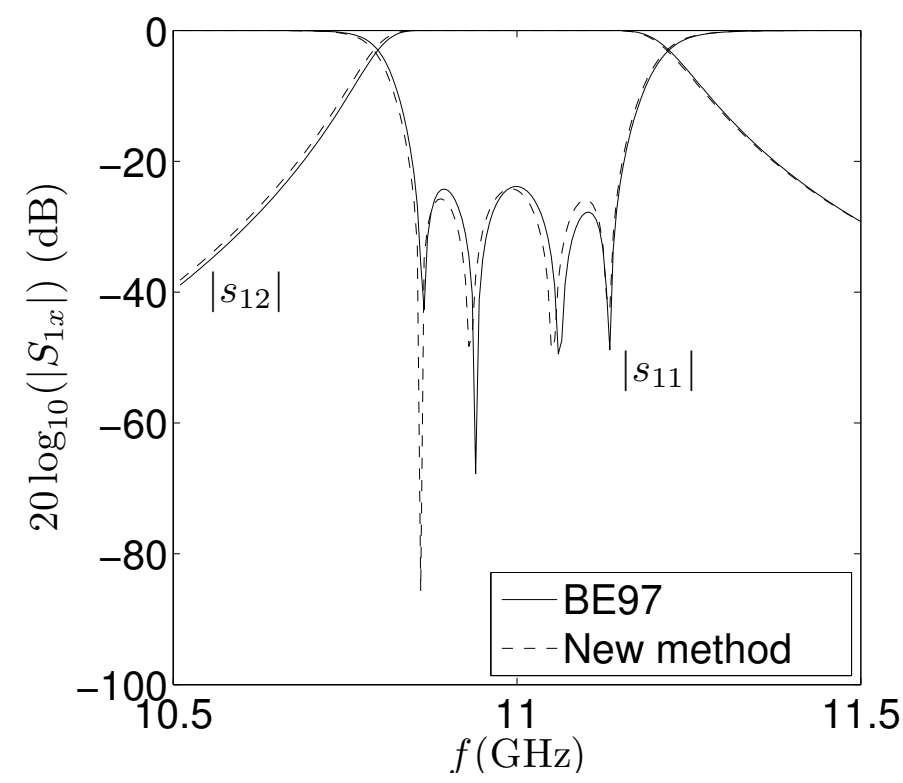

Figura 3.31: Scattering parameters for the four-cavity filter $\left(N_{d}=100, P_{\max }=50, \eta=\right.$ $\left.10^{-3}\right)$.

Finally, the accuracy and efficiency of the new method are tested with the analysis of an inductive filter with four rectangular resonator cavities, but considering rounded corners in the coupling windows. These rounded corners appear due to the mechanization of these 
filters using milling and die casting techniques [MGBB07]. The top view of the filter with all the dimensions is shown in Figure 3.32. The radius of the rounded corners is $1 \mathrm{~mm}$.

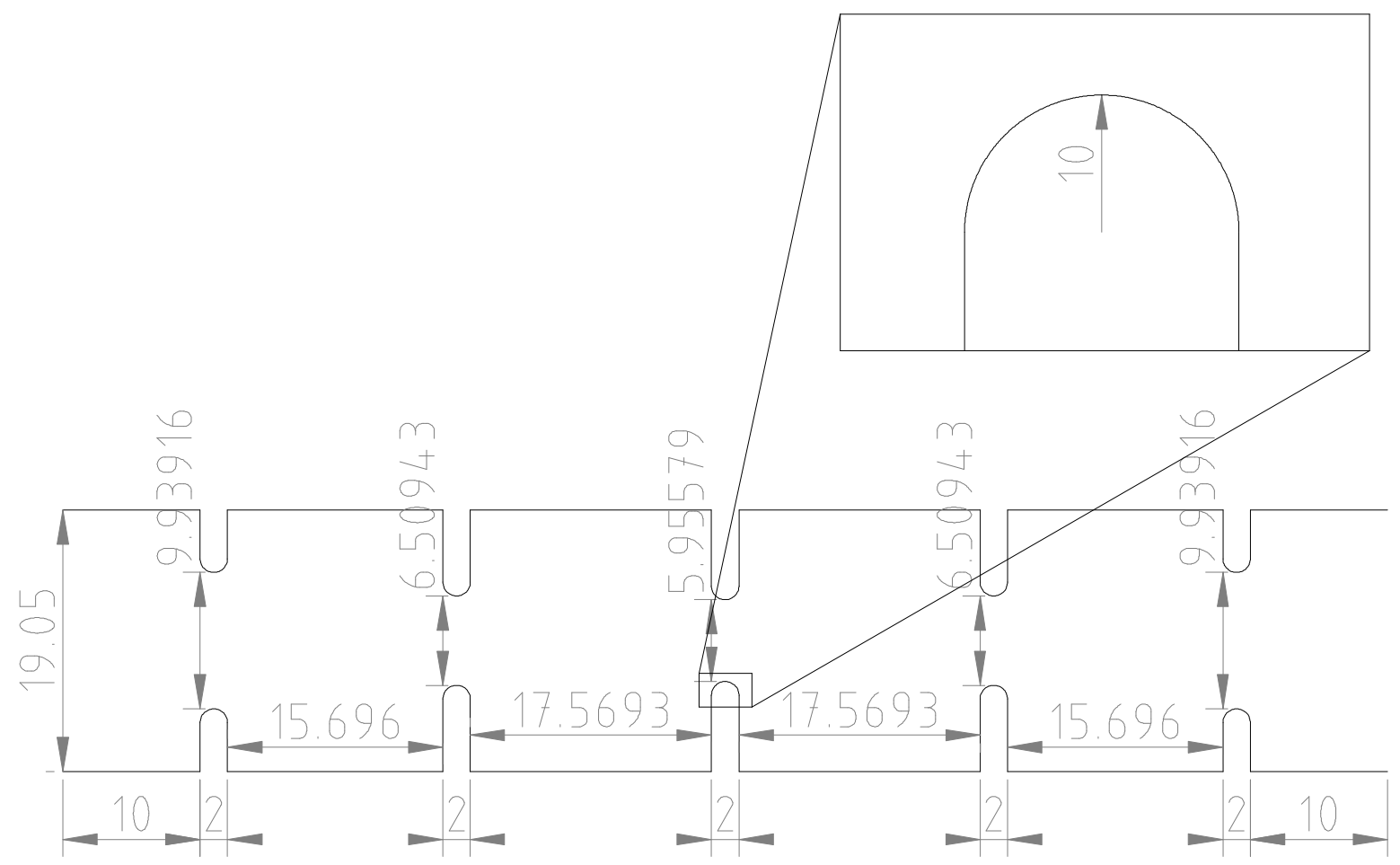

Figura 3.32: Filter with rounded corners $(r=1 \mathrm{~mm})$. All dimensions are in $\mathrm{mm}$.

Figure 3.33 compares the scattering parameters of the filter with rounded corners with the results from $\left[\mathrm{MEB}^{+} 04\right]$. A good agreement between both curves can be observed. The CPU time required was only $0.94 \mathrm{~s}$ per frequency point.

\subsubsection{Conclusions}

A new method for the full-wave analysis of arbitrarily shaped H-plane two-port structures in rectangular waveguide technology is presented. The method is based on the use of the Green's function of an infinite line source placed inside two parallel plates, which is expressed as the summation of an infinite series of guided modes. The new method presented here improves the numerical efficiency of previous classical techniques, which were based on the direct summation of the series related to the cited Green's function. Instead, we propose to integrate the terms of such series within the frame of the MoM, thus resulting in new series expressions which converges faster. 


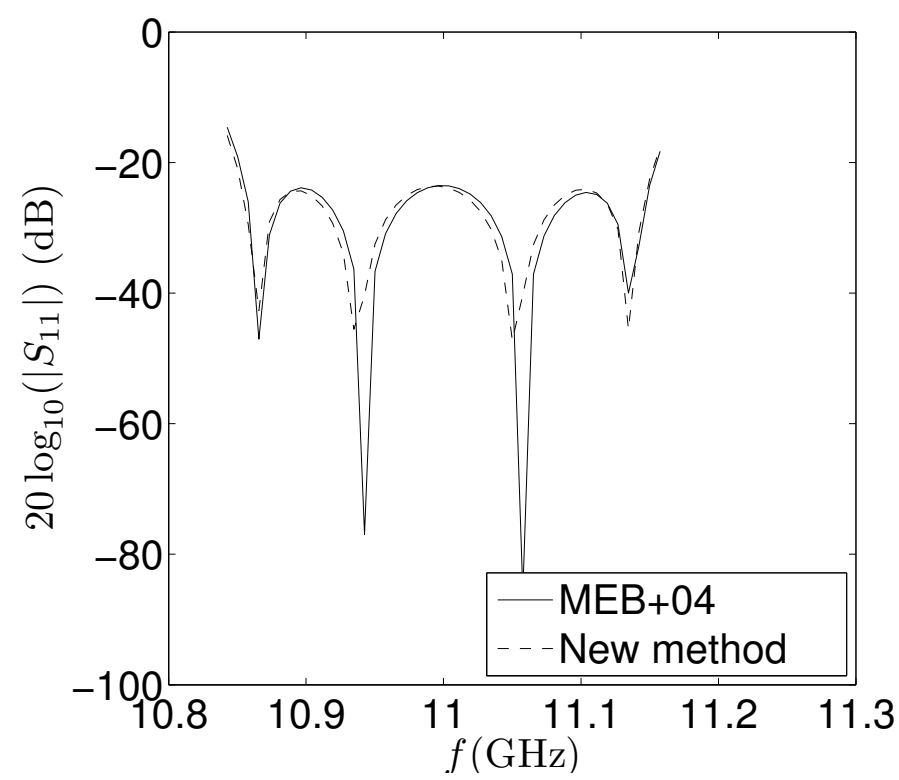

Figura 3.33: Scattering parameters for the four-cavity filter with rounded corners $(r=$ $1 \mathrm{~mm})\left(N_{d}=100, P_{\max }=50, \eta=10^{-3}, \Omega=24 / \pi\right)$.

An exhaustive analysis of the convergence of the new method proposed has been performed, and optimal values for the parameters of the method have been found and used in all calculations, thus ensuring the accuracy of the results in a a very reduced computational effort. Then, the new method has been validated with the analysis of some simple canonical structures. Finally, it has been successfully applied to the efficient analysis of other more complex structures, such as a four-cavity rectangular waveguide filter with rounded corners in the coupling windows. 


\subsection{Highly Efficient Grouping Strategy for the Analysis of Two-Port Arbitrarily Shaped H-Plane Waveguide De- vices}

\subsubsection{Introduction}

The well known method of moments (MoM) [Har93] is typically employed for the analysis of antennas and scattering problems in free-space [PRM97, CJMS00] where no boundary conditions are imposed on the corresponding Green's function. However, the MoM can also be applied to the analysis of electromagnetic problems with boundary conditions, such as $\mathrm{H}$-plane devices in waveguide technology [GN90, $\mathrm{RMM}^{+}$92, CABP96], which are widely used in telecommunication applications, as can be inferred from several recent publications [Gug94, $\mathrm{ABR}^{+}$97, YVP98, MW99, $\mathrm{ECB}^{+}$02b]. To apply the MoM to the analysis of rectangular waveguide H-plane devices, the Green's function of an infinite line source between two parallel plates must be used [Tai94]. This Green's function, defined as the summation of a series of guided modes [Co190], has been previously used to solve the scattering of single [LLAP83, LSA84] or multiple [LALP84, AB84] H-plane posts in a rectangular waveguide. The convergence rate of the summation of this Green's function has been accelerated, either using the Kummer's transformation [LLAP83, AB84], or by employing particular basis functions in the application of MoM [LALP84]. Recently $\left[\mathrm{BEB}^{+} 09\right]$, the convergence rate of the MoM with the Green's function of a line source between parallel plates has been improved by first evaluating the integrals related to the application of MoM, and then summing the resulting terms, instead of first summing the Green's function and then solving the integral equations of MoM, as this was traditionally handled. This new approach simultaneously reduces the computational cost and increases accuracy, as the distributed sources can now be placed along the surface of the scatterer, and no singularity arises bacause it disappears through integration before the Green's function is summed. In this paper we significantly improve the numerical efficiency of the technique presented in $\left[\mathrm{BEB}^{+} 09\right]$ by grouping the radiation of neighbouring MoM contour cells.

The idea of grouping the electromagnetic fields produced by certain groups of cells is not new. This technique has been typically employed in the Fast Multipole Method (FMM) [Rok90, EMRV92, CRW93, SC95a] and in the multilevel fast multipole algorithm [SC95b, SLC97, SJS ${ }^{+}$98], in both cases providing important efficiency improvements. These methods accelerate the solution of the matrix system provided by the MoM, by using an iterative technique such as conjugate gradients, biconjugate gradients, biconjugate gradients stabilized, and others $\left[\mathrm{BCD}^{+} 87\right.$, Saa03, LZL03, PM86, SC95a]. These iterative techniques do not directly solve the matrix system $\boldsymbol{Z} \boldsymbol{\alpha}=\boldsymbol{g}$ of MoM, but instead they approximate the solution $\alpha$ iteratively through multiple matrix-vector products of the form $Z \boldsymbol{a}$. Again these products are not computed directly, but they are evaluated more efficiently thanks to a 
strategy based on three steps: aggregation of the radiation of neighbouring cells into a single radiation pattern; translation; and disaggregation of the incoming field into each MoM cell. Those grouping strategies imply a cost reduction of the matrix-vector product from $O\left(N^{2}\right)$ to $O\left(N^{3 / 2}\right)$ for the fast multipole method, and $O(N \log (N))$ for the multilevel fast multipole algorithm, where $N$ represents the number of discretization cells considered along the scatterer contours.

Due to this important cost reduction, the fast multipole method and the multilevel fast multipole algorithm are widely used in the analysis of complex and large scattering structures. Recent works are focused on improving the accuracy by refining several subprocesses of the grouping strategy, for example, by the anterpolation/interpolation of radiation diagrams of groups [Sar03, EG06], or by using better sets of basis functions in the MoM current expansion [EG07, LCZ07]. Other works try to improve the efficiency by accelerating the convergence of the iterative algorithm used in the matrix system solution [DRCF07, RCWY07, MG07], or trying to parallelize the computations [PS06, $\mathrm{WSC}^{+} 07, \mathrm{VC05}, \mathrm{EG08b}, \mathrm{EG08a]}$. Finally, there are other papers that are focused on using these algorithms for analyzing new $2 \mathrm{D}$ or $3 \mathrm{D}$ structures in free space or in free semi-spaces, as in [ZLL05, LX06, WX06, LLZ08, ZLL08].

In this paper we propose a method for analyzing two-port arbitrarily shaped H-plane devices in rectangular waveguides. This new method uses the technique proposed in [BEB $\left.{ }^{+} 09\right]$ for accelerating the convergence and improving the accuracy of the MoM using the Green's function of a line source among parallel plates waveguide. The numerical efficiency of this technique is improved here with the use of a new grouping strategy inspired by the fast multipole method.

\subsubsection{Acceleration Procedure}

The arbitrarily shaped H-plane waveguide devices are analyzed by applying MoM (pulses as basis functions and deltas as test functions, that is, Point Matching) [Har93], which leads to the following matrix system,

$$
E_{i}=\boldsymbol{Z} \boldsymbol{j}
$$

Once this matrix system is solved, we obtain a set of coefficients $j$ which can be used to reconstruct the current induced over the scatterers contours due to the excitation $\boldsymbol{E}_{i}$. Using the coefficients $\boldsymbol{j}$ it is possible to compute the generalized scattering matrix of the global structure according to the algorithm recently presented in $\left[\mathrm{BEB}^{+} 09\right]$.

The most time consuming process of MoM is solving the matrix system. An alternative to directly solving the matrix system, especially with large matrix systems, is the use of an iterative algorithm such as conjugate gradients, biconjugate gradients, biconjugate gradients 
stabilized, and others [BCD ${ }^{+} 87$, Saa03, LZL03, PM86, SC95a]. These algorithms approximate the solution $\boldsymbol{j}$ iteratively through multiple matrix-vector products of the form $\boldsymbol{Z} \boldsymbol{a}$. These matrix products are also time consuming, but we can obtain an accurate approximation for them if we take into account that they represent the field scattered by the whole structure with current distribution $\boldsymbol{a}$ at the center of each MoM cell. Using this physical interpretation for the product $\boldsymbol{Z} \boldsymbol{a}$ we propose a grouping strategy similar to that used in the fast multipole method. The main difference between those techniques and our method is that they are typically applied to open space problems (i.e. antennas) while our method will be applied to H-plane devices in a rectangular waveguide (see Fig. 3.34). As in the fast multipole method, we approximate the matrix product $\boldsymbol{Z} \boldsymbol{a}$ with a grouping strategy in three independent steps [CRW93, EMRV92]:

1. First, grouping of neighbour cells with the proper combination of their scattered fields into a single "modal radiation pattern".

2. Next, the "modal radiation pattern" is translated to the reference plane of each target group.

3. Finally, the summation of all the "modal radiation patterns" incident over each target group is evaluated at each one of the cells belonging to that group, and this completes a process which is equivalent to the matrix-vector computation.

In the fast multipole method terminology, the first process is named "aggregation", the second one "translation", and the third and last one "disaggregation". We must adapt this grouping strategy to closed problems in order to achieve an important improvement in the global numerical efficiency.

\subsubsection{Aggregation}

In open space, where the field is expanded into open space modes that propagate radially, the grouping of the radiation of neighbour cells is based on a 2-D or 3-D proximity criterion. However, inside an H-plane device in rectangular waveguide, the geometry is invariant in height ( $z$ dimension in Fig. 3.34). Considering that the exciting field is the fundamental $T E_{10}$ mode, which is also invariant along $z$, then all the scattered fields by the H-plane structure are also invariant in height ( $T E_{p 0}$ modes). Therefore the 3-D structure of Fig. 3.34(a) can be reduced to the equivalent 2-D problem of Fig. 3.34(b).

In this case we have to choose another criterion to make groups. Since our field spectrum is a set of guided modes $T E_{p 0}$ propagating either to the right $(+\hat{x})$ or to the left $(-\hat{x})$, we have to make groups according to their separation along the propagation axis $\hat{x}$, so we apply 


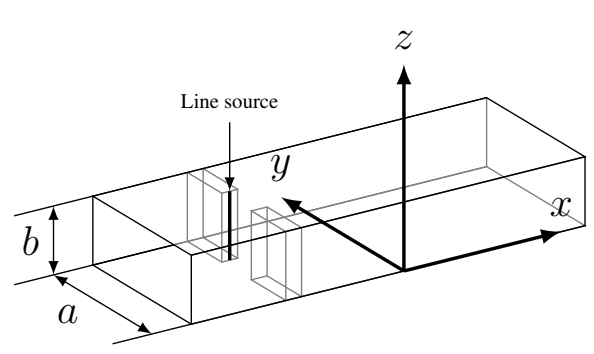

(a) 3-D view

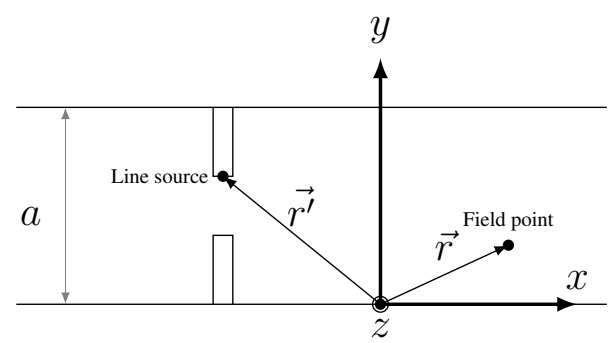

(b) Top view

Figura 3.34: Rectangular waveguide with line source.

a 1-D proximity criterion, and group the $N$ MoM cells (line sources) into $G$ groups as shown in the example of Fig. 3.35. The groups are always ordered from left to right.

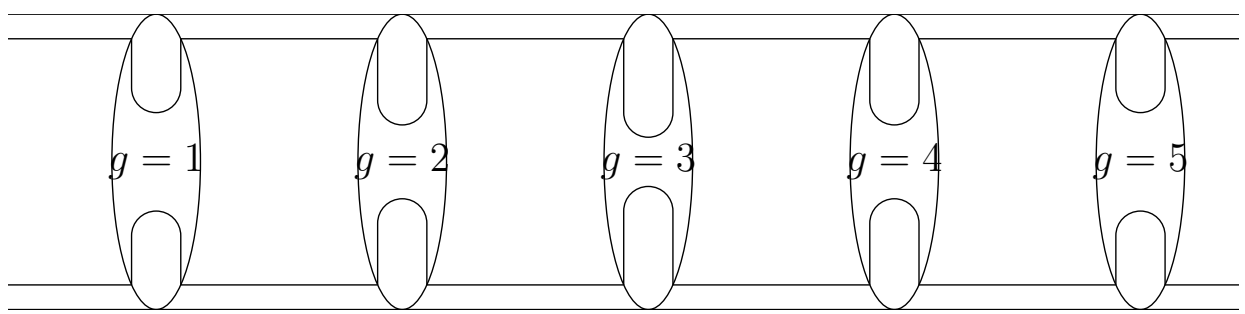

Figura 3.35: Example of the 1-D grouping strategy for a 4-pole coupled cavities H-plane filter with rounded corners in the coupling windows. The MoM cells are grouped into $G=5$ groups.

As in the fast multipole method, we should now find a way to combine the field scattered by all the cells of the same group. Since the field scattered by a line source inside the parallel plates is expanded as a summation of modes propagating either to the right or to the left, we must aggregate the total field scattered by all the cells of a group to the right (propagating towards $+\hat{x}$ ), and to the left (propagating towards $-\hat{x}$ ). We must specify two reference planes, one for the set of modes propagating to the right, and another for the modes propagating to the left (see Fig. 3.36).

Let $g$ be the group that is being processed, $X_{l}^{(g)}$ the position in the $\hat{x}$ axis of the reference plane for left propagating modes, and $X_{r}^{(g)}$ for the right propagating modes. Let $N_{g}$ be the number of cells in the group $g$, and $j_{n}^{(g)}$ the weight of the MoM basis function of the $n$-th cell belonging to that group. Taking everything into consideration and applying the results 


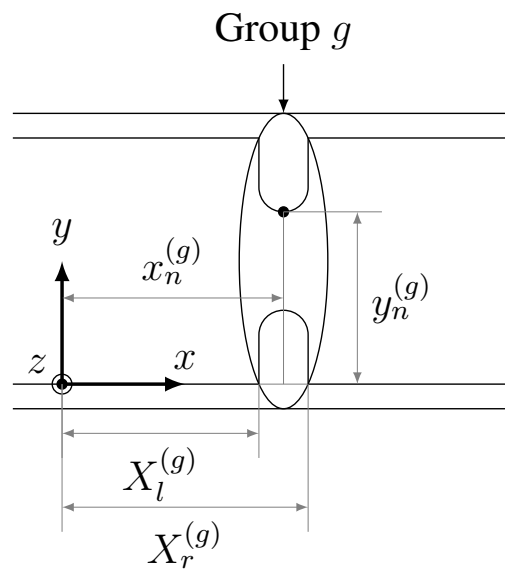

Figura 3.36: Position of the reference planes for right and left propagating modes for the $g$-th group in an H-plane coupled cavities filter. The coordinates of the $n$-th MoM cell are also shown.

of [BEB $\left.{ }^{+} 09\right]$, we can compute the left $\left(\boldsymbol{e}_{l}\right)$ and right $\left(\boldsymbol{e}_{r}\right)$ propagating spectra as:

$$
\begin{aligned}
e_{l, p}^{(g)} & =\sum_{n=1}^{N_{g}} j_{n}^{(g)} A_{p n}^{-} e^{\jmath \beta_{x, p}\left(X_{l}^{(g)}-x_{n}^{(g)}\right)} \\
e_{r, p}^{(g)} & =\sum_{n=1}^{N_{g}} j_{n}^{(g)} A_{p n}^{+} e^{-\jmath \beta_{x, p}\left(X_{r}^{(g)}-x_{n}^{(g)}\right)}
\end{aligned}
$$

where $n$ identifies the MoM cell and $p \in[1 \ldots P]$ identifies the $T E_{p 0}$ guided mode, $T E_{P 0}$ being the higher mode considered for the analysis. The values of $A_{p n}^{+}$and $A_{p n}^{-}$can be found in $\left[\mathrm{BEB}^{+} 09\right]$.

To simplify the expressions we can put them in matrix form. For that purpose we define two new matrices of $P \times N_{g}$ elements:

$$
\begin{aligned}
& \beta_{l, p n}^{(g)}=A_{p n}^{-} e^{j \beta_{x, p}\left(x_{n}^{(g)}-X_{l}^{(g)}\right)} \\
& \beta_{r, p n}^{(g)}=A_{p n}^{+} e^{-j \beta_{x, p}\left(X_{r}^{(g)}-x_{n}^{(g)}\right)}
\end{aligned}
$$

Now the left and right propagating spectra of group $g$ can be computed in matrix form as:

$$
\begin{aligned}
& \boldsymbol{e}_{l}^{(g)}=\boldsymbol{\beta}_{l}^{(g)} \boldsymbol{j}^{(g)} \\
& \boldsymbol{e}_{r}^{(g)}=\boldsymbol{\beta}_{r}^{(g)} \boldsymbol{j}^{(g)}
\end{aligned}
$$

where $\boldsymbol{j}^{(g)}$ is a vector of size $N_{g} \times 1$ and stores the current weights of the MoM cells of the $g$-th $\operatorname{group}\left(j_{n}^{(g)}, n \in\left[1, \ldots, N_{g}\right]\right)$. 


\subsubsection{Translation}

In the aggregation step we have combined the field scattered by all the cells of a group into two spectra, one propagating to the left and another one to the right. The spectra of each group are related to their own reference plane, so to compute the total field incident to a particular group $g$ we must translate all the incoming spectra from other groups to the same reference planes; one for the spectra that come from the left $X_{l}^{(g)}$ and another for the spectra that come from the right $X_{r}^{(g)}$.

The translation of a guided modes spectrum from one to another reference plane only requires a phase shift for each mode, and that depends on the distance from one to another reference plane. To translate the right propagating spectrum of group $g_{1}\left(\boldsymbol{e}_{r}^{\left(g_{1}\right)}\right)$, whose reference plane is $X_{r}^{\left(g_{1}\right)}$, to the left reference plane of group $g_{2}\left(g_{2}\right.$ must be to the right of $\left.g_{1}\right)$, that is, to $X_{l}^{\left(g_{2}\right)}$, we just multiply $\boldsymbol{e}_{r}^{\left(g_{1}\right)}$ by a diagonal matrix $\alpha_{r}^{\left(g_{1}, g_{2}\right)}$ whose elements are

$$
\alpha_{r, p q}^{\left(g_{1}, g_{2}\right)}= \begin{cases}e^{-\jmath \beta_{x, p}\left(X_{l}^{\left(g_{2}\right)}-X_{r}^{\left(g_{1}\right)}\right)} & p=q \\ 0 & p \neq q\end{cases}
$$

Similarly, if we want to translate the left propagating spectrum of group $g_{2}$ to the right reference plane of group $g_{1}$, we must use the diagonal matrix $\alpha_{l}^{\left(g_{2}, g_{1}\right)}$, whose elements are

$$
\alpha_{l, p q}^{\left(g_{2}, g_{1}\right)}= \begin{cases}e^{\jmath \beta_{x, p}\left(X_{r}^{\left(g_{1}\right)}-X_{l}^{\left(g_{2}\right)}\right)} & p=q \\ 0 & p \neq q\end{cases}
$$

Equations (3.71) and (3.72) are identical. Therefore

$$
\boldsymbol{\alpha}_{r}^{\left(g_{1}, g_{2}\right)}=\boldsymbol{\alpha}_{l}^{\left(g_{2}, g_{1}\right)}
$$

and therefore we only need to compute left or right translation matrices.

Once we have computed the translation matrices, we can write an expression for the total field incident to a particular group $g$ coming from the MoM cells of the rest of the groups:

$$
\begin{aligned}
\boldsymbol{i}_{l}^{(g)} & =\sum_{g^{\prime}=g+1}^{G} \boldsymbol{\alpha}_{l}^{\left(g^{\prime}, g\right)} \boldsymbol{e}_{l}^{\left(g^{\prime}\right)} \\
\boldsymbol{i}_{r}^{(g)} & =\sum_{g^{\prime}=1}^{g-1} \boldsymbol{\alpha}_{r}^{\left(g^{\prime}, g\right)} \boldsymbol{e}_{r}^{\left(g^{\prime}\right)}
\end{aligned}
$$

where $\boldsymbol{i}_{l}^{(g)}$ and $\boldsymbol{i}_{r}^{(g)}$ are, respectively, the incoming field spectra from the right and left. The groups are ordered from left to right, so that for a particular group $g$ the groups $g^{\prime}=[1, \ldots, g-1]$ are at the left side of group $g$, and the groups $g^{\prime}=[g+1, \ldots, G]$ are placed at the right side of group $g$, and $G$ being the total number of groups. 


\subsubsection{Disaggregation}

Once we have computed for each group $g$ the incoming spectra from the right $\left(i_{l}^{(g)}\right)$ and from the left $\left(i_{r}^{(g)}\right)$, we must translate each spectrum and evaluate the field at the center $\left(x_{n}^{(g)}, y_{n}^{(g)}\right)$ of each MoM cell $n$ of group $g$. This step is called disaggregation.

The right and left incoming spectra that propagate, respectively, to the left $\left(\boldsymbol{i}_{l}^{(g)}\right)$ and to the right $\left(\boldsymbol{i}_{r}^{(g)}\right)$ can be translated and evaluated at the center $\left(x_{n}^{(g)}, y_{n}^{(g)}\right)$ of the $n$-th cell of group $g$ in matrix form using:

$$
\begin{aligned}
& \boldsymbol{b}_{l}^{(g)}=\boldsymbol{\gamma}_{l}^{(g)} \boldsymbol{i}_{l}^{(g)} \\
& \boldsymbol{b}_{r}^{(g)}=\boldsymbol{\gamma}_{r}^{(g)} \boldsymbol{i}_{r}^{(g)}
\end{aligned}
$$

where $\gamma_{l}^{(g)}$ and $\gamma_{r}^{(g)}$ are matrices of $N_{g} \times P$ elements of the form

$$
\begin{aligned}
& \gamma_{l, n p}^{(g)}=e^{\jmath \beta_{x, p}\left(x_{n}^{(g)}-X_{r}^{(g)}\right)} \sin \left(\frac{p \pi}{a} y_{n}^{(g)}\right) \\
& \gamma_{r, n p}^{(g)}=e^{-\jmath \beta_{x, p}\left(x_{n}^{(g)}-X_{l}^{(g)}\right)} \sin \left(\frac{p \pi}{a} y_{n}^{(g)}\right)
\end{aligned}
$$

The total field over each cell in group $g\left(\boldsymbol{b}_{\text {others }}^{(g)}\right)$ due to the scattering of the rest of the groups is

$$
\boldsymbol{b}_{\text {others }}^{(g)}=\boldsymbol{b}_{l}^{(g)}+\boldsymbol{b}_{r}^{(g)}
$$

$\boldsymbol{b}_{\text {others }}^{(g)}$ is a vector of $N_{g}$ elements. Each element represents the field scattered over the $n$-th cell in group $g$ by all the cells except those in group $g$.

Substituting (3.76) and (3.77) in (3.80)

$$
\boldsymbol{b}_{\text {others }}^{(g)}=\boldsymbol{\gamma}_{l}^{(g)} \boldsymbol{i}_{l}^{(g)}+\boldsymbol{\gamma}_{r}^{(g)} \boldsymbol{i}_{r}^{(g)}
$$

Substituting (3.74) and (3.75) in the former equation:

$$
\begin{aligned}
\boldsymbol{b}_{\text {others }}^{(g)} & =\boldsymbol{\gamma}_{l}^{(g)} \sum_{g^{\prime}=g+1}^{G} \boldsymbol{\alpha}_{l}^{\left(g^{\prime}, g\right)} \boldsymbol{e}_{l}^{\left(g^{\prime}\right)} \\
& +\boldsymbol{\gamma}_{r}^{(g)} \sum_{g^{\prime}=1}^{g-1} \boldsymbol{\alpha}_{r}^{\left(g^{\prime}, g\right)} \boldsymbol{e}_{r}^{\left(g^{\prime}\right)}
\end{aligned}
$$


And finally substituting (3.69) and (3.70) we obtain:

$$
\begin{aligned}
\boldsymbol{b}_{\text {others }}^{(g)} & =\boldsymbol{\gamma}_{l}^{(g)} \sum_{g^{\prime}=g+1}^{G} \boldsymbol{\alpha}_{l}^{\left(g^{\prime}, g\right)} \boldsymbol{\beta}_{l}^{\left(g^{\prime}\right)} \boldsymbol{j}^{\left(g^{\prime}\right)} \\
& +\boldsymbol{\gamma}_{r}^{(g)} \sum_{g^{\prime}=1}^{g-1} \boldsymbol{\alpha}_{r}^{\left(g^{\prime}, g\right)} \boldsymbol{\beta}_{r}^{\left(g^{\prime}\right)} \boldsymbol{j}^{\left(g^{\prime}\right)}
\end{aligned}
$$

\subsubsection{Intra-group scattering}

Equation (3.83) provides the field scattered over the cells of group $g$ by all the cells of the other groups. To compute the total field incident for these cells, we must still consider the field that comes from the other cells of the same group $\left(\boldsymbol{b}_{\text {self }}^{(g)}\right)$.

$$
\boldsymbol{b}_{\text {self }}^{(g)}=\boldsymbol{Z}^{(g)} \boldsymbol{j}^{(g)}
$$

where $\boldsymbol{Z}^{(g)}$ is the submatrix of the whole MoM coefficients matrix of equation (3.64), that contains the interactions among cells of group $g$. In $\left[\mathrm{BEB}^{+} 09\right]$ there is a complete study of the value of the different parameters involved that have to be used to obtain a good trade-off between accuracy and efficiency.

Finally, the total field incident over the cells of group $g$ is

$$
\boldsymbol{b}^{(g)}=\boldsymbol{b}_{\text {self }}^{(g)}+\boldsymbol{b}_{\text {others }}^{(g)}
$$

where the whole vector $\boldsymbol{b}$, with the field incident to all the cells of the MoM problem, is

$$
\boldsymbol{b}=\left(\begin{array}{c}
\boldsymbol{b}^{(1)} \\
\boldsymbol{b}^{(2)} \\
\vdots \\
\boldsymbol{b}^{(G)}
\end{array}\right)=\boldsymbol{Z} \boldsymbol{j}
$$

With the new grouping strategy we avoid the computation of the whole MoM coefficients matrix $\boldsymbol{Z}$, since we only compute the interactions among cells of the same group. Besides, we do not compute the matrix product $Z j$. The computational cost is reduced and the only loss of accuracy comes from the truncation of the Green's function, as in [BEB $\left.{ }^{+} 09\right]$. The new grouping strategy does not add any additional loss of accuracy since we obtain exactly the same vector $\boldsymbol{Z} \boldsymbol{j}$ but using expression (3.85), instead of computing $\boldsymbol{Z}$ and multiplying by $j$. 


\subsubsection{Number of modes}

The number of guided modes $T E_{p 0}$ considered for the aggregation, translation, and disaggregation stages cannot be infinite. The highest order used in all calculations is $P$ $(p \in[1,2, \cdots, P])$. The optimum value for $P$ depends on the distance between groups. If we call this distance $D$, the criterion that we have chosen is to ensure for each frequency point that the scattered field corresponding to the highest order mode $T E_{P 0}$ vanishes from one group to another below some threshold value $\eta$, so that

$$
e^{-\gamma_{P} D}=e^{-\sqrt{\frac{P \pi}{a}-k^{2}} D} \leq \eta
$$

And therefore $P$ must be

$$
P \geq \frac{a}{\pi}\left[\left(\frac{\ln \eta}{D}\right)^{2}+k^{2}\right]
$$

where $\eta=10^{-3}$ has been proved to provide a good trade-off between accuracy and efficiency.

\subsubsection{Computational cost}

Below we are going to analyze which is the number of operations required for the computation of the matrix product $\boldsymbol{b}=\boldsymbol{Z} \boldsymbol{j}$ using the new grouping strategy, that is, equation (3.85). The number of operations needed for filling all the matrices $\left(\boldsymbol{Z}^{(g)}, \boldsymbol{\beta}_{r}^{(g)}, \boldsymbol{\beta}_{l}^{(g)}, \boldsymbol{\alpha}_{r}^{(g)}\right.$, $\left.\boldsymbol{\alpha}_{l}^{(g)}, \boldsymbol{\gamma}_{r}^{(g)}, \boldsymbol{\gamma}_{l}^{(g)}\right)$ is not considered since this is done only once, while the matrix product $Z \boldsymbol{j}$ is performed several times by the iterative technique (biconjugate gradients stabilized) that solves the MoM matrix system, so these matrix products are the most time consuming process. The number of operations needed to evaluate the matrix product $\boldsymbol{Z} \boldsymbol{j}$ for each step of the grouping strategy is analyzed separately:

1. Aggregation step: the products $\boldsymbol{\beta}_{l}^{(g)} \boldsymbol{j}^{(g)}$ and $\boldsymbol{\beta}_{r}^{(g)} \boldsymbol{j}^{(g)}$ must be computed for all the groups (there are $G$ groups). For all these products we need $2 G P N_{g}=2 P N$ operations since $N=G N_{g}$, and $N$ is the number of MoM cells.

2. Translation step: we need to compute the products $\boldsymbol{\alpha}_{r}^{\left(g^{\prime}, g\right)} \boldsymbol{e}_{r}^{\left(g^{\prime}\right)}$ for $g^{\prime}=1, \cdots, g-1$ and $\boldsymbol{\alpha}_{l}^{\left(g^{\prime}, g\right)} \boldsymbol{e}_{l}^{\left(g^{\prime}\right)}$ for $g^{\prime}=g+1, \cdots, G$. Since $\boldsymbol{\alpha}_{r}^{\left(g^{\prime}, g\right)}$ and $\boldsymbol{\alpha}_{l}^{\left(g^{\prime}, g\right)}$ are diagonal matrices of size $P$, those products suppose $(G-1) P$ operations. And this must be repeated for all the groups with $g=1,2, \ldots G$. In the end, we need $G(G-1) P$ operations for this step.

3. Disaggregation step: the products $\boldsymbol{\gamma}_{l}^{(g)} \boldsymbol{i}_{r}^{(g)}$ and $\boldsymbol{\gamma}_{r}^{(g)} \boldsymbol{i}_{l}^{(g)}$ must be computed for all groups. That means $2 G N_{g} P=2 P N$ operations for this step. 
4. The computational cost of computing the field scattered by cells of the same group over themselves $\left(\boldsymbol{Z}^{(g)} \boldsymbol{j}^{(g)}\right)$ supposes $G N_{g}^{2}=N^{2} / G$ operations.

Finally, the total number of operations needed with the new grouping strategy to compute the vector $\boldsymbol{b}=\boldsymbol{Z} \boldsymbol{j}$ is of the order of:

$$
C_{T O T}=O\left(N^{2} / G\right)+O(4 P N)+O(G(G-1) P)
$$

If the number of MoM cells $N$ is much bigger than the number of groups $G$, and groups are placed far away so that $P$ is small compared with $N$, we expect a number of operations of the order of $O\left(N^{2} / G\right)$.

If we do not use the grouping strategy, and compute the whole matrix $Z$, and then multiply by vector $\boldsymbol{j}$, this matrix product needs a number of operations of the order of

$$
C_{T O T}=O\left(N^{2}\right)
$$

The order in number of operations can therefore be reduced up to a factor of $G$ provided that $N$ is much bigger than $G$ and $P$. However the relation between $N, G$ and $P$ depends on the particular geometry that we are analyzing, since we can not freely chose the number of subgroups $G$ as in FMM, and $P$ depends on the separation along the propagation axis of the different groups. The same reduction of the computational time applies to the computer memory needed to store the matrices involved in the calculations when the grouping strategy is used.

This result is especially important since the MoM matrix system of (3.64) is solved using an iterative technique that does not directly solve the matrix system of (3.64), but instead approximates the solution iteratively through multiple matrix-vector products of the form $Z \boldsymbol{a}$. With the new grouping strategy the cost of these products and the memory needed is reduced by $G$, the number of groups used in the grouping strategy.

Besides, with the new grouping strategy it is not necessary to compute the whole matrix $\boldsymbol{Z}$, since only the smaller matrices $\boldsymbol{Z}^{(g)}$ with $g \in[1, \cdots, G]$ must be computed.

\subsubsection{Results}

The accuracy and efficiency of the new grouping strategy is tested with the analysis of five H-plane filters in rectangular waveguide. These filters, whose top view is shown in Fig. 3.37, are: 
1. Four cavity H-plane coupled cavity filters. The coupling windows present rounded corners (radii $r=1 \mathrm{~mm}$ ) due to low cost manufacturing techniques $\left[\mathrm{MEB}^{+} 04\right]$.

2. Six cavity H-plane coupled cavity filters. The coupling windows present rounded corners (radii $r=2 \mathrm{~mm}$ ) due to low cost manufacturing techniques [MEB $\left.{ }^{+} 08\right]$.

3. Six cavity H-plane coupled cavity filters. The resonant cavities present rounded corners (radii $r=3 \mathrm{~mm}$ ) due to low cost manufacturing techniques [MEB $\left.{ }^{+} 08\right]$.

4. Bandpass filter with seven round rods [YVP98].

5. Nine pole bandpass filter with wedges [LM04].

The frequency response (reflection coefficient) of these five filters has been computed using the MoM method of $\left[\mathrm{BEB}^{+} 09\right]$ accelerated with the new grouping strategy presented here. The biconjugate gradients stabilized method has been used to accelerate the solution of the MoM matrix system of (3.64). Since the MoM method uses the Green's function of a line source between two parallel plates, only the portions of the metallic surface of the structure that are outside of the parallel plate waveguide must be segmented using MoM. This means that only the coupling windows for the first three filters, or the round rods and wedges for the last two filters, must be segmented into MoM cells. The new grouping strategy groups the MoM cells into $G$ groups, so that those MoM cells that are close together in the propagation direction must be enclosed in the same group for the grouping strategy to be efficient. This means, for instance, that the first filter is analyzed with all MoM cells split into $G=5$ groups, one for each coupling window, and similarly the MoM cells of the fourth filter are grouped into $G=7$ groups, one for each round rod.

The results of the analysis of the five filters are presented at Fig. 3.38, where they are compared with other analysis methods $\left[\mathrm{MEB}^{+} 04, \mathrm{MEB}^{+}\right.$08, LM04, YVP98]. Fig. 3.38 shows a very good agreement with the results from the literature for the five filters analyzed.

Once the accuracy of the new method is fully proven, we will test the efficiency improvement of the new grouping strategy. For that purpose we present in Table 3.19 the CPU time (in seconds per frequency point) required to analyze each one of the five H-plane filters of Fig. 3.37. Table 3.19 shows both the CPU time required by the MoM with the Green's function of a line source between parallel plates $\left[\mathrm{BEB}^{+} 09\right]$ and the CPU time of the same analysis method accelerated with the new grouping strategy.

Results from Table 3.19 show that the time is reduced by a significant factor of 2 or 3 , depending on the filter. However, the number of groups $G$ varies from 5 in the first filter to 10 in the last filter. As mentioned before, a time reduction of $G$ could be expected when the number of MoM cells is much bigger than the number of groups $G$ and the number of guided 


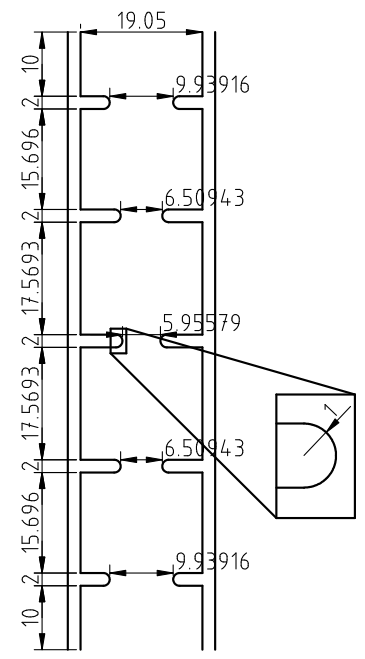

(a)

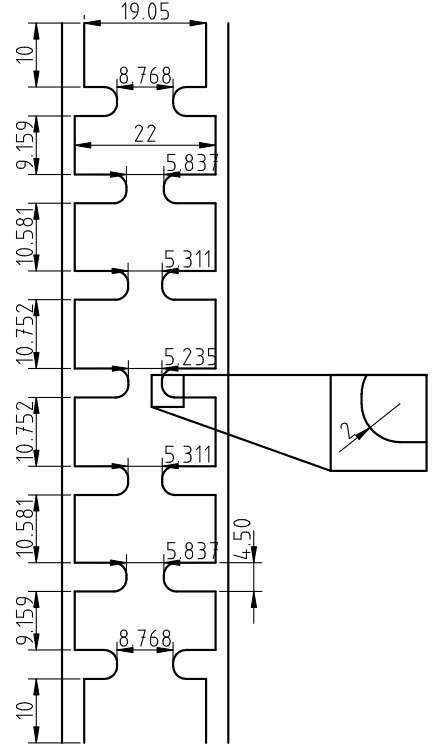

(b)

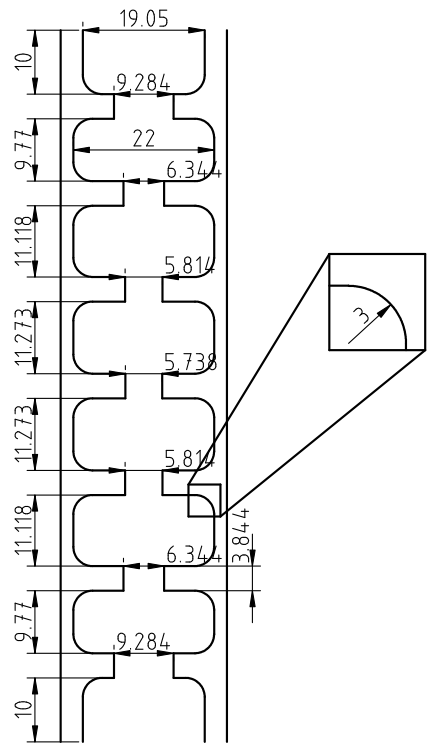

(c)

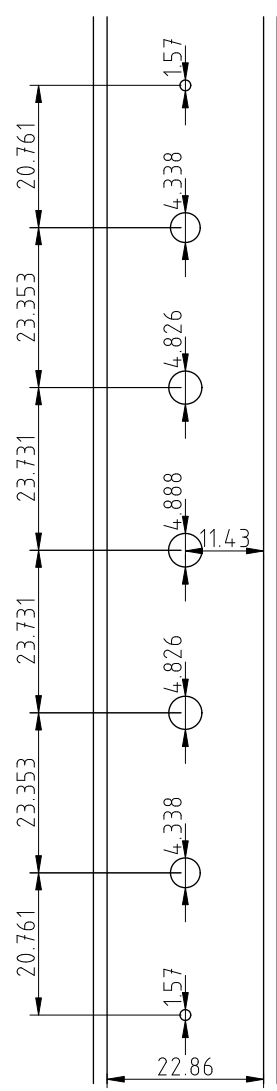

(d)

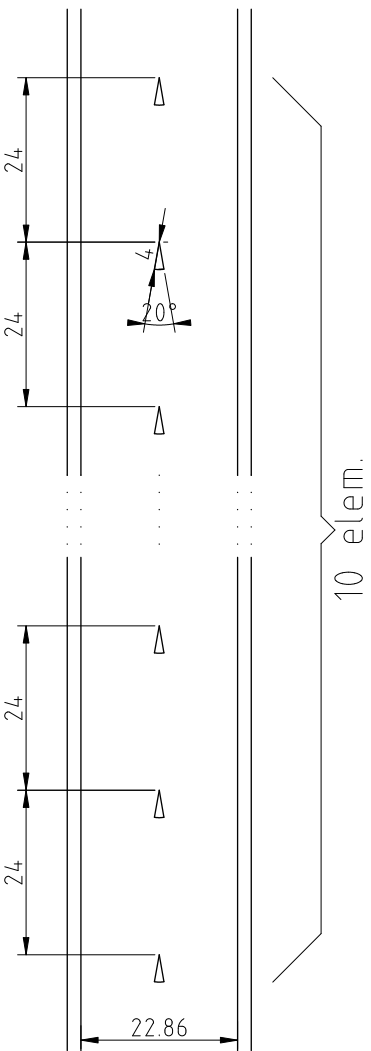

(e)

Figura 3.37: H-plane filters (measures in mm.). a) Four cavity filter with rounded corners at coupling windows $r=1 \mathrm{~mm}$, b) Six cavity filter with rounded corners at coupling windows $r=2 \mathrm{~mm}$, c) Six cavity filter with rounded corners at resonant cavities $r=3 \mathrm{~mm}$. d) Round rod bandpass filter from [YVP98]. e) Wedge bandpass filter from [LM04]. 


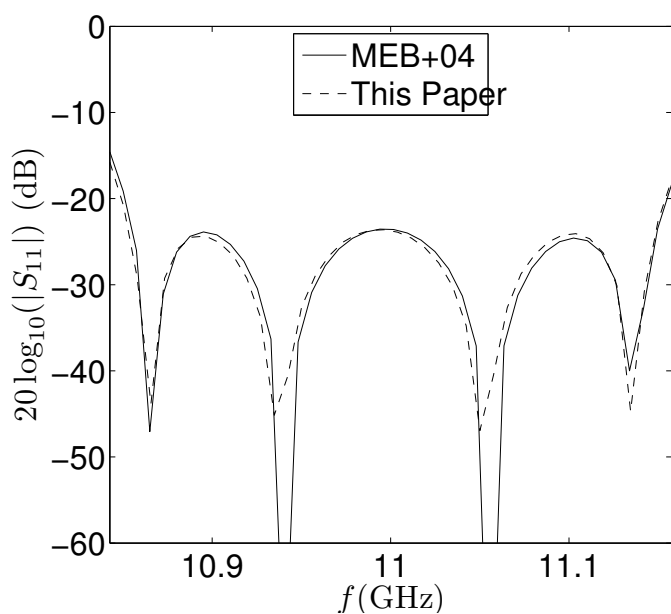

(a)

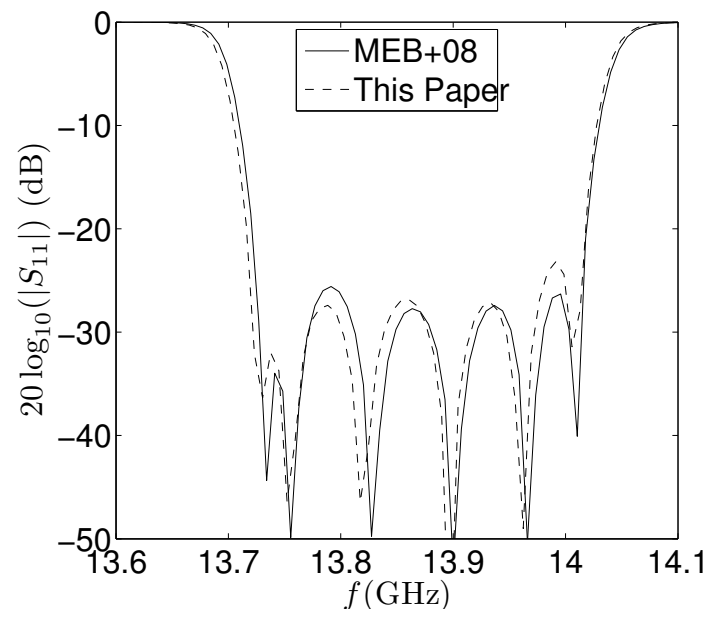

(c)

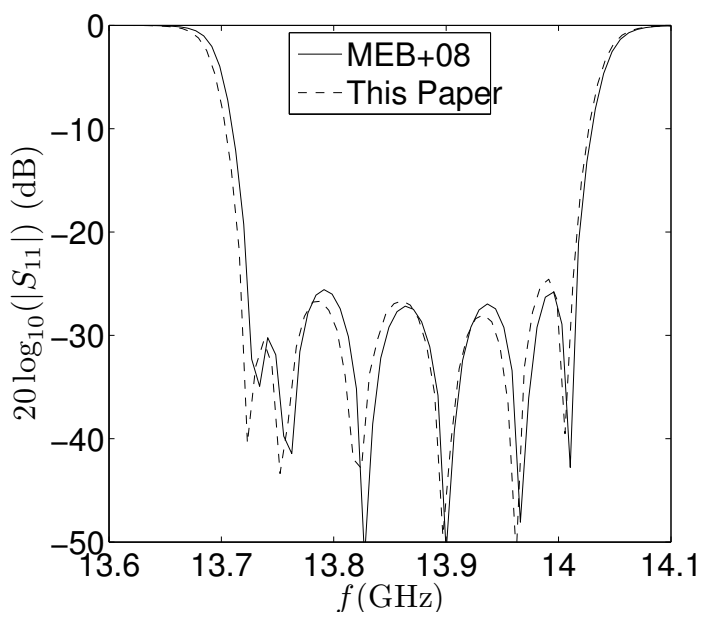

(b)

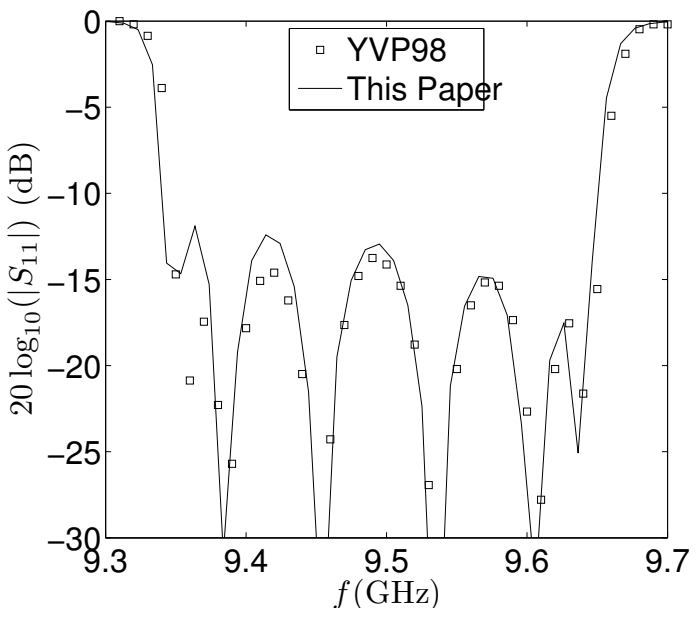

(d)

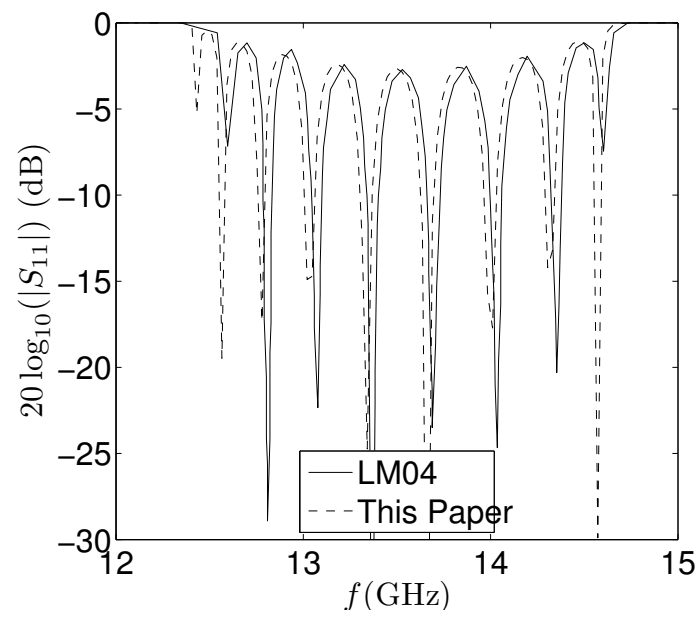

(e)

Figura 3.38: Frequency response of the H-plane filters of Fig. 3.37 compared with results from the bibliography. 


\begin{tabular}{|l|c|c|c|}
\hline Filter & MoM [BEB $\left.{ }^{+} 09\right]$ & MoM+Grouping & Reduction \\
\hline \hline$r=1 \mathrm{~mm}$ windows & $0.91 \mathrm{~s} / \mathrm{pt}$ & $0.31 \mathrm{~s} / \mathrm{pt}$ & $66 \%$ \\
\hline$r=2 \mathrm{~mm}$ windows & $5.18 \mathrm{~s} / \mathrm{pt}$ & $1.91 \mathrm{~s} / \mathrm{pt}$ & $63 \%$ \\
\hline$r=3 \mathrm{~mm}$ cavities & $8.69 \mathrm{~s} / \mathrm{pt}$ & $3.03 \mathrm{~s} / \mathrm{pt}$ & $65 \%$ \\
\hline Round rods & $0.57 \mathrm{~s} / \mathrm{pt}$ & $0.34 \mathrm{~s} / \mathrm{pt}$ & $40 \%$ \\
\hline Wedges & $0.59 \mathrm{~s} / \mathrm{pt}$ & $0.29 \mathrm{~s} / \mathrm{pt}$ & $51 \%$ \\
\hline
\end{tabular}

Tabla 3.19: Computational cost for the analysis of the five filters of Fig. 3.37. Comparison between the MoM method of $\left[\mathrm{BEB}^{+} 09\right]$ and the same method accelerated with the new grouping strategy proposed in this paper. CPU time is in seconds per frequency point.

modes $P$. Since $G$ and $P$ are not selectable, we can not ensure a time reduction of $G$. In the geometry of the last two filters there is a much shorter metallic surface for each group, so the ratio $N / G=N_{g}$, that is, the number of MoM cells per group, is much smaller, and so the last term in equation (3.89) is more important than in the case of the three first filters. This results in a smaller time reduction. However, this time reduction becomes especially significant in design processes where many simulations of the structure must be performed in order to obtain the optimal values of the design parameters.

There are other factors that could explain that the time reduction is lower than $G$, such as the fact that we have not considered other processes that consume time, such as the computation of the elements needed to fill the matrices $\boldsymbol{Z}^{(g)}, \boldsymbol{\beta}_{r}^{(g)}, \boldsymbol{\beta}_{l}^{(g)}, \boldsymbol{\alpha}_{r}^{(g)}, \boldsymbol{\alpha}_{l}^{(g)}, \boldsymbol{\gamma}_{r}^{(g)}$ and $\boldsymbol{\gamma}_{l}^{(g)}$, or the time spent in reading and writing in memory and disk.

A similar time reduction could have been obtained with a classical segmentation approach [BGMM07], where a generalized matrix of circuit parameters is obtained for each group and then all the matrices are cascaded in order to obtain the global circuit parameters of the problem. However, the segmentation strategy presented here provides much more accurately the field inside the structure, since all the currents in all the structure are obtained at the same time, and the field is directly computed from the amplitudes of these currents. With a classical segmentation structure a complex process must be followed in order to find the modal amplitudes in each intermmediate point of the structure. Next these modal amplitudes are used to expand the field inside each segment of the filter, and small discontinuities usually appear between adjacent segments due to loss of accuracy inherent to the segmentation process.

\subsubsection{Conclusions}

A new grouping strategy has been presented in this paper. This new strategy accelerates the MoM method with the Green's function of a line source between two parallel plates presented in $\left[\mathrm{BEB}^{+} 09\right]$. The efficiency improvement of the new grouping strategy is especially 
important when the MoM matrix system is solved using an iterative technique such as conjugate gradients, biconjugate gradients, biconjugate gradients stabilized, and others; since these techniques require multiple matrix-vector products of the MoM coefficients matrix by a vector that iteratively converges to the solution. This matrix product is not solved directly with the new grouping strategy, but is instead solved without loss of accuracy using a more efficient three-step procedure.

The accuracy and efficiency of the new grouping strategy has been tested with the analysis of five H-plane filters. The reflection coefficient of these filters has been successfully compared with results from the technical literature, and a significant time reduction of $40 \%$, $50 \%$ or $60 \%$ has been obtained depending on the type of filter and the number of MoM cells per group. 


\subsection{Automated Design of Complex Waveguide Filters for Space Systems: A Case Study}

\subsubsection{Introduction}

Complex waveguide filters, such as H-plane filters, tunable filters, and dielectric resonator filters are key devices in the equipment of numerous microwave and millimeter-wave communication systems. The accurate design of EM structures requires a tradeoff between accuracy and computation time. When designing complex structures, the use of a very accurate simulation tool can be unaffordable. The Aggressive Space Mapping (ASM) methodologies address this issue. Aggressive Space mapping [BBS $\left.{ }^{+} 95\right]$ can be used to reduce the computational burden by using two different simulation tools of different accuracy and efficiency: an efficient but not very accurate tool (coarse model) in the optimization space (OS), and an accurate but not very efficient tool (fine model) in the validation space (VS). These methodologies move the computational burden to the OS, thus reducing the overall computation time, while the accuracy is still guaranteed by the use of the fine model. Although ASM has proved to be very useful for EM design, there is still much research dedicated to improve the robustness and performance of $\mathrm{ASM}\left[\mathrm{BCD}^{+} 04\right]$. As an alternative to those extensions of ASM, we proposed to improve the ASM approach by using a segmentation and hybridization strategy. The speed and robustness of the optimization process can be greatly improved by decomposing the structure as proposed in [Gug94] and [AG97]. Moreover, the design process can still be improved by using a suitable combination of several optimization algorithms instead of using a single all-purpose technique such as a genetic algorithm. In this review, the completely automated CAD tool recently proposed in $\left[\mathrm{MSE}^{+} 05\right]$, which does not require human intervention, is adapted for the accurate design of several complex waveguide filters: H-plane coupled cavities filters with and without tuning elements, and novel designs with dielectric resonators.

\subsubsection{Aggressive Space Mapping Method}

The original ASM strategy describes the behavior of a system by models in two spaces: the optimization space (OS), denoted by $\mathbf{X}_{o s}$, and the validation space (VS), denoted by $\mathbf{X}_{e m}$. We represent the designable model parameters in these spaces by the vectors $\mathbf{x}_{o s}$ and $\mathbf{x}_{e m}$, respectively. The objective of the ASM procedure is to find the optimum point $\mathbf{x}_{e m}$ in VS that minimizes the following non-linear function:

$$
\mathbf{f}\left(\mathbf{x}_{e m}\right)=\mathbf{P}\left(\mathbf{x}_{e m}\right)-\mathbf{x}_{o s}^{*}
$$

where $\mathbf{x}_{o s}^{*}$ is the optimum point in OS and $\mathbf{P}\left(\mathbf{x}_{e m}\right)$ is the point in OS that satisfies $\mathbf{R}_{f}\left(\mathbf{x}_{e m}\right)=$ $\mathbf{R}_{c}\left(\mathbf{P}\left(\mathbf{x}_{e m}\right)\right), \mathbf{R}_{f}$ and $\mathbf{R}_{c}$ being the vectors with the responses of the fine and coarse models. 
The ASM procedure finishes when $\left\|\mathbf{f}\left(\mathbf{x}_{e m}\right)\right\|$ is below some threshold $\eta$ near zero. At each iteration $j$, the next iterate is found by a quasi-Newton iteration:

$$
\mathbf{x}_{e m}^{(j+1)}=\mathbf{x}_{e m}^{(j)}+\mathbf{h}^{(j)}
$$

where $\mathbf{x}_{e m}^{(0)}=\mathbf{x}_{o s}^{*}$ and $\mathbf{h}^{(j)}$ solves the linear system:

$$
\mathbf{B}^{(j)} \mathbf{h}^{(j)}=-\mathbf{f}^{(j)}
$$

$\mathbf{B}^{(j)}$ is an approximation to the Jacobian matrix and is obtained from $\mathbf{B}^{(j-1)}$ using the Broyden update $\left[\mathrm{BBS}^{+} 95\right]$.

\subsubsection{Aggressive Space Mapping with Segmentation and Hybridiza- tion}

\subsubsection{Segmentation}

In [AG97] and [Gug94], a segmentation strategy was proposed for the design of some filter structures, such as H-plane coupled cavity filters composed of $N$ resonant cavities and $N+1$ coupling windows. This segmentation technique transforms a slow multidimensional design process into several efficient and robust design steps, where a small number of parameters are designed at the same time. However, there is the risk that the coupling among all cavities (not just among adjacent cavities) is not properly taken into account. To solve this problem, the segmentation strategy proposed in $\left[\mathrm{MES}^{+} 03\right]$ adds new steps to the original strategy. The resulting new segmentation strategy designs the filter through the steps summarized in Table 3.20.

\begin{tabular}{|c|c|c|c|c|}
\hline Step & Structure Simulated & Design Parameters & Error Function & Performed \\
\hline \hline Ordinary & $i$ first cavities & Dimensions of cavity $i$ & $S_{21}$ & For each cavity \\
\hline Coupling & $i$ first cavities & Dimensions of the $i$ first cavities & $S_{21}$ & Each three cavities \\
\hline Central Cavity & whole & Dimensions of the central cavity & $S_{21}$ & Once \\
\hline Full Structure & whole & Dimensions of all the cavities & $S_{11}$ & Once \\
\hline
\end{tabular}

Tabla 3.20: Characteristics of each step of the segmentation strategy

The Ordinary step designs the parameters related to cavity $i$ simulating the $i$ first cavities and using for the rest of parameters of the $i-1$ first cavities the values obtained in former iterations. The error function is computed comparing the response of the $i$ first cavities with the ideal response. The ideal response of the $i$ first cavities is obtained using the first $i$ resonators of the prototype composed of impedance inverters and half-wavelength transmission lines. The Coupling step adjusts, each three cavities, all the design parameters of the cavities 
previously designed, thus achieving the required small changes in the values of the parameters due to couplings among cavities. The Central Cavity step designs the dimensions of the central cavity simulating the whole filter structure, and the Final step refines the design taking into account all possible interactions among cavities.

\subsubsection{Hybrid Optimization}

Both the efficiency and robustness of the optimization process can be drastically improved when a suitable combination of optimization algorithms is used instead of a single algorithm. If only a gradient method is used, it may fail to reach the optimum if the starting point is far from it. On the other hand, the use of a robust method such as the simplex method or genetic algorithm, largely used in circuit design, ensures convergence, but at the cost of a low efficiency. So, the design procedure has been improved using a suitable combination of optimization algorithms in each parameter extraction phase and also in the optimization needed to obtain $\mathrm{x}_{o s}^{*}$. Robust non-gradient methods (direct search and simplex) are used at the beginning, and, after some iterations, when we are close to the minimum, an efficient gradient algorithms (Broyden-Fletcher-Goldfarb-Shanno (BFGS)) is used to refine the solution. This combination of algorithms is expected to perform better than one algorithm alone.

The shift from one kind of algorithm to the other one is controlled by the parameter termination tolerance $\mathbf{x}_{\mathrm{tol}}$, the termination tolerance of the error function $\left(f_{\mathrm{tol}}\right)$, and the maximum number of function evaluations $\left(n F_{\max }\right)$ permitted to each method. $f_{\text {tol }}$ is higher for the first algorithm, and its value is decreased in each subsequent algorithm. The shift from one algorithm to another, as well as the rest of the whole design process, is fully automated, so that no human intervention is needed.

\subsubsection{Results}

\subsubsection{High-Order $\mathrm{H}$-plane waveguide filter for space applications at K-Band}

The first example under consideration is a conventional H-plane waveguide filter with coupled cavities for space applications at the $K$-band. The ideal transfer function is a standard nine-pole Chebychev response of $96 \mathrm{MHz}$ bandwidth centered at $17.3 \mathrm{GHz}$.

The cavity lengths and coupling aperture widths of the filter have been chosen as design parameters (see Fig. 3.39). The input and output waveguides of the filter, as well as the resonant cavities, are standard WR-62 waveguides $(a=15.799 \mathrm{~mm}, b=7.899 \mathrm{~mm})$. The length of all the coupling windows have been chosen to be $2 \mathrm{~mm}$. 


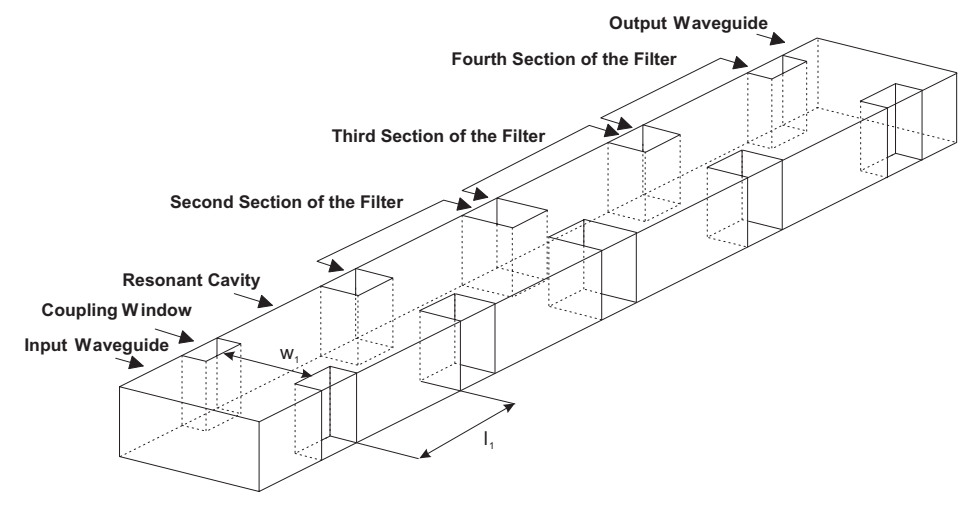

Figura 3.39: A four cavities $H$ plane rectangular waveguide filter

For the design of this filter, the same modal simulator has been used both as the coarse and the fine model. This modal simulator characterizes the planar discontinuities using the Method of the Moments (MoM) according to the traditional Galerkin procedure [GG98]. When used as a fine model, the number of accessible modes, number of basis functions in the MoM, and number of kernel terms in the integral-equation are high enough to obtain very accurate results. On the other hand, when used as a coarse model, a small number of modes is considered in order to obtain a faster simulator at the expense of a less accuracy. The initial values of the design parameters $\left(\mathbf{x}_{o s}^{(0)}\right)$ have been calculated according to the method described in $\left[\mathrm{SGB}^{+} 00\right]$. Figure 3.40 shows the comparison between the response of the fine model at the final solution in VS $\left(\mathrm{x}_{e m}\right)$ and the response of the coarse model at $\mathrm{x}_{o s}^{*}$. It can be observed that the desired objective function has been satisfactorily recovered in the VS. This solution has required $185 \mathrm{~s}$ of CPU time in a $2.4 \mathrm{GHz}$ Pentium IV PC platform.

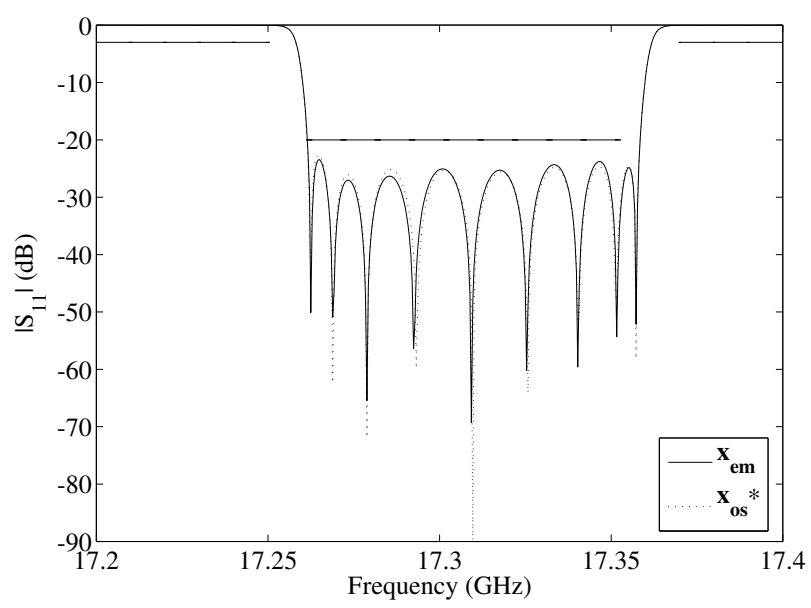

Figura 3.40: Responses of the waveguide filter. Coarse model response at $x_{o s}^{*}$ versus the fine model response at $\mathbf{x}_{e m}$ 


\subsubsection{Tunable H-plane waveguide filter for Space Systems}

In order to test the performance of the design procedure with more complex structures, two tunable H-plane coupled cavity filters have been considered. These filters were originally designed and manufactured in [BGA98], where the design was performed manually. These same filters have been redesigned with the CAD tool just proposed before. The tuning elements are penetrating posts of square section placed at the center of each cavity and each coupling window (see Fig. 3.41). As proposed in [BGA98], the use of these tuning posts allows the use of a common base structure for obtaining filters at different frequency bands. The only difference in the filters at each frequency band is the penetration of the tuning posts.

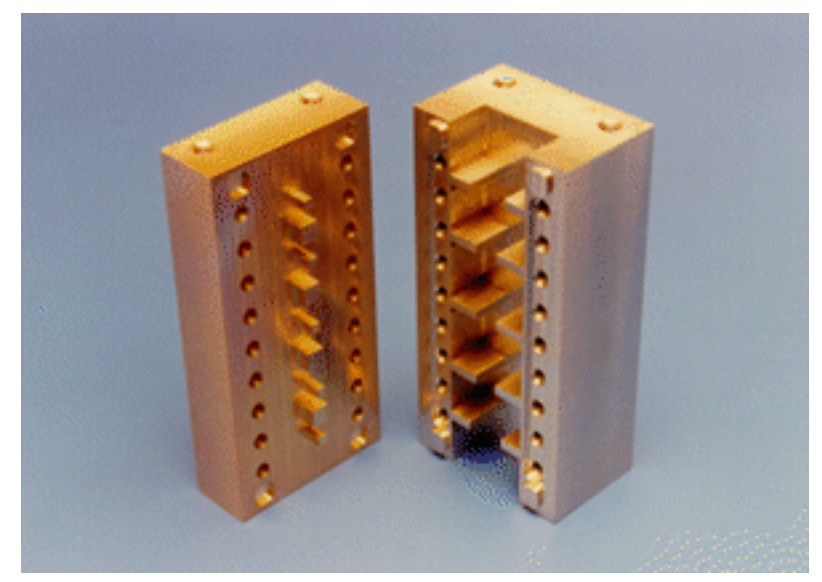

Figura 3.41: Manufactured filters with tuning elements. Common base and $11 \mathrm{GHz}$ top

The ideal transfer function is a four-pole standard Chebychev response of $300 \mathrm{MHz}$ bandwidth centered at $11 \mathrm{GHz}$ and $13 \mathrm{GHz}$. The input and output waveguides of the filter, as well as the resonant cavities, are standard WR-75 waveguides ( $a=19.050 \mathrm{~mm}, b=9.525 \mathrm{~mm})$. The length of all the coupling windows have been chosen to be $2 \mathrm{~mm}$. The side of the posts is set to $4 \mathrm{~mm}$ in the cavities, whereas in the coupling window it is set to $2 \mathrm{~mm}$.

The design with ASM using segmentation and hybrid optimization required 3 ASM iterations for both filters under severe convergence criterion. The design for the filters centered at 11 and $13 \mathrm{GHz}$ required a total CPU time of 49'50" and 33'42", respectively, in a PC with Pentium IV processor at $1.7 \mathrm{GHz}$. Since the fine model is about 250 times slower than the coarse model, the total CPU time required for the direct design of such filters without ASM would be of about 25 hours. This represents an improvement by a factor of 30, and clearly proves the advantage of using ASM for the design of complex waveguide devices. The filters have been manufactured in two different pieces, an $\mathrm{H}$ plane base structure and a separated top including all the tuning elements. To reduce costs, the same $\mathrm{H}$ plane base has been used for both filters. The common $\mathrm{H}$ plane base and the two different tops including the tuning 


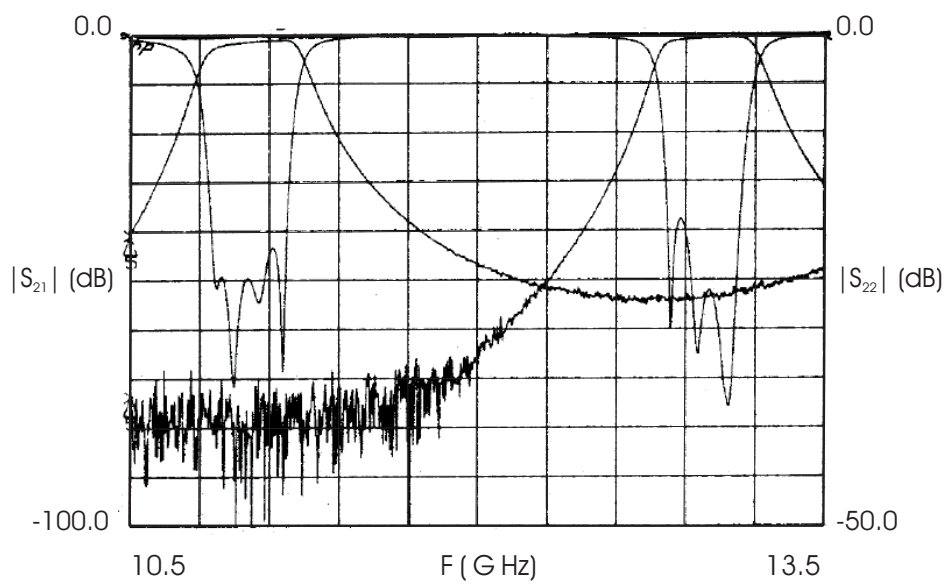

Figura 3.42: Measurements of the manufactured prototypes with tuning elements

elements for the filters at 11 and $13 \mathrm{GHz}$ were manufactured (see Fig. 3.41) and measured (see Fig. 3.42).

\subsubsection{H-plane waveguide filter with dielectric resonators}

The last structure under consideration is an H-plane coupled cavities filter with circular dielectric posts placed in the middle of each cavity (see Fig. 3.43(a)). The ideal transfer function is a standard four-pole Chebychev response of $300 \mathrm{MHz}$ bandwidth centered at $11 \mathrm{GHz}$. The input and output waveguides of the filter, as well as the resonant cavities, are standard WR-75 waveguides $(a=19.050 \mathrm{~mm}, b=9.525 \mathrm{~mm})$. The relative permittivity of the dielectric posts is chosen to be 24 , and the length of all the coupling windows have been chosen to be $2 \mathrm{~mm}$. The remaining dimensions of the structure (cavity lengths, coupling aperture widths and radii of the dielectric posts) have been chosen as design parameters.

The design procedure described in section 3.6.3 can not be directly applied to the design of this kind of filters. It is necessary to use a genetic algorithm, since a good starting point can not be easily obtained, and to suppress the segmentation, since the coupling among cavities is much stronger that in all-metallic filters.

Again the same simulation tool is used as the coarse and fine model. This simulation tool is described in $\left[\mathrm{BEB}^{+} 05\right]$. It uses a suitable combination of an analytical method and a hybrid technique that cope with the different parts of the filter structure.

Figure 3.43(b) shows the comparison between the response of the fine model at $\mathbf{x}_{e m}$ and the ideal response of the filter. It can be observed that the desired objective function has been satisfactorily recovered in the VS. This solution has required about 2 hours of CPU time in a $3 \mathrm{GHz}$ Pentium IV platform. The total length of the filter $\left(l_{1}+l_{2}+l_{3}+l_{4}+5 t\right)$ is 
reduced by almost $50 \%$ when compared with the same filter without dielectric posts, with the correspondent benefit in volume and mass reduction, so critic in satellite communication systems.

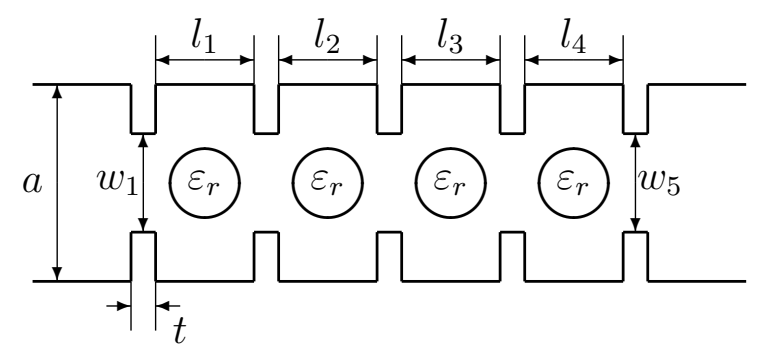

(a) Four cavities H-plane filter with dielectric resonators

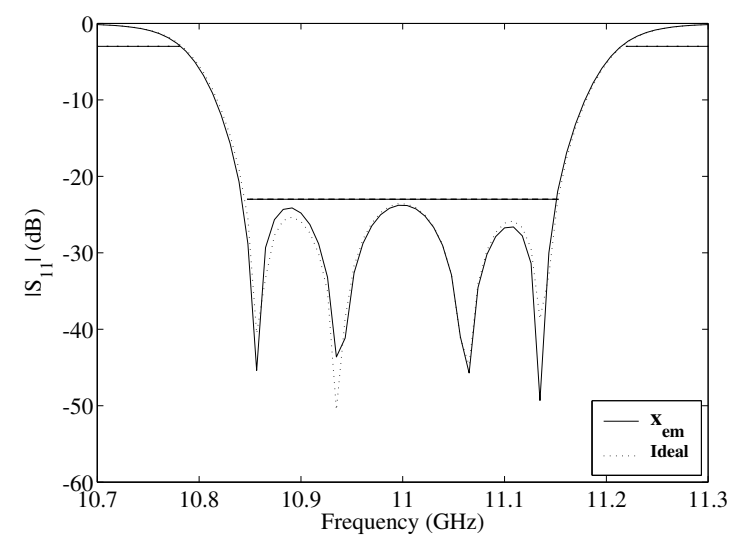

(b) Ideal response versus the fine model response at $\mathbf{x}_{e m}$

Figura 3.43: H-plane waveguide filter with dielectric resonators

\subsubsection{Conclusions}

A case study of advanced optimization techniques for the automated design of complex waveguide filters for space applications has been presented in this paper. A complete automated design tool has been developed based on ASM enhanced with segmentation and hybridization. This tool has been successfully applied to the practical design of H-plane coupled cavities filters with and without tuning elements, and for the design of H-plane filters with dielectric posts. 


\subsection{New efficient and robust automated design strategy for H plane direct-coupled-cavities filters with dielectric resonators}

\subsubsection{Introduction}

The use of dielectric resonators in waveguide microwave communications filters is increasing due to the important reductions on mass and volume (about $50 \%$ ) and additional thermic stability for high power applications. Nevertheless, the accurate modelling of this type of filters is far more complex than for conventional metallic structures, since the geometry includes circular and rectangular, metallic and dielectric parts. For this reason, the automated Computer Aided Design (CAD) of these filters becomes a new challenge that is being oject of intense research in the last years. Among all types of dielectric loaded filters, the $\mathrm{H}$ plane filters with circular dielectric rods [IK89] offer the advantages of easy manufacturing and more power handling capacity $\left[\mathrm{QGP}^{+} 05\right]$.

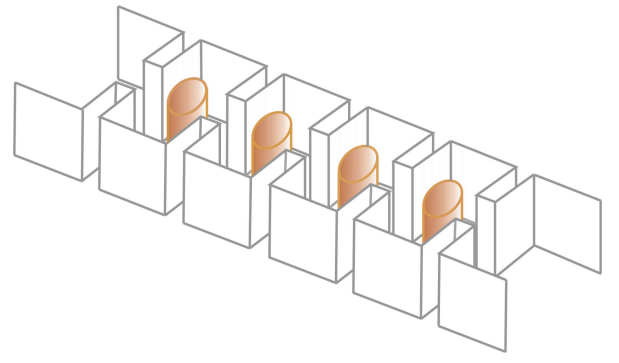

(a) 3-D view

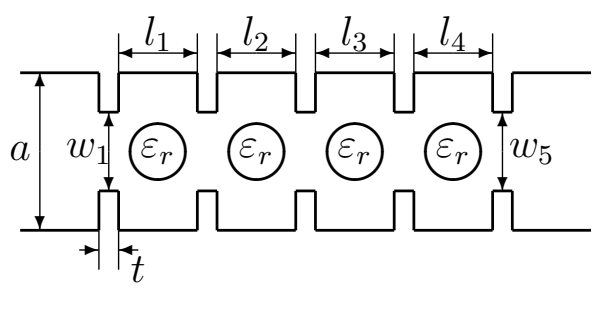

(b) Top view

Figura 3.44: Outline of a 4-pole direct-coupled-cavities filters with dielectric resonators.

In [BEB $\left.{ }^{+} 05\right]$, a design strategy for all-metallic $\mathrm{H}$ plane direct-coupled cavities filters was intended to be applied to the design of the same type of filters, but with circular dielectric resonators placed in the middle of each cavity (see Fig. 3.44). This strategy proved to be very robust and fast to converge (see $\left[\mathrm{MSE}^{+} 05\right]$ ) due to the use of a good starting point, a hybridization of fast optimization algorithms, a segmentation process and Aggressive Space Mapping (ASM). A good starting point places the design process near the global minimum and reduces the risk of being trapped in local minima. The hybridization of fast optimization algorithms (Nelder-Mead simplex method, BFGS gradient method, and direct search with coordinate rotation) outperforms the use of a unique algorithm. The segmentation process consists on dividing the design process in several steps, so that at each step only a small number of parameters are designed instead of designing the whole filter at the same time, which is time consuming and with high risk of local minima. And finally, the Aggressive Space Mapping (ASM) algorithm consists on using two different analysis models of different 
accuracy and speed, so that the computation burden moves to the fast and not accurate model while the accuracy is still ensured by the accurate and slow model.

Since the coupling among cavities was much stronger with resonators, the previous design strategy failed to converge for dielectric loaded filters and had to be adapted. A design for a 4-pole filter was successfully obtained using a genetic algorithm without segmentation or ASM. Therefore the use of segmentation, ASM and hybridization of fast algorithms had to be replaced by a time-consuming and not so robust design process due to the such strong couplings (see $\left[\mathrm{BEB}^{+} 05\right]$ ).

In this paper a new design strategy for $\mathrm{H}$ plane coupled-cavities filters with circular dielectric resonators is presented which makes use of segmentation, hybridization of fast optimization algorithms, and two different simulators with different accuracy and speed. The design process has been successfully applied to the design of filters at different frequency bands, with different number of cavities and dielectric permittivities, thus proving the robustness, efficiency, and validity of the new design strategy.

\subsubsection{New automated design strategy}

The new design strategy designs the filter through the following steps:

I) An initial point is obtained for an $\mathrm{H}$ plane filter with the same geometry but without dielectric resonators. This point is obtained very quickly by using an equivalent ideal network (see $\left[\mathrm{MSE}^{+} 05\right]$ ). The starting point gives an initial guess for the lengths $\left(l_{i}^{\text {without }}\right)$ of the cavities and widths $\left(w_{i}^{\text {without }}\right)$ of the coupling windows of the filter (see Fig. 3.44).

II) An evolutionary genetic algorithm is started for the filter with dielectric resonators. The lengths of the cavities with dielectric resonators $\left(l_{i}^{\text {with }}\right)$ are given a variation range of $0,5 l_{i}^{\text {without }} \leq l_{i}^{\text {with }} \leq l_{i}^{\text {without }}$. The widths of the coupling windows are let to vary in the range $0,9 w_{i}^{\text {without }} \leq w_{i}^{\text {with }} \leq 1,5 w_{i}^{\text {without }}$. The radii of the circular dielectric resonators are also given a variation range that depends on the frequency band. The transmission parameter $S_{21}$ is used for computing the error between simulated and ideal filter responses. When the evolutionary algorithm stops and we are closer to the global minimum, a faster but not so robust optimization algorithm (the Nelder-Mead simplex algorithm) is used to continue the optimization and to find a good starting point.

III) The dimensions provided by the previous step are used as the starting point of a new optimization phase. The radii of the resonators are fixed and not considered as design parameters in this phase since there would be too many design parameters and the op- 
timizer could be confused. All optimizations in this phase are performed with a combination of the Nelder-Mead simplex algorithm and the Broyden-Fletcher-GoldfarbShanno (BFGS) gradient algorithm. A segmentation strategy is used in this phase, so that the dimensions of the first cavity are designed in the first step. Then the dimensions of the second cavity, and so on until the dimensions of the central cavity are designed. In the next step the whole filter is re-designed, adjusting all the dimensions of the filter at the same time in order to take into account the possible couplings among all cavities. All these designs are performed comparing the transmission coefficient. In the final step the dimensions of the whole filter are again re-designed, but this time the reflection coefficient $S_{11}$ is used for comparison between simulated and ideal responses. A two level optimization is performed in each step of this phase. In the first level the optimization uses a simulator that only considers 7 guided modes all along the filter structure. In the second level, a new optimization is launched that uses a simulator that considers 11 guided modes. This is not exactly ASM, but exploits the same idea of using two different simulators in order to improve the convergence and speed.

\subsubsection{Results}

The new design strategy has been successfully applied to the design of six different filters. Two different filter specifications have been considered:

C band Central frequency $\left(f_{0}\right)=6,966 \mathrm{GHz}$, Bandwidth $(B W)=249 \mathrm{MHz}$, Return Loss $(R L)>26 \mathrm{~dB}$.

$\mathbf{X}$ band $f_{0}=11 \mathrm{GHz}, B W=300 \mathrm{MHz}, R L>23 \mathrm{~dB}$.

For the $\mathrm{C}$ band, 4-pole and 5-pole filters have been designed either with relative electric permittivity $\left(\varepsilon_{r}\right)$ equal to 20 or 30 . This gives 4 different filters. For the $\mathrm{X}$ band, 4-pole filters with $\varepsilon_{r}$ equal to 19,5 and 30 have been designed. Thus a total of six filters have been designed with different frequency band, number of resonators and permittivity. The results of the design for the six filters are shown in table 3.21. The total number of simulations $(n F)$, the total CPU time (Pentium IV @ 3,4 GHz) and the error between simulated and ideal filter responses (Huber norm, $k=5$ ) are listed for each filter.

Figure 3.45 shows a comparison between the ideal response of a Tchebyshev filter with the simulated response of the designed filters with numbers 4 and 5 in table 3.21 . It can be observed that the design process has successfully converged to the optimum, and that the design filter is in very good agreement with the ideal response. The final error between ideal and simulated response for all the six filters is very low, and therefore we can conclude that all designs have converged successfully. 


\begin{tabular}{|c|c|c|c|c|c|c|}
\hline Filter no. & Specs. & Resonators & $\varepsilon_{\mathbf{r}}$ & $\mathbf{n F}$ & Time & Error \\
\hline \hline 1 & C band & 4 & 20 & 4322 & 1h9'38' & 0,26 \\
\hline 2 & C band & 4 & 30 & 5488 & 1 h15'49” & 5,09 \\
\hline 3 & X band & 4 & 19,5 & 5067 & 1 h18'09' & 0,61 \\
\hline 4 & X band & 4 & 30 & 3863 & $52^{\prime} 02^{\prime \prime}$ & 1,52 \\
\hline 5 & C band & 5 & 20 & 5064 & 2h08'17' & 0,34 \\
\hline 6 & C band & 5 & 30 & 5097 & 2h09'18” & 1,2 \\
\hline
\end{tabular}

Tabla 3.21: Design results for several $\mathrm{H}$ plane filters with circular dielectric resonators

\subsubsection{Conclusions}

A new design procedure for H-plane coupled-cavities filters with circular dielectric resonators has been presented. The new design procedure uses segmentation, hybridization of optimization algorithms and ASM. The results prove the efficiency and robustness of the design process for filters with different number of cavities, frequency band, and electric permittivity of the resonators.

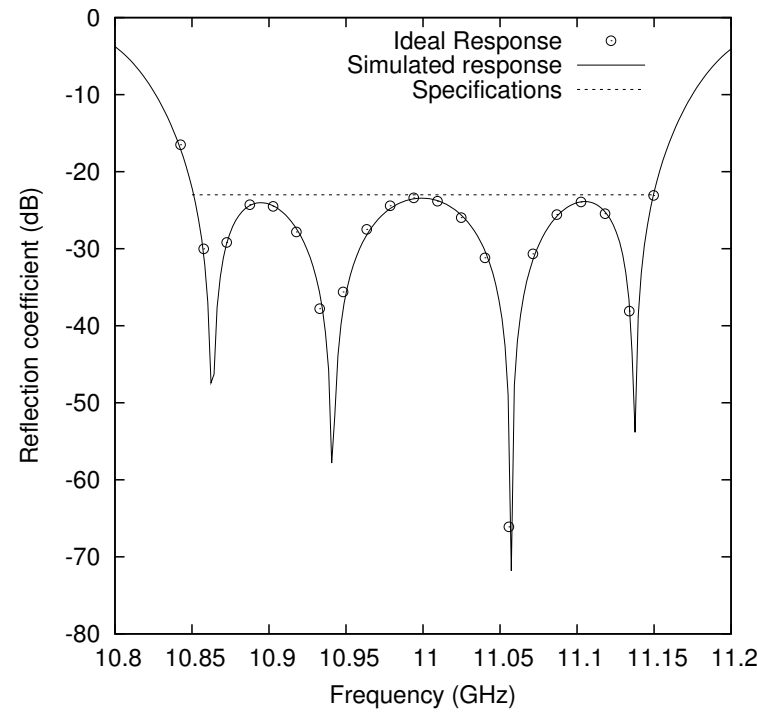

(a) $\mathrm{X}$ band. 4 resonators. $\varepsilon_{r}=30$.

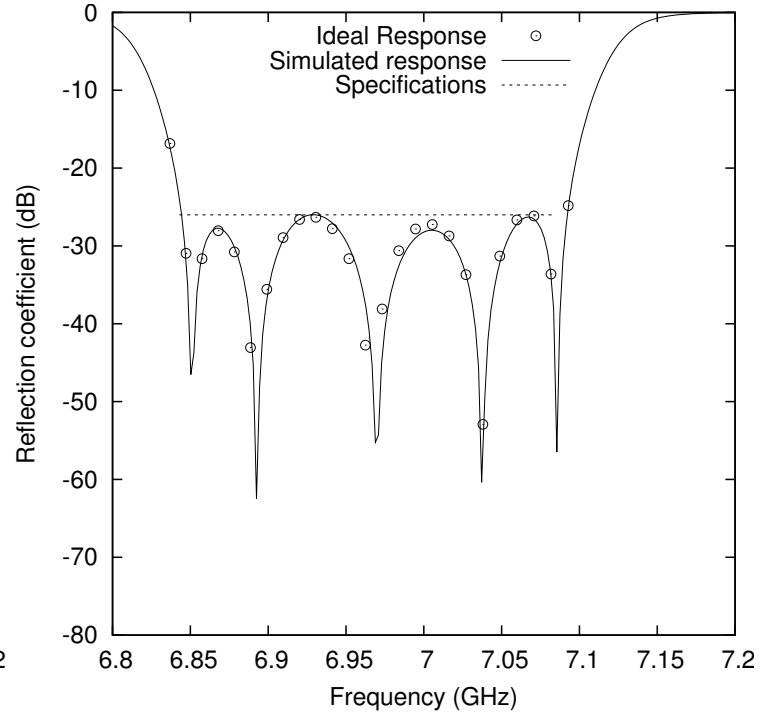

(b) $\mathrm{C}$ band. 5 resonators. $\varepsilon_{r}=20$.

Figura 3.45: Ideal response vs. simulated response for two designed filters. 


\subsection{El método SQP de optimización con restricciones apli- cado al diseño de filtros con resonadores dieléctricos}

\subsubsection{Introducción}

En muchas aplicaciones de diseño de dispositivos de microondas se pueden utilizar herramientas de optimización que no consideran ninguna restricción sobre los parámetros de diseño. Esto es así especialmente cuando se dispone de una idea inicial sobre los parámetros de diseño muy cercana a los valores finales. No obstante, si no se dispone de herramientas para obtener una buena estimación inicial de los valores de los parámetros de diseño, o en casos en los que la estructura que se diseña es muy compleja, puede suceder que un algoritmo de optimización sin restricciones derive hacia valores de los parámetros de diseño sin sentido físico (longitudes negativas, por ejemplo). También puede suceder que se desee que, por ejemplo, la longitud total del dispositivo no exceda de una cierta cantidad, aunque esto suponga una cierta degradación de otras prestaciones. En estos casos hay que utilizar optimizadores que sí consideran restricciones sobre los parámetros de diseño, y que nos proporcionan el mejor punto dentro de la región permitida. Una posibilidad es utilizar algoritmos genéticos o evolutivos, que permiten establecer límites inferiores y superiores a los parámetros de diseño. La desventaja de estos algoritmos es que convergen muy lentamente. Una alternativa es el método de Programación Cuadrática Secuencial (SQP) [Fle00], que converge de forma más rápida que los algoritmos genéticos o evolutivos, y que además permite establecer restricciones, lineales o no, en las que se combinan varios parámetros de diseño.

En el presente trabajo se ha realizado una implementación del algoritmo SQP con excelentes prestaciones en el caso de que las restricciones sobre los parámetros de diseño sean lineales, que es lo más frecuente en el diseño de dispositivos de microondas.

Esta implementación del SQP se ha realizado con el objetivo de poder diseñar filtros en guía de onda rectangular con resonadores dieléctricos, como los que se muestran en la Fig. 3.46, ya que el diseño de dichos filtros con optimizadores sin restricciones resulta imposible. Gracias al uso del SQP se ha conseguido desarrollar una nueva técnica automatizada y muy eficiente de diseño de filtros en guía con resonadores dieléctricos.

En la siguiente sección de detalla la teoría del algoritmo SQP implementado, y se comparan sus prestaciones con el algoritmo SQP implementado en MATLAB. Y en la siguiente sección se describe la nueva estrategia de diseño automatizado de filtros con dieléctricos y se muestra el diseño de dos filtros de 4 cavidades. 


\subsubsection{El método SQP}

El método de Programación Cuadrática Secuencial o Método de Lagrange-Newton (SQP) [Fle00] es un método de búsqueda del mínimo de una función $n$-dimensional no lineal donde las $n$ variables de las que depende la función están sujetas a restricciones no lineales. Matemáticamente lo podemos expresar de la siguiente forma:

$$
\text { Minimizar } f(\mathbf{x})
$$

donde $f(\mathbf{x})$ es una función no lineal del tipo $\mathbb{R}^{n} \rightarrow \mathbb{R}, \mathbf{y} \mathbf{x}=\left[x_{1}, x_{2}, \cdots, x_{n}\right]^{T}$ está sujeto a $m$ restricciones no lineales, de las cuales $m_{e}$ son de igualdad y el resto de desigualdad:

$$
\begin{aligned}
& c_{i}(\mathbf{x})=0, i=1,2, \cdots, m_{e}(i \in E) \\
& c_{i}(\mathbf{x}) \geq 0, i=m_{e}+1, \cdots, m(i \in I)
\end{aligned}
$$

En el caso de los filtros con resonadores dieléctricos, el vector $\mathrm{x}$ contiene los $n$ parámetros de diseño (longitudes de las cavidades resonantes, radios de los postes dieléctricos, etc.). Y la función $f(\mathbf{x})$ es una estimación de la diferencia (o error) entre la respuesta en frecuencia del filtro con las dimensiones dadas por el vector $\mathrm{x}$ y la respuesta ideal en frecuencia que buscamos (respuesta de tipo Chebyshev). La respuesta ideal y la simulada del filtro se comparan mediante la norma Huber $(k=5)\left[\mathrm{BCB}^{+} 93\right]$.

El método SQP a cada paso aproxima localmente la función $f$ no lineal por una función $q$ cuadrática, y las restricciones no lineales por restricciones lineales. Para encontrar el mínimo de una función cuadrática con restricciones lineales se utiliza el método del conjunto activo (ver [Fle00]), el cual resuelve subproblemas cuadráticos con restricciones de igualdad, los cuales tienen solución analítica. Una vez encontrado el mínimo de esta función cuadrática aproximada con restricciones linealizadas, se aproximan de nuevo la función y las restricciones en torno al nuevo punto y se da un nuevo paso. Así se continúa hasta que se cumple algún criterio de parada (valor de la función muy pequeño, se excede un número máximo de evaluaciones de la función, etc.).

En este trabajo se ha mejorado el SQP estándar añadiendo una búsqueda lineal. Si estamos en el punto $\mathbf{x}^{(k)}$, mediante el método del conjunto activo se obtiene el incremento $\mathbf{s}$ que me lleva al mínimo de la función cuadrática $q$ con restricciones lineales. En lugar de tomar $\mathbf{x}^{(k+1)}=\mathbf{x}^{(k)}+\mathbf{s}$, se toma

$$
\mathbf{x}^{(k+1)}=\mathbf{x}^{(k)}+\alpha \mathbf{s}
$$

donde $\alpha$ se elige para que $f\left(\mathbf{x}^{(k)}+\alpha \mathbf{s}\right)$ sea lo menor posible. A este procedimiento se le llama búsqueda lineal.

Por otro lado, se utiliza la fórmula del método de Broyden-Fletcher-Goldbarb-Shanno (BFGS) [FP63] para obtener en cada iteración una estimación de la Hessiana del Lagrangiano 
(ver [Fle00]) a partir del valor en la iteración anterior, evitando así el cálculo de segundas derivadas.

También se han programado algoritmos que permiten obtener un punto dentro de la región permitida cuando el usuario proporciona un punto inicial que está fuera de dicha región.

La implementación del método SQP realizada se ha validado aplicándola a la obtención del mínimo de la función de Rosenbrock, que es una función de test muy utilizada para probar algoritmos de optimización, con el mínimo en el fondo de un valle curvado muy largo y estrecho. La función de Rosenbrock es de dos variables $\left(f: \mathbb{R}^{2} \rightarrow \mathbb{R}\right)$, y tiene el siguiente aspecto:

$$
f(\mathbf{x})=100\left(x_{2}-x_{1}^{2}\right)^{2}+\left(1-x_{1}\right)^{2}
$$

El mínimo de esta función está en el punto $\mathbf{x}=\left[\begin{array}{ll}1 & 1\end{array}\right]^{T}$, donde la función vale 0 .

\begin{tabular}{|c|c|c|c|}
\hline Punto Inicial & SQP & SQP2 & MATLAB \\
\hline $\left.\begin{array}{lll}0 & 0\end{array}\right]^{T}$ & No converge & $\overline{\overline{666}}$ & $\overline{\overline{88}}$ \\
\hline$\left[\begin{array}{ll}-2 & 1\end{array}\right]^{T}$ & 298 & 86 & Converge a $[0,0]^{T}$ \\
\hline$[2,53,5]^{T}$ & No converge & 77 & Converge a $[0,0]^{T}$ \\
\hline$\left[\begin{array}{ll}-3,5 & -2\end{array}\right]^{T}$ & 37 & 21 & 51 \\
\hline$\left[\begin{array}{ll}-2 & -3,5\end{array}\right]^{T}$ & 154 & 75 & 96 \\
\hline$\left[\begin{array}{ll}10 & -3\end{array}\right]^{T}$ & 277 & 87 & Converge a $[0,0]^{T}$ \\
\hline$\left[\begin{array}{ll}-1,9 & 2\end{array}\right]^{T}$ & 289 & 72 & Converge a $[0,0]^{T}$ \\
\hline$\left[\begin{array}{ll}5 & 0\end{array}\right]^{T}$ & 151 & 76 & Converge a $[0,0]^{T}$ \\
\hline
\end{tabular}

Tabla 3.22: Número de evaluaciones de la función empleadas en encontrar el mínimo de la función de Rosenbrock con restricciones lineales

En la Tabla 3.22 muestra el número de evaluaciones de la función empleadas para encontrar el mínimo de la función de Rosenbrock con las siguientes restricciones lineales:

$$
\begin{array}{ll}
x_{1} \geq 0 & -x_{1} \geq-3 \\
x_{2} \geq 0 & -x_{2} \geq-2
\end{array}
$$

Con estas restricciones el mínimo está en el punto $\left[\begin{array}{ll}1 & 1\end{array}\right]^{T}$, que está dentro de la región permitida. 
En la Tabla 3.22 se compara el comportamiento del algoritmo SQP estándar, el SQP mejorado con la búsqueda lineal (al que se ha llamado SQP2), y la función fmincon de MATLAB [Mat, Mat02]. Esta función de MATLAB utiliza una implementación del SQP con una búsqueda lineal en la que se busca un descenso suficiente en una función de mérito similar a las de Han [Han77] y Powell [Pow78]. También se utiliza la fórmula de BFGS para la actualización de la Hessiana del Lagrangiano. Se puede observar que el método SQP2 funciona bien para todos los puntos de partida, mientras que MATLAB a veces converge al punto erróneo, y cuando converge al punto correcto utiliza más evaluaciones de la función que SQP2. También se puede apreciar la mejora sustancial que supone la utilización de la búsqueda lineal.

\begin{tabular}{|c|c|c|c|}
\hline Punto Inicial & SQP & SQP2 & MATLAB \\
\hline \hline$\left[\begin{array}{ll}0 & 0\end{array}\right]^{T}$ & 19 & 19 & 25 \\
\hline$\left[\begin{array}{ll}-2 & 1\end{array}\right]^{T}$ & No converge & No converge & 146 \\
\hline$\left[\begin{array}{ll}2,5 & 3,5\end{array}\right]^{T}$ & 25 & 25 & 192 \\
\hline$\left[\begin{array}{ll}10 & -3\end{array}\right]^{T}$ & No converge & No converge & No converge \\
\hline$\left[\begin{array}{ll}1,9 & 2\end{array}\right]^{T}$ & No converge & No converge & 32 \\
\hline
\end{tabular}

Tabla 3.23: Número de evaluaciones de la función empleadas en encontrar el mínimo de la función de Rosenbrock con restricciones no lineales

En la Tabla 3.23 se muestra el resultado de la optimización de la función de Rosenbrock con las siguientes restricciones no lineales:

$$
\begin{array}{r}
x_{2}-x_{1}^{2}-1 \geq 0 \\
-x_{2}-x_{1}^{2}+2 \geq 0
\end{array}
$$

Se puede observar que los métodos SQP y SQP2 no son tan robustos como el algoritmo de MATLAB cuando las restricciones no son lineales. Este es un aspecto que convendría mejorar, aunque también es cierto que en los problemas de diseño de dispositivos de microondas no es frecuente utilizar restricciones no lineales sobre los parámetros de diseño. Y especialmente en la aplicación que nos interesa (filtros con resonadores dieléctricos), es suficiente con restricciones lineales.

\subsubsection{Aplicación al diseño de filtros con resonadores dieléctricos}

El uso de resonadores dieléctricos en filtros de comunicaciones de microondas está aumentando debido a que proporcionan importantes reducciones en la masa y el volumen del 
filtro (alrededor del 50\%). Además se consigue mayor estabilidad térmica en aplicaciones de alta potencia. Entre todos los tipos de filtros cargados con resonadores dieléctricos, los filtros en plano $\mathrm{H}$ con postes dieléctricos cilíndricos [IK89] ofrecen las ventajas de que son fáciles de fabricar y de que tienen mayor capacidad de manejo de potencia [QGP $\left.{ }^{+} 05\right]$. En la Fig. 3.46 se muestra la geometría de este tipo de filtros.

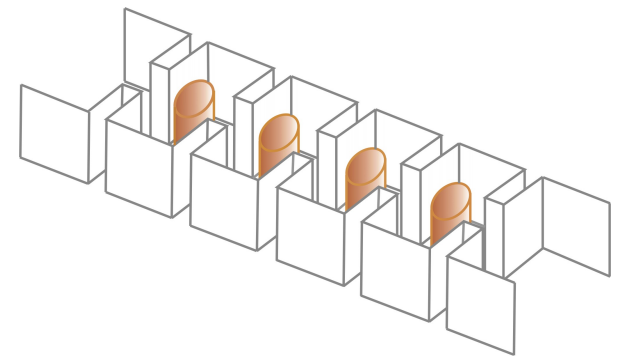

(a) Vista 3-D

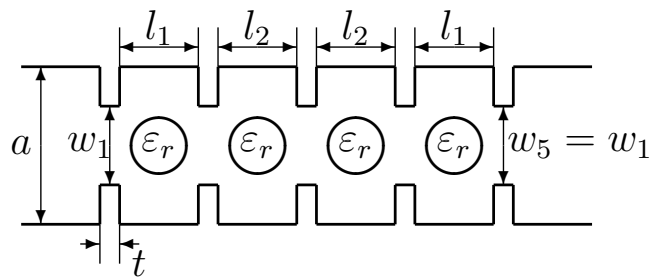

(b) Sección longitudinal

Figura 3.46: Esquema de un filtro de cavidades acopladas de 4 polos con resonadores dieléctricos (simétrico).

Una primera aproximación al diseño de los filtros de la Fig. 3.46 se puede encontrar en $\left[\mathrm{BEB}^{+} 05\right]$. En este trabajo se intentó en primer lugar utilizar la estrategia de diseño de $\left[\mathrm{MSE}^{+}\right.$05]. Esta estrategia está adaptada para el diseño de los filtros de cavidades acopladas en plano $\mathrm{H}$ sin postes dieléctricos, para lo que ha demostrado ser muy rápida y robusta. Se basa en la obtención de un buen punto inicial, una hibridación de varios algoritmos de optimización, la segmentación de la estructura y el algoritmo de Mapeado Espacial Agresivo (ASM) $\left[\mathrm{BBS}^{+} 94, \mathrm{BCD}^{+} 04\right]$.

A pesar de las bondades de la estrategia de $\left[\mathrm{MSE}^{+} 05\right]$ para el diseño de filtros plano $\mathrm{H}$ sin postes dieléctricos, en $\left[\mathrm{BEB}^{+} 05\right]$ se comprobó que dicha estrategia fracasaba para el diseño de filtros con con postes dieléctricos. El motivo es que el acoplo entre cavidades resonantes era mucho más fuerte debido a la presencia de los dieléctricos. Como consecuencia de este factor, el proceso de diseño evolucionaba hacia valores de los parámetros de diseño sin sentido físico (postes dieléctricos mayores que la cavidad resonante, etc.). Por tanto, en $\left[\mathrm{BEB}^{+} 05\right]$ se renunció a dicha estrategia y se consiguió diseñar un filtro con 4 cavidades resonantes con postes dieléctricos circulares utilizando tan sólo algoritmos evolutivos, lo que resultó en un tiempo de diseño mucho mayor que en el caso de filtros sin postes dieléctricos.

En este trabajo se ha modificado la estrategia de diseño de [ $\left.\mathrm{MSE}^{+} 05\right]$, incluyendo un uso combinado de algoritmos evolutivos y del SQP, aprovechando la robustez del primero y la rapidez del segundo.

A continuación se detallan los pasos que se siguen para el diseño automatizado de filtros con resonadores dieléctricos como el que se muestra en la Fig. 3.46. 
En primer lugar se obtienen unos valores iniciales para el mismo filtro pero sin los postes dieléctricos mediante una red ideal equivalente (ver $\left.\left[\mathrm{MSE}^{+} 05\right]\right)$. Esto nos proporciona una estimación inicial para las longitudes $\left(l_{i}^{\text {sin }}\right)$ y para las anchuras $\left(w_{i}^{\text {sin }}\right)$ de las ventanas de acoplo (ver Fig. 3.46).

A continuación se utiliza un algoritmo evolutivo para el filtro con los postes dieléctricos. A las longitudes de las cavidades con postes dieléctricos se les da un margen de variación de $0,5 l_{i}^{\text {sin }} \leq l_{i}^{\text {con }} \leq l_{i}^{\text {sin }}$. Las anchuras de las ventanas de acoplo se dejan variar en el rango $0,9 w_{i}^{\text {sin }} \leq w_{i}^{\text {con }} \leq 1,5 w_{i}^{\text {sin }}$. A los radios de los resonadores dieléctricos $\left(r_{i}\right)$ se les da un margen de variación que depende de la frecuencia y de la permitividad. Cuando el algoritmo evolutivo termina y estamos más cerca del mínimo global, un algoritmo más rápido pero menos robusto (el de descenso del simplex de Nelder y Mead) se usa para continuar la optimización y encontrar un buen punto inicial.

A continuación se toma el valor de los radios proporcionado por la optimización, y se calcula el promedio. Los radios de todos los resonadores se mantienen fijos e igual a ese promedio de ahora en adelante. De esta manera la fabricación del filtro resultará más económica puesto que todos los resonadores serán iguales.

Las dimensiones $\left(l_{i}, w_{i}\right.$ y $\left.r_{i}\right)$ obtenidas en los pasos anteriores se usan como punto inicial de una nueva fase de diseño. Todas las optimizaciones en esta fase se realizan con una combinación del método de descenso del simplex de Nelder y Mead y del método de gradiente BFGS. En esta fase se utiliza una estrategia de segmentación, de manera que en primer lugar se diseñan las dimensiones de la primera cavidad. A continuación las de la segunda, y así hasta que se alcanza la cavidad central. En el siguiente paso se rediseña el filtro al completo, ajustando los posibles acoplos entre cavidades. Todos estos diseños se realizan comparando el parámetro de transmisión de la respuesta ideal con el de la simulación. En un último paso se vuelven a rediseñar todas las dimensiones del filtro pero comparando esta vez el parámetro de reflexión $\left|S_{11}\right|$. Cada uno de estos pasos se divide en dos niveles. En el primer nivel se utiliza el simulador descrito en $\left[\mathrm{BEB}^{+} 05\right]$ pero considerando 7 modos guiados en toda la estructura. En un segundo nivel se repite la misma optimización pero utilizando 11 modos. De esta forma se incrementa la convergencia y rapidez del proceso de diseño.

La Tabla 3.24 muestra los pasos seguidos para el diseño de un filtro con 4 cavidades. En todos los pasos se utiliza norma Huber relativa para calcular el error. Con esta estrategia automatizada se han diseñado dos filtros en guía de onda WR-75 ( $a=19,05 \mathrm{~mm}, \mathrm{~b}=9,525 \mathrm{~mm}$ ) con frecuencia central de $11 \mathrm{GHz}, 300 \mathrm{MHz}$ de ancho de banda y pérdidas de retorno superiores a $23 \mathrm{~dB}$. Para uno de los filtros se ha considerado una permitividad eléctrica relativa de $\varepsilon_{r}=19,5$ en los resonadores, y de $\varepsilon_{r}=30$ para el otro filtro. Para diseñar el primer filtro han sido necesarias 4974 simulaciones, y 4890 para el segundo, lo que supone aproximadamente unos 58' en un Pentium IV @ 3,4 GHz. El número de simulaciones realizadas por cada uno de los algoritmos de optimización para el caso del primer filtro se ha incluido entre paréntesis en la Tabla 3.24. En la Tabla 3.25 se listan los valores finales de los parámetros 
de diseño para los dos filtros. En la Fig. 3.47 se muestra una comparación entre la respuesta ideal del filtro (respuesta tipo Chebyshev) y la respuesta simulada del filtro diseñado con $\varepsilon_{r}=30$. Se puede observar que el diseño se ajusta muy bien a la respuesta ideal deseada.

\begin{tabular}{|c|c|c|c|c|}
\hline Paso & Parámetros & Simulador & Error & Algoritmos \\
\hline 1 & $\begin{array}{l}w_{1}, w_{2}, w_{3} \\
l_{1}, l_{2}\end{array}$ & $\begin{array}{l}\text { Red equivalente } \\
\text { ideal }\end{array}$ & & \\
\hline \multirow{2}{*}{2} & \multirow{2}{*}{$\begin{array}{l}w_{1}, w_{2}, w_{3} \\
l_{1}, l_{2}, r_{1}, r_{2}\end{array}$} & \multirow{2}{*}{$\begin{array}{c}{\left[\mathrm{BEB}^{+} 05\right] \text { con } 7 \text { modos }} \\
\text { Todo el filtro }\end{array}$} & \multirow{2}{*}{$\left|S_{21}\right|$} & Evolutivo (1474) \\
\hline & & & & Simplex (500) \\
\hline \multirow{2}{*}{3} & \multirow{2}{*}{$\begin{array}{l}w_{1}, w_{2}, w_{3} \\
\quad l_{1}, l_{2}\end{array}$} & \multirow{2}{*}{$\begin{array}{c}{\left[\mathrm{BEB}^{+} 05\right] \text { con } 7 \text { modos }} \\
\text { Todo el filtro }\end{array}$} & \multirow{2}{*}{$\left|S_{21}\right|$} & Evolutivo (393) \\
\hline & & & & SQP2 (37) \\
\hline \multirow{3}{*}{4.1} & \multirow{3}{*}{$w_{1}, w_{2}, l_{1}$} & \multirow{3}{*}{$\begin{array}{c}{\left[\mathrm{BEB}^{+} 05\right] \text { con } 7 \text { modos }} \\
\text { Cavidad } 1\end{array}$} & \multirow{3}{*}{$\left|S_{21}\right|$} & SQP2 (68) \\
\hline & & & & Simplex (52) \\
\hline & & & & BFGS (80) \\
\hline \multirow{2}{*}{4.2} & \multirow{2}{*}{$w_{1}, w_{2}, l_{1}$} & \multirow{2}{*}{$\begin{array}{c}{\left[\mathrm{BEB}^{+} 05\right] \text { con } 11 \text { modos }} \\
\text { Cavidad } 1\end{array}$} & \multirow{2}{*}{$\left|S_{21}\right|$} & Simplex (37) \\
\hline & & & & BFGS (40) \\
\hline \multirow{2}{*}{5.1} & \multirow{2}{*}{$\begin{array}{l}l_{1}, w_{2} \\
l_{2}, w_{3}\end{array}$} & \multirow{2}{*}{$\begin{array}{c}{\left[\mathrm{BEB}^{+} 05\right] \text { con } 7 \text { modos }} \\
\text { Cavidades } 1 \text { y } 2\end{array}$} & \multirow{2}{*}{$\left|S_{21}\right|$} & Simplex (202) \\
\hline & & & & BFGS (110) \\
\hline \multirow{2}{*}{5.2} & \multirow{2}{*}{$\begin{array}{l}l_{1}, w_{2} \\
l_{2}, w_{3}\end{array}$} & \multirow{2}{*}{$\begin{array}{c}{\left[\mathrm{BEB}^{+} 05\right] \text { con } 11 \text { modos }} \\
\text { Cavidades } 1 \text { y } 2\end{array}$} & \multirow{2}{*}{$\left|S_{21}\right|$} & Simplex (202) \\
\hline & & & & BFGS (110) \\
\hline \multirow{2}{*}{6.1} & \multirow{2}{*}{$\begin{array}{l}l_{1}, w_{2} \\
l_{2}, w_{3}\end{array}$} & \multirow{2}{*}{$\begin{array}{l}{\left[\mathrm{BEB}^{+} 05\right] \text { con } 7 \text { modos }} \\
\text { Todo el filtro }\end{array}$} & \multirow{2}{*}{$\left|S_{21}\right|$} & Simplex (400) \\
\hline & & & & BFGS (105) \\
\hline \multirow{2}{*}{6.2} & \multirow{2}{*}{$\begin{array}{l}l_{1}, w_{2} \\
l_{2}, w_{3}\end{array}$} & \multirow{2}{*}{$\begin{array}{c}{\left[\mathrm{BEB}^{+} 05\right] \text { con } 11 \text { modos }} \\
\text { Todo el filtro }\end{array}$} & \multirow{2}{*}{$\left|S_{21}\right|$} & Simplex (29) \\
\hline & & & & BFGS (205) \\
\hline \multirow{2}{*}{7.1} & \multirow{2}{*}{$\begin{array}{c}w_{1}, w_{2}, w_{3} \\
\quad l_{1}, l_{2}\end{array}$} & \multirow{2}{*}{$\begin{array}{l}{\left[\mathrm{BEB}^{+} 05\right] \text { con } 7 \text { modos }} \\
\text { Todo el filtro }\end{array}$} & I & Simplex (200) \\
\hline & & & $\left|S_{11}\right|$ & BFGS (106) \\
\hline 72 & & {$\left[\mathrm{BEB}^{+} 05\right]$ con 11 modos } & $1 \mathrm{~S}$ & Simplex (400) \\
\hline 1.2 & $l_{1}, l_{2}$ & Todo el filtro & $\left|S_{11}\right|$ & BFGS (224) \\
\hline
\end{tabular}

Tabla 3.24: Características de las diferentes etapas del proceso de diseño

\begin{tabular}{|c|c|c|c|c|c|c|}
\hline$\varepsilon_{r}$ & $l_{1}$ & $l_{2}$ & $w_{1}$ & $w_{2}$ & $w_{3}$ & $r_{1}$ a $r_{4}$ \\
\hline \hline 19,5 & 8,489 & 13,02 & 13,18 & 8,520 & 8,962 & 2,3 \\
\hline 30 & 7,304 & 12,54 & 14,32 & 9,809 & 10,26 & 1,85 \\
\hline
\end{tabular}

Tabla 3.25: Dimensiones finales de los filtos diseñados 


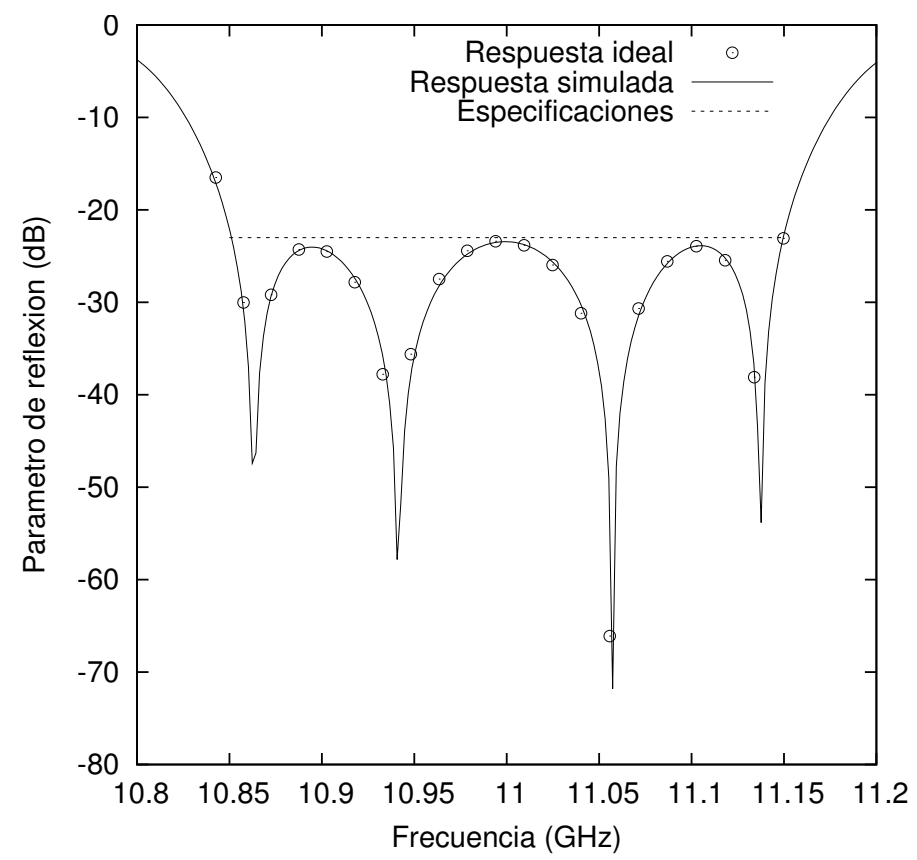

Figura 3.47: Respuesta ideal del filtro de 4 cavidades comparada con la respuesta simulada del filtro diseñado $\left(\varepsilon_{r}=30\right)$

\subsubsection{Conclusiones}

En este trabajo se ha presentado una nueva implementación del algoritmo SQP. Sus prestaciones han demostrado ser mejores que las del SQP de MATLAB cuando las restricciones son lineales. Esta nueva implementación del SQP junto con algoritmos evolutivos han sido utilizados para adaptar una estrategia de diseño anterior al diseño de filtros con resonadores dieléctricos cilíndricos. Dos filtros de 4 cavidades han sido diseñados con éxito con esta nueva estrategia. Se ha conseguido que los radios de todos los resonadores dieléctricos del filtro sean iguales, lo cual abarata la fabricación. 


\subsection{Efficient Technique for the Cascade Connection of Multiple Two Port Scattering Matrices}

\subsubsection{Introduction}

Most two port high frequency networks are characterized in terms of scattering parameters, which have been arranged in matrix form and relate transmitted and reflected waves in the input and output ports [Kur65]. Therefore, the characterization of high frequency systems or components formed by networks connected in cascade requires the connection of two port scattering matrices in order to obtain the overall scattering parameters. For instance, the modelling of communication systems formed by subsystems is usually characterized by monomodal scattering matrices.

On the other hand, the electromagnetic characterization of complex microwave devices requires the cascaded connection of Generalized Scattering Matrices (GSMs). The structure of the microwave device is often divided into simple building blocks (steps, resonators, lines, etc.), and the circuit parameters of each building block are obtained using a suitable electromagnetic analysis method. The most common choice for the circuit parameters is the Generalized Scattering Matrix (GSM), where the reflection and transmission parameters are matrix blocks that take into account all the couplings between the guided modes that have been considered for the analysis. Once the GSMs of all the building blocks have been obtained, the global reflection and transmission parameters of the whole structure must be computed. This requires the cascade connection of the GSMs of all the building blocks. And this process must be typically repeated for each frequency point that we want to analyze. Since the microwave device is divided into very simple building blocks, usually the GSM of each block can be computed using very efficient methods, such as mode-matching [RA95], boundary elements [AM94], or integral equation methods [GG98]. As a consequence, the time required to cascade the GSMs cannot be neglected when compared with the time required by the electromagnetic simulators to compute the GSMs, as shown in the results section. Therefore an improvement in the efficiency of the method used to cascade the matrices results in most cases in an appreciable reduction of the time required to obtain the reflection and transmission parameters of the whole microwave device.

Current methods for the analysis of high frequency networks are the conversion of the scattering matrices to $\mathrm{ABCD}$ or T matrices [Poz04], the use of methods based on signal flow analysis and numerical simulations [Sim81, Hun60], or the recursive connection by pairs of the scattering matrices [Bud98]. All these techniques either fail to cascade multimodal scattering matrices due to the inversion of an ill-conditioned matrix, and/or their efficiency can still be improved. Another alternative is to use impedance matrices instead of scattering matrices [DETS96]. A very efficient technique for cascading impedance matrices is presented in [BGG97]. However, this technique is only suitable when all the networks are characterized 


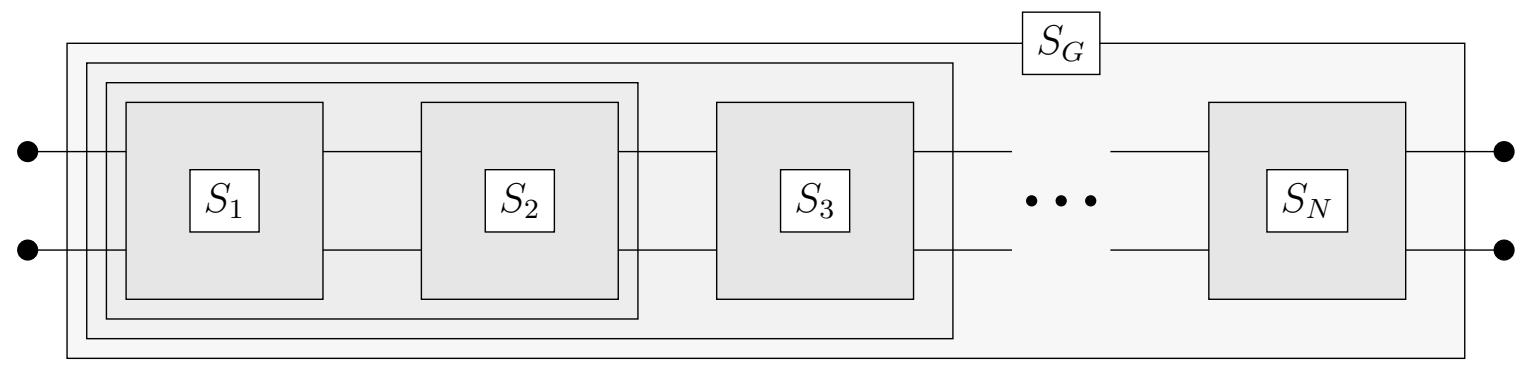

Figura 3.48: Cascade connection of $\mathrm{N}$ scattering matrices by pairs.

with impedance matrices, since the conversion from scattering to impedance matrices would decrease the efficiency significantly.

In this paper we present a new technique for the efficient cascade connection of $N$ monomodal or multimodal two port scattering matrices. This new method improves the efficiency of currently existing methods. In sections 3.9.2 and 3.9.3, classical techniques currently used are briefly recalled in order to study their computational burden, whereas the new method proposed here is fully described in 3.9.4. In order to test the efficiency of the new method, two practical examples are analyzed: the cascade connection of monomodal scattering matrices of a Tchebyshev filter formed by lumped elements, and the cascade connection of multimodal scattering matrices (GSMs) of an $\mathrm{H}$ plane filter with dielectric resonators.

\subsubsection{Conversion to ABCD matrices}

In order to cascade $N$ scattering matrices with this method, the first step is to convert each scattering matrix $S_{i}(i \in[1, \cdots, N])$ to the corresponding normalized ABCD matrix $L_{i}$. The following expressions may be used [Poz04]:

$$
\begin{aligned}
A_{i} & =\frac{1}{2}\left[\left(1+S_{i, 11}\right) R\left(1-S_{i, 22}\right)+S_{i, 12}\right] \\
B_{i} & =\frac{1}{2}\left[\left(1+S_{i, 11}\right) R\left(1+S_{i, 22}\right)-S_{i, 12}\right] \\
C_{i} & =\frac{1}{2}\left[\left(1-S_{i, 11}\right) R\left(1-S_{i, 22}\right)-S_{i, 12}\right] \\
D_{i} & =\frac{1}{2}\left[\left(1-S_{i, 11}\right) R\left(1+S_{i, 22}\right)+S_{i, 12}\right] \\
R & =\left(S_{i, 21}\right)^{-1}
\end{aligned}
$$


The ABCD matrix of the global structure $\left(L_{G}\right)$ is then easily obtained as:

$$
\begin{aligned}
L_{G} & =L_{1} \cdot L_{2} \cdots L_{N} \\
& =\left[\begin{array}{c|c}
A_{G} & B_{G} \\
\hline & \\
C_{G} & D_{G}
\end{array}\right]
\end{aligned}
$$

And finally the global scattering matrix $S_{G}$ is obtained by the conversion of $L_{G}$ to scattering matrix through [Poz04]:

$$
\begin{aligned}
S_{G, 11}= & 2\left(A_{G}+B_{G}\right) R-I \\
S_{G, 12}= & \frac{1}{2}\left(A_{G}-B_{G}-C_{G}+D_{G}\right) \\
+ & \frac{1}{2}\left(A_{G}+B_{G}-C_{G}-D_{G}\right) R . \\
& \cdot\left(-A_{G}+B_{G}-C_{G}+D_{G}\right) \\
S_{G, 21}= & 2 R \\
S_{G, 22}= & R\left(-A_{G}+B_{G}-C_{G}+D_{G}\right) \\
R= & \left(A_{G}+B_{G}+C_{G}+D_{G}\right)^{-1}
\end{aligned}
$$

where $I$ is the identity matrix of $M \times M$ elements, and $M$ is the number of guided modes considered for the analysis. If the matrices are monomodal $M=1$.

The whole process requires $N+1$ matrix inversions and $14 N-4$ matrix products in order to get the final scattering matrix. All matrices are of dimension $M \times M$. If the scattering matrices are multimodal, the method fails since $S_{i, 21}$ becomes a matrix that is generally illconditioned and therefore cannot be inverted in equation (3.105).

If $\mathrm{T}$ matrices are used instead of $\mathrm{ABCD}$ matrices, the number of inversions and products are very similar. As with ABCD matrices, the ill-conditioned $S_{i, 21}$ matrix must be inverted and therefore this method is also not suitable for multimodal analysis. 


\subsubsection{Connection of Scattering Matrices by Pairs}

This method cascades two scattering matrices $S_{A}$ and $S_{B}$ providing a global matrix $S_{T}$. The following equations are used to cascade $S_{A}$ and $S_{B}$ [Bud98]:

$$
\begin{aligned}
S_{T, 11} & =S_{A, 11}+S_{A, 12} S_{B, 11} F S_{A, 21} \\
S_{T, 12} & =S_{A, 12}\left(I+S_{B, 11} F S_{A, 22}\right) S_{B, 12} \\
S_{T, 21} & =S_{B, 21} F S_{A, 21} \\
S_{T, 22} & =S_{B, 22}+S_{B, 21} F S_{A, 22} S_{B, 12}
\end{aligned}
$$

where $F$ is:

$$
F=\left(I-S_{A, 22} S_{B, 11}\right)^{-1}
$$

Using this method, the first and second matrices $\left(S_{1}\right.$ and $\left.S_{2}\right)$ are cascaded and a global matrix is obtained. This global matrix is then cascaded to the third matrix $S_{3}$, and a new global matrix is obtained. The process follows until the last scattering matrix has been cascaded and a global matrix $S_{G}$ that characterizes the whole structure is obtained (see Figure 3.48).

Each time that two matrices are connected using equations (3.112) to (3.115), 10 matrix products and 1 matrix inversion is required. The connection of $N$ networks requires $N-1$ iterations. Thus the overall process requires $10(N-1)$ matrix products and $N-1$ matrix inversions. In most practical situations all the scattering matrices are reciprocal. In that case $S_{T, 12}=S_{T, 21}^{T}$, and equation (3.113) or (3.114) can be avoided. Equation (3.114) is preferred since it involves less matrix products. Therefore if all matrices are reciprocal, the connection by pairs requires $8(N-1)$ matrix products and $N-1$ matrix inversions.

\subsubsection{New Method for the Efficient Connection of $N$ Multimodal Scat- tering Matrices}

In most two-port passive microwave devices the global network is reciprocal (not containing any nonreciprocal media such as ferrites or plasmas) and physically symmetric, even though the individual networks (i.e the steps), are reciprocal but not symmetric. In such cases the global network is symmetric, and only $S_{G, 11}$ and $S_{G, 21}$ need to be computed, since $S_{G, 22}=S_{G, 11}$ and $S_{G, 12}=S_{G, 21}$. When this happens, the efficiency of the connection by pairs can be improved, since the fact that the global network is symmetric cannot be used to simplify equations (3.112), (3.114) and (3.115), since intermediate networks (with scattering matrices $S_{A}, S_{B}$ and $S_{T}$ ) may be not symmetric.

In order to exploit the fact that the global network is symmetric, a different approach is used. The idea is to iteratively relate the forward and backward waves between each two 
networks with the waves in the previous step. At the end, the waves at the input and output ports of the global network are related and the reflection and transmission parameters $\left(S_{G, 11}\right.$ and $S_{G, 21}$ ) are obtained. In this process we must be careful to avoid the inversion of illconditioned matrices, such as $S_{i, 21}$.

Figure 3.49 shows the names assigned to the forward and backward normalized voltage waves in the input and output ports of each network. $a_{i}$ is the forward wave in the input port of network $i$, and $b_{i}$ is the backward wave. In the output port of the last network, the convention is changed, and $b_{N+1}$ is the forward wave and $a_{N+1}$ is the backward wave.

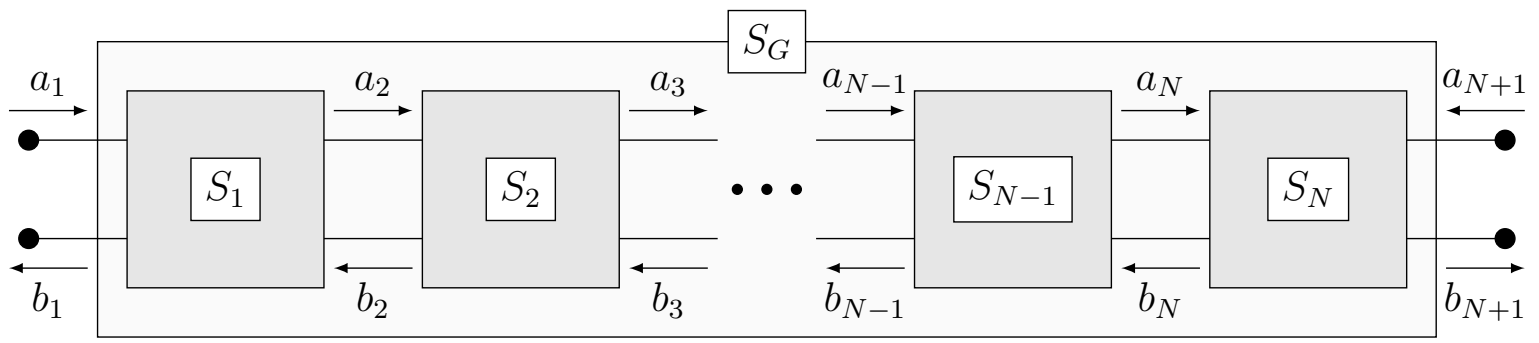

Figura 3.49: Cascade connection of $\mathrm{N}$ scattering matrices with the new method.

In the case of multimodal voltage waves, $a_{i}$ and $b_{i}$ are vectors of $M$ elements. In this case the scattering matrices $S_{i}$ are of $2 M \times 2 M$ elements, and each matrix block $S_{i, \delta \gamma}$ (with $\delta, \gamma=1,2)$ is of $M \times M$ elements.

Our objective is to obtain the scattering parameters of the global network $\left(S_{G}\right)$ that relate the incident and reflected waves at the input and output ports:

$$
\begin{aligned}
b_{1} & =S_{G, 11} a_{1}+S_{G, 12} a_{N+1} \\
b_{N+1} & =S_{G, 21} a_{1}+S_{G, 22} a_{N+1}
\end{aligned}
$$

Assuming that the global network is symmetric, only $S_{G, 11}$ and $S_{G, 21}$ need to be computed. In order to compute $S_{G, 11}$ and $S_{G, 21}$ we can consider that there is no incidence in the output port, that is, $a_{N+1}=0$. Thus:

$$
\begin{aligned}
b_{1} & =S_{G, 11} a_{1} \\
b_{N+1} & =S_{G, 21} a_{1}
\end{aligned}
$$

Attending to the definition of the scattering parameters, and according to Figure 3.49, the following equations apply for each network $i, i \in[1, \cdots, N-1]$ :

$$
\begin{aligned}
b_{i} & =S_{i, 11} a_{i}+S_{i, 12} b_{i+1} \\
a_{i+1} & =S_{i, 21} a_{i}+S_{i, 22} b_{i+1}
\end{aligned}
$$


For the last network, the forward and backward waves in the output port (see Figure 3.49) are defined in a different way. So the equations for the last network are:

$$
\begin{aligned}
b_{N} & =S_{N, 11} a_{N}+S_{N, 12} a_{N+1} \\
b_{N+1} & =S_{N, 21} a_{N}+S_{N, 22} a_{N+1}
\end{aligned}
$$

Substituting $a_{N+1}=0$ in equations (3.123) and (3.124):

$$
\begin{aligned}
b_{N} & =S_{N, 11} a_{N} \\
b_{N+1} & =S_{N, 21} a_{N}
\end{aligned}
$$

Substituting (3.125) in equation (3.122) with $i=N-1$ we can express $a_{N}$ as a function of $a_{N-1}$ :

$$
a_{N}=\left(I-S_{N-1,22} S_{N, 11}\right)^{-1} S_{N-1,21} a_{N-1}
$$

where $I$ is the identity matrix of dimension $M \times M$. It must be noted that the matrix that is inverted in (3.127) is not ill-conditioned.

Substituting (3.127) in (3.125) we also express $b_{N}$ as a function of $a_{N-1}$ :

$$
b_{N}=S_{N, 11}\left(I-S_{N-1,22} S_{N, 11}\right)^{-1} S_{N-1,21} a_{N-1}
$$

We define:

$$
\begin{aligned}
& A_{N}=\left(I-S_{N-1,22} S_{N, 11}\right)^{-1} S_{N-1,21} \\
& C_{N}=S_{N, 11} \\
& B_{N}=C_{N} A_{N}
\end{aligned}
$$

Thus:

$$
\begin{aligned}
a_{N} & =A_{N} a_{N-1} \\
b_{N} & =C_{N} a_{N}=C_{N} A_{N} a_{N-1}=B_{N} a_{N-1}
\end{aligned}
$$

Next we try to express $a_{N-1}$ and $b_{N-1}$ as a function of $a_{N-2}$. To accomplish this we first substitute (3.133) in (3.121) with $i=N-1$, and we obtain:

$$
\begin{aligned}
b_{N-1} & =\left(S_{N-1,11}+S_{N-1,12} B_{N}\right) a_{N-1} \\
& =C_{N-1} a_{N-1}
\end{aligned}
$$

where

$$
C_{N-1}=S_{N-1,11}+S_{N-1,12} B_{N}
$$


Substituting (3.134) in (3.122) with $i=N-2$ :

$$
\begin{aligned}
a_{N-1} & =\left(I-S_{N-2,22} C_{N-1}\right)^{-1} S_{N-2,21} a_{N-2} \\
& =A_{N-1} a_{N-2}
\end{aligned}
$$

where

$$
A_{N-1}=\left(I-S_{N-2,22} C_{N-1}\right)^{-1} S_{N-2,21}
$$

Substituting (3.136) in (3.134):

$$
\begin{aligned}
b_{N-1} & =C_{N-1} a_{N-1}=C_{N-1} A_{N-1} a_{N-2} \\
& =B_{N-1} a_{N-2}
\end{aligned}
$$

where

$$
B_{N-1}=C_{N-1} A_{N-1}
$$

The same procedure can be followed in order to relate $b_{i}$ and $a_{i}$ with $a_{i-1}$ for $i=[N-$ $2, \cdots, 2]$ :

$$
\begin{aligned}
a_{i} & =A_{i} a_{i-1} \\
b_{i} & =B_{i} a_{i-1}
\end{aligned}
$$

where

$$
\begin{aligned}
C_{i} & =S_{i, 11}+S_{i, 12} B_{i+1} \\
A_{i} & =\left(I-S_{i-1,22} C_{i}\right)^{-1} S_{i-1,21} \\
B_{i} & =C_{i} A_{i}
\end{aligned}
$$

Equations (3.140) to (3.144) are valid for all values of $i(i=[2, \cdots, N])$, except for $C_{N}$, whose correct value is $C_{N}=S_{N, 11}$.

Once we have related all $a_{i}$ and $b_{i}$ with $a_{i-1}$, we can determine the scattering parameters of the global network. Using equation (3.121) with $i=1$ :

$$
\begin{aligned}
& b_{1}=S_{1,11} a_{1}+S_{1,12} b_{2}=S_{1,11} a_{1}+S_{1,12} B_{2} a_{1} \\
& b_{1}=\left(S_{1,11}+S_{1,12} B_{2}\right) a_{1}
\end{aligned}
$$

and comparing with equation (3.119):

$$
S_{G, 11}=S_{1,11}+S_{1,12} B_{2}
$$




\begin{tabular}{c|ccc} 
& ABCD & By pairs & New method \\
\hline Matrix products & $14 N-4$ & $8(N-1)$ & $5 N-5$ \\
Matrix inversions & $N+1$ & $N-1$ & $N-1$
\end{tabular}

Tabla 3.26: Comparison of the operations required to cascade $N$ scattering matrices.

On the other hand, using equation (3.126):

$$
\begin{aligned}
b_{N+1} & =S_{N, 21} a_{N}=S_{N, 21} A_{N} a_{N-1} \\
b_{N+1} & =S_{N, 21} A_{N} A_{N-1} a_{N-2} \\
b_{N+1} & =S_{N, 21} A_{N} A_{N-1} A_{N-2} a_{N-3} \\
& \vdots \\
b_{N+1} & =S_{N, 21}\left(\prod_{i=N}^{2} A_{i}\right) a_{1}
\end{aligned}
$$

Comparing with equation (3.120):

$$
S_{G, 21}=S_{N, 21}\left(\prod_{i=N}^{2} A_{i}\right)
$$

If the global network is symmetric, and using equations (3.146) and (3.148), the global scattering matrix is:

$$
S_{G}=\left[\begin{array}{c|c}
S_{1,11}+S_{1,12} B_{2} & S_{N, 21}\left(\prod_{i=N}^{2} A_{i}\right) \\
\hline S_{N, 21}\left(\prod_{i=N}^{2} A_{i}\right) & S_{1,11}+S_{1,12} B_{2}
\end{array}\right]
$$

The procedure requires of $N-1$ matrix inversions and $5 N-5$ matrix products. Besides, the authors have verified that for electromagnetic problems the matrices that should be inverted with this method are all well conditioned and do not present problems of unreliability.

Table 3.26 summarizes the operations required to cascade $N$ scattering matrices by the three methods discussed in this paper, assuming that all networks are reciprocal and the global network is symmetric. 

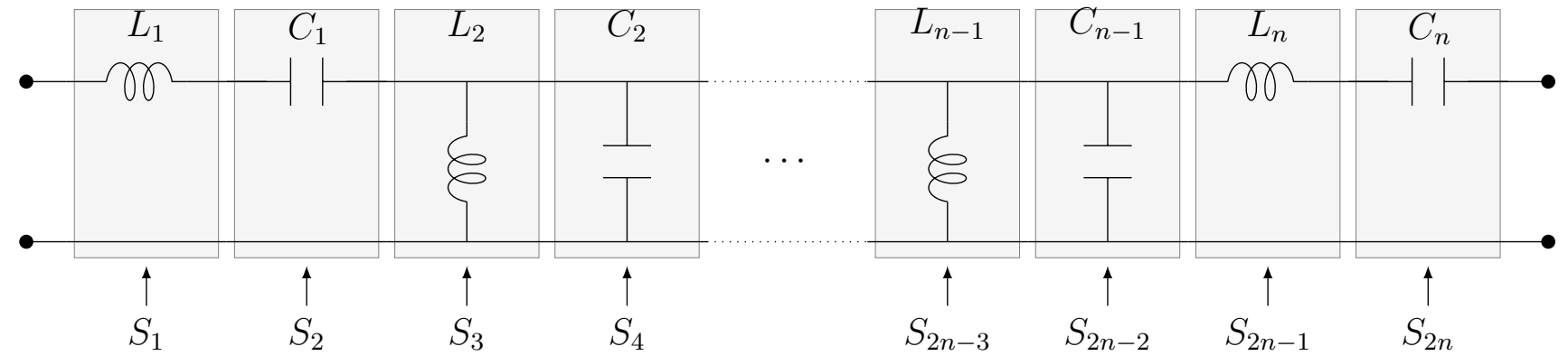

Figura 3.50: Tchebyshev LC bandpass filter of order $n$ ( $n$ is odd).

\subsubsection{Results}

\subsubsection{Monomodal scattering matrices}

The new method has first been tested with monomodal scattering matrices. For that purpose, a standard Tchebyshev bandpass filter formed with inductors and capacitors has been considered (see Figure 3.50). The filter is centered at $4.75 \mathrm{GHz}$, and the bandwidth is $500 \mathrm{MHz}$. The values of the inductors and capacitors are easily obtained from the Tchebyshev low pass prototype using the frequency band pass transformation [MJY80].

As shown in Figure 3.50, each reactance has been considered as a two port network, and its correspondent monomodal scattering matrix has been computed. Thus, for a filter of order $n$ ( $n$ has been chosen to be always odd), there are $2 n$ reactances, and therefore $2 n$ scattering matrices.

The $2 n$ scattering matrices have been cascaded using three different methods: the traditional ABCD matrix method, the recursive connection by pairs of matrices and the new method described in the article.

Figure 3.51 depicts the CPU time needed to cascade the $2 n$ scattering matrices for different values of $n$. It can be observed that the connection time increases linearly with the number of networks $(2 n)$. It can also be observed that the new method requires only around $65 \%$ of the CPU time required by the connection by pairs, and around $25 \%$ of the time required by the $A B C D$ matrix method.

In order to test the accuracy of the new method, the reflection coefficient of the Tchebyshev filter of order 5 has been depicted in Figure 3.52. The reflection coefficient has been 


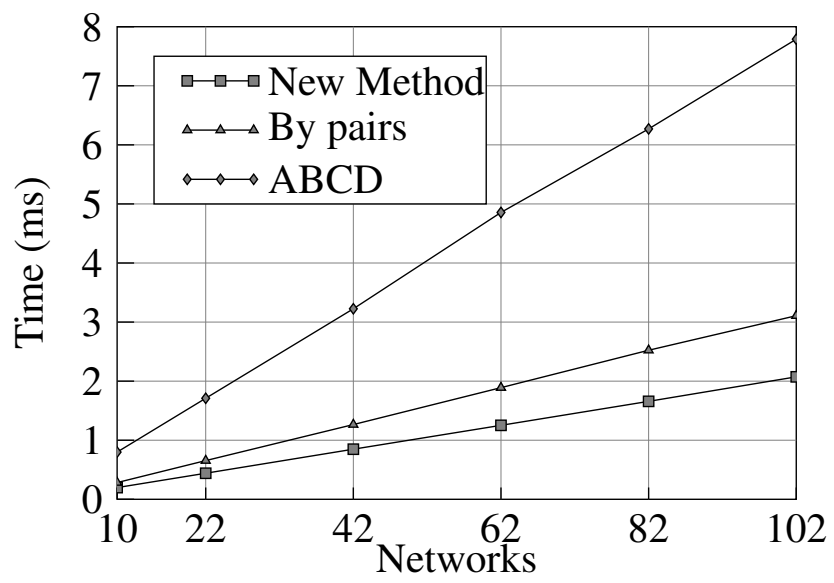

Figura 3.51: Connection time of $\mathrm{N}$ monomodal scattering matrices.

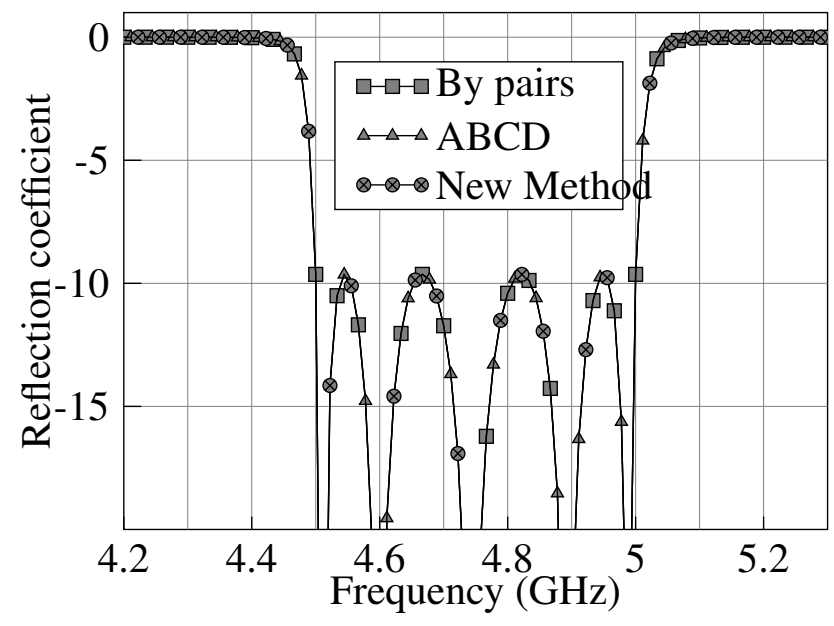

Figura 3.52: Reflection coefficient of a Tchebyshev LC bandpass filter of order 5 . 
obtained cascading the scattering matrices with the three different methods, and there is a very good agreement between all the curves. The root mean square error (RMSE) between curves of the reflection coefficient has been computed for different number of networks. The result is summarized in Table 3.27, where RMSE 1-2 is the error between curves computed with the new method and the connection by pairs, RMSE 1-3 is the error between the new method and the method of ABCD matrices, and RMSE 2-3 is the error between the connection by pairs and the method of ABCD matrices. It can be observed that the error increases slightly with the number of networks, but it is nevertheless quite stable and of the order of $10^{-14}$. Therefore we can conclude that all three methods are very accurate for cascading monomodal matrices.

\begin{tabular}{c|ccc} 
Number of networks & RMSE 1-2 & RMSE 1-3 & RMSE 2-3 \\
\hline 10 & $1,32 \cdot 10^{-14}$ & $1,6 \cdot 10^{-14}$ & $1,55 \cdot 10^{-14}$ \\
22 & $2,56 \cdot 10^{-14}$ & $5,56 \cdot 10^{-14}$ & $5,11 \cdot 10^{-14}$ \\
42 & $4,83 \cdot 10^{-14}$ & $5,99 \cdot 10^{-14}$ & $7,77 \cdot 10^{-14}$ \\
62 & $14,7 \cdot 10^{-14}$ & $17,5 \cdot 10^{-14}$ & $16,1 \cdot 10^{-14}$ \\
82 & $17,6 \cdot 10^{-14}$ & $14,4 \cdot 10^{-14}$ & $13,2 \cdot 10^{-14}$ \\
102 & $13,2 \cdot 10^{-14}$ & $15,0 \cdot 10^{-14}$ & $16,5 \cdot 10^{-14}$
\end{tabular}

Tabla 3.27: RMSE of the reflection coefficient versus number of networks. Tchebyshev LC bandpass filter.

\subsubsection{Multimodal scattering matrices}

The efficiency and accuracy of the new method for cascading GSMs is tested here. The structure that has been chosen for the test is an $\mathrm{H}$ plane coupled cavities filter with dielectric resonators. A 3D view of this structure is shown in Figure 3.53. For the electromagnetic analysis the structure is segmented into simple building blocks, as shown in Figure 3.54. These blocks are of one of these types: transmission lines, steps or dielectric resonators. The GSM of the transmission lines can be easily obtained using basic Microwave Theory [Mar86]. The GSM of the steps is computed using the integral equation technique described in [GG98], and the GSM of the dielectric resonators is obtained using the hybrid method proposed in $\left[\mathrm{ECB}^{+} 02 \mathrm{~b}\right]$. This combination of analysis methods has already been used in $\left[\mathrm{BEB}^{+} 05\right]$ and [MGBB07], and its accuracy was successfully tested in $\left[\mathrm{BEB}^{+} 05\right]$ through comparison with a commercial Finite Element Method (HFSS [Cor]).

In the case of connection of multimodal scattering matrices, the $\mathrm{ABCD}$ connection does 


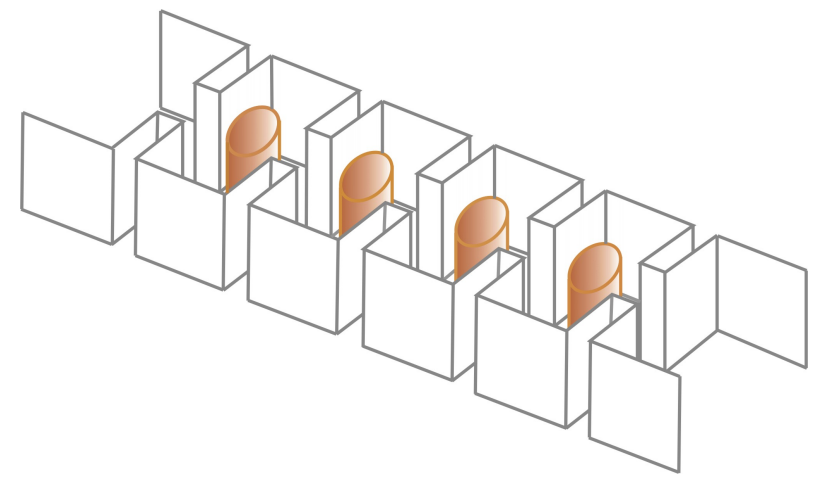

Figura 3.53: $\mathrm{H}$ plane coupled cavities filter with dielectric resonators. 3D view.

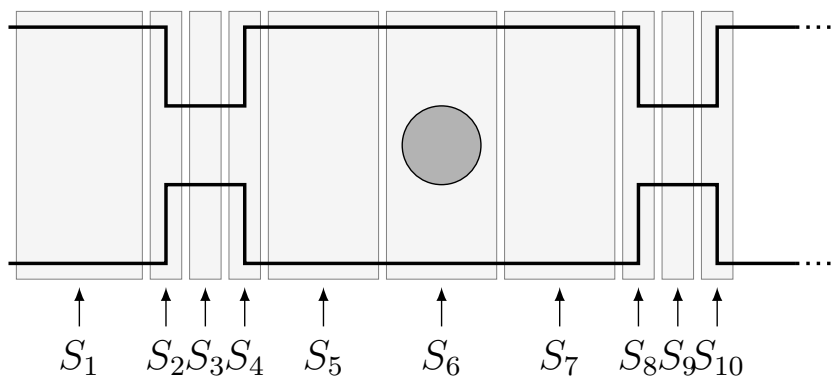

Figura 3.54: $\mathrm{H}$ plane coupled cavities filter with dielectric resonators. Segmentation into simple building blocks.

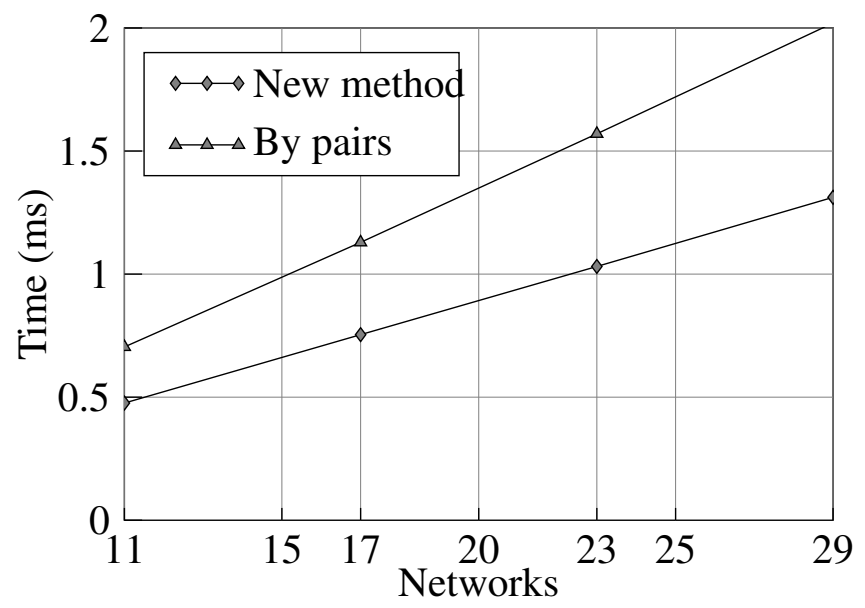

Figura 3.55: Connection time of $\mathrm{N}$ multimodal scattering matrices $(M=7)$. 
not provide good results, since the matrices that should be inverted become ill-conditioned when more than one mode is considered. When only two modes are considered, the 1-norm condition number of the matrix to be inverted is already of the order of $10^{16}$. So in this case we have compared only the iterative connection by pairs and the new method. Figure 3.55 shows the CPU time required for the cascade connection of all the GSMs of an $\mathrm{H}$ plane filter with 1 to 4 resonators. The dimensions of the 4 resonator filter have been obtained using the design procedure described in [MBEB06]. 7 guided modes have been considered for the analysis, so the GSMs are of $14 \times 14$ elements. The number of networks $N$ is a function of the number of resonator cavities $n_{r}\left(N=5+6 n_{r}\right)$. Thus in Figure 3.55 the computation time for $1,2,3$ and 4 resonators cavities is presented. It can be observed again that the computation time increases linearly, and that the new method requires around $65 \%$ of the time required by the connection by pairs. And these results are not dependant of the number of modes considered for the analysis, as proved in Figure 3.56, where the ratio in computation time between both methods is maintained regardless of the number of modes $M$.

For a 4 pole filter with $M=7$ modes, the computation time required to compute all the scattering matrices is 22.4 seconds, whereas the time required to connect these matrices is 2.07 seconds if we use the connection by pairs, and 1.35 seconds if we use the new method. Therefore, the connection by pairs requires the $8.5 \%$ of the total time, whereas the new method only requires the $5.7 \%$ of the total time required to obtain the scattering parameters of the whole filter.

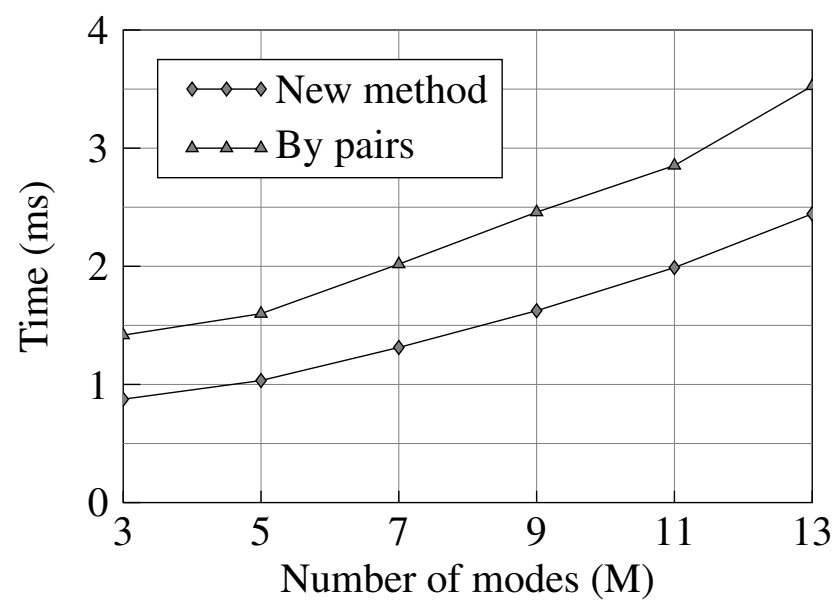

Figura 3.56: Connection time versus number of modes. H plane filter with 4 resonator cavities (29 networks, 11 modes).

Finally, the accuracy of the new method for connecting multimodal matrices is tested in Figure 3.57. The reflection and transmission coefficients of an $\mathrm{H}$ plane filter with four resonator cavities have been computed. It can be observed that the curves are in very good agreement for the new method and the connection by pairs. The root mean square error 
between curves of the reflection coefficient is $1,99 \cdot 10^{-15}$ for 11 guided modes. This error between the new method and the connection by pairs is quite stable with the number of networks and the number of modes, as shown in Tables 3.28 and 3.29.

\begin{tabular}{c|c} 
Number of modes & Root mean square error \\
\hline 3 & $1,35 \cdot 10^{-15}$ \\
5 & $1,53 \cdot 10^{-15}$ \\
7 & $1,99 \cdot 10^{-15}$ \\
9 & $1,81 \cdot 10^{-15}$ \\
11 & $1,99 \cdot 10^{-15}$ \\
13 & $4,64 \cdot 10^{-15}$
\end{tabular}

Tabla 3.28: RMSE of the reflection coefficient versus number of modes ( 29 networks).

\begin{tabular}{c|c} 
Number of networks & Root mean square error \\
\hline 11 & $1,63 \cdot 10^{-15}$ \\
17 & $2,38 \cdot 10^{-15}$ \\
23 & $2,79 \cdot 10^{-15}$ \\
29 & $1,99 \cdot 10^{-15}$
\end{tabular}

Tabla 3.29: RMSE of the reflection coefficient versus number of networks (7 modes).

\subsubsection{Conclusions}

A new method for the cascade connection of scattering matrices has been presented in this paper. This new method is very efficient if the global structure is symmetric, which is the case of the majority of two port microwave devices.

The method has been first applied to the analysis of lumped element bandpass Tchebyshev filters formed by inductors and capacitors. The computation time required by the new method was around $65 \%$ of the time required by the connection by pairs, and around $25 \%$ of the time required by the connection using $\mathrm{ABCD}$ matrices. This reduction was maintained regardless of the order of the filter and therefore regardless of the number of matrices to be cascaded.

The method has also been tested with the cascading of the multimodal scattering matrices that characterize the building blocks (lines, steps and resonators) of an $\mathrm{H}$ plane coupled 


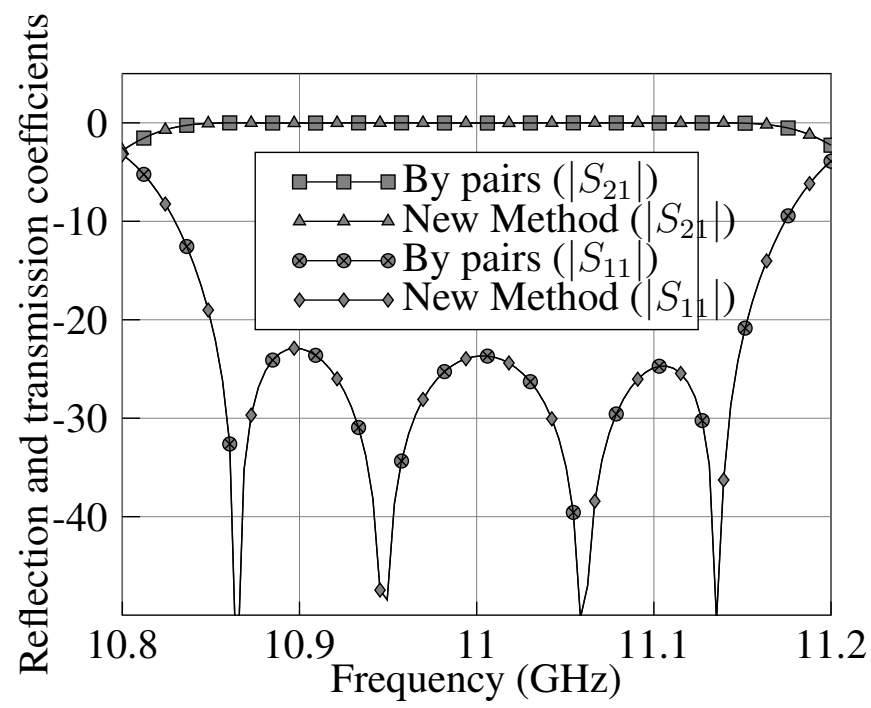

Figura 3.57: Reflection coefficient of an 4-pole $\mathrm{H}$ plane coupled cavities filter with dielectric resonators. $M=11$.

cavities filters with dielectric resonators. Again the new method reduces the computation time by $35 \%$ when compared with the connection by pairs, regardless of the number of matrices to be cascaded, and also regardless of the number of guided modes considered for the analysis. 


\subsection{CAD of Evanescent Mode Waveguide Filters with Circular Dielectric Resonators}

\subsubsection{Introduction}

The development of new structures for the implementation of high frequency filters in communication systems is motivated by some of these reasons: reduction on mass and volume, increase on thermic stability for high power applications, increase on out of band rejection, reduction on manufacturing effort, and/or availability of analysis and design tools for synthesizing a desired response. Rectangular waveguide $\mathrm{H}$-plane evanescent mode filters with dielectric resonators provide very good response to the three first items $\left[\mathrm{BBC}^{+} 03, \mathrm{CPG} 01\right]$. If the dielectric resonators are circular, the manufacturing effort is dramatically reduced when compared to square resonators. However, the accurate modelling of the circular dielectric resonators is far more complex than for square ones, since circular and square geometries must be analyzed together.

In this paper, we propose a fast and accurate CAD tool of evanescent mode waveguide filters with circular dielectric resonators. The development of this CAD tool has been possible thanks to a novel analysis and design technique. The analysis tool applies a suitable combination of an analytical method and a hybrid technique that cope with the different parts of the filter structure $\left[\mathrm{BEB}^{+} 05\right]$. A combination of an evolutionary and the Nelder-Mead simplex algorithm is used to design the filters.

\subsubsection{Analysis and Design of the Structure}

The structure under analysis is an H-plane evanescent mode waveguide filter loaded with circular dielectric resonators (see Fig. 3.58(a)). The theory states that this structure can cope with the main objectives of a high frequency filter: small dimensions, good response to high power applications and out of band rejection $\left[\mathrm{BBC}^{+} 03, \mathrm{CPG} 01\right]$.

When designing the structure for a desired frequency response of the filter, a CAD tool is required, since the complexity of the structure and the strong couplings that appear between the resonators make impossible a manual design. Any CAD tool requires an efficient and accurate analysis tool. Nevertheless the accurate analysis of these kind of filters was far from being efficient: numerical methods were too time consuming and analytical methods were not appropriated.

We have developed an analysis tool that divides the structure into a set of building blocks, 


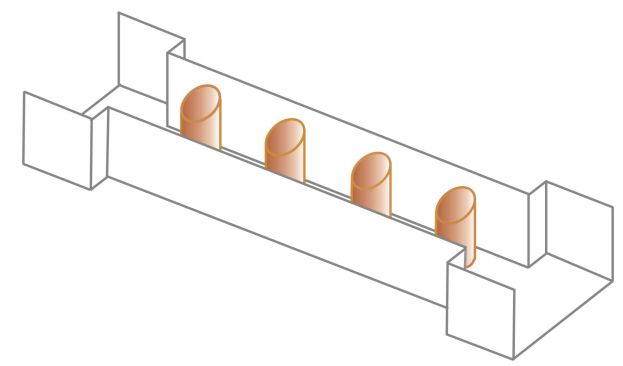

(a) 3-D view

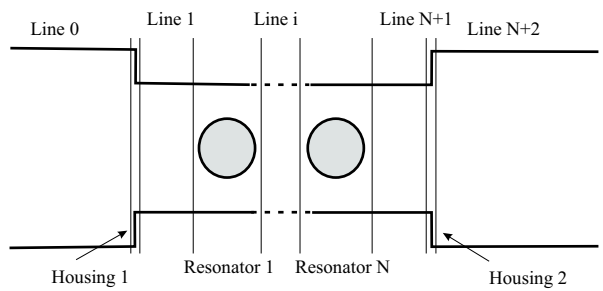

(b) 2-D view. Segmentation strategy followed by the analysis tool

Figura 3.58: H-plane evanescent filter loaded with circular dielectric resonators.

as shown in Fig. 3.58(b).

The housing between rectangular waveguides are characterized in terms of the Generalized Impedance Matrix (GIM) by the integral equation technique described in [GG98]. The dielectric resonators are characterized using the hybrid method described in $\left[\mathrm{ECB}^{+} 02 \mathrm{~b}\right.$ ] with the modifications described in $\left[\mathrm{BEB}^{+} 05\right]$. Once the GIMs of the different resonators that constitute the structure are obtained, we calculate the GIMs of the linking lines between those blocks. At this point the filter is modeled by $\mathrm{N}$ networks in cascade, each one characterized by its GIM and two more at the beginning and the end that characterize the housing of the evanescent structure. In order to obtain the S-parameters of the global structure, the continuity of the modal voltages and currents between each pair of networks is enforced. This leads to a band tridiagonal by blocks matrix system that can be solved very efficiently $\left[\mathrm{BEB}^{+} 05\right]$.

For the automated design of the evanescent mode filters a combination of two optimization algorithms has been used. The optimization starts with an evolutionary genetic algorithm. Once the evolutionary algorithm has obtained a good point near the minimum, the optimization continues with the Nelder-Mead simplex algorithm until convergence is reached. The transmission coefficient $S_{21}$ is used to compute the error between an ideal Tchebyshev filter response that fulfils the specifications and the simulated response.

\subsubsection{Results}

In this section the CAD tool is used to design a band-pass filter centered at $11 \mathrm{GHz}$ with $300 \mathrm{MHz}$ bandwidth and return losses greater than $23 \mathrm{~dB}$. The filter is an H-plane evanescent mode filter with circular dielectric resonators (see Fig. 3.58(a)). In order to achieve the desired specifications, four cavities must be considered.

The height of all the structure is $9.525 \mathrm{~mm}$. The widths of the input and output wavegui- 
des are fixed to $19.05 \mathrm{~mm}$ (standard WR-75). The housing of the filter is fixed to $8 \mathrm{~mm}$ in order to provide the desired bandwidth and similar spurious frequency bands than a directcoupled-cavities filter with the same specifications. The relative permittivity of the dielectric resonators is chosen to be 24 . The radii of the dielectric posts $\left(r_{i}\right)$, the distance between the housing and the first resonator $\left(l_{1}\right)$, and the distances among resonators $\left(l_{i}\right)$ are the design parameters.

Table 3.30 shows the final values for the design parameters after the combination of evolutionary and simplex algorithms has been used. The table also presents the dimensions of the same filter ( $11 \mathrm{GHz}$ central frequency, $300 \mathrm{MHz}$ bandwidth, $23 \mathrm{~dB}$ return loss) designed with different structures: all metallic H-plane coupled-cavities filter $\left[\mathrm{BEB}^{+} 05\right]\left(w_{i}\right.$ are the width of the coupling windows and $l_{i}$ the lengths of the cavities), H-plane coupled-cavities filter loaded with circular dielectric resonators $\left[\mathrm{BEB}^{+} 05\right]$ ( $r_{i}$ are the radii of the resonators), and $\mathrm{H}$-plane evanescent mode filter loaded with square dielectric resonators $\left[\mathrm{BBC}^{+} 03\right.$ ] (the cross section of each resonator is $2 \mathrm{~mm} \times a_{i}$ ). It can be observed that the evanescent mode filter with circular resonators reduces the length and volume when compared with the other types of filters. The reduction when compared with the all-metallic coupled-cavities filter is $53 \%$ in length and $80 \%$ in volume.

\begin{tabular}{|c|c|c|c|c|c|c|}
\hline \multicolumn{3}{|c|}{ Coupled-cavities filters } & \multicolumn{3}{c|}{ Evanescent mode filters } \\
\hline \hline & with resonators & without & & circular & rectangular \\
\hline \hline$w_{1}, w_{5}$ & 13.37 & 10.52 & $l_{1}, l_{5}$ & 2.4179 & 2.559 \\
\hline$w_{2}, w_{4}$ & 6.286 & 7.098 & $l_{2}, l_{4}$ & 10.182 & 10.4875 \\
\hline$w_{3}$ & 6.1 & 6.52 & $l_{3}$ & 10.9919 & 11.344 \\
\hline$l_{1}, l_{4}$ & 6.98 & 15.68 & $r_{1}, r_{4}$ & 0.777 & - \\
\hline$l_{2}, l_{3}$ & 8.28 & 17.605 & $r_{2}, r_{3}$ & 2.169 & - \\
\hline$r_{1}, r_{4}$ & 2.111 & - & $a_{1}, a_{4}$ & - & 0.996 \\
\hline$r_{2}, r_{3}$ & 2.172 & - & $a_{2}, a_{3}$ & - & 1.043 \\
\hline Total length & 40.52 & 76.57 & Total length & 36.19 & 37.44 \\
\cline { 5 - 7 } & & & &
\end{tabular}

Tabla 3.30: Dimensions of H-plane filters in $\mathrm{mm}$

Besides length and volume reduction, another advantage of the evanescent mode filters is the out of band rejection. Fig. 3.59(b) shows the out of band behaviour of the evanescent mode filter with circular resonators and the coupled-cavities filter with and without resonators. It can be observed a much better rejection for the evanescent mode filter with a narrower spurious band. The spurious band can be pushed to higher frequencies varying the size of the housing. 


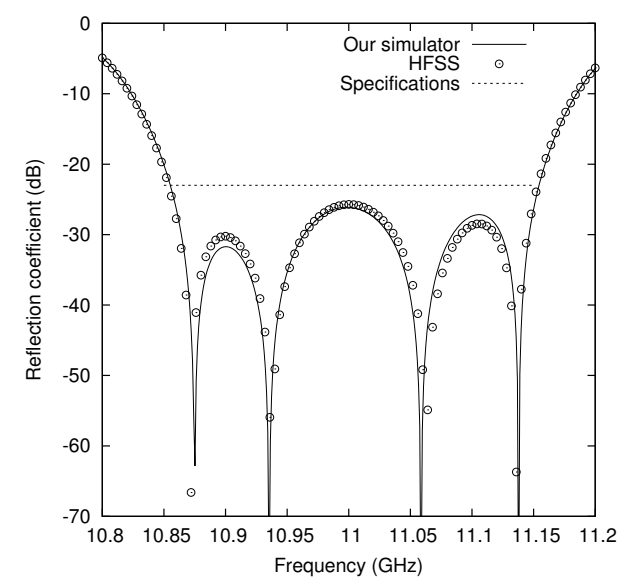

(a) In-band behaviour. Comparison with commercial software

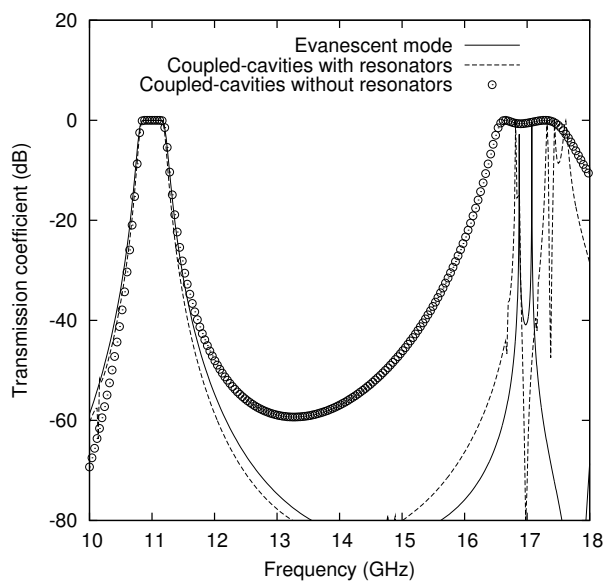

(b) Out of band rejection. Comparison with other types of filters

Figura 3.59: Evanescent mode 4-pole filter with circular dielectric posts

The accuracy of the simulator used in the CAD tool has been validated through comparison with a commercial simulator based on the finite elements method (HFSS). The results are presented in Fig. 3.59(a). It can be observed that there is a good agreement between both simulators. However, the simulation time in a Pentium IV processor at $2.8 \mathrm{GHz}$ was 8 " for our simulator and 15' for HFSS. This enhances the high efficiency of the new simulator used by the CAD tool. Without such a highly efficient simulator the automated design would be impossible, since a huge number of simulations are needed to complete the design process. A total computation time of 19' was needed for the automated design of the 4-pole filter.

\subsubsection{Conclusions}

An accurate and efficient CAD tool for evanescent mode waveguide filters with circular dielectric resonators has been presented. The accuracy of the CAD tool has been validated through comparison with HFSS. The length and volume reduction, as well as the better out of band rejection of the evanescent mode filter when compared to other types of filters, has been fully demonstrated. 


\subsection{Optimización multiobjetivo aplicado al diseño de fil- tros evanescentes con resonadores dieléctricos}

\subsubsection{Introducción}

Tradicionalmente, el diseño de dispositivos de microondas se basa en obtener una estructura cuya respuesta verifique las especificaciones de diseño. Sin embargo, el desarrollo de nuevas estructuras para la implementación de filtros que operan a altas frecuencias intenta cumplir una serie de especificaciones adicionales, entre las que destacan: una masa y volumen reducidos, una buena estabilidad térmica para su uso en aplicaciones con altas potencias, y un incremento en la banda libre de frecuencias espúreas o banda de rechazo.

Estas nuevas especificaciones representan una serie de objetivos adicionales a la hora de diseñar los filtros de microondas, por lo que se necesita aplicar una optimización multiobjetivo, es decir, no basta con imponer unos límites a los parámetros de diseño y optimizar la respuesta del filtro, sino que en base a las especificaciones, se han de añadir otros objetivos a optimizar, como ampliar la banda de rechazo o reducir el tamaño y peso de la estructura.

En el presente trabajo se ha realizado una implementación del algoritmo de optimización multiobjetivo Goal Attainment (consecución de objetivos) que reduce el problema a varias optimizaciones con un sólo objetivo. Para estas optimizaciones se hace uso de la hibridación de diferentes algoritmos de optimización tradicionales (simplex, evolutivos y SQP). Esta hibridación permitirá al diseñador manejar diferentes tipos de objetivos sujetos a una serie de restricciones en los parámetros de diseño de forma muy robusta. Esta implementación del algoritmo de consecución de objetivos se ha aplicado al diseño de filtros en guía de onda rectangular en modo evanescente con resonadores dieléctricos, como los que se muestran en la figura 3.60.

En la siguiente sección se detalla la teoría del algoritmo de consecución de objetivos implementado, y se comparan sus prestaciones con el algoritmo implementado en MATLAB. Y en la siguiente sección se describe la nueva estrategia de diseño automatizado de filtros en modo evanescente con dieléctricos y se muestra el diseño de un filtro de 2 cavidades. 


\subsubsection{El método de consecución de objetivos}

\subsubsection{Programación multiobjetivo}

La optimización multiobjetivo se basa en la optimización simultánea de un conjunto de objetivos que pueden estar sujetos a varias restricciones tanto de igualdad como de desigualdad. De este modo, el problema se formula matemáticamente de la siguiente forma:

$$
\text { Minimizar } \quad \mathbf{F}(\mathbf{x})=\left[f_{1}(\mathbf{x}), f_{2}(\mathbf{x}), \cdots, f_{k}(\mathbf{x})\right]^{T}
$$

donde $\mathbf{F}(\mathbf{x})$ es el vector que contiene las $k(\geq 2)$ funciones objetivo del tipo $\mathbb{R}^{n} \rightarrow \mathbb{R}, \mathrm{y}$ $\mathbf{x}=\left[x_{1}, x_{2}, \cdots, x_{n}\right]^{T}$ está sujeto a m restricciones, de las cuales $m_{e}$ son de igualdad y el resto de desigualdad.

$$
\begin{array}{ll}
c_{i}(\mathbf{x})=0 & , \quad i=1,2, \cdots, m_{e}(i \in E) \\
c_{i}(\mathbf{x}) \geq 0 & , \quad i=m_{e}+1, \cdots, m(i \in I)
\end{array}
$$

En el caso de los filtros en modo evanescente con resonadores dieléctricos, el vector $\mathbf{x}$ contiene los $n$ parámetros de diseño (dimensiones de las guías de onda, radios de los postes dieléctricos, etc). Y el vector $\mathbf{F}(\mathbf{x})$ estará compuesto por dos funciones objetivo:

- $f_{1}(\mathbf{x})$ : Diferencia (o error) entre la respuesta en frecuencia del filtro con las dimensiones dadas por el vector $\mathbf{x}$ y la respuesta ideal en frecuencia que buscamos (repuesta de tipo Chebyshev). Para comparar ambas respuestas se utiliza la norma Huber $(k=5)$ $\left[\mathrm{BCB}^{+}\right.$93].

- $f_{2}(\mathbf{x})$ : Inversa del ancho de banda libre de espúreos ya que se pretende maximizar el tamaño de esta banda.

\subsubsection{Método de consecución de objetivos}

El método de consecución de objetivos [GH75] expresa el problema multiobjetivo como un problema de optimización escalar que se puede expresar como:

$$
\underset{\gamma \in \mathbb{R}, x \in S}{\operatorname{minimizar}} \quad \gamma \quad \text { tal que } \quad \gamma=\max \left\{\frac{f_{i}(x)-f_{i}^{*}}{w_{i}}\right\}
$$


donde el vector $\mathbf{F}^{*}=\left[f_{1}^{*}, f_{2}^{*}, \cdots, f_{k}^{*}\right]$ es un conjunto de valores objetivos dados por el diseñador, que pueden ser alcanzables o no por los puntos de la región permitida. Los pesos $w_{i}>0$ indican la importancia relativa de cada función objetivo, ya que marcan junto con $\gamma$, la distancia entre el valor de cada función y su valor objetivo, estableciendo, al mismo tiempo, la dirección de búsqueda de la solución no inferior del frente de Pareto. De este modo, el método puede obtener todos los puntos del frente de Pareto utilizando diferentes valores de los pesos $w_{i}$ y de los valores objetivo $f^{*}$.

La estrategia de optimización escalar que se utilizará para resolver el problema de optimización mostrado en (3.152) depende de si se han definido o no restricciones en el espacio de las variables de decisión. En el caso de que no existan restricciones se ha decido utilizar únicamente el algoritmo de optimización simplex[Fle00], mientras que si existen restricciones se ha decidido aplicar una hibridación de algoritmos de optimización para conseguir mejorar la convergencia y robustez del proceso de diseño tal y cómo se muestra en la tabla 3.31 .

Esta hibridación comenzará utilizando el método simplex, cuyo resultado se tomará como solución, en aquellos puntos que estén dentro de la región permitida, o como punto inicial para el método de la programación cuadrática secuencial [Fle00] (SQP) o para el algoritmo evolutivo [HH04] ya que estos dos métodos nos permiten una optimización con restricciones. La aplicación de uno de estos dos métodos en segundo lugar depende de si el método SQP diverge o no. Ya que el método SQP obtiene buenos resultados cuando la solución no diverge, por lo que no hace falta aplicar el algoritmo evolutivo. Sin embargo, en los puntos donde el método SQP diverge, es mejor acercar el punto inicial mediante el algoritmo evolutivo evitando así que diverja. De esta forma se consigue una estrategia de hibridación más robusta.

\begin{tabular}{|l|l|}
\hline Restricciones & Métodos \\
\hline No & Simplex \\
\hline Si & Simplex, SQP ó Algoritmo Evolutivo+SQP \\
\hline
\end{tabular}

Tabla 3.31: Algoritmos de optimización escogidos

Para validar la estrategia de optimización anterior se han resuelto los dos problemas de optimización multiobjetivo mostrados en las ecuaciones 3.153 - 3.154. Ambos problemas tienen cómo primer objetivo la función de Rosenbrock, que es una función de test muy utilizada para probar algoritmos de optimización, con el mínimo en el fondo de un valle curvado muy largo y estrecho. El mínimo de esta función está en el punto $x=\left[\begin{array}{ll}1 & 1\end{array}\right]^{T}$.

$$
\mathbf{F}(\mathbf{x})=\left[100\left(x_{2}-x_{1}^{2}\right)^{2}+\left(1-x_{1}\right)^{2},\left|x_{1}+x_{2}\right|\right]^{T}
$$




$$
\mathbf{F}(\mathbf{x})=\left[100\left(x_{2}-x_{1}^{2}\right)^{2}+\left(1-x_{1}\right)^{2}, \operatorname{sen}\left(x_{1}\right)\right]^{T}
$$

En todas las pruebas se ha tomado un peso fijo para la primera función objetivo del problema, $w_{1}=1$, y un total de 100 pesos para la segunda función $\left(w_{2}\right)$ entre los valores 0,1 y 10,1. De este modo, se calcula todo el frente de Pareto.

La medida del error en las pruebas se ha basado en la diferencia entre los valores hallados con el algoritmo desarrollado y los obtenidos con la función fgoalattain de MATLAB [Mat02].

A continuación se muestran los resultados de las pruebas realizadas, distribuidas en tablas, diferenciando los dos tipos de problemas de optimización, es decir, con y sin restricciones.

\begin{tabular}{|c|c|c|}
\hline$f^{*}$ & Punto Inicial & Error máximo \\
\hline$\left[\begin{array}{ll}0 & 0\end{array}\right]$ & $\begin{array}{c}{\left[\begin{array}{ll}0 & 0\end{array}\right]} \\
{[10-3]}\end{array}$ & $\begin{array}{l}3 \cdot 10^{-3} \\
3 \cdot 10^{-3}\end{array}$ \\
\hline$\left[\begin{array}{ll}-0,212 & -0,12]\end{array}\right.$ & 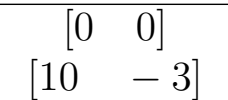 & $\begin{array}{l}2,4 \cdot 10^{-3} \\
2,4 \cdot 10^{-3}\end{array}$ \\
\hline
\end{tabular}

Tabla 3.32: Resultados para la ecuación 3.153 sin restricciones

\begin{tabular}{|c|c|c|c|}
\hline Restricciones & $f^{*}$ & Error Máximo & Ptos. Divergen \\
\hline $0 \leq x_{1} \leq 2$ & {$\left[\begin{array}{ll}0 & 0\end{array}\right]$} & $2 \cdot 10^{-3}$ & 0 \\
$0 \leq x_{2} \leq 2$ & {$\left[\begin{array}{ll}0,1 & 0,1\end{array}\right]$} & $1,4 \cdot 10^{-3}$ & 0 \\
& {$[-0,096-0,11]$} & $7,2 \cdot 10^{-2}$ & 0 \\
\hline $0 \leq x_{1} \leq 0,5$ & {$\left[\begin{array}{ll}0 & 0\end{array}\right]$} & $1,5 \cdot 10^{-2}$ & 0 \\
$0 \leq x_{2} \leq 0,4$ & {$[0,20,4]$} & $0,32 \cdot 10^{-3}$ & 0 \\
& {$[-0,096-0,11]$} & 13,97 & 0 \\
\hline
\end{tabular}

Tabla 3.33: Resultados para la ecuación 3.154 con restricciones

En las tablas 3.32 y 3.33 se muestran los resultados tanto para el problema sin restricciones como para el problema con restricciones. Para el caso con restricciones se considera como punto inicial $x^{(0)}=\left[\begin{array}{ll}0 & 0\end{array}\right]$. Como se observa en ambos casos el algoritmo implementado funciona correctamente ya que el error máximo es muy pequeño y no hay ningún punto en el frente de Pareto que diverga hacia los extremos del área permitida. 


\subsubsection{Aplicación al diseño de filtros en modo evanescente con resona- dores dieléctricos}

Los filtros evanescentes en plano $\mathrm{H}$ con resonadores dieléctricos tienen una longitud y volumen más reducidos comparado con los filtros plano $\mathrm{H}$ de cavidades acopladas todo metálico y los de cavidades acopladas con resonadores dieléctricos circulares, como se demostró en $\left[\mathrm{BEB}^{+} 05\right]$, donde se obtuvo una reducción de un $53 \%$ en longitud y un $80 \%$ en volumen con respecto al filtro todo metálico de cavidades acopladas. Los filtros evanescentes ofrecen, además, un mejor rechazo y una banda libre de espúreos que los filtros con cavidades acopladas con y sin resonadores dieléctricos.

Otra ventaja de los filtros evanescentes con resonadores dieléctricos, a parte de una buena estabilidad térmica por el uso de estos resonadores, es un menor riesgo de multipactor, lo que los hace muy útiles para las aplicaciones de alta potencia. Esto se debe a que los postes dieléctricos se sitúan normalmente en el centro de la guía rectangular donde el campo eléctrico es máximo, aumentando de este modo la potencia máxima sin riesgo de multipactor. Además, su fabricación se simplifica cuando los resonadores son cilíndricos. En la figura 3.60 se muestra la geometría de este tipo de filtros.

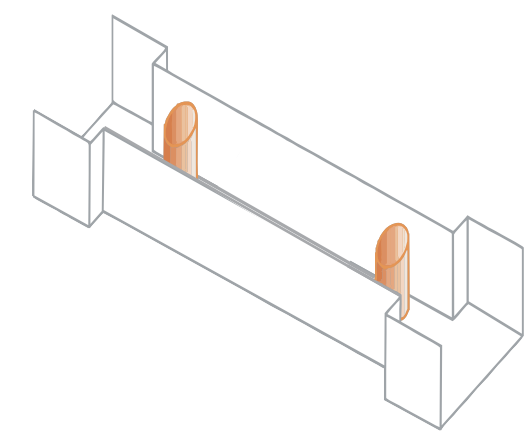

(a) Vista 3-D

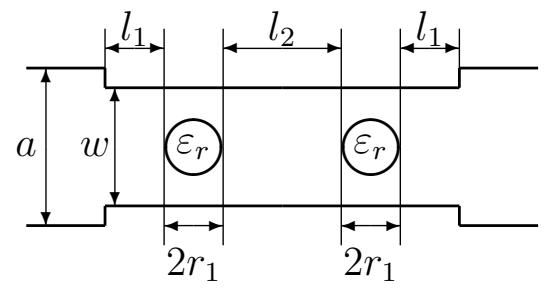

(b) Sección longitudinal

Figura 3.60: Filtro evanescente de 2 polos con resonadores dieléctricos

En este trabajo se ha desarrollado un proceso de diseño para estos filtros, donde se ha aplicado la optimización multiobjetivo como parte de él, en vista de las mejoras que se pueden conseguir. Para ello, se ha diseñado un filtro evanescente simétrico con sólo dos resonadores. De este modo, este proceso puede servir como base para futuras estructuras 
más complejas de este tipo de filtro.

Se ha diseñado un filtro en modo evanescente con dos objetivos:

- Respuesta pasobanda centrado a $7 \mathrm{GHz}$ con un ancho de banda de $250 \mathrm{MHz}$ y unas pérdidas de retorno superiores a $23 \mathrm{~dB}$.

- Ancho de banda libre de espúreos superior a $8 \mathrm{GHz}$.

Las guías de onda de entrada y salida son guías de onda estándar WR-137 ( $a=$ $34,85 \mathrm{~mm}, b=15,80 \mathrm{~mm}$ ) y longitud $10 \mathrm{~mm}$. La altura de estas guías fija la altura de toda la estructura. También se fija la permitividad de resonadores a $\varepsilon_{r}=20$, dejando el resto de dimensiones como parámetros de diseño. Estos son la anchura de la guía central o housing $(\omega)$, el radio de los resonadores dieléctricos $\left(r_{1}\right)$, la distancia entre la guía de entrada y el primer resonador $\left(l_{1}\right)$, y la distancia entre los dos resonadores $\left(l_{2}\right)$.

Estos parámetros están limitados, tal y cómo se muestra en la ecuación 3.155.

$$
8 \leq \omega \leq 10 \quad 0 \leq l_{1} \leq 5 \quad 0,5 \leq r_{1} \leq 3,75 \quad 1 \leq l_{2} \leq 10
$$

En primer lugar, se tiene que hallar el punto inicial necesario para la optimización multiobjetivo. La importancia de este punto inicial se debe a que el primer método que se utiliza en el algorimo multiobjetivo es el método simplex, el cual, como no considera restricciones en la variable de decisión, siempre intenta buscar el mínimo global de la función que puede estar lejos de los límites impuestos.

Este punto inicial se consigue mediante el diseño de la estructura con el único objetivo de conseguir la respuesta real en la banda de paso lo más parecida posible a la ideal. Además para esta optimización, se fija la anchura de la guía central $\omega=10 \mathrm{~mm}$ con el fin de obtener una frecuencia de corte mínima del modo fundamental de esta guía $\left(T E_{10}\right)$ de $15 \mathrm{GHz}$.

El proceso aplicado en este paso inicial consta de dos etapas de optimización, en donde se ha aplicado una optimización híbrida. De este modo, en la primera etapa se optimiza la estructura a partir de un punto inicial aleatorio con un algoritmo evolutivo, y el método simplex para ajustar los resultados.

Así, el punto inicial hallado mediante este diseño es el mostrado en la tabla 3.34, donde se ha incluido el valor que toman las funciones objetivo para este punto.

Una vez obtenido un buen punto inicial, se aplica la optimización multiobjetivo esperando mejorar tanto la respuesta del filtro como la banda de rechazo, permitiendo al mismo 


\begin{tabular}{|l|l|l|l|l|l|}
\hline$f_{1}(x)$ & $1 / f_{2} \mathrm{GHz}$ & $\omega(\mathrm{mm})$ & $l_{1}(\mathrm{~mm})$ & $r(\mathrm{~mm})$ & $l_{2}(\mathrm{~mm})$ \\
\hline 0.7128 & 7.9581 & 10 & $\approx 0$ & 1.5428 & 7.4922 \\
\hline
\end{tabular}

Tabla 3.34: Punto inicial

tiempo que esta mejora sea más en uno de los objetivos que en el otro según los pesos $w$ introducidos por el diseñador, lo cual es la base de la optimización multiobjetivo. Para ello, el siguiente paso del proceso de diseño trata de optimizar la estructura inicial mediante el algoritmo multiobjetivo desarrollado en el apartado anterior. En este paso se consideran todos los parámetros de diseño explicados anteriormente, sin fijar ninguno de ellos, y restringidos dentro de los límites descritos en la ecuación 3.155.

Como resultado del algoritmo multiobjetivo, se consigue el frente de Pareto de estas dos funciones objetivo mostrado en la figura 3.61 con el vector de valores objetivos inalcanzables $f^{*}=\left[\begin{array}{ll}0 & 0\end{array}\right]$ y para veinte pesos. Tomando el peso de la primera función $w_{1}=1$ en todos los puntos y variando el segundo peso de 0,1 a 10,1 .

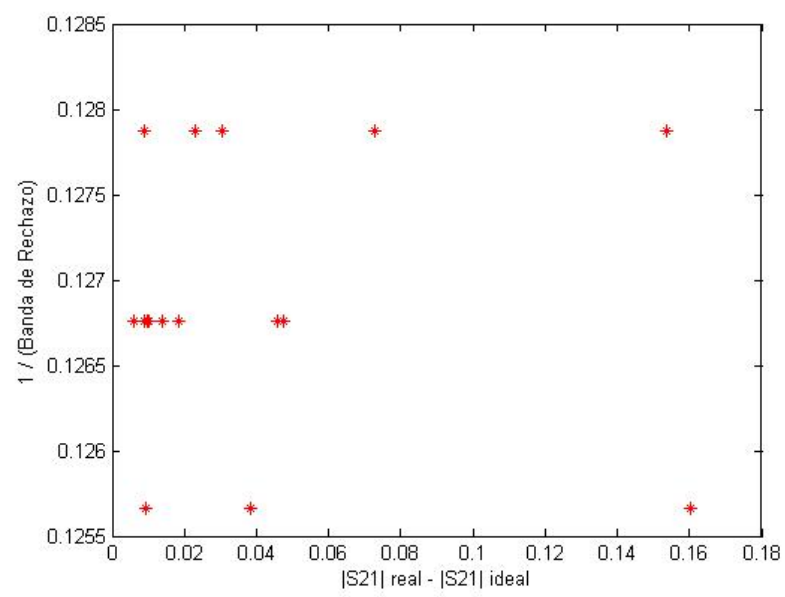

Figura 3.61: Frente de Pareto con $f^{*}=\left[\begin{array}{ll}0 & 0\end{array}\right]$

A partir del frente de Pareto obtenido, se decidió probar un algoritmo sin restricciones (simplex) para intentar ajustar los resultados, mejorándose los dos objetivos a la vez, como se observa en la figura 3.62. Lo que nos indica que se pueden conseguir mejores soluciones si se relajan las restricciones. De hecho si permitimos que $8 \leq \omega \leq 12$ podemos obtener una mejor solución tal y cómo se indica en la tabla 3.35. Sin embargo, el filtro deja de ser evanescente.

Tal y cómo se muestra en la figura 3.62 el segundo objetivo no puede tomar cualquier 


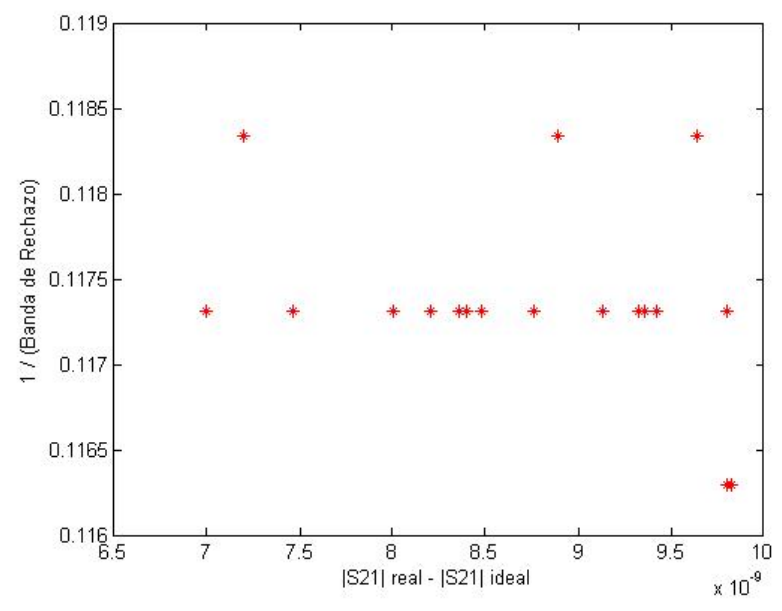

Figura 3.62: Frente de Pareto tras aplicar el método simplex

valor obteniéndose un frente de Pareto discreto, de hecho se puede observar que estará compuesto únicamente por dos puntos. Según a que objetivo le demos más importancia elegiremos uno u otro. En nuestro caso, cómo el error de la primera función objetivo es muy pequeño en ambos, se escoge el de menor error en el segundo objetivo tal y como se muestra en la tabla 3.35.

En las figuras 3.63(a) y 3.63(b) se representa la respuesta de la solución escogida del frente para unos pesos $w=\left[\begin{array}{ll}1 & 1,6789\end{array}\right]$, comparada con la respuesta ideal, la estructura inicial y la del filtro todo metal con dos cavidades acopladas.

\begin{tabular}{|l|l|l|l|l|l|}
\hline$f_{1}(x)$ & $1 / f_{2} \mathrm{GHz}$ & $\omega(\mathrm{mm})$ & $l_{1}(\mathrm{~mm})$ & $r(\mathrm{~mm})$ & $l_{2}(\mathrm{~mm})$ \\
\hline $9,8 \cdot 10^{-9}$ & 8.6 & 11.68 & 0.35 & 1.42 & 8.6 \\
\hline
\end{tabular}

Tabla 3.35: Parámetros del mejor punto del frente

En estas gráficas se ve como se ajusta casi perfectamente la respuesta real a la ideal en la banda de paso y como se ha mejorado en $0,64 \mathrm{GHz}$ la banda de rechazo de la estructura inicial, teniendo unos valores de las dimensiones más adecuados para su fabricación al no ser prácticamente 0 la distancia entre la guía de entrada y el primer poste. Respecto a la respuesta del filtro con cavidades acopladas la mejora ha sido mucho mayor, habiendo mejorado la banda de rechazo en $5 \mathrm{GHz}$, aproximadamente, y reducido la longitud total del filtro casi a la mitad pasando de $68,21 \mathrm{~mm}$ a $34,96 \mathrm{~mm}$ 


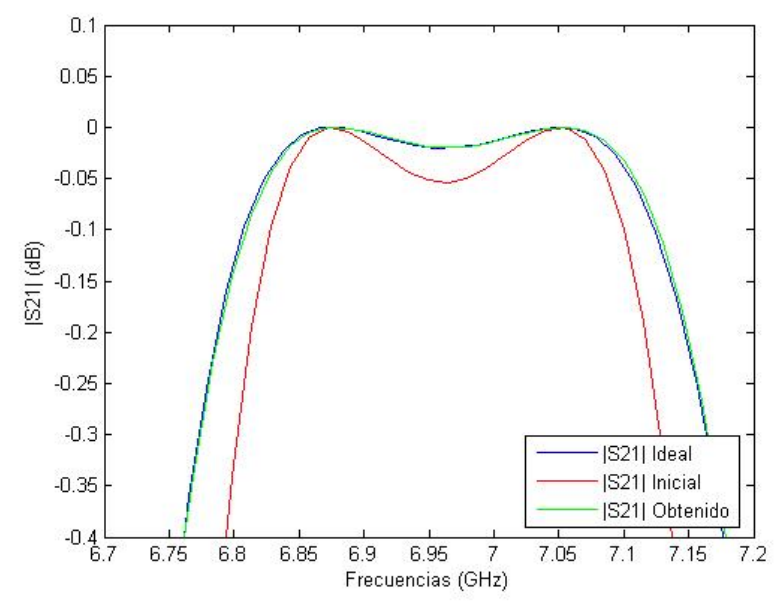

(a) Respuesta en la banda de paso

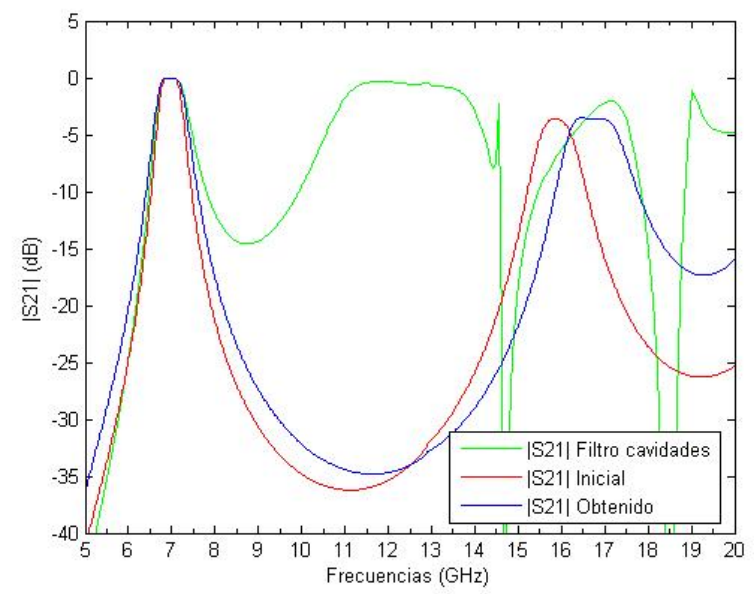

(b) Respuesta en la banda de paso

Figura 3.63: Respuesta del filtro diseñado

\subsubsection{Conclusiones}

En este trabajo se ha presentado una nueva estrategia de diseño multiobjetivo para filtros evanescentes con resonadores dieléctricos, en concreto se han considerado dos objetivos: conseguir una diferencia mínima entre la respuesta real e ideal, intentando obtener la mayor banda de rechazo posible.

Esta nueva estrategia ha sido utilizada para diseñar una estructura con muy buena respuesta, con una diferencia respecto a la ideal del orden de $10^{-9}$ y con una banda de rechazo aproximada de $8,5 \mathrm{GHz}$, con lo que se ha comprobado también las ventajas de este tipo de filtros frente a otros como el filtro todo metal con cavidades acopladas, ya que se ha obtenido 
una banda de rechazo $5 \mathrm{GHz}$ mayor que la de este filtro y se ha reducido la longitud total de la estructura casi a la mitad.

Sin embargo, se ha observado que el segundo objetivo no puede tomar cualquier valor por lo que el frente de Pareto deja de ser continuo. 


\subsection{Hybrid mode matching method for the efficient analysis of metal and dielectric rods in $\mathrm{H}$ Plane rec- tangular waveguide devices}

\subsubsection{Introduction}

Circular metallic and dielectric rods inside a rectangular waveguide are frequently found in the geometry of many passive microwave devices, such as passband or stopband filters, diplexers or oscillators [LM04, PCL81]. Ceramic dielectrics with high dielectric constant and temperature stability are commercially available. They allow the replacement of bulky and expensive waveguide resonant cavities in microwave filters or oscillators by low-cost, small size, good temperature stability, and high-Q dielectric resonators [HA86, $\mathrm{ABB}^{+} 02$ ]. If the height of the dielectric posts is the same as the height of the waveguide, that is, if the posts are all inductive or H-plane, better out of band rejection and multipactor response can be obtained $\left[\mathrm{BED}^{+} 08\right]$.

The authors have developed a technique for the analysis of these passive devices which consists on dividing the device in simpler building blocks: empty waveguides, steps and sections of waveguide loaded with the dielectric or metallic posts. The generalized scattering matrix of each block is obtained by the most suitable analysis method, and then all the matrices are connected by a new and efficient iterative technique [BGMM07] that provides the generalized scattering matrix of the whole filter.

For instance, the generalized scattering matrix of the empty sections of the waveguide is well known from the literature [Poz04], and the waveguide step can be analyzed by means of several modal techniques, such as the well know mode matching method [RA95] or the integral equation technique [GG98].

However, the analysis of waveguide sections loaded with circular obstacles is far more complex. In order to characterize these structures, circular and rectangular geometries must be considered at the same time. This complexity in the geometry makes it difficult to use purely analytic techniques, while the numerical methods are highly time-consuming. This is a serious drawback when using the simulator in a design process, since it typically demands a huge number of simulations before it finds a suitable design that fulfils the specifications. For this reason the accurate and efficient analysis of $\mathrm{H}$-plane circular rods inside rectangular waveguides has received considerable attention for more than 60 years.

Using variational methods, Marcuvitz [Mar86] calculated the circuit parameters of circular posts of small radius. This method was invalid near resonance. Lewin [Lew51] calculated the reflection coefficient of a metallic post assuming that the radius was small. Araneta et al. 
[ABK84] improved the variational method attributed to Schwinger and used by Marcuvitz in [Mar86], and was able to accurately analyze large dielectric circular rods.

Leviatan et al. [LLAP83] developed a moment solution for the analysis of a single circular metallic post placing fictitious currents inside the post. Next a multiple point matching of the boundary condition is applied and the unknown filamentary currents are obtained. This allows the accurate analysis of large posts. This method was extended in [LSA84], [LS87] and [SL88] to, respectively, the analysis of multiple metallic posts, multiple dielectric posts and multilayer posts of arbitrary and smooth cross section.

Hsu and Auda [HA86] derived a volume integral field equation for the equivalent polarization current of a general problem of multiple dielectric posts of arbitrary cross section. This equation was solved numerically using a subsectional point matching moment method.

Koshiba and Suzuki [KS86a] applied a combination of the finite element method and an analytical method to the analysis of H-plane waveguide junctions with an arbitrarily shaped ferrite post, such as the Y-junction circulator with ferrite post. Ise and Koshiba [IK89, IK90] used a combination of the finite and boundary element methods to solve the scattering of circular dielectric posts. Then, they derive the corresponding equivalent circuit using a lattice network and demonstrated the three different types of resonances of the dielectric post inside a waveguide. Similarly, Auda and Smith [AS90] applied the resonance method for evaluating the impedances of the equivalent network of a dielectric post.

In $\left[\mathrm{ABB}^{+} 02\right]$, Arcioni et al. use the boundary integral-resonant mode expansion (BI$\mathrm{RME}$ ) method to the analysis of $\mathrm{H}$-plane cavities with dielectric resonators, where both the cavity and the dielectric post can be of arbitrary cross section. Catina et al. [CAB05] use a surface integral method for the analysis of any arbitrarily shaped 2D problem including dielectric posts.

Recently, Bhattacharya and Gupta [BG08] have used a neural network model for the analysis of a circular dielectric post.

Nielsen [Nie69] was the first to characterize a circular post using open space cylindrical waves. Then a discrete mode-matching with the external guided waves of the rectangular waveguide was performed using a rectangular boundary which included the waveguide walls in order to calculate the circuit parameters. In [Lew70] Lewin discussed the inadequacy of the discrete mode-matching technique with some waveguide discontinuities problems, such as the geometry used by Nielsen. To overcome this limitation, Sahalos and Vafiadis [SV85] used a circular boundary to perform the discrete mode-matching between cylindrical and guided waves, thus avoiding the waveguide walls in the boundary region. This improves the convergence rate, although only centered circular posts can still be analyzed. Gesche and Löchel [GL88] also used a cylindrical boundary and cylindrical waves inside and guided waves outside that boundary to expand the fields. Using the orthogonal expansion method, they forced 
field continuity at the cylindrical boundary and obtained the scattering parameters of an offcentered dielectric cylinder with not too large radius and permittivity values. This method provides the field distribution and Poynting vector inside the waveguide and the cylinder. The same authors extended their method to the analysis of resonators with two cylinders in [GL89]. Abdulnour and Marchildon [AM93] analyzed circular and rectangular posts using, respectively, rectangular and circular boundaries. Instead of using point matching as previous authors did, they used an integral method which converges faster and provides more accurate results, but they must perform numerical integration.

In $\left[\mathrm{ECB}^{+} 02 \mathrm{~b}\right]$ Esteban et al. also used a circular boundary to match cylindrical and guided waves, so that they could analyze an arbitrarily shaped $\mathrm{H}$-plane post, providing greater accuracy and efficiency than previous methods, and being able to analyze any arbitrary geometry. However, when this method is used to compute the generalized scattering matrix of a large post placed very close to other discontinuities (i.e. steps), which is the case of some filtering structures, an instability in the results appears. This is because in those cases the accuracy of the results is limited to the fundamental mode, since there is a poor accuracy for the coefficients of the scattering matrix correspondant to higher order modes. This means that when the scattering matrix of the post is cascaded with the matrices of adjacent building blocks of the structure (i.e. steps, lines), the overall accuracy rapidly decreases and the whole filter response is not correct.

In this paper the authors propose an improvement of the method presented in [ECB $\left.{ }^{+} 02 \mathrm{~b}\right]$ in order to increase the accuracy and stability of the analysis, no matter the number of modes or the nature of the H-plane problem under study. This is accomplished with a new mode matching procedure which uses the fast Fourier transform to solve the matching between cylindrical and guided modes. Analytical expressions are used to characterize the circular posts in the inner region, thus resulting in a highly efficient technique for the analysis of single or multiple posts inside a rectangular waveguide.

\subsubsection{Description of the method}

In order to characterize one or various metallic or dielectric rods placed inside a rectangular waveguide, two regions are defined (see Fig. 3.64).

In order to find the circuit parameters of the structure, the fields in region B are expanded in series of cylindrical modes and the fields in region A in series of guided modes. Next a mode matching is performed between the guided modes of region $\mathrm{A}$ and the cylindrical modes of region $\mathrm{B}$, enforcing the continuity of the tangential electric and magnetic fields across the circular boundary and projecting the resulting equations to the modes of regions $\mathrm{A}$ and $\mathrm{B}$. 


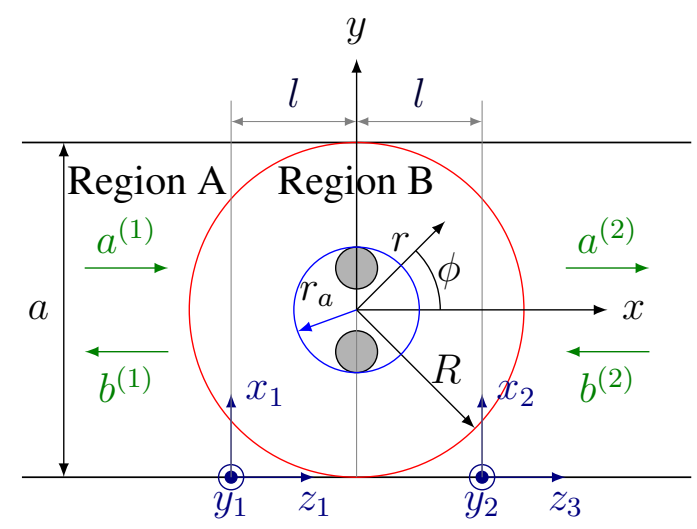

Figura 3.64: General layout of the problem and different regions for the analysis method

In region B the field is expanded as summations of incident and scattered cylindrical open space modes,

$$
\begin{aligned}
\vec{E} & =\vec{E}^{i n}(\rho, \phi)+\vec{E}^{s c}(\rho, \phi) \\
\vec{E}^{i n}(\rho, \phi) & =\sum_{n=-N_{i}}^{N_{i}} i_{n} J_{n}(k \rho) e^{j n \phi} \hat{z} \\
\vec{E}^{s c}(\rho, \phi) & =\sum_{q=-N_{s c}}^{N_{s c}} c_{q} H_{q}^{(2)}(k \rho) e^{j q \phi} \hat{z}
\end{aligned}
$$

where $i_{n}$ and $c_{q}$ are the incident and scattered field spectra in open space, $J_{n}(k \rho(\phi)) e^{j n \phi}$ and $H_{q}^{(2)}(k \rho(\phi)) e^{j q \phi}$ are the $n$-th incident and $q$-th scattered cylindrical modes, and $N_{i}$ and $N_{s c}$ are the truncation indexes for the summations of incident and scattered cylindrical modes. Both numbers must be high enough to ensure good accuracy of the results [ $\left.\mathrm{ECB}^{+} 02 \mathrm{~b}\right]$.

In region $\mathrm{B}$, the scattered field spectrum $c_{q}$ can be related to the incident field spectrum $i_{n}$ by means of a scattering matrix $D$ that provides the full wave characterization of the scattering structure inside region $\mathrm{B}\left[\mathrm{ECB}^{+} 02 \mathrm{~b}\right]$, and so we can write

$$
c_{q}=\sum_{q=-N_{i}}^{N_{i}} d_{q n} i_{n}
$$

In matrix form $c=D i$. Using (3.159), the scattered field is

$$
\vec{E}^{s c}(\rho, \phi)=\sum_{q=-N_{s c}}^{N_{s c}} \sum_{n=-N_{i}}^{N_{i}} d_{q n} i_{n} H_{q}^{(2)}(k \rho) e^{j q \phi} \hat{z}
$$

In the outer region, or region $\mathrm{A}$, the tangential fields are expanded as summations of the guided modes of the canonical rectangular waveguide. Since both the geometry and the exci- 
tation are invariant in height (dimension $z$ ), only the family of $T E_{m 0}$ modes are considered, and the fields can be expanded as

$$
\begin{gathered}
\vec{E}_{t}^{(i)}=\sum_{m=1}^{M i}\left(a_{m}^{(i)} e^{-\gamma_{m}^{(i)} z_{i}}+b_{m}^{(i)} e^{\gamma_{m}^{(i)} z_{i}}\right) \vec{e}_{m}^{(i)^{\prime}}\left(x_{i}\right) \\
\vec{H}_{t}^{(i)}=\sum_{m=1}^{M i}\left(a_{m}^{(i)} e^{-\gamma_{m}^{(i)} z_{i}}-b_{m}^{(i)} e^{\gamma_{m}^{(i)} z_{i}}\right) Y_{0 m}^{(i)} \vec{h}_{m}^{(i)^{\prime}}\left(x_{i}\right)
\end{gathered}
$$

where $i=1$ for the input port and $i=2$ for the output port, and

$$
\begin{aligned}
\vec{e}_{m}^{(i)^{\prime}}\left(x_{i}\right) & =\hat{y}_{i} \sqrt{\frac{2 Z_{0 m}^{(i)}}{a_{i} b_{i}}} \sin \left(\frac{m \pi}{a_{i}} x_{i}\right) \\
\vec{h}_{m}^{(i)^{\prime}}\left(x_{i}\right) & =-\hat{x}_{i} \sqrt{\frac{2 Z_{0 m}^{(i)}}{a_{i} b_{i}}} \sin \left(\frac{m \pi}{a_{i}} x_{i}\right) \\
\gamma_{m}^{(i)} & =\sqrt{\left(\frac{m \pi}{a_{i}}\right)^{2}-k^{2}} \\
Y_{0 m}^{(i)} & =\frac{1}{Z_{0 m}^{(i)}}=\frac{\gamma_{m}^{(i)}}{j w \mu}=\frac{\gamma_{m}^{(i)}}{j k \eta}
\end{aligned}
$$

In these equations

- $m$ is the index of the correspondant guided mode.

- $M_{i}, a_{i}$ and $b_{i}$ are, respectively, the number of guided modes, the width and the height of the input $(i=1)$ and output $(i=2)$ ports. In the structures considered in this work $M_{2}=M_{1}, a_{2}=a_{1}$ and $b_{2}=b_{1}$.

- $a_{m}^{(i)}$ and $b_{m}^{(i)}$ are, respectively, the amplitudes of the waves in the input $(i=1)$ and output $(i=2)$ ports.

- $x_{i}$ and $z_{i}$ are the coordinates local to the input $(i=1)$ and output $(i=2)$ waveguides (see Fig. 3.64).

The amplitudes and admitances of the guided waves can be referenced in a more compact way defining the following vectors $\boldsymbol{a}, \boldsymbol{b}$ and $\boldsymbol{Y}_{\mathbf{0}}$, each of one of $M=M_{1}+M_{2}$ elements,

$$
\boldsymbol{a}=\left[\begin{array}{l}
a^{(1)} \\
b^{(2)}
\end{array}\right], \boldsymbol{b}=\left[\begin{array}{c}
b^{(1)} \\
a^{(2)}
\end{array}\right], \boldsymbol{Y}_{\mathbf{0}}=\left[\begin{array}{c}
-Y_{0}^{(1)} \\
Y_{0}^{(2)}
\end{array}\right]
$$


where

$$
\begin{aligned}
a^{(i)} & =\left[a_{1}^{(i)}, \cdots, a_{M_{i}}^{(i)}\right]^{T}, i \in[1,2] \\
b^{(i)} & =\left[b_{1}^{(i)}, \cdots, b_{M_{i}}^{(i)}\right]^{T}, i \in[1,2] \\
Y_{0}^{(i)} & =\left[Y_{01}^{(i)}, \cdots, Y_{0 M_{i}}^{(i)}\right]^{T}, i \in[1,2]
\end{aligned}
$$

Using (3.167) we can express in a compact way the tangential fields outside the boundary,

$$
\begin{gathered}
\vec{E}_{t}(\phi)=\sum_{n=1}^{M}\left(a_{n} e_{n}^{+}(\phi)+b_{n} e_{n}^{-}(\phi)\right) g_{n}(\phi) \hat{z} \\
\vec{H}_{t}(\phi)=\sum_{n=1}^{M}\left(a_{n} e_{n}^{+}(\phi)-b_{n} e_{n}^{-}(\phi)\right) Y_{0 n} g_{n}(\phi) \hat{y}
\end{gathered}
$$

where $M=M_{1}+M_{2}$ and,

$$
\begin{gathered}
e_{n}^{ \pm}(\phi)= \begin{cases}e^{\mp \gamma_{n}^{(1)} z_{1}(\phi)} & \phi \in\left[\frac{\pi}{2}, \frac{3 \pi}{2}\right], n \leq M_{1} \\
e^{ \pm \gamma_{n-M_{1}}^{(2)} z_{2}(\phi)} & \phi \in\left[-\frac{\pi}{2}, \frac{\pi}{2}\right], n>M_{1} \\
0 & \text { other }\end{cases} \\
g_{n}(\phi)= \begin{cases}e_{n}^{(1)^{\prime}}\left(x_{1}(\phi)\right) & \phi \in\left[\frac{\pi}{2}, \frac{3 \pi}{2}\right], n \leq M_{1} \\
e_{n-M_{1}}^{(2)^{\prime}}\left(x_{2}(\phi)\right) & \phi \in\left[-\frac{\pi}{2}, \frac{\pi}{2}\right], n>M_{1} \\
0 & \text { other }\end{cases}
\end{gathered}
$$

The choice of a circular boundary for the mode matching avoids the waveguide walls in the boundary region. And instead of using discrete mode matching, in this work the mode matching is solved by projecting the equations resulting from enforcing field continuity to the modes of regions $\mathrm{A}$ and $\mathrm{B}$. This provides with a set of equations, and after selecting the proper ones, a matrix system is obtained whose solution is the generalized scattering matrix of the structure. If the right set of equations is selected the matrix system is very well conditioned and a very good accuracy can be obtained. Moreover the integrals that must be solved in order to compute the elements of the matrices involved can be solved by using the fast Fourier transform instead of using other numerical methods.

The application of this mode matching procedure can be very simple if the obstacle is a centered circular post, but can be generalized for arbitrary single or multiple obstacles. In the next sections, we describe the mode matching procedure for the case of a single centered circular cylinder and for arbitrary obstacles. The theory of arbitrary obstacles has also been detailed for the cases of an off-centered circular post and for two circular posts. 


\subsubsection{Centered circular post}

\subsubsection{Generalized Scattering Matrix}

When the post inside the circular boundary is a single centered circular post, as shown in Fig. 3.65, each incident cylindrical mode excites only the scattered cylindrical mode of the same order. Thus the scattering matrix that relates incident and scattered cylindrical spectra is a diagonal matrix, and

$$
\begin{gathered}
d_{q n}=0, \quad \forall q \neq n \\
c_{q}=\sum_{n=-N_{i}}^{N_{i}} d_{q n} i_{n}=d_{q q} i_{q}
\end{gathered}
$$

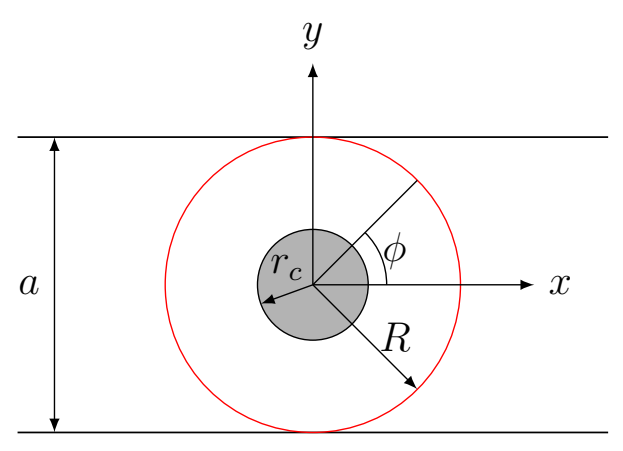

Figura 3.65: Single centered circular cylinder.

And for a single centered circular cylinder the elements $d_{n n}$ of the scattering matrix can be easily obtained analytically [Bal89], either for a metallic

$$
d_{n n}=-\frac{J_{n}\left(k r_{c}\right)}{H_{n}^{(2)}\left(k r_{c}\right)}
$$

or a dielectric cylinder

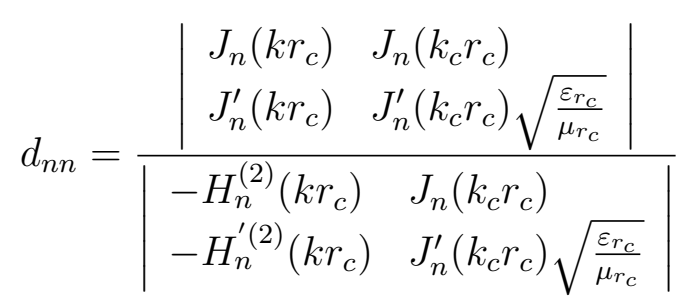

where $r_{c}$ is the radius of the cylinder, $k_{c}=k \sqrt{\varepsilon_{r_{c}} \mu_{r_{c}}}$, and $\varepsilon_{r_{c}}$ and $\mu_{r_{c}}$ are, respectively, the relative permittivity and permeability of the cylinder. 
Assuming that $d_{n n}=0, \forall n,|n|>N_{s c}$, we can merge (3.157) and (3.158) and obtain the total field $\left(\vec{E}=\overrightarrow{E^{i n}}+\overrightarrow{E^{s c}}\right)$ inside the circular boundary

$$
\vec{E}=\sum_{n=-N_{i}}^{N_{i}}\left(J_{n}(k \rho)+d_{n n} \cdot H_{n}^{(2)}(k \rho)\right) i_{n} e^{j n \phi} \hat{z}
$$

And using Maxwell's curl equation, we can also obtain the total magnetic field in the inner region

$$
\begin{aligned}
& \vec{H}=-\frac{1}{j w \mu} \nabla \times \vec{E}= \\
& =-\frac{1}{\eta} \sum_{n=-N_{i}}^{N_{i}}\left[\frac{n}{k \rho}\left(J_{n}(k \rho)+d_{n n} H_{n}^{(2)}(k \rho)\right) \hat{\rho}+\right. \\
& \left.j\left(J_{n}^{\prime}(k \rho)+d_{n n} H_{n}^{(2)^{\prime}}(k \rho)\right) \hat{\phi}\right] i_{n} e^{j n \phi}
\end{aligned}
$$

In the circular boundary, where the continuity of the fields must be enforced, $\rho=R$, the Bessel functions are constant, and thus the fields of the inner region are reduced to

$$
\begin{aligned}
\vec{E} & =\sum_{n=-N_{i}}^{N_{i}} A_{n} e^{j n \phi} i_{n} \hat{z} \\
\vec{H} & =\sum_{n=-N_{i}}^{N_{i}}\left(B_{n} \hat{\rho}+C_{n} \hat{\phi}\right) e^{j n \phi} i_{n}
\end{aligned}
$$

where

$$
\begin{aligned}
A_{n} & =\left[J_{n}(k R)+d_{n n} H_{n}^{(2)}(k R)\right] \\
B_{n} & =-\frac{1}{\eta} \frac{n}{k R} A_{n} \\
C_{n} & =-\frac{1}{\eta}\left(J_{n}^{\prime}(k R)+d_{n n} H_{n}^{(2)^{\prime}}(k R)\right)
\end{aligned}
$$

Enforcing the continuity of tangential fields on the circular boundary between regions A and $\mathrm{B}$ gives

$$
\sum_{n=-N_{i}}^{N_{i}} A_{n} e^{j n \phi} i_{n}=\sum_{n=1}^{M}\left(a_{n} e_{n}^{+}(\phi)+b_{n} e_{n}^{-}(\phi)\right) g_{n}(\phi)
$$




$$
\begin{aligned}
& \sum_{n=-N_{i}}^{N_{i}}\left(B_{n}(\hat{\rho} . \hat{y})+C_{n}(\hat{\phi} \cdot \hat{y})\right) e^{j n \phi} i_{n}= \\
= & \sum_{n=1}^{M}\left(a_{n} e_{n}^{+}(\phi)-b_{n} e_{n}^{-}(\phi)\right) Y_{0 n} g_{n}(\phi)
\end{aligned}
$$

where $(\hat{\rho} . \hat{y})=\sin (\phi)$ and $(\hat{\phi} . \hat{y})=\cos (\phi)$. In order to obtain a matrix system (3.186) and (3.187) must be projected over the modes of either region A or B. Projecting over the inner modes of region $\mathrm{B} e^{-j m \phi}$ in both sides of the equality, we obtain

$$
\begin{aligned}
& \sum_{n=-N_{i}}^{N_{i}} I_{m n} i_{n}=\sum_{n=1}^{M}\left(J_{m n} a_{n}+K_{m n} b_{n}\right) \\
& \sum_{n=-N_{i}}^{N_{i}} L_{m n} i_{n}=\sum_{n=1}^{M}\left(M_{m n} a_{n}-N_{m n} b_{n}\right)
\end{aligned}
$$

where $m \in\left[-N_{i}, N_{i}\right]$ and

$$
\begin{aligned}
& I_{m n}=\int_{0}^{2 \pi} A_{n} e^{j n \cdot \phi} e^{-j m \phi} d \phi \\
& L_{m n}=\int_{0}^{2 \pi}\left(B_{n} \sin (\phi)+C_{n} \cos (\phi)\right) e^{j n \phi} e^{-j m \phi} d \phi \\
& J_{m n}=\int_{0}^{2 \pi} e_{n}^{+}(\phi) g_{n}(\phi) e^{-j m \phi} d \phi \\
& K_{m n}=\int_{0}^{2 \pi} e_{n}^{-}(\phi) g_{n}(\phi) e^{-j m \phi} d \phi \\
& M_{m n}=\int_{0}^{2 \pi} e_{n}^{+}(\phi) Y_{0 n} g_{n}(\phi) e^{-j m \phi} d \phi=Y_{0 n} J_{m n} \\
& N_{m n}=\int_{0}^{2 \pi} e_{n}^{-}(\phi) Y_{0 n} g_{n}(\phi) e^{-j m \phi} d \phi=Y_{0 n} K_{m n}
\end{aligned}
$$


Projecting (3.186) and (3.187) to the modes of the outer region A $g_{m}^{*}(\phi)$ gives

$$
\begin{aligned}
& \sum_{n=-N_{i}}^{N_{i}} O_{m n} i_{n}=\sum_{n=1}^{M}\left(P_{m n} a_{n}+Q_{m n} b_{n}\right) \\
& \sum_{n=-N_{i}}^{N_{i}} V_{m n} i_{n}=\sum_{n=1}^{M}\left(U_{m n} a_{n}-T_{m n} b_{n}\right)
\end{aligned}
$$

With $m \in[1, M]$ and

$$
\begin{gathered}
O_{m n}=\int_{0}^{2 \pi} A_{n} e^{j n \cdot \phi} g_{m}^{*}(\phi) d \phi \\
V_{m n}=\int_{0}^{2 \pi}\left(B_{n} \sin (\phi)+C_{n} \cos (\phi)\right) e^{j n \phi} g_{m}^{*}(\phi) d \phi \\
P_{m n}=\int_{0}^{2 \pi} e_{n}^{+}(\phi) g_{n}(\phi) g_{m}^{*}(\phi) d \phi \\
Q_{m n}=\int_{0}^{2 \pi} e_{n}^{-}(\phi) g_{n}(\phi) g_{m}^{*}(\phi) d \phi \\
U_{m n}=\int_{0}^{2 \pi} e_{n}^{+}(\phi) g_{n}(\phi) Y_{0 n} g_{m}^{*}(\phi) d \phi=Y_{0 n} \cdot P_{m n} \\
T_{m n}=\int_{0}^{2 \pi} e_{n}^{-}(\phi) g_{n}(\phi) Y_{0 n} g_{m}^{*}(\phi) d \phi=Y_{0 n} \cdot Q_{m n}
\end{gathered}
$$

Expressing (3.188), (3.189), (3.196) and (3.197) in matrix form,

$$
\begin{gathered}
I i=J a+K b \\
L i=M a-N b
\end{gathered}
$$




$$
\begin{aligned}
& O i=P a+Q b \\
& V i=U a-T b
\end{aligned}
$$

In order to obtain the generalized scattering matrix only two equations of the four are required. One equation must be of electric field and another of magnetic field. The only possibility is to use (3.204) or (3.205) to extract $i$, since $O$ and $V$ are not square. If we choose (3.205) the matrix $L$ must be inverted, but this matrix is bidiagonal and is ill-conditioned. Then (3.204) must be used for extracting $i$,

$$
i=I^{-1}(J a+K b)
$$

Now a magnetic field equation must be used. It can be (3.205) or (3.207). If we use (3.207), which comes from enforcing continuity of magnetic field and projecting over modes of region $\mathrm{A}$, we use both the electric and magnetic field and we use one equation with projection over the modes of region A and another equation with projection over the modes of region B. Substituting (3.208) in (3.207) and reordering, we obtain the generalized scattering matrix $(b=S a)$,

$$
S=\left(T+V I^{-1} K\right)^{-1}\left(U-V I^{-1} J\right)
$$

The integrals needed to fill matrices $I, J, K, V, T$ and $U$ can be solved either analytically or by using the fast Fourier transform.

\subsubsection{Solution of the integrals}

There are six integrals that need to be solved: $I_{m n}, J_{m n}, K_{m n}, V_{m n}, T_{m n}$ and $U_{m n}$.

$I_{m n}$ can be solved analytically,

$$
I_{m n}= \begin{cases}A_{n} 2 \pi & m=n \\ 0 & m \neq n\end{cases}
$$

Since $I_{m n}$ is a diagonal matrix, its inverse is very simple to calculate, just by inverting each element of the main diagonal.

The second integral $J_{m n}$ is

$$
J_{m n}=x^{(n)}[-m] 2 \pi
$$


where

$$
x^{(n)}[m]=D T F T^{-1}\left\{e_{n}^{+}(\phi) g_{n}(\phi)\right\}
$$

In order to obtain $x^{(n)}[m]$ the continuous value of $e_{n}^{+}(\phi) g_{n}(\phi)$ should be considered. We can accelerate the calculus if we consider the value of $e_{n}^{+}(\phi) g_{n}(\phi)$ only over some discrete points along $\phi$, using the fast Fourier transform,

$$
x^{(n)}[m] \approx \tilde{x}^{(n)}[m]=F F T^{-1}\left\{e_{n}^{+}(\phi) g_{n}(\phi)\right\}
$$

$\tilde{x}^{(n)}$ is a periodic signal of period equal to the number of discrete points considered along $\phi$ for performing the fast Fourier transform. Nevertheless the duration of the original signal $x^{(n)}[\mathrm{m}]$ can exceed that period, and therefore an error of aliasing can appear. In order to minimize this error we must choose a proper number of points for the fast Fourier transform. This number of points must be at least of $2 N_{i}+1$ (the number of rows of $J$ ), and we will use $N f f t \geq 2 N_{i}+1$ points. As $N f f t$ increases, the error due to aliasing decreases.

Using the fast Fourier transform the remaining integrals can also be easily obtained,

$$
\begin{aligned}
K_{m n}= & \approx 2 \pi \tilde{x}^{-(n)}[-m] \\
V_{m n}= & \approx \pi \tilde{y}^{(m)}[n+1]\left[C_{n}-j B_{n}\right]+ \\
& +\pi \tilde{y}^{(m)}[n-1]\left[C_{n}+j B_{n}\right] \\
T_{m n}= & \approx Y_{0 n} \sum_{k=-\frac{N f f t}{2}}^{\frac{N f f t}{2}} \tilde{x}^{-(n)}[k] \tilde{y}^{(m)}[-k] 2 \pi \\
U_{m n}= & \approx Y_{0 n} \sum_{k=-\frac{N f f t}{2}}^{\frac{N f f t}{2}} \tilde{x}^{(n)}[k] \tilde{y}^{(m)}[-k] 2 \pi
\end{aligned}
$$

where

$$
\begin{aligned}
\tilde{x}^{-(n)}[m] & =F F T^{-1}\left\{e_{n}^{-}(\phi) g_{n}(\phi)\right\} \\
\tilde{y}^{(m)}[n] & =F F T^{-1}\left\{g_{m}^{*}(\phi)\right\}
\end{aligned}
$$

\subsubsection{Study of the parameters that control the method}

For computational reasons there are several summations with infinite terms that must be truncated in order to obtain the scattering parameters of the structure. For that purpose the following truncation indexes have been defined:

- Number of modes of the incident field spectrum: $N_{i}=P_{N_{i}} k R$ 


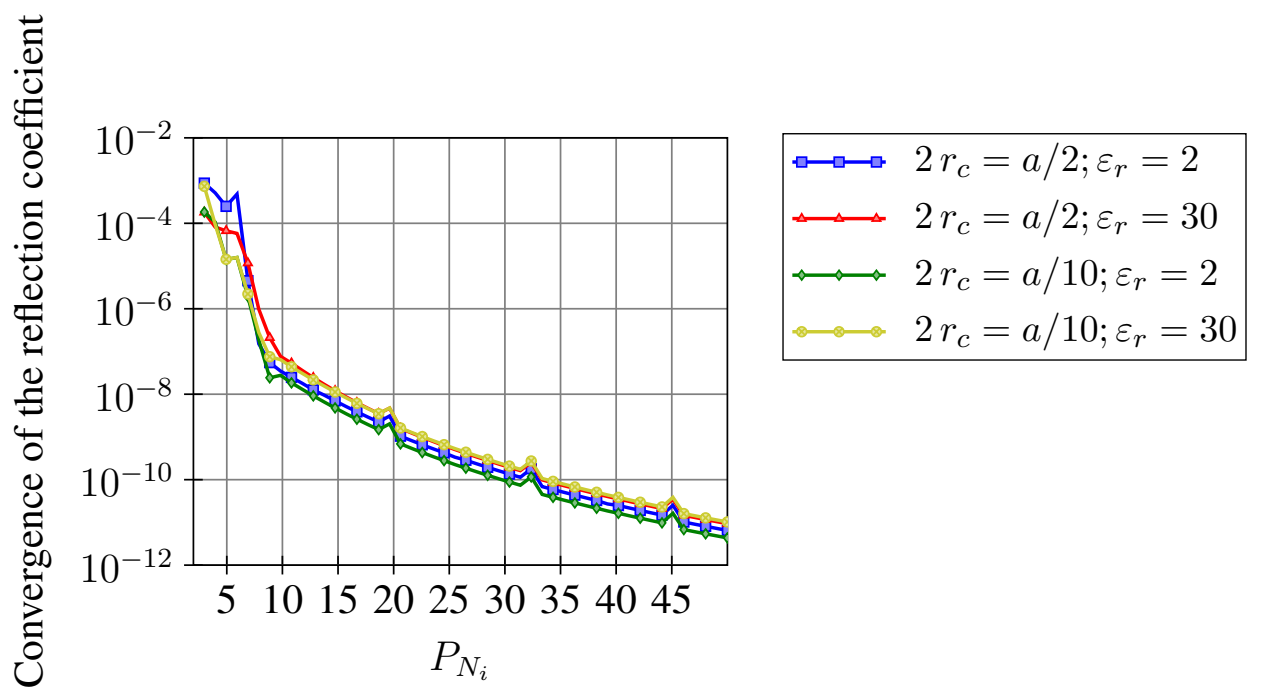

Figura 3.66: Convergence of the reflection coefficient with $P_{N_{i}}$

- Number of points for the FFT: $N_{f f t}=2 \operatorname{ceil}\left(N_{i}\left(1+P_{N_{f f t}}\right)\right)+1$

The number of modes for the scattered field spectrum $N_{s c}$ has been fixed to $2 k r_{a}$, since according to $\left[\mathrm{ECB}^{+} 02 \mathrm{~b}\right]$ it is enough to consider $N_{s c} \geq k r_{a}$.

In order to test the convergence of the method and choose the adequate values for these indexes the convergence (difference with the previous value) of the computed $S_{11}$ scattering parameter with each one of these indexes has been represented. In all the graphics there are four plots representing four different combinations of post size and electric permittivity: large and small posts with either high or small permittivity. This ensures that the chosen value for the truncation indexes are valid for a wide range of post types.

Fig. 3.66 shows the convergence of $S_{11}$ with the parameter $\left(P_{N_{i}}\right)$ that controls the number of modes of the incident field spectrum $\left(N_{i}\right)$. The value of $P_{N_{i}}$ is gradually increased and the variation of $S_{11}$ with the previous value of $P_{N_{i}}$ is depicted. As the number of modes of the incident field spectrum increases, the value of $S_{11}$ is stabilized, and the difference with the previous value is constantly decreased. This convergence in the value of $S_{11}$ does not depend on the size or permittivity of the post. The value $P_{N_{i}}=15$ has been chosen for all calculations because the value of $S_{11}$ is already stabilized to variations under $-160 \mathrm{~dB}$, which ensures a very good accuracy. Greater values of $P_{N_{i}}$ would not significantly increase the accuracy at the cost of highly increasing the computational cost. 


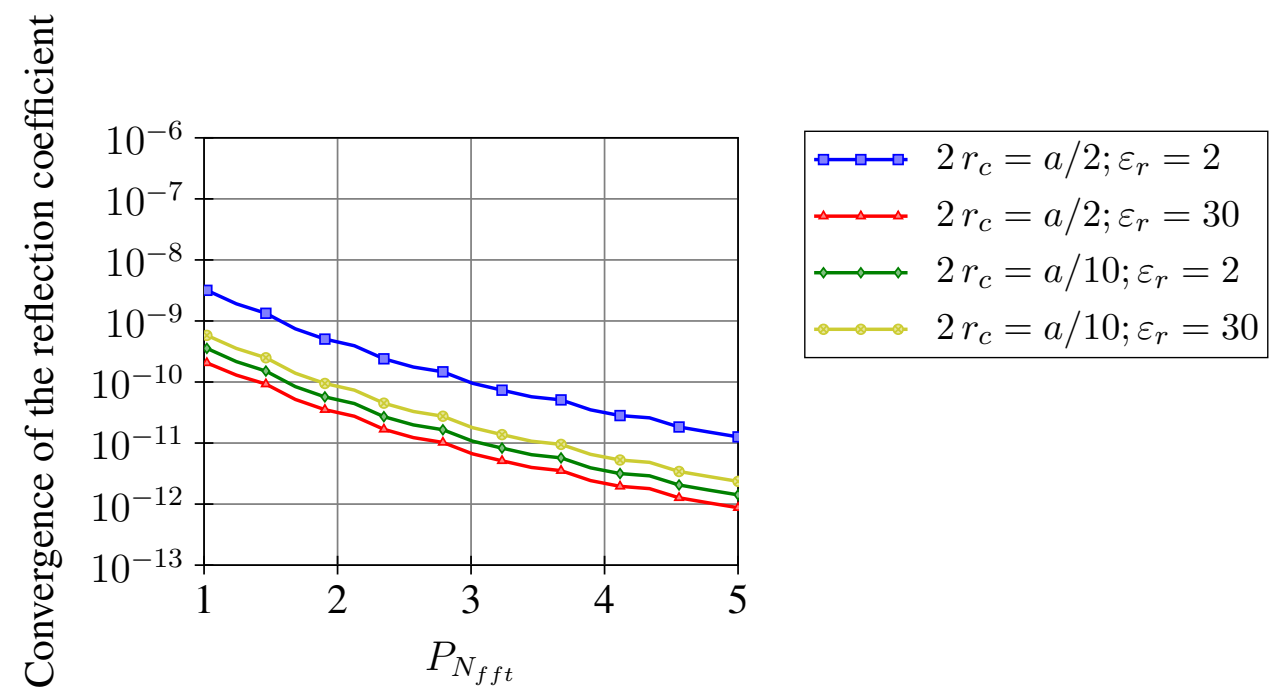

Figura 3.67: Convergence of the reflection coefficient with $P_{N_{f f t}}$

Fig. 3.67 shows the convergence of $S_{11}$ with $P_{N_{f f t}}$. Again the convergence does not depend on the post size and permittivity. $P_{N_{f f t}}=2$ is the value chosen to ensure very good accuracy and low computational cost.

The circular boundary chosen for the mode matching simplifies the expressions of the cylindrical modes in that surface, but this implies that the propagation exponentials of the guided waves are not constant as happens when the transversal section of the guide is chosen as boundary for the mode matching. For that reason there is certain sensitivity of the method to the placement of the reference planes. Fig. 3.68 shows the dependence of the reciprocal of the condition number of the matrix that is inverted in (3.209) in the 1-norm with the distance from the reference planes of the input and output waveguides to the center of the dielectric cylinder $(l)$. It can be observed that there is an optimum distance $l=0,25 a$ for the reference planes where the matrix is better conditioned.

\subsubsection{Arbitrarily shaped obstacles}

\subsubsection{General theory}

The method can be extended to other problems than the single centered circular post. The most important difference is that the scattering matrix $D$ that relates incident and scattered field spectra will not be a diagonal matrix any more, even for a circular post if it is not placed at the center of the waveguide. 


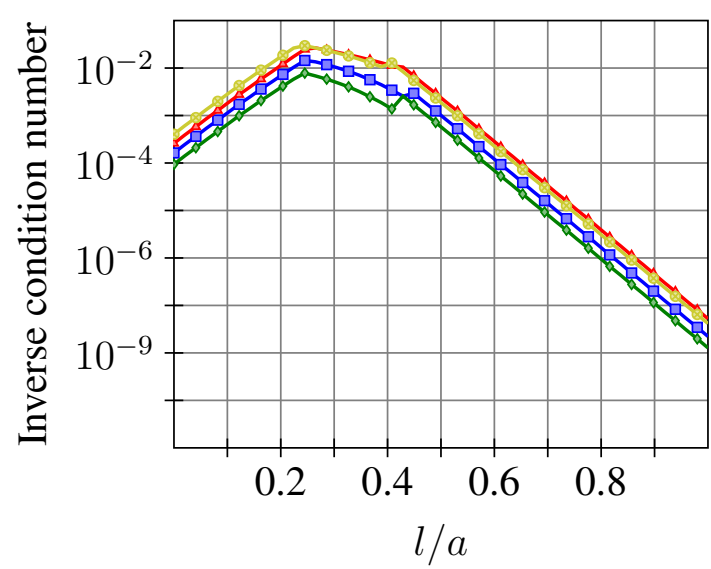

$\because 2 r_{c}=a / 2 ; \varepsilon_{r}=2$

$\longleftrightarrow 2 r_{c}=a / 2 ; \varepsilon_{r}=30$

$\leadsto 2 r_{c}=a / 10 ; \varepsilon_{r}=2$

$\leftrightarrow 2 r_{c}=a / 10 ; \varepsilon_{r}=30$

Figura 3.68: Inverse condition number as a function of the distance to the reference planes

As in the case of the centered circular post the generalized scattering matrix can be obtained using (3.209), and the matrices involved in that equation are the ones described in section 3.12.3.2 except for matrices $I$ and $V$ that change due to the change of matrix $D$ which is no longer diagonal.

Matrix $I$ comes from projecting the transversal electric field of the inner region on the circular boundary to the cylindrical modes, which using (3.157) and (3.160) gives,

$$
\begin{aligned}
I_{m n}= & \int_{0}^{2 \pi} E_{t}(\rho=R) \cdot e^{-j m \phi} \\
= & \sum_{n=-N_{i}}^{N_{i}}\left(J_{n}(k R) \int_{2 \pi}^{0} e^{j(n-m) \phi} d \phi+\right. \\
& \left.\sum_{q=-N_{s c}}^{N_{s c}} d_{q n} H_{q}^{(2)}(k R) \int_{2 \pi}^{0} e^{j(q-m) \phi} d \phi\right)
\end{aligned}
$$

Defining

$$
\begin{aligned}
I_{m n}^{A}= & J_{n}(k R) \int_{0}^{2 \pi} e^{j(n-m) \phi} d \phi \\
& = \begin{cases}J_{n}(k R) 2 \pi & n=m \\
0 & n \neq m\end{cases} \\
I_{m n}^{B}= & H_{q}^{(2)}(k R) \int_{0}^{2 \pi} e^{j(q-m) \phi} d \phi \\
= & \begin{cases}H_{n}^{(2)}(k R) 2 \pi & n=m \\
0 & n \neq m\end{cases}
\end{aligned}
$$


the new matrix $I$ can be written as

$$
I=I^{A}+I^{B} D
$$

Matrix $V$ comes from projecting the transversal magnetic field of the inner region on the circular boundary to the guided modes. The transversal magnetic field of the inner region on the circular boundary is

$$
\begin{aligned}
& H_{t}(\rho=R)= \\
& \sum_{n=-N_{i}}^{N_{i}}\left[-\frac{\sin \phi}{\eta k R}\left(n J_{n}(k R) e^{j n \phi}+\sum_{q} q d_{q n} H_{q}^{(2)}(k R) e^{j q \phi}\right)\right. \\
& \left.-\frac{j \cos \phi}{\eta}\left(J_{n}^{\prime}(k R) e^{j n \phi}+\sum_{q} d_{q n} H_{q}^{(2)^{\prime}}(k R) e^{j q \phi}\right)\right] i_{n}
\end{aligned}
$$

Projecting to guided modes

$$
\begin{gathered}
V_{m n}=\int_{0}^{2 \pi} H_{t}(\rho=R) g_{m}^{*}(\phi) d \phi \\
V_{m n}=\int_{0}^{2 \pi}-\frac{1}{\eta} \frac{n}{k R} J_{n}(k R) e^{j n \phi}\left(\frac{e^{j \phi}-e^{-j \phi}}{2 j}\right) g_{m}^{*}(\phi) d \phi+ \\
+\int_{0}^{2 \pi}-\frac{1}{\eta} \frac{q}{k R} \sum_{q} d_{q n} H_{q}^{(2)}(k R) e^{j q \phi}\left(\frac{e^{j \phi}-e^{-j \phi}}{2 j}\right) g_{m}^{*}(\phi) d \phi+ \\
+\int_{0}^{2 \pi}-\frac{j}{\eta} J_{n}^{\prime}(k R) e^{j n \phi}\left(\frac{e^{j \phi}+e^{-j \phi}}{2}\right) g_{m}^{*}(\phi) d \phi+ \\
+\int_{0}^{2 \pi}-\frac{j}{\eta} \sum_{q} d_{q n} H_{q}^{(2)^{\prime}}(k R) e^{j q \phi}\left(\frac{e^{j \phi}+e^{-j \phi}}{2}\right) g_{m}^{*}(\phi) d \phi
\end{gathered}
$$

Using (3.220) and the properties of the discrete time Fourier transform,

$$
\begin{aligned}
& \frac{1}{2 \pi} \int_{0}^{2 \pi} g_{m}^{*}(\phi) e^{j \phi} e^{j n \phi} d \phi=y^{(m)}[n+1] \simeq \tilde{y}^{(m)}[n+1] \\
& \frac{1}{2 \pi} \int_{0}^{2 \pi} g_{m}^{*}(\phi) e^{-j \phi} e^{j n \phi} d \phi=y^{(m)}[n-1] \simeq \tilde{y}^{(m)}[n-1]
\end{aligned}
$$

Substituting in (3.225),

$$
\begin{aligned}
& V_{m n} \simeq-\frac{\pi}{\eta} \frac{n}{k R} \frac{J_{n}(k R)}{j}\left(\tilde{y}^{(m)}[n+1]-\tilde{y}^{(m)}[n-1]\right)+ \\
& -\frac{\pi}{\eta} \frac{q}{k R} \sum_{q} d_{q n} \frac{H_{q}^{(2)}(k R)}{j}\left(\tilde{y}^{(m)}[q+1]-\tilde{y}^{(m)}[q-1]\right)+ \\
& -\frac{3 \pi}{\eta} J_{n}^{\prime}(k R)\left(\tilde{y}^{(m)}[n+1]+\tilde{y}^{(m)}[n-1]\right)+ \\
& -\frac{j \pi}{\eta} \sum_{q} d_{q n} H_{q}^{(2)^{\prime}}(k R)\left(\tilde{y}^{(m)}[q+1]+\tilde{y}^{(m)}[q-1]\right)
\end{aligned}
$$


In matrix form,

$$
V=\pi Y^{+}\left(V^{A}+V^{B} D\right)+\pi Y^{-}\left(V^{C}+V^{D} D\right)
$$

Where

$$
\begin{aligned}
Y^{+}= & {\left[\begin{array}{l}
\tilde{y}^{(1)}[n+1] \\
\tilde{y}^{(2)}[n+1] \\
\cdot \\
\cdot \\
\tilde{y}^{(M)}[n+1]
\end{array}\right]_{M \times\left(2 N_{i}+1\right)} } \\
Y^{-}= & {\left[\begin{array}{l}
\tilde{y}^{(1)}[n-1] \\
\tilde{y}^{(2)}[n-1] \\
\cdot \\
\cdot \\
\tilde{y}^{(M)}[n-1]
\end{array}\right]_{M \times\left(2 N_{i}+1\right)} }
\end{aligned}
$$

and $V^{A}, V^{B}, V^{C}$ and $V^{D}$ are diagonal matrices with

$$
\begin{aligned}
V_{n n}^{A} & =-\frac{1}{\eta} \frac{n}{k R} \frac{J_{n}(k R)}{j}-\frac{j J_{n}^{\prime}(k R)}{\eta} \\
V_{n n}^{B} & =\frac{1}{\eta} \frac{n}{k R} \frac{J_{n}(k R)}{j}-\frac{j J_{n}^{\prime}(k R)}{\eta} \\
V_{n n}^{C} & =-\frac{1}{\eta} \frac{n}{k R} \frac{H_{q}^{(2)}(k R)}{j}-\frac{j H_{q}^{(2)^{\prime}}(k R)}{\eta} \\
V_{n n}^{D} & =\frac{1}{\eta} \frac{n}{k R} \frac{H_{q}^{(2)}(k R)}{j}-\frac{j H_{q}^{(2)^{\prime}}(k R)}{\eta}
\end{aligned}
$$

Using (3.209) and the expressions of section 3.12.3.2 substituting $I$ and $V$ with (3.224) and (3.229) we obtain the generalized scattering matrix of any arbitrarily shaped single or multiple obstacle geometry inside a rectangular waveguide. For each specific obstacle the problem is now reduced to the computation of the open space scattering matrix $D$.

If the post is circular matrix $D$ can be found analytically, as shown in (3.177) and (3.178). For other geometries, i. e. a square post, the scattering matrix must be obtained using a suitable numerical method such as the method of moments.

If there is a single off-centered post, the matrix $D$ can be obtained as

$$
D=T J^{B A} D_{c} T J^{A B}
$$

where $D_{c}$ is the scattering matrix of the centered circular post and $T J^{B A}$ and $T J^{A B}$ are translation matrices that translate cylindrical field spectrum either from A to B or from $\mathrm{B}$ to A using the addition theorem for Bessel functions (see [ECB ${ }^{+} 02 \mathrm{~b}, \mathrm{EHT} 93$, Har01]). 


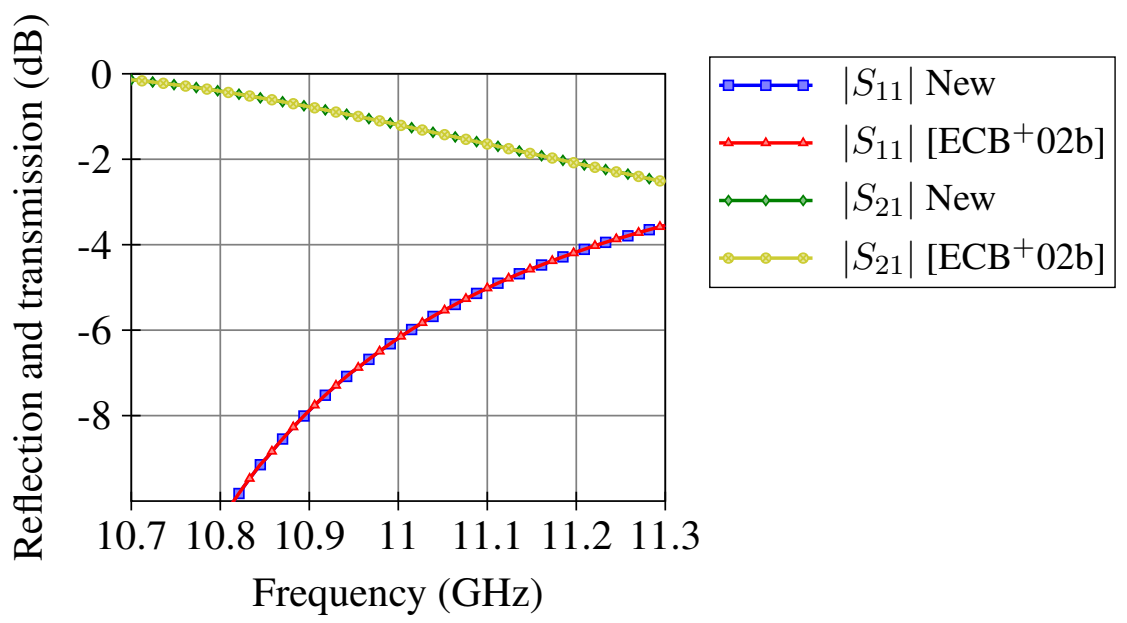

Figura 3.69: Single centered dielectric post. $a=19,05 \mathrm{~mm}, r_{c}=0,11 a, \varepsilon_{r_{c}}=24$.

If there are multiple scattering posts inside region B (see Fig. 3.64), the method described in $\left[\mathrm{ECB}^{+} 02 \mathrm{a}\right]$ can be used to analytically obtain the joint scattering matrix $D$ once the individual scattering matrices of each scatterer have been computed.

\subsubsection{Results}

The new method presented in this paper has been first tested with the analysis of a single centered circular post. Results are shown in Fig. 3.69 and compared with the results provided by the method presented in $\left[\mathrm{ECB}^{+} 02 \mathrm{~b}\right]$ by Esteban et al. Although there is a good agreement between both results, the new method is much more accurate. In $\left[\mathrm{ECB}^{+} 02 \mathrm{~b}\right]$ two matrices had to be inverted in order to obtain the scattering parameters, whereas the new method only needs to invert one matrix (see (3.209)). Furthermore, the matrix in (3.209) is better conditioned than the matrices in $\left[\mathrm{ECB}^{+} 02 \mathrm{~b}\right]$, as shown in Fig. 3.70. Although this circumstance does not imply a significant difference between both methods for the results of the fundamental mode, as shown in Fig. 3.69, the method of $\left[\mathrm{ECB}^{+} 02 \mathrm{~b}\right]$ has very poor accuracy for high order modes, and when the generalized scattering matrix of the post is cascaded with the multimodal matrices of adjacent building blocks (steps, lines) of the structure the overall 


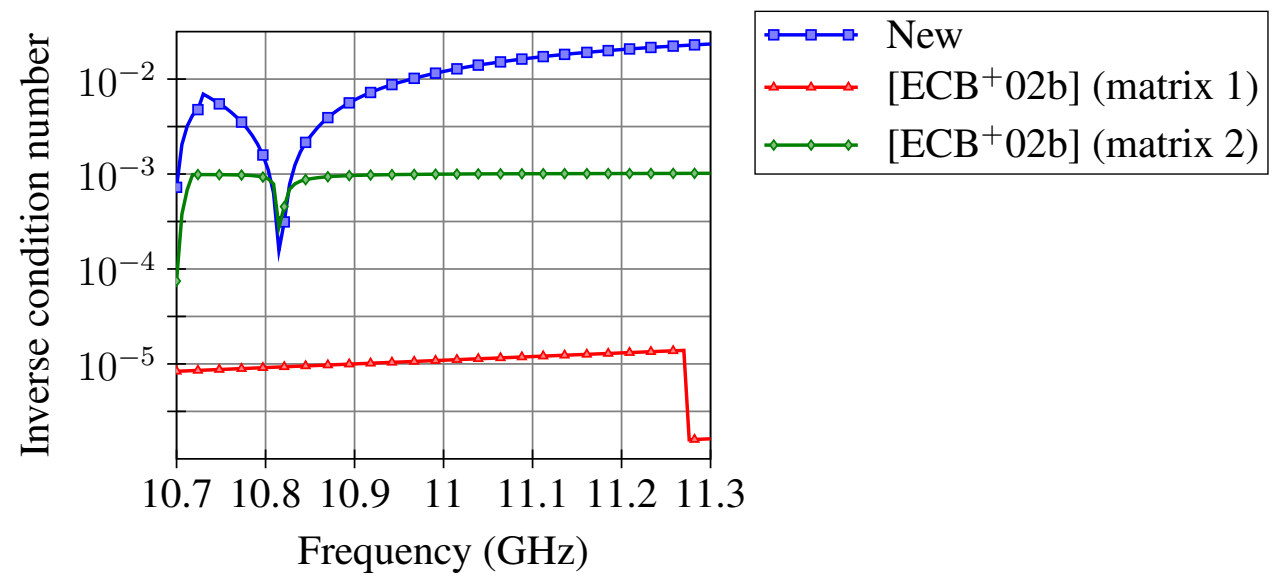

Figura 3.70: Inverse condition number as a function of the frequency for a centered dielectric post. $a=19,05 \mathrm{~mm}, r_{c}=0,11 a, \varepsilon_{r_{c}}=24$.

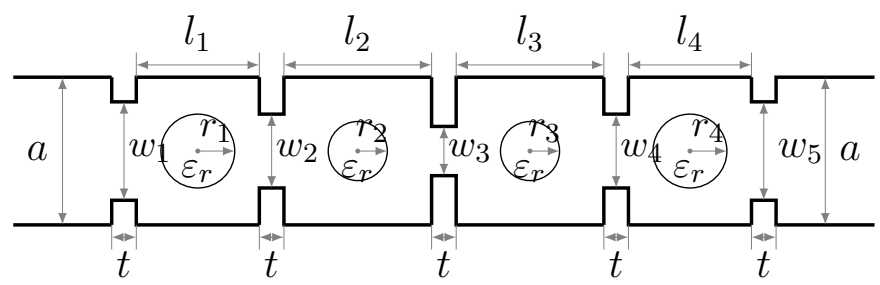

Figura 3.71: Four pole $\mathrm{H}$-plane cavities filter loaded with centered cylindrical resonators. $a=19,05 \mathrm{~mm}, \varepsilon_{r}=24, l_{1}=l_{4}=6,98 \mathrm{~mm}, l_{2}=l_{3}=8,28 \mathrm{~mm}, w_{1}=w_{5}=13,37 \mathrm{~mm}, w_{2}=$ $w_{4}=6,286 \mathrm{~mm}, w_{3}=6,1 \mathrm{~mm}, t=2 \mathrm{~mm}, r_{1}=r_{4}=2,111 \mathrm{~mm}, r_{2}=r_{3}=2,172 \mathrm{~mm}$.

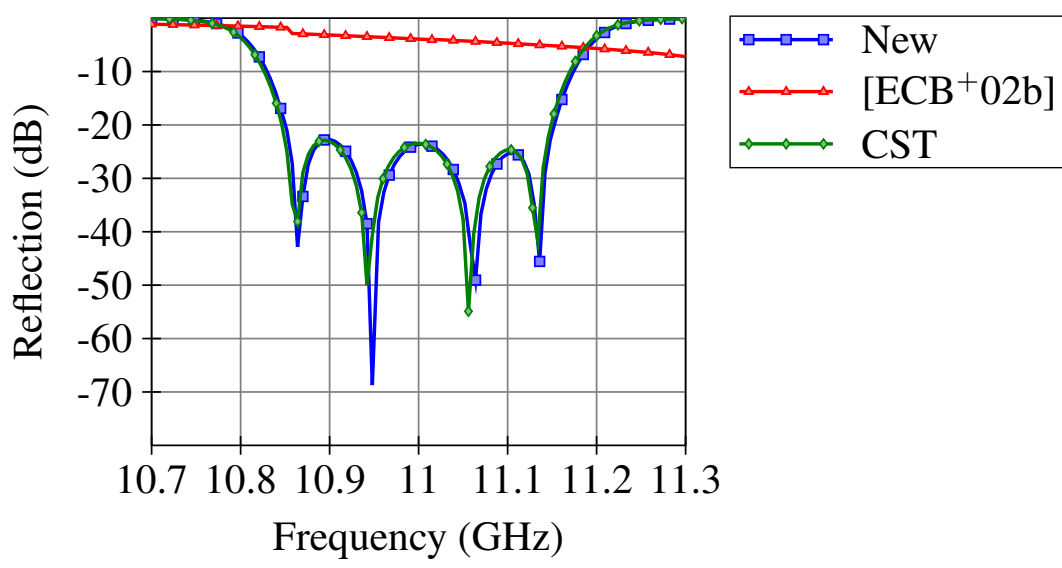

Figura 3.72: Reflection coefficient of the cavities filter loaded with dielectric cylinders 


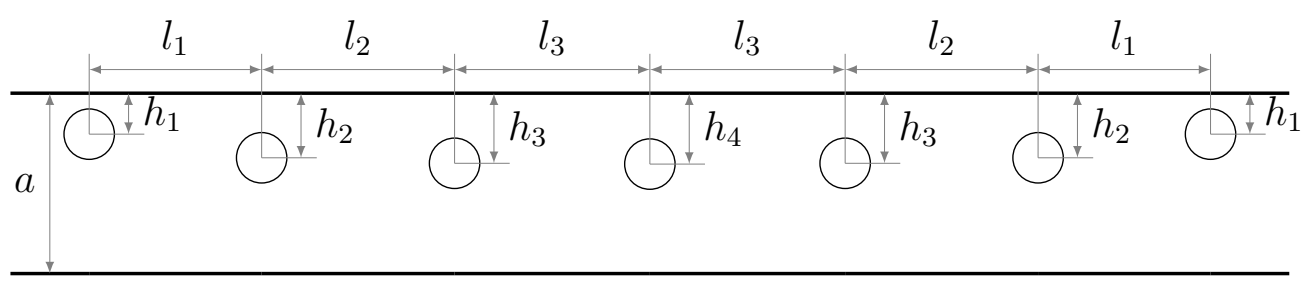

Figura 3.73: Geometry of a constant diameter off-centered single metallic rod filter

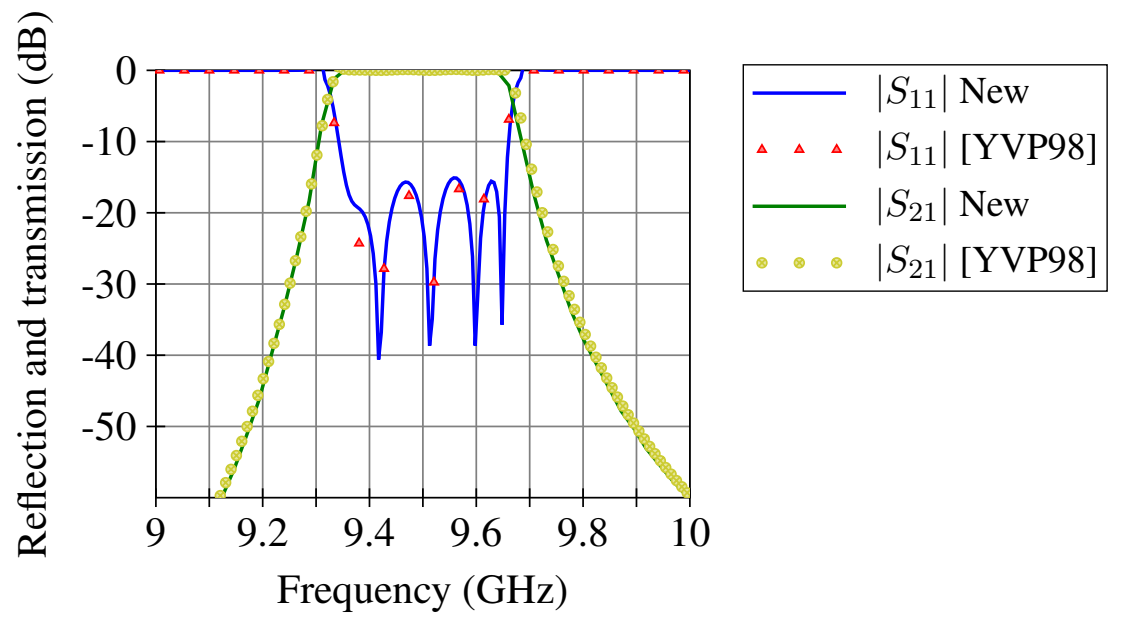

Figura 3.74: Scattering parameters of a constant diameter off-centered single metallic rod filter. $a=22.86 \mathrm{~mm}$, rod radii $=3.21 \mathrm{~mm}, h_{1}=5.215 \mathrm{~mm}, h_{2}=8.172 \mathrm{~mm}, h_{3}=8.863 \mathrm{~mm}$, $h_{4}=8.971 \mathrm{~mm}, l_{1}=21.895 \mathrm{~mm}, l_{2}=24.461 \mathrm{~mm}, l_{3}=24.797 \mathrm{~mm}$.

accuracy rapidly decreases, and the results provided for the whole filter response has a very poor convergence.

In $\left[\mathrm{BEB}^{+} 05\right]$ and $[\mathrm{MBEB} 06]$ the method of $\left[\mathrm{ECB}^{+} 02 \mathrm{~b}\right]$ was used to analyze a four pole coupled cavities filter loaded with centered circular cylinders (see geometry in Fig. 3.71). The results were accurate only for 11 guided modes. If a lower or higher number of guided modes was used, the results became inaccurate. This poor convergence of the method of $\left[\mathrm{ECB}^{+} 02 \mathrm{~b}\right]$ can be appreciated in Fig. 3.72, where the results are computed with the method of $\left[\mathrm{ECB}^{+} 02 \mathrm{~b}\right]$ using 15 guided modes, and the results have completely diverged. This poor converge proved to be due to the bad conditioning of the matrix that had to be inverted when the reference planes had to be placed close to the center of the post, and this fact lead us to develop a new method that could overcome this limitation. Fig. 3.72 shows that the new method, presented in this paper, provides very accurate results, in good agreement with the results from the CST commercial software. This results are stable with the number of guided modes once the convergence has been reached at approximatedly 7 guided modes. The CPU time required with a PIV processor at $2.4 \mathrm{GHz}$ was 24 seconds per frequency point with CST 


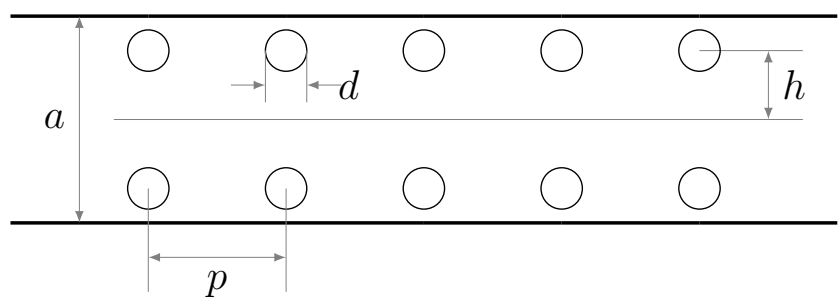

Figura 3.75: Geometry of a rectangular waveguide filter periodically loaded with double cylindrical posts

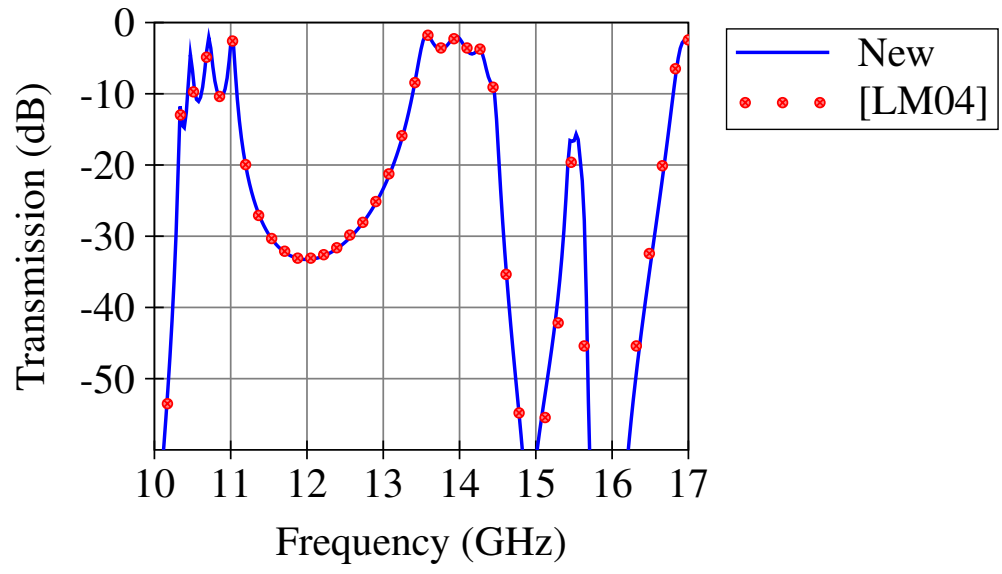

Figura 3.76: Scattering parameters of a rectangular waveguide periodically loaded with double cylindrical posts. $a=22.86 \mathrm{~mm}, p=15.7 \mathrm{~mm}, h=7.8 \mathrm{~mm}, d=4 \mathrm{~mm}, \varepsilon_{r}=14,8(1-j 0,005)$.

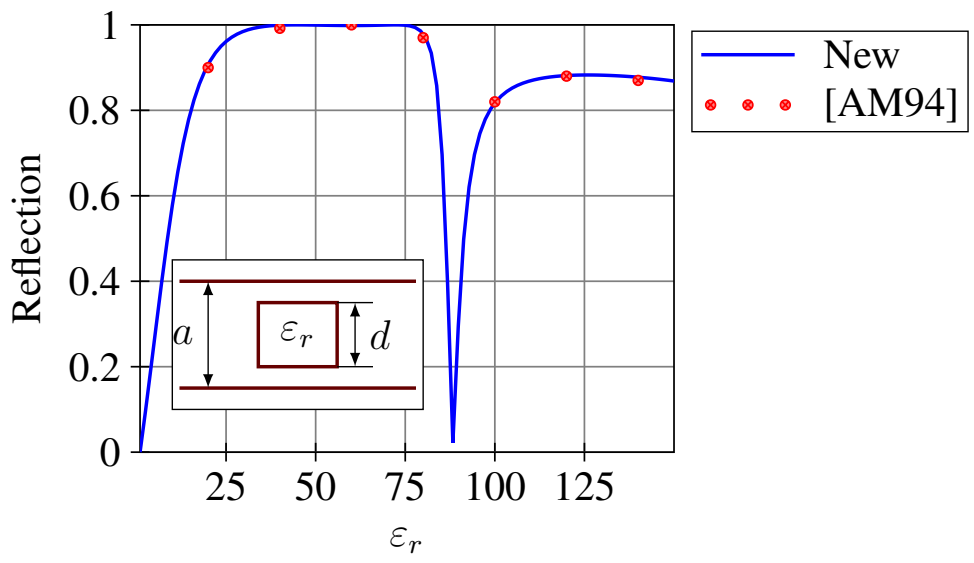

Figura 3.77: Reflection of a square dielectric post centered in a rectangular waveguide as a function of the relative electric permittivity $\varepsilon_{r}(d / a=0.1, \lambda / 1=1.4)$ 
and 0.05 seconds with the method of $\left[\mathrm{ECB}^{+} 02 \mathrm{~b}\right]$, whereas the new method only required 0.03 seconds. The generalized scattering matrices of the empty lines have been obtained analytically using standard transmission line theory, and the generalized scattering matrices of the steps have been computed using the well-known mode matching method [RA95].

The new method has also been tested with the analysis of an H-plane filter loaded with constant diameter off-centered circular metallic cylinders (see Fig. 3.73 and 3.74), and with an H-plane filter periodically loaded with double cylindrical lossy dielectric posts (see Fig. 3.75 and 3.76). In both cases the results provided with the new method are in good agreement with the results from the literature. The CPU time required was, respectively, 0.04 and 0.05 seconds per frequency point.

The new method can also be used for the analysis of arbitrarily shaped, non-circular rods. Figure 3.77 shows the analysis of a square dielectric post inside a rectangular waveguide. Since the post is not circular, the numerical method of [Ric65] has been used to compute the open space scattering matrix $D$. This reduces the efficiency, and while the analysis of the circular post inside the waveguide needs only 0.005 seconds, the square post needs 0.035 seconds.

\subsubsection{Conclusions}

A new hybrid open space and guided modes mode matching method for the analysis of $\mathrm{H}$-plane single or multiple obstacles inside a rectangular waveguide has been presented. The use of a circular boundary to match guided and open space cylindrical modes avoids the walls of the guide and allows the solution of the required integrals using the fast Fourier transform algorithm. The efficiency of this technique is maximum for circular obstacles, though the method is valid for general arbitrarily shaped posts. The new mode matching procedure overcomes the limitation of a previous method that provided accurate results only for the fundamental mode. The new method is better conditioned, highly accurate also for high order modes, and reduces the computation time by approximately $40 \%$. The new method has been tested with the analysis of a single circular post and several filter topologies with single and multiple circular posts. 


\subsection{Hybrid full-wave simulator for the multipaction mo- delling of low-cost H-plane filters}

\subsubsection{Introduction}

The new multimedia applications demand for communication systems that operate at high frequencies (microwave and milimmetric waves). Among these systems are WLL (wireless local loop), LMDS (local multipoint distribution system) and MVDS (multipoint video distribution system), which operate at $20-30 \mathrm{GHz}$ and $40 \mathrm{GHz}$ [Gmb], the digital mobile broadband access networks (MBS) in the $40 \mathrm{GHz}$ band [Eur98], and the future satellite communication systems operating in the Ka band $(30 / 20 \mathrm{GHz})$ and even in higher frequency bands [MB10].

The equipment present in these communication systems is usually integrated by passive devices manufactured in waveguide technology [CGS00], such as coupled cavities filters, diplexers and multiplexers, phase shifters, beam-forming networks and orthomodal transducers. The techniques used to manufacture these devices (i.e. milling, spark erosion, electroforming, die-casting [BCEB02]) usually introduce unwanted effects during the mechanization process. The appearance of rounded corners is one of the most important effects [ABR ${ }^{+}$97]. These effects are more relevant in devices operating at high frequencies, since their physical dimensions are very small, and therefore more sensitive to the tolerances associated to the production process. When the mechanization effects are not considered in the design phase, a deviation appears between the measured and predicted electrical responses. This deviation is traditionally corrected using tuning elements (i.e. screws) that must be tuned by human intervention, thus increasing the overall production cost. Many efforts have been recently devoted to the full-wave analysis and automated design of passive waveguide devices taking into account the presence of rounded corners [BBCO97]. The Computer Aided Design (CAD) process of devices with rounded corners avoids the use of tuning elements, and allows the fabrication with less restrictive tolerances, thus reducing the production cost significantly. In order to complete the design of satellite waveguide components, power handling capabilities must also be taken into account, thus analysing the multipactor effect, which is a vacuum discharge produced by an electron avalanche multiplication in presence of RF field [Cla78].

In this work, the new full-wave hybrid analysis technique described in $\left[\mathrm{ECB}^{+} 02 \mathrm{~b}\right]$ is used in combination with a field-based multipaction model [LVVA00] to calculate the peak power causing multipactor discharge inside an H-plane coupled cavities filter. The filter is designed using the novel CAD tool presented in $\left[\mathrm{MES}^{+} 02 \mathrm{a}\right]$. The presence of rounded corners due to low-cost production is also considered, and its effect in multipactor discharge is analysed. It has been demonstrated that the presence of rounded corners both in the cavities and in the coupling windows that appear with low-cost manufacturing techniques does not significantly 
affect the maximum transmission power. The use of the hybrid full-wave simulator for the multipaction analysis reduces the computational cost by a factor of 10 when compared to commercial Finite Elements Method (FEM) software like Ansoft HFSS [Cor], and allows the analysis of arbitrarily shaped H-plane structures, such as coupled cavities filters with rounded corners.

\subsubsection{Field-based multipaction modelling procedure}

The development of procedures for the analysis of the power handling capacity of microwave devices has recently lead to intense research [LVVA00], [LZAR01], [WZ01], $\left[\mathrm{BBA}^{+} 00\right]$. Among all these techniques, the field-based multipaction model proposed in [LVVA00] offers a simple and relatively fast procedure for the computation of the maximum transmit power without multipactor discharge by using a full-wave EM simulator. This method is an extension of the Hatch \& Williams model [HW54], which provides multipaction diagrams relating threshold voltage, gap size, and frequency for the parallel plate waveguide with uniform fields. The method in [LVVA00] extends the Hatch \& Williams model to the analysis of waveguide components with complex field distribution patterns.

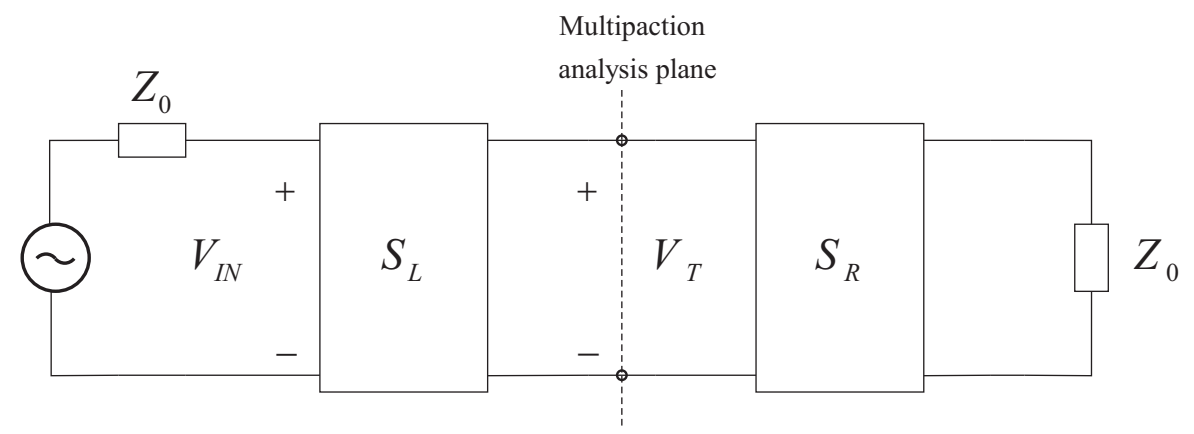

Figura 3.78: Input and maximum equivalent voltage in a guided device

The field-based multipaction model computes equivalent voltages inside the waveguide device. Assuming rectangular waveguide and single-mode $T E_{10}$ propagation, this equivalent voltage can be defined as:

$$
V=b E_{y}(x=a / 2)
$$

where $E_{y}(x=a / 2)$ is the maximum electric field associated to the $T E_{10}$ mode, $a$ is the width and $b$ is the height of the waveguide cross-section. Using a full-wave electromagnetic simulator, the voltage inside the guided device is computed, and the plane where the maximum voltage occurs is identified as the multipaction analysis plane. A Voltage Magnification 
Factor (VMF) is defined as the ratio between the voltage at the multipaction analysis plane $V_{t}$ and the voltage at the input plane $V_{i n}$ (see Fig. 3.78):

$$
V M F(\omega)=\frac{V_{t}(\omega)}{V_{i n}(\omega)}
$$

The transmit power at the input plane is:

$$
\begin{aligned}
P & =\frac{\left|E_{y}(x=a / 2, z=0)\right|^{2}}{4 Z_{T E_{10}}} a_{i n} b_{i n}=\frac{V_{i n}^{2}}{2 Z_{0}} \\
& =\frac{1}{(V M F)^{2}} \frac{V_{t}^{2}}{2 Z_{0}}
\end{aligned}
$$

where $a_{i n}, b_{i n}$ and $Z_{0}$ are the width, height and impedance of the input guide. $Z_{0}$ is calculated as:

$$
Z_{0}=2 Z_{T E_{10}} \frac{b_{i n}}{a_{i n}}=240 \pi \frac{\lambda_{g} b_{i n}}{\lambda a_{i n}}
$$

where $\lambda_{g}$ is the wave length in the input guide, and $\lambda$ is the wave length in open space.

Using the susceptibility limit $V_{d i s}$ proposed in [WP89], the maximum transmit power can be easily calculated. The susceptibility limit is obtained from the breakdown curves of a specific material and surface treatment, and according to a conservative design criterion. To avoid multipactor discharge, the maximum voltage $V_{t}$ must satisfy $V_{t} \leq V_{d i s}$. Using (3.239), the maximum transmit power at the input plane is:

$$
P \leq P_{\max }=\frac{1}{(V M F)^{2}} \frac{V_{d i s}^{2}}{2 Z_{0}}
$$

Once the multipaction analysis plane has been located, the VMF is computed in the operating frequency range, and the maximum transmit power is evaluated using (3.241). The minimum value of $P_{\max }$ in the entire bandwidth is accepted as the power handling capability of the microwave device. 


\subsubsection{Hybrid full-wave simulator}

The full-wave EM simulator used for the multipaction analysis is a hybrid method that combines spectral open-space techniques with a new mode-matching procedure [ $\left.\mathrm{ECB}^{+} 02 \mathrm{~b}\right]$. This method analyses arbitrary H-plane structures in rectangular waveguide excited with $T E_{m 0}$ modes. In these structures both the exciting fields and the geometry are invariant in one dimension, so the problem can be reduced to an equivalent 2-D multiple scattering structure as depicted in Fig. 3.79(a). The method can analyse devices with multiple accessing ports, as well as with several obstacles of arbitrary geometry and composition (metallic, lossy dielectric and/or magnetic), and with irises and windows.

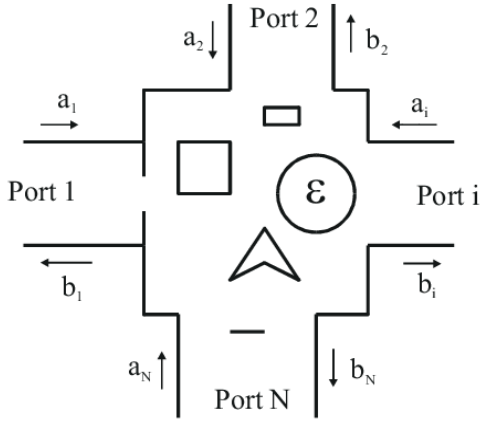

(a)

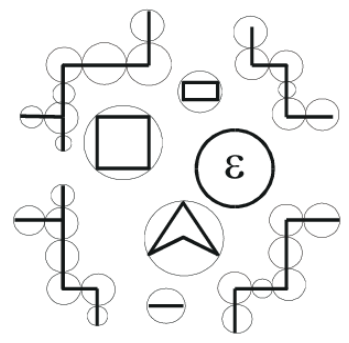

(b)

Figura 3.79: H-plane structure in a rectangular waveguide with multiple ports and several obstacles in (a). Equivalent open-space 2-D multiple scattering problem after segmentation in (b)

The 2-D structure in Fig. 3.79(a) is split into several individual scatterers, and a 2-D multiple scattering problem is obtained, as shown in Fig. 3.79(b). Each scatterer is characterized individually using the analytical solution for canonical geometries, and the numerical Method of Moments (MoM) for non-canonical objects. The coupling among objects is solved using the new spectral technique proposed in $\left[\mathrm{ECB}^{+} 02 \mathrm{a}\right]$, obtaining a full-wave characterization of the whole structure in terms of open-space spectral modes. In order to obtain the Generalised Scattering Matrix (GSM) that relates guided modes of the standard rectangular guide in all ports, the new Mode-Matching procedure described in $\left[\mathrm{ECB}^{+} 02 \mathrm{~b}\right]$ is applied. 


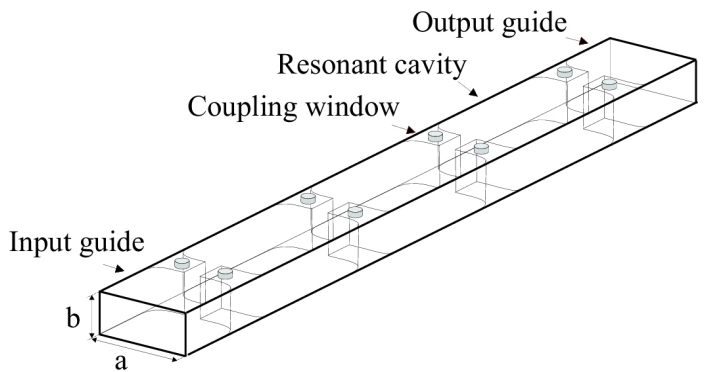

(a)

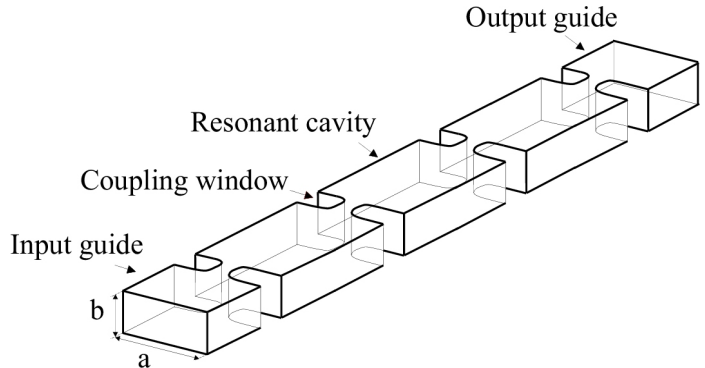

(b)

Figura 3.80: Rounded corners in a 3-pole H-plane filter due to low-cost fabrication techniques. Rounded corners in the cavities due to milling in (a), and in the coupling windows due to die-casting in $(b)$

The hybrid method has been successfully applied to the analysis of multiple H-plane structures, such as junctions, bends, steps, filters with dielectric posts, inductively coupled filters, etc. (see $\left[\mathrm{ECB}^{+} 02 \mathrm{~b}\right]$ ). In this work the hybrid method has been used for the analysis and design of inductively coupled filters. The presence of rounded corners in the cavities (see Fig. 3.80(a)) and in the coupling windows (see Fig. 3.80(b)) due to the use of low-cost manufacturing techniques has been included in the design. Fig. 3.81 validates the accuracy of the hybrid method for the analysis of these filters. The return loss of a 3-pole inductively coupled filter with rounded corners in the coupling windows is compared with the results provided by HFSS. A good agreement between the hybrid method and HFSS is demonstrated. The computation time was around 10 times shorter than using HFSS.

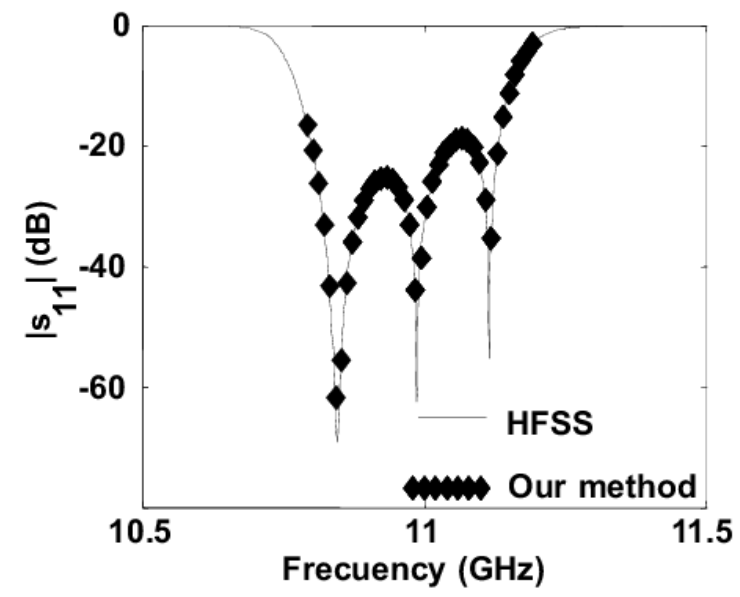

Figura 3.81: Return loss for a 3-pole H-plane filter with rounded corners in the coupling windows. Comparison between HFSS and our method. The radius on the rounded corners is $0.5 \mathrm{~mm}$

In order to compute the VMF needed for the multipaction analysis, the hybrid method 
has been used to compute the left $\left(S^{L}\right)$ and right $\left(S^{R}\right)$ Generalised Scattering Matrices in Fig. 3.78. From (3.237) and (3.238), the VMF can be evaluated as:

$$
V M F=\frac{b_{t} \cdot E_{y}^{(t)}\left(x_{t}=a / 2\right)}{b_{i n} \cdot E_{y}^{(i n)}\left(x_{t}=a / 2\right)}=\frac{E_{y}^{(t)}\left(x_{t}=a / 2\right)}{E_{y}^{(i n)}\left(x_{t}=a / 2\right)}
$$

where $b_{t}$ and $b_{i n}$ are, respectively, the heights of the guide at the input and multipaction analysis plane. Since the structure under analysis is invariant in height (H-plane device), $b_{t}=b_{i n} . E_{y}^{(t)}$ and $E_{y}^{(i n)}$ are, respectively, the electric field at the input and multipaction analysis plane. They are computed as:

$$
E_{y}^{(i)}\left(x_{i}\right)=\sum_{m=1}^{M_{i}} \sqrt{Z_{0 m}^{(i)}} e_{m}^{(i)}\left(x_{i}\right)\left[a_{m}^{(i)} e^{-\gamma_{m}(i) z_{i}}+b_{m}^{(i)} e^{\gamma_{m}(i) z_{i}}\right]
$$

where the subscript $i$ and the superscript $(i)$ denote either the input plane $(i=i n)$ or the multipaction analysis plane $(i=t) . z_{i}$ is the coordinate that indicates the position of the plane $i$ in relation to the reference plane of the scattering parameters in the correspondent access plane. $M_{i}$ is the number of $T E_{m 0}$ modes considered in the corresponding access port. $Z_{0 m}^{(i)}$ and $\gamma_{m}^{(i)}$ are, respectively, the impedance and propagation constant of the $T E_{m 0}$ mode at the plane $i$ :

$$
\begin{aligned}
Z_{0 m}^{(i)} & =\frac{j \omega \mu}{\gamma_{m}^{(i)}} \\
\gamma_{m}^{(i)} & =\sqrt{\left.\left(\frac{n \pi}{a_{i}}\right)^{2}\right)+\left(\frac{2 \pi}{\lambda}\right)^{2}}
\end{aligned}
$$

The function $e_{m}^{(i)}\left(x_{i}\right)$ is the normalized vector mode function corresponding to the $T E_{m 0}$ mode at the plane $i\left[\mathrm{ECB}^{+} 02 \mathrm{~b}\right]$ :

$$
e_{m}^{(i)}\left(x_{i}\right)=-\frac{\sqrt{2}}{\sqrt{a_{i} b_{i}}} \sin \left(\frac{m \pi}{a_{i}} x_{i}\right)
$$

The modal amplitudes $a_{m}^{(t)}$ and $b_{m}^{(t)}$ of the incident and reflected waves at the plane $t$, as well as the amplitudes of the reflected waves at the input plane $b_{m}^{(i n)}$ can be related to the amplitudes $a_{m}^{(i n)}$ from $S^{L}$ and $S^{R}$ as: 


$$
\begin{aligned}
A^{(t)} & =\left[a_{1}^{(t)}, \ldots, a_{M_{t}}^{(t)}\right]^{T}=\left(I-S_{11}^{R} S_{22}^{L}\right)^{-1} S_{11}^{R} S_{21}^{L} A^{(i n)} \\
B^{(t)} & =\left[b_{1}^{(t)}, \ldots, b_{M_{t}}^{(t)}\right]^{T}=\left(I-S_{11}^{R} S_{22}^{L}\right)^{-1} S_{21}^{L} A^{(i n)} \\
B^{(i n)} & =\left[b_{1}^{(i n)}, \ldots, b_{M_{i n}}^{(i n)}\right]^{T} \\
& =\left[S_{11}^{L}+S_{12}^{L}\left(I-S_{11}^{R} S_{22}^{L}\right)^{-1} S_{11}^{R} S_{21}^{L}\right] A^{(i n)}
\end{aligned}
$$

where, for the $T E_{10}$ incidence at the input plane:

$$
A^{(i n)}=\left[a_{1}^{(i n)}, \ldots, a_{M_{i n}}^{(i n)}\right]^{T}=[1,0, \ldots, 0]^{T}
$$

Substituting (3.247) in (3.246), the modal amplitudes needed for computing the multimodal expression of the electric field in (3.243) are obtained. Finally, the substitution of (3.243) in (3.242) provides the Voltage Magnification factor. It must be noted that in previous implementations of the field-based multipaction modelling procedure [LVVA00] only the fundamental $T E_{10}$ mode was considered in the computation of the VMF from $S^{R}$ and $S^{L}$.

\subsubsection{Results}

The power handling capability of a 4-pole inductively coupled cavities filter in bare aluminium WR-75 has been analysed. The filter band pass is centred at $13.86 \mathrm{GHz}$, and the bandwidth is $300 \mathrm{MHz}$. The filter has been designed with the novel CAD technique described in $\left[\mathrm{MES}^{+} 02 \mathrm{a}\right]$, in combination with the full-wave hybrid simulator previously described. The design parameters have been the widths of the coupling windows, and the length of the resonant cavities. The filter has been designed considering right angle corners (Fig. 3.82), the rounded corners in the resonant cavities that appear with milling (Fig. 3.83), and the rounded corners that appear with die-casting (Fig. 3.84). Fig. 3.82, 3.83 and 3.84 show the equivalent 2-D multiple scattering problem and the field distribution inside the filter at the central frequency $(13.86 \mathrm{GHz})$.

Fig. 3.85(a) shows the return loss of the 4-pole filter for right angle corners and rounded corners in the cavities and windows, computed using the hybrid full-wave simulator. The VMF has been computed at the central frequency and along the propagation direction inside 


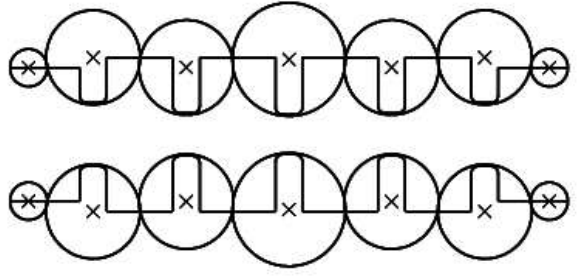

(a)

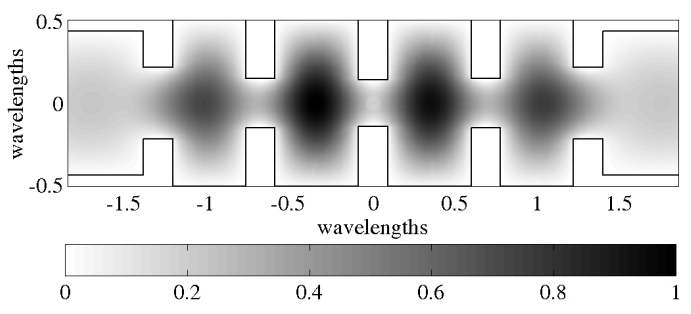

(b)

Figura 3.82: Field distribution inside a 4-pole H-plane filter at the central frequency with right angle corners. The segmentation used to analyse the filter is depicted in (a). Pseudocolor plot in (b)

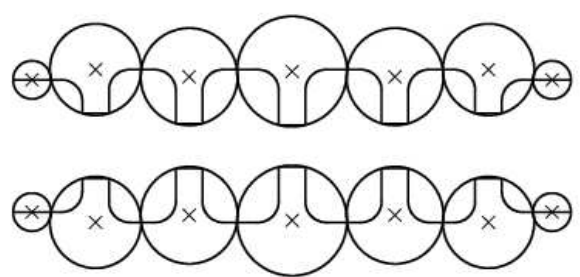

(a)

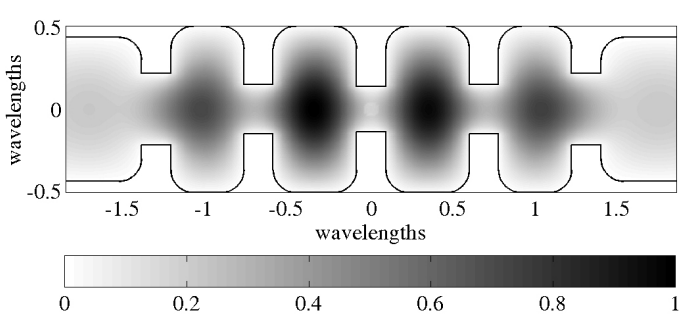

(b)

Figura 3.83: Field distribution inside a 4-pole H-plane filter at the central frequency with rounded corners in the cavities. The segmentation used to analyse the filter is depicted in (a). Pseudocolor plot in (b) 


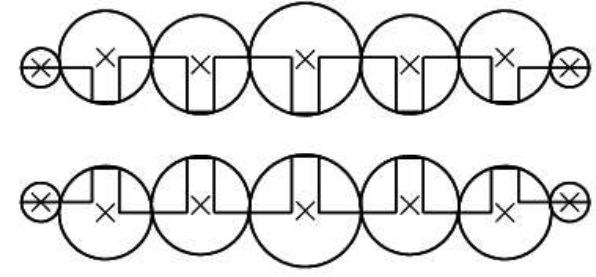

(a)

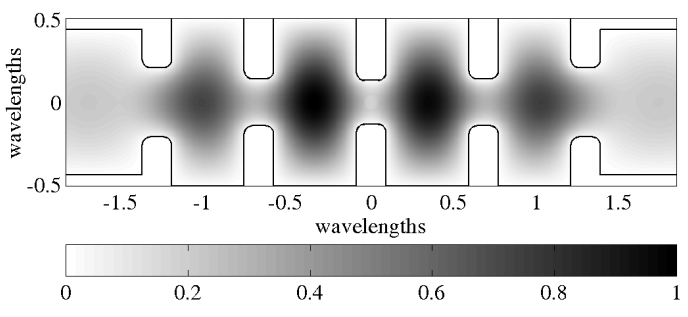

(b)

Figura 3.84: Field distribution inside a 4-pole H-plane filter at the central frequency with rounded corners in the coupling windows. The segmentation used to analyse the filter is depicted in (a). Pseudocolor plot in (b)

the filter, and it is shown in Fig. 3.85(b). It can be derived from the VMF plot that the maximum values of the VMF occur at the middle of the resonant cavities. At the central frequency the maxim of VMF occurs in the middle of the second cavity, but for other frequencies the multipaction analysis plane can be shifted to the middle of other cavity.

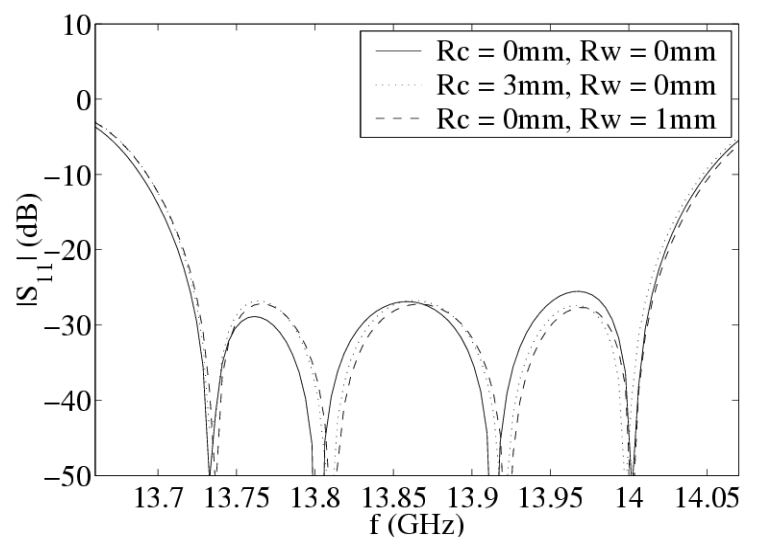

(a)

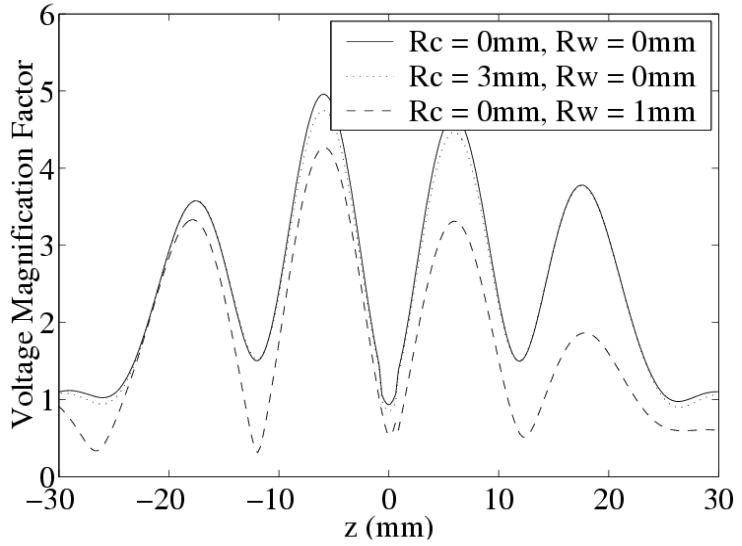

(b)

Figura 3.85: Return loss for a 4-pole bare-aluminium H-plane filter in (a), and voltage magnification factor behaviour along $z$ in (b). Results are given for the filter with right angle and rounded corners. Rc and Rw are, respectively, the radii of the rounded corners in the cavities and in the coupling windows

Therefore, (3.242) is used in order to compute the VMF in the middle of each cavity for each frequency point. The maximum VMF is selected for each frequency point, and 
the result is depicted in Fig. 3.86(a). Once the VMF is computed, the susceptibility limit for bare aluminium is taken from the curves in [WP89], and using (3.241) the maximum transmit power at the input plane is calculated. The result is shown in Fig. 3.86(b). It can be appreciated that the maximum VMF and the minimum transmit power occurs in the extremes of the band pass. It can also be observed that the rounded corners do not significantly affect the power handling capabilities of the filter, either the rounded corners are placed in the coupling windows or in the resonant cavities. It must be noted that the dimensions of the filters with rounded corners are different to the dimensions of the filter with right angle corners, since they have been designed to have the same electrical response.

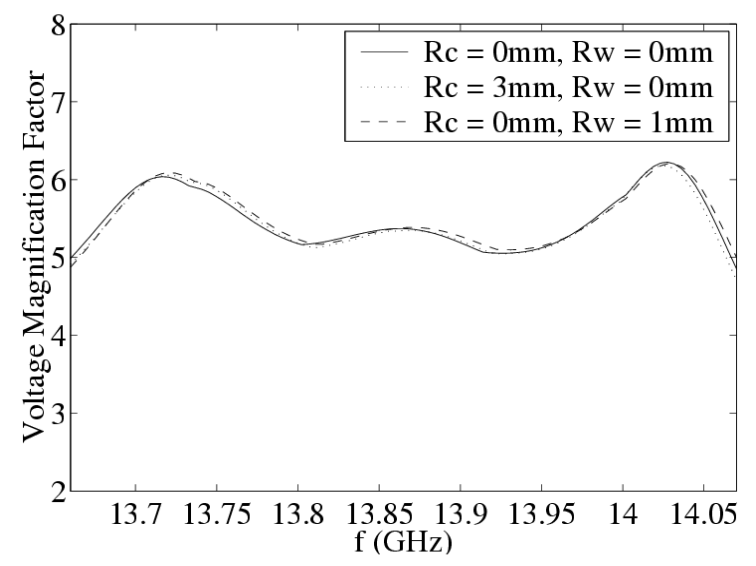

(a)

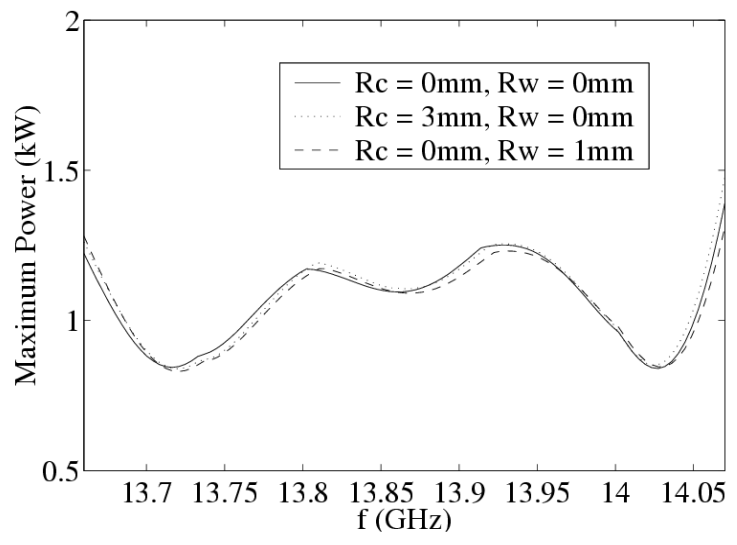

(b)

Figura 3.86: Voltage magnification factor (a) and maximum power (b) as a function of frequency for the 4-pole filter with right angle and rounded corners

Fig. 3.87 compares the maximum transmit power for a 6-pole bare aluminium WR-75 filter. The filter is centred at $13.86 \mathrm{GHz}$, and the bandwidth is $300 \mathrm{MHz}$. The results compare right angle corners and rounded corners in the resonant cavities. Again the presence of rounded corners does not affect the multipactor effect. Fig. 3.87(a) shows the maximum transmit power using the maximum VMF for each frequency point. In Fig. 3.87(b) the maximum transmit power has been computed using for all frequencies the same multipaction analysis plane than for the central frequency (middle of the 5-th cavity), as it is done in [LVVA00]. It can be observed that the use of the same multipaction analysis plane in the whole frequency range underestimates the possibility of multipactor discharge at some frequencies (see $14.025 \mathrm{GHz}$ ). 


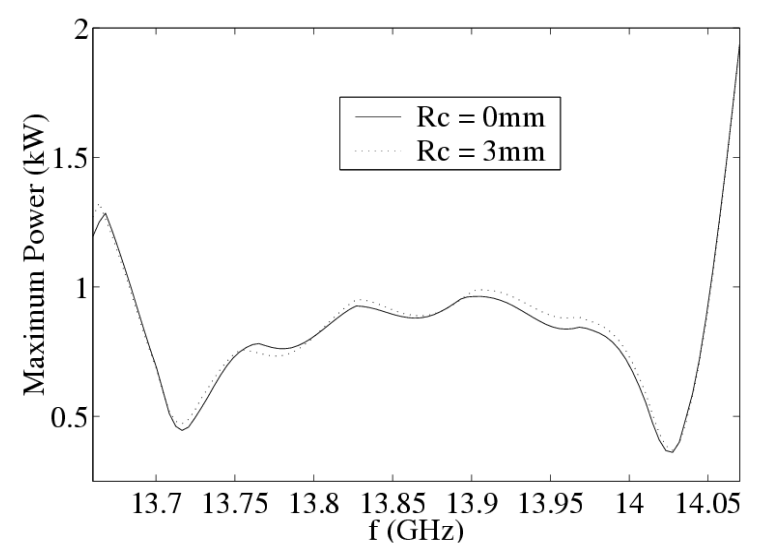

(a)

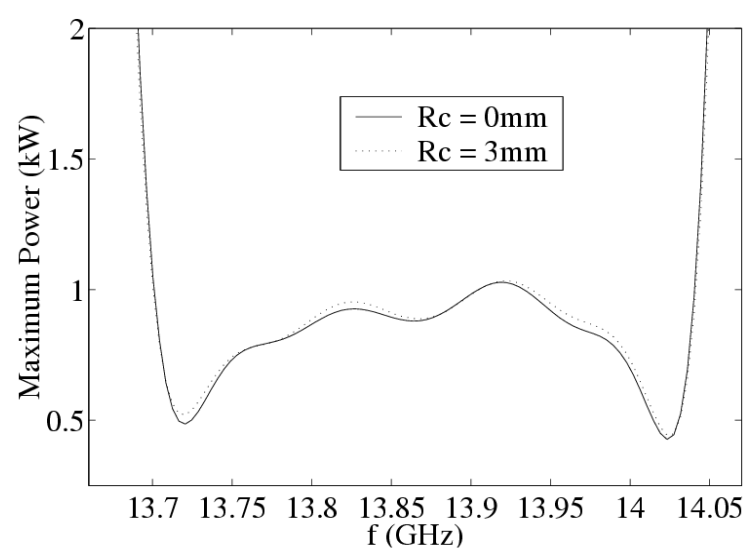

(b)

Figura 3.87: Maximum transmit power with maximum VMF (a) and with VMF related to the 5-th cavity (b) as a function of frequency for the 6-pole filter with right angle and rounded corners

\subsubsection{Conclusion}

A novel hybrid full-wave EM simulator has been applied to the multipactor analysis of inductively coupled cavities in rectangular waveguide. The method has proved to be accurate and around 10 times faster than HFSS. A field-based multipactor analysis technique has been used in combination with the hybrid simulator to evaluate the power handling capabilities of a 4-pole and a 6-pole filter with right angle corners and with the rounded corners that appear when using low-cost manufacturing techniques (milling and die-casting). A novel CAD technique has been used to design the filters.

The results have shown that the presence of rounded corners does not affect the maximum transmit power of the filter. The maximum VMF has been computed at each frequency point, thus avoiding the possibility of underestimation of the multipactor effect that occurs when the same multipactor analysis plane is used in the whole frequency range. 


\subsection{Comparative Study of Multipactor Breakdown in Waveguide H-plane Filters Loaded with Dielectric Resonators}

\subsubsection{Introduction}

There are many reasons that lead to develop new topologies of high frequency filters for space applications, i.e: reduction of mass and volume, increase of thermal stability for high power applications, increase of out-of-band rejection, reduction of manufacturing effort, availability of analysis and design tools for synthesizing a desired response and reduction of risk of radio frequency breakdown (i.e. Multipactor effect [Udi04], [Udi07]).

Rectangular waveguide H-plane filters are one of the most popular technologies for satellite communications filters, and many efforts are devoted to improve their capabilities. This work presents a comparative study about the risk of multipactor breakdown effect in H-plane filters. Different topologies of filters are considered, such as all metallic ones, filters loaded with circular dielectric posts and evanescent mode filters loaded with dielectric posts (see Fig. 3.88). The study has been made on the basis of a multimodal analysis method $\left[\mathrm{ECB}^{+} 02 \mathrm{~b}\right]$ that enables the computation of the electromagnetic fields inside the filter and the dielectric posts in a very accurate and efficient way. First, the results for such electromagnetic fields have been successfully compared to results obtained with a commercial simulator (Ansoft HFSS [Cor]). Then a comparative study of the multipactor effect that can appear between the two metallic surfaces of each filter has been performed. In order to achieve a fair comparison, the study was made on several filters with the same frequency response. The filters loaded with dielectric posts are smaller than the all metallic ones, and some of them have also a better out of band rejection behavior. Considering the multipactor discharge, the study concludes that the dielectric posts concentrate the electric field inside them, thus producing a smaller level of electromagnetic field outside the dielectric posts than for the all-metallic filters. Following the premise that the multipactor discharge can only appear between the metallic surfaces of the filter, the dielectric loaded filters can handle more power without risk of multipactor breakdown.

\subsubsection{Multipactor breakdown in waveguide filters}

The Hatch and Williams [HW54] model has been used for the study of the multipactor effect inside the filters. In this model, the maximum input power without multipactor breakdown is calculated by using the electric field distribution inside the structure. 


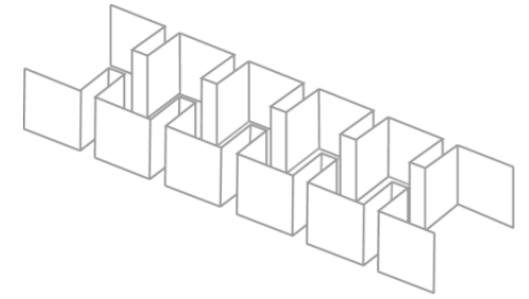

(a)

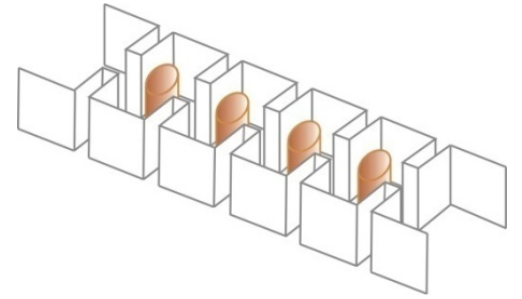

(b)

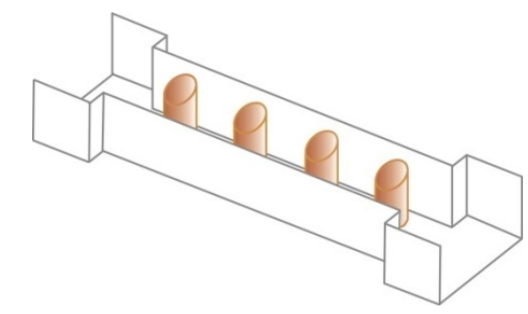

(c)

Figura 3.88: Types of filters considered in this work

In the model, the "Voltage Magnification Factor" $V M F$ [LVVA00] is defined as the maximum voltage in the structure versus the input voltage $\left(V_{i n}\right)$ for all the frequencies. This factor is calculated for all the points inside the filter and the $V M F_{\max }$ is defined as the maximum of $V M F s$. During this work we have found that the maximum of electrical field appeared always in the same point inside the filter, independently of the frequency value.

The input threshold power is also a function of the frequency and can be calculated by using the $V M F_{\max }$, the characteristic impedance $Z_{0}$ and the threshold voltage $V_{\text {multi }}$ that enables the multipactor breakdown. This value can be obtained by using Multipactor Calculator [ESA07] and depends on the type of metal surface and the frequency.

$$
\begin{gathered}
P_{t h r}(f)=\frac{1}{V M F_{\text {max }}^{2}(f)} \frac{V_{\text {multi }}^{2}(f)}{2 Z_{0}} \\
Z_{0}=\eta_{0} \frac{\lambda_{g} 2 b}{\lambda a}
\end{gathered}
$$

The minimum of equation 3.248 in the whole frequency band provides the maximum power that the device can handle without multipactor breakdown. 


\subsubsection{Distribution of electromagnetic field inside the filters}

This section describes the procedure for obtaining the distribution of electrical field inside the structures as a function of the frequency.

\subsubsection{All-metal cavities filter}

The field distribution is obtained from the multimodal scattering matrices (GSMs) of each one of the segments that compose the structure of the filter. In Fig. 3.89 the different segments and matrices are shown. GSMs of the step $\left(S_{2}, S_{4}, S_{6}, S_{8}, \ldots\right)$ can be calculated following the well-known Mode Matching Method [RA95], and the GSMs of the lines $\left(S_{1}\right.$, $S_{3}, S_{5}, S_{7} \ldots$ ) are obtained through analytic expressions. The global GSM is obtained using a new efficient recursively connection technique proposed in [BGMM07].

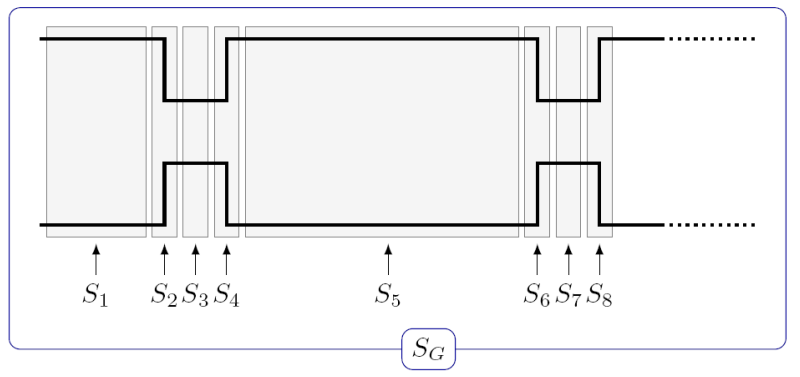

Figura 3.89: Segments and GSMs matrices of all metal cavities filter.

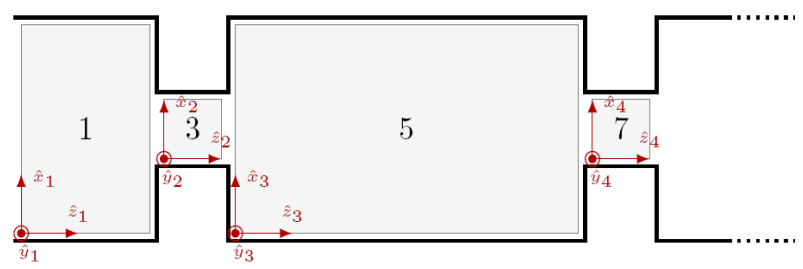

Figura 3.90: Regions for the computation of the electric field

Fig. 3.90 shows the regions where the electric field is calculated. For each region the field distribution is obtained by using the following equation [EG02]:

$$
\vec{E}_{t}^{(i)}(\rho, \phi)=\sum_{m=1}^{M_{i}} a_{m}^{(i)} \vec{e}_{m}^{(i)^{\prime}} e^{-\gamma_{m}^{(i)} z_{i}}+\sum_{m=1}^{M_{i}} b_{m}^{(i)} \vec{e}_{m}^{(i)^{\prime}} e^{-\gamma_{m}^{(i)} z_{i}}
$$

where: 
- $M_{i}$ is the number of modes in the $i$ segment of the filter. Typically $M_{i}=11$.

- $x_{i}$ and $z_{i}$ are the coordinates as defined in 3.90 .

- $a_{m}^{i)}$ and $b_{m}^{(i)}$ are the modal vectors of incident and reflected waves between segments $i-1$ and $i$ as defined in 3.89 .

- $\vec{e}_{m}^{(i)^{\prime}}\left(x_{i}\right)$ is defined in equation 3.251 .

$$
\vec{e}_{m}^{(i)^{\prime}}\left(x_{i}\right)=\hat{y}_{i} \sqrt{\frac{2 Z_{0 m}^{(i)}}{a_{i} b_{i}}} \sin \left(\frac{m \pi}{a_{i}} x_{i}\right)
$$

- $b_{i}$ is the height and $a_{i}$ the width of each section.

\subsubsection{Filter loaded with dielectric cylinders}

Fig. 3.91 shows the filter with dielectric cylinders and the different segments in which the filter is divided. There are three different types of segments: lines, steps and segment of line loaded with dielectric cylinder. For each one of them a different method is used for the computation of GSMs and the electric field.

As in the previous filter, the GSMs of the steps $\left(S_{2}, S_{4}, S_{8}, S_{10} \ldots\right)$ are calculated by using the Mode Matching Method [RA95] and the GSMs of the lines $\left(S_{1}, S_{3}, S_{5}, S_{7} \ldots\right)$ are computed analytically. For obtaining the GSMs of the segments loaded with dielectric cylinders $\left(S_{6}, S_{12} \ldots\right)$ the hybrid mode matching method is used [EG02]. Then all the matrices are connected as described in [BGMM07] in order to get the global GSM of the filter.

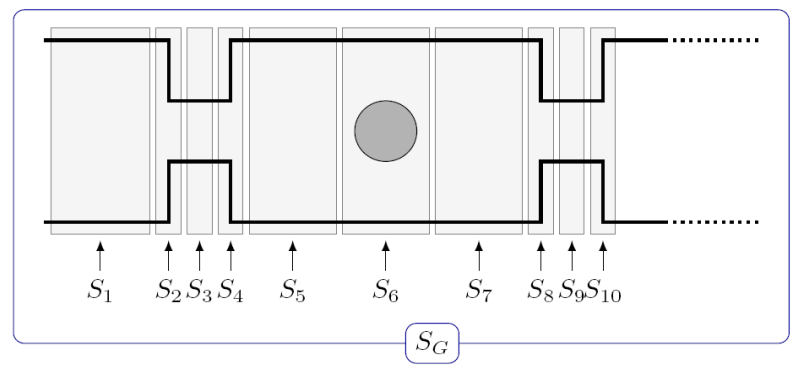

Figura 3.91: Segments and GSMs matrices of the filter loaded with dielectric cylinders.

For regions $i=1,3,5,6 a, 7,9,11 \ldots$ (see Fig. 3.92) the electric field is calculated as described in the previous subsection. The field in regions $6 b, 12 b \ldots$ (see Fig. 3.92) is obtained by using the equation 3.252 , where $J_{p}$ and $H_{p}^{(2)}$ are the Bessel and second order Hankel 


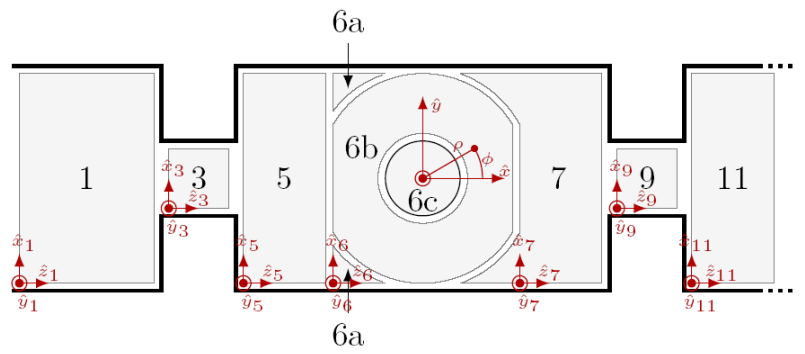

Figura 3.92: Regions for the computation of the electric field of the filter loaded with dielectric cylinders

functions, and $i_{n}$ and $c_{n}$ are the incident and scattered spectrum coefficients in cylindrical coordinates.

$$
\vec{E}_{t}^{i n t}(\rho, \phi) \approx \sum_{n=-N_{i}}^{N_{i}} i_{n} \cdot J_{n}(k \rho) \cdot e^{j n \phi} \cdot \hat{z}+\sum_{n=-N_{s c}}^{N_{s c}} c_{n} \cdot H_{n}^{(2)}(k \rho) \cdot e^{j n \phi} \cdot \hat{z}
$$

Finally, in regions $6 c, 12 c \ldots$ the field is obtained by the method described in $\left[\mathrm{ECB}^{+} 02 \mathrm{~b}\right.$ ], as follows:

$$
\vec{E}_{t}^{i n t}(\rho, \phi)=\sum_{n=-N_{i}}^{N_{i}} s_{n} \cdot J_{n}\left(k \sqrt{\varepsilon_{r} \mu_{r}} \rho\right) \cdot e^{j n \phi}
$$

where coefficient $s_{n}$ is:

$$
s_{n}=\frac{\left|\begin{array}{cc}
-H_{n}^{(2)}(k r) & J_{n}(k r) \\
-H_{n}^{(2)^{\prime}}(k r) & J_{n}^{\prime}(k r)
\end{array}\right|}{\left|\begin{array}{cc}
-H_{n}^{(2)}(k r) & J_{n}\left(k \sqrt{\varepsilon_{r} \mu_{r}} r\right) \\
-H_{n}^{(2)^{\prime}}(k r) & \sqrt{\frac{\varepsilon_{r}}{\mu_{r}}} J_{n}^{\prime}\left(k \sqrt{\varepsilon_{r} \mu_{r}} r\right)
\end{array}\right|} i_{n}
$$

and $r$ the radius of the dielectric post. 


\subsubsection{Evanescent mode filter loaded with dielectric cylinders}

In an evanescent mode filter, the fundamental mode $T E_{10}$, is below the cutoff frequency in the narrow waveguide, while it is propagating in the input wider waveguide.

The procedure followed to calculate the field inside this filter is similar to the methodology described in the two previous sections.

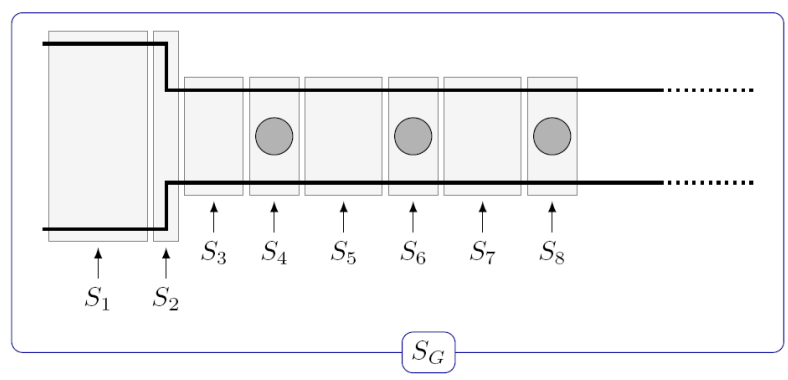

Figura 3.93: Segments and GSMs matrices of evanescent filter with dielectric cylinders

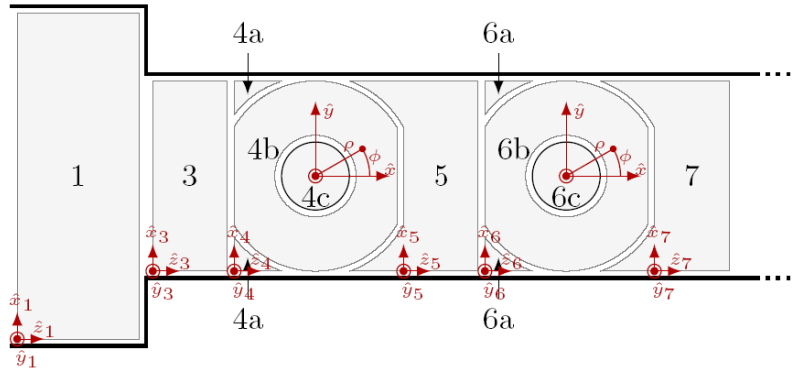

Figura 3.94: Regions for calculating the electric field of the evanescent filter with dielectric cylinders

\subsubsection{Results}

The motivation of the work is to evaluate the risk of multipactor breakdown in a set of filters. In order to have a fair comparison the filters should provide the same frequency response, so we designed three different filters: all metal cavities, cavities loaded with dielectric cylinders and evanescent mode loaded with dielectric cylinders filters, that present the same frequency response shown in Fig. 3.95.

It is important to notice that during the work we have considered that the multipactor breakdown can only appear between two electric plates containing a normal field, so for the 


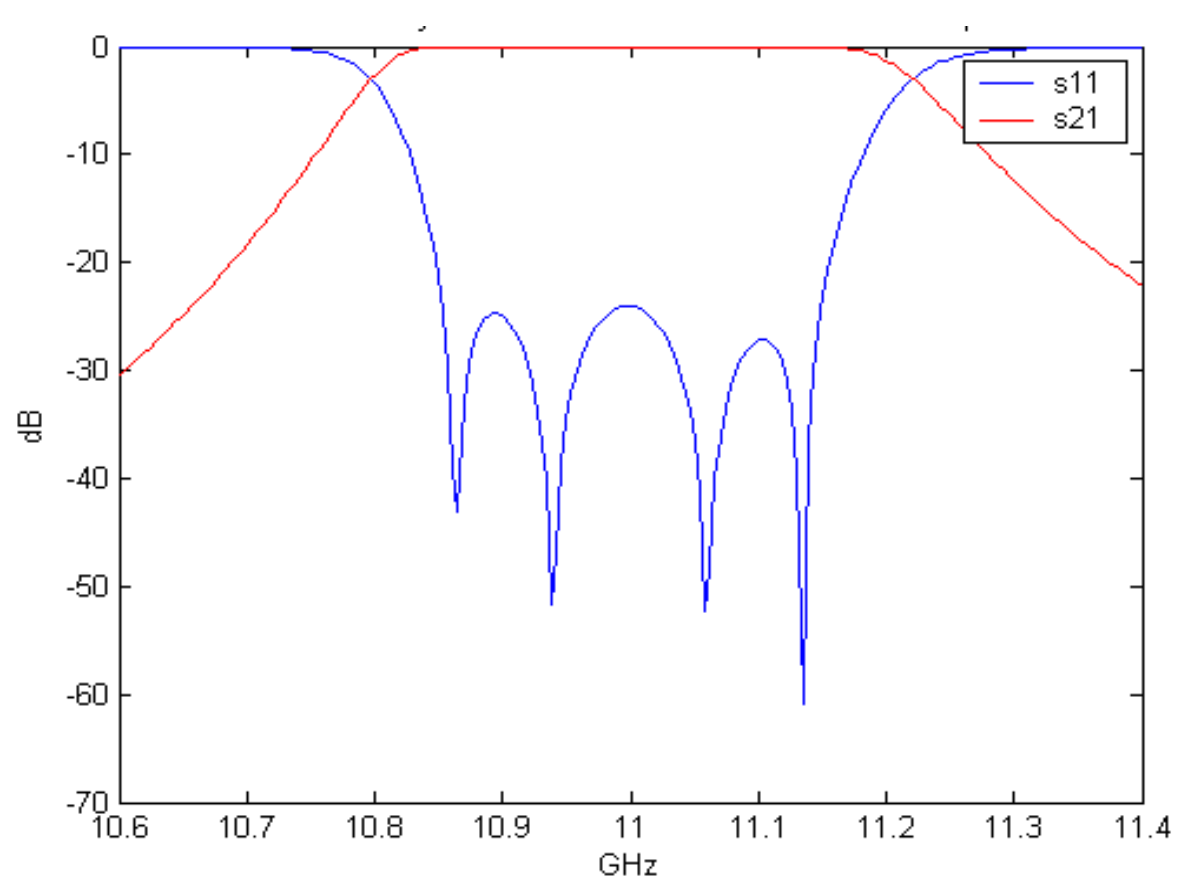

Figura 3.95: Scattering parameters $S_{11}$ and $S_{21}$ of the H-plane filters under study

calculation of the power that a particular filter can handle we have used the field inside that filter but outside the dielectric cylinders.

All the dielectric cylinders used in the filters have a dielectric permittivity $\varepsilon_{r}=24$.

\subsubsection{All-metal cavities filter}

During the study the authors found that the maximum of the electric field was always located on the central longitudinal axis of the filter, and in the middle of the second cavity independently of the frequency value.

Fig. 3.96 shows the maximum input and output power without multipactor breakdown as a function of the frequency. It is interesting that inside the pass band the amount of input and output power that the filter can handle is the same, around $2500 \mathrm{~W}$, and that outside this band the power is not limited by the multipactor risk but by the electromagnetic response of the filter. 


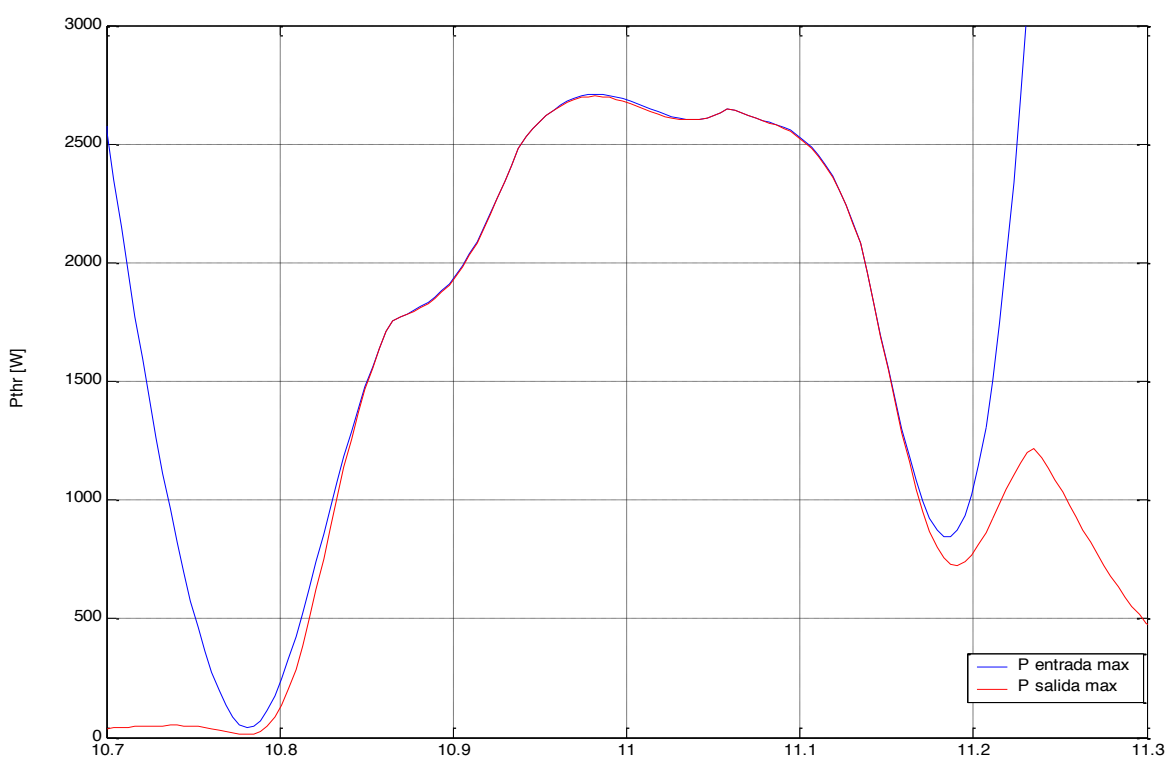

Figura 3.96: Maximum input and output power that the all-metal cavities filter can handle without multipactor breakdown as a function of frequency

\subsubsection{Filter loaded with dielectric cylinders}

In this filter the electric field was concentrated inside the dielectric cylinders, specifically there was a maximum of field inside the second cylinder, being the maximum of field outside the dielectric cylinders considerably lower than in the case of the all-metal filter. Nevertheless, loading the filters with a dielectric material can introduce losses in the filter response that can affect the output power that the filter can handle.

Fig. 3.97 shows the output power that the filter can handle without the risk of multipactor breakdown for dielectric materials with different loss factors. Even with a loss tangent of $10^{-3}$ this filter can handle the double of power than the all-metal one. Moreover, with a rather high quality factor $\left(\tan \delta=10^{-4}\right)$ the behavior of the filter does not divert from the ideal (lossless) case.

\subsubsection{Evanescent mode filter loaded with dielectric cylinders}

The evanescent mode filter is substantially smaller than the all-metal one, which makes that the electric field is more concentrated in the filter and that the risk of multipactor breakdown increases. Nevertheless, when loading this filter with dielectric cylinders, the output power without multipactor breakdown (see Fig. 3.98) can be higher than in the all-metal filter, since the field trends to concentrate inside the dielectric cylinders. The figure also shows 


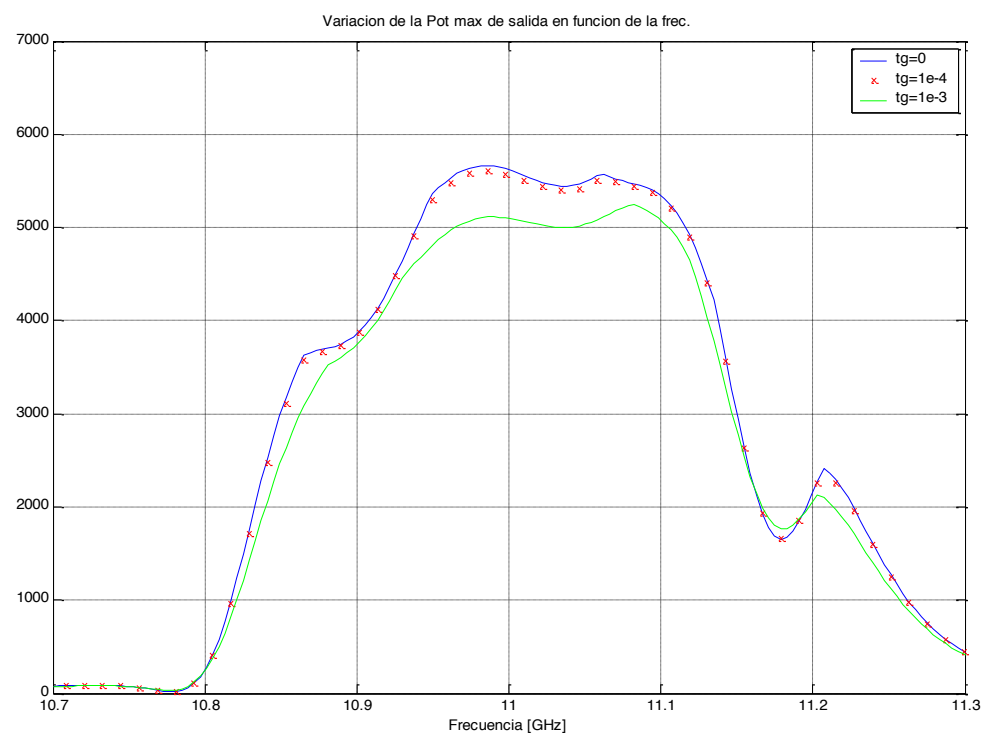

Figura 3.97: Maximum output power without multipactor breakdown for the cavities filter loaded with dielectric cylinders, loss tangents $\tan \delta=0, \tan \delta=10^{-3}, \tan \delta=10^{-4}$

the output power for different dielectric materials, with different loss tangent factors, concluding that a good quality factor dielectric $\left(\tan \delta=10^{-4}\right)$ can provide a power response similar to the ideal one, while a worse dielectric reduces this power handling but maintains it above the all-metal one.

\subsubsection{Comparison of results}

It is interesting to show a comparative study of the three filters considering three relevant items: size, maximum field inside the filters and maximum output power without multipactor risk. Table 3.36 lists the total length of the three filters. The evanescent filter presents a reduction in size of about $50 \%$ comparing to the all-metal case, and the cavities filter with dielectric cylinders is about $60 \%$ of the original size.

\begin{tabular}{|l|c|c|c|}
\hline & Filter 1: all-metal & Filter 2: cavities with dielectric & Filter 3: evanescent with dielectric \\
\hline Total length & $96.57 \mathrm{~mm}$ & $60.52 \mathrm{~mm}$ & $56.19 \mathrm{~mm}$ \\
\hline
\end{tabular}

Tabla 3.36: Lengths of the three filters

The following table presents the maximum value of the electric field inside the filters, for both cases: inside the dielectric cylinders and outside them. When having filters loaded with 


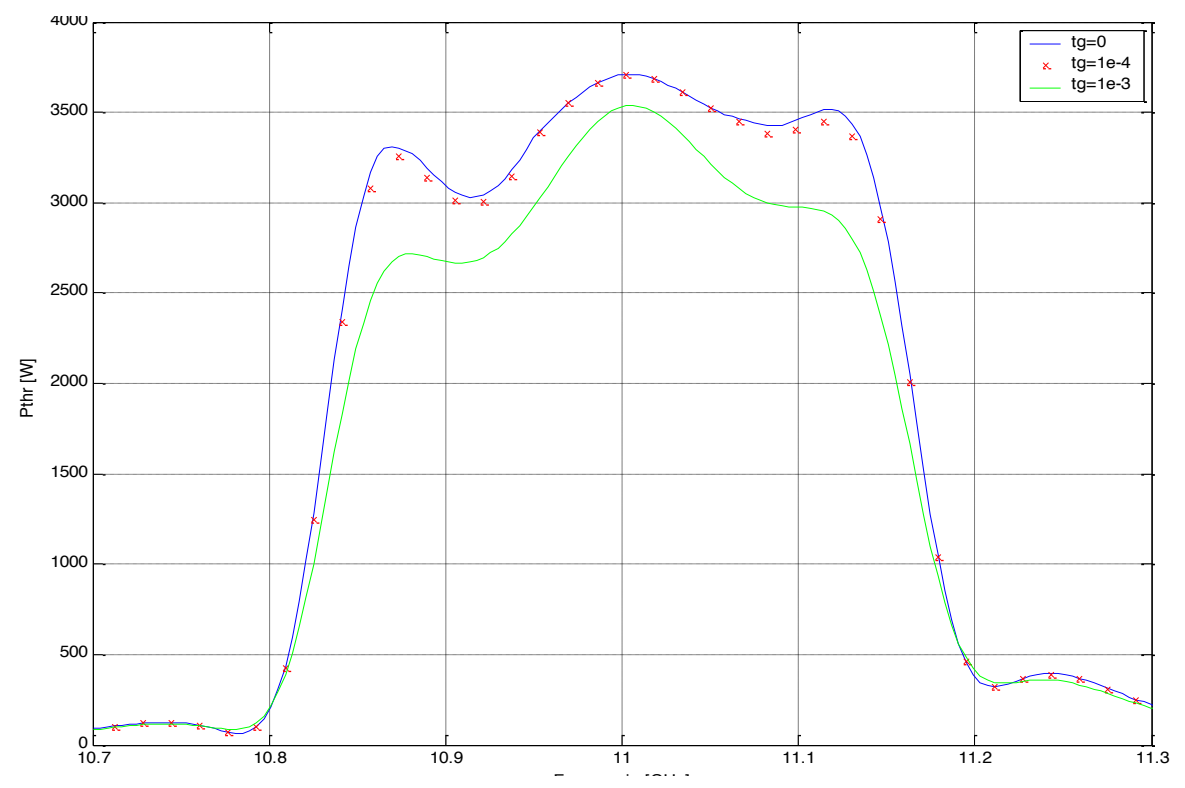

Figura 3.98: Maximum output power without multipactor breakdown for the evanescent mode filter loaded with dielectric cylinders, loss tangents $\tan \delta=0, \tan \delta=10^{-3}, \tan \delta=$ $10^{-4}$

dielectric materials, the maximum of field is always located inside the dielectric cylinders. This phenomenon enables the increase of power without risk of multipactor as shown in Fig. 3.99 .

\begin{tabular}{|c|c|c|c|}
\hline & Filter 1 & Filter 2 & Filter 3 \\
\hline E max (inside dielectric) & - & $11357 \mathrm{~V} / \mathrm{m}$ & $17166 \mathrm{~V} / \mathrm{m}$ \\
\hline Frequency & - & $11.188 \mathrm{GHz}$ & $11.24 \mathrm{GHz}$ \\
\hline E max (outside dielectric) & $14618 \mathrm{~V} / \mathrm{m}$ & $9987 \mathrm{~V} / \mathrm{m}$ & $14281 \mathrm{~V} / \mathrm{m}$ \\
\hline Frequency & $10.816 \mathrm{GHz}$ & $10.82 \mathrm{GHz}$ & $10.772 \mathrm{GHz}$ \\
\hline
\end{tabular}

Tabla 3.37: Maximum field $\left(\tan \delta=10^{-4}\right)$

Fig. 3.99 presents a comparative of the maximum output power without multipactor risk for the three filters under analysis considering that the filters loaded with dielectric cylinders present low losses $\left(\tan \delta=10^{-4}\right)$. It can be observed that the cavity filter loaded with dielectric cylinders can handle more than double the power of an all-metal filter. 


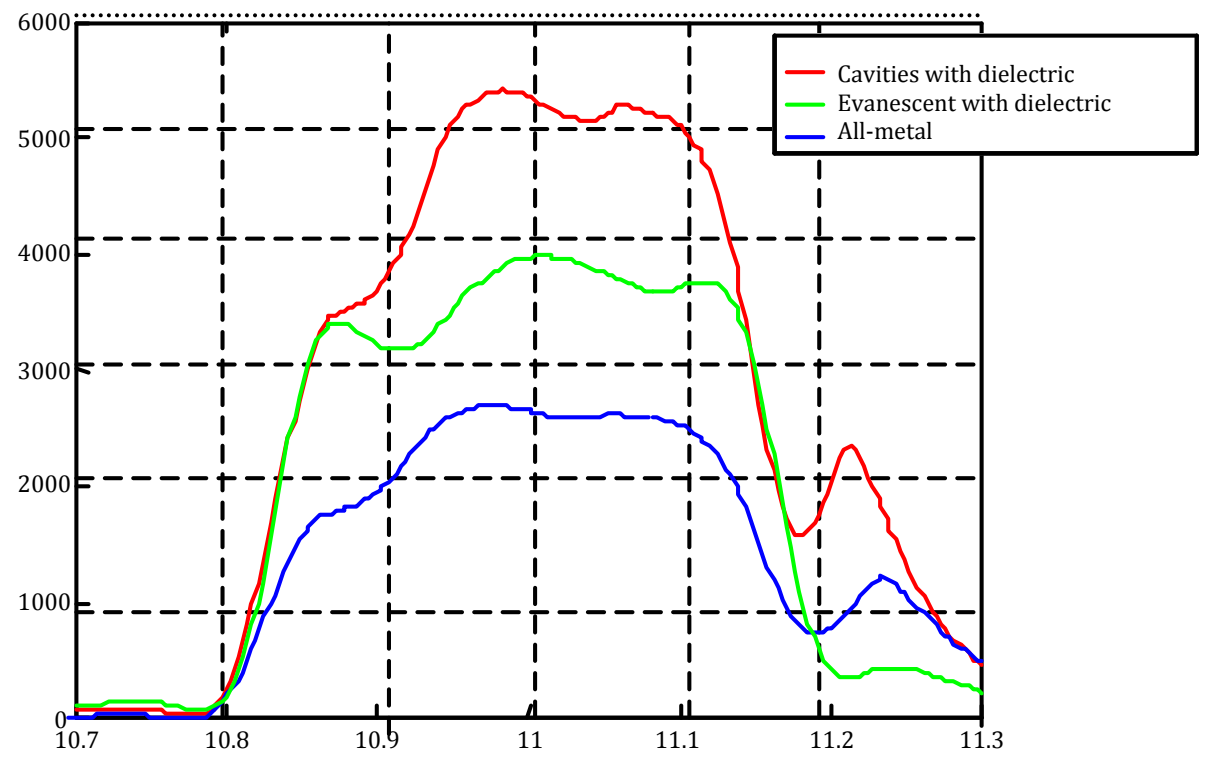

Figura 3.99: Comparative chart of the output power for all the filters (dielectric loss factor: $\tan \delta=10^{-4}$ 


\section{Capítulo 4}

\section{Discusión general de resultados}

Generalmente, el proceso de diseño de dispositivos de microondas se realiza a través de una herramienta de diseño automatizado CAD, ya que la complejidad de las estructuras actuales hace imposible su diseño manual. Por lo tanto, en el presente capítulo se analizan los resultados obtenidos con las herramientas CAD descritas en los artículos anteriores. También se analizarán los resultados obtenidos con nuevas estrategias de diseño pendientes de publicar.

\subsection{Filtros propagativos de cavidades acopladas en plano $\mathbf{H}$}

Los filtros de cavidades acopladas en plano H (ver Fig. 1.4(a)) son dispositivos de microondas muy utilizados en los sistemas de comunicaciones vía satélite. Por ello, durante los últimos años se han dedicado muchos recursos en el desarrollo de herramientas que faciliten el diseño automatizado de este tipo de filtros.

Una de ellas es la presentada en la sección 3.1. Esta herramienta presenta las siguientes ventajas: robustez, eficiencia y precisión. Para ello hace uso de las siguientes técnicas:

- Síntesis de un buen punto inicial.

- ASM.

- Segmentación de la estructura bajo diseño. 
- Hibridación de los algoritmos de optimización utilizados en cada fase de la optimización

Para verificar las propiedades de la herramienta CAD se han diseñado y fabricado diferentes filtros de cavidades acopladas en plano H. A continuación, vamos a analizar los resultados obtenidos en el diseño de dos ejemplos: un filtro de 7 cavidades en banda $\mathrm{K}$ y otro filtro de 4 cavidades en banda $X$.

A través del análisis de los resultados obtenidos en el primer ejemplo se pretende demostrar las principales propiedades de la herramienta de diseño, mientras que a través del segundo caso se pretende caracterizar las propiedades de esta tipología de filtros: longitud total, respuesta fuera de la banda de paso del filtro y capacidad de manejo de potencia.

\section{A. Filtro de cavidades acopladas en plano $H$ en banda $K$}

El primer ejemplo considerado es un filtro de 7 cavidades para aplicaciones espaciales, el cual se desea que tenga una respuesta de tipo Chebyshev centrada a una frecuencia de 17.55 GHz con un ancho de banda de $200 \mathrm{MHz}$, con las siguientes especificaciones:

$$
\begin{cases}L_{R} \leq 3 d B, & \text { para } f \leq 17,435 \mathrm{GHz} \text { y } f \geq 17,665 \mathrm{GHz} \\ L_{R} \geq 20 d B, & \text { para } 17,45 \leq f \leq 17,65 \mathrm{GHz}\end{cases}
$$

A la hora de diseñar esta estructura se han considerado cómo parámetros de diseño las longitudes de las cavidades resonantes y la anchura de las ventanas de acoplo (ver Fig. 3.1). Las guías de entrada y salida de la estructura se consideran son guías de onda con dimensiones estándar WR-62 ( $a=15,80 \mathrm{~mm}, b=7,90 \mathrm{~mm})$, mientras que la longitud de las ventanas de acoplo se ha fijo para que sea igual a $3,60 \mathrm{~mm}$.

\section{A.1. Síntesis del Punto Inicial}

La primera propiedad que se intenta demostrar es la robustez de la estrategia de diseño y la mejora de su eficiencia cuando se dispone de un buen punto inicial. Para ello se realizaron dos diseños: uno que toma como punto de partida el valor obtenido por la técnica de síntesis implementada en la herramienta mientras que en el segundo diseño utiliza un punto inicial malo.

Si nos centramos en el primer caso, en la tabla 3.6 se muestra las dimensiones iniciales de los parámetros de diseño $\left(\mathbf{x}_{O S}^{(0)_{G}}\right)$, los valores óptimos en el espacio de optimización $\left(\mathbf{x}_{O S}^{*}\right)$, y la solución final en el espacio de validación $\left(\mathbf{x}_{E M}\right)$. 
Sin embargo, para evaluar la convergencia del proceso del diseño nos deberemos fijar en las respuestas del filtro diseñado mostradas en la figura 3.3. En la primera de ellas (Fig. 3.3(a)), se muestra la comparación entre la respuesta ideal buscada, y la respuesta del modelo grueso en el punto inicial $\left(\mathbf{x}_{O S}^{(0)_{G}}\right)$ y en el punto óptimo del espacio de optimización $\left(\mathbf{x}_{O S}^{*}\right)$. Se puede observar que la respuesta de la estructura obtenida por el proceso de diseño en el espacio de optimización es prácticamente igual a la respuesta ideal buscada. También se observa que la estrategia de síntesis proporciona una solución que está muy próxima a la solución buscada. A continuación, en la figura 3.3(b) se muestra la comparación entre la respuesta del modelo fino en la solución final del proceso de diseño $\left(\mathbf{x}_{E M}\right)$ y la respuesta del modelo grueso en el punto óptimo del espacio de optimización $\left(\mathrm{x}_{O S}^{*}\right)$. En ella se puede observar, que la respuesta deseada se ha conseguido recuperar en el espacio de validación.

Finalmente, en la tabla 3.7 se muestran las dimensiones iniciales de los parámetros de diseño $\left(\mathbf{x}_{O S}^{(0)_{B}}\right)$, los valores óptimos en el espacio de optimización $\left(\mathbf{x}_{O S}^{*}\right)$, y la solución final en el espacio de validación $\left(\mathbf{x}_{E M}\right)$ para el segundo diseño (punto inicial malo).

Al igual que antes para evaluar la convergencia del proceso del diseño nos fijaremos en las respuestas del filtro diseñado mostradas en la figura 3.4. En la primera de ellas (Fig. 3.4(a)), se muestra la comparación entre la respuesta ideal buscada, y la respuesta del modelo grueso en el punto inicial $\left(\mathbf{x}_{O S}^{(0)_{B}}\right)$ y en el punto óptimo del espacio de optimización $\left(\mathbf{x}_{O S}^{*}\right)$. Se puede observar que la respuesta de la estructura obtenida por el proceso de diseño en el espacio de optimización es prácticamente igual a la respuesta ideal buscada a pesar de que la respuesta del punto inicial del proceso de optimización se encuentra muy alejada de la solución final buscada. A continuación, en la figura 3.3(b) se muestra la comparación entre la respuesta del modelo fino en la solución final del proceso de diseño $\left(\mathbf{x}_{E M}\right)$ y la respuesta del modelo grueso en el punto óptimo del espacio de optimización $\left(\mathrm{x}_{O S}^{*}\right)$. En ella se puede observar, que la respuesta deseada se ha conseguido recuperar en el espacio de validación aunque el punto inicial del proceso de optimización era malo. Una comparación de los valores mostrados en las tablas 3.6 y 3.7 revela que la estructura final obtenida en ambos casos prácticamente son iguales lo que demuestra la robustez del proceso de optimización.

A pesar de que la robustez del proceso de diseño haya quedado demostrada, se converge a la solución óptima aunque la respuesta del punto inicial esté alejada de la solución buscada, se observa que existe un reducción del tiempo de diseño de más del $30 \%$ si se utiliza un buen punto de partida cómo lo hace la herramienta de diseño presentada (Ver Tbl. 3.8).

\section{A.2. Segmentación y ASM}

La mejora en la eficiencia del proceso de diseño gracias al uso del ASM y la segmentación de la estructura bajo diseño se muestra en la tabla 3.9. Esta tabla muestra el error final del proceso de diseño en el espacio de validación, el tiempo de diseño requerido y si el proceso de diseño ha convergido a una solución válida. 
Los resultados demuestran que la robustez del proceso de diseño mejora cuando se utiliza la técnica de segmentación de la estructura. De hecho, aunque en todos los casos se parta de un buen punto inicial en los casos en los que no se ha utilizado esta técnica el resultado del proceso de diseño no cumple las especificaciones de diseño. Por el otro lado, el uso del ASM no aporta una mejora sustancial del tiempo de diseño (alrededor del 30\%). Sin embargo, cuando se diseñan estructuras más complejas (ver Sec. 4.2) la reducción en el tiempo de diseño gracias al uso del ASM será mucho mayor.

\section{A.3. Hibridación}

En cuanto al uso de la hibridación de los algoritmos de optimización, la mejora en la eficiencia y la robustez que aporta al proceso de diseño se refleja en la tabla 3.10. Tal y como indica, si se utiliza un único algoritmo de optimización la solución obtenida no siempre cumple con las especificaciones de diseño, y aún en el caso que lo cumpla el tiempo empleado en el proceso es muy superior al empleado si se utiliza la hibridación de algoritmos de optimización (en el mejor de los casos es prácticamente el doble).

\section{A.4. Análisis de tiempos}

Finalmente, se ha pretendido estimar el tiempo de diseño requerido por la herramienta para diseñar un filtro en función de su complejidad, es decir, en función de su orden. Para ello se ha diseñado el filtro cuyas especificaciones se indican en la ecuación 4.1 variando el número de cavidades. El resultado de este análisis se puede observar en la figura 3.5. Se puede concluir que el tiempo empleado por la estrategia de diseño implementada en la herramienta CAD es directamente proporcional al orden del filtro, mientras que en otras estrategias el tiempo de diseño tienen una variación de orden superior.

\section{B. Filtro de cavidades acopladas en plano $\mathrm{H}$ en banda $\mathrm{X}$}

El siguiente ejemplo que se ha considerado es un filtro en banda $X$ de 4 cavidades para aplicaciones espaciales, el cual se desea que tenga una respuesta de tipo Chebyshev centrada a $11 \mathrm{GHz}$ con un ancho de banda de $300 \mathrm{MHz}$, con las siguientes especificaciones:

$$
\begin{cases}L_{R} \leq 3 d B, & \text { para } f \leq 10,8 \mathrm{GHz} \text { y } f \geq 11,2 \mathrm{GHz} \\ L_{R} \geq 25 d B, & \text { para } 10,85 \leq f \leq 11,15 \mathrm{GHz}\end{cases}
$$

Estas especificaciones eléctricas, utilizadas en la literatura en numerosas ocasiones, se van a emplear porque nos van a permitir poder comparar las ventajas e inconvenientes de las 
diferentes topologías de filtros diseñados en la tesis en igualdad de condiciones.

A la hora de diseñar esta estructura se han considerado cómo parámetros de diseño las longitudes de las cavidades resonantes y la anchura de las ventanas de acoplo (ver Fig. 4.1). Las guías de entrada y salida de la estructura se consideran guías de onda con dimensiones estándar WR-75 ( $a=19,05 \mathrm{~mm}, b=9,525 \mathrm{~mm})$, mientras que la longitud de las ventanas de acoplo se ha fijo para que sea igual a $2 \mathrm{~mm}$.

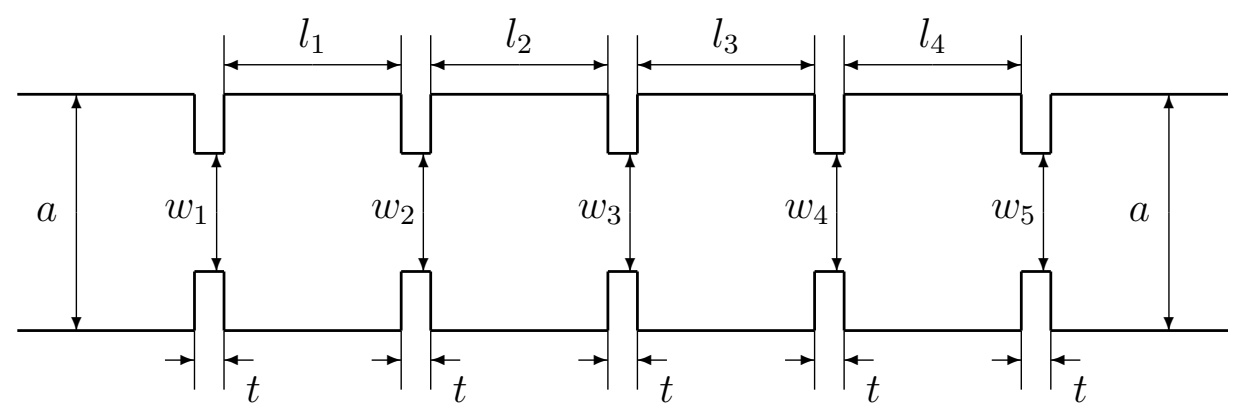

Figura 4.1: Filtro de 4 cavidades en plano $\mathrm{H}$.

Para diseñar este filtro se ha utilizado la herramienta CAD totalmente descrita en la sección 3.1 utilizando un Intel@ Core ${ }^{\mathrm{TM}} 2$ Quad Q660 @ $2.4 \mathrm{GHz}$. El tiempo de diseño ha sido de tan sólo 7 segundos mientras que el error final en el espacio de validación ha sido de $U\left(\mathbf{x}_{\mathbf{E M}}\right)=0,0067$. El valor de los parámetros de diseño ( $\left.\mathbf{x}_{\mathbf{E M}}\right)$ se muestran en la tabla 4.1.

\begin{tabular}{|c|c|}
\hline$a$ & $19.05 \mathrm{~mm}$ \\
\hline$b$ & $9.525 \mathrm{~mm}$ \\
\hline$t$ & $2 \mathrm{~mm}$ \\
\hline$w_{1}, w_{5}$ & $10.439 \mathrm{~mm}$ \\
\hline$w_{2}, w_{4}$ & $7.030 \mathrm{~mm}$ \\
\hline$w_{3}$ & $6.499 \mathrm{~mm}$ \\
\hline$l_{0}, l_{5}$ (líneas de entrada/salida) & $10 \mathrm{~mm}$ \\
\hline$l_{1}, l_{4}$ & $15.778 \mathrm{~mm}$ \\
\hline$l_{2}, l_{3}$ & $17.660 \mathrm{~mm}$ \\
\hline Longitud total (sin líneas de entrada/salida) & $76.876 \mathrm{~mm}$ \\
\hline Longitud total & $96.876 \mathrm{~mm}$ \\
\hline
\end{tabular}

Tabla 4.1: Parámetros de diseño del filtro de cavidades acopladas en plano $\mathrm{H}$

Como se observa en la figura 4.2, el filtro diseñado cumple con las especificaciones de diseño. De hecho, en la figura 4.2(a) se muestra la comparación entre la respuesta ideal buscada y la respuesta del modelo en el punto óptimo del espacio de optimización. En ella se puede observar que la respuesta de la estructura obtenida por el proceso de diseño en el 
espacio de optimización es prácticamente igual a la respuesta ideal buscada. A continuación, en la figura 4.2(b) se muestra la comparación entre la respuesta del modelo fino en la solución final del proceso de diseño $\left(\mathbf{x}_{E M}\right)$ y la respuesta del modelo grueso en el punto óptimo del espacio de optimización $\left(\mathrm{x}_{O S}^{*}\right)$. En ella se puede observar que la respuesta deseada se ha conseguido recuperar en el espacio de validación.

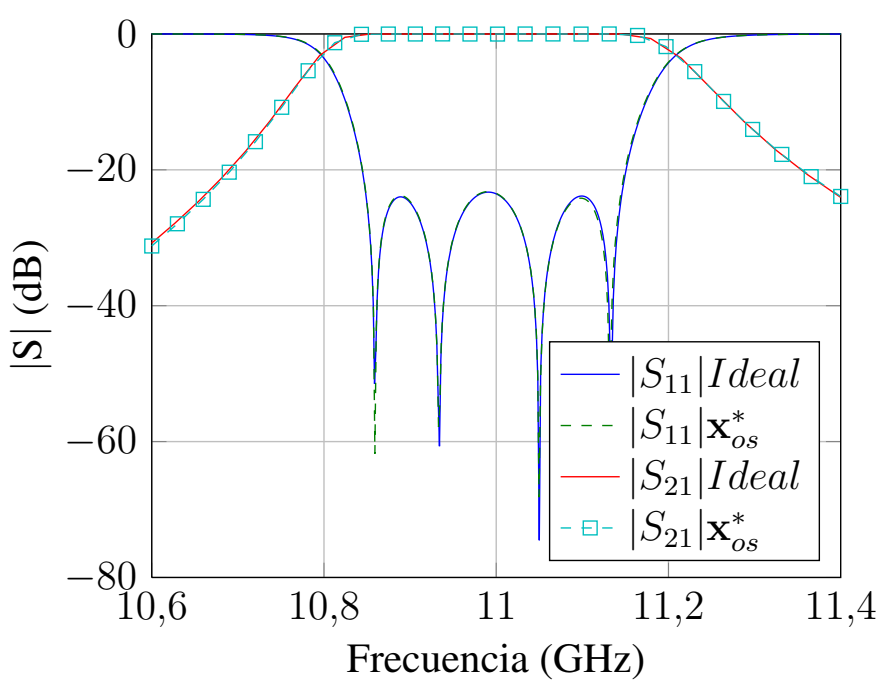

(a)

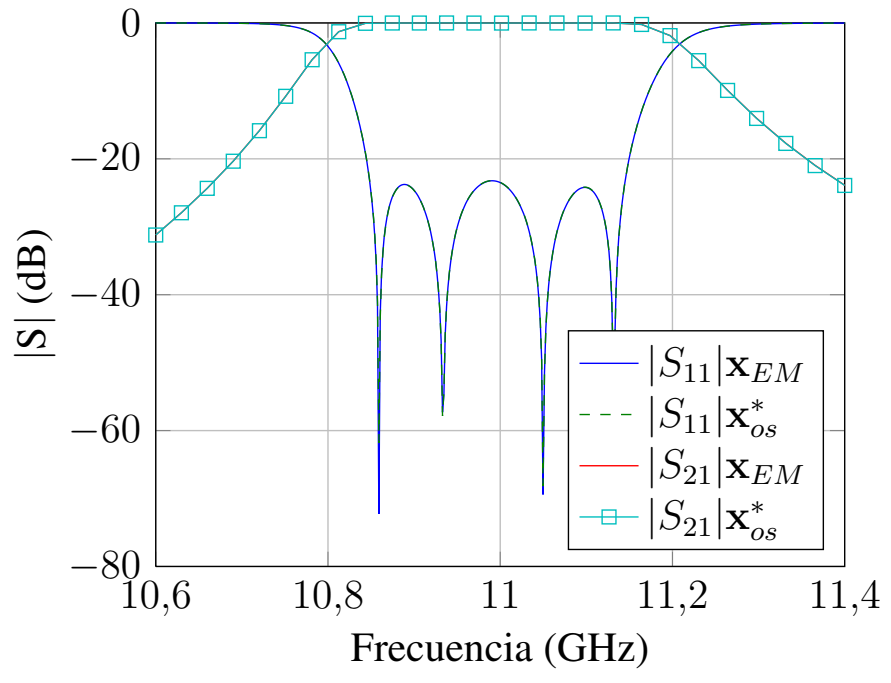

(b)

Figura 4.2: Respuesta en frecuencia del filtro de cavidades resonantes en plano H.(a) Respuesta del modelo grueso en $\mathrm{x}_{O S}^{*}$ frente a la respuesta ideal.(b) Respuesta del modelo grueso en $\mathbf{x}_{O S}^{*}$ frente a la respuesta del modelo fino en $\mathbf{x}_{E M}$

En la figura 4.3 se aprecia que el parámetro de transmisión $S_{21}$ es inferior a $3 \mathrm{~dB}$ entre las frecuencias $11.209 \mathrm{GHz}$ y $16.502 \mathrm{GHz}$, por lo tanto el ancho de banda libre de espurios es de $5.293 \mathrm{GHz}$.

A continuación se ha analizado la capacidad de manejo de potencia de este tipo de filtro. Para ello, haciendo uso de la herramienta de análisis presentada en 3.14, se ha calculado la distribución de campo eléctrico a la frecuencia central del filtro (Fig. 4.4) y el Voltage Magnification Factor (VMF) para todas las frecuencias (Fig. 4.5). Cómo se observa en esta última, el valor máximo de $V M F$ se produce a la frecuencia $f=10,78 \mathrm{GHz}$.

En la figura 4.6 se representa la distribución del campo eléctrico para la frecuencia a la cual se produce el $V M F_{\text {max }}$, en ella se puede apreciar que el campo eléctrico se concentra mucho más en la primera cavidad y llega menos potencia a la salida. Como consecuencia, la potencia máxima que podemos introducir en el filtro sin riesgo de multipactor es más baja a 


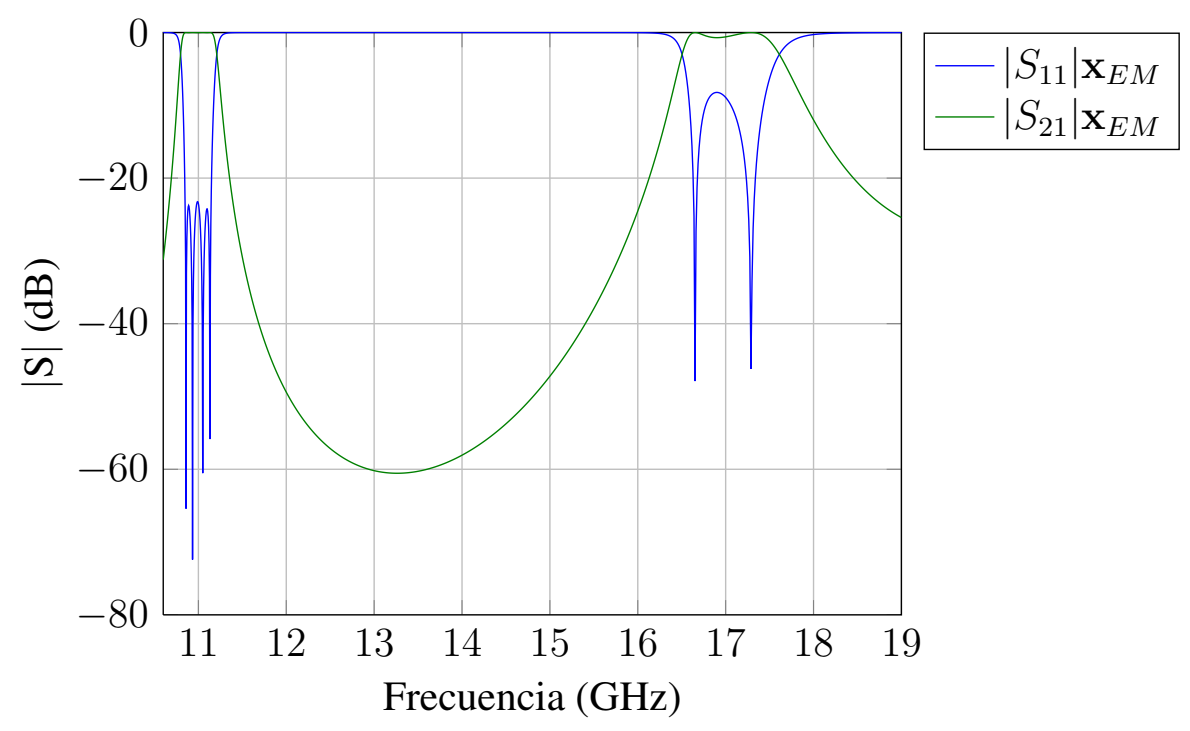

Figura 4.3: Respuesta fuera de banda del filtro de cavidades resonantes en plano $\mathrm{H}$.

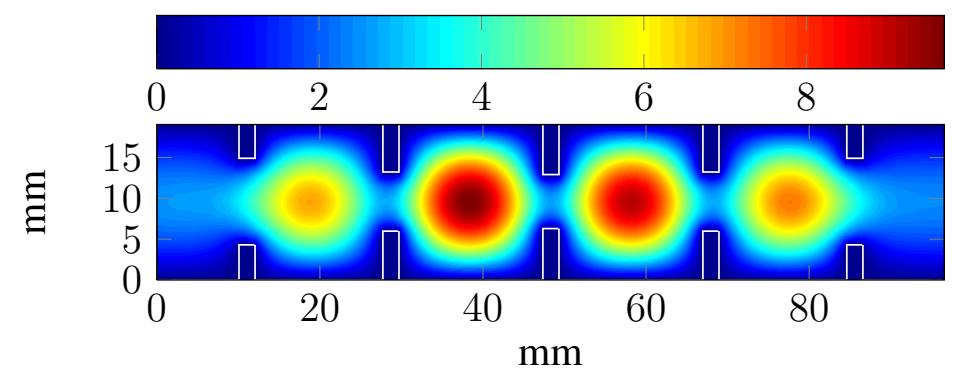

Figura 4.4: Módulo del campo eléctrico $(\mathrm{kV} / \mathrm{m})$ dentro del filtro de cavidades acopladas en plano $\mathrm{H}$ para $f=11 G H z$. 


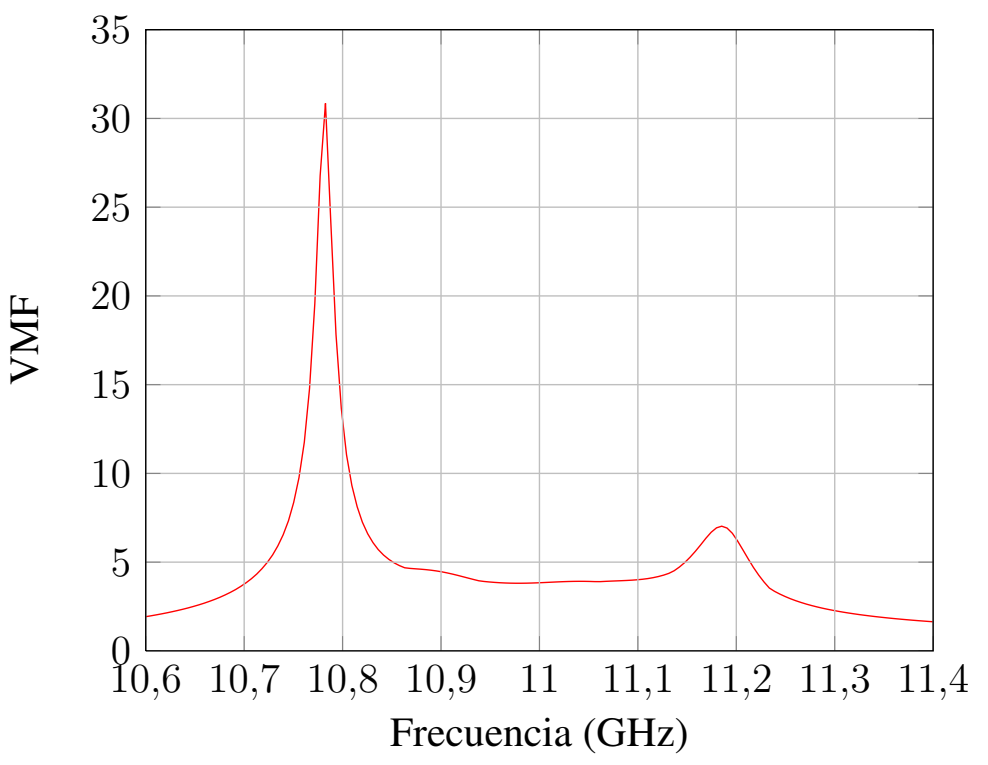

Figura 4.5: $V M F$ para el filtro de cavidades acopladas en plano $\mathrm{H}$.

esta frecuencia que para las frecuencias centrales que cuentan con un VMF más bajo y por lo tanto la concentración de potencia en la primera cavidad es mucho menor. El máximo del campo eléctrico siempre se encontrará en el centro del filtro (según la dirección longitudinal) para todas las frecuencias, y será máximo en el centro de las cavidades, como se puede apreciar en la figura 4.7.

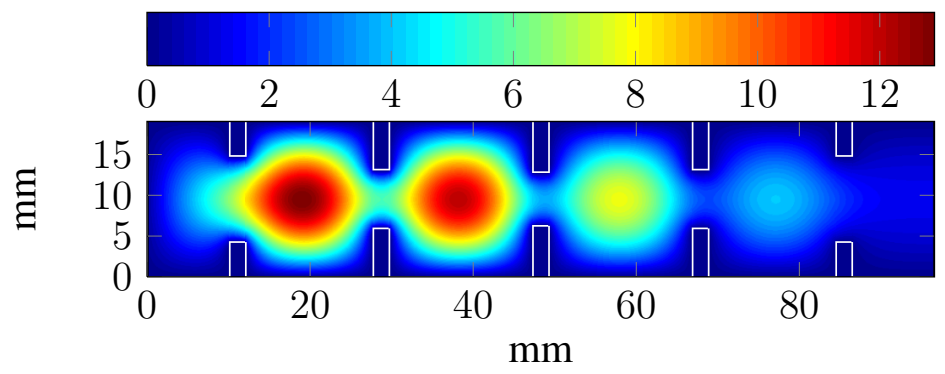

Figura 4.6: Módulo del campo eléctrico $(\mathrm{kV} / \mathrm{m})$ dentro del filtro de cavidades acopladas en plano $\mathrm{H} f=10,78 G H z$.

En la figura 4.8 se puede apreciar cómo el máximo del campo eléctrico se produce alrededor de las frecuencias de corte de la banda de paso (ver Ec. 4.2), y siempre en la segunda cavidad. También se puede observar que apenas se transmite potencia para las frecuencias que se encuentran fuera de la banda de paso del filtro.

Seguidamente en la figura 4.9 se representa la potencia máxima a la entrada y a la salida 


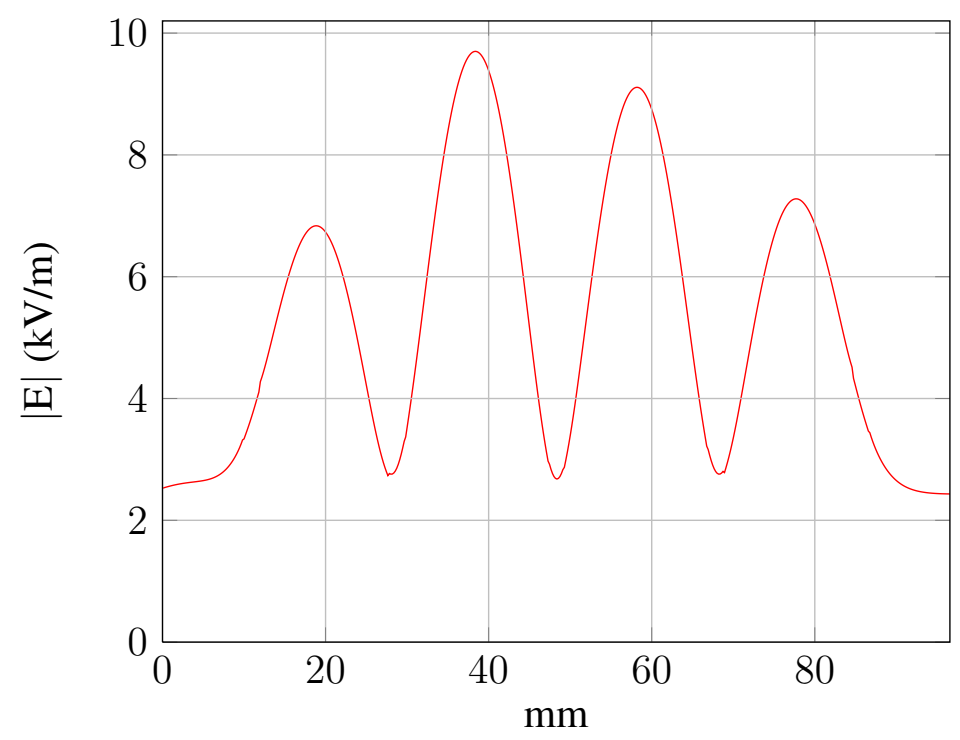

Figura 4.7: Módulo de E en la línea longitudinal central del filtro de cavidades acopladas en plano $\mathrm{H}$ para $f=11 G H z$.

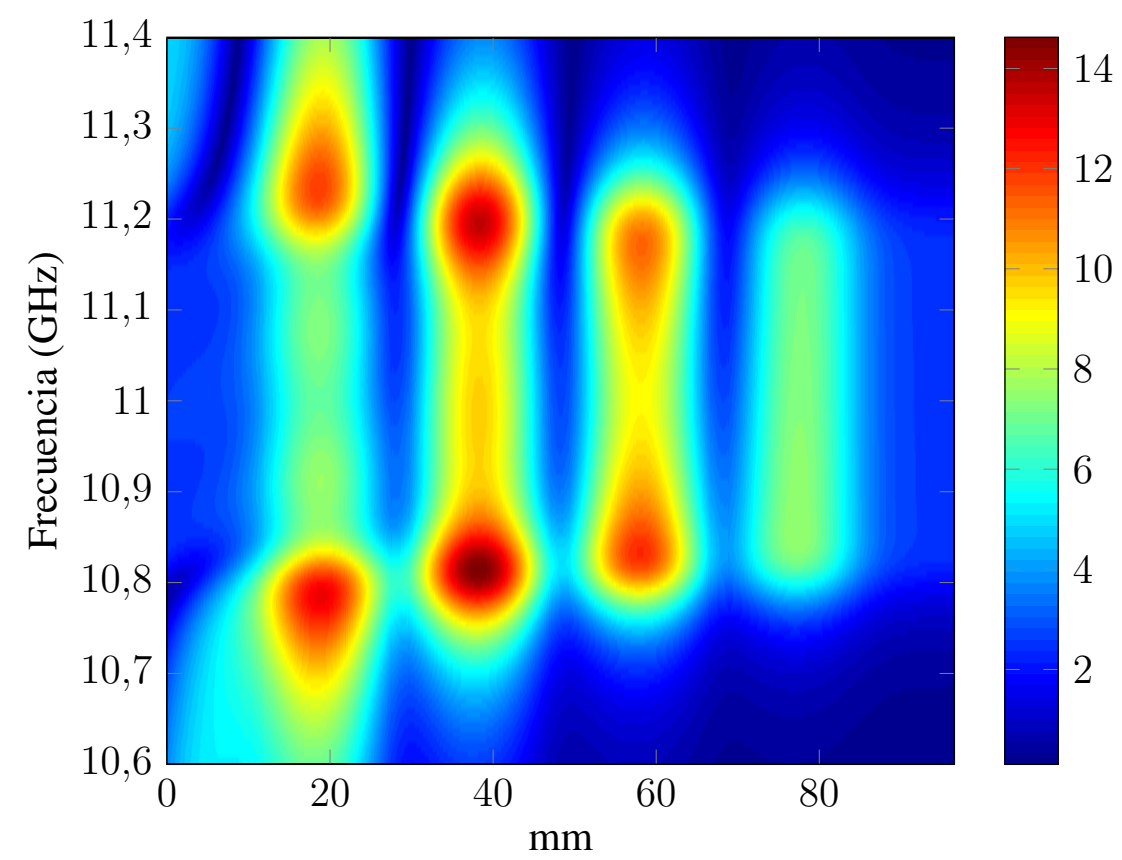

Figura 4.8: Módulo de $\mathrm{E}(\mathrm{kV} / \mathrm{m})$ en la línea longitudinal central del filtro de cavidades acopladas en plano $\mathrm{H}$ para las distintas frecuencias. 
del filtro sin riesgo de ruptura por efecto Multipactor en función de la frecuencia. En esta gráfica se puede apreciar cómo alrededor de la frecuencia central podemos inyectar más de $2.5 \mathrm{~kW}$ de potencia a la entrada del filtro obteniéndose a la salida prácticamente la misma potencia, por lo que no hay pérdidas apreciables. También se puede observar que fuera de la banda de paso la potencia de salida es muy pequeña debido a la respuesta en frecuencia del filtro.

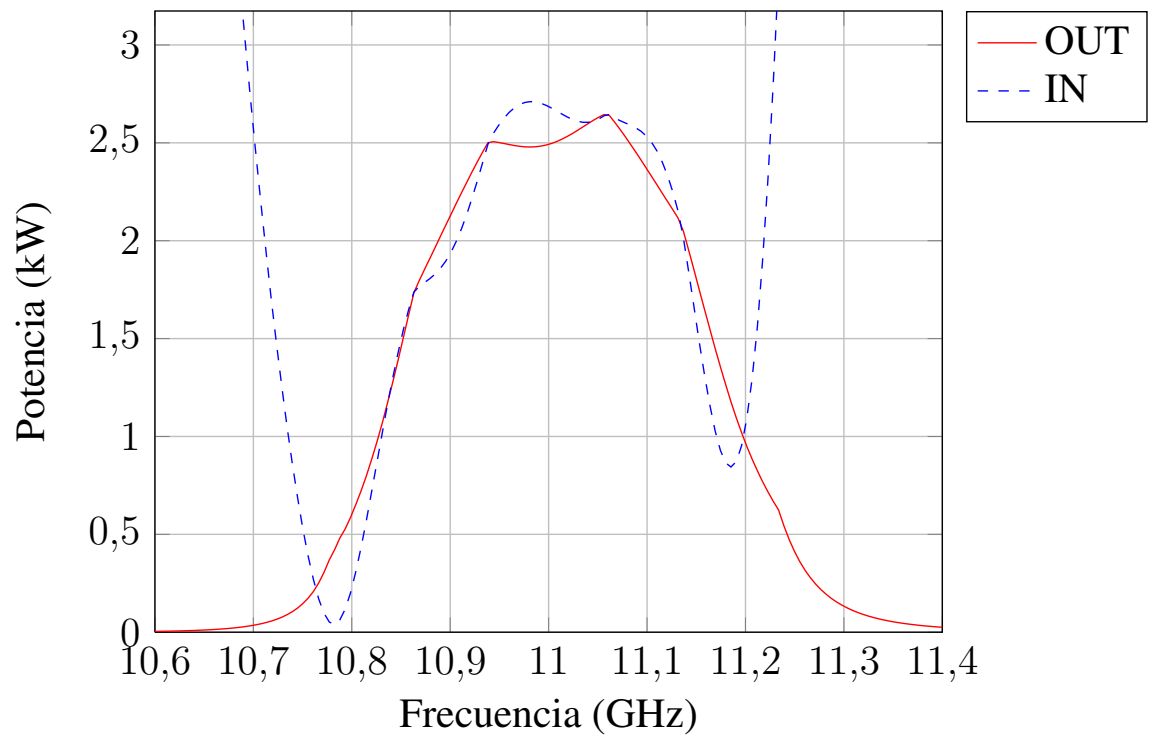

Figura 4.9: Potencia máxima a la entrada y salida sin riesgo de ruptura por Multipactor para el filtro de cavidades acopladas en plano $\mathrm{H}$ en función de la frecuencia.

Finalmente, el filtro diseñado se fabricó en cobre, sin deposito de plata, mediante un sistema de fresado y electroerosión en las esquinas interiores de las cavidades con una precisión nominal de $30 \mu \mathrm{m}$ (ver Fig. 4.10). Para verificar las dimensiones del prototipo el Instituto Tecnológico Metalmecánico (AIMME) realizó una control dimensional, observándose que la fabricación siempre proporcionaba dimensiones interiores menores que las nominales en un valor promedio de $80 \mu \mathrm{m}$. En la tabla 4.2 se aprecian las dimensiones nominales y las reales. Las longitudes de las cavidades $l_{i}$ y de las ventanas $t_{i}$ se han medido en los dos lados de la estructura, por eso hay dos valores para cada una de ellas. Las anchuras de las cavidades $a_{i}$ y de los irises $w_{i}$ se miden desde el centro de la estructura.

En la figura 4.11 se comparan la respuesta medida del prototipo fabricado con la respuesta del filtro diseñado. En ella se aprecia un ligero incremento de las pérdidas de inserción, debido principalmente a las pérdidas en las conexiones que se utilizan para hacer la medida, un desplazamiento en frecuencia de aproximadamente $40 \mathrm{MHz}$ y una disminución del ancho de banda. Estas degradaciones se pueden atribuir a la reducción de las longitudes de las cavidades (las cavidades resuenan a una frecuencia mayor), y de las anchuras de las ventanas 


\begin{tabular}{|c|c|c|c|}
\hline Medida & Valor nominal $(\mathrm{mm})$ & Valor real $(\mathrm{mm})$ & Deriva $(\mathrm{mm})$ \\
\hline$l_{0}$ & 10.000 & 9.879 & -0.121 \\
\hline$l_{0}^{\prime}$ & 10.000 & 9.901 & -0.099 \\
\hline$l_{1}$ & 15.778 & 15.598 & -0.180 \\
\hline$l_{1}^{\prime}$ & 15.778 & 15.638 & -0.140 \\
\hline$l_{2}$ & 17.660 & 17.534 & -0.126 \\
\hline$l_{2}^{\prime}$ & 17.660 & 17.556 & -0.104 \\
\hline$l_{3}$ & 17.660 & 17.543 & -0.117 \\
\hline$l_{3}^{\prime}$ & 17.660 & 17.559 & -0.101 \\
\hline$l_{4}$ & 15.778 & 15.602 & -0.176 \\
\hline$l_{4}^{\prime}$ & 15.778 & 15.625 & -0.153 \\
\hline$l_{5}$ & 10.000 & 10.024 & 0.024 \\
\hline$l_{5}^{\prime}$ & 10.000 & 10.034 & 0.034 \\
\hline$a_{0}$ & 19.050 & 18.936 & -0.114 \\
\hline$a_{1}$ & 19.050 & 18.932 & -0.118 \\
\hline$a_{2}$ & 19.050 & 18.953 & -0.097 \\
\hline$a_{3}$ & 19.050 & 18.959 & -0.091 \\
\hline$a_{4}$ & 19.050 & 18.966 & -0.084 \\
\hline$a_{5}$ & 19.050 & 18.961 & -0.089 \\
\hline$w_{1}$ & 10.439 & 10.428 & -0.011 \\
\hline$w_{2}$ & 7.030 & 7.002 & -0.028 \\
\hline$w_{3}$ & 6.499 & 6.419 & -0.080 \\
\hline$w_{4}$ & 7.030 & 7.014 & -0.016 \\
\hline$w_{5}$ & 10.439 & 10.440 & 0.001 \\
\hline$t_{1}$ & 2.000 & 2.090 & 0.090 \\
\hline$t_{1}^{\prime}$ & 2.000 & 2.057 & 0.057 \\
\hline$t_{2}$ & 2.000 & 2.087 & 0.087 \\
\hline$t_{2}^{\prime}$ & 2.000 & 2.061 & 0.061 \\
\hline$t_{3}$ & 2.000 & 2.081 & 0.081 \\
\hline$t_{3}^{\prime}$ & 2.000 & 2.061 & 0.061 \\
\hline$t_{4}$ & 2.000 & 2.076 & 0.076 \\
\hline$t_{4}^{\prime}$ & 2.000 & 2.052 & 0.052 \\
\hline$t_{5}$ & 2.000 & 2.082 & 0.082 \\
\hline$t_{5}^{\prime}$ & 2.000 & & 0.052 \\
\hline & & \\
\hline
\end{tabular}

Tabla 4.2: Control dimensional del filtro de cavidades acopladas en plano H. 


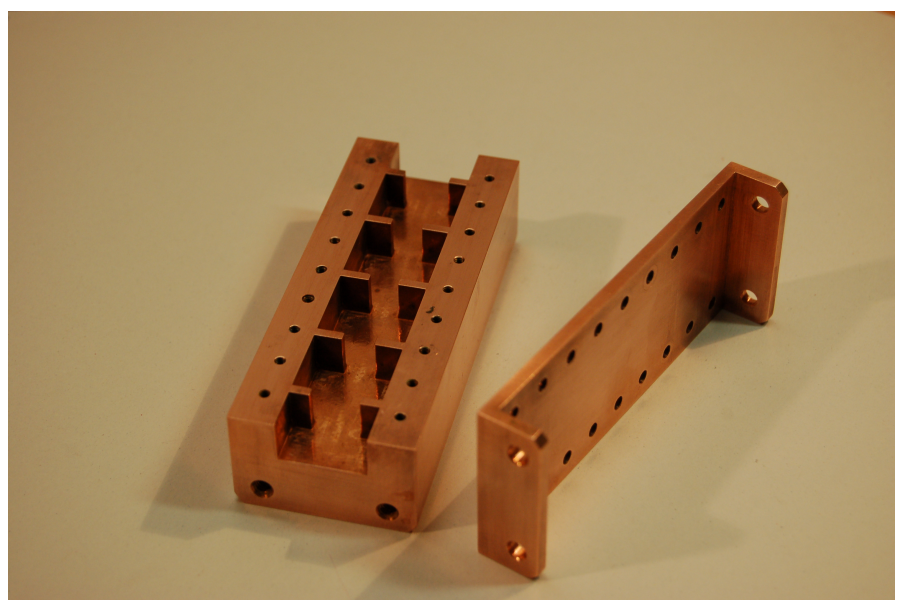

Figura 4.10: Filtro de cavidades acopladas en plano $\mathrm{H}$ fabricado.

de acoplo (varía el acoplo entre las cavidades).

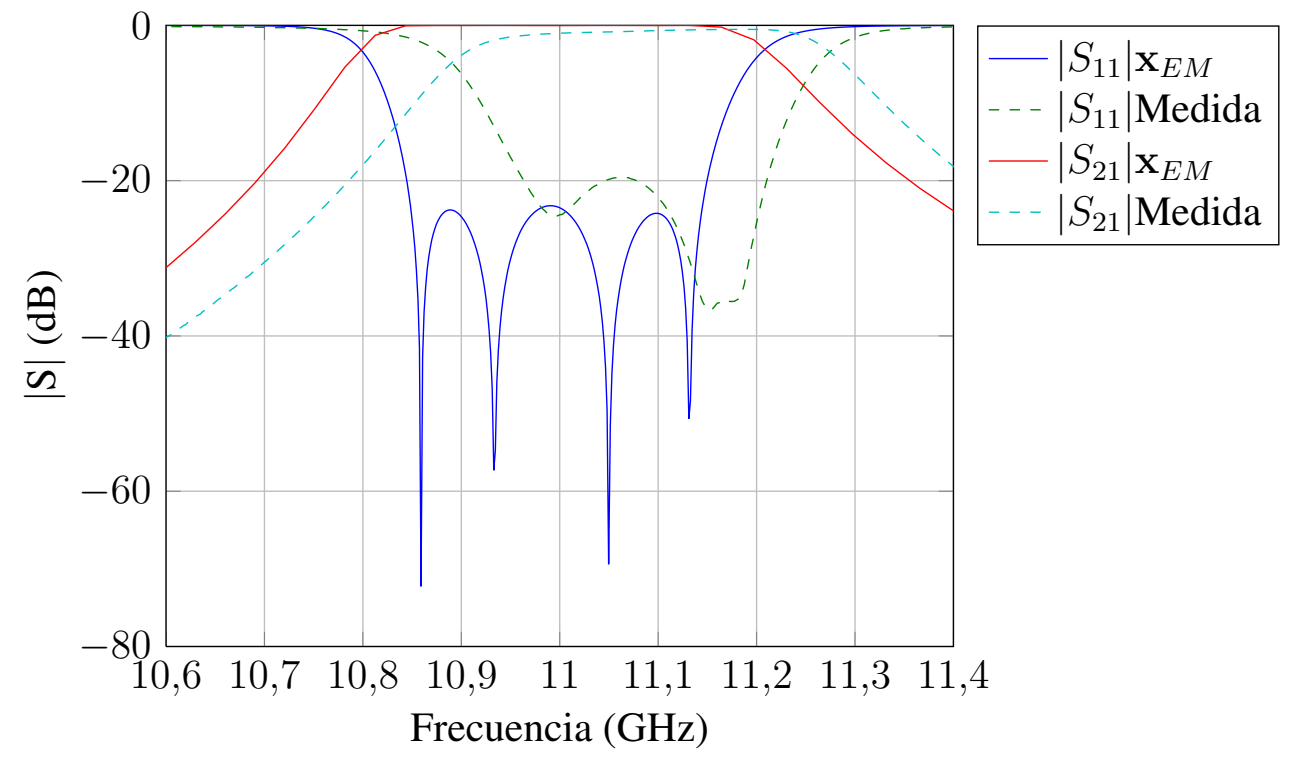

Figura 4.11: Respuesta en frecuencia del prototipo respecto al filtro diseñado.

Para delimitar la fuente del error se ha introducido en el diseño la distorsión producida por los errores de fabricación (ver Fig. 4.12), se puede comprobar que la respuesta de la medida y la respuesta del diseño corregido casan prácticamente a la perfección, demostrándose que el error se debe por completo a las tolerancias de fabricación.

Por lo tanto, para que el prototipo fabricado cumpla las especificaciones de diseño (ver Ec. 4.2), es necesario introducir postes de sintonía en su tapa. Estos elementos permiten 


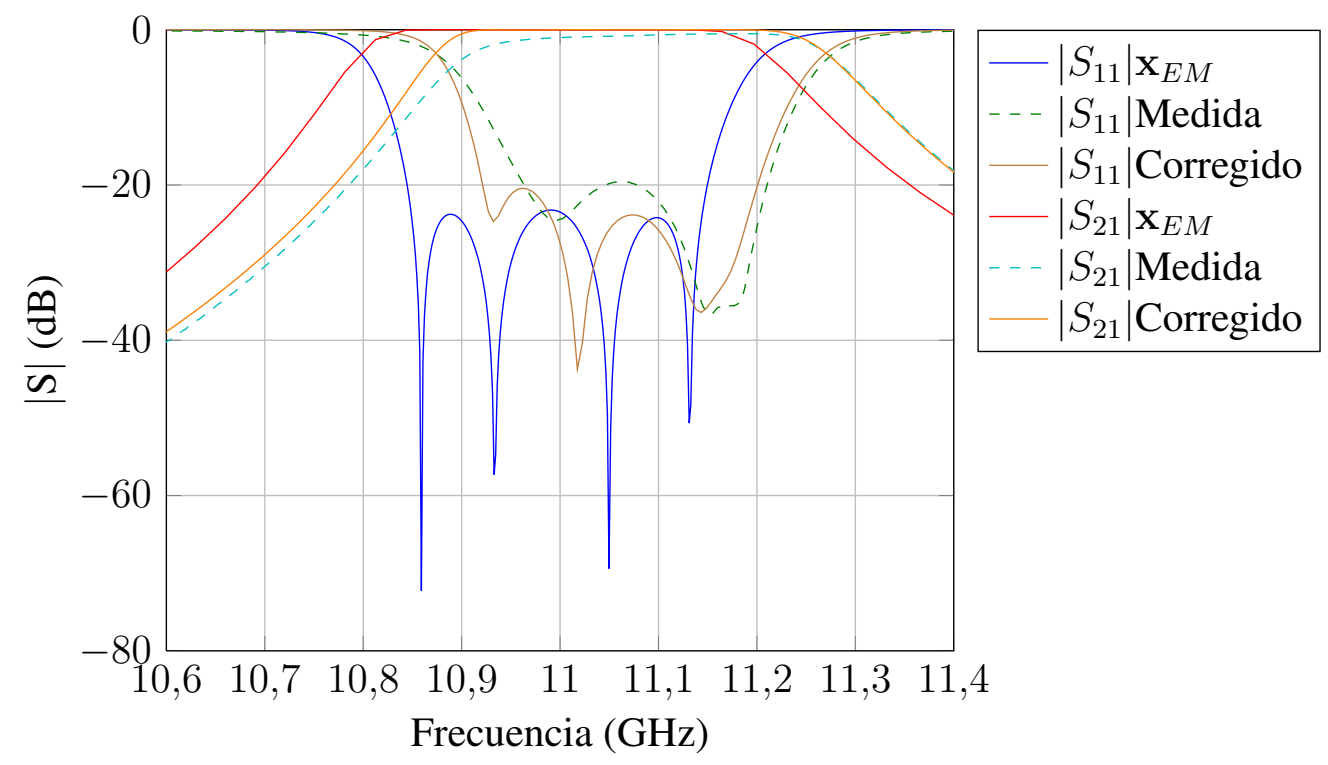

Figura 4.12: Respuesta en frecuencia del prototipo con correcciones del control dimensional.

ajustar la frecuencia central del filtro y su ancho de banda; sin embargo, su presencia implica una reducción de la capacidad de manejo de potencia junto con un ajuste manual de cada uno de ellos. 


\subsection{Filtros propagativos de cavidades acopladas en plano $H$ con esquinas redondeadas}

Si comparamos las respuestas de los filtros de microondas fabricados con las especificaciones de diseño, podemos observar que habitualmente se aprecian las siguientes degradaciones en la respuesta de los dispositivos fabricados:

- Desplazamiento de la frecuencia central del filtro.

- Variación del ancho de banda del filtro.

- Reducción del nivel de pérdidas de retorno.

- Aumento del nivel de las pérdidas de inserción.

Estás degradaciones se pueden atribuir a diferentes factores, pero principalmente se deben a limitaciones de los diferentes métodos de fabricación:

- Conductividad finita de los materiales conductores.

- Tolerancia en las dimensiones de los dispositivos fabricados.

- Presencia de esquinas redondeadas en las ventanas de acoplo (Fig. 1.5(b)) o en las esquinas de las cavidades resonantes (Fig. 1.5(a)).

Para compensar estas defectos de fabricación se utilizan elementos de sintonía (p. ej. tornillos) que permiten ajustar la respuesta eléctrica de los dispositivos fabricados. Sin embargo, estos elementos de sintonía deben ajustarse de forma manual para cada dispositivo, incrementando de forma sustancial los costes de fabricación.

Para reducir al máximo la necesidad del proceso de ajuste (y reducir el coste de fabricación) en esta tesis se han desarrollado diferentes herramientas CAD que tienen en cuenta los defectos de fabricación, en particular la presencia de las esquinas redondeadas producidas por las técnicas de fabricación de bajo coste. A continuación, se van a analizar los resultados obtenidos con el diseño y fabricación de varios filtros de cavidades acopladas en plano $\mathrm{H}$.

\subsubsection{Implementación original}

La primera consideración que se realizó a la hora de implementar esta nueva herramienta CAD fue el estudio de las capacidades de análisis de las herramientas disponibles. En la 
herramienta CAD descrita en el apartado 3.1 se propone una implementación del algoritmo ASM que utiliza como modelo grueso y fino la misma herramienta de simulación, una herramienta de simulación muy eficiente capaz de analizar filtros de cavidades acopladas en plano H. Sin embargo, no es capaz de analizar el efecto de la presencia de las esquinas redondeadas. Por otro lado, se dispone de una herramienta de análisis de propósito general $\left[\mathrm{ECB}^{+} 02 \mathrm{~b}\right]$ capaz de analizar estructuras en plano $\mathrm{H}$ de geometría arbitraria incluyendo la presencia de esquinas redondeadas. Con el inconveniente de su elevado coste computacional.

Por todo ello, con el objetivo de asegurar la eficiencia y la robustez del proceso de diseño en la herramienta CAD implementada (ver sección 3.3) se ha empleado la técnica del ASM multimodelo (MASM) (ver sección 3.2), utilizando como modelo grueso el simulador modal empleado en la herramienta CAD descrita en la sección 3.1, y cómo modelos finos la herramienta de análisis genérica indicada en el párrafo anterior. La principal ventaja que presenta la técnica MASM frente al clásico ASM es la reducción de la separación de los espacios de optimización y validación mediante la introducción de espacios de validación intermedios de creciente precisión. Asimismo, si la separación entre espacios es muy pequeña el MASM se puede ajustar para que se comporte como el ASM clásico.

Cabe destacar que el hecho de no considerar las esquinas redondeadas en el espacio de optimización hace que la nueva herramienta $\mathrm{CAD}$ incorpore las técnicas de síntesis del punto inicial, segmentación de la estructura e hibridación de algoritmos descritos en la sección 3.1.

A continuación vamos a analizar los resultados obtenidos en el proceso de diseño y fabricación de una serie de prototipos cuyas especificaciones fueron proporcionadas por Thales Alenia Space España y fabricados por INASMET-Tecnalia (ver Fig. 3.17). Para fabricar estos prototipos se han utilizado las técnica del fresado y el fundido, produciendo esquinas redondeadas en las esquinas de las cavidades resonantes y en las ventanas de acoplo respectivamente. Lo que ha obligado a tenerlas en cuenta durante el proceso de diseño y utilizar la nueva herramienta CAD.

Los prototipos considerados están compuestos de 6 cavidades resonantes no homogéneas, es decir, la anchura de éstas no coincide con la anchura de las guías de entrada/salida; siendo su respuesta eléctrica de tipo Chebyshev centrada a una frecuencia de 13.869 GHz con un ancho de banda de $290 \mathrm{MHz}$, con las siguientes especificaciones:

$$
\begin{cases}L_{R} \leq 3 d B, & \text { para } f \leq 13,694 \mathrm{GHz} \text { y } f \geq 14,046 \mathrm{GHz} \\ L_{R} \geq 25 d B, & \text { para } 13,725 \leq f \leq 14,015 \mathrm{GHz}\end{cases}
$$

A la hora de diseñar esta estructura se han considerado cómo parámetros de diseño las longitudes de las cavidades resonantes y la anchura de las ventanas de acoplo (ver Fig. 3.15) mientras que el resto de parámetros se han considerado fijos. Con respecto a las guías de entrada/salida de la estructura se consideran guías de onda con dimensiones estándar WR-75 
$(a=19,05 \mathrm{~mm}, b=9,525 \mathrm{~mm})$.

A partir de las especificaciones proporcionadas, se ha realizado un estudio sistemático del rendimiento del MASM. Para ello, se diseñaron los filtros considerando diferentes configuraciones del MASM (diferente número de modelos intermedios y precisión), y valores de los radios de las esquinas redondeadas. El resultado de este análisis se plasma en la tabla 3.17 dónde se indica: el radio y la ubicación de las esquinas redondeadas, la configuración del MASM utilizada, el número de simulaciones realizadas por cada uno de los modelos finos utilizados, el tiempo de computación, y el error final.

Si analizamos los datos mostrados en la tabla 3.17 en conjunción con las respuestas mostradas en la gráfica 3.16(b) en la que se nos muestra el desalineamiento entre el modelo grueso y el modelo fino de mayor precisión, el único modelo que utiliza la técnica del ASM, podemos extraer las siguientes conclusiones:

- Cuando la diferencia entre el modelo grueso y el modelo fino no es muy grande, la introducción de modelos intermedios ralentiza el proceso de diseño. Sin embargo, proporcionan una solución más próxima a la respuesta ideal buscada.

- Cuando la diferencia entre el modelo grueso y el modelo fino es grande, la introducción de modelos intermedios mejora la eficiencia y garantiza la convergencia del proceso de diseño.

- La respuesta eléctrica del filtro es más sensible a la presencia de las esquinas redondeadas en las ventanas de acoplo produciendo un mayor desalineamiento entre los espacios de optimización y validación. Esto se debe a que la intensidad de campo eléctrico es mayor en las ventanas de acoplo que en las esquinas de las cavidades resonantes (ver figuras 3.83(b), 3.84(b)).

Debido a las limitaciones en el proceso de fabricación, radio de la fresa en el proceso de mecanización, se escogieron tres configuraciones de las mostradas en la tabla 3.17: dos con las esquinas redondeadas en las cavidades resonantes $\left(r_{c}=3 \mathrm{~mm}, 4 \mathrm{~mm}\right)$, y uno con las esquinas redondeadas en las ventanas de acoplo $\left(r_{w}=2 \mathrm{~mm}\right)$; para su manufactura con un nuevo material más ligero, el magnesio. En la tabla 3.18 se muestra las dimensiones proporcionadas por el proceso de diseño para cada uno de los filtros.

La figura 3.16(a) muestra la comparación entre la respuesta de los filtros diseñados y la respuesta ideal, en ella se observa que los tres filtros cumplen con las especificaciones de diseño. A pesar de que, tal y cómo se observa en la figura 3.16(b), los espacios de validación y de optimización puedan llegar a estar muy desalineados.

La respuesta eléctrica de los prototipos fabricados se muestra en la figura 3.18(a) en ella se puede observar que existe una cierta desviación con las especificaciones de diseño. Para 
determinar la causa de este desplazamiento, tal y cómo se realizó con el prototipo fabricado en 4.1, se han sometido a un control dimensional los tres prototipos fabricados obteniéndose una desviación media de $\pm 20 \mu \mathrm{m}$.

La figura 3.18(b) compara la respuesta medida con la respuesta proporcionada del análisis electromagnético realizado al filtro de $r_{w}=2 \mathrm{~mm}$ pero utilizando las dimensiones reales del prototipo (Tbl. 4.5). En ella se observa que la respuesta proporcionada por el simulador incluido en la herramienta de diseño se asemeja a la medida, demostrando de esta forma que la desviación con la respuesta deseada se debe principalmente a la tolerancia en las dimensiones de la estructura.

Hay que resaltar que la única razón del desplazamiento entre la respuesta buscada y la respuesta deseada se debe a la tolerancia en las dimensiones de los prototipos fabricados, parámetro que no tiene en cuenta la herramienta de diseño. Si bien la tolerancia media de las dimensiones de los nuevos prototipos fabricados es inferior a la del primer filtro fabricado $( \pm 80 \mu \mathrm{m})$, ésta todavía se encuentra lejos de la tolerancia media requerida por los filtros para aplicaciones vía satélite $( \pm 10 \mu \mathrm{m})$. Además, si hacemos un análisis con más detalle de las tolerancias de las dimensiones se observa que:

- Tolerancia en las dimensiones rectas: $\pm 13,5 \mu \mathrm{m}$.

- Tolerancia en las dimensiones de las esquinas redondeadas: $\pm 31,6 \mu \mathrm{m}$.

Lo que nos permite determinar que la principal razón de la desviación entre las respuestas es debida principalmente a la tolerancia en las dimensiones de la fresa proporcionadas por el fabricante (determinan el radio de las esquinas redondeadas). Por otra parte, si nos fijamos en la respuesta medida de los diferentes prototipos (ver Fig. 3.18(a)) podemos concluir que cuanto más cerca estén las esquinas redondeadas del centro de la guía mayor será la desviación entre la respuesta medida y la deseada.

Finalmente, no se ha realizado un análisis de la capacidad de manejo de potencia de los prototipos fabricados porque en 3.13 se concluye que la presencia de las esquinas redondeadas no la modifica. 


\begin{tabular}{|c|c|c|c|}
\hline Medida & Valor nominal (mm) & Valor real (mm) & Deriva $(\mathrm{mm})$ \\
\hline$l_{1}$ & 9.770 & 9.713 & -0.0570 \\
\hline$l_{2}$ & 11.118 & 11.120 & 0.0020 \\
\hline$l_{3}$ & 11.273 & 11.264 & -0.0090 \\
\hline$l_{4}$ & 11.273 & 11.276 & 0.0030 \\
\hline$l_{5}$ & 11.118 & 11.112 & -0.0060 \\
\hline$l_{6}$ & 9.770 & 9.762 & -0.0080 \\
\hline$a_{0}$ & 19.050 & 19.016 & -0.0340 \\
\hline$d_{1}$ & 22.000 & 21.977 & -0.0230 \\
\hline$d_{2}$ & 22.000 & 21.984 & -0.0160 \\
\hline$d_{3}$ & 22.000 & 21.987 & -0.0130 \\
\hline$d_{4}$ & 22.000 & 21.985 & -0.0150 \\
\hline$d_{5}$ & 22.000 & 21.991 & -0.0090 \\
\hline$d_{6}$ & 22.000 & 21.986 & -0.0140 \\
\hline$a_{7}$ & 19.050 & 19.028 & -0.0220 \\
\hline$t_{1}$ & 3.844 & 3.851 & 0.0070 \\
\hline$t_{2}$ & 3.844 & 3.852 & 0.0080 \\
\hline$t_{3}$ & 3.844 & 3.852 & 0.0080 \\
\hline$t_{4}$ & 3.844 & 3.841 & -0.0030 \\
\hline$t_{5}$ & 3.844 & 3.846 & 0.0020 \\
\hline$t_{6}$ & 3.844 & 3.844 & 0.0000 \\
\hline$t_{7}$ & 3.844 & 3.847 & 0.0030 \\
\hline$w_{1}$ & 9.284 & 9.255 & -0.0290 \\
\hline$w_{2}$ & 6.344 & 6.323 & -0.0210 \\
\hline$w_{3}$ & 5.814 & 5.810 & -0.0040 \\
\hline$w_{4}$ & 5.738 & 5.724 & -0.0140 \\
\hline$w_{5}$ & 5.814 & 5.800 & -0.0140 \\
\hline$w_{6}$ & 6.344 & 6.336 & -0.0080 \\
\hline$w_{7}$ & 9.284 & 9.283 & -0.0010 \\
\hline$r_{c 0}$ & 3.000 & 2.990 & -0.0100 \\
\hline$r_{c 1 i}$ & 3.000 & 2.964 & -0.0360 \\
\hline$r_{c 1 d}$ & 3.000 & 3.006 & 0.0060 \\
\hline$r_{c 2 i}$ & 3.000 & 3.019 & 0.0190 \\
\hline$r_{c 2 d}$ & 3.000 & 3.053 & 0.0530 \\
\hline$r_{c 3 i}$ & 3.000 & 2.994 & -0.0060 \\
\hline$r_{c 3 d}$ & 3.000 & 3.056 & 0.0560 \\
\hline$r_{c 4 i}$ & 3.000 & 3.029 & 0.0290 \\
\hline$r_{c 4 d}$ & 3.000 & 3.056 & 0.0560 \\
\hline$r_{c 5 i}$ & 3.000 & 3.085 & 0.0850 \\
\hline$r_{c 5 d}$ & 3.000 & 3.020 & 0.0200 \\
\hline$r_{c 6 i}$ & 3.000 & 3.014 & 0.0140 \\
\hline$r_{c 6 d}$ & 3.000 & 3.057 & 0.0570 \\
\hline$r_{c 7}$ & 3.000 & 2.990 & -0.0100 \\
\hline$r_{w}$ & - & - & - \\
\hline
\end{tabular}

Tabla 4.3: Control dimensional del prototipo con esquinas redondeadas en la cavidad resonante $r_{c}=3 \mathrm{~mm}$. 


\begin{tabular}{|c|c|c|c|}
\hline Medida & Valor nominal (mm) & Valor real (mm) & Deriva $(\mathrm{mm})$ \\
\hline$l_{1}$ & 9.809 & 9.822 & 0.0130 \\
\hline$l_{2}$ & 11.166 & 11.169 & 0.0030 \\
\hline$l_{3}$ & 11.322 & 11.331 & 0.0090 \\
\hline$l_{4}$ & 11.322 & 11.332 & 0.0100 \\
\hline$l_{5}$ & 11.166 & 11.182 & 0.0160 \\
\hline$l_{6}$ & 9.809 & 9.813 & 0.0040 \\
\hline$a_{0}$ & 19.050 & 19.023 & -0.0270 \\
\hline$d_{1}$ & 22.000 & 22.004 & 0.0040 \\
\hline$d_{2}$ & 22.000 & 22.005 & 0.0050 \\
\hline$d_{3}$ & 22.000 & 22.005 & 0.0050 \\
\hline$d_{4}$ & 22.000 & 22.000 & 0.0000 \\
\hline$d_{5}$ & 22.000 & 22.020 & 0.0200 \\
\hline$d_{6}$ & 22.000 & 22.008 & 0.0080 \\
\hline$a_{7}$ & 19.050 & 19.029 & -0.0210 \\
\hline$t_{1}$ & 3.844 & 3.832 & -0.0120 \\
\hline$t_{2}$ & 3.844 & 3.823 & -0.0210 \\
\hline$t_{3}$ & 3.844 & 3.844 & 0.0000 \\
\hline$t_{4}$ & 3.844 & 3.837 & -0.0070 \\
\hline$t_{5}$ & 3.844 & 3.831 & -0.0130 \\
\hline$t_{6}$ & 3.844 & 3.822 & -0.0220 \\
\hline$t_{7}$ & 3.844 & 3.850 & 0.0060 \\
\hline$w_{1}$ & 9.289 & 9.279 & -0.0100 \\
\hline$w_{2}$ & 6.348 & 6.361 & 0.0130 \\
\hline$w_{3}$ & 5.816 & 5.805 & -0.0110 \\
\hline$w_{4}$ & 5.739 & 5.743 & 0.0040 \\
\hline$w_{5}$ & 5.816 & 5.820 & 0.0040 \\
\hline$w_{6}$ & 6.348 & 6.339 & -0.0090 \\
\hline$w_{7}$ & 9.289 & 9.283 & -0.0060 \\
\hline$r_{c 0}$ & 4.000 & 4.011 & 0.0110 \\
\hline$r_{c 1 i}$ & 4.000 & 4.066 & 0.0660 \\
\hline$r_{c 1 d}$ & 4.000 & 3.983 & -0.0170 \\
\hline$r_{c 2 i}$ & 4.000 & 3.979 & -0.0210 \\
\hline$r_{c 2 d}$ & 4.000 & 4.016 & 0.0160 \\
\hline$r_{c 3 i}$ & 4.000 & 4.062 & 0.0620 \\
\hline$r_{c 3 d}$ & 4.000 & 3.983 & -0.0170 \\
\hline$r_{c 4 i}$ & 4.000 & 3.986 & -0.0140 \\
\hline$r_{c 4 d}$ & 4.000 & 4.014 & 0.0140 \\
\hline$r_{c 5 i}$ & 4.000 & 4.072 & 0.0720 \\
\hline$r_{c 5 d}$ & 4.000 & 3.964 & -0.0360 \\
\hline$r_{c 6 i}$ & 4.000 & 3.961 & -0.0390 \\
\hline$r_{c 6 d}$ & 4.000 & 4.012 & 0.0120 \\
\hline$r_{c 7}$ & 4.000 & 3.992 & -0.0080 \\
\hline$r_{w}$ & - & - & - \\
\hline
\end{tabular}

Tabla 4.4: Control dimensional del prototipo con esquinas redondeadas en la cavidad resonante $r_{c}=4 \mathrm{~mm}$. 


\begin{tabular}{|c|c|c|c|}
\hline Medida & Valor nominal (mm) & Valor real (mm) & Deriva $(\mathrm{mm})$ \\
\hline$l_{1}$ & 9.159 & 9.175 & 0.0160 \\
\hline$l_{2}$ & 10.581 & 10.594 & 0.0130 \\
\hline$l_{3}$ & 10.752 & 10.759 & 0.0070 \\
\hline$l_{4}$ & 10.752 & 10.773 & 0.0210 \\
\hline$l_{5}$ & 10.581 & 10.598 & 0.0170 \\
\hline$l_{6}$ & 9.159 & 9.175 & 0.0160 \\
\hline$a_{0}$ & 19.050 & 19.014 & -0.0360 \\
\hline$d_{1}$ & 22.000 & 21.994 & -0.0060 \\
\hline$d_{2}$ & 22.000 & 22.000 & 0.0000 \\
\hline$d_{3}$ & 22.000 & 22.006 & 0.0060 \\
\hline$d_{4}$ & 22.000 & 21.995 & -0.0050 \\
\hline$d_{5}$ & 22.000 & 22.017 & 0.0170 \\
\hline$d_{6}$ & 22.000 & 21.999 & -0.0010 \\
\hline$a_{7}$ & 19.050 & 19.022 & -0.0280 \\
\hline$t_{1}$ & 4.500 & 4.499 & -0.0010 \\
\hline$t_{2}$ & 4.500 & 4.483 & -0.0170 \\
\hline$t_{3}$ & 4.500 & 4.482 & -0.0180 \\
\hline$t_{4}$ & 4.500 & 4.481 & -0.0190 \\
\hline$t_{5}$ & 4.500 & 4.486 & -0.0140 \\
\hline$t_{6}$ & 4.500 & 4.486 & -0.0140 \\
\hline$t_{7}$ & 4.500 & 4.486 & -0.0140 \\
\hline$w_{1}$ & 8.768 & 8.751 & -0.0170 \\
\hline$w_{2}$ & 5.837 & 5.830 & -0.0070 \\
\hline$w_{3}$ & 5.311 & 5.312 & 0.0010 \\
\hline$w_{4}$ & 5.235 & 5.234 & -0.0010 \\
\hline$w_{5}$ & 5.311 & 5.307 & -0.0040 \\
\hline$w_{6}$ & 5.837 & 5.826 & -0.0110 \\
\hline$w_{7}$ & 8.768 & 8.733 & -0.0350 \\
\hline$r_{c}$ & - & - & - \\
\hline$r_{w 1 i}$ & 2.000 & 2.043 & 0.0430 \\
\hline$r_{w 1 d}$ & 2.000 & 1.962 & -0.0380 \\
\hline$r_{w 2 i}$ & 2.000 & 2.019 & 0.0190 \\
\hline$r_{w 2 d}$ & 2.000 & 1.970 & -0.0300 \\
\hline$r_{w 3 i}$ & 2.000 & 1.995 & -0.0050 \\
\hline$r_{w 3 d}$ & 2.000 & 2.003 & 0.0030 \\
\hline$r_{w 4 i}$ & 2.000 & 2.052 & 0.0520 \\
\hline$r_{w 4 d}$ & 2.000 & 1.966 & -0.0340 \\
\hline$r_{w 5 i}$ & 2.000 & 2.036 & 0.0360 \\
\hline$r_{w 5 d}$ & 2.000 & 1.981 & -0.0190 \\
\hline$r_{w 6 i}$ & 2.000 & 2.036 & 0.0360 \\
\hline$r_{w 6 d}$ & 2.000 & 1.980 & -0.0200 \\
\hline$r_{w 7 i}$ & 2.000 & 2.058 & 0.0580 \\
\hline$r_{w 7 i}$ & 2.000 & 2.072 & 0.0720 \\
\hline
\end{tabular}

Tabla 4.5: Control dimensional del prototipo con esquinas redondeadas en la ventana de acoplo $r_{w}=2 \mathrm{~mm}$. 


\subsubsection{Mejora computacional}

Si comparamos los resultados del diseño de filtros de cavidades acopladas en plano $\mathrm{H}$ con los resultados mostrados en la tabla 3.17, se puede observar que el uso de la herramienta de propósito general como modelo fino ha ralentizado el proceso de diseño. De hecho, se puede observar que sólo 2 simulaciones del modelo fino han empleado aproximadamente 4 horas de tiempo de cómputo.

Para mejorar la eficiencia de la herramienta de diseño se ha colaborado con otros miembros del grupo de investigación en el desarrollo de un nuevo módulo capaz de analizar estructuras en plano $\mathrm{H}$ de sección arbitraria (ver apartados 3.4 y 3.5), el cual se ha integrado dentro de la herramienta CAD descrita en el apartado 3.3 cómo modelo fino.

En este nuevo módulo su precisión, y por lo tanto su eficiencia, se puede ajustar fijando la densidad celdas en las que se dividen: las secciones rectas por longitud de onda $\left(N_{d}\right), \mathrm{y}$ los tramos curvos por radián $(\Omega)$ de la estructura bajo análisis.

Para poder comparar el rendimiento de la versión actualizada de la herramienta CAD se han diseñado una serie de filtros que cumplen las mismas especificaciones eléctricas que los fabricados en el apartado anterior (ver ecuación 4.3). Sin embargo, en este caso sólo vamos a considerar el uso de hasta dos modelos finos en el algoritmo MASM con las siguientes precisiones:

- Modelo fino 1 (F1): $N_{d}=50, \Omega=12 / \pi$.

- Modelo fino 2 (F2): $N_{d}=100, \Omega=24 / \pi$.

En todos los diseños se han considerado cómo parámetros de diseño las longitudes de las cavidades resonantes y la anchura de las ventanas de acoplo (ver Fig. 3.15). Las guías de entrada y salida de la estructura, así como las cavidades resonantes, se consideran guías de onda de dimensiones estándar WR-75 ( $a=19,05 \mathrm{~mm}, b=9,525 \mathrm{~mm})$, considerando el resto de parámetros cómo fijos.

El resultado de los diferentes diseños realizados se muestra en la tabla 4.6. En ella se refleja la combinación de modelos finos utilizados y el número de simulaciones realizadas por cada modelo fino para diseñar filtros con diferentes radios en las cavidades resonantes $\left(r_{c}=3 \mathrm{~mm}\right.$ y $\left.4 \mathrm{~mm}\right)$ o en la ventanas de acoplo $\left(r_{w}=1 \mathrm{~mm}\right.$ y $\left.2 \mathrm{~mm}\right)$. Hay que recordar que si se utiliza el modelo grueso (C) y el modelo fino 2 (F2) el MASM se reduce a aplicar la técnica del ASM tradicional.

Para ayudar a analizar los resultados mostrados en la tabla 4.6, en la gráfica 4.13 se muestra la comparación de la respuesta del punto óptimo en el espacio de optimización $\left(\mathrm{x}_{O S}^{*}\right)$ 
utilizando el modelo fino (F2) considerando diferentes radios de curvaturas con su respuesta en el modelo grueso, mientras que en las figuras 4.14 y 4.15 se muestra la comparación de la respuesta de los filtros diseñados con la respuesta buscada utilizando el ASM y MASM respectivamente.

\begin{tabular}{|lc|c|c|c|c|}
\hline \multirow{2}{*}{ Radio(mm) } & Modelos & $\begin{array}{c}\text { Simulaciones con } \\
\text { el modelo fino }\end{array}$ & Error Final & Coste computacional \\
\hline \hline \multirow{3}{*}{$r_{w}=0$} & \multirow{2}{*}{$r_{c}=3$} & $\mathrm{C}+\mathrm{F} 2$ & 2 & 1.692 & $3^{\prime} 33^{\prime \prime}$ \\
\cline { 3 - 6 } & & $\mathrm{C}+\mathrm{F} 1+\mathrm{F} 2$ & $5+2$ & 0.854 & $12^{\prime} 19^{\prime \prime}$ \\
\cline { 3 - 6 } & \multirow{2}{*}{$r_{c}=4$} & $\mathrm{C}+\mathrm{F} 2$ & 4 & 1.760 & $7^{\prime} 52^{\prime \prime}$ \\
\cline { 3 - 6 } & $\mathrm{C}+\mathrm{F} 1+\mathrm{F} 2$ & $5+3$ & 0.256 & $16^{\prime} 25^{\prime \prime}$ \\
\hline \hline \multirow{3}{*}{$r_{c}=0$} & \multirow{2}{*}{$r_{w}=1$} & $\mathrm{C}+\mathrm{F} 2$ & 4 & 0.477 & $4^{\prime} 24^{\prime \prime}$ \\
\cline { 3 - 6 } & & $\mathrm{C}+\mathrm{F} 1+\mathrm{F} 2$ & $5+5$ & 0.213 & $9^{\prime} 36^{\prime \prime}$ \\
\cline { 3 - 6 } & \multirow{2}{*}{$r_{w}=2$} & $\mathrm{C}+\mathrm{F} 2$ & - & No converge & - \\
\cline { 3 - 6 } & $\mathrm{C}+\mathrm{F} 1+\mathrm{F} 2$ & $5+3$ & 0.194 & $8^{\prime} 52^{\prime \prime}$ \\
\hline
\end{tabular}

Tabla 4.6: Resultado del diseño para filtros con esquinas redondeadas

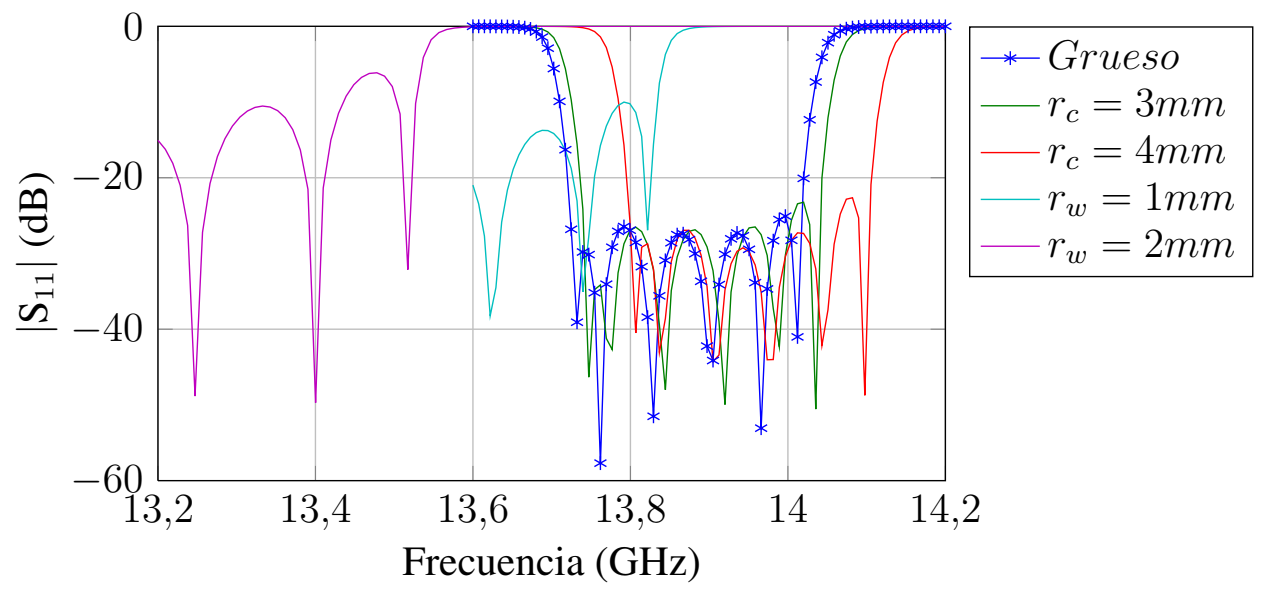

Figura 4.13: Desalineamiento entre el modelo grueso y el modelo fino para diferentes radios de curvatura

Del análisis de los resultados mostrados en la tabla 4.6 y en las figuras 4.13-4.15 se puede observar que el ASM clásico es más eficiente que el MASM cuando los espacios de optimización y validación no están muy separados. Sin embargo, en el caso de que los espacios estén muy separados entre sí, la primera técnica no converge a una solución válida. No obstante, el MASM siempre converge a una solución válida más precisa. 


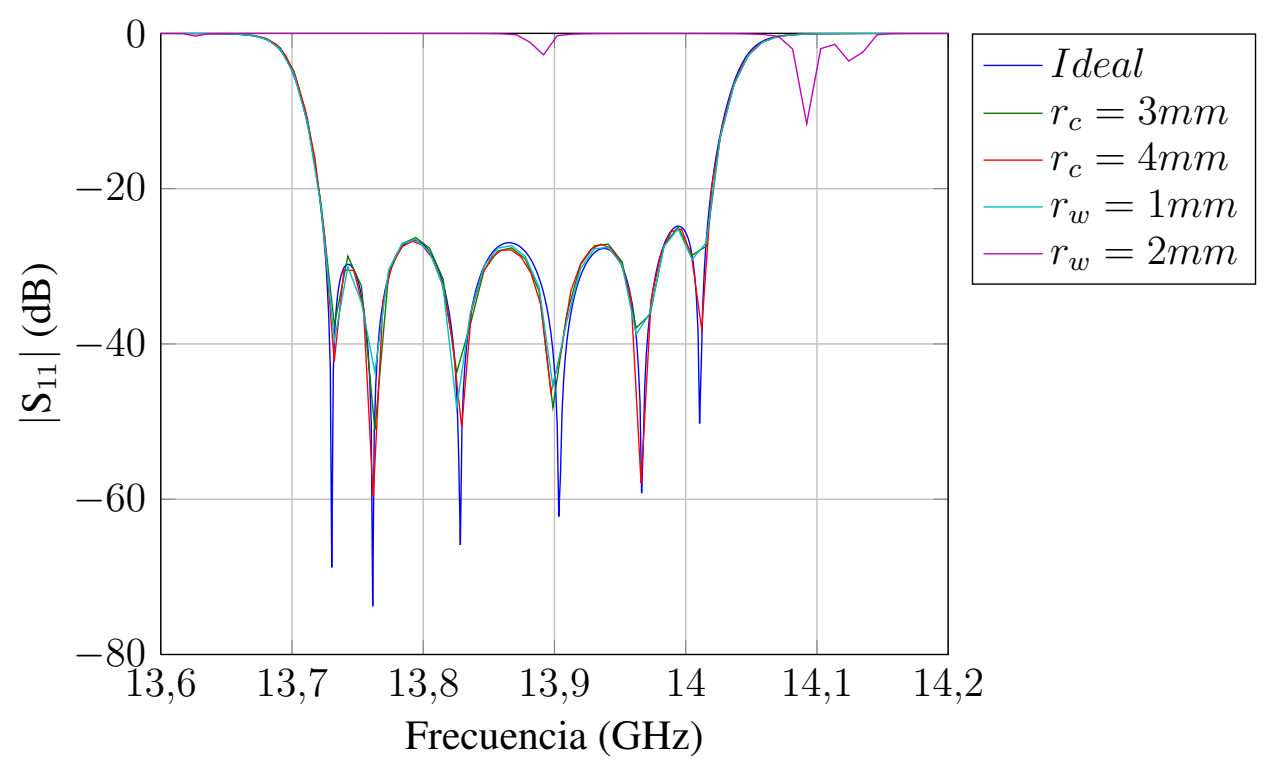

Figura 4.14: Comparación de la respuesta de los filtros diseñados con la respuesta buscada utilizando ASM

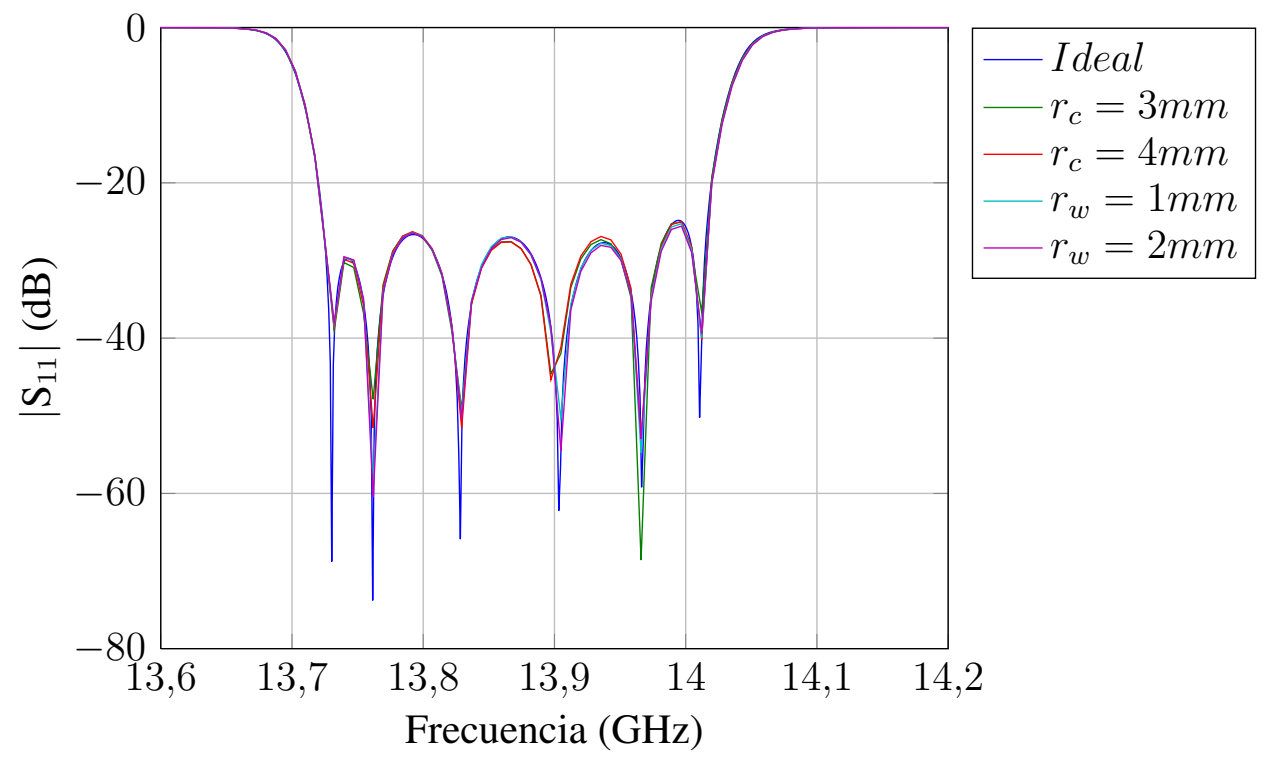

Figura 4.15: Comparación de la respuesta de los filtros diseñados con la respuesta buscada utilizando MASM 
Si comparamos los resultados obtenidos con la nueva versión de la herramienta CAD con los reflejados en la tabla 3.17, se puede observar que si bien se han realizado más simulaciones en el espacio de validación el tiempo de diseño se ha reducido drásticamente. A pesar de que los diseños se han realizado con diferentes ordenadores, para el diseño de estos dispositivos se ha utilizado un Intel@Core ${ }^{\mathrm{TM}} 2$ Quad Q660 @ $2.4 \mathrm{GHz}$, la enorme diferencia de tiempos refleja que la mejora es debida al incremento de la eficiencia de la nueva herramienta de análisis y no a las mejoras en los recursos de computación.

Finalmente, las dimensiones de los parámetros proporcionados por el proceso de diseño para cada uno de los filtros se muestran en las tablas 4.7 y 4.8 .

\begin{tabular}{|c|c|c|c|}
\hline Dimensions & $\begin{array}{c}\mathbf{r}_{c}=\mathbf{3} \mathbf{~ m m} \\
\mathbf{r}_{w}=\mathbf{0} \mathbf{~ m m}\end{array}$ & $\begin{array}{c}\mathbf{r}_{c}=\mathbf{4} \mathbf{~ m m} \\
\mathbf{r}_{w}=\mathbf{0} \mathbf{~ m m}\end{array}$ & $\begin{array}{c}\mathbf{r}_{c}=\mathbf{0} \mathbf{~ m m} \\
\mathbf{r}_{w}=\mathbf{1} \mathbf{~ m m}\end{array}$ \\
\hline \hline$a$ & 19.05 & 19.05 & 19.05 \\
\hline$d$ & 19.05 & 19.05 & 19.05 \\
\hline$t$ & 3.844 & 3.844 & 3.844 \\
\hline$w_{1}=w_{7}$ & 9.296 & 9.324 & 8.973 \\
\hline$w_{2}=w_{6}$ & 6.383 & 6.405 & 6.026 \\
\hline$w_{3}=w_{5}$ & 5.850 & 5.864 & 5.495 \\
\hline$w_{4}$ & 5.771 & 5.783 & 5.415 \\
\hline$l_{1}=l_{6}$ & 10.134 & 10.208 & 9.954 \\
\hline$l_{2}=l_{5}$ & 11.644 & 11.722 & 11.462 \\
\hline$l_{3}=l_{4}$ & 11.824 & 11.905 & 11.642 \\
\hline
\end{tabular}

Tabla 4.7: Parámetros obtenidos por el proceso de diseño utilizando la técnica del ASM

\begin{tabular}{|c|c|c|c|c|}
\hline Dimensions & $\mathbf{r}_{c}=\mathbf{3} \mathbf{~ m m}$ & $\mathbf{r}_{c}=\mathbf{4} \mathbf{~ m m}$ & $\mathbf{r}_{c}=\mathbf{0} \mathbf{~ m m}$ & $\mathbf{r}_{c}=\mathbf{0} \mathbf{~ m m}$ \\
& $\mathbf{r}_{w}=\mathbf{0} \mathbf{~ m m}$ & $\mathbf{r}_{w}=\mathbf{0} \mathbf{~ m m}$ & $\mathbf{r}_{w}=\mathbf{1} \mathbf{~ m m}$ & $\mathbf{r}_{w}=\mathbf{2} \mathbf{~ m m}$ \\
\hline \hline$a$ & 19.05 & 19.05 & 19.05 & 19.05 \\
\hline$d$ & 19.05 & 19.05 & 19.05 & 19.05 \\
\hline$t$ & 3.844 & 3.844 & 3.844 & 4.5 \\
\hline$w_{1}=w_{7}$ & 9.303 & 9.315 & 8.968 & 8.776 \\
\hline$w_{2}=w_{6}$ & 6.388 & 6.400 & 6.023 & 5.864 \\
\hline$w_{3}=w_{5}$ & 5.853 & 5.864 & 5.493 & 5.335 \\
\hline$w_{4}$ & 5.773 & 5.783 & 5.415 & 5.257 \\
\hline$l_{1}=l_{6}$ & 10.129 & 10.215 & 9.957 & 9.441 \\
\hline$l_{2}=l_{5}$ & 11.642 & 11.724 & 11.463 & 11.026 \\
\hline$l_{3}=l_{4}$ & 11.823 & 11.905 & 11.642 & 11.222 \\
\hline
\end{tabular}

Tabla 4.8: Parámetros obtenidos por el proceso de diseño utilizando la técnica del MASM 


\subsubsection{Diseño directo}

Debido a la eficiencia del nuevo módulo de análisis se ha considerado la opción de realizar todo el proceso de diseño considerando el efecto de las esquinas redondeadas. Para ello, se ha modificado la herramienta CAD descrita en 3.1 para que el algoritmo del ASM utilice como modelo fino y grueso el módulo de análisis descrito en las secciones 3.4 y 3.5.

También ha sido necesario tener en cuenta la presencia de las esquinas redondeadas en la síntesis del punto inicial. Así que el parámetro de diseño de cada ventana de acoplo se ajusta para proporcionar la constante $K$ del inversor del circuito equivalente [MJY80] en presencia de las esquinas redondeadas, mientras que las longitudes de las cavidades se ajustan para que resuenen a la frecuencia central del filtro. Este proceso se ha automatizado utilizando el modelo grueso en combinación con el algoritmo de búsqueda de ceros de Brent.

Para verificar las propiedades de la herramienta CAD se han diseñado diferentes filtros de cavidades acopladas en plano H. A continuación, vamos a analizar los resultados obtenidos en el diseño de un filtro de cavidades acopladas en plano $\mathrm{H}$ con esquinas redondeadas únicamente en las cavidades resonantes $\left(r_{c}=3 \mathrm{~mm}\right)$ con las mismas especificaciones eléctricas que los filtros diseñados en 4.2.1

A la hora de diseñar esta estructura se han considerado cómo parámetros de diseño las longitudes de las cavidades resonantes y la anchura de las ventanas de acoplo (ver Fig. 3.15). Las guías de entrada y salida de la estructura, así como las cavidades resonantes, se consideran guías de onda con dimensiones estándar WR-75 ( $a=19,05 \mathrm{~mm}, b=9,525 \mathrm{~mm})$, mientras que la longitud de las ventanas de acoplo se ha fijado para que sea igual a $3,844 \mathrm{~mm}$.

En la tabla 4.9 se muestran los valores iniciales de los parámetros de diseño $\left(\mathbf{x}_{O S}^{(0)}\right)$, el punto óptimo en el espacio de optimización $\left(\mathrm{x}_{O S}^{*}\right)$ y la solución final en el espacio de validación $\left(\mathbf{x}_{E M}\right)$.

\begin{tabular}{|c|c|c|c|}
\hline Parámetros de diseño & $\mathbf{x}_{O S}^{(0)}$ & $\mathbf{x}_{O S}^{*}$ & $\mathbf{x}_{E M}$ \\
\hline$w_{1}, w_{7}(\mathrm{~mm})$ & 9.215 & 9.304 & 9.30414 \\
\hline$w_{2}, w_{6}(\mathrm{~mm})$ & 6.32911 & 6.3895 & 6.38903 \\
\hline$w_{3}, w_{5}(\mathrm{~mm})$ & 5.8254 & 5.85034 & 5.84989 \\
\hline$w_{4}(\mathrm{~mm})$ & 5.7504 & 5.7708 & 5.77043 \\
\hline$l_{1}, l_{6}(\mathrm{~mm})$ & 10.1759 & 10.1282 & 10.1271 \\
\hline$l_{2}, l_{5}(\mathrm{~mm})$ & 11.6293 & 11.6439 & 11.643 \\
\hline$l_{3}, l_{4}(\mathrm{~mm})$ & 11.7958 & 11.8257 & 11.825 \\
\hline
\end{tabular}

Tabla 4.9: Parámetros de diseño del filtro de cavidades acopladas en plano $\mathrm{H}$ con esquinas redondeadas en las cavidades resonantes $\left(r_{c}=3 \mathrm{~mm}\right)$ 
Para demostrar la eficiencia de la rutina de síntesis del punto inicial, en la figura 4.16(a) se compara la respuesta del modelo grueso en el punto $\mathbf{x}_{O S}^{(0)}$ con la respuesta ideal buscada, la respuesta del punto inicial está próxima a la respuesta ideal buscada. A continuación, en la figura 4.16(b) se muestra que la respuesta ideal se ha conseguido recuperar en el espacio de optimización. Mientras, que en la figura 4.16(c) se refleja que la respuesta ideal se ha recuperado en el espacio de validación con tan sólo 2 iteraciones de ASM.

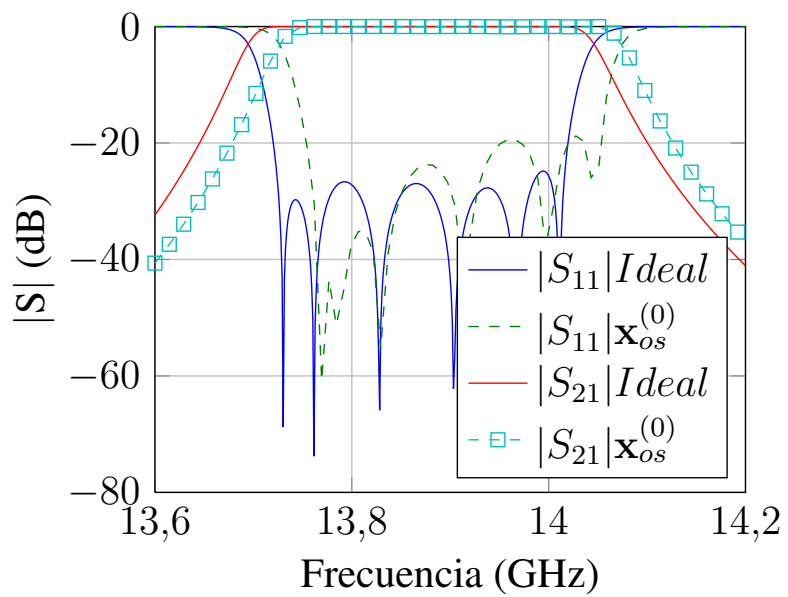

(a) Respuesta del modelo grueso en $\mathbf{x}_{O S}^{(0)}$ frente a la respuesta ideal

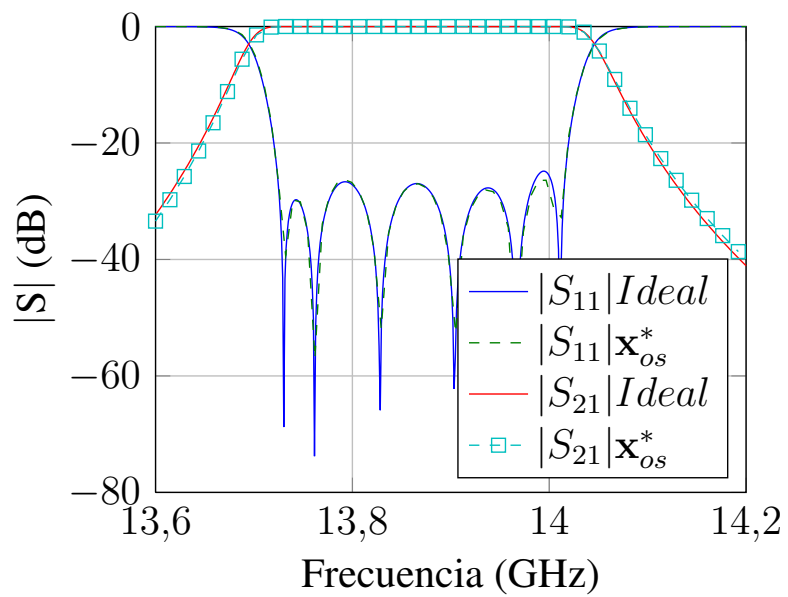

(b) Respuesta del modelo grueso en $\mathbf{x}_{O S}^{*}$ frente a la respuesta ideal

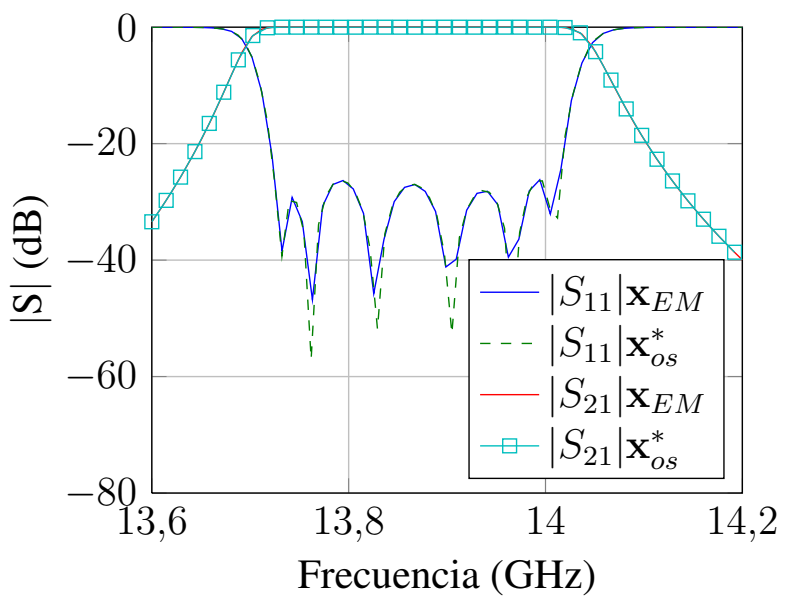

(c) Respuesta del modelo grueso en $\mathbf{x}_{O S}^{*}$ frente a la respuesta del modelo fino en $\mathbf{x}_{E M}$

Figura 4.16: Respuesta en frecuencia del filtro de cavidades resonantes en plano $\mathrm{H}$ con esquinas redondeadas en las cavidades resonantes $r_{c}=3 \mathrm{~mm}$.

Finalmente, para evaluar el rendimiento global de la herramienta de diseño en la tabla 4.10 se muestra el valor de la función de error al final de cada una de las fases junto con el tiempo total requerido por el proceso de diseño. 


\begin{tabular}{|l|l|l|l|}
\hline$U\left(\mathbf{x}_{O S}^{(0)}\right)$ & $U\left(\mathbf{x}_{O S}^{*}\right)$ & $U\left(\mathbf{x}_{E M}\right)$ & Tiempo \\
\hline 104,201 & 0,0243037 & 0,0246463 & $12 \mathrm{~h} 36^{\prime} 56^{\prime \prime}$ \\
\hline
\end{tabular}

Tabla 4.10: Rendimiento del proceso de diseño

A la vista de los resultados anteriores, se puede concluir que aunque se haya recuperado la respuesta deseada el tiempo computacional empleado (muy superior al de las herramientas descritas en los apartados 4.2.1 y 4.2.2) nos obliga a considerar que el diseño teniendo en cuenta en todo momento las presencia de las esquinas redondeadas es todavía inabordable. Siendo, la opción más adecuada la implementada en la herramienta CAD descrita en el apartado anterior. 


\subsection{Filtros propagativos de cavidades acopladas en plano H con resonadores dieléctricos}

El desarrollo de los sistemas de comunicaciones vía satélite modernos ha supuesto una creciente demanda de nuevas topologías de dispositivos de microondas que dispongan de ventajas adicionales frente a otras topologías más clásicas. Entre las nuevas tecnologías que están apareciendo en la bibliografía especializada surge con fuerza el uso de materiales dieléctricos. En nuestro caso, nos vamos a centrar en el diseño de filtros de cavidades acopladas en plano $\mathrm{H}$ con postes dieléctricos en las cavidades resonantes (ver Fig. 3.44) cuyas características han sido descritas en apartados anteriores (ver secciones 3.6-3.9). A continuación, se van a discutir los resultados obtenidos con las dos herramientas CAD que se han desarrollado para el diseño de este tipo de dispositivos. Cómo se puede observar, la principal diferencia que existe entre ellas es la estrategia de síntesis del punto inicial que condicionará por completo la estrategia de diseño.

\subsubsection{Implementación original}

La principal limitación que surgió a la hora de diseñar este tipo de estructuras fue la falta de una técnica adecuada que permitiera sintetizar un buen punto inicial. Por ello, en las secciones 3.6, 3.7, y 3.8 se describen diferentes estrategias de optimización para obtener un punto inicial, pero todas ellas tienen varios elementos en común: el uso de la computación evolutiva y la hibridación de algoritmos.

Con el término de computación evolutiva, se hace referencia a un conjunto de algoritmos de búsqueda y aprendizaje estocásticos que emulan los procesos de la naturaleza (cruce, mutación, selección natural) para encontrar la solución más adecuada a un determinado problema. Sin embargo, su solución no es determinista, es decir, dos ejecuciones consecutivas del algoritmo no proporcionan la misma solución en el mismo número de generaciones. Para solucionar este problema, en las diferentes implementaciones del método de obtención del punto inicial, se ha utilizado la hibridación de un algoritmo evolutivo con diferentes algoritmos de optimización (simplex, SQP).

Como resultado de esta primera fase de optimización se obtendrá una estimación inicial de las dimensiones de la estructura bajo diseño (ver Fig. 3.44), es decir, el parámetro de diseño de las ventanas de acoplo, la longitud de las cavidades resonantes y el radio de los postes dieléctricos.

Una vez determinado un punto inicial, se inicia la fase de optimización. En este caso, al igual que en las herramientas de diseño anteriormente presentadas, nos vamos a basar en la segmentación de la estructura bajo diseño y la hibridación de algoritmos de optimización 
que tan buenos resultados han proporcionado. Sin embargo, debido a las particularidades de la estructura bajo diseño ha sido necesario:

- Reducir el número de parámetros de diseño. Para simplificar y hacer más robusta esta fase, además de reducir los costes de fabricación, se ha fijado el valor de los radios de todos los postes dieléctricos al valor promedio de los valores obtenidos en la fase de obtención del punto inicial.

- Introducir el manejo de restricciones en los algoritmos de optimización. Para ello se ha incluido en la hibridación el algoritmo de optimización con restricciones SQP. Además, de un mecanismo de penalización en el algoritmo del descenso del simplex. La necesidad de introducir restricciones en la estrategia de optimización viene determinada por el hecho de que no disponer de un buen punto inicial puede hacer que los diferentes algoritmos de optimización empleados proporcionen como resultado dimensiones sin sentido físico (p. ej. dimensiones negativas, longitudes de las cavidades resonantes inferiores al diámetro de los postes dieléctricos, etc.).

- Realizar una optimización multinivel. Una de las principales limitaciones del módulo de análisis utilizado $\left[\mathrm{BEB}^{+} 05\right]$ es su estabilidad numérica si se requiere una elevada precisión. De hecho, cuando las dimensiones proporcionadas por los algoritmos de optimización son extremas, p. ej. anchuras de las ventanas de acoplo muy próximas a las anchuras de las guías de onda a las que conecta, la técnica de análisis numérico que implementa precisa de la inversión de matrices mal condicionadas. Para solucionar esta limitación cada etapa de optimización se divide en dos pasos: en el primero se realiza una hibridación de algoritmos de optimización pero reduciendo la precisión del módulo de análisis; mientras que en el segundo, una vez que nos encontramos cerca de la solución óptima, se realiza otra hibridación de algoritmos de optimización pero aumentando la precisión de la herramienta de análisis. Cómo se puede observar, se utiliza la misma idea que el mapeado espacial pero sin serlo realmente.

Las herramientas CAD presentadas en 3.6, 3.7, y 3.8, las cuales implementan la estrategia de optimización cuyas particularidades se han comentado anteriormente y que únicamente difieren en la hibridación empleada, se han aplicado con éxito al diseño de este tipo de filtros de microondas considerando diferentes especificaciones eléctricas: bandas de frecuencia, número de cavidades, permitividad eléctrica del poste dieléctrico, etc. Mostrándose un análisis más detallado del proceso de diseño de este tipo de filtros en el apartado 4.3.2.

\subsubsection{Comparación de tecnologías}

Para demostrar de forma empírica las características de una nueva tipología de filtros es necesario diseñar y construir un prototipo que cumpla las mismas especificaciones que un 
determinado dispositivo patrón. Por ello, se ha diseñado ${ }^{1}$ y fabricado un filtro de cavidades acopladas en plano $\mathrm{H}$ con resonadores dieléctricos que cumplen las mismas especificaciones que el filtro diseñado y fabricado en el apartado 4.1 en tecnología sólo metal. A continuación, el resultado de este proceso se analizará de forma detallada.

\section{A. Proceso de diseño}

Se pretende diseñar un filtro de microondas en banda $X$ de 4 cavidades para aplicaciones espaciales, el cual tiene una respuesta de tipo Chebyshev centrada a $11 \mathrm{GHz}$ con un ancho de banda de $300 \mathrm{MHz}$, con las siguientes especificaciones:

$$
\begin{cases}L_{R} \leq 3 d B, & \text { para } f \leq 10,8 \mathrm{GHz} \text { y } f \geq 11,2 \mathrm{GHz} \\ L_{R} \geq 25 d B, & \text { para } 10,85 \leq f \leq 11,15 \mathrm{GHz}\end{cases}
$$

A la hora de diseñar esta estructura se han considerado cómo parámetros de diseño las longitudes de las cavidades resonantes, el radio de los postes dieléctricos y la anchura de las ventanas de acoplo (ver Fig. 4.17). Las guías de entrada y salida de la estructura así cómo las cavidades resonantes son guías de onda con dimensiones estándar WR-75 ( $a=19,05$ mm, $b=9,525 \mathrm{~mm}$ ), mientras que la longitud de las ventanas de acoplo se ha fijado para que sea igual a $2 \mathrm{~mm}$ y para la permitividad eléctrica relativa de los postes dieléctricos se ha considerado un valor de 19,5 .

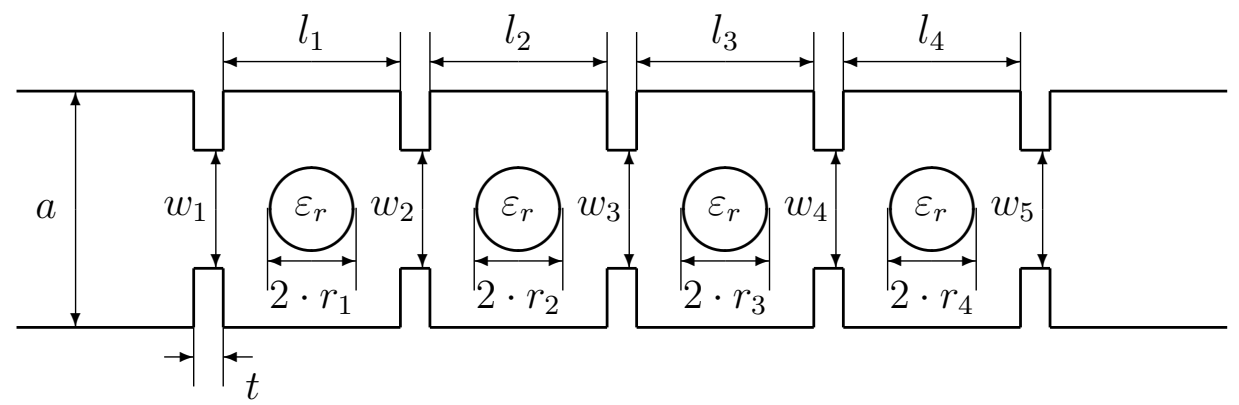

Figura 4.17: Filtro de 4 cavidades acopladas en plano $\mathrm{H}$ con resonadores dieléctricos.

En primer lugar se analizará el proceso de obtención del punto inicial $\left(\mathbf{x}_{I N I}\right)$. Cabe recordar que en esta fase se parte de un punto totalmente aleatorio por ello, en la tabla 4.11 se indica que el error inicial es $\infty$. En la misma tabla también se observa que el valor del error cometido en esta fase del proceso de diseño es relativamente alto. Sin embargo, en la figura 4.18 se muestra la comparación entre la respuesta ideal buscada y la respuesta del modelo

\footnotetext{
${ }^{1}$ Para diseñar este filtro se ha utilizado la herramienta CAD totalmente descrita en la sección 3.7 utilizando un Intel@Core ${ }^{\mathrm{TM}} 2$ Quad Q660 @ $2.4 \mathrm{GHz}$.
} 
grueso en el punto inicial $\mathbf{x}_{I N I}$, en ella podemos comprobar que este elevado error se debe a que la respuesta del filtro ha perdido dos polos de reflexión mientras que se ha conseguido ajustar el valor de las pérdidas de retorno en prácticamente todo el ancho de banda del dispositivo. En la misma tabla también se indica el número de evaluaciones de la función de error ejecutadas, y el tiempo de cómputo requerido para obtener el punto inicial.

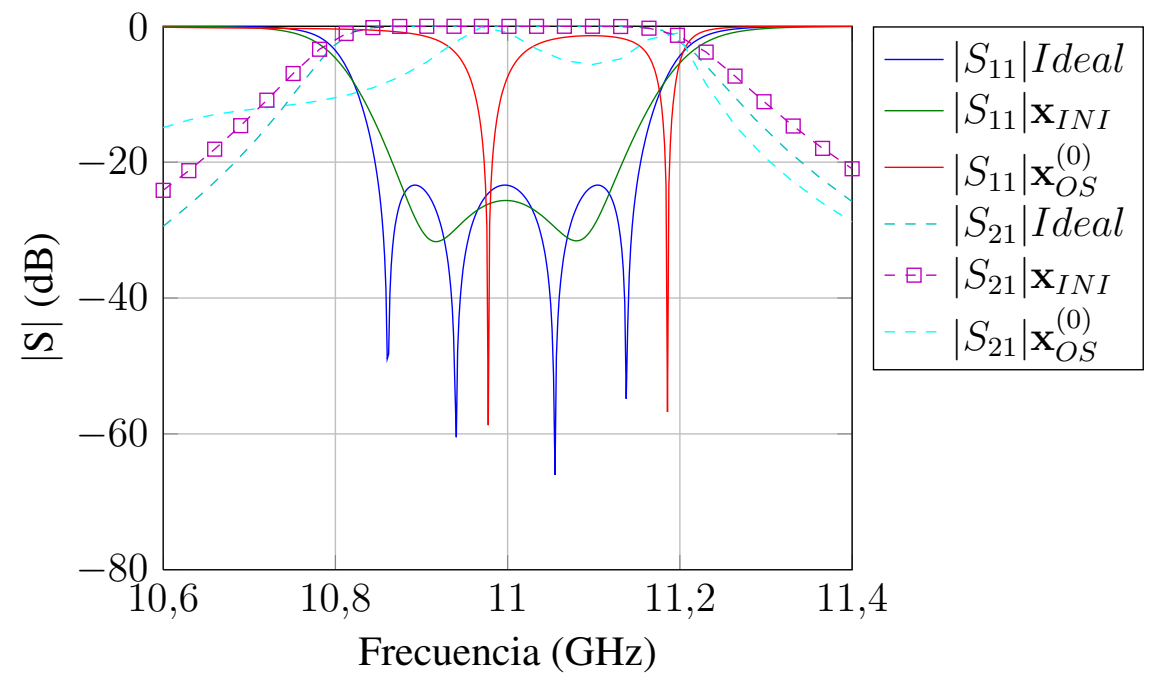

Figura 4.18: Respuesta del modelo grueso en $\mathbf{x}_{I N I} \mathbf{y} \mathbf{x}_{O S}^{(0)}$ frente a la respuesta ideal

\begin{tabular}{|c|c|c|c|}
\hline$U\left(\mathbf{x}_{I N I}^{(0)}\right)$ & $U\left(\mathbf{x}_{I N I}\right)$ & $\mathrm{nF}$ & Tiempo \\
\hline$\infty$ & 14,1466 & 1974 & $1 \mathrm{~h} 01^{\prime}$ \\
\hline
\end{tabular}

Tabla 4.11: Rendimiento del proceso de obtención del punto inicial

El punto obtenido en la fase de síntesis se utilizará como punto de partida $\left(\mathbf{x}_{O S}^{(0)}\right)$ de la estrategia de optimización multinivel implementada, con la salvedad de que el radio de los postes dieléctricos se ha fijado a un valor promedio de los valores obtenidos. En la figura 4.18 se representa la respuesta de $\mathrm{x}_{O S}^{(0)}$ comparada con la respuesta ideal buscada. Cómo se observa, el hecho de fijar el radio de los postes al mismo valor hace que la respuesta se desplace en frecuencia y el valor de las pérdidas de retorno sea muy bajo.

Para evaluar el funcionamiento de la estrategia de optimización implementada nos debemos fijar en la figura 4.19. En ella se puede observar que la respuesta del filtro diseñado consigue recuperar la respuesta ideal buscada. Además, en la tabla 4.12 se muestra el error final cometido en la estrategia de optimización, el número de evaluaciones de la función de error ejecutadas, y el tiempo de diseño requerido, sin incluir el tiempo necesario para calcular el punto inicial. 


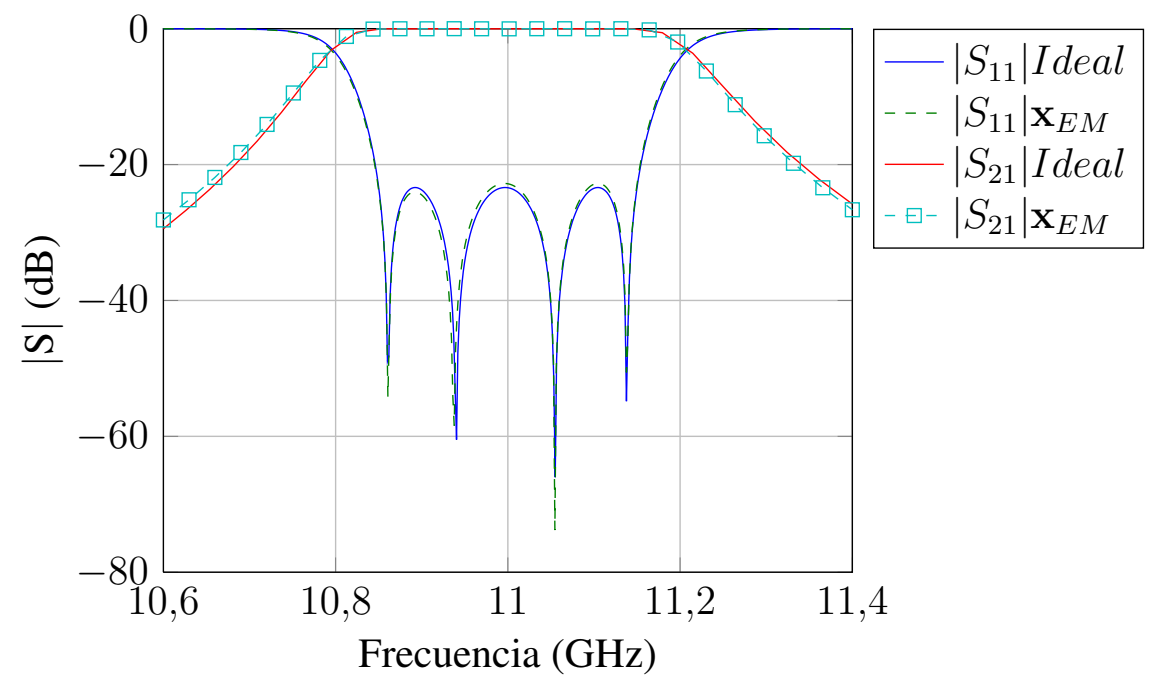

Figura 4.19: Respuesta del modelo fino en $\mathbf{x}_{E M}$ frente a la respuesta ideal

\begin{tabular}{|c|c|c|c|}
\hline$U\left(\mathbf{x}_{O S}^{(0)}\right)$ & $U\left(\mathbf{x}_{E M}\right)$ & $\mathrm{nF}$ & Tiempo \\
\hline 248,71 & 0,0106 & 3457 & $5 \mathrm{~h} 31^{\prime} 3^{\prime \prime}$ \\
\hline
\end{tabular}

Tabla 4.12: Rendimiento del proceso de diseño

Finalmente, en la tabla 4.13 se muestran las dimensiones iniciales de los parámetros de diseño obtenidos tras la estrategia de síntesis del punto inicial $\left(\mathbf{x}_{I N I}\right)$, los valores iniciales utilizados por la estrategia de optimización $\left(\mathbf{x}_{O S}^{(0)}\right)$ y la solución final del proceso de diseño $\left(\mathbf{x}_{E M}\right)$ 


\begin{tabular}{|c|c|c|c|}
\hline Dimensiones & $\mathbf{x}_{I N I}$ & $\mathbf{x}_{O S}^{(0)}$ & $\mathbf{x}_{E M}$ \\
\hline$a$ & \multicolumn{3}{|c|}{$19.05 \mathrm{~mm}$} \\
\hline$b$ & \multicolumn{3}{|c|}{$9.525 \mathrm{~mm}$} \\
\hline$t$ & \multicolumn{3}{|c|}{$2 \mathrm{~mm}$} \\
\hline$w_{1}, w_{5}$ & $14.995 \mathrm{~mm}$ & $14.995 \mathrm{~mm}$ & $13.014 \mathrm{~mm}$ \\
\hline$w_{2}, w_{4}$ & $10.611 \mathrm{~mm}$ & $10.611 \mathrm{~mm}$ & $8.141 \mathrm{~mm}$ \\
\hline$w_{3}$ & $7.780 \mathrm{~mm}$ & $7.780 \mathrm{~mm}$ & $8.780 \mathrm{~mm}$ \\
\hline$l_{1}, l_{4}$ & \multicolumn{3}{|c|}{} \\
\hline$l_{2}, l_{3}, l_{5}$ (líneas de entrada/salida) & $14.171 \mathrm{~mm}$ & $14.171 \mathrm{~mm}$ & $8.040 \mathrm{~mm}$ \\
\hline$r_{1}, r_{4}$ & $10.694 \mathrm{~mm}$ & $10.694 \mathrm{~mm}$ & $12.585 \mathrm{~mm}$ \\
\hline$r_{2}, r_{3}$ & $2.235 \mathrm{~mm}$ & $2.31 \mathrm{~mm}$ & $2.31 \mathrm{~mm}$ \\
\hline Longitud total (sin líneas de entrada/salida) & $2.315 \mathrm{~mm}$ & $2.31 \mathrm{~mm}$ & $2.31 \mathrm{~mm}$ \\
\hline Longitud total & $79.73 \mathrm{~mm}$ & $59.73 \mathrm{~mm}$ & $51.25 \mathrm{~mm}$ \\
\hline
\end{tabular}

Tabla 4.13: Dimensiones del filtro de 4 cavidades acopladas en plano $\mathrm{H}$ con resonadores dieléctricos

\section{B. Filtros de cavidades acopladas en plano $H$ vs Filtros de cavidades acopladas en plano $\mathrm{H}$ con postes dieléctricos}

Una vez comprobado que la herramienta CAD proporciona una estructura capaz de recuperar las especificaciones de diseño vamos a verificar las propiedades adicionales que ofrece esta tipología de filtros de microondas frente a los filtros de cavidades acopladas en plano $\mathrm{H}$ todo metálico.

\section{B.1. Reducción en el tamaño}

En primer lugar nos vamos a fijar en la reducción de tamaño de la nueva tipología de filtros. En la tabla 4.14 se compara la longitud total de los prototipos diseñados, sin tener en cuenta las guías de entrada y salida, en tecnología sólo metal y con resonadores dieléctricos. En ella se observa que el uso de los postes dieléctricos permite una reducción en la longitud del filtro de aproximadamente un $35 \%$.

\begin{tabular}{|c|c|c|}
\hline Sólo metal (4.1) & Con postes dieléctricos (4.13) & Reducción \\
\hline $76,88 \mathrm{~mm}$ & $51,25 \mathrm{~mm}$ & $35 \%$ \\
\hline
\end{tabular}

Tabla 4.14: Longitud del filtro de cavidades acopladas en plano $\mathrm{H}$ sin resonadores dieléctricos frente al caso con resonadores dieléctricos 


\section{B.2. Respuesta fuera de banda}

En la figura 4.20 se comparan las respuestas en transmisión del filtro con resonadores sólo metálicos frente a la del filtro con resonadores dieléctricos en banda ancha. Observándose que el uso de los postes dieléctricos mejora el rechazo fuera de la banda de paso y aumenta el ancho de banda libre de espurios.

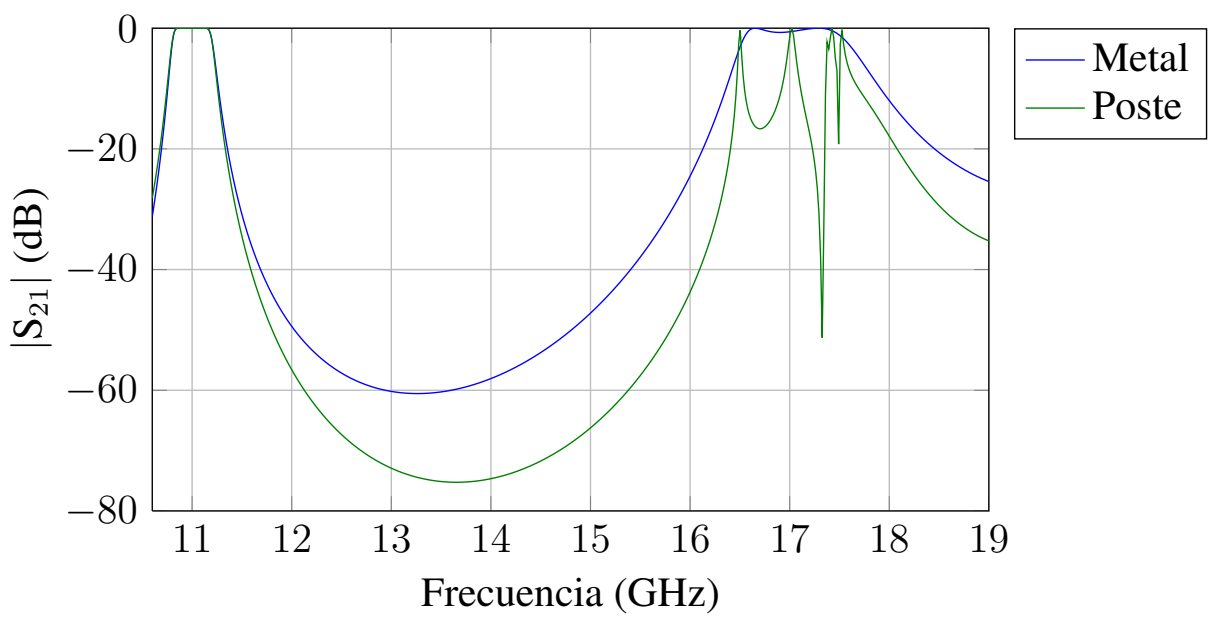

Figura 4.20: Respuesta fuera de banda el filtro de cavidades resonantes en plano $\mathrm{H}$ frente a la respuesta del filtro de cavidades acopladas en plano $\mathrm{H}$ con postes dieléctricos

\section{B.3. Pérdidas en el material dieléctrico}

Uno de los inconvenientes que se esperan de este tipo de filtros es el aumento de las pérdidas de inserción debido a las pérdidas en los postes dieléctricos. Para ver el efecto de estas, la figura 4.21 muestra la respuesta en frecuencia del filtro en la banda de paso utilizando postes dieléctricos con diferentes valores de pérdidas, como se puede apreciar en la vista en detalle mostrada en la figura 4.22 las diferencias son apreciables cuando se tiene un dieléctrico con pérdidas correspondientes a $\tan \delta=10^{-3}$, pero son muy pequeñas cuando se considera un dieléctrico de bajas pérdidas, p. ej. $\tan \delta=10^{-4}$. Por lo tanto, de esta forma se demuestra que si se utilizan dieléctricos de bajas pérdidas, los cuales se pueden obtener con facilidad a las frecuencias de trabajo de esta clase de dispositivos, la respuesta del filtro no se degrada prácticamente.

En la tabla 4.15 se comparan las pérdidas de inserción en la banda de paso de los filtros de cavidades acopladas en plano $\mathrm{H}$ sin resonadores dieléctricos y con resonadores dieléctricos considerando diferentes valores de pérdidas en el material dieléctrico. En ella se puede observar que si se utilizan dieléctricos de bajas pérdidas, tal y cómo se ha indicado anterior- 


\begin{tabular}{|c|c|c|}
\hline Sólo metal & Con postes dieléctricos $\left(\tan \delta=10^{-3}\right)$ & Con postes dieléctricos $\left(\tan \delta=10^{-4}\right)$ \\
\hline $0,021 \mathrm{~dB}$ & $0,32 \mathrm{~dB}$ & $0,047 \mathrm{~dB}$ \\
\hline
\end{tabular}

Tabla 4.15: Pérdidas de inserción del filtro de cavidades acopladas en plano H sin resonadores dieléctricos frente al caso con resonadores dieléctricos

mente, las pérdidas de inserción son del orden de magnitud del filtro de cavidades acopladas sin resonadores dieléctricos.

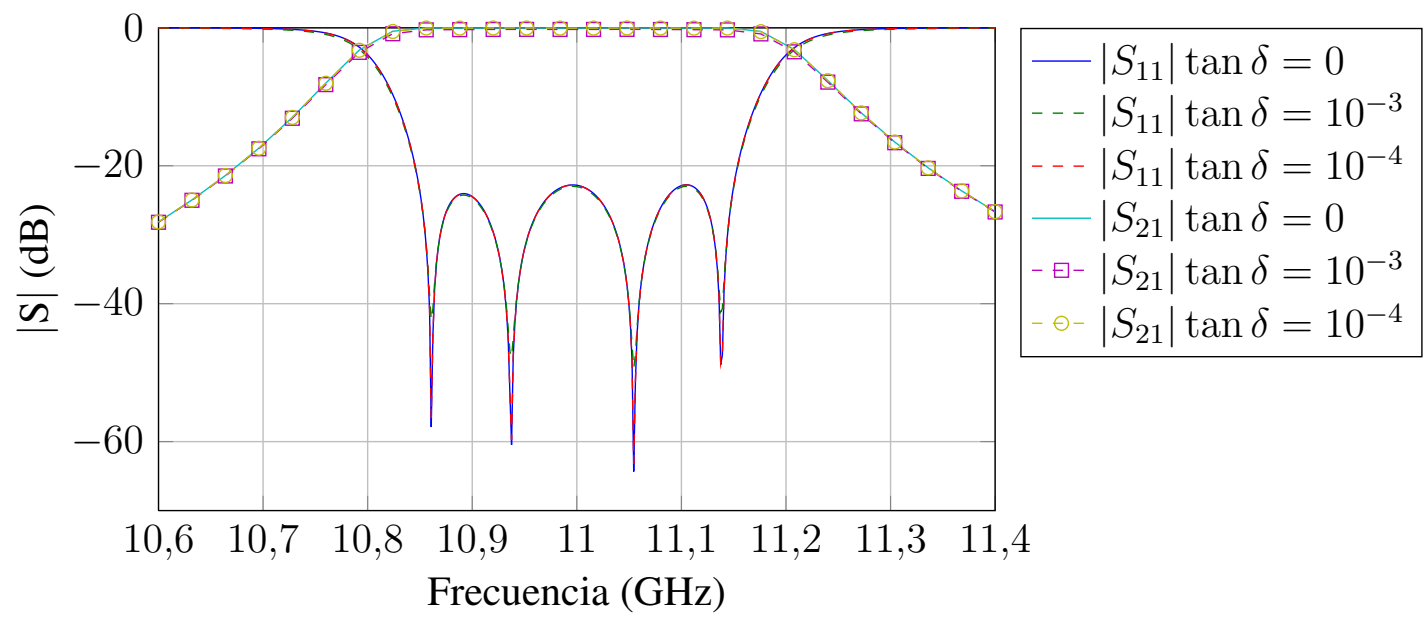

Figura 4.21: Respuesta del filtro de cavidades con resonadores dieléctricos diseñado en los casos: $\tan \delta=0, \tan \delta=10^{-3}, \tan \delta=10^{-4}$.

\section{B.4. Capacidad de manejo de potencia}

A continuación se ha analizado la capacidad de manejo de potencia de este tipo de filtros. Para ello, haciendo uso de la herramienta de análisis presentada en la sección 3.14, se ha calculado la distribución de campo eléctrico a la frecuencia central (Fig. 4.23 ), y el $V M F$ para todas las frecuencias y diferentes valores de pérdidas en el dieléctrico (Fig. 4.24). Cómo se observa en esta última, el valor máximo de $V M F$ se produce a la frecuencia $f=10,78 \mathrm{GHz}$.

En la figura 4.25 se representa la distribución del campo eléctrico para la frecuencia a la cual se produce el $V M F_{\text {max }}$, en ella se puede apreciar que no pasa apenas potencia a través del filtro debido a que este valor se encuentra fuera de la banda de paso.

Es importante recalcar que el efecto de rotura por multipactor se da cuando existe un 


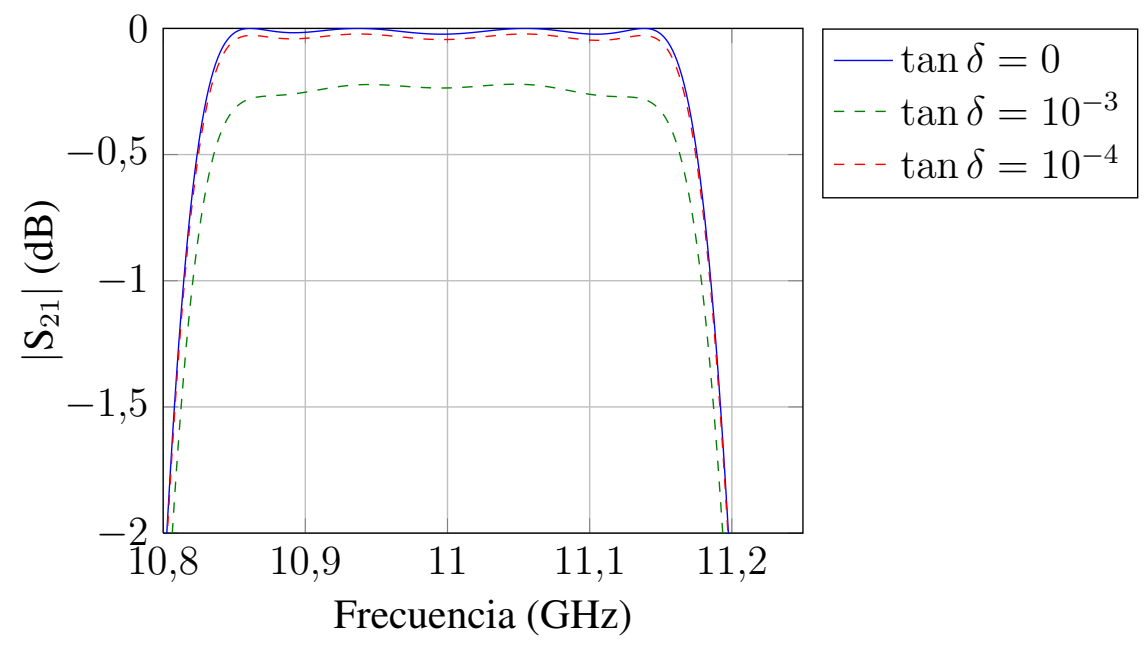

Figura 4.22: Vista en detalle del parámetro $\left|S_{21}\right|$ del filtro de cavidades con resonadores dieléctricos diseñado en los casos: $\tan \delta=0, \tan \delta=10^{-3}, \tan \delta=10^{-4}$.

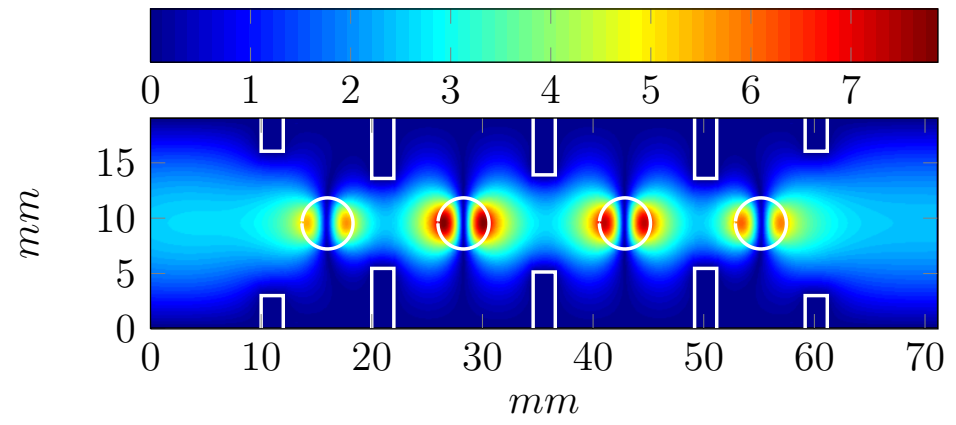

Figura 4.23: Módulo del campo eléctrico $(\mathrm{kV} / \mathrm{m})$ dentro del filtro de cavidades con resonadores dieléctricos para $\mathrm{f}=11 \mathrm{GHz}(\tan \delta=0)$.

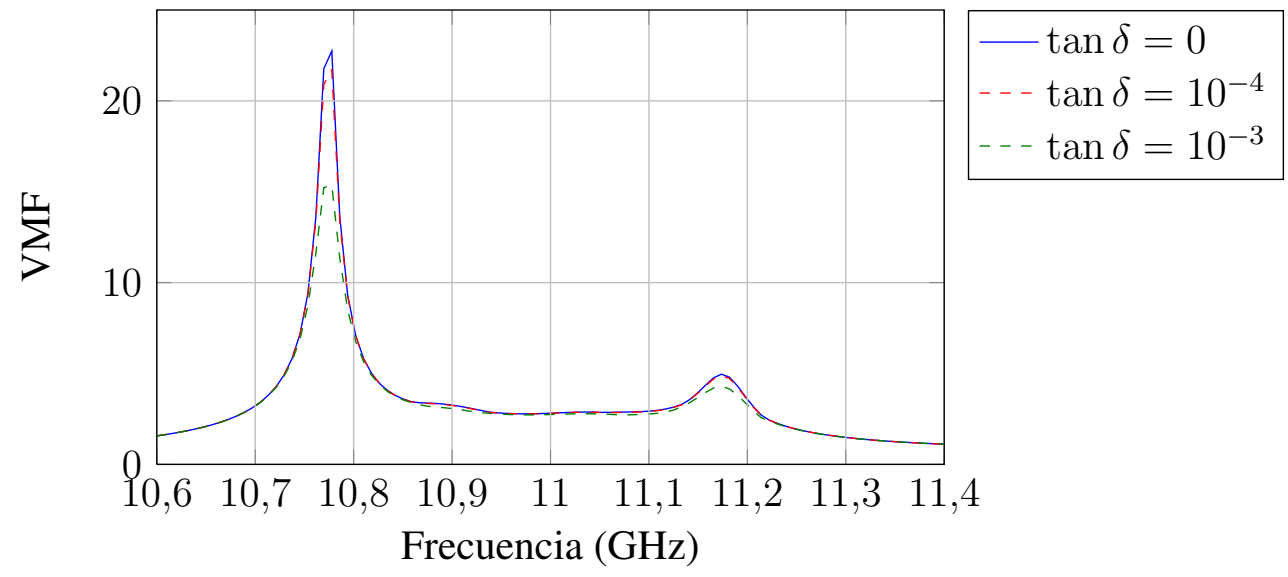

Figura 4.24: VMF para el filtro de cavidades con resonadores dieléctricos en los casos: $\tan \delta=0, \tan \delta=10^{-3}, \tan \delta=10^{-4}$. 


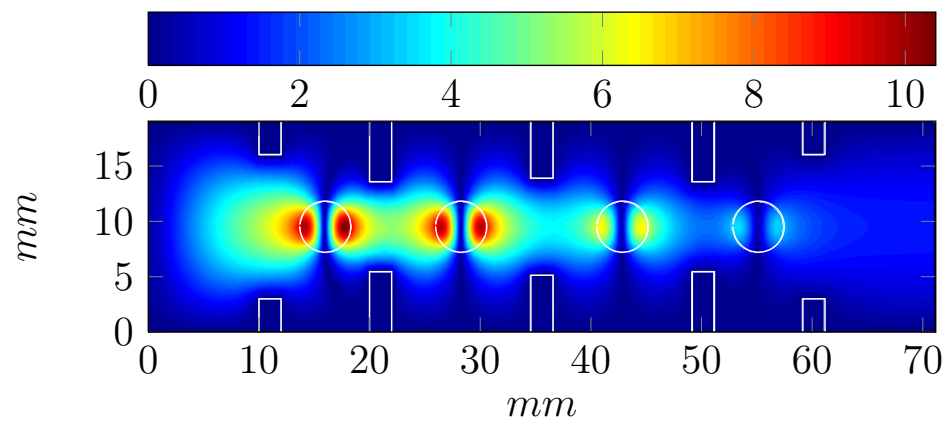

Figura 4.25: Módulo del campo eléctrico $(\mathrm{kV} / \mathrm{m})$ dentro del filtro de cavidades con resonadores dieléctricos para $\mathrm{f}=10,78 \mathrm{GHz}(\tan \delta=0)$.

campo eléctrico normal, de alta potencia, ente dos láminas o superficies metálicas en condiciones de vacío. Por lo tanto, al existir un dieléctrico pasante entre esas dos superficies metálicas la potencia necesaria para una avalancha de electrones sería muchísimo mayor que en el vacío. De hecho, en la práctica se considera que el efecto multipactor únicamente podrá ocurrir entre las dos superficies metálicas si no hay dieléctrico presente. Así pues, al concentrarse el campo eléctrico en el interior de los postes dieléctricos (ver Figs. 4.23, 4.25, 4.26 y 4.27), los niveles de campo en las zonas del filtro vacía son menores, lo que conlleva que se reduzca el valor de $V M F_{\max }$ dentro del filtro y aumente la potencia máxima que podemos introducir en el filtro sin riesgo de rotura por efecto multipactor, aumentando de esa manera la cantidad de potencia de salida del filtro en condiciones de seguridad.

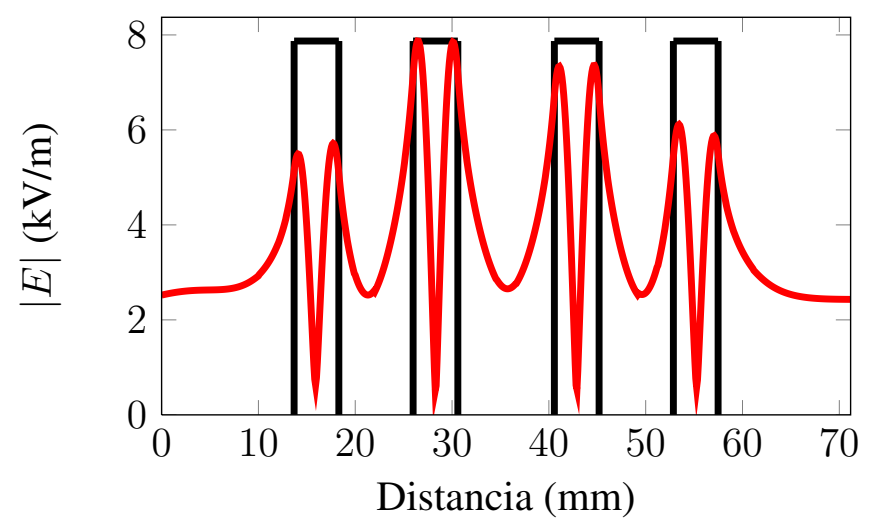

Figura 4.26: Modulo de E en el centro del filtro de cavidades con resonadores dieléctrico para $\mathrm{f}=11 \mathrm{GHz}(\tan \delta=0)$.

Sin embargo, los postes dieléctricos introducen pérdidas que pueden reducir la potencia de salida que aporta el filtro, por lo que a la hora de calcular la potencia máxima sin riesgo de efecto multipactor se deberá tener en cuenta el efecto de dichas pérdidas.

En la figura 4.24 podemos apreciar como el $V M F$ disminuye cuando aumentan las pérdi- 


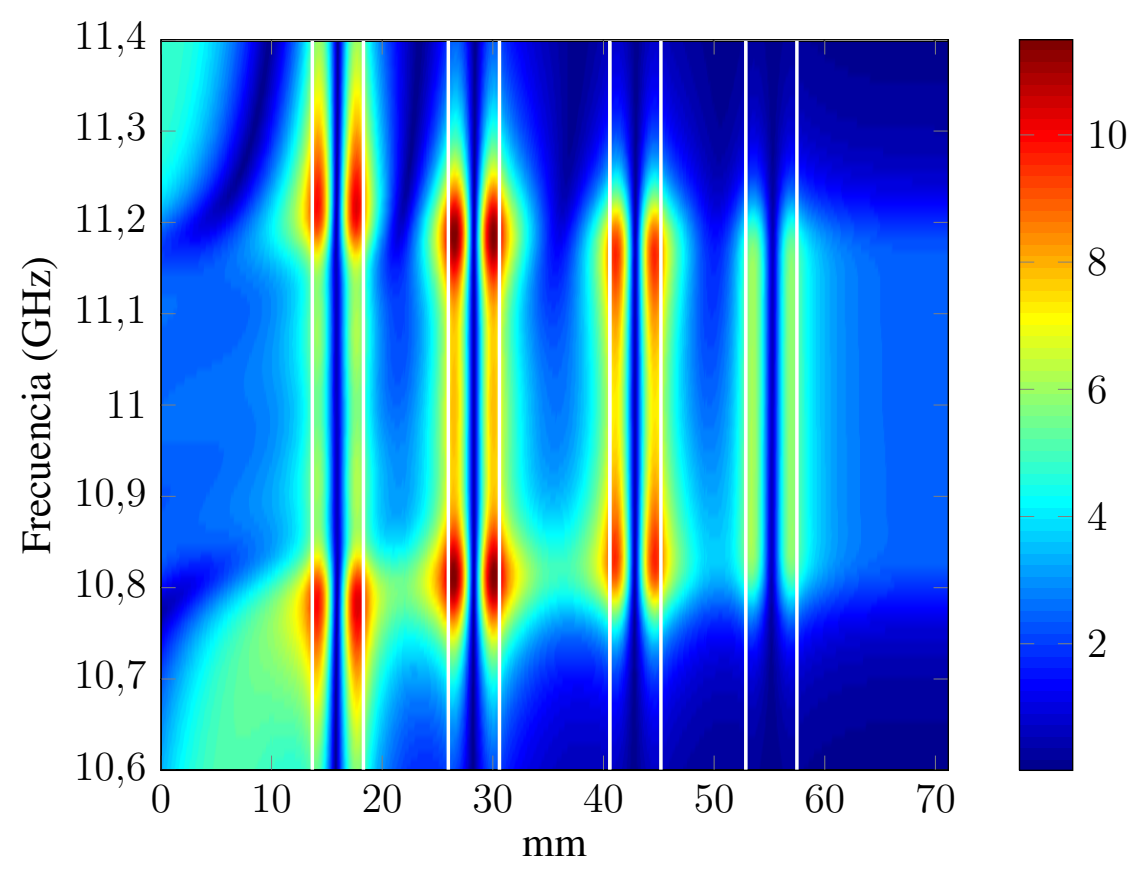

Figura 4.27: Módulo de $\mathrm{E}(\mathrm{kV} / \mathrm{m})$ en el centro del filtro de cavidades con resonadores dieléctricos para cada frecuencia.

das, lo cual se debe a que las pérdidas no dejan que se acumule tanto el campo eléctrico en el interior del filtro. Al ser el $V M F$ más bajo podemos introducir más potencia a la entrada sin riesgo de multipactor (Fig. 4.28), ya que las pérdidas hacen que la potencia disminuya al atravesar el filtro.

A pesar de todo, lo que realmente nos importa es la potencia máxima que ofrece el filtro a la salida y no la potencia a la entrada. Estudiando la figura 4.29 se aprecia que en los casos con pérdidas la potencia máxima de salida sin riesgo de multipactor es siempre menor que en el caso sin pérdidas, lo que es debido al aumento de las pérdidas de inserción debido al uso de materiales dieléctricos.

Si comparamos la potencia máxima sin riesgo a rotura por efecto multipactor a la salida de los filtros con resonadores metálicos (ver Fig. 4.9) y la de los filtros con resonadores dieléctricos (ver Fig. 4.29), el uso de los postes dieléctricos permite pasar mucha más potencia a través del filtro ya que los máximos del campo eléctrico se van a concentrar en los postes donde no se puede producir el efecto de rotura por este efecto. Además, es interesante resaltar que el uso de un dieléctrico de bajas pérdidas (p. ej. $\tan \delta=10^{-4}$ ) no degrada las prestaciones del filtro.

Finalmente, en la tabla 4.16 se comparan la potencia máxima de salida sin riesgo de 


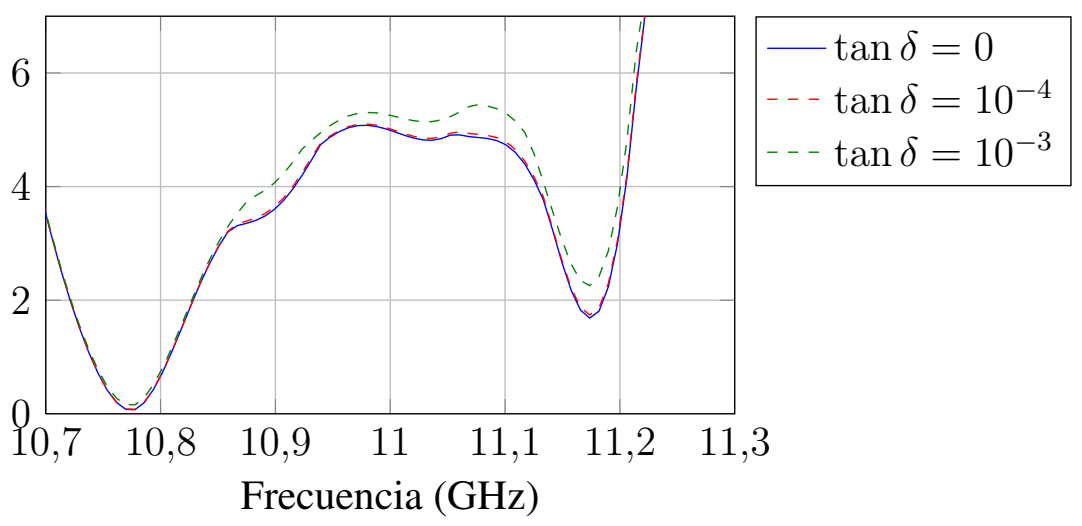

Figura 4.28: Potencia máxima a la entrada $(\mathrm{kW})$ sin riesgo de efecto multipactor para el filtro de cavidades con resonadores dieléctricos en los casos: $\tan \delta=0, \tan \delta=10^{-3}$, $\tan \delta=10^{-4}$.

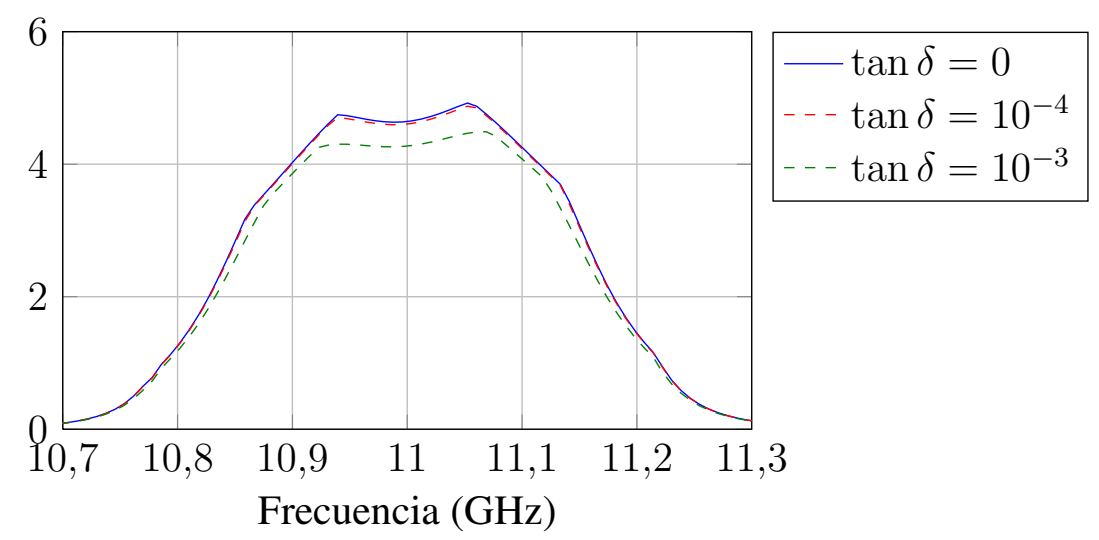

Figura 4.29: Potencia máxima a la salida $(\mathrm{kW})$ sin riesgo de efecto multipactor para el filtro de cavidades con resonadores dieléctricos en los casos: $\tan \delta=0, \tan \delta=10^{-3}$, $\tan \delta=10^{-4}$. 
rotura por multipactor en una banda de $100 \mathrm{MHz}$ para el caso de los filtros de cavidades acopladas en plano $\mathrm{H}$ sin resonadores dieléctricos y con resonadores dieléctricos considerando diferentes valores de pérdidas en el material dieléctrico. En ella se puede observar que el uso de resonadores dieléctricos aumenta la capacidad de manejo de potencia del filtro sin riesgo de rotura por efecto multipactor.

\begin{tabular}{|c|c|c|}
\hline Sólo metal & Con postes dieléctricos $\left(\tan \delta=10^{-3}\right)$ & Con postes dieléctricos $\left(\tan \delta=10^{-4}\right)$ \\
\hline $2478 \mathrm{~W}$ & $4262 \mathrm{~W}$ & $4595 \mathrm{~W}$ \\
\hline
\end{tabular}

Tabla 4.16: Potencia máxima a la salida del dispositivo sin riesgo de multipactor para el caso de filtros de cavidades acopladas en plano $\mathrm{H}$ sin resonadores dieléctricos frente al caso con resonadores dieléctricos

\section{Fabricación y medida}

El último paso en nuestra comparación entre tipologías de filtros consiste en la fabricación y medida de un prototipo con las dimensiones obtenidas durante el proceso de diseño (ver Tbl. 4.13). A la hora de fabricar este prototipo fue necesario abordar por un lado la elección del material dieléctrico empleado y por el otro la técnica de manufactura del cuerpo del filtro.

Respecto a la primera consideración fue necesario encontrar un material dieléctrico cuya permitividad eléctrica relativa fuera igual a 19,5 a la frecuencia de trabajo y que tuviera bajas pérdidas. Tras numerosas conversaciones con diferentes proveedores de materiales dieléctricos se decidió emplear el material D20 (CaMgTi) de Morgan Electro Ceramics. Este material tiene unas propiedades que lo hacen muy interesante ya que cumple con las características eléctricas requeridas $\left(\varepsilon_{r}=20 \pm 1, Q=6000 @ 12 \mathrm{GHz}\right)$ además de estar estabilizado térmicamente en un amplio rango de temperaturas $\left(\left[-30^{\circ} \mathrm{C}, 85^{\circ} \mathrm{C}\right]\right)$ cubriendo por completo el margen de funcionamiento del dispositivo.

Una vez determinado el material de los postes dieléctricos se procedió a fabricar el cuerpo del filtro en aluminio utilizando fresado y eletroerosión en las esquinas internas de las cavidades para eliminar las esquinas redondeadas. Siendo la tolerancia nominal del proceso de fabricación de $30 \mu \mathrm{m}$. Una vez fabricado éste, se fijaron los postes dieléctricos utilizando una resina epoxi. El prototipo fabricado se muestra en la figura 4.30.

En la figura 4.31 se comparan la respuesta medida del prototipo fabricado con la respuesta del filtro diseñado. Se aprecia claramente que el filtro se ha desplazado en frecuencia aproximadamente $150 \mathrm{MHz}$ y las pérdidas de retorno se han reducido $15 \mathrm{~dB}$. Para acotar la fuente de error, al igual que se hizo con el prototipo fabricado en el apartado 4.1 se realizó un control dimensional de la estructura y de los postes dieléctricos. Obteniéndose una deriva sis- 


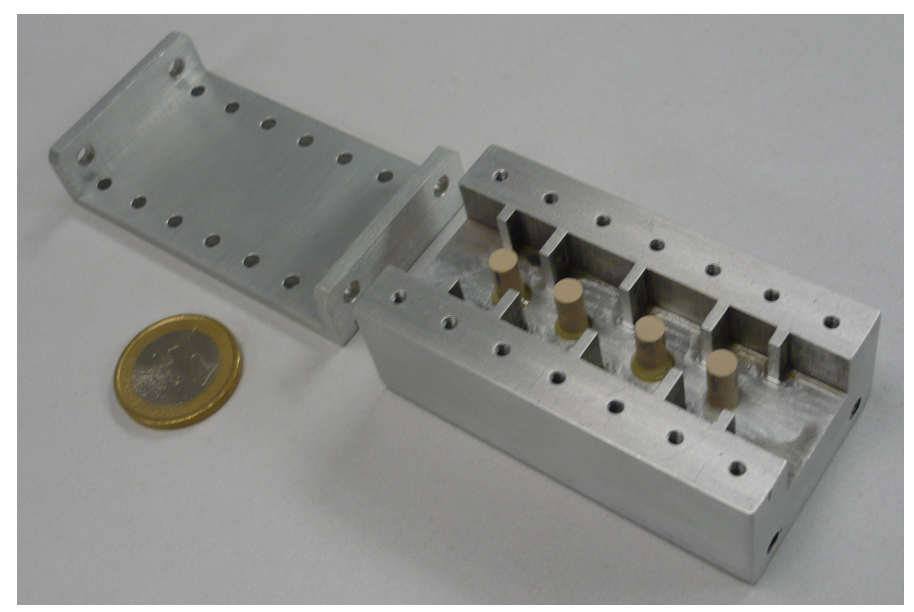

Figura 4.30: Filtro de cavidades acopladas en plano $\mathrm{H}$ con postes dieléctricos fabricado.

temática de $-80 \mu \mathrm{m}$ en las dimensiones físicas del cuerpo del filtro. Sin embargo, tal y como se muestra en la tabla 4.17 en los diámetros de los postes había variaciones máximas de $\pm 20 \mu \mathrm{m}$, pero que esa deriva era aleatoria, tal y como se muestra en la tabla 4.17, en ella se indican tres medidas del diámetro para cada poste: parte superior, centro y parte inferior.

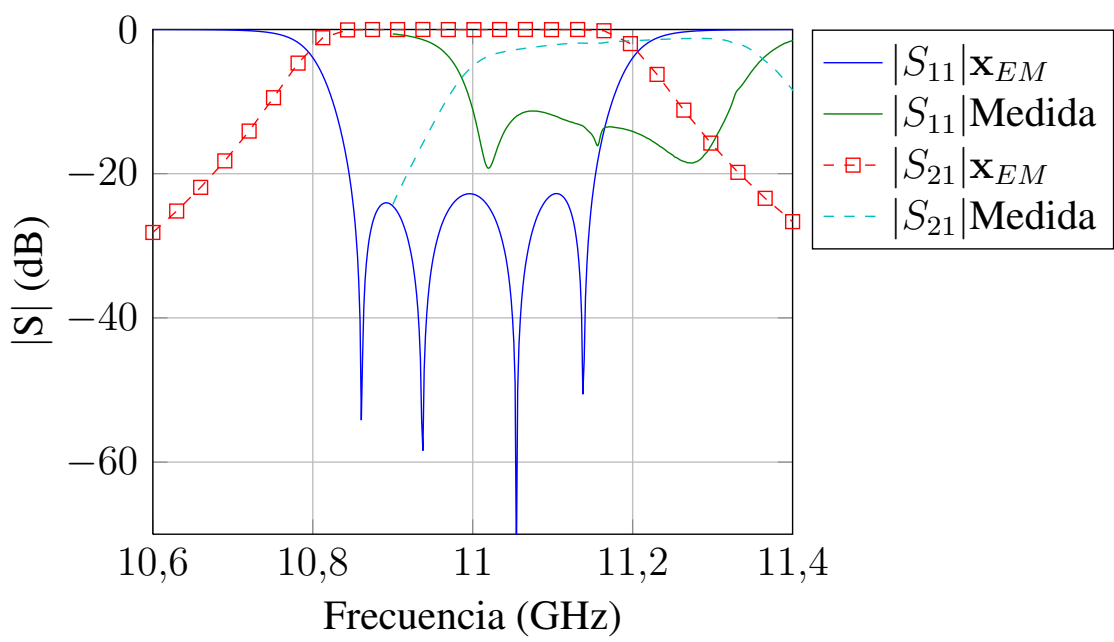

Figura 4.31: Respuesta en frecuencia del prototipo fabricado respecto al filtro diseñado

Para determinar la fuente del error se ha introducido en el diseño la distorsión producida por la deriva en las dimensiones producida por los errores de fabricación del cuerpo y de los postes dieléctricos. Como se observa en la figura 4.32 la deriva en las dimensiones produce una reducción en las pérdidas de retorno pero no justifica el desplazamiento en frecuencia de la respuesta. Por lo tanto, se supuso que el origen del problema podría deberse a la elevada 


\begin{tabular}{|c|c|c|c|c|}
\hline Medida & Posición & Valor nominal $(\mathrm{mm})$ & Valor real $(\mathrm{mm})$ & Deriva $(\mathrm{mm})$ \\
\hline \multirow{4}{*}{$d_{1}$} & Superior & 4,62 & 4,627 & 0,007 \\
\cline { 2 - 5 } & Centro & 4,62 & 4,639 & 0,019 \\
\cline { 2 - 5 } & Inferior & 4,62 & 4,637 & 0,017 \\
\hline \multirow{4}{*}{$d_{2}$} & Superior & 4,62 & 4,640 & 0,020 \\
\cline { 2 - 5 } & Centro & 4,62 & 4,642 & 0,022 \\
\cline { 2 - 5 } & Inferior & 4,62 & 4,641 & 0,021 \\
\hline \multirow{3}{*}{$d_{3}$} & Superior & 4,62 & 4,599 & $-0,021$ \\
\cline { 2 - 5 } & Centro & 4,62 & 4,612 & $-0,008$ \\
\cline { 2 - 5 } & Inferior & 4,62 & 4,616 & $-0,004$ \\
\hline \multirow{3}{*}{$d_{4}$} & Superior & 4,62 & 4,625 & 0,005 \\
\cline { 2 - 5 } & Centro & 4,62 & 4,619 & $-0,001$ \\
\cline { 2 - 5 } & Inferior & 4,62 & 4,599 & $-0,0021$ \\
\hline
\end{tabular}

Tabla 4.17: Control dimensional del diámetro de los cilindros

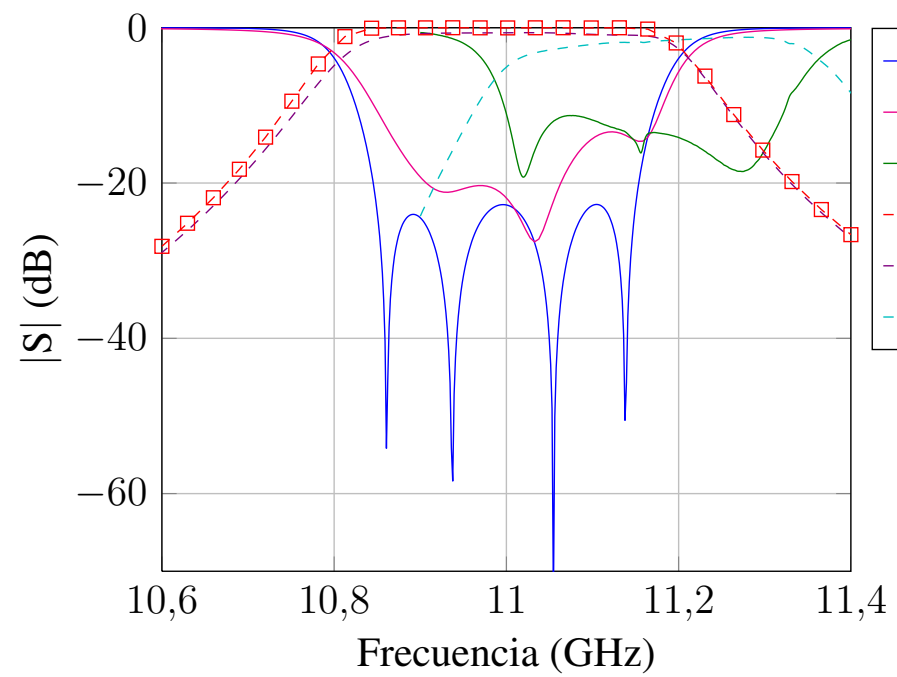

\begin{tabular}{|l|}
$-\left|S_{11}\right| \mathbf{x}_{E M}$ \\
$-\left|S_{11}\right|$ Correción \\
$-\left|S_{11}\right|$ Medida \\
- - $\left|S_{21}\right| \mathbf{x}_{E M}$ \\
$--\left|S_{21}\right|$ Corrección \\
$--\left|S_{21}\right|$ Medida
\end{tabular}

Figura 4.32: Respuesta en frecuencia del prototipo con correcciones del control dimensional 
tolerancia en la permitividad eléctrica relativa $( \pm 1)$ y a las pérdidas del material dieléctrico.

Para poder caracterizar las propiedades eléctricas del material dieléctrico, se fabricó una sección de guía de onda estándar WR-90 en cuyo centro se insertó el cilindro dieléctrico (ver Fig. 4.33), y se midió la respuesta en frecuencia de esa estructura. A continuación utilizando la herramienta de análisis descrita en 3.12 junto el algoritmo de optimización de descenso de simplex se obtuvo el valor de permitividad eléctrica que proporciona la respuesta medida. En la figura 4.34 se muestra la comparación entre la respuesta medida y la simulada para una permitividad eléctrica relativa de 18,85 y una tangente de pérdidas de 0,002 .

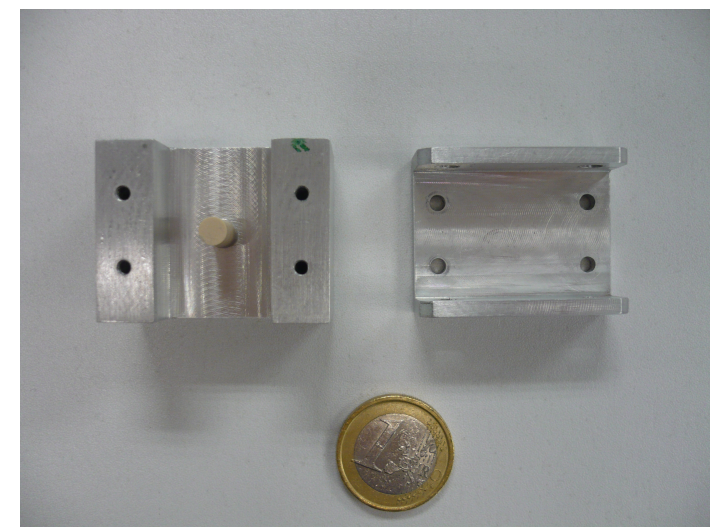

(a) Planta

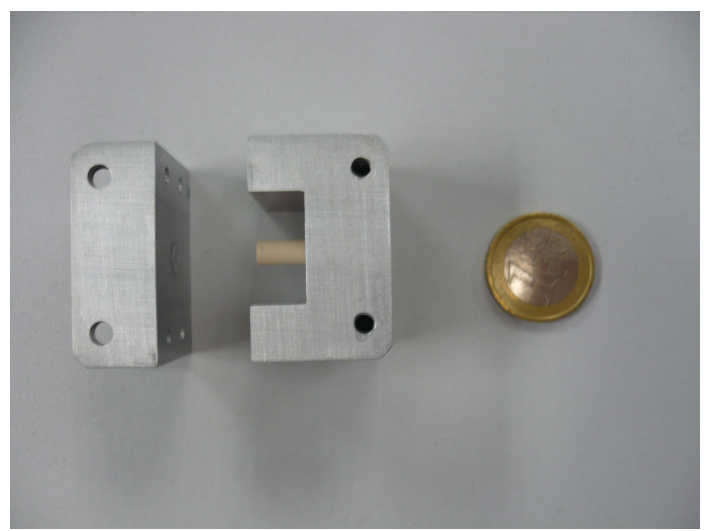

(b) Alzado

Figura 4.33: Sección de guía de onda WR90 con cilindro dieléctrico insertado.

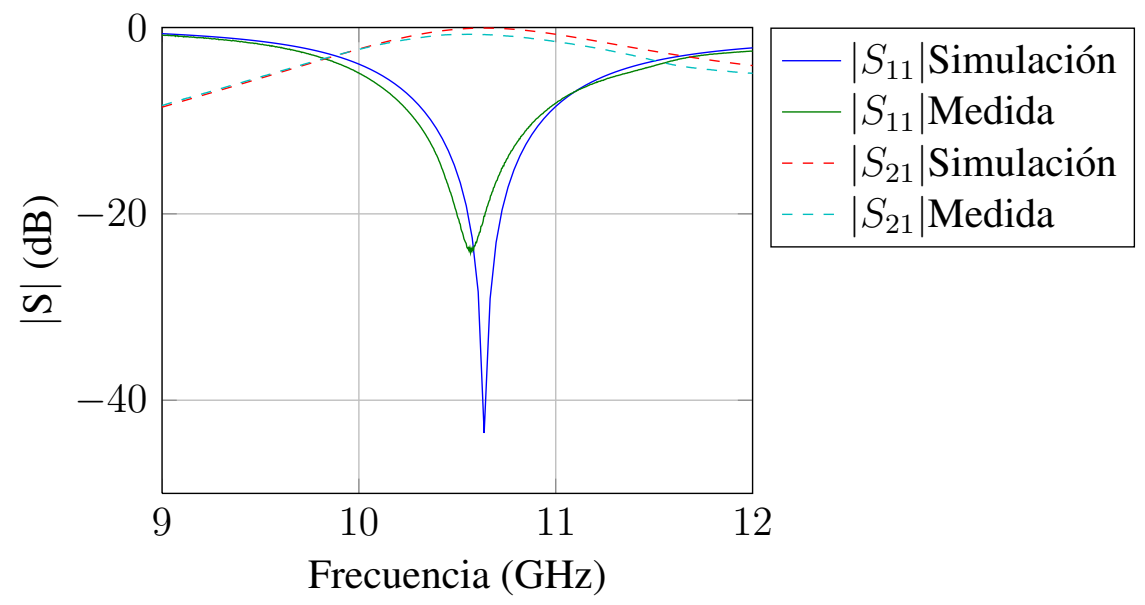

Figura 4.34: Respuesta en frecuencia de un poste dieléctrico en guía de onda WR-90 simulada y medida

Una vez determinados los valores de la permitividad eléctrica relativa y las pérdidas de inserción del material dieléctrico a la frecuencia de trabajo, se han introducido en el diseño 
mostrándose el resultado en la figura 4.35. En ella se aprecia que la respuesta medida y la respuesta del diseño corregido están centradas a la misma frecuencia con prácticamente el mismo ancho de banda. Con respecto a las pérdidas de inserción adicionales que presenta el prototipo fabricado se pueden justificar con las pérdidas que introducen los conectores al realizar la medida. De esta forma se demuestra que la principal fuente de error en el proceso de manufactura de este tipo de dispositivos son las características eléctricas del material dieléctrico. Por lo tanto, antes de diseñar un filtro de cavidades acopladas en plano $\mathrm{H}$ con postes dieléctricos será necesario caracterizar completamente el compuesto dieléctrico a la frecuencia de trabajo. Utilizándose durante el proceso de diseño los valores medidos en lugar de los datos de catálogo.

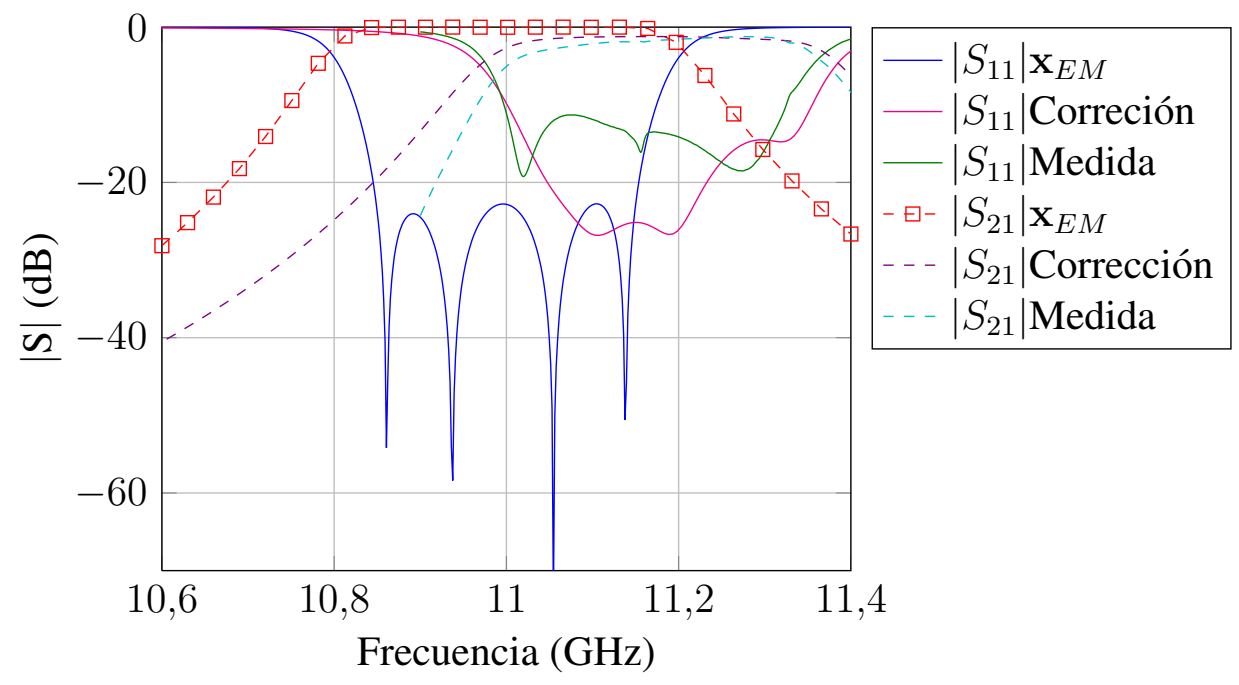

Figura 4.35: Respuesta en frecuencia del prototipo con respecto al filtro diseñado con $\varepsilon_{r}=$ $18,85, \tan \delta=0,002$ considerando el control dimensional realizado

\subsubsection{Matriz de dispersión (S)}

La principal limitación de la herramienta CAD presentada en los apartados anteriores es la necesidad de integrar la computación evolutiva dentro de la fase de síntesis del punto inicial. Para solucionar este problema en este apartado se presenta un procedimiento alternativo de obtención del punto inicial.

El algoritmo de síntesis nos debe proporcionar una estimación inicial de las dimensiones de la estructura bajo diseño (ver Fig. 4.17), es decir, el parámetro de diseño de las ventanas de acoplo, la longitud de las cavidades resonantes y el radio de los postes dieléctricos. Dado que la topología de filtros de cavidades acopladas implementa el prototipo de filtro paso banda compuesto por inversores y cavidades resonantes, se puede ajustar el parámetro de diseño de 
cada ventana de acoplo para proporcionar la constante $K$ del inversor del circuito equivalente [MJY80], mientras que las longitudes de las cavidades y los radios de los postes dieléctricos se ajustan para que su matriz de dispersión coincida con la de una cavidad resonante.

Si tenemos en cuenta que la matriz de dispersión $\mathrm{S}$ de una cavidad a la frecuencia de resonancia es de la forma:

$$
\mathbf{S}=\left(\begin{array}{cc}
0 & -1 \\
-1 & 0
\end{array}\right)
$$

El algoritmo de síntesis obtiene el radio del poste dieléctrico que hace que el parámetro $S_{11}$ de la cavidad resonante sea igual a 0 a la frecuencia de resonancia, y a continuación ajusta la longitud de la cavidad para que la fase del parámetro $S_{21}$ sea igual a $-\pi$ radianes.

Esta nueva técnica de síntesis del punto inicial se integró en la herramienta CAD presentada en los apartados anteriores con la excepción de que sí se van a tener en cuenta los radios de los postes dieléctricos en la fase de optimización. Para evaluar el rendimiento de la versión actualizada de la herramienta CAD se ha vuelto a diseñar el filtro patrón propuesto en el apartado anterior.

En primer lugar se analizará el proceso de obtención del punto inicial $\left(\mathbf{x}_{I N I}\right)$. Para ello en la figura 4.36 se muestra la comparación entre la respuesta ideal buscada y la respuesta del modelo grueso en el punto inicial $\mathbf{x}_{I N I}$ obtenido en tan sólo 3,7 s. En ella se puede comprobar que el punto inicial obtenido tiene el tipo de respuesta deseada pero su ancho de banda se ha reducido a $130 \mathrm{MHz}$. Esta reducción en el ancho de banda, como se muestra en la tabla 4.19, es debida a la excesiva longitud de las cavidades resonantes obtenidas, muy superiores a las del filtro sin postes dieléctricos.

La estructura obtenida durante la fase de síntesis se utilizará como punto de partida $\left(\mathbf{x}_{O S}^{(0)}\right)$ de la estrategia de optimización multinivel implementada, con la salvedad que debido a la excesiva longitud de las cavidades obtenidas se considera que el valor inicial de las cavidades es igual a $\lambda_{g} / 2$ a la frecuencia central del filtro. En la figura 4.36 se representa la respuesta de $\mathbf{x}_{O S}^{(0)}$ comparada con la respuesta ideal buscada. Cómo se observa, el hecho de considerar la nueva longitud hace que el ancho de banda se reduzca todavía más y la respuesta del filtro esté muy alejada de la deseada.

Al igual que en ocasiones anteriores para evaluar el funcionamiento de la estrategia de optimización implementada nos debemos fijar en la figura 4.37. En ella se puede observar que la respuesta del filtro diseñado consigue recuperar la respuesta ideal buscada.

Para evaluar el rendimiento de la nueva estrategia de obtención inicial en la tabla 4.18 se comparan la eficiencia y la precisión de la herramienta CAD que utiliza los algoritmos evo- 


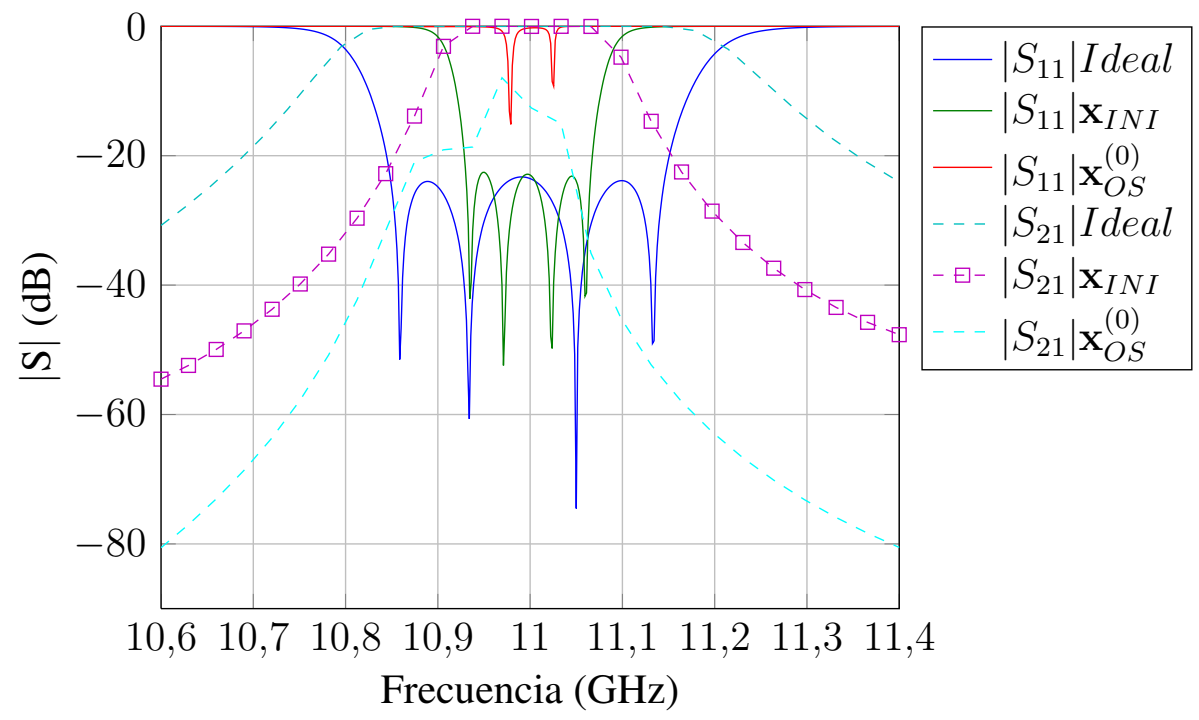

Figura 4.36: Respuesta del modelo grueso en $\mathbf{x}_{I N I} \mathrm{y} \mathbf{x}_{O S}^{(0)}$ frente a la respuesta ideal

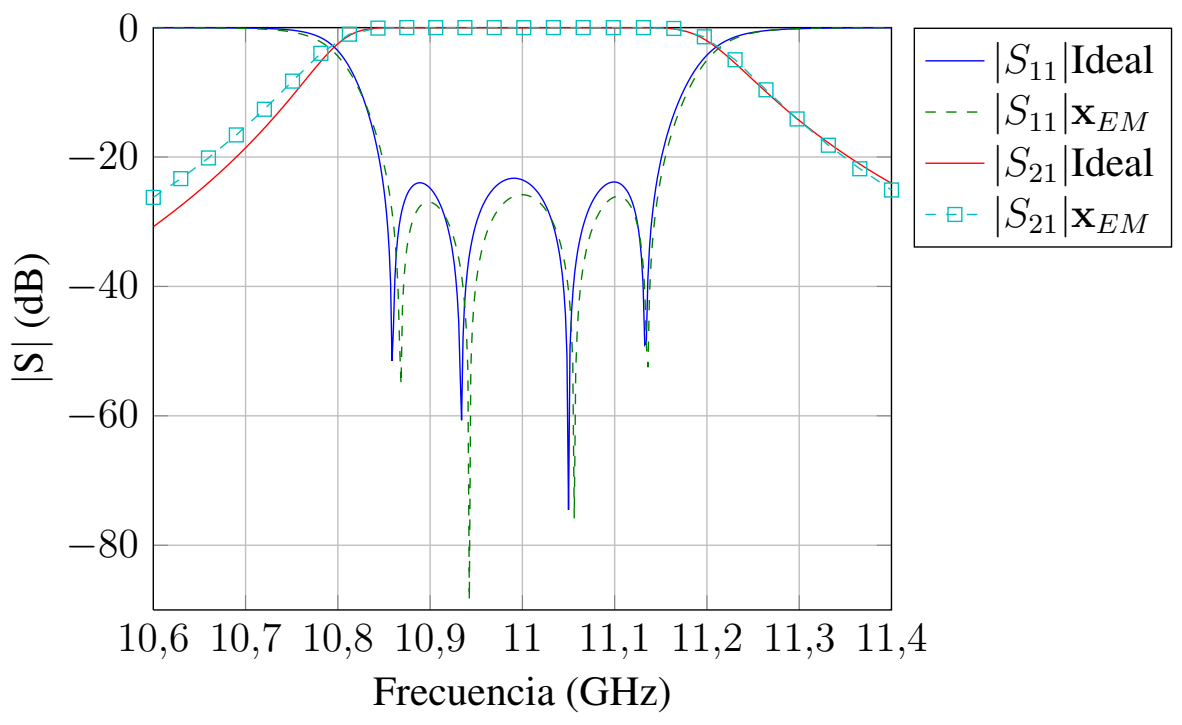

Figura 4.37: Respuesta del modelo fino en $\mathrm{x}_{E M}$ frente a la respuesta ideal 
lutivos para calcular el punto inicial y la herramienta CAD que utiliza la matriz de dispersión para calcular el punto inicial. A priori podría considerarse que la nueva estrategia proporciona un punto inicial peor, ya que el valor de $U\left(\mathbf{x}_{O S}^{(0)}\right)$ es más elevado, pero esto es debido a que la longitud inicial se considera que es igual a $\lambda_{g} / 2$. Sin embargo el resto de parámetros están próximos a la solución óptima. Esto produce que el proceso de diseño converja más rápidamente a la solución final. También se observa que el error final del proceso de diseño es mayor. Sin embargo tal y cómo se puede comprobar en la figura 4.37, el filtro diseñado cumple las especificaciones de diseño.

\begin{tabular}{|l|c|c|c|c|}
\hline Algoritmo Punto Inicial & $U\left(\mathbf{x}_{O S}^{(0)}\right)$ & $U\left(\mathbf{x}_{E M}\right)$ & $\mathrm{nF}$ & Tiempo \\
\hline Evolutivos & 248,71 & 0,0106 & 3457 & $5 \mathrm{~h} 31^{\prime} 3^{\prime \prime}$ \\
\hline Matriz S & 406,358 & 1,172 & 1482 & $21^{\prime} 12^{\prime \prime}$ \\
\hline
\end{tabular}

Tabla 4.18: Rendimiento del proceso de diseño

Finalmente, en la tabla 4.19 se muestran las dimensiones iniciales de los parámetros de diseño obtenidos tras la estrategia de síntesis del punto inicial $\left(\mathrm{x}_{I N I}\right)$, los valores iniciales utilizados por la estrategia de optimización $\left(\mathbf{x}_{O S}^{(0)}\right)$ y la solución final del proceso de diseño $\left(\mathbf{x}_{E M}\right)$

\begin{tabular}{|c|c|c|c|}
\hline Dimensiones & $\mathbf{x}_{I N I}$ & $\mathbf{x}_{O S}^{(0)}$ & $\mathbf{x}_{E M}$ \\
\hline$a$ & \multicolumn{3}{|c|}{$19.05 \mathrm{~mm}$} \\
\hline$b$ & \multicolumn{3}{|c|}{$2.525 \mathrm{~mm}$} \\
\hline$t$ & \multicolumn{3}{|c|}{$10 \mathrm{~mm}$} \\
\hline$w_{1}, w_{5}$ & $10.437 \mathrm{~mm}$ & $10.437 \mathrm{~mm}$ & $13.596 \mathrm{~mm}$ \\
\hline$w_{2}, w_{4}$ & $7.022 \mathrm{~mm}$ & $7.022 \mathrm{~mm}$ & $7.261 \mathrm{~mm}$ \\
\hline$w_{3}$ & $6.461 \mathrm{~mm}$ & $6.461 \mathrm{~mm}$ & $6.535 \mathrm{~mm}$ \\
\hline$l_{1}, l_{4}$ & $37.199 \mathrm{~mm}$ & $19.05 \mathrm{~mm}$ & $8.664 \mathrm{~mm}$ \\
\hline$l_{2}, l_{3} l_{5}$ (líneas de entrada/salida) & $39.084 \mathrm{~mm}$ & $19.05 \mathrm{~mm}$ & $9.321 \mathrm{~mm}$ \\
\hline$r_{1}, r_{4}$ & $2.242 \mathrm{~mm}$ & $2.242 \mathrm{~mm}$ & $2.315 \mathrm{~mm}$ \\
\hline$r_{2}, r_{3}$ & $2.242 \mathrm{~mm}$ & $2.242 \mathrm{~mm}$ & $2.390 \mathrm{~mm}$ \\
\hline Longitud total (sin líneas de entrada/salida) & $162.57 \mathrm{~mm}$ & $86.2 \mathrm{~mm}$ & $45.97 \mathrm{~mm}$ \\
\hline Longitud total & $182.57 \mathrm{~mm}$ & $106.2 \mathrm{~mm}$ & $65.97 \mathrm{~mm}$ \\
\hline
\end{tabular}

Tabla 4.19: Dimensiones del filtro de 4 cavidades acopladas en plano $\mathrm{H}$ con resonadores dieléctricos 


\subsection{Filtros evanescentes con resonadores dieléctricos}

El constante aumento de los servicios de telecomunicación prestados por los satélites ha supuesto un incremento de los requisitos técnicos de los sistemas de filtrado. Sin embargo, este aumento en las prestaciones de los filtros de microondas debe ir acompañado con una reducción en la masa y volumen de los dispositivos, manteniendo una alta estabilidad en la respuesta en frecuencia frente a fluctuaciones en su temperatura de funcionamiento, junto con una gran capacidad de manejo de potencia (en el caso de filtros a la salida). Además, de ser lo suficientemente robustos para soportar el rigor del proceso de lanzamiento.

Con el objetivo de cumplir estos requisitos, durante los años 70 se desarrollaron dos tipologías de filtros muy utilizadas en la actualidad, los filtros en modo dual y los filtros en modo evanescente. Si nos centramos en esta última tecnología, su implementación clásica está formada por un tramo de guía de onda rectangular al corte, denominada housing, con inserciones metálicas en su interior (ridges). De forma que escogiendo la separación entre las inserciones metálicas se consigue una respuesta de tipo paso banda. Esta tecnología tiene cómo ventaja que los filtros diseñados tienen un tamaño compacto con unas dimensiones reducidas presentando un gran ancho de banda libre de espurios. Sin embargo, la presencia de las inserciones metálicas limita la capacidad de manejo de potencia del filtro. Para solucionar esta limitación, conservando las prestaciones de los filtros en modo evanescente, en esta tesis se propone el uso de postes dieléctricos de sección cilíndrica en lugar de inserciones metálicas y para ello se ha desarrollado una herramienta CAD de este tipo de dispositivos de microondas.

Siendo los parámetros de diseño de este tipo de filtros (ver Fig. 4.38):

- Anchura $\left(a_{h}\right)$ y altura $\left(b_{h}\right)$ de la guía al corte (housing).

- Longitudes $\left(l_{i}\right)$ de los tramos de guía al corte (housing).

- Radios $\left(r_{i}\right)$ de los postes dieléctricos.

Seguidamente se enumeran las principales características de este tipo de filtros que pueden controlarse mediante los citados parámetros de diseño:

- Pérdidas de inserción (Factor de calidad Q). Las pérdidas de este tipo de filtros están principalmente asociadas a las pérdidas del material dieléctrico que componen los postes cilíndricos. En consecuencia, las pérdidas de inserción serán mayores (y por tanto el factor de calidad Q del filtro disminuirá) cuanto mayor sea el valor de la $\tan \delta$ de los postes dieléctricos. 


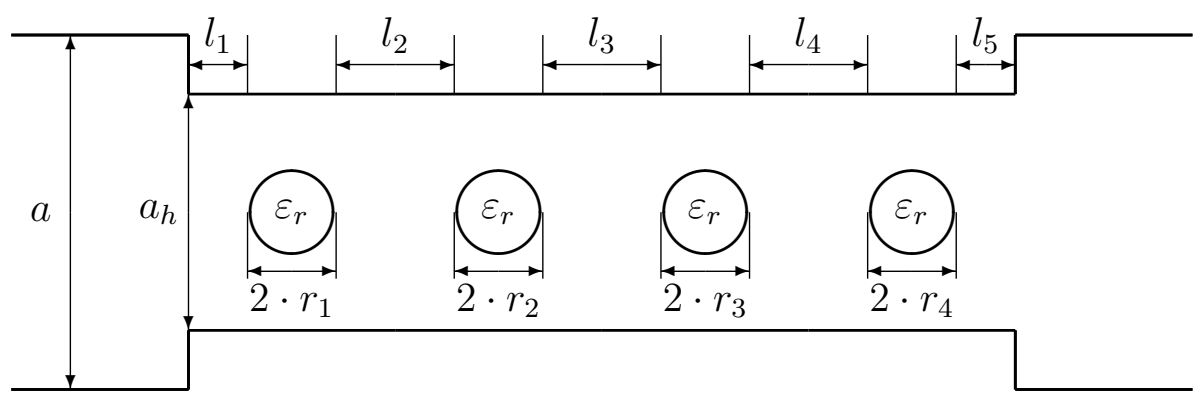

Figura 4.38: Filtro de modo evanescente con postes dieléctricos.

- Ancho de banda del filtro. Queda limitado por la longitud de las guías al corte $\left(l_{i}\right)$ y por la discontinuidad entre la guía de entrada del filtro y el housing. Este ancho de banda será mayor cuanto menor sea la longitud del primer inversor (menor tramo de guía housing al corte) y la discontinuidad entre las guías de entrada y el housing.

- Posición en frecuencia. La inserción de los postes dieléctricos hace que el tramo de guía de onda parcialmente relleno de material dieléctrico entre en propagación, por lo que el radio de los postes dieléctricos determinará la posición en frecuencia de la respuesta paso banda del filtro.

- Posición de la primera frecuencia espuria. La aparición de frecuencias espurias se da cuando la longitud de los tramos de guía al corte se hacen igual a $\lambda_{g} / 2$ con el modo fundamental $\mathrm{TE}_{10}$ en propagación. Por lo tanto, el valor de esta frecuencia espuria quedará determinado por la anchura del housing $\left(a_{h}\right)$.

Por lo tanto, gracias a la correcta elección de los parámetros de diseño, se puede conseguir de forma simultánea diferentes objetivos de diseño: una determinada respuesta eléctrica fijando el ancho de banda libre de espurios con un tamaño mínimo y minimizando el riesgo de rotura por multipactor debido a la eliminación de las inserciones metálicas. Sin embargo, una de las limitaciones que surge al diseñar este tipo de estructuras es la falta de una técnica de síntesis válida para este tipo de estructuras. Por lo tanto, el proceso de diseño implementado en la herramienta CAD es el siguiente:

- En primer lugar se ajustan las dimensiones del housing para conseguir que la primera frecuencia espuria esté por encima de un determinado valor.

- Se ajusta el valor de $a_{h}$ para que el modo fundamental $\mathrm{TE}_{10}$ entre en propagación en el housing a una frecuencia superior a la especificada.

$$
f_{c \mathrm{TE}_{10}}=\frac{c_{0}}{2 \cdot a_{h}}>f_{\text {esp }} \Rightarrow a_{h}<\frac{c_{0}}{2 \cdot f_{\text {esp }}}
$$


- Debido a que las herramientas de simulación incluidas en la herramienta CAD sólo son capaces de analizar estructuras invariantes en altura, ver secciones 3.10 y 3.12, el valor de $b_{h}$ se ajusta para que sea igual al valor de la guía de entrada.

- Se determina el valor de las longitudes de los tramos de guía al corte $\left(l_{i}\right)$ y el radio de los postes dieléctricos $\left(r_{i}\right)$ que permiten recuperar una determinada respuesta eléctrica. Para ello, se utiliza la estrategia de optimización descrita en el apartado 3.10. Tal y como se indica, debido al elevado acoplo entre los diferentes postes dieléctricos, no se ha podido utilizar la técnica de la segmentación de la estructura.

Como se observa en el proceso de diseño implementado primero se fija el ancho de banda libre de espurios mediante la elección del tamaño del housing para posteriormente recuperar la respuesta deseada. Esto nos hace plantearnos la idea de maximizar la respuesta libre de espurios a la vez que se recupera la respuesta deseada, es decir, realizar una estrategia de optimización multiobjetivo. Para ello en el apartado 3.11 se presenta una estrategia de diseño multiobjetivo basada en una implementación mejorada del algoritmo Goal Attainment. Esta mejora, le permite por un lado considerar diferentes objetivos de diseño con diferentes pesos a la vez que tiene en cuenta las restricciones en los parámetros de diseño. Sin embargo, tal y cómo se concluye en el apartado 3.11, el conjunto de soluciones posibles de ancho de banda libre de espurios es discreto.

El procedimiento de diseño que se acaba de resumir, se ha integrado dentro de una herramienta CAD la cual se ha aplicado con éxito al diseño de filtros en modo evanescente con postes dieléctricos considerando diferentes especificaciones eléctricas: bandas de frecuencia, ancho de banda, permitividad eléctrica del poste dieléctrico, etc. Sin embargo, para analizar las características de esta nueva topología de filtros se ha diseñado un prototipo que cumple las mismas especificaciones que el dispositivo patrón utilizado en apartados anteriores. Por lo tanto, se va a diseñar un filtro de microondas en banda $X$ de 4 cavidades para aplicaciones espaciales, con una respuesta de tipo Chebyshev centrada a $11 \mathrm{GHz}$ y un ancho de banda de $300 \mathrm{MHz}$, con las siguientes especificaciones:

$$
\begin{cases}L_{R} \leq 3 d B, & \text { para } f \leq 10,8 \mathrm{GHz} \text { y } f \geq 11,2 \mathrm{GHz} \\ L_{R} \geq 25 d B, & \text { para } 10,85 \leq f \leq 11,15 \mathrm{GHz} \\ f_{\text {esp }} \geq 18 \mathrm{GHz} & \end{cases}
$$

A partir de estas especificaciones, se ha considerado que las guías de entrada y salida son guías de onda con dimensiones estándar WR-75 ( $a=19,05 \mathrm{~mm}, b=9,525 \mathrm{~mm})$ mientras que para la permitividad eléctrica relativa de los postes dieléctricos se ha considerado un valor de $24^{2}$. A continuación, se ha fijado el valor de $a_{h}$ para que el modo fundamental $\mathrm{TE}_{10}$

\footnotetext{
${ }^{2}$ Aunque en el proceso de diseño no se han considerado las pérdidas en el material dieléctrico $(\tan \delta=0)$, la herramienta CAD está preparada para tenerlas en cuenta en el proceso de diseño.
} 
entre en propagación en el housing a una frecuencia superior a $18 \mathrm{GHz}$, considerándose un valor de $8 \mathrm{~mm}$.

$$
a_{h}<\frac{c_{0}}{2 \cdot f_{e s p}}=8,3 \mathrm{~mm}
$$

Una vez determinado el housing utilizando la herramienta $\mathrm{CAD}^{3}$ descrita se obtienen las dimensiones de la estructura que recupera la respuesta deseada (ver Tbl. 4.20).

\begin{tabular}{|c|c|}
\hline Dimensiones & $\mathbf{x}$ \\
\hline$a$ & $19.05 \mathrm{~mm}$ \\
\hline$b$ & $9.525 \mathrm{~mm}$ \\
\hline$a_{h}$ & $8 \mathrm{~mm}$ \\
\hline$b_{h}$ & $9.525 \mathrm{~mm}$ \\
\hline$l_{1}, l_{5}$ & $1.869 \mathrm{~mm}$ \\
\hline$l_{2}, l_{4}$ & $7.502 \mathrm{~mm}$ \\
\hline$l_{3}$ & $6.836 \mathrm{~mm}$ \\
\hline$r_{1}, r_{4}$ & $10 \mathrm{~mm}$ \\
\hline$r_{2}, r_{3}$ & $0.780 \mathrm{~mm}$ \\
\hline$l_{0} l_{6}$ (líneas de entrada/salida) & $2.170 \mathrm{~mm}$ \\
\hline Longitud total (sin líneas de entrada/salida) & $31.478 \mathrm{~mm}$ \\
\hline Longitud total & $51.478 \mathrm{~mm}$ \\
\hline
\end{tabular}

Tabla 4.20: Dimensiones del filtro en modo evanescente con postes dieléctricos

En la tabla 4.21 se muestra el rendimiento del proceso de diseño, al utilizarse una estrategia evolutiva y considerarse un punto inicial aleatorio el error inicial es muy grande $(\infty)$. Sin embargo, a pesar de no disponer de un buen punto inicial el proceso de diseño ha convergido a una solución con un error muy pequeño a costa de un elevado número de evaluaciones de la función de error.

\begin{tabular}{|c|c|c|c|}
\hline$U\left(\mathbf{x}_{I N I}^{(0)}\right)$ & $U(\mathbf{x})$ & $\mathrm{nF}$ & Tiempo \\
\hline$\infty$ & 0,0046 & 17547 & $1 \mathrm{~h} 32^{\prime} 12^{\prime \prime}$ \\
\hline
\end{tabular}

Tabla 4.21: Rendimiento del proceso de obtención de la estructura

Finalmente, en la figura 4.39 se muestra la comparación entre la respuesta del filtro diseñado y la respuesta ideal buscada. En ella se observa que el filtro diseñado consigue recuperar perfectamente la respuesta deseada.

\footnotetext{
${ }^{3}$ Se ha utilizado un Intel@Core ${ }^{\mathrm{TM}} 2$ Quad Q660 @ $2.4 \mathrm{GHz}$.
} 


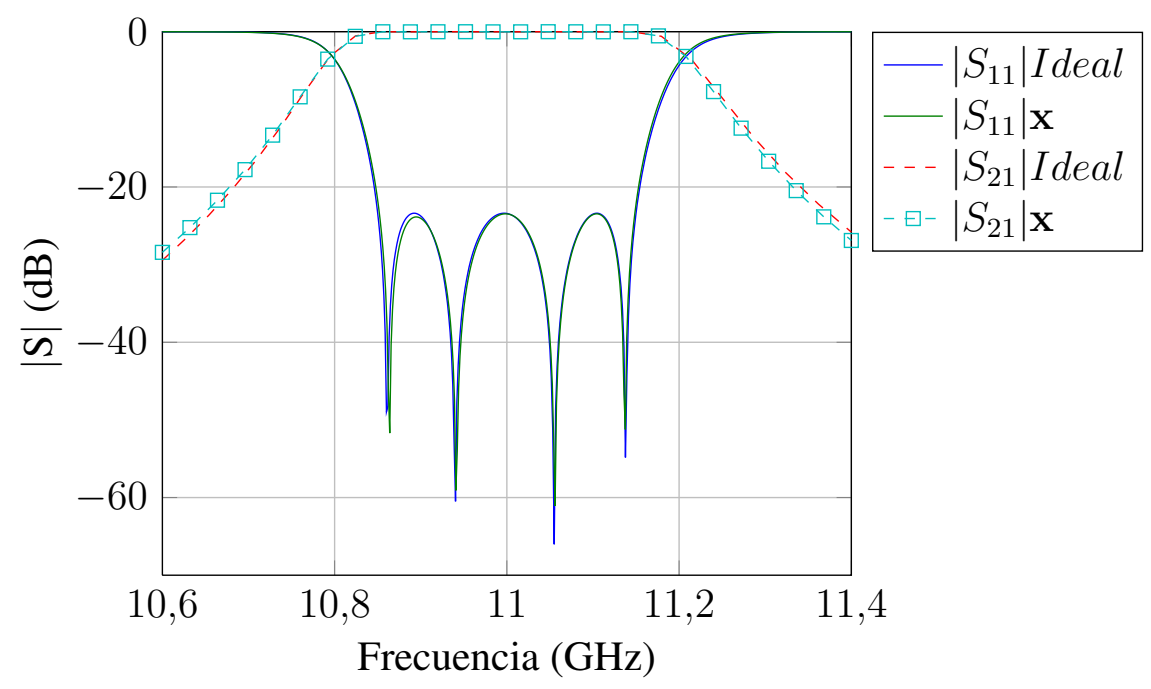

Figura 4.39: Respuesta del filtro diseñado frente a la respuesta ideal

Una vez comprobado que la herramienta CAD proporciona una estructura capaz de recuperar las especificaciones de diseño vamos a verificar las propiedades adicionales que ofrece esta tipología de filtros frente a los filtros de cavidades acopladas en plano $\mathrm{H}$ con postes dieléctricos. Para ello se va a analizar la reducción en tamaño, la respuesta fuera de banda, las pérdidas en el material dieléctrico y la capacidad de manejo de potencia.

\section{A. Reducción en el tamaño}

En primer lugar nos vamos a fijar en la reducción de tamaño de la nueva tipología de filtros. En la tabla 4.22 se compara la longitud total de los prototipos diseñados, sin tener en cuenta las guías de entrada y salida, en tecnología de filtros de cavidades acopladas y en modo evanescente con postes dieléctricos. En ella se observa que el uso de los filtros en modo evanescente permite una reducción en la longitud del filtro de aproximadamente un $40 \%$. Llegándose a obtener una reducción frente a los filtros de cavidades acopladas en tecnología sólo metal de aproximadamente un $60 \%$.

\begin{tabular}{|c|c|c|}
\hline Evanescentes (4.20) & Cavidades acopladas (4.13) & Reducción \\
\hline $31,478 \mathrm{~mm} \mathrm{~mm}$ & $51,25 \mathrm{~mm}$ & $40 \%$ \\
\hline
\end{tabular}

Tabla 4.22: Longitud del filtro en modo evanescente con postes dieléctricos frente a la longitud del filtro de cavidades acopladas en plano $\mathrm{H}$ con resonadores dieléctricos 


\section{B. Respuesta fuera de banda}

En la figura 4.40 se comparan las respuestas en transmisión del filtro de cavidades acopladas en plano $\mathrm{H}$ con resonadores dieléctricos frente a la del filtro en modo evanescente con postes dieléctricos. Observándose que el filtro en modo evanescente tiene un mejor rechazo fuera de la banda de paso junto con un mayor ancho de banda libre de espurios. De hecho, el primer armónico a $17 \mathrm{GHz}$ no está afectando a la respuesta del filtro, siendo su nivel muy inferior a $-3 \mathrm{~dB}$. Por lo tanto, el ancho de banda libre de espurios es de $12.28 \mathrm{GHz}$ que es prácticamente el doble que en los demás filtros.

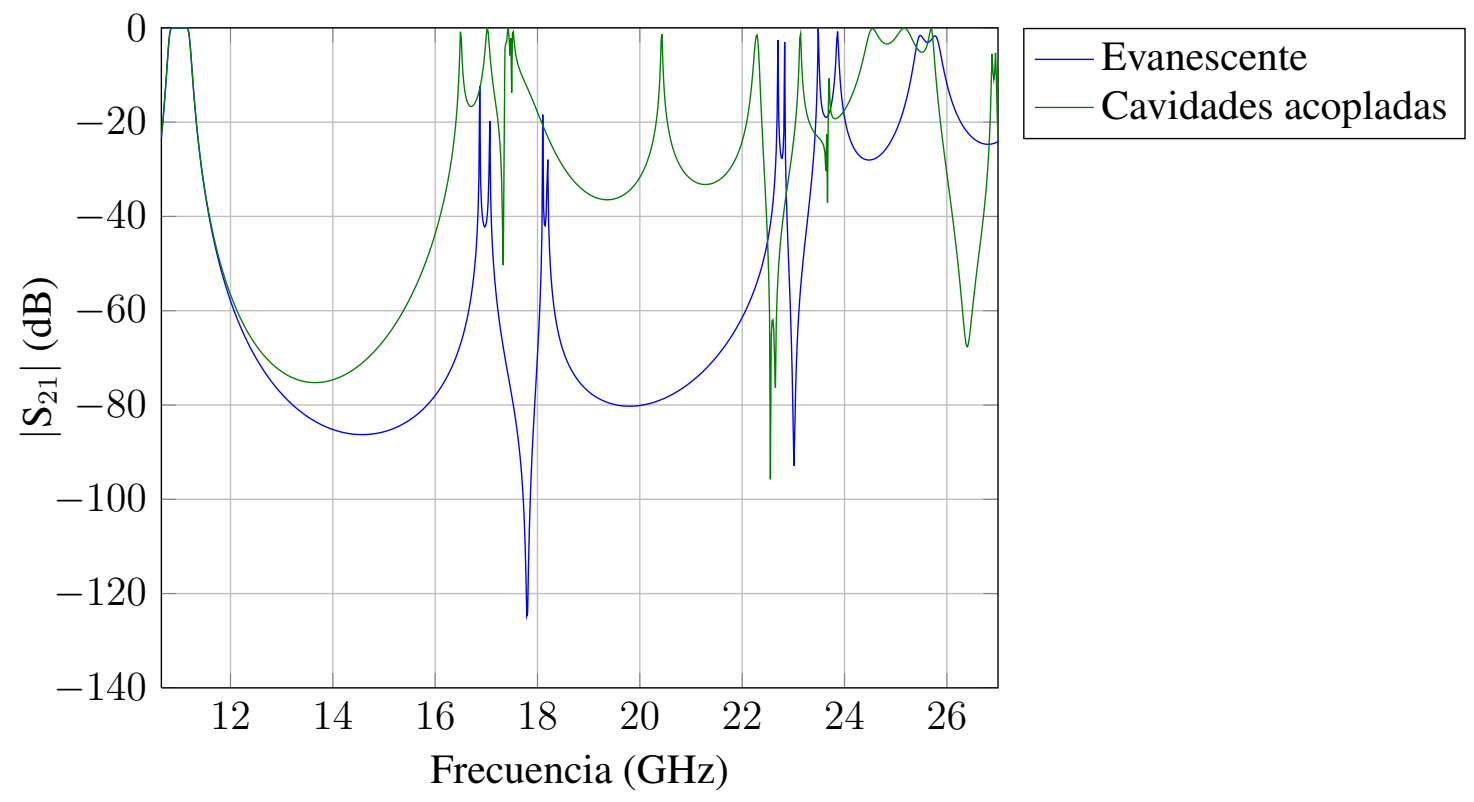

Figura 4.40: Respuesta fuera de banda en modo evanescente con postes dieléctricos frente a la respuesta del filtro de cavidades acopladas en plano $\mathrm{H}$ con postes dieléctricos

\section{Pérdidas en el material dieléctrico}

Uno de los inconvenientes que se esperan de este tipo de filtros es el aumento de las pérdidas de inserción debido a las pérdidas en los postes dieléctricos. Para ver el efecto de estas, la figura 4.41 muestra la respuesta en frecuencia del filtro evanescente en la banda de paso considerando diferentes valores de pérdidas, como se puede apreciar en la vista en detalle mostrada en la figura 4.42 las diferencias son apreciables cuando se tiene un dieléctrico con pérdidas correspondientes a $\tan \delta=10^{-3}$, pero son muy pequeñas cuando se considera un dieléctrico de bajas pérdidas, p. ej. $\tan \delta=10^{-4}$. Por lo tanto, de esta forma se demuestra que si se utilizan dieléctricos de bajas pérdidas, los cuales se pueden obtener con facilidad a las frecuencias de trabajo de esta clase de dispositivos, la respuesta del filtro no se degrada prácticamente. 
En la tabla 4.23 se comparan las pérdidas de inserción en la banda de paso de los filtros de cavidades acopladas en plano $\mathrm{H}$ sin resonadores dieléctricos, con resonadores dieléctricos y evanescentes con postes dieléctricos considerando diferentes valores de pérdidas en el material dieléctrico. En ella se puede observar que:

- Los filtros de cavidades acopladas con resonadores dieléctricos y evanescentes con resonadores dieléctricos presentan prácticamente las mismas pérdidas de inserción.

- Si se utilizan materiales dieléctricos de bajas pérdidas el uso de los postes dieléctricos no incrementa en gran medida las pérdidas de inserción, siendo del orden de las centésimas de decibelio.

\begin{tabular}{|c|c|c|c|c|}
\hline \multirow{2}{*}{ Metal } & \multicolumn{2}{|c|}{ Propagativo } & \multicolumn{2}{c|}{ Evanescente } \\
\cline { 2 - 5 } & $\tan \delta=10^{-3}$ & $\tan \delta=10^{-4}$ & $\tan \delta=10^{-3}$ & $\tan \delta=10^{-4}$ \\
\hline $0,021 \mathrm{~dB}$ & $0,32 \mathrm{~dB}$ & $0,047 \mathrm{~dB}$ & $0,35 \mathrm{~dB}$ & $0,056 \mathrm{~dB}$ \\
\hline
\end{tabular}

Tabla 4.23: Pérdidas de inserción del filtro de cavidades acopladas en plano $\mathrm{H}$ sin resonadores dieléctricos vs con resonadores dieléctricos vs evanescentes con postes dieléctricos

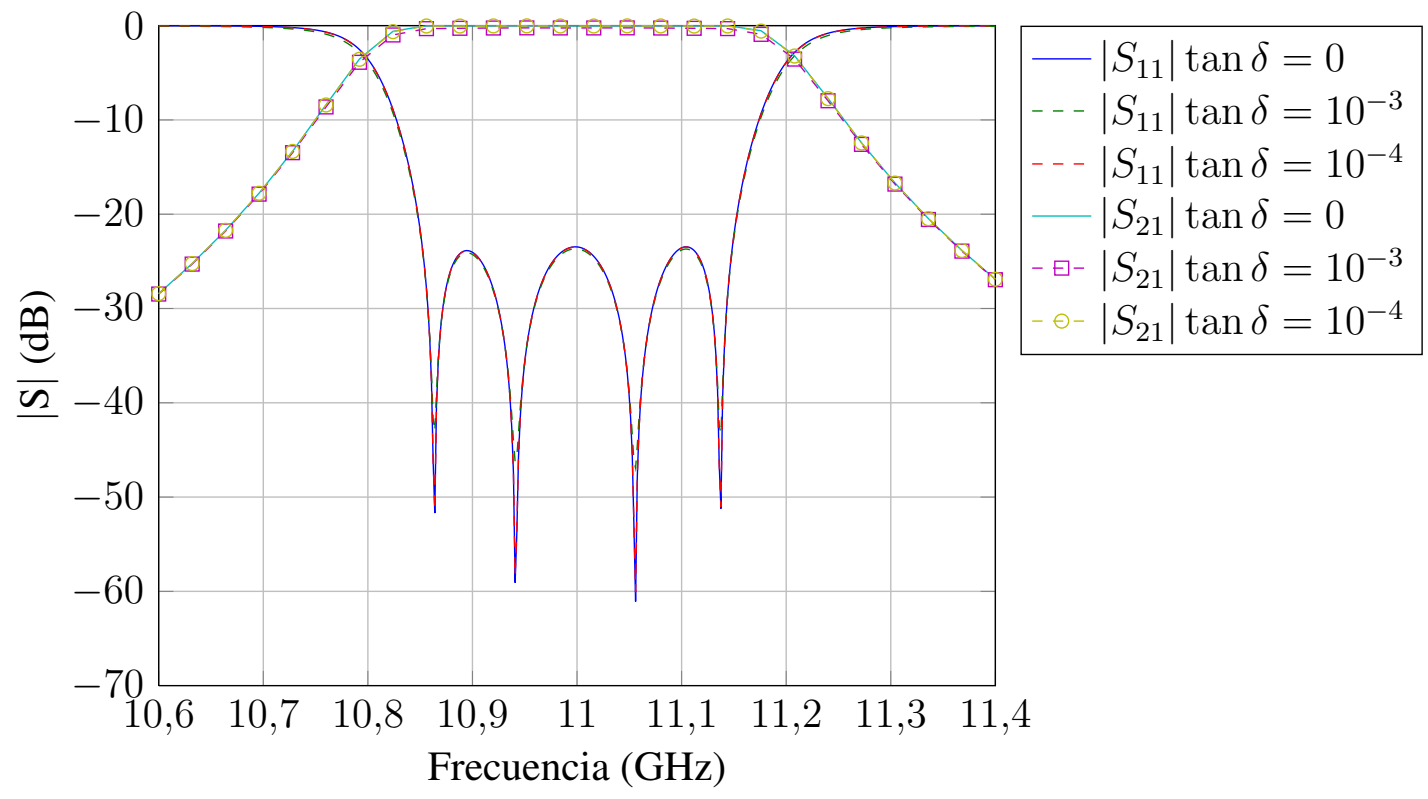

Figura 4.41: Respuesta del filtro en modo evanescente diseñado en los casos: $\tan \delta=0$, $\tan \delta=10^{-3}, \tan \delta=10^{-4}$. 


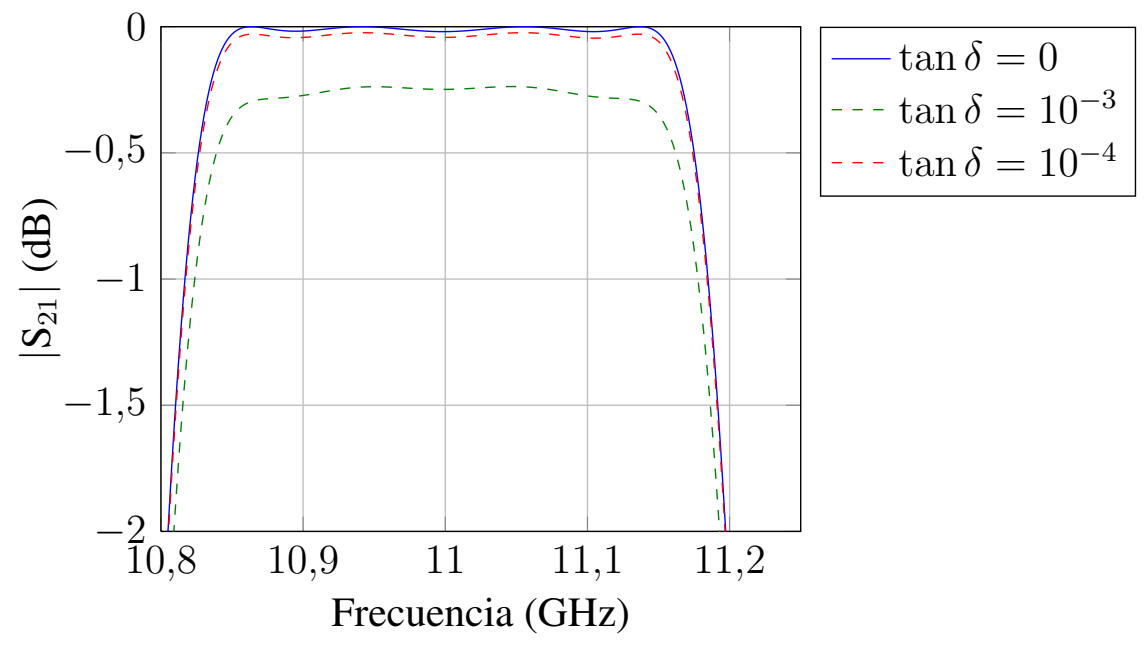

Figura 4.42: Vista en detalle del parámetro $\left|S_{21}\right|$ del filtro en modo evanescente diseñado en los casos: $\tan \delta=0, \tan \delta=10^{-3}, \tan \delta=10^{-4}$.

\section{Capacidad de manejo de potencia}

A continuación se ha analizado la capacidad de manejo de potencia de este tipo de filtros. Para ello, haciendo uso de la herramienta de análisis presentada en la sección 3.14, se ha calculado la distribución de campo eléctrico a la frecuencia central (Fig. 4.43), y el $V M F$ para todas las frecuencias y diferentes valores de pérdidas en el dieléctrico (Fig. 4.44). Como se observa en esta última, el valor máximo de $V M F$ se produce a la frecuencia de $10,78 \mathrm{GHz}$.

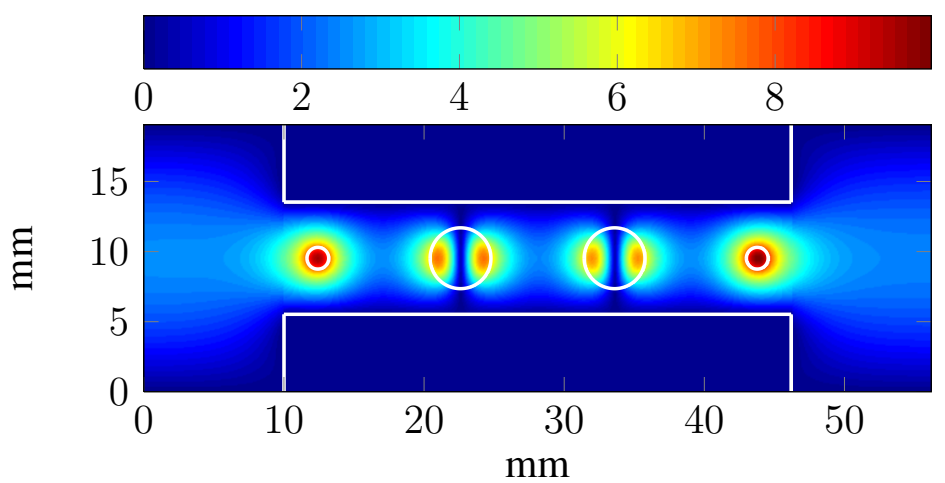

Figura 4.43: Módulo del campo eléctrico $(\mathrm{kV} / \mathrm{m})$ dentro del filtro de modo evanescente con postes dieléctricos para $\mathrm{f}=11 \mathrm{GHz}(\tan \delta=0)$.

En la figura 4.45 se representa la distribución del campo eléctrico para la frecuencia a la cual se produce el $V M F_{\max }$, en ella se puede apreciar que no pasa apenas potencia a través del filtro debido a que este valor se encuentra fuera de la banda de paso. 


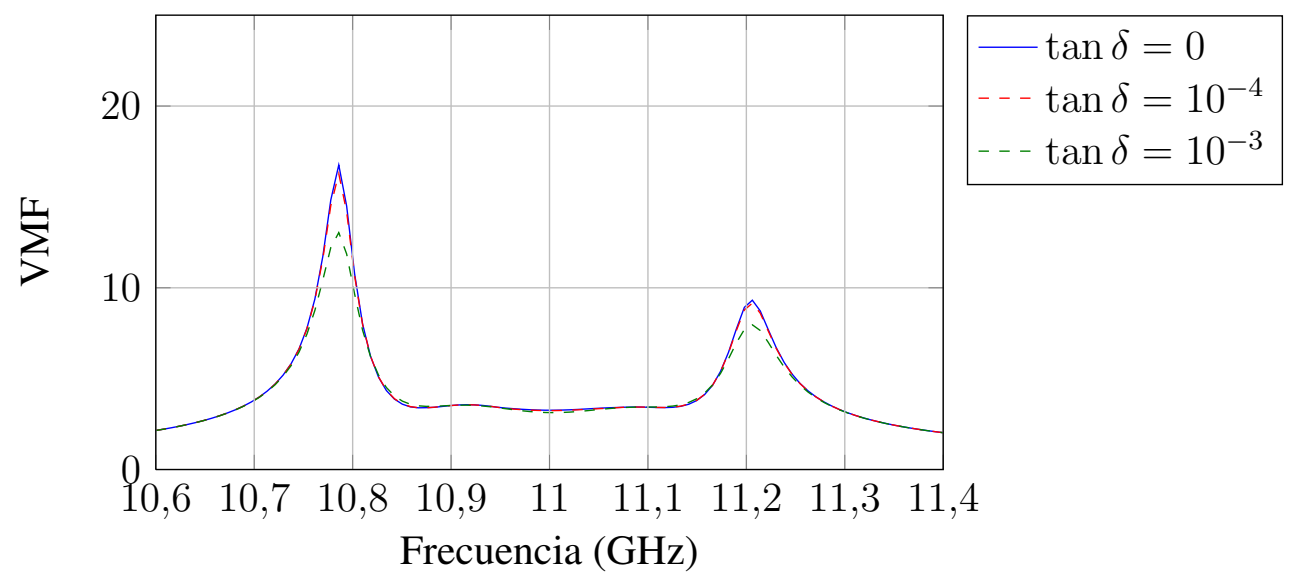

Figura 4.44: VMF para el filtro en modo evanescente con postes dieléctricos en los casos: $\tan \delta=0, \tan \delta=10^{-3}, \tan \delta=10^{-4}$.

En la figuras 4.43, 4.45, 4.46, 4.47 se muestra la distribución del campo eléctrico en el interior del filtro. Como se puede observar, debido al reducido tamaño del primer y cuarto poste dieléctricos el campo eléctrico se concentra en el interior de ellos, apareciendo un único máximo de campo eléctrico a diferencia de lo que sucedía con los filtros de cavidades acopladas en plano $\mathrm{H}$ con postes dieléctricos en los que el máximo de campo eléctrico se concentraba en el segundo poste.

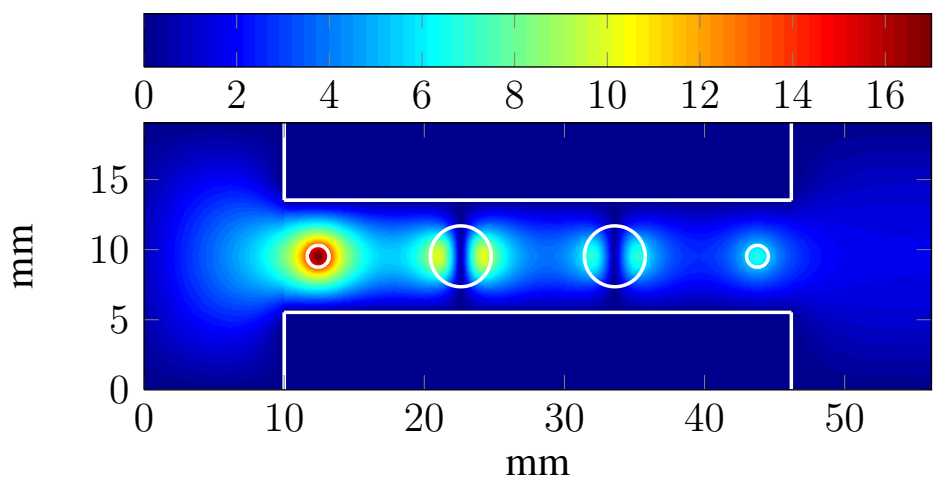

Figura 4.45: Módulo del campo eléctrico $(\mathrm{kV} / \mathrm{m})$ dentro del filtro en modo evanescente con postes dieléctricos para $\mathrm{f}=10,78 \mathrm{GHz}(\tan \delta=0)$.

En la figura 4.44 podemos apreciar como el $V M F$ disminuye cuando aumentan las pérdidas, lo cual se debe a que las pérdidas no dejan que se acumule tanto el campo eléctrico en el interior del filtro. Al ser el $V M F$ más bajo podemos introducir más potencia a la entrada sin riesgo de rotura por efecto multipactor (Fig. 4.48), ya que las pérdidas hacen que la potencia disminuya al atravesar el filtro. 


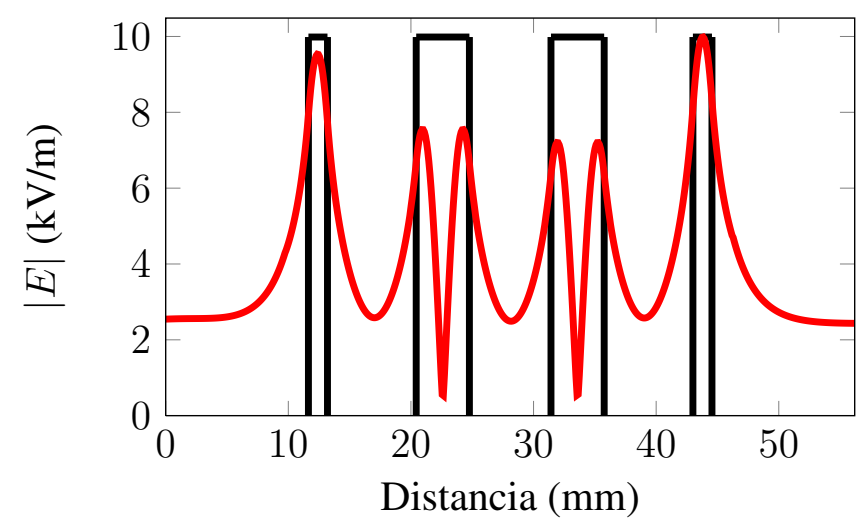

Figura 4.46: Modulo de E en el centro del filtro en modo evanescente con postes dieléctrico para $\mathrm{f}=11 \mathrm{GHz}(\tan \delta=0)$.

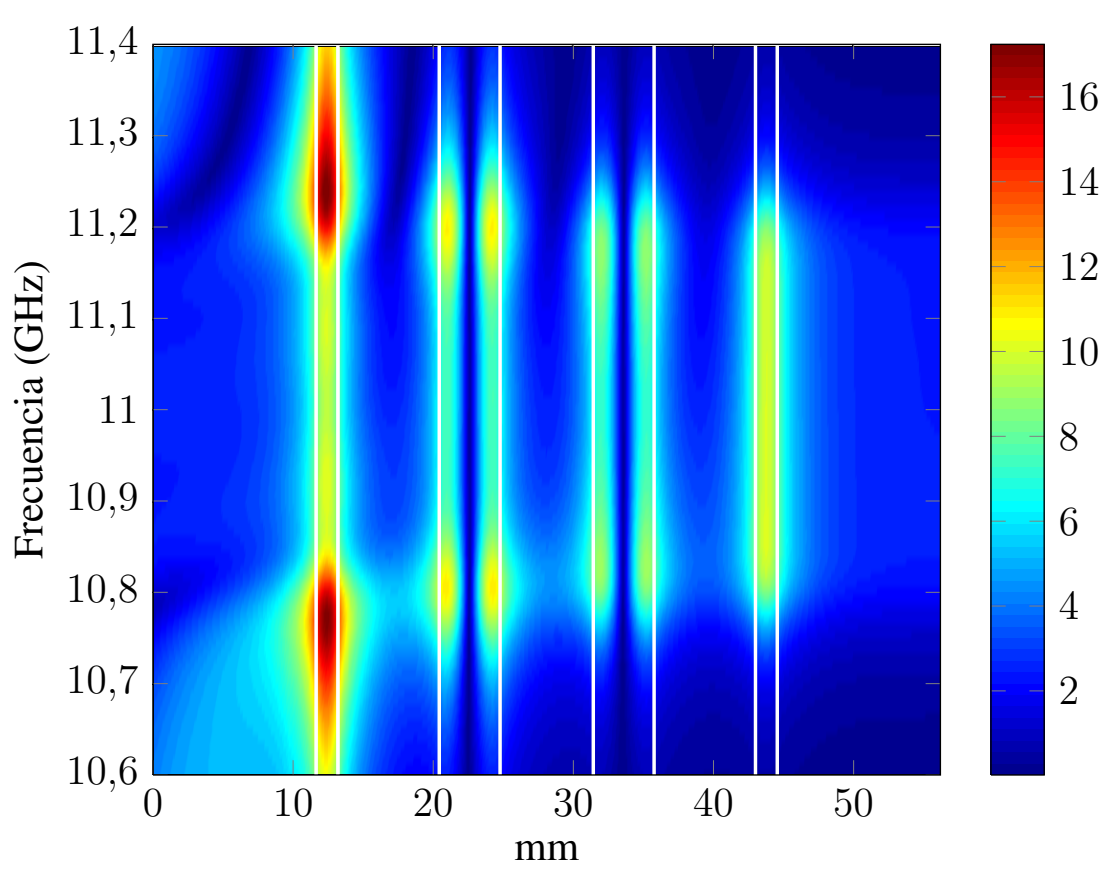

Figura 4.47: Módulo de $\mathrm{E}(\mathrm{kV} / \mathrm{m})$ en el centro del filtro en modo evanescente con postes dieléctricos para cada frecuencia. 


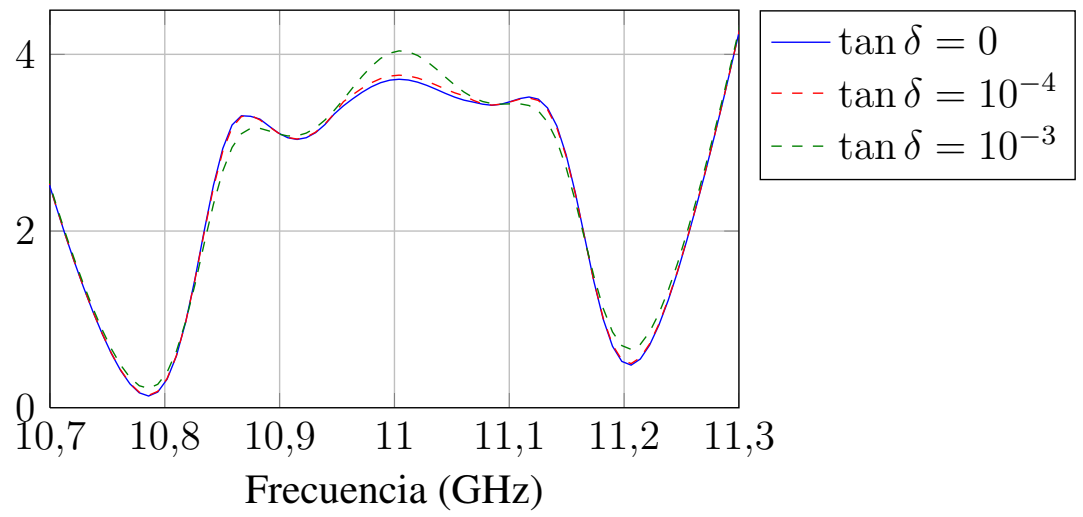

Figura 4.48: Potencia máxima a la entrada $(\mathrm{kW})$ sin riesgo de efecto multipactor para el filtro en modo evanescente con dieléctricos en los casos: $\tan \delta=0, \tan \delta=10^{-3}, \tan \delta=10^{-4}$.

A pesar de todo, lo que realmente nos importa es la potencia máxima que ofrece el filtro a la salida y no la potencia a la entrada. Estudiando la figura 4.49 se aprecia que en los casos con pérdidas la potencia máxima de salida sin riesgo de multipactor es siempre menor que en el caso sin pérdidas, lo que es debido al aumento de las pérdidas de inserción debido al uso de materiales dieléctricos. Además, es interesante resaltar que el uso de un dieléctrico de bajas pérdidas (p. ej. $\tan \delta=10^{-4}$ ) no degrada las prestaciones del filtro.

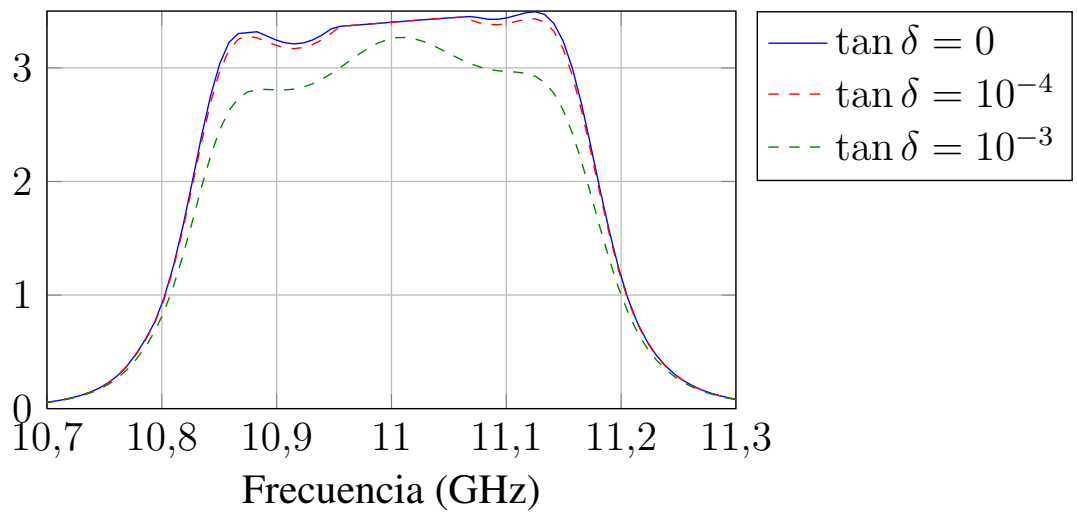

Figura 4.49: Potencia máxima a la salida $(\mathrm{kW})$ sin riesgo de efecto multipactor para el filtro en modo evanescente con postes dieléctricos en los casos: $\tan \delta=0, \tan \delta=10^{-3}$, $\tan \delta=10^{-4}$.

Finalmente, si comparamos la potencia máxima sin riesgo de rotura por efecto multipactor a la salida de los filtros de cavidades acopladas con postes dieléctricos (ver Fig. 4.29) y la de los filtros en modo evanescente (ver Fig. 4.49), podemos observar que la potencia máxima a la salida de estos últimos sin efecto multipactor es mucho menor. Esto es debido al reducido tamaño del filtro que produce una concentración mucho mayor en el interior del filtro sobretodo en los postes de menor radio. A pesar de esta limitación, el filtro en modo evanescente con postes dieléctricos permitirá una potencia máxima a la salida superior a la 
de los filtros de cavidades acopladas en tecnología solo metal (ver Tbl. 4.24)

\begin{tabular}{|c|c|c|c|c|}
\hline \multirow{2}{*}{ Metal } & \multicolumn{2}{|c|}{ Propagativo } & \multicolumn{2}{c|}{ Evanescente } \\
\cline { 2 - 5 } & $\tan \delta=10^{-3}$ & $\tan \delta=10^{-4}$ & $\tan \delta=10^{-3}$ & $\tan \delta=10^{-4}$ \\
\hline $2478 \mathrm{~W}$ & $4262 \mathrm{~W}$ & $4595 \mathrm{~W}$ & $3004 \mathrm{~W}$ & $3366 \mathrm{~W}$ \\
\hline
\end{tabular}

Tabla 4.24: Potencia máxima a la salida sin riesgo de rotura por efecto multipactor para los siguientes casos: filtro de cavidades acopladas en plano $\mathrm{H}$ sin resonadores dieléctricos, con resonadores dieléctricos, y evanescentes con postes dieléctricos 


\section{Capítulo 5}

\section{Conclusiones y líneas futuras}

La idea en la que se basa esta tesis es que es posible desarrollar una filosofía común de diseño de dispositivos avanzados de microondas. En la actualidad, las herramientas comerciales presentes en el mercado se basan en herramientas de análisis de propósito general basadas en métodos numéricos, por lo que el diseño de dispositivos de microondas haciendo uso de estas herramientas requieren por un lado de un elevado coste temporal y por el otro de la habilidad del diseñador para dirigir el proceso de diseño. Otra alternativa que está surgiendo con fuerza, gracias a la disponibilidad de recursos computacionales cada vez más potentes y a precios más asequibles, es el desarrollo de herramientas de análisis específicas para un problema concreto lo que reduce el tiempo de cómputo. Sin embargo, aunque este enfoque supone una mejora sustancial, el proceso de diseño requiere que el diseñador, además de las técnicas de diseño, domine el funcionamiento de cada una de las diferentes herramientas de análisis que debe utilizar. Por lo tanto, en esta Tesis se presenta un nuevo enfoque: integrar diferentes herramientas de análisis específicas dentro de un marco de diseño común, la cual haga uso de forma automatizada de diferentes estrategias de diseño. Las ventajas de este enfoque se pueden analizar desde dos puntos de vista diferentes:

- Desde el punto de vista del desarrollador. La incorporación de nuevas funcionalidades a la filosofía de diseño únicamente supondrá añadir nuevos módulos y/o modificar la estrategia de diseño (algoritmos, orden de ejecución). Además, cualquier mejora en un determinado módulo se aplicará de forma automática a todas las estrategias de diseño basadas en él.

- Desde el punto de vista del usuario. El proceso de diseño se resumirá a definir las especificaciones del dispositivo (respuesta eléctrica, topología, etc.) y verificar que el dispositivo obtenido las cumple. 
Con esta idea en mente, en primer lugar se ha definido la filosofía de diseño denominada FALLAS, la cual define claramente las interfaces entre los módulos de análisis y los algoritmos de diseño, además de integrar las siguientes técnicas de diseño: segmentación de la estructura, hibridación de algoritmos de optimización, y el concepto del mapeado espacial. A continuación, se han integrado diferentes módulos de análisis electromagnético y definido estrategias de optimización que se han aplicado con éxito al:

- Diseño de filtros de cavidades acopladas en plano H. La herramienta CAD implementada para diseñar esta topología de filtros clásica se basa en el uso de la segmentación de la estructura y la hibridación de diferentes algoritmos de optimización para garantizar la eficiencia y la robustez del proceso de diseño. Además, hace uso del mapeado espacial para mejorar la eficiencia del proceso de diseño a la vez que se garantiza su precisión. Sin embargo, se ha demostrado que el uso del ASM no ha reducido de forma sustancial el tiempo de diseño gracias a: disponer de una buena técnica de síntesis del punto inicial, y una herramienta de análisis eficiente y precisa.

- Diseño de filtros de cavidades acopladas en plano $H$ teniendo en cuenta los defectos de fabricación. Se han desarrollado diferentes herramientas CAD para diseñar esta topología de filtros, todas ellas con el objetivo de mejorar la eficiencia, la precisión y la robustez del proceso de diseño. Para ello, las diferentes herramientas CAD han hecho uso de las mismas técnicas de diseño que en caso anterior. Sin embargo, si bien se dispone de una buena técnica de síntesis del punto inicial, debido a que las herramientas de análisis empleadas no son tan eficientes cómo las utilizadas en el caso anterior, el uso del concepto del mapeado espacial (ASM y ASM multimodelo) ha sido clave para mejorar la eficiencia garantizando la precisión del proceso de diseño.

- Diseño de filtros de cavidades acopladas en plano $\mathbf{H}$ con postes dieléctricos. Se han implementado diferentes estrategias de diseño de esta topología de filtros. Las cuáles hacen uso de la segmentación de la estructura, la hibridación de diferentes algoritmos de optimización (con y sin restricciones) y la optimización multinivel. Radicando su principal diferencia en el algoritmo de síntesis del punto inicial empleado.

- Diseño de filtros en modo evanescente con postes dieléctricos. El diseño de este tipo de estructuras ha tenido que manejar dos limitaciones: la no disponibilidad de un algoritmo de síntesis del punto inicial y el alto nivel de acoplamiento entre los postes dieléctricos. Por ello, la herramienta de diseño implementada se ha basado en la hibridación de diferentes algoritmos de optimización.

Haciendo uso de las herramientas CAD implementadas se han diseñado y fabricado con éxito diferentes prototipos de filtros en plano $\mathrm{H}$ : de cavidades acopladas sin postes dieléctricos, con postes dieléctricos y en modo evanescente con postes dieléctricos. Además, el estudio de los resultados obtenidos ha permitido: 
- Validar el correcto funcionamiento de las herramientas de diseño.

- Comparar las ventajas y limitaciones de cada una de las topologías diseñadas. De hecho, se ha observado que la topología con menores pérdidas de inserción son los filtros de cavidades acopladas en plano $\mathrm{H}$ en tecnología sólo metal, pero tiene como principales limitaciones: una mayor longitud y una menor capacidad de manejo de potencia sin riesgo de rotura por efecto multipactor. Por otro lado, el uso de los postes dieléctricos permite la reducción en la longitud del filtro así como la mejora en la capacidad de manejo de potencia.

Finalmente, los filtros en modo evanescente tienen una longitud muy reducida junto con un gran ancho de banda libre de espurios. Sin embargo, su reducido tamaño limita su capacidad de manejo de potencia.

- Identificar cuáles son las limitaciones a tener en cuenta en el proceso de manufactura de los diferentes dispositivos de microondas considerados con el objetivo de introducirlas en el proceso de diseño. Se ha observado, que el uso de técnicas de fabricación de bajo coste introduce esquinas redondeadas que pueden incluirse en el proceso de diseño, siendo la presencia de las esquinas redondeadas en las ventanas de acoplo las que van a producir un mayor desplazamiento entre la respuesta deseada y la medida. Además de ser necesaria la caracterización del material dieléctrico empleado en la fabricación de los postes a la frecuencia de trabajo para introducirlas en el rediseño del cuerpo del filtro.

Finalmente, entre las posibles líneas futuras de investigación relacionadas con el trabajo realizado en la presente Tesis cabe citar: la mejora en las técnicas de síntesis del punto inicial de estructuras en las que se incluyan postes dieléctricos, la integración de nuevos lenguajes de programación (p.ej. MATLAB), incluir nuevos algoritmos de optimización (p. ej. mínimos cuadrados), implementar nuevas técnicas de mapeado espacial que mejoren la robustez, hacer uso del acoplo entre cavidades resonantes en el proceso de diseño de nuevas topologías de dispositivos (p.ej. dispositivos en tecnología SIW y multiplexores), y la paralelización de los algoritmos de diseño. 


\title{
Lista de Acrónimos
}

\author{
ASM Aggressive Space Mapping \\ BFGS Broyden Fletcher Goldfarb Shanno \\ CAD Diseño Asistido por Ordenador \\ EDM Electrical Discharge Machining \\ EM Electromagnetic \\ FDTD Finite-Difference Time-Domain \\ FE Finite element \\ FMM Fast Multipole Method \\ FSS Fixed Service Satellite \\ GIM Generalized Impedance Matrix \\ GSM Generalized Scattering Matrix \\ GSM Global System for Mobile Communications \\ HASM Hybrid Aggressive Space Mapping \\ IE Integral Equation \\ LMDS Local Multipoint Distribution System \\ MASM Multimodel Aggressive Space Mapping \\ MBS Mobile Broadband System \\ MM Mode Matching \\ MoM Method of Moments \\ MVDS Multipoint Video Distribution System \\ OS Optimization Space
}


PIM productos de intermodulación pasivos

PPW Parallel-plate waveguide

SM $\quad$ Space Mapping

SQP Sequential Quadratic Programming

TRASM Trust Region Aggressive Space Mapping

UMTS Universal Mobile Telecommunication System

VMF Voltage Magnification Factor

VS Validation Space

Wi-Fi IEEE 802.11

WiMAX Worldwide Interoperability for Microwave Access

WLL Wireless Local Loop 


\section{Bibliografía}

[AB84] H. Auda and R.F. Barrington. Inductive posts and diaphragms of arbitrary shape and number in a rectangular waveguide. Microwave Theory and Techniques, IEEE Transactions on, 32(6):606-613, 1984.

[ABB ${ }^{+}$02] Paolo Arcioni, Vicente Boria, Maurizio Bozzi, Giuseppe Conciauro, and Benito Gimeno. Analysis of h-plane waveguide components with dielectric obstacles by the bi-rme method. In Microwave Conference, 2002. 32nd European, pages 1-4, 2002. ID: 1 .

[ABK84] J. C. Araneta, M. E. Brodwin, and G. A. Kriegsmann. High-temperature microwave characterization of dielectric rods. IEEE Transactions on Microwave Theory and Techniques, 32(10):1328-1335, 1984. PT: J; J9: IEEE TRANS MICROWAVE THEORY; PG: 8; GA: TK434; UT: ISI:A1984TK43400008.

[ABR ${ }^{+97]}$ F. Arndt, R. Beyer, J.M. Reiter, T. Sieverding, and T. Wolf. Automated design of waveguide components using hybrid mode-matching/numerical EM buildingblocks in optimization-oriented CAD frameworks-state of the art and recent advances. Microwave Theory and Techniques, IEEE Transactions on, 45(5):747760, 1997.

[ADS95] F. Alessandri, M. Dionigi, and R. Sorrentino. A fullwave CAD tool for waveguide components using a high speed direct optimizer. Microwave Theory and Techniques, IEEE Transactions on, 43(9):2046-2052, 1995.

[AG97] J.T. Alos and M. Guglielmi. Simple and effective em-based optimization procedure for microwave filters. Microwave Theory and Techniques, IEEE Transactions on DOI - 10.1109/22.141345, 45(5):856-858, 1997.

[AM93] J. Abdulnour and L. Marchildon. Scattering by a dielectric obstacle in a rectangular wave-guide. IEEE Transactions on Microwave Theory and Techniques, 41(11):1988-1994, NOV 1993. PT: J; J9: IEEE TRANS MICROWAVE THEORY; PG: 7; GA: MN048; UT: ISI:A1993MN04800017.

[AM94] J. Abdulnour and L. Marchildon. Boundary elements and analytic expansions applied to h-plane wave-guide junctions. IEEE Transactions on Microwave 
Theory and Techniques, 42(6):1038-1045, JUN 1994. PT: J; J9: IEEE TRANS MICROWAVE THEORY; PG: 8; GA: NV883; UT: ISI:A1994NV88300016.

[Arc96] P. Arcioni. Fast evaluation of modal coupling coefficients of waveguide step discontinuities. Microwave and Guided Wave Letters, IEEE, 6(6):232-234, 1996.

[AS90] H. A. Auda and C. E. Smith. The resonance method for evaluating the impedances of the equivalent network for dielectric posts in a rectangular wave-guide. IEEE Transactions on Microwave Theory and Techniques, 38(11):1595-1602, NOV 1990. PT: J; J9: IEEE TRANS MICROWAVE THEORY; PG: 8; GA: ED789; UT: ISI:A1990ED78900006.

[Bal89] Constantine A. Balanis. Advanced Engineering Electromagnetics. Wiley, solution manual edition, May 1989.

[Ban69] J.W. Bandler. Optimization methods for computer-aided design. Microwave Theory and Techniques, IEEE Transactions on DOI - 10.1109/22.141345, 17(8):533-552, 1969.

[Ban97] J.W. Bandler. Guest editorial. Microwave Theory and Techniques, IEEE Transactions on, 45(5):709-711, 1997.

$\left[\mathrm{BBA}^{+} 00\right]$ C. Boussavie, D. Baillargeat, M. Aubourg, S. Verdeyme, P. Guillon, A. Catherinot, S. Vigneron, and J. Herren. Microwave breakdown in OMUX filters: A theoretical investigaction. In Proceedings of the Workshop on Multipactor, $R F$ and DC Corona and Passive Intermodulation in Space RF Hardware, pages 139-143, 2000.

[BBB ${ }^{+98]}$ M.H. Bakr, J.W. Bandler, R.M. Biernacki, Hua Chen Shao, and K. Madsen. A trust region aggressive space mapping algorithm for em optimization. Microwave Theory and Techniques, IEEE Transactions on DOI - 10.1109/22.141345, 46(12):2412-2425, 1998.

[BBC $\left.{ }^{+} 97\right] \quad J . W$. Bandler, R.M. Biernacki, Shao Hua Chen, L.W. Hendrick, and D. Omeragic. Electromagnetic optimization of 3-D structures. Microwave Theory and Techniques, IEEE Transactions on, 45(5):770-779, 1997.

$\left[\mathrm{BBC}^{+}\right.$03] V.E. Boria, M. Bozzi, D. Camilleri, A. Coves, H. Esteban, B. Gimeno, M. Guglielmi, and L. Polini. Contributions to the analysis and design of all-inductive filters with dielectric resonators. In Microwave Conference, 2003. 33rd European, volume 3, pages 1247-1250 Vol.3, 2003.

[BBCH97] J.W. Bandler, R.M. Biernacki, Shao Hua Chen, and Ya Fei Huang. Design optimization of interdigital filters using aggressive space mapping and decomposition. Microwave Theory and Techniques, IEEE Transactions on, 45(5):761769, 1997. 
[BBC097] J.W. Bandler, R.M. Biernacki, S.H. Chen, and D. Omeragic. Space mapping optimization of waveguide filters using finite element and mode-matching electromagnetic simulators. In Microwave Symposium Digest, 1997., IEEE MTT-S International, volume 2, pages 635-638 vol.2, 1997.

[BBGM99] M.H. Bakr, J.W. Bandler, N. Georgieva, and K. Madsen. A hybrid aggressive space-mapping algorithm for EM optimization. Microwave Theory and Techniques, IEEE Transactions on, 47(12):2440-2449, 1999.

$\left[\mathrm{BBI}^{+} 00\right] \quad$ M.H. Bakr, J.W. Bandler, M.A. Ismail, J.E. Rayas-Sanchez, and Qi-Jun Zhang. Neural space-mapping optimization for EM-based design. Microwave Theory and Techniques, IEEE Transactions on, 48(12):2307-2315, 2000.

$\left[\mathrm{BBS}^{+}\right.$94] J.W. Bandler, R.M. Biernacki, Hua Chen Shao, P.A. Grobelny, and R.H. Hemmers. Space mapping technique for electromagnetic optimization. Microwave Theory and Techniques, IEEE Transactions on DOI - 10.1109/22.141345, 42(12):2536-2544, 1994.

[BBS ${ }^{+95] \quad J . W . ~ B a n d l e r, ~ R . M . ~ B i e r n a c k i, ~ H u a ~ C h e n ~ S h a o, ~ R . H . ~ H e m m e r s, ~ a n d ~ K . ~ M a d s e n . ~}$ Electromagnetic optimization exploiting aggressive space mapping. Microwave Theory and Techniques, IEEE Transactions on DOI - 10.1109/22.141345, 43(12):2874-2882, 1995.

$\left[\mathrm{BCB}^{+} 93\right]$ J.W. Bandler, Shao Hua Chen, R.M. Biernacki, Li Gao, K. Madsen, and Huanyu Yu. Huber optimization of circuits: a robust approach. Microwave Theory and Techniques, IEEE Transactions on, 41(12):2279-2287, 1993.

$\left[\mathrm{BCD}^{+} 87\right]$ Michael Berry, Tony F. Chan, James Demmel, June Donato, Jack Dongarra, Victor Eijkhout, Charles Romine, and Henk van der Vorst. Templates for the Solution of Linear Systems: Building Blocks for Iterative Methods. Society for Industrial Mathematics, 1 edition, January 1987.

$\left[\mathrm{BCD}^{+} 04\right] \quad$ J.W. Bandler, Q.S. Cheng, S.A. Dakroury, A.S. Mohamed, M.H. Bakr, K. Madsen, and J. Sondergaard. Space mapping: the state of the art. Microwave Theory and Techniques, IEEE Transactions on DOI - 10.1109/22.141345, 52(1):337361, 2004.

[BCEB02] V. E. Boria, S. Cogollos, H. Esteban, and A. A. San Blas. Efficient techniques for the accurate analysis and design of passive waveguide components with arbitrary geometry. In Progress in Electromagnetics Research Symposium PIERS, editor, Proceedings of PIERS 2002, page 615, Boston, July 2002.

[BCNI04] J.W. Bandler, Q.S. Cheng, N.K. Nikolova, and M.A. Ismail. Implicit space mapping optimization exploiting preassigned parameters. Microwave Theory and Techniques, IEEE Transactions on, 52(1):378-385, 2004. 
[BE97] V. E. Boria Esbert. Análisis de problemas electromagnéticos mediante métodos modales y matrices generalizadas, y aplicaciones. doctoral thesis, Universidad Politécnica de Valencia, 1997.

$\left[\mathrm{BEB}^{+}\right.$05] C. Bachiller, H. Esteban, V. E. Boria, J. V. Morro, L. J. Rogla, M. Taroncher, and A. Belenguer. Efficient cad tool of direct-coupled-cavities filters with dielectric resonators. In Antennas and Propagation Society International Symposium, 2005 IEEE, volume 1B, pages 578-581 vol. 1B, 2005. ID: 1.

$\left[\mathrm{BEB}^{+}\right.$09] A. Belenguer, H. Esteban, V.E. Boria, J.V. Morro, and C. Bachiller. Efficient modal analysis of arbitrarily shaped h-plane two-port waveguide devices using the 2D parallel-plate green's function. Microwaves, Antennas \& Propagation, IET, 3(1):62-70, 2009.

$\left[\mathrm{BED}^{+} 08\right] \quad$ C. Bachiller, H. Esteban, F. Diaz, V.E. Boria, and J.V. Morro. Comparative study of multipactor breakdown in waveguide H-plane filters loaded with dielectric resonators. In Int. Workshop on Multipactor, Corona and Passive Intermodulation, pages 1-8, Valencia, Sept. 2008.

[BG08] Manidipa Bhattacharya and B. Gupta. Neural Network Model of S-Parameters for a Dielectric Post in Rectangular Waveguide. IEEE, NEW YORK; $345 \mathrm{E}$ 47TH ST, NEW YORK, NY 10017 USA, 2008. PT: B; CT: International Conference on Recent Advances in Microwave Theory and Applications; CY: NOV 21-24, 2008; CL: Jaipur, INDIA; SP: IEEE MTT S, Natl Inst Technol, IEEE AP S, IEEE GRSS, IEEE LEOS, URSI, IETE, EuMA, IEEE India MTTS, IEEE MTTS, Delhi Chapter, IEEE India EDS, Dept Sci \& Technol, Indo US Sci \& Tech Forum, BARC, DRDO, CSIR, AICTE, KITE, Vidyut Yantra Udyog; PG: 3; GA: BJA61; UT: ISI:000264178700176.

[BGA98] V. E. Boria, M. Guglielmi, and P. Arcioni. Computer-aided design of inductively coupled rectangular waveguide filters including tuning elements. International Journal of RF and Microwave Computer-Aided Engineering, 8(3):226235, 1998.

[BGG97] V.E. Boria, G. Gerini, and M. Guglielmi. An efficient inversion technique for banded linear systems. In Microwave Symposium Digest, 1997., IEEE MTT-S International, volume 3, pages 1567-1570 vol.3, 1997.

[BGMM07] Carmen Bachiller, Hector Esteban Gonzalez, Angel Belenguer Martinez, and Jose Vicente Morro. Efficient technique for the cascade connection of multiple two-port scattering matrices. IEEE Transactions on Microwave Theory and Techniques, 55(9):1880-1886, SEP 2007. PT: J; J9: IEEE TRANS MICROWAVE THEORY; PG: 7; GA: 206WI; UT: ISI:000249213200008.

[BIRZ03] John W. Bandler, Mostafa A. Ismail, José E. Rayas-Sánchez, and Qi-Jun Zhang. Neural inverse space mapping (NISM) optimization for EM-based microwave 
design. International Journal of RF and Microwave Computer-Aided Engineering, 13(2):136-147, 2003.

[BM04] J.W. Bandler and M. Mongiardo. Special issue on electromagnetics-based optimization of microwave components and circuits. IEEE Trans.Microwave Theory Techn., 52(1):245-456, 2004.

[BM09] Ángel Belenguer Martínez. Análisis eficiente de dispositivos pasivos de microondas en el dominio de la frecuencia. PhD thesis, Universidad Politécnica de Valencia, April 2009.

[BM10] Carmen Bachiller Martín. Métodos híbridos para el análisis y diseño eficiente de filtros avanzados para sistemas de comunicaciones espaciales. PhD thesis, Universidad Politécnica de Valencia, 2010.

[BP99] Raju Balasubramanian and Protap Pramanick. Computer aided design of hplane tapered corrugated waveguide bandpass filters. International Journal of $R F$ and Microwave Computer-Aided Engineering, 9(1):14-21, 1999.

[Bro65] C. G. Broyden. A class of methods for solving nonlinear simultaneous equations. Mathematics of Computation, 19(92):577-593, October 1965. ArticleType: research-article / Full publication date: Oct., 1965 / Copyright (c) 1965 American Mathematical Society.

[Bud98] Djuradj Budimir. Generalized Filter Design by Computer Optimization. Artech House Publishers, February 1998.

[CAB05] V. Catina, F. Arndt, and J. Brandt. A surface integral equation formulation for dielectric post structures in waveguides. In Microwave Symposium Digest, 2005 IEEE MTT-S International, page 4 pp., 2005. ID: 1.

[CABP96] G. Conciauro, P. Arcioni, M. Bressan, and L. Perregrini. Wideband modeling of arbitrarily shaped h-plane waveguide components by the "boundary integralresonant mode expansion method". Microwave Theory and Techniques, IEEE Transactions on, 44(7):1057-1066, 1996.

[CB02] Santiago Cogollos Borras. Caracterizacin modal de guías arbitrarias y aplicación a dispositivos de microondas. PhD thesis, Universidad Politécnica de Valencia, 2002.

$\left[\mathrm{CBS}^{+}\right.$01] S. Cogollos, V.E. Boria, P. Soto, B. Gimeno, and M. Guglielmi. Efficient CAD tool for inductively coupled rectangular waveguide filters with rounded corners. In Microwave Conference, 2001. 31st European, pages 1-4, 2001.

[CBZ84] G. Conciauro, M. Bressan, and C. Zuffada. Waveguide modes via an integral equation leading to a linear matrix eigenvalue problem. Microwave Theory and Techniques, IEEE Transactions on, 32(11):1495-1504, 1984. 
[CFG ${ }^{+92}$ R. Coirault, S.J. Feltham, G. Gatti, M. Guglielmi, and D. Perring. Overview of microwave components activities at the european space agency. Microwave Theory and Techniques, IEEE Transactions on DOI - 10.1109/22.141345, 40(6):1150-1158, 1992.

[CGS00] Giuseppe Conciauro, Marco Guglielmi, and Roberto Sorrentino. Advanced Modal Analysis. Wiley, 1 edition, April 2000.

[CJMS00] Weng Cho Chew, Jian-Ming Jin, Eric Michielssen, and Jiming Song. Fast and Efficient Algorithms in Computational Electromagnetics. Artech House Publishers, July 2000.

[Cla78] P.F. Clancy. Multipactor control in microwave space systems. Microwave Journal, 21:77, 78, 81-83, March 1978.

[CMK07] Richard J. Cameron, Raafat Mansour, and Chandra M. Kudsia. Microwave Filters for Communication Systems: Fundamentals, Design and Applications. Wiley-Interscience, July 2007.

[CMR99] J. Couet, D.; Maugars, and D. Rouffet. Satélites y multimedia. Revista de Telecomunicaciones de Alcatel, (4):-, 1999.

[Coh57] S.B. Cohn. Direct-coupled-resonator filters. Proceedings of the IRE DOI 10.1109/JRPROC.1957.278389, 45(2):187-196, 1957.

[Co190] Robert E. Collin. Field Theory of Guided Waves. Wiley-IEEE Press, 2 edition, December 1990.

[Col00] Robert E. Collin. Foundations for Microwave Engineering. Wiley-IEEE Press, December 2000.

[Cor] Ansoft Corporation. Hfss: 3d high-frequency electromagnetic simulation.

[CPG01] M. Capurso, M. Piloni, and M. Guglielmi. Resonant aperture filters: Improved Out-Of-Band rejection and size reduction. In Microwave Conference, 2001. 31st European, pages 1-4, 2001.

[CRW93] R. Coifman, V. Rokhlin, and S. Wandzura. The fast multipole method for the wave equation: a pedestrian prescription. Antennas and Propagation Magazine, IEEE, 35(3):7-12, 1993.

[DETS96] M. Dionigi, A. Esposito, L. Tarricone, and R. Sorrentino. Optimum port numbering in the electromagnetic simulation of complex networks. In Microwave Symposium Digest, 1996., IEEE MTT-S International, volume 1, pages 189192 vol.1, 1996. 
[DRCF07] D. Z. Ding, P. L. Rui, R. S. Chen, and Z. H. Fan. Loose GMRES method for efficient solution of EFIE in the MLFMA context. Microwave and Optical Technology Letters, 49(11):2661-2665, 2007.

[Duf01] Dean G. Duffy. Green's Functions with Applications. Chapman and Hall/CRC, 1 edition, May 2001.

$\left[\mathrm{ECB}^{+}\right.$02a] H. Esteban, S. Cogollos, C. Bachiller, A. A. San Blas, and V. Boria. A new analytical method for the analysis of multiple scattering problems using spectral techniques. In Antennas and Propagation Society International Symposium, 2002. IEEE, volume 2, pages 82-85 vol.2, 2002. ID: 1.

$\left[\mathrm{ECB}^{+}\right.$02b] H. Esteban, S. Cogollos, V. E. Boria, A. S. Blas, and M. Ferrando. A new hybrid mode-matching/numerical method for the analysis of arbitrarily shaped inductive obstacles and discontinuities in rectangular waveguides. IEEE Transactions on Microwave Theory and Techniques, 50(4):1219-1224, APR 2002. PT: J; J9: IEEE TRANS MICROWAVE THEORY; PG: 6; GA: 541FJ; UT: ISI:000174974300020.

[EG02] Héctor Esteban González. Análisis de problemas arbitrarios de dispersión electromagnética mediante métodos híbridos. $\mathrm{PhD}$ thesis, Universidad Politécnica de Valencia, 2002.

[EG06] O. Ergul and L. Gurel. Enhancing the accuracy of the interpolations and anterpolations in MLFMA. Antennas and Wireless Propagation Letters, IEEE, 5(1):467-470, 2006.

[EG07] O. Ergul and L. Gurel. Linear-Linear basis functions for MLFMA solutions of Magnetic-Field and Combined-Field integral equations. Antennas and Propagation, IEEE Transactions on, 55(4):1103-1110, 2007.

[EG08a] O. Ergul and L. Gurel. Efficient parallelization of the multilevel fast multipole algorithm for the solution of Large-Scale scattering problems. Antennas and Propagation, IEEE Transactions on, 56(8):2335-2345, 2008.

[EG08b] O. Ergul and L. Gurel. Hierarchical parallelisation strategy for multilevel fast multipole algorithm in computational electromagnetics. Electronics Letters, 44(1):3-5, 2008.

[EHT93] A. Z. Elsherbeni, M. Hamid, and G. Tian. Iterative scattering of a gaussianbeam by an array of circular conducting and dielectric cylinders. Journal of Electromagnetic Waves and Applications, 7(10):1323-1342, 1993. PT: J; J9: J ELECTROMAGNET WAVE APPLICAT; PG: 20; GA: MA315; UT: ISI:A1993MA31500003. 
[EMRV92] N. Engheta, W.D. Murphy, V. Rokhlin, and M.S. Vassiliou. The fast multipole method (FMM) for electromagnetic scattering problems. Antennas and Propagation, IEEE Transactions on, 40(6):634-641, 1992.

[ESA07] ESA/ESTEC. Multipactor calculator, April 2007.

[Eur98] Proyecto ACTS AC204 (Comunidad Europea). System for Advanced Mobile Broadband Applications (SAMBA). 1998.

[Fle00] R. Fletcher. Practical Methods of Optimization. Wiley, May 2000.

[FP63] R. Fletcher and M.J.D. Powell. A rapidly convergent descent method for minimization. Computer Journal, 6:163-168, 1963.

[GG98] G. Gerini and M. Guglielmi. Efficient integral equation formulations for admittance or impedance representation of planar waveguide junctions. In $\mathrm{Mi}$ crowave Symposium Digest, 1998 IEEE MTT-S International, volume 3, pages 1747-1750 vol.3, 1998. ID: 1.

[GH75] F. Gembicki and Y. Haimes. Approach to performance and sensitivity multiobjective optimization: The goal attainment method. Automatic Control, IEEE Transactions on, 20(6):769-771, 1975.

[GL88] R. Gesche and N. Lochel. Scattering by a lossy dielectric cylinder in a rectangular waveguide. Microwave Theory and Techniques, IEEE Transactions on, 36(1):137-144, 1988. ID: 1.

[GL89] R. Gesche and N. Lochel. Two cylindrical obstacles in a rectangular waveguideresonances and filter applications. Microwave Theory and Techniques, IEEE Transactions on, 37(6):962-968, 1989. ID: 1.

[Gmb] Bosch Telecom GmbH. Bosch Access Networks: Broadband Radio Access Systems. Digital Multipoint System Series (DMS). Catálogo de Bosch Telecom $\mathrm{GmbH}$.

[GN90] M. Guglielmi and C. Newport. Rigorous, multimode equivalent network representation of inductive discontinuities. Microwave Theory and Techniques, IEEE Transactions on, 38(11):1651-1659, 1990.

[Gol89] David E. Goldberg. Genetic Algorithms in Search, Optimization, and Machine Learning. Addison-Wesley Professional, January 1989.

[Gug94] M. Guglielmi. Simple cad procedure for microwave filters and multiplexers. Microwave Theory and Techniques, IEEE Transactions on DOI 10.1109/22.141345, 42(7):1347-1352, 1994. 
[HA86] C. I. G. Hsu and H. A. Auda. Multiple dielectric posts in a rectangular waveguide. IEEE Transactions on Microwave Theory and Techniques, 34(8):883891, AUG 1986. PT: J; J9: IEEE TRANS MICROWAVE THEORY; PG: 9; GA: D3231; UT: ISI:A1986D323100006.

[Han77] S.P. Han. A globally convergent method for nonlinear programming. J. Optimization Theory and Applications, 22:297, 1977.

[Har93] Roger F. Harrington. Field Computation by Moment Methods. Wiley-IEEE Press, April 1993.

[Har01] Roger F. Harrington. Time-Harmonic Electromagnetic Fields. Wiley-IEEE Press, 2nd edition, August 2001.

[HH04] Randy L. Haupt and Sue Ellen Haupt. Practical Genetic Algorithms. WileyInterscience, May 2004.

[Hun60] J.K. Hunton. Analysis of microwave measurement techniques by means of signal flow graphs. Microwave Theory and Techniques, IRE Transactions on, 8(2):206-212, 1960.

[Hun01] Ian C. Hunter. Theory and Design of Microwave Filters. The Institution of Engineering and Technology, May 2001.

[HW54] Albert J. Hatch and H. Bartel Williams. The secondary electron resonance mechanism of Low-Pressure High-Frequency gas breakdown. Journal of Applied Physics, 25(4):417-423, April 1954.

[IK89] K. Ise and M. Koshiba. Equivalent-circuits for dielectric posts in a rectangular wave-guide. IEEE Transactions on Microwave Theory and Techniques, 37(11):1823-1825, NOV 1989. PT: J; J9: IEEE TRANS MICROWAVE THEORY; PG: 3; GA: AU830; UT: ISI:A1989AU83000026.

[IK90] K. Ise and M. Koshiba. Dielectric post resonances in a rectangular wave-guide. Iee Proceedings-H Microwaves Antennas and Propagation, 137(1):61-66, FEB 1990. PT: J; J9: IEE PROC-H MICROWAVE ANT PROP; PG: 6; GA: CM197; UT: ISI:A1990CM19700011.

[JB08] Pierre Jarry and Jacques Beneat. Advanced Design Techniques and Realizations of Microwave and RF Filters. Wiley-IEEE Press, July 2008.

[JBKB98] P. Jarry, J. Beneat, E. Kerherve, and H. Baher. New class of rectangular and circular evanescent-mode waveguide filter. Int J RF and Microwave Comp Aid Eng, 8(2):161-192, 1998.

[KB08] S. Koziel and J.W. Bandler. Space mapping with multiple coarse models for optimization of microwave components. Microwave and Wireless Components Letters, IEEE DOI - 10.1109/LMWC.2007.911969, 18(1):1-3, 2008. 
[KCT92] C. Kudsia, R. Cameron, and W.C. Tang. Innovations in microwave filters and multiplexing networks for communications satellite systems. Microwave Theory and Techniques, IEEE Transactions on DOI - 10.1109/22.141345, 40(6):1133-1149, 1992.

[KM02] P. Kozakowski and M. Mrozowski. Gradient-based optimization of filters using FDTD software. Microwave and Wireless Components Letters, IEEE, 12(10):389-391, 2002.

[KS86a] M. Koshiba and M. Suzuki. Finite-element analysis of h-plane wave-guide junction with arbitrarily shaped ferrite post. IEEE Transactions on Microwave Theory and Techniques, 34(1):103-109, JAN 1986. PT: J; J9: IEEE TRANS MICROWAVE THEORY; PG: 7; GA: AYV03; UT: ISI:A1986AYV0300014.

[KS86b] M. Koshiba and M. Suzuki. Finite-Element analysis of H-Plane waveguide junction with arbitrarily shaped ferrite post. Microwave Theory and Techniques, IEEE Transactions on, 34(1):103-109, 1986.

[Kur65] K. Kurokawa. Power waves and the scattering matrix. Microwave Theory and Techniques, IEEE Transactions on, 13(2):194-202, 1965.

[LALP84] Ping Guan Li, A.T. Adams, Y. Leviatan, and J. Perini. Multiple-Post inductive obstacles in rectangular waveguide. Microwave Theory and Techniques, IEEE Transactions on, 32(4):365-373, 1984.

[LC84] R. Levy and S.B. Cohn. A history of microwave filter research, design, and development. Microwave Theory and Techniques, IEEE Transactions on DOI - 10.1109/22.141345, 32(9):1055-1067, 1984.

[LCZ07] Wei Bing Lu, Tie Jun Cui, and Hui Zhao. Acceleration of fast multipole method for Large-Scale periodic structures with finite sizes using Sub-Entire-Domain basis functions. Antennas and Propagation, IEEE Transactions on, 55(2):414421, 2007.

[Lew51] Leon Lewin. Advanced theory of waveguides. Published for Wireless Engineer by Iliffe, 1951.

[Lew70] L. Lewin. On inadequacy of discrete mode-matching techniques in some waveguide discontinuity problems. IEEE Transactions on Microwave Theory and Techniques, MT18(7):364-\&, 1970. PT: J; J9: IEEE TRANS MICROWAVE THEORY; PG: 0; GA: G7419; UT: ISI:A1970G741900005.

$\left[\mathrm{LJK}^{+} 00\right] \quad$ M. Lecouve, P. Jarry, E. Kerherve, N. Boutheiller, and F. Marc. Genetic algorithm optimisation for evanescent mode waveguide filter design. In Circuits and Systems, 2000. Proceedings. ISCAS 2000 Geneva. The 2000 IEEE International Symposium on, volume 3, pages 411-414 vol.3, 2000. 
[LLAP83] Y. Leviatan, P. G. Li, A. T. Adams, and J. Perini. Single-post inductive obstacle in rectangular waveguide. IEEE Transactions on Microwave Theory and Techniques, 31(10):806-812, 1983. PT: J; J9: IEEE TRANS MICROWAVE THEORY; PG: 7; GA: RP903; UT: ISI:A1983RP90300002.

[LLZ08] Xu Liu, Changhong Liang, and Xunwang Zhao. Analysis of waveguide slot antennas using MLFMA. Microwave and Optical Technology Letters, 50(1):6568, 2008.

[LM04] R. Lech and J. Mazur. Propagation in rectangular waveguides periodically loaded with cylindrical posts. Microwave and Wireless Components Letters, IEEE DOI - 10.1109/LMWC.2007.911969, 14(4):177-179, April 2004.

[LS87] Y. Leviatan and G. S. Sheaffer. Analysis of inductive dielectric posts in rectangular wave-guide. IEEE Transactions on Microwave Theory and Techniques, 35(1):48-59, JAN 1987. PT: J; J9: IEEE TRANS MICROWAVE THEORY; PG: 12; GA: F4648; UT: ISI:A1987F464800009.

[LSA84] Y. Leviatan, D. H. Shau, and A. T. Adams. Numerical study of the current distribution on a post in a rectangular waveguide. IEEE Transactions on Microwave Theory and Techniques, 32(10):1411-1415, 1984. PT: J; J9: IEEE TRANS MICROWAVE THEORY; PG: 5; GA: TK434; UT: ISI:A1984TK43400022.

[LSM02] R. Levy, R.V. Snyder, and G. Matthaei. Design of microwave filters. Microwave Theory and Techniques, IEEE Transactions on DOI - 10.1109/22.141345, 50(3):783-793, 2002.

[Ltd06] COM DEV Ltd. Robotic computer-aided tuning. Microwave Journal, 49(3):142-144, March 2006.

[LVVA00] M. Ludovico, G. Vercellino, A. Verdolini, and L. Accatino. Multipaction analysis in high power antenna diplexers for satellite applications. In Proceedings of the Workshop on Multipactor, RF and DC Corona and Passive Intermodulation in Space RF Hardware, page 109, ESTEC, Noordwijk, The Netherlands, September 2000.

[LX06] L. Li and Y. Xie. Efficient algorithm for analyzing microstrip antennas using fast-multipole algorithm combined with fixed real-image simulated method. Journal of Electromagnetic Waves and Applications, 20(15):2177-2188, 2006.

[LZAR01] M. Ludovico, G. Zarba, L. Accatino, and D. Raboso. Multipaction analysis and power handling evaluation in waveguide components for satellite antenna applications. In 2001 IEEE AP-S International Symposium and USNC / URSI National Radio Science Meeting, 2001. 
[LZL03] J Lee, J Zhang, and C.-C. Lu. Performance of preconditioned krylov iterative methods for solving hybrid integral equations in electromagnetics. Journal of the Applied Computational Electromagnetics Society, 18(3):54-61, 2003.

[Mar86] Nathan Marcuvitz. Waveguide Handbook. The Institution of Engineering and Technology, April 1986.

[Mat] The Mathworks. Matlab.

[Mat02] The Mathworks. Optimization Toolbox User's Guide. Release Notes. The Mathworks, 2002.

[MB10] Gerard Maral and Michel Bousquet. Satellite Communications Systems: Systems, Techniques and Technology. Wiley, February 2010.

[MBEB06] J. V. Morro, C. Bachiller, H. Esteban, and V. E. Boria. New efficient and robust automated design strategy for $\mathrm{h}$ plane direct-coupled-cavities filters with dielectric resonators. In Antennas and Propagation Society International Symposium 2006, IEEE, pages 597-600, 2006. ID: 1.

$\left[\mathrm{MEB}^{+}\right.$04] J.V. Morro, H. Esteban, V.E. Boria, C. Bachiller, S. Cogollos, and A. Coves. Efficient automated design of $\mathrm{h}$ plane filters with rounded corners using ASM with a segmentation strategy and hybrid optimization techniques. In Antennas and Propagation Society International Symposium, 2004. IEEE, volume 3, pages 2735-2738 Vol.3, 2004.

$\left[\mathrm{MEB}^{+} 05\right]$ J.V. Morro, H. Esteban, V.E. Boria, C. Bachiller, and A. Coves. New multimodel aggressive space mapping technique for the efficient design of complex microwave circuits. In Microwave Symposium Digest, 2005 IEEE MTT-S International, page 4 pp., 2005.

$\left[\mathrm{MEB}^{+}\right.$08] J. V. Morro, H. Esteban, V. E. Boria, C. Bachiller, and A. Belenguer. Optimization techniques for the efficient design of low-cost satellite filters considering new light materials. International Journal of RF and Microwave ComputerAided Engineering, 18(2):168-175, 2008.

$\left[\mathrm{MES}^{+}\right.$02a] J. V. Morro, H. Esteban, P. Soto, A. A. San Blas, V. E. Boria, and B. Gimeno. DESAFIO 1.0: A novel CAD tools for the automated design of inductively coupled rectangular waveguide filters. In Proceedings of PIERS 2002, page 882, Boston, July 2002.

$\left[\mathrm{MES}^{+}\right.$02b] J.V. Morro, H. Esteban, P. Soto, A.A. San Blas, V.E. Boria, and B. Gimeno. Optimization methods for the automated electromagnetic design of inductively coupled rectangular waveguide filters. In Antennas and Propagation Society International Symposium, 2002. IEEE, volume 2, pages 350-353 vol.2, 2002. 
$\left[\mathrm{MES}^{+}\right.$03] J.V. Morro, H. Esteban, P. Soto, V.E. Boria, C. Bachiller, S. Cogollos, and B. Gimeno. Automated design of waveguide filters using aggressive space mapping with a segmentation strategy and hybrid optimization techniques. In Microwave Symposium Digest, 2003 IEEE MTT-S International, volume 2, pages 1215-1218 vol.2, 2003.

[MG07] Tah'Ir Malas and Levent Gurel. Incomplete LU preconditioning with the multilevel fast multipole algorithm for electromagnetic scattering. SIAM J. Sci. Comput., 29(4):1476-1494, 2007.

[MGBB07] José V. Morro, H. Esteban González, Carmen Bachiller, and Vicente E. Boria. Automated design of complex waveguide filters for space systems: A case study. International Journal of RF and Microwave Computer-Aided Engineering, 17(1):84-89, 2007.

[Mic11] Zbigniew Michalewicz. Genetic Algorithms + Data Structures $=$ Evolution Programs. Springer, April 2011.

[Min07] Yu Ming. Power-handling capability for rf filters. Microwave Magazine, IEEE DOI - 10.1109/MMW.2007.335528, 8(5):88-97, 2007.

[MJY80] G. Matthaei, E.M.T. Jones, and L. Young. Microwave Filters, ImpedanceMatching Networks, and Coupling Structures. Artech House Publishers, February 1980.

[MSE ${ }^{+}$05] J.V. Morro, P. Soto, H. Esteban, V.E. Boriat, C. Bachiller, M. Taroncher, S. Cogollos, and B. Gimeno. Fast automated design of waveguide filters using aggressive space mapping with a new segmentation strategy and a hybrid optimization algorithm. Microwave Theory and Techniques, IEEE Transactions on, 53(4):1130-1142, 2005.

[MW99] R.H. MacPhie and Ke-Li Wu. A full-wave modal analysis of arbitrarily shaped waveguide discontinuities using the finite plane-wave series expansion. Microwave Theory and Techniques, IEEE Transactions on, 47(2):232-237, 1999.

[Nie69] E. D. Nielsen. Scattering by a cylindrical post of complex permittivity in a waveguide. IEEE Transactions on Microwave Theory and Techniques, MT17(3):148-\&, 1969. PT: J; J9: IEEE TRANS MICROWAVE THEORY; PG: 0; GA: D2611; UT: ISI:A1969D261100003.

[NM65] J.A. Nelder and R. Mead. A simplex method for function minimization. The Computer Journal, 7(4):308-313, January 1965.

[OSTT95] R. Orta, P. Savi, R. Tascone, and D. Trinchero. Rectangular waveguide dualmode filters without discontinuities inside the resonators. Microwave and Guided Wave Letters, IEEE, 5(9):302-304, 1995. 
[Pag95] J. E. Page. The effect of the machining method on the performances of rectangular waveguide devices. Proc. of ESA workshop on advanced CAD for microwave filters and passive devices, 1:329-336, 1995.

[PCL81] J.K. Plourde and Ren Chung-Li. Application of dielectric resonators in microwave components. Microwave Theory and Techniques, IEEE Transactions on DOI - 10.1109/22.141345, 29(8):754-770, August 1981.

[PM86] Andrew F. Peterson and Raj Mittra. Convergence of the Conjugate Gradients Method when applied to matrix equations representing electromagnetic scattering problems. IEEE Transactions on Antennas and Propagation, 34(12):14471454, December 1986.

[Pow78] M.J.D. Powell. The Convergence of Variable Metric Methods For Nonlinearly Constrained Optimization Calculations. Academic Press, 1978.

[Poz04] David M. Pozar. Microwave Engineering. Wiley, February 2004.

[PRM97] Andrew F. Peterson, Scott L. Ray, and Raj Mittra. Computational Methods for Electromagnetics. Wiley-IEEE Press, December 1997.

[PS06] X.-M. Pan and X.-Q. Sheng. A highly efficient parallel approach of multi-level fast multipole algorithm. Journal of Electromagnetic Waves and Applications, 20(8):1081-1092, 2006.

[PTVF07] William H. Press, Saul A. Teukolsky, William T. Vetterling, and Brian P. Flannery. Numerical Recipes 3rd Edition: The Art of Scientific Computing. Cambridge University Press, September 2007.

[QGP ${ }^{+}$05] F. Quesada, J. L. Gomez, J. Pascual, D. Ca nete, A. Alvarez, B. Gimeno, A. Vidal, and V. E. Boria. Investigation of multipaction phenomena in cavity filters loaded with dielectric posts and tuning elements. In 5th Int. Workshop on Multipactor, Corona and Passive Intermodulation in Space RF hardware, pages 9-16, ESA-ESTEC. The Netherlands, Sept. 2005.

[RA95] J. M. Reiter and F. Arndt. Rigorous analysis of arbitrarily-shaped h-plane and eplane discontinuities in rectangular wave-guides by a full-wave boundary contour mode-matching method. IEEE Transactions on Microwave Theory and Techniques, 43(4):796-801, APR 1995. PT: J; J9: IEEE TRANS MICROWAVE THEORY; PN: Part 1; PG: 6; GA: QT615; UT: ISI:A1995QT61500012.

[RCWY07] Ping-Liang Rui, Ru-Shan Chen, Dao-Xiang Wang, and E.K.-N. Yung. Spectral Two-Step preconditioning of multilevel fast multipole algorithm for the fast monostatic RCS calculation. Antennas and Propagation, IEEE Transactions on, 55(8):2268-2275, 2007. 
[Ric65] J. H. Richmond. Scattering by a dielectric cylinder of arbitrary cross section shape. Ieee Transactions on Antennas and Propagation, AP13(3):334-\&, 1965. PT: J; J9: IEEE TRANS ANTENNAS PROPAGAT; PG: 0; GA: 65125; UT: ISI:A19656512500001.

$\left[\mathrm{RMM}^{+}\right.$92] T. Rozzi, F. Moglie, A. Morini, W. Gulloch, and M. Politi. Accurate full-band equivalent circuits of inductive posts in rectangular waveguide. Microwave Theory and Techniques, IEEE Transactions on, 40(5):1000-1009, 1992.

[Rok90] V. Rokhlin. Rapid solution of integral equations of scattering theory in two dimensions. J. Comput. Phys., 86(2):414-439, 1990.

[Ros60] H. H. Rosenbrock. An automatic method for finding the greatest or least value of a function. The Computer Journal, 3(3):175 -184, January 1960.

[Saa03] Yousef Saad. Iterative Methods for Sparse Linear Systems, Second Edition. Society for Industrial and Applied Mathematics, 2 edition, April 2003.

[Sar03] Jukka Sarvas. Performing interpolation and anterpolation entirely by fast fourier transform in the 3-D multilevel fast multipole algorithm. SIAM J. Numer. Anal., 41(6):2180-2196, 2003.

[SBS02] M.B. Steer, J.W. Bandler, and C.M. Snowden. Computer-aided design of rf and microwave circuits and systems. Microwave Theory and Techniques, IEEE Transactions on DOI - 10.1109/22.141345, 50(3):996-1005, 2002.

[SC95a] J. M Song and W. C Chew. Fast multipole method solution of combined field integral equation. 11TH ANNUAL REVIEW OF PROGRESS IN APPLIED COMPUTATIONAL ELECTROMAGNETICS, 1:629—636, 1995.

[SC95b] J. M. Song and W. C. Chew. Multilevel fast-multipole algorithm for solving combined field integral equations of electromagnetic scattering. Microwave and Optical Technology Letters, 10(1):14-19, 1995.

[SGB $\left.{ }^{+} 00\right]$ P. Soto, J.L. Gómez, A. Bergner, V. E. Boria, and R. Chismol. Automated design of waveguide filters using space mapping optimization. In Proc. of 3 rd Eu. Conf. on Numerical Meth. in Electromagnetism, pages 228-229, Poitiers, March 2000.

[Sim81] G.R. Simpson. A generalized n-Port cascade connection. In Microwave Symposium Digest, 1981 IEEE MTT-S International, pages 507-509, 1981.

[SJS ${ }^{+98] ~ X . Q . ~ S h e n g, ~ J .-M . ~ J i n, ~ J . ~ S o n g, ~ W . C . ~ C h e w, ~ a n d ~ C .-C . ~ L u . ~ S o l u t i o n ~ o f ~}$ combined-field integral equation using multilevel fast multipole algorithm for scattering by homogeneous bodies. Antennas and Propagation, IEEE Transactions on, 46(11):1718-1726, 1998. 
[SL88] G. S. Sheaffer and Y. Leviatan. Composite inductive posts in wave-guide - a multifilament analysis. IEEE Transactions on Microwave Theory and Techniques, 36(4):779-783, APR 1988. PT: J; J9: IEEE TRANS MICROWAVE THEORY; PG: 5; GA: M6040; UT: ISI:A1988M604000024.

[SLC97] J. Song, Cai-Cheng Lu, and Weng Cho Chew. Multilevel fast multipole algorithm for electromagnetic scattering by large complex objects. Antennas and Propagation, IEEE Transactions on, 45(10):1488-1493, 1997.

[Sny07] R.V. Snyder. Practical aspects of microwave filter development. Microwave Magazine, IEEE DOI - 10.1109/MMW.2007.335528, 8(2):42-54, 2007.

$\left[\mathrm{STB}^{+} 10\right]$ P. Soto, E. Tarin, V.E. Boria, C. Vicente, J. Gil, and B. Gimeno. Accurate synthesis and design of wideband and inhomogeneous inductive waveguide filters. Microwave Theory and Techniques, IEEE Transactions on DOI 10.1109/22.141345, 58(8):2220-2230, 2010.

[SV85] J. N. Sahalos and E. Vafiadis. On the narrow-band microwave filter design using a dielectric rod. IEEE Transactions on Microwave Theory and Techniques, 33(11):1165-1171, 1985. PT: J; J9: IEEE TRANS MICROWAVE THEORY; PG: 7; GA: AUL65; UT: ISI:A1985AUL6500011.

[Tai94] Chen-To Tai. Dyadic Green Functions in Electromagnetic Theory. Institute of Electrical \& Electronics Enginee, 2 sub edition, January 1994.

[TH05] Allen Taflove and Susan C. Hagness. Computational Electrodynamics: The Finite-Difference Time-Domain Method, Third Edition. Artech House Publishers, 3 edition, June 2005.

[UB93] Jaroslaw Uher and Jens Bornemann. Waveguide Components for Antenna Feed Systems: Theory and CAD. Artech Print on Demand, December 1993.

[Udi04] R. Udiljak. Multipactor in low pressure gas. Master's thesis, Department of Electromagnetics, School of Electrical Engineering, Chalmers University of Technology, Göteborg, Sweeden, 2004.

[Udi07] R. Udiljak. Multipactor in low pressure gas and in nonuniform RF field structures. PhD thesis, Department of Radio and Space Science, School of Electrical Engineering, Chalmers University of Technology, Göteborg, Sweeden, 2007.

[VC05] S. Velamparambil and W.C. Chew. Analysis and performance of a distributed memory multilevel fast multipole algorithm. Antennas and Propagation, IEEE Transactions on, 53(8):2719-2727, 2005.

[WP86] J.P. Webb and S. Parihar. Finite element analysis of h-plane rectangular waveguide problems. Microwaves, Antennas and Propagation, IEE Proceedings $H$, 133(2):91-94, 1986. 
[WP89] A. Woode and J. Petit. Diagnostic investigations into the multipactor effect, susceptibility zone measuremenets and parameters affecting a discharge. Technical report, ESA Working paper no. 1556, Noordwijk, The Netherlands, November 1989.

[WSC ${ }^{+}$07] C. Waltz, K. Sertel, M.A. Carr, B.C. Usner, and J.L. Volakis. Massively parallel fast multipole method solutions of large electromagnetic scattering problems. Antennas and Propagation, IEEE Transactions on, 55(6):1810-1816, 2007.

[WX06] P. Wang and Y. Xie. Scattering and radiation problem of Surface/Surface junction structure with multilevel fast multipole algorithm. Journal of Electromagnetic Waves and Applications, 20(15):2189-2200, 2006.

[WZ01] Chi Wang and K.A. Zaki. Analysis of power handling capacity of band pass filters. In Microwave Symposium Digest, 2001 IEEE MTT-S International, volume 3, pages 1611-1614 vol.3, 2001.

[YVP98] S. Yin, T. Vasilyeva, and P. Pramanick. Use of three-dimensional field simulators in the synthesis of waveguide round rod bandpass filters. International Journal of Rf and Microwave Computer-Aided Engineering, 8(6):484-497, NOV 1998. PT: J; J9: INT J RF MICROW COMPUT-AID EN; PG: 14; GA: 130MZ; UT: ISI:000076525000008.

[ZLL05] Z. O Zaw, E. P Li, and L. W Li. Analysis and design on aperture antenna systems with large electrical size using multilevel fast multipole method. Journal of Electromagnetic Waves and Applications, 19:1485-1500(16), September 2005.

[ZLL08] Xun-Wang Zhao, Chang-Hong Liang, and Le Liang. MULTILEVEL FAST MULTIPOLE ALGORITHM FOR RADIATION CHARACTERISTICS OF SHIPBORNE ANTENNAS ABOVE SEAWATER. Progress In Electromagnetics Research, 81:291-302, 2008.

[Zve05] Anatol I. Zverev. Handbook of Filter Synthesis. Wiley-Interscience, June 2005. 